\title{
A general copper-catalyzed synthesis of ynamides from 1,2-dichloroenamides
}

Steven J. Mansfield, Russell C. Smith, Jonathan R. J. Yong, Olivia L. Garry and Edward A. Anderson

\section{Supporting Information}

1 General

1.1 Additional experimental results

1.1a Sulfonyl chloroynamide coupling: optimisation details

1.1b Carbonyl chloroynamide coupling: optimisation details

1.1c Dichloroenamide formation: important observations

1.1d Full list of organometallic coupling partners screened

1.1e Full list of dichloroenamide partners screened

1.2 General information

1.3 General procedures

2 Experimental details \& characterisation data

$2.1 \quad$ Organometallic Scope

2.1a Dichloroenamide 3a

2.1b Ynamides

2.1c Miscellaneous

2.2 Sulfonamide Scope

2.2a Dichloroenamides

2.2b Ynamides

2.3 Carbamate Scope

2.3a Dichloroenamides

2.3b Ynamides

2.3c Miscellaneous

$2.4 \quad$ Urea Scope

2.4a Dichloroenamides

2.4b Ynamides

2.4c Miscellaneous

\subsection{Amide Scope}

2.5a Dichloroenamides

2.5b Ynamides

2.5c Miscellaneous 
4.1 Organometallic Scope

4.1a Dichloroenamide 3a 163

4.1b Ynamides 164

$\begin{array}{ll}\text { 4.1c Miscellaneous } & 207\end{array}$

4.2 Sulfonamide Scope

4.2a Dichloroenamides 218

4.2b Ynamides 232

4.3 Carbamate Scope

4.3a Dichloroenamides 251

4.3b Ynamides 258

4.3c Miscellaneous 266

4.4 Urea Scope

4.4a Dichloroenamides 271

4.4b Ynamides 276

4.4c Miscellaneous $\quad 281$

\subsection{Amide Scope}

4.5a Dichloroenamides 283

4.5b Ynamides 294

4.5c Miscellaneous 298

Safety Note: $:$ Extreme care must be taken when working with dichloroacetylene (DCA), generated here in situ from trichloroethylene, as exposure to air (specifically oxygen) may result in sparking. As a general precaution, it is recommended to conduct these reactions under an inert atmosphere (Ar or $\mathrm{N}_{2}$ ), and to add the trichloroethylene dropwise over 2-30 minutes (depending on the scale, also see 1.1c). For most sulfonamides, the generation and consumption of DCA occurs at a comparable rate, and there is minimal to no accumulation of DCA in the reaction vessel. For the carbamate, urea and amide substrates, the rate of consumption is generally slower than generation and DCA can accumulate in the vessel (generally seen as a white vapour that dissipates as the reaction proceeds). 


\subsection{Additional experimental results.}

\section{1a Sulfonyl chloroynamide couplings: optimisation details.}

The initial viability of the route was tested using pure $N$-phenyl- $N$-tosyl chloroynamide 2a with the conditions reported by Cahiez. ${ }^{[1]}$ Full conversion was achieved and the desired ynamide products were obtained in good yields (Scheme S1). The (Z)-chloroenamide 4 was a significant byproduct when using phenylmagnesium bromide, though chloroenamides were not observed when using the alkyl Grignard reagents. Without copper salt, there was no reaction between 2a and phenylmagnesium bromide, and the $2^{\circ} / 3^{\circ}$ alkyl Grignard reagents underwent magnesium-chlorine exchange to give the terminal ynamide $(\mathrm{R}=\mathrm{H})$.

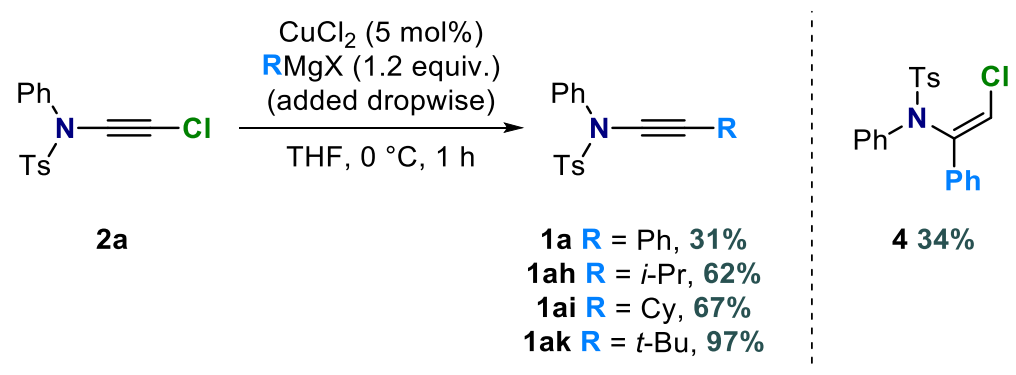

Scheme S1: Viability test for the coupling of chloroynamide 3a with Grignard reagents.

These reactions were repeated using the dichloroenamide $\mathbf{3 a}$, and proceeded without issue to afford the ynamides 1a and 1ah with yields that were comparable to those using the pure chloroynamide (Scheme S2). We also noted that higher yields were obtained when using a freshly prepared solution of LiHMDS in THF instead of a commercial solution (1.0 M in THF, Sigma-Aldrich).

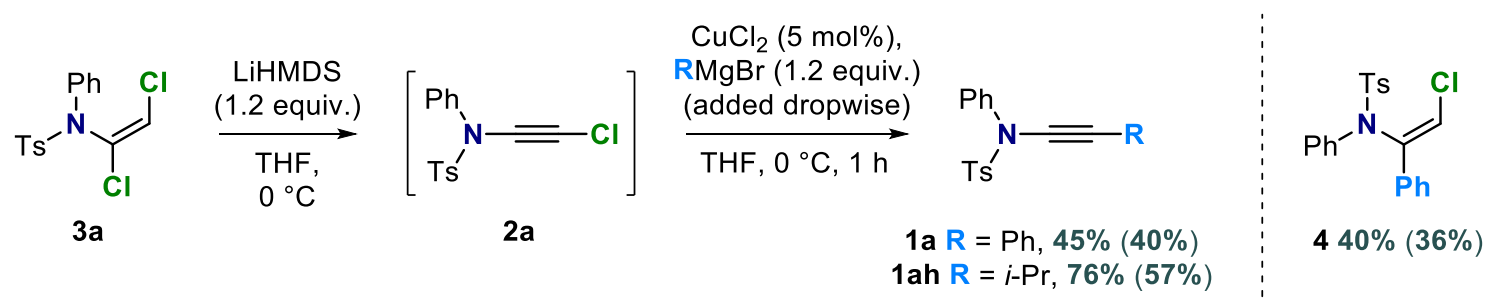

Scheme S2: Initial results for the conversion of dichloroenamide 3a to ynamides. Yields in parentheses are for the reactions carried out using commercial LiHMDS.

Our focus was then directed towards solving the selectivity issue and minimising the formation of the chloroenamide side product. Unfortunately, there was a negligible influence using those additives that have been shown to enhance similar reactions (Figure S1). ${ }^{[1]}$ We next considered the carbometallation reactions of "typical" ynamides, using Grignard reagents and copper salts, which typically require low temperatures $\left(<-30{ }^{\circ} \mathrm{C}\right)$ and poorly coordinating solvents, to give a high selectivity. ${ }^{[2]}$ Here, the 
chloroynamide behaved in the opposite fashion: increased temperature gave a greater selectivity for the desired ynamide, albeit the selectivity gain was not sufficient (Figure S2).
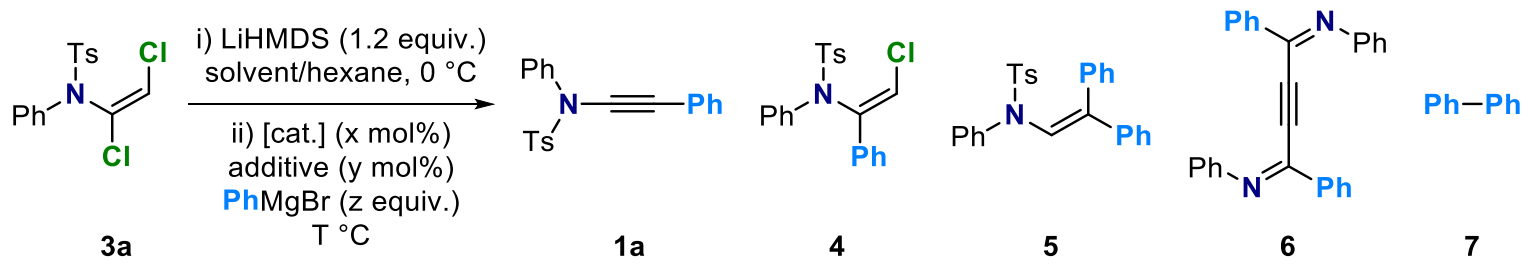

Scheme S3: General reaction scheme showing the products formed during the elimination/coupling of dichloroenamide 3a. Conditions: $\mathrm{THF}(0.34 \mathrm{M}), \mathrm{CuCl}_{2}$ (5 mol\%), no additive, $\mathrm{PhMgBr}\left(1.2\right.$ equiv.), $0{ }^{\circ} \mathrm{C}$.

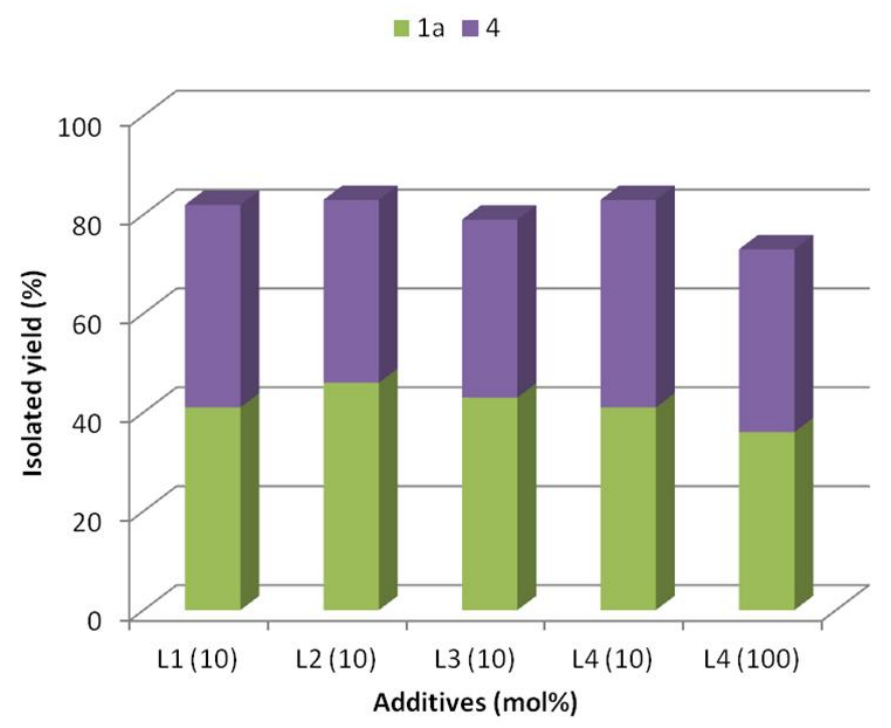

Figure S1: The effect of additives on the ratio of ynamide and chloroenamide. Conditions: THF (0.34 M), $\mathrm{CuCl}_{2}\left(5 \mathrm{~mol}^{\%}\right)$, additive (y mol\%), $\mathrm{PhMgBr}\left(1.2\right.$ equiv.), $0{ }^{\circ} \mathrm{C} . \mathrm{L} 1=\mathrm{PhC} \equiv \mathrm{CMe} ; \mathrm{L} 2=\mathrm{PPh}_{3} ; \mathrm{L} 3=\mathrm{TMEDA} ; \mathrm{L} 4=\mathrm{NMP}$.

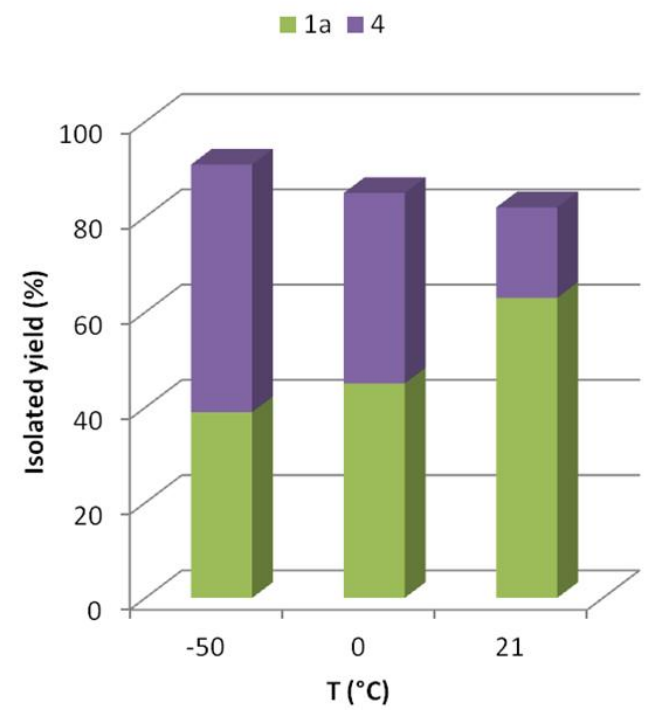

Figure S2: The effect of temperature on the ratio of ynamide and chloroenamide. Conditions: THF $(0.34 \mathrm{M}), \mathrm{CuCl}_{2}$ (5 mol\%), no additive, $\mathrm{PhMgBr}$ (1.2 equiv.), $\mathrm{T}^{\circ} \mathrm{C}$. 


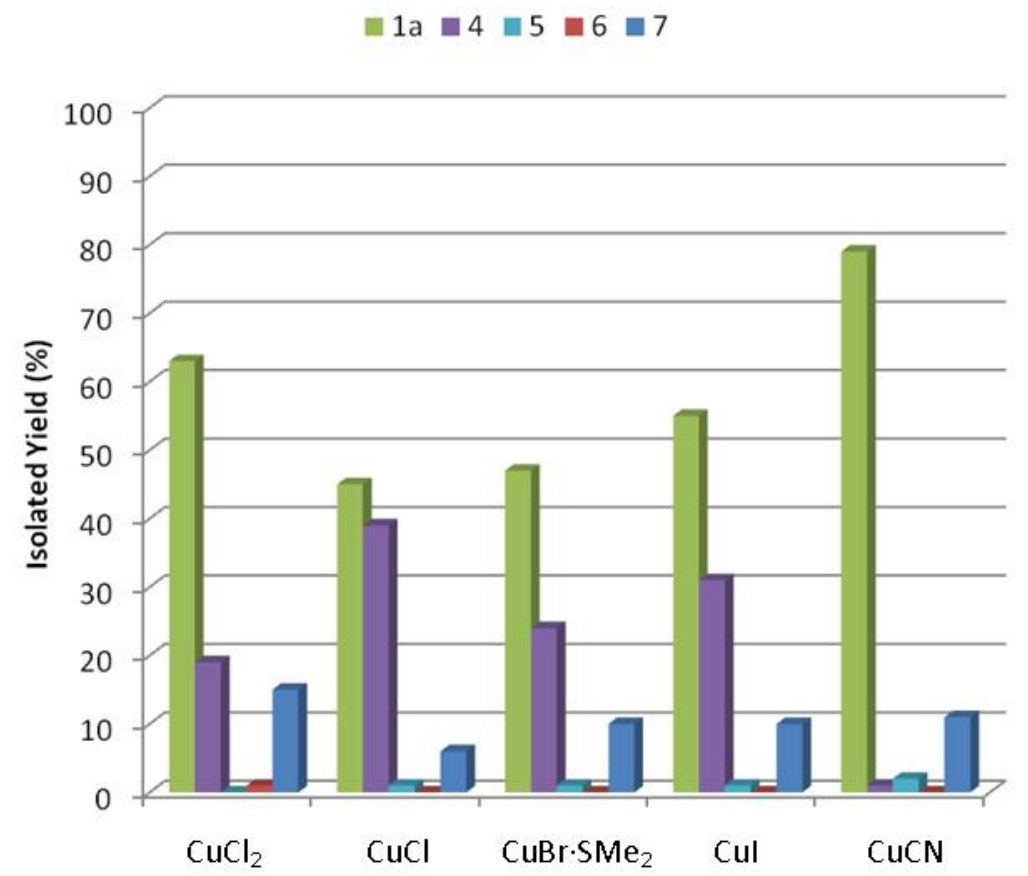

Figure S3: The effect of various copper salts on the ratio of products in the couplings. Conditions: copper salt (5 mol\%), no additive, $\mathrm{PhMgBr}\left(1.2\right.$ equiv.), $\mathrm{THF}(0.34 \mathrm{M}), 21^{\circ} \mathrm{C}$.

$\square 1 \mathrm{a} \square 4 \square 5 \square 6 \square$

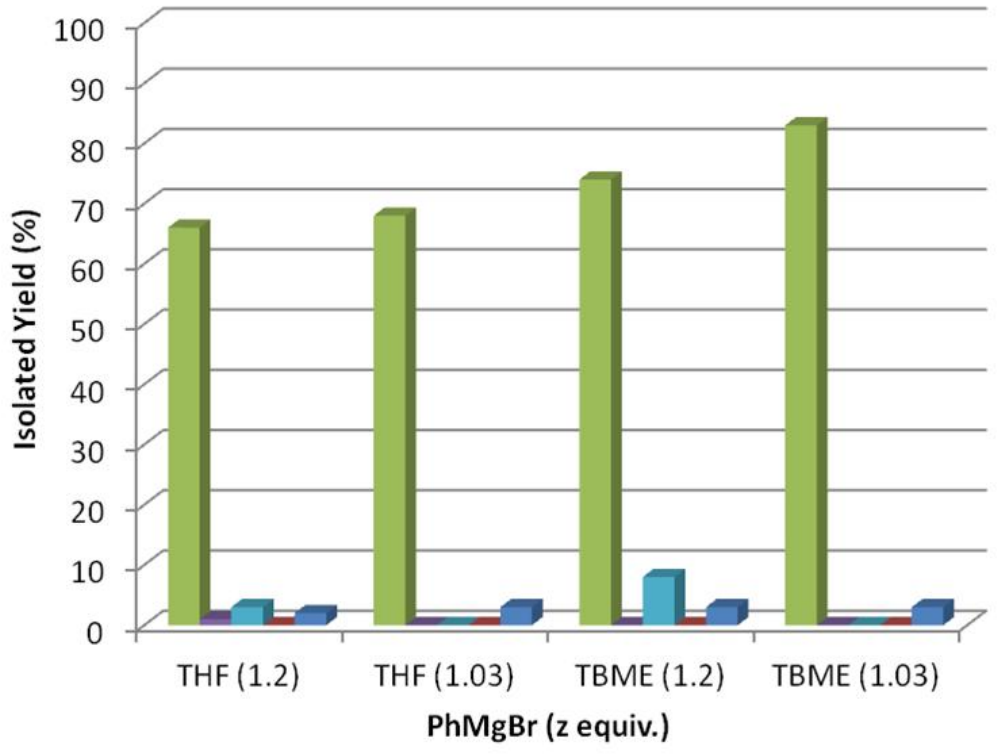

Figure S4: The effect of decreasing the amount of $\mathrm{PhMgBr}$ to 1.03 equiv. Conditions: $\mathrm{CuCN}(5 \mathrm{~mol} \%), \mathrm{P}(\mathrm{OMe})_{3}(10$ mol\%), $\mathrm{PhMgBr}$ (z equiv.), solvent $(0.24 \mathrm{M}), 21^{\circ} \mathrm{C}$. TBME $=t$-butyl methyl ether. 


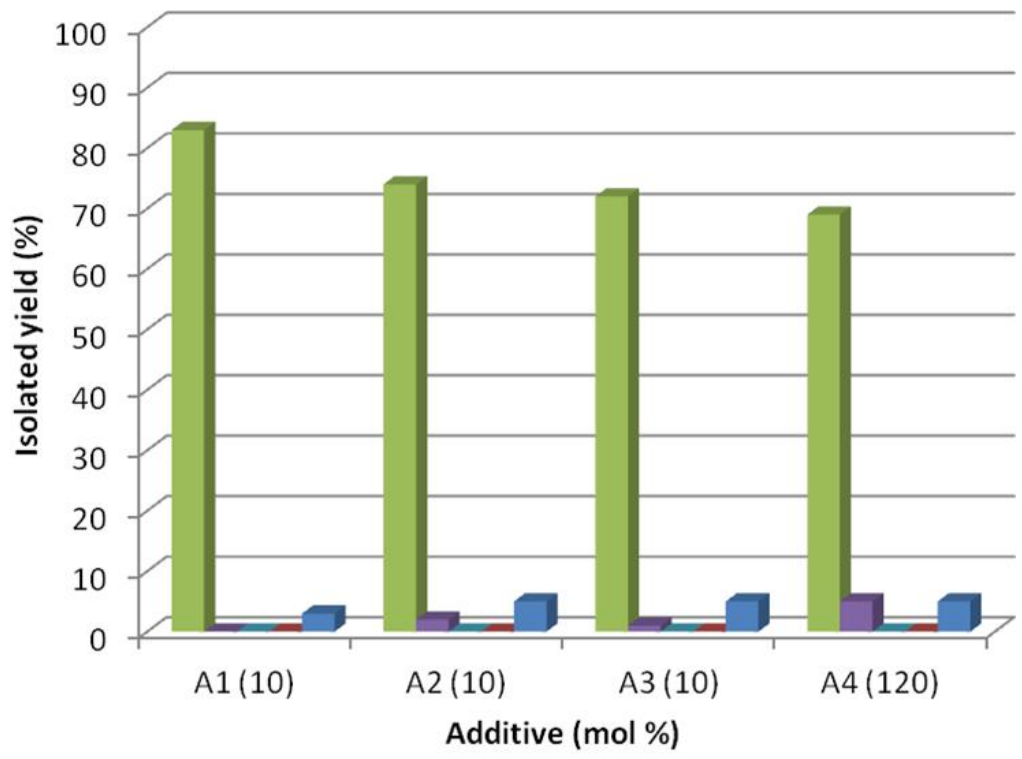

Figure S5: The effect of additives. Conditions: CuCN (5 mol\%), additive (y mol\%), PhMgBr (1.03 equiv.), TBME (0.24 $\mathrm{M}), 21^{\circ} \mathrm{C} . \mathrm{A} 1=\mathrm{P}(\mathrm{OMe})_{3}, \mathrm{~A} 2=\mathrm{PPh}_{3}, \mathrm{~A} 3=\mathrm{PBu}_{3}, \mathrm{~A} 4=\mathrm{LiHMDS}$

1a $\square 4 \square \square 6 \square 7$

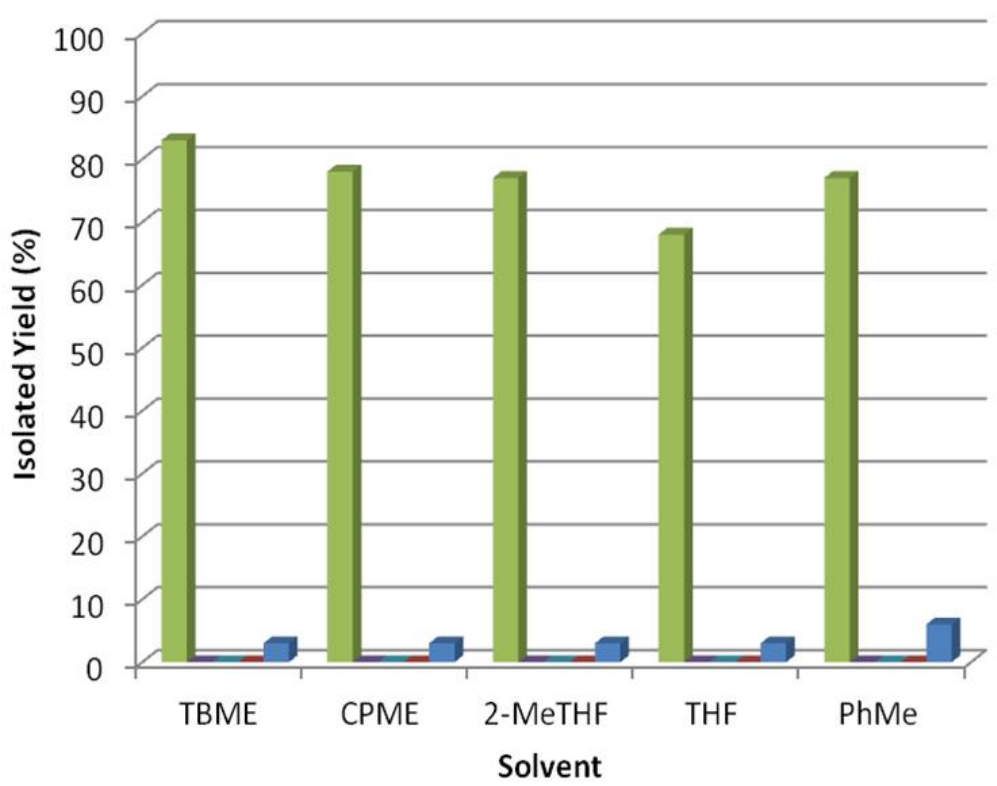

Figure S6: The effect of solvent. Conditions: $\mathrm{CuCN}$ (5 mol\%), $\mathrm{P}(\mathrm{OMe})_{3}(10 \mathrm{~mol} \%), \mathrm{PhMgBr}(1.03$ equiv.), solvent $(0.24$ $\mathrm{M}), 21^{\circ} \mathrm{C} . \mathrm{CPME}=$ cyclopentyl methyl ether. 
The effect of various copper salts was then screened (Figure S3). Whilst $\mathrm{CuCl}, \mathrm{CuBr} \cdot \mathrm{SMe}_{2}$ and $\mathrm{CuI}$ did not provide satisfactory results, $\mathrm{CuCN}$ gave a significant enhancement of selectivity $(>20: 1)$ with $1 \%$ of the chloroenamide observed in the ${ }^{1} \mathrm{H}$ NMR spectrum of the crude reaction mixture. Decreasing the amount of phenylmagnesium bromide from 1.2 to 1.03 equiv. suppressed the formation of diphenylenamide 6 (Figure S4), and the inclusion of trimethyl phosphite (10 mol\%) minimised the formation of biphenyl from $11 \%$ to $2 \%$ (Figure S5). ${ }^{[3]}$

Throughout our optimisation, it was apparent that the "yield-determining" step in this sequence was the dichloroenamide elimination. Having found a suitable catalyst for the transformation, we revisited chloroynamide formation to improve the overall yield, and a range of solvents were screened (Figure S6). The study began by comparing the reactions in TBME and THF. Dichloroenamide 3a was less soluble in TBME at $0.34 \mathrm{M}$ and the reaction was diluted to $0.24 \mathrm{M}$ to provide both increased solubility and faster reaction with LiHMDS (from 1 hour to $\sim 30-40$ minutes). Whilst the reaction was cleaner upon dilution, the yield of ynamide 1a decreased from $86 \%$ to $81 \%$. Performing the same comparison with THF had a similar effect in the elimination step, but a decreased yield (from $79 \%$ to $66 \%$ ) of the desired ynamide. Switching to cyclopentyl methyl ether (CPME), 2-methyl THF (2-MeTHF) and toluene gave similar outcomes, but were less effective than TBME.

The use of $\mathrm{Fe}(\mathrm{acac})_{3}$ was also investigated, and provided a slightly different reaction outcome: the ynamide 1a was formed in 55\% yield and the chloroenamide 4 was not observed, but there was a significant increase of biphenyl (28\%) and bis-imine 6 (6\%). As supported by later observations, it is likely that 6 results from dimerisation of the chloroenamide itself.

Overall, the chloroynamide 2a was prepared in $~ 95 \%$ yield in TBME $(0.24 \mathrm{M})$ and, using $5 \mathrm{~mol} \%$ of $\mathrm{CuCN} \cdot 2 \mathrm{P}(\mathrm{OMe})_{3}$ with 1.03 equiv. of phenylmagnesium bromide $(1.0 \mathrm{M}$ in THF), the coupled ynamide was isolated in $83 \%$ yield. Reducing the catalyst loading to $1.25 \mathrm{~mol} \%$ afforded the ynamide in $85 \%$ yield and this reaction was repeated a further four times with $82-86 \%$ yields. This reaction was also performed using commercially available anhydrous TBME and a commercial solution of LiHMDS (1.0 M solution in TBME, Sigma-Aldrich), which afforded ynamide 1a in $79 \%$ yield (compare with 1.2 General Information, reagents, solvents \& techniques).

These conditions were of broad applicability to both Grignard and organozinc reagents, with 38 coupling partners spanning a range of electron-rich and electron-poor (hetero)aromatics, and $1^{\circ} / 2^{\circ} /$ $3^{\circ}$ alkyl groups, being successful (Figure S12, Section 1.1d). Only a few coupling partners were unsuccessful: imidazol-4-yl or thiazol-2-ylmagnesium chlorides gave negligible conversion, and alkynylmagnesium bromides gave the (E)-chloroenamide as the major product instead (Scheme S4): their structures were identified by single crystal X-ray analysis. The $(Z)$-isomer was not observed. Only when using $i$-propylacetylene could we observe a small amount of the desired diyne. 


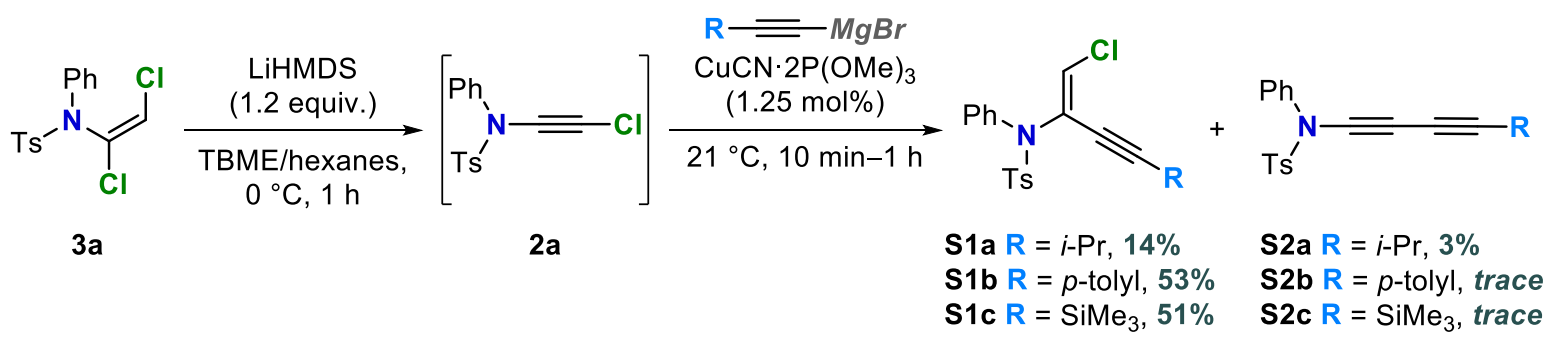

Scheme S4: Application of alkynyl Grignard reagents. $p$-tolyl $=4-\mathrm{MeC}_{6} \mathrm{H}_{4}$.

\section{1b Carbonyl chloroynamide coupling: optimisation details.}

Having completed the scope of organometallic partners and explored the synthesis of a range of sulfonyl ynamides, our attention shifted to the utility of carbonyl-protected dichloroenamides in this chemistry. These represent a different ynamide class, and whilst many unhindered, acyclic carbamates are successful substrates using traditional cross-coupling methods, acyclic ureas and amides are not. Using the previously optimised conditions, coupling of $\mathbf{1 0}$ with phenylmagnesium bromide led to the formation of chloroenamides $(Z)-/(E)$-11 and $(E)$-chloroester $\mathbf{1 2}$ as significant byproducts, in addition to the desired ynamide 13a (Scheme S5). In the absence of copper salt, the chloroynamide $\mathbf{1 0}$ is transformed to adduct $(E)-\mathbf{S 3}$ (which was stable below $-10{ }^{\circ} \mathrm{C}$ ), and rearranged to $\mathbf{S 4}$ over time at higher temperatures. The structures of $(E)-\mathbf{1 1}$ and $\mathbf{1 2}$ were identified by single crystal X-ray analysis.

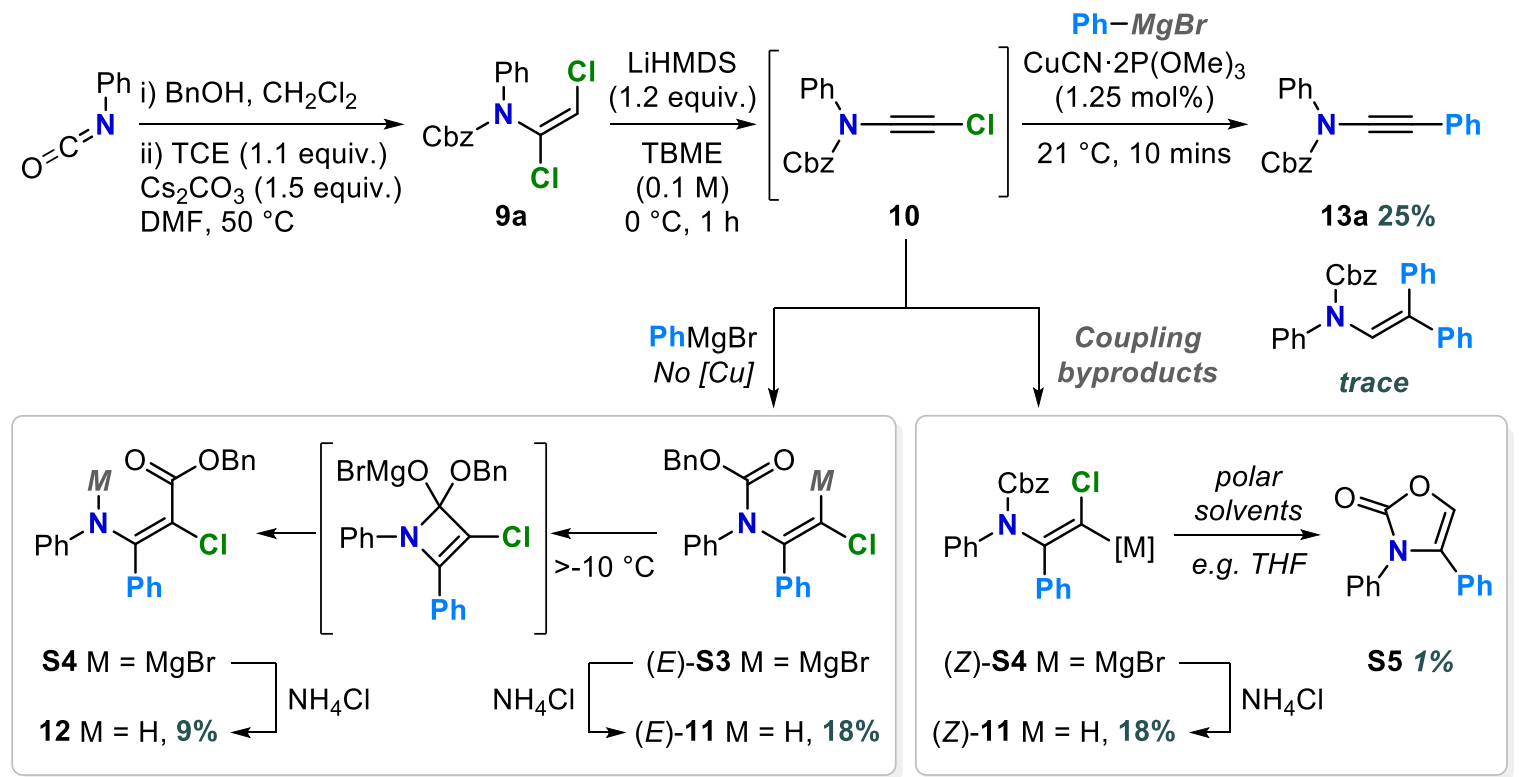

Scheme S5: Distribution of products formed in the initial screening using carbamate dichloroenamide 9a. $\mathrm{PhMgBr}$ (1.2 equiv., $1.0 \mathrm{M}$ in THF) was used. $\mathrm{Cbz}=\mathrm{CO}_{2} \mathrm{CH}_{2} \mathrm{Ph}$.

It is evident that this carbamate-derived chloroynamide is more reactive towards organomagnesium nucleophiles than its sulfonylated cousins; though it is uncertain whether this is a measure of the different inherent electrophilicities of the two or an increased ability of the electron-withdrawing group to direct nucleophilic attack through coordination. 


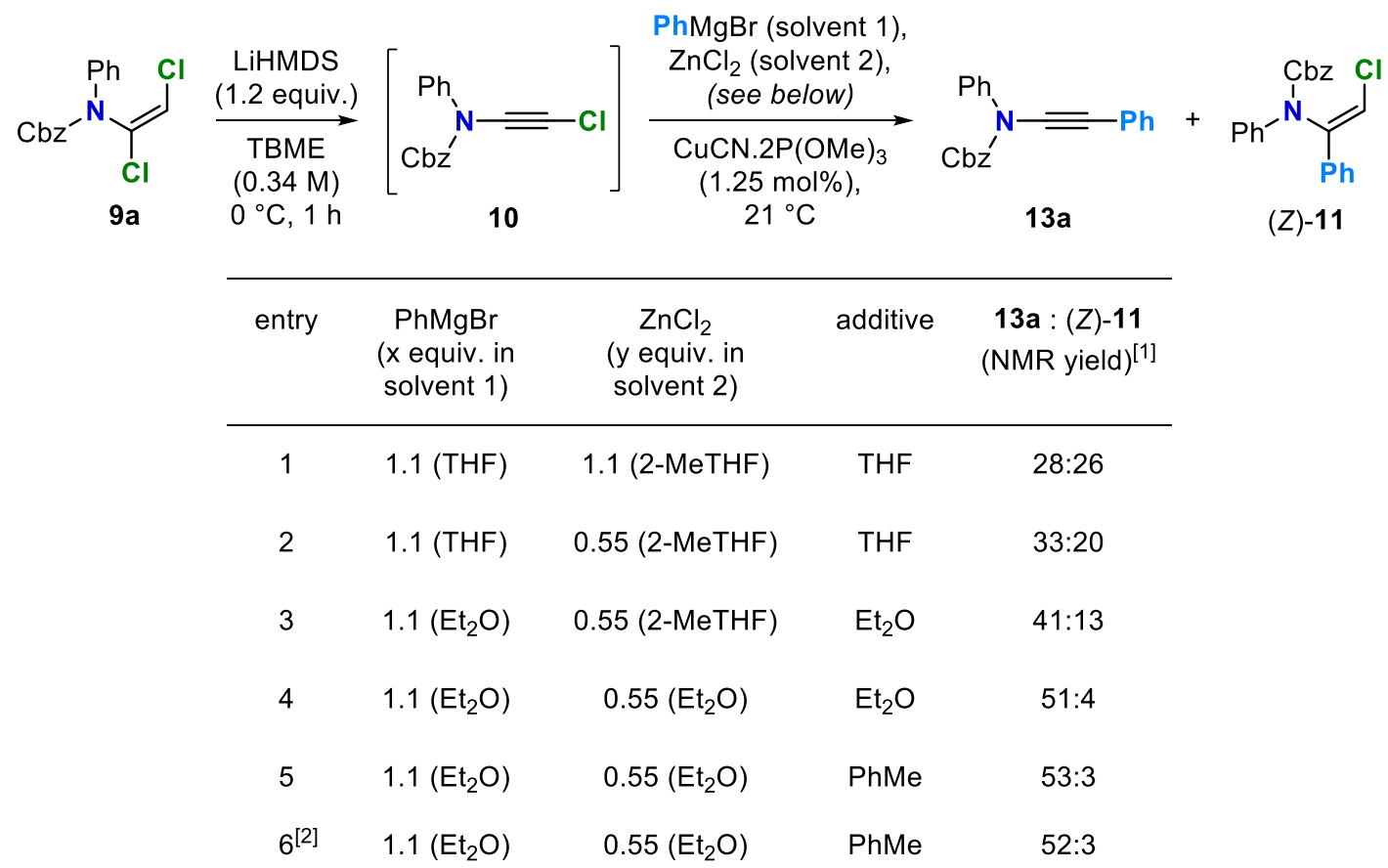

Table S1: The effect of solvent in the preparation of arylzinc reagent on product selectivity. Conditions: Dichloroenamide (500 mg), $\mathrm{PhMgBr}$ (1.0 M solution in solvent 1, x equiv.), $\mathrm{ZnCl}_{2}$ (1.0 M solution in solvent 2, y equiv.), additive (1.0 mL), $\mathrm{CuCN} \cdot 2 \mathrm{P}(\mathrm{OMe})_{3}(1.25 \mathrm{~mol} \%)$, TBME $(0.34 \mathrm{M}), 2{ }^{\circ} \mathrm{C}$. [1] Determined by ${ }^{1} \mathrm{H}$ NMR spectroscopic analysis of the crude reaction mixture using 1,3,5-trimethoxybenzene as the internal standard. [2] $\mathrm{CuCN} \cdot 2 \mathrm{LiCl}(1.0 \mathrm{M}$ solution in $\mathrm{THF}, 1.25$ $\mathrm{mol} \%)$ was used instead of $\mathrm{CuCN} \cdot 2 \mathrm{P}(\mathrm{OMe})_{3}$.

We switched to using organozinc reagents; they are readily prepared by a number of routes, ${ }^{[4]}$ and we chose to prepare them by transmetallation of a Grignard reagent with zinc(II) chloride. In this chemistry, both the monoarylzinc and diarylzinc reagents gave full conversion in the coupling reaction (Entries $1 \& 2$, Table S1). A few interesting features were noted: first, using either 1.1 equiv. of the monoarylzinc or 0.55 equiv. of the diarylzinc gave full conversion to the ynamide at room temperature. There was no discernible background reaction between the organozinc and the chloroynamide, and only biphenyl, ynamide 13a and the chloroenamide $(Z)-\mathbf{1 1}$ were observed. The reaction with the monoarylzinc required stirring overnight at room temperature (cf. sulfonamide cases) whereas the diarylzinc reacted within 30 minutes. The reaction with $\mathrm{Ph}_{2} \mathrm{Zn} \cdot 2 \mathrm{LiCl}$ was also successful, giving the ynamide (30\%) and chloroenamide (16\%).

Throughout this optimisation process, the combined yield of the ynamide and chloroenamide coupling products did not significantly exceed $50 \%$. This prompted us to revisit the chloroynamide formation, and in particular reexamine the effect of the solvent and concentration. Our attention was drawn to the work of Collum, ${ }^{[5]}$ in which the combination of LiHMDS in toluene $/ \mathrm{Et}_{3} \mathrm{~N}$ was shown to be a highly effective system for ketone enolisation. The effect of toluene/cosolvent mixtures was thus investigated (Scheme S6, Figure S7). These reactions proceeded well, but they were accompanied by the formation of oxazolone S5 and cumulene S6. The following trends were observed: firstly, increased 
concentration from $0.17 \mathrm{M}$ to $0.34 \mathrm{M}\left(2: 1\right.$ toluene/ $\left.\mathrm{Et}_{3} \mathrm{~N}\right)$ had a significant negative impact, with the yield of ynamide 13a dropping from $50 \%$ to $32 \%$. Secondly, there was a direct correlation between the formation of the oxazolone and the depletion of the chloroenamide. In fact, when the reaction in toluene/diethyl ether was repeated, the subsequent addition of $\mathrm{Et}_{3} \mathrm{~N}$ (10 equiv. with respect to lithium) gave significant conversion of the metallated chloroenamide (Z)-S4 to the oxazolone. The formation of both the oxazolone and the cumulene is reminiscent of carbene reactivity; though it is unclear whether this is the case here and whether these transformations are catalysed by copper or not.

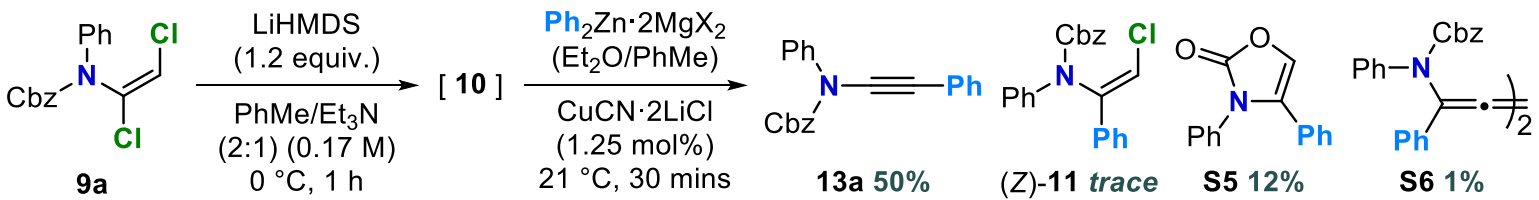

Scheme S6 Distribution of products formed from elimination/coupling using $\mathrm{PhMe} / \mathrm{Et}_{3} \mathrm{~N}$ solvent mixture.

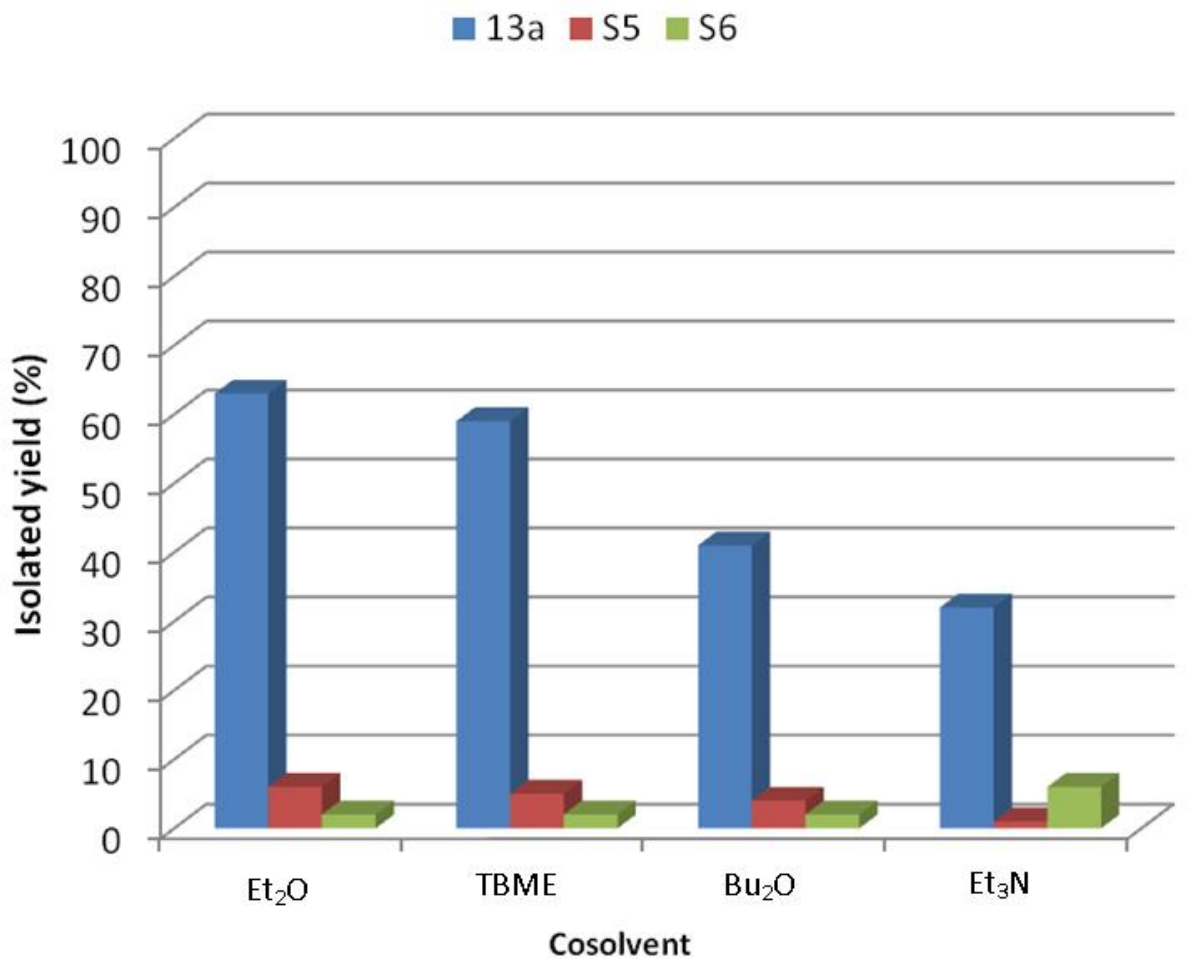

Figure S7: The effect of solvent mixtures on the yield of ynamide Conditions: " $\mathrm{Ph}_{2} \mathrm{Zn}$ " (solution in $\mathrm{PhMe} / \mathrm{Et}_{2} \mathrm{O}$, 0.55 equiv.), $\mathrm{CuCN} \cdot 2 \mathrm{LiCl}(1.25 \mathrm{~mol} \%), \mathrm{PhMe} /$ cosolvent $(2: 1,0.34 \mathrm{M}), 21^{\circ} \mathrm{C}$.

Given the stark concentration effect observed in these reactions (contrasting with sulfonamide case), we further investigated the concentration effect. Increased dilution gave a significantly higher yield in all of these reactions, and toluene/cosolvent mixtures gave slightly higher yields of the ynamide as compared to the use of diethyl ether or TBME alone (Figure S8). For overall convenience, TBME $(0.1 \mathrm{M})$ was chosen for our studies, but one should be mindful of the slight benefit of toluene in these reactions. This reaction was repeated three additional times to afford ynamide 13a in 71-76\% yield. 


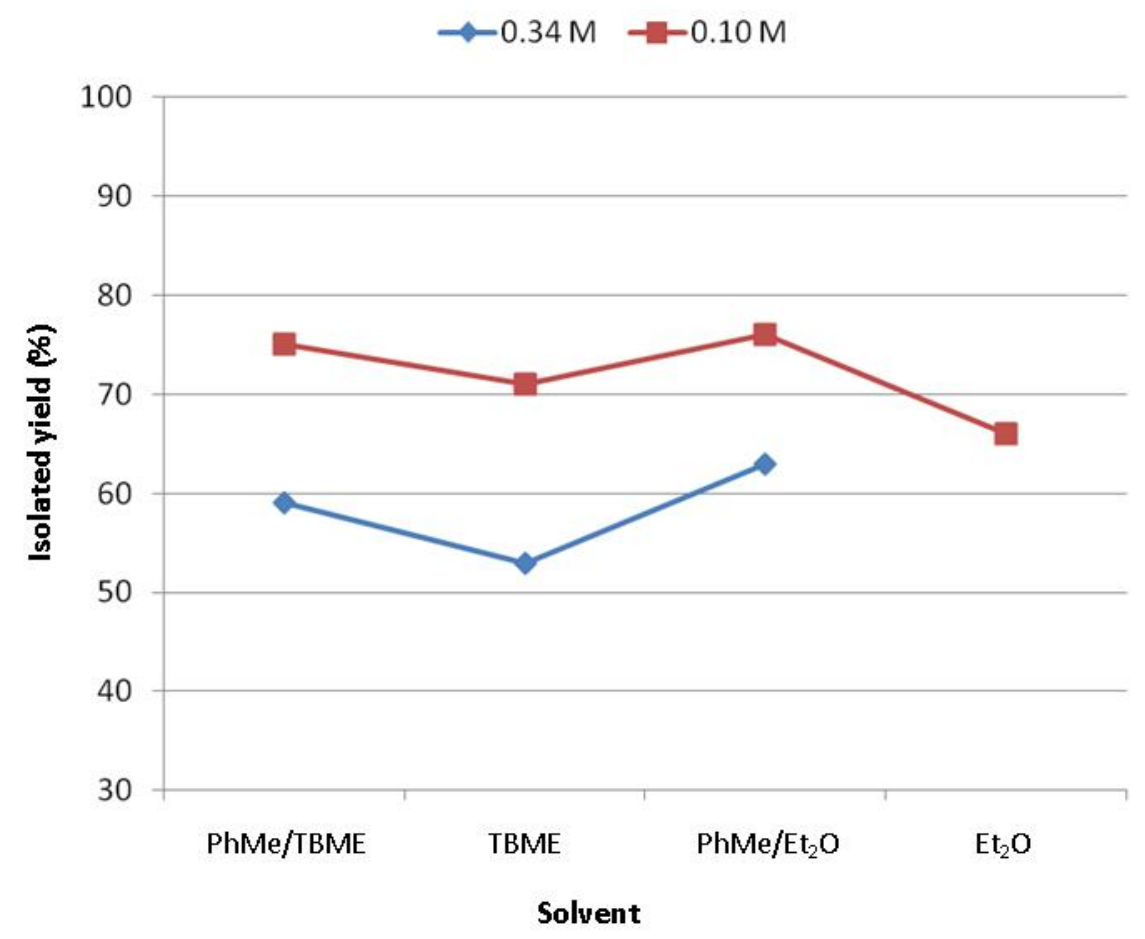

Figure S8: The effect of concentration and solvent mixtures on the yield of the ynamide. Conditions: " $\mathrm{Ph}_{2} \mathrm{Zn}$ (solution in $\mathrm{PhMe} / \mathrm{Et}_{2} \mathrm{O}, 0.55$ equiv.), $\mathrm{CuCN} \cdot 2 \mathrm{LiCl}(1.25 \mathrm{~mol} \%)$, solvent $(0 . \mathrm{X} \mathrm{M})$ or PhMe/cosolvent $(2: 1,0 . \mathrm{X} \mathrm{M}), 21^{\circ} \mathrm{C}$.

During our substrate scoping (Figures 3-5 in the manuscript), the stoichiometry of Grignard reagent to zinc(II) chloride was found to be very important - with a molar ratio of 2.0-2.1 Grignard reagent to 1.0 of zinc deemed optimal. If the proportion of Grignard reagent was significantly lower than this, the solution had a significant build of white precipitate, making transferral to the reaction mixture problematic, and the coupling reaction was also particularly slow. On the other hand, increased amounts of Grignard reagent led to competing chlorine-metal exchange on the chloroynamide, with small amounts of the terminal ynamide produced in the reaction. This was more of an issue when using the alkyl Grignard reagents. It should be noted that where only 0.55 equiv. of the diarylzinc reagent was required to reach full conversion, the dialkylzincs required 1.05 equiv. As a final comment, no chloroenamide byproducts were observed when using the dialkylzinc reagents, as compared to the diaryl cases where small amounts were constantly observed. This has been a consistent feature of this chemistry, and might indicate a mechanistic difference between the two.

In the case of ureas, we observed increased formation of the chloroenamide, but the combined yield of the ynamide and chloroenamide was excellent (86\%, Figure S9). Although not enhancing the selectivity, the addition of TMEDA enabled a more convenient purification: the $\mathrm{R}_{\mathrm{f}}$ difference between the chloroenamide $\mathbf{S 7}$ and the ynamide $\mathbf{1 3 i}$ was slight, and careful chromatography was required for their separation, whereas the cumulene $\mathbf{S 8}$ was significantly more polar and was easily separated. At 
this point, no further screening of conditions was performed and our attention shifted to explore a substrate scope of both ureas and amides (see manuscript).

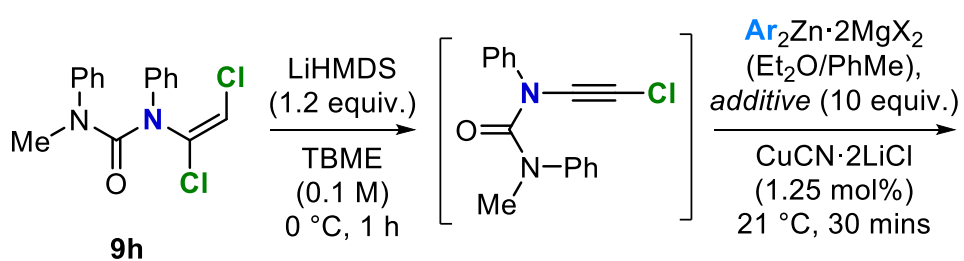

$9 \mathrm{~h}$ $0^{\circ} \mathrm{C}, 1 \mathrm{~h}$

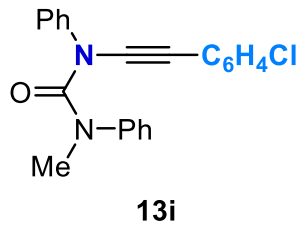

No additive: $70 \%$ TMEDA: $70 \%$

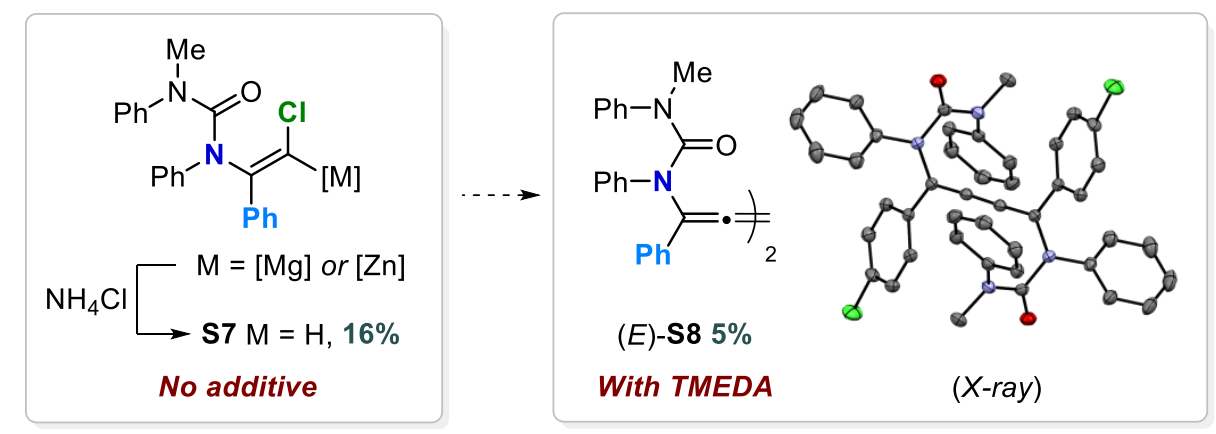

Figure S9: Distribution of products formed when using urea dichloroenamide $\mathbf{9 h}$.

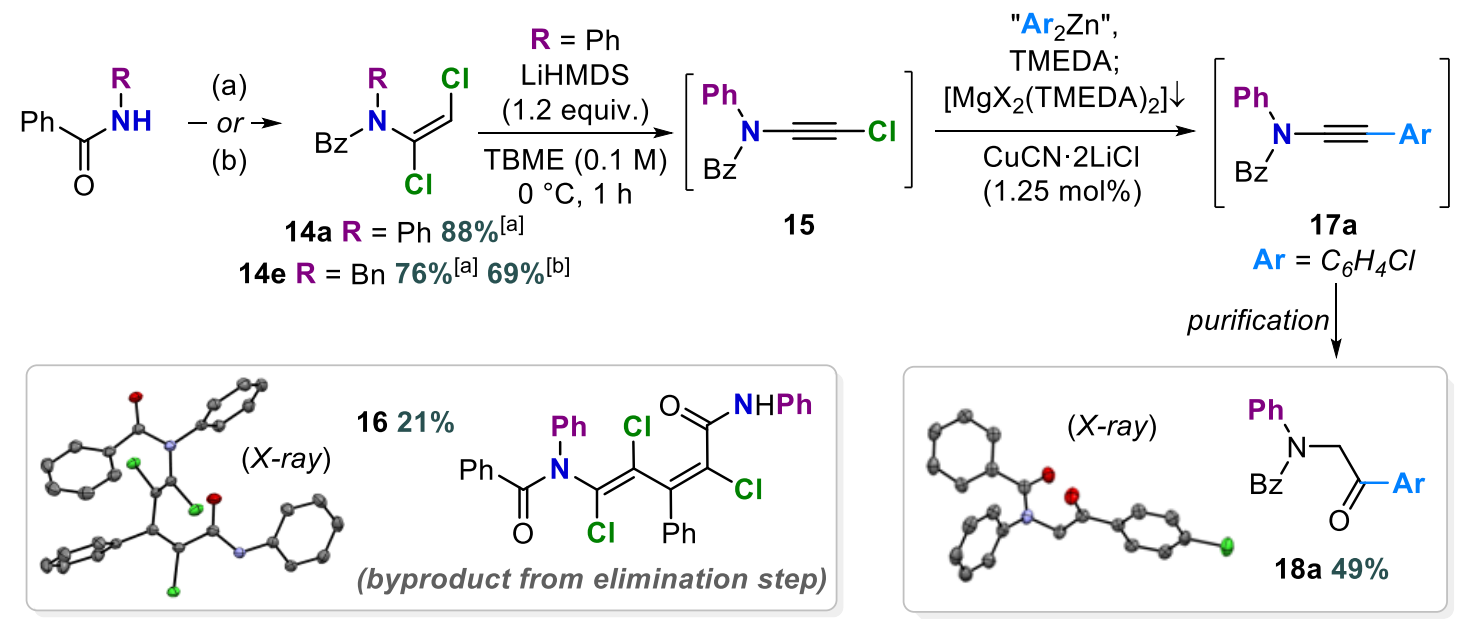

Figure S10: Initial attempts to prepare yne-amides. Conditions (a) Trichloroethylene (3.0 equiv.), $n$ - $\mathrm{Bu}_{4} \mathrm{NHSO}_{4}$ (0.25 equiv.), $50 \%$ aq. $\mathrm{KOH}, \mathrm{PhMe}, 60^{\circ} \mathrm{C}$; (b) Trichloroethylene (1.5 equiv.), $\mathrm{NaH}$ (2.5 equiv.), 2-MeTHF, $75^{\circ} \mathrm{C}$.

Amide-derived substrates were less well-behaved, and were found to be more reactive than the carbamates and ureas. The dichloroenamides were readily prepared, but, as described in the manuscript, the chloroynamide formation was competitive with the formation of trichloroenamide $\mathbf{1 6 .}$ This could be reduced by conducting the elimination at room temperature and/or by decreasing the reaction concentration further. A putative mechanism that explains its formation is outlined in Scheme S7. It is known that lithiation of the dichloroalkene is followed by elimination of chloride to give the chloroalkyne ${ }^{[6]}$ however the formation of $\mathbf{1 6}$ is best explained by the nucleophilic 
addition/elimination of vinyllithium $\mathbf{S 9}$ at the carbonyl of the chloroynamide 15. This would give the $N$-lithio ynamine S10, a species that is expected to be highly nucleophilic, that could add to the carbonyl through the alkyne $\beta$-carbon to give ketenimine S11. Cyclisation to oxetene S12 and subsequent electrocyclic ring-opening would give S13 and then 16 upon workup.

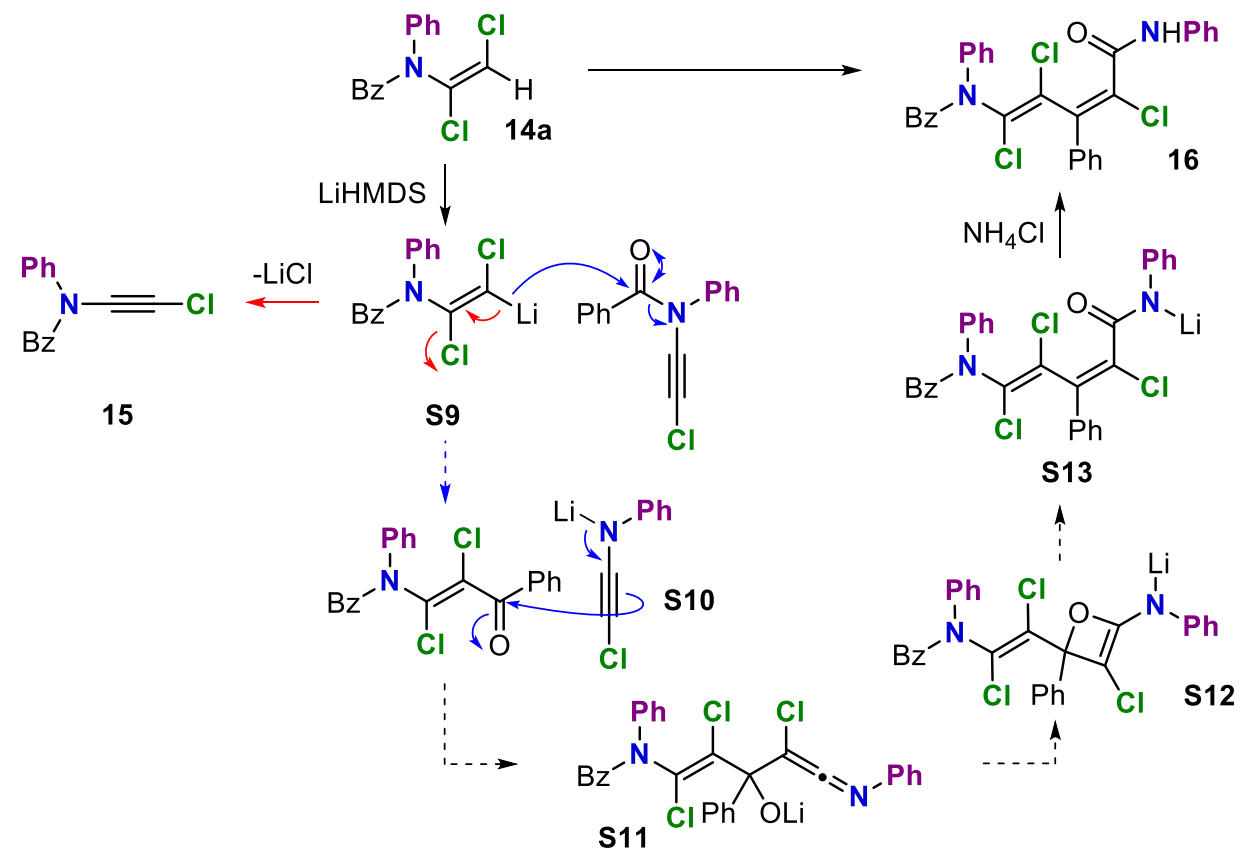

Scheme S7: Proposed mechanism for the formation of trichloroenamide $\mathbf{1 6 .}$

$\mathrm{N}$-Acetyl/propionyl dichloroenamides were not successful in this chemistry, which we attribute to instability of the chloroynamide under the reaction conditions. By TLC analysis, there was complete decomposition of the dichloroenamide upon treatment with 1.2 equiv. of LiHMDS, but substoichiometric amounts (0.6 equiv.) of LiHMDS led to the formation of a compound with an $\mathrm{R}_{\mathrm{f}}$ consistent with the formation of the desired chloroynamide, but this compound could not be isolated; the mass spectra obtained from the reaction mixture were inconclusive and attempted coupling led to decomposition. It is unknown whether there was competitive enolisation occurring in these reactions. Similarly, pyrrolidinone and oxazolidinone-derived dichloroenamides are not suitable in this chemistry as their conversion to the chloroynamides leads to decomposition. These results, and those discussed in the manuscript, suggest that the nature of both the electron-withdrawing group, and the second nitrogen substituent, are very important in modulating the stability and reactivity of these compounds; this was much more apparent for these amide cases as compared with the sulfonamides, carbamates and ureas. 


\section{1c Dichloroenamide formation: important observations.}

As a final discussion, we return to the synthesis of dichloroenamides from trichloroethylene (TCE). The use of $\mathrm{Cs}_{2} \mathrm{CO}_{3}$ in DMF at $60{ }^{\circ} \mathrm{C}$ works very well for sulfonamides, electron-deficient aromatic heterocycles and unhindered carbamates (the reactions were typically complete within 1-4 hours), and the crude dichloroenamide products were usually of sufficient purity for use in the subsequent chemistry. ${ }^{[7]} t$-Butyl carbamates and acyclic amides/ureas were typically poor substrates, and in these cases, the reaction turned black and there was negligible conversion. The phase transfer catalysed (PTC) conditions using sodium or potassium hydroxide are more effective for these substrates (Figure S12, Section 1.1e).

During our investigations, we gained evidence that the dichloroenamide formation using $N$-alkyl amides, carbamates and ureas is affected by three factors: the temperature at which the reaction is conducted, the rate of addition of trichloroethylene and the substrate itself. Following the observations of a process development route, ${ }^{[8]}$ we looked at using sodium hydride in 2-MeTHF to prepare the $N$-benzyl dichloroenamide 14e (Figure S10). Following their procedure, a solution of $\mathrm{N}$-benzylbenzamide $(500 \mathrm{mg}, 2.37 \mathrm{mmol}$ ) was added dropwise to a suspension of sodium hydride (2.5 equiv.) in 2-MeTHF under argon at $75^{\circ} \mathrm{C}$, such that the rate of evolution of hydrogen gas was controlled by the rate of addition of the amide. This was stirred for 1 hour at $75{ }^{\circ} \mathrm{C}$ before a solution of trichloroethylene (1.5 equiv.) in 2-MeTHF ( $\sim 3.6 \mathrm{M})$ was added dropwise to this reaction mixture at $75^{\circ} \mathrm{C}$. This was the crucial point in the reaction - the solution of trichloroethylene should be added over 3-4 minutes. If the addition was too fast ( $<1$ minute), the reaction stalled at $\sim 20 \%$ conversion and if the addition was too slow ( $>5$ minutes), then the chloroynamide was also formed, the reaction became very dark and there was a poor yield of the desired product. At room temperature, the addition of trichloroethylene over 3-4 minutes was also unsuccessful, with the reaction stalling at $<10 \%$. This was repeated exactly for $N$-phenylbenzamide ( $467 \mathrm{mg}, 2.37 \mathrm{mmol}$ ), at $75{ }^{\circ} \mathrm{C}$, and the reaction stalled at $\sim 50 \%$ conversion; this likely reflects the lower nucleophilicity and basicity of the $N$-phenyl benzamidate anion. This was the first direct evidence that the required rate of addition of trichloroethylene was substrate and temperature dependant; though it is unclear why the reaction would stall if it were added too quickly, because dichloroacetylene was formed in all cases.

This is important for the PTC reactions using $N$-alkyl amides, carbamates and ureas: they are less acidic ( $\mathrm{p} K_{\mathrm{a}}$ ) than the $N$-aryl analogues or the sulfonamides, and the rate of equilibrium between the amide and amidate is also likely to be an important factor in all cases. Refluxing with sodium hydride would drive the equilibrium entirely to the amidate and negate this. Thus when using these substrates with the PTC conditions, it is recommended that trichloroethylene is added slowly to the reaction mixture, but, as described, this would also be substrate and temperature dependent. 


\section{1d Full list of organometallic coupling partners screened.}

The following organometallic coupling partners were screened: blue indicates successful coupling, red indicates failed coupling. Yields are for the coupled ynamides.

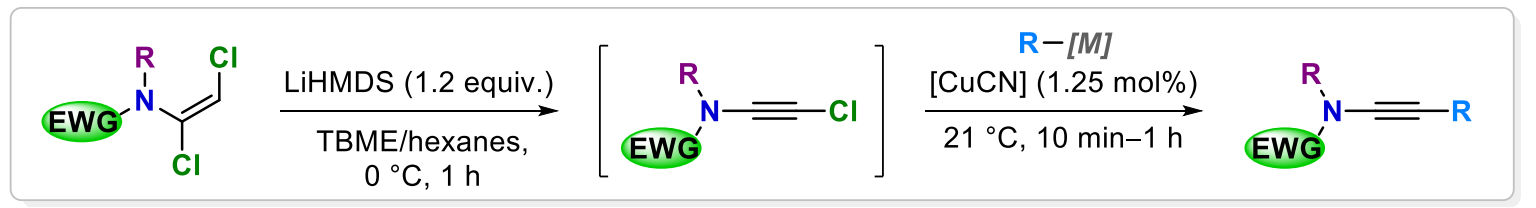

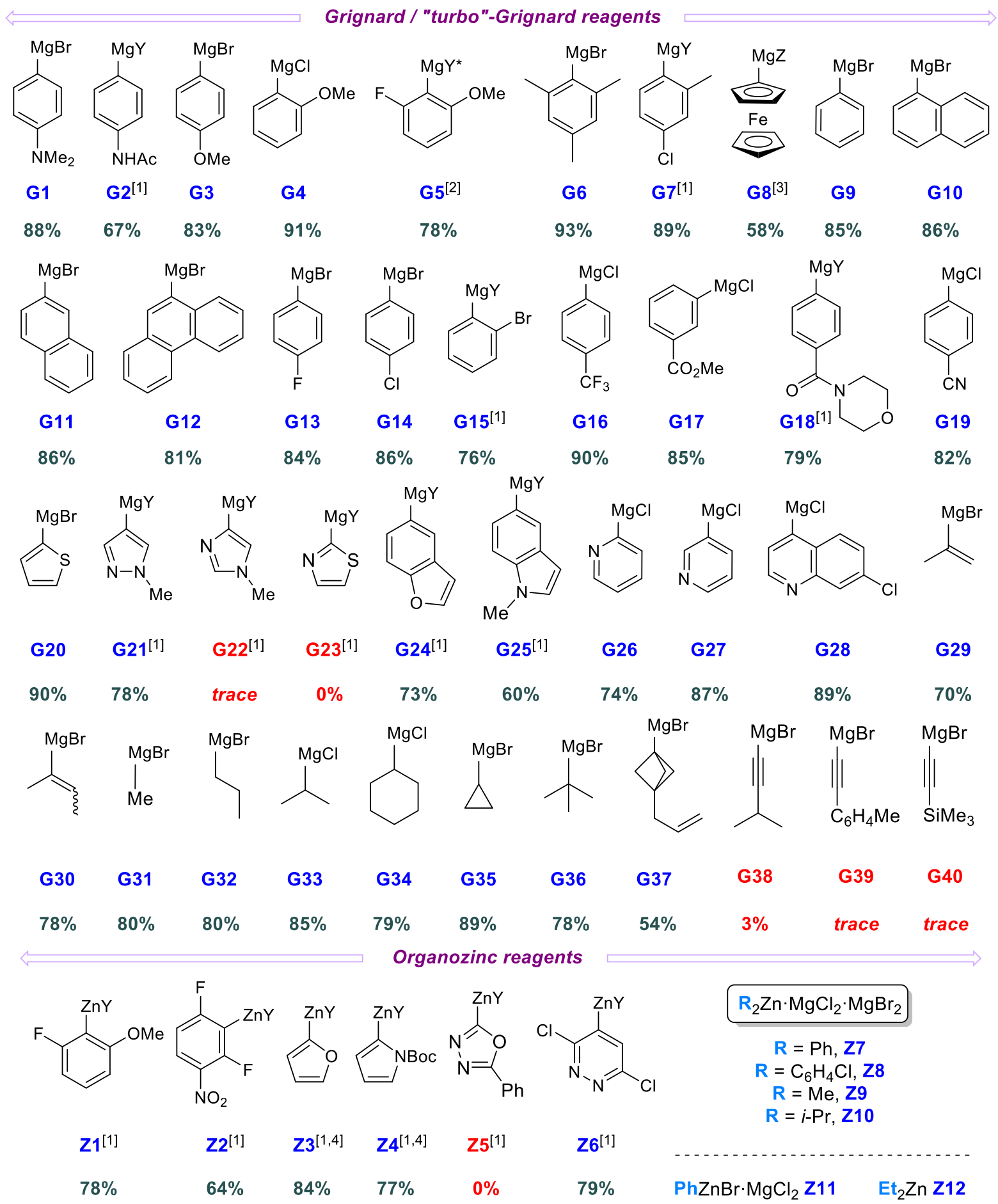

Figure S11: [1] Y $=\mathrm{Cl} \cdot \mathrm{LiCl}$, [2] $\mathrm{Y}^{*}=\mathrm{Br} \cdot \mathrm{LiBr}$; [3] Z = TMP· $\mathrm{LiCl}$; [4] TMEDA (1.3 equiv.) was added. [CuCN] refers to either $\mathrm{CuCN} \cdot 2 \mathrm{P}(\mathrm{OMe})_{3}$ or $\mathrm{CuCN} \cdot 2 \mathrm{LiCl}$ (see experimental details). TMP = 2,2,6,6,-tetramethylpiperidinyl. 


\section{1e Full list of dichloroenamide partners screened.}

The following dichloroenamides were screened: blue indicates a successful elimination and coupling, pink indicates successful elimination and coupling, but the product ynamide was unstable, and red indicates decomposition upon attempted elimination.

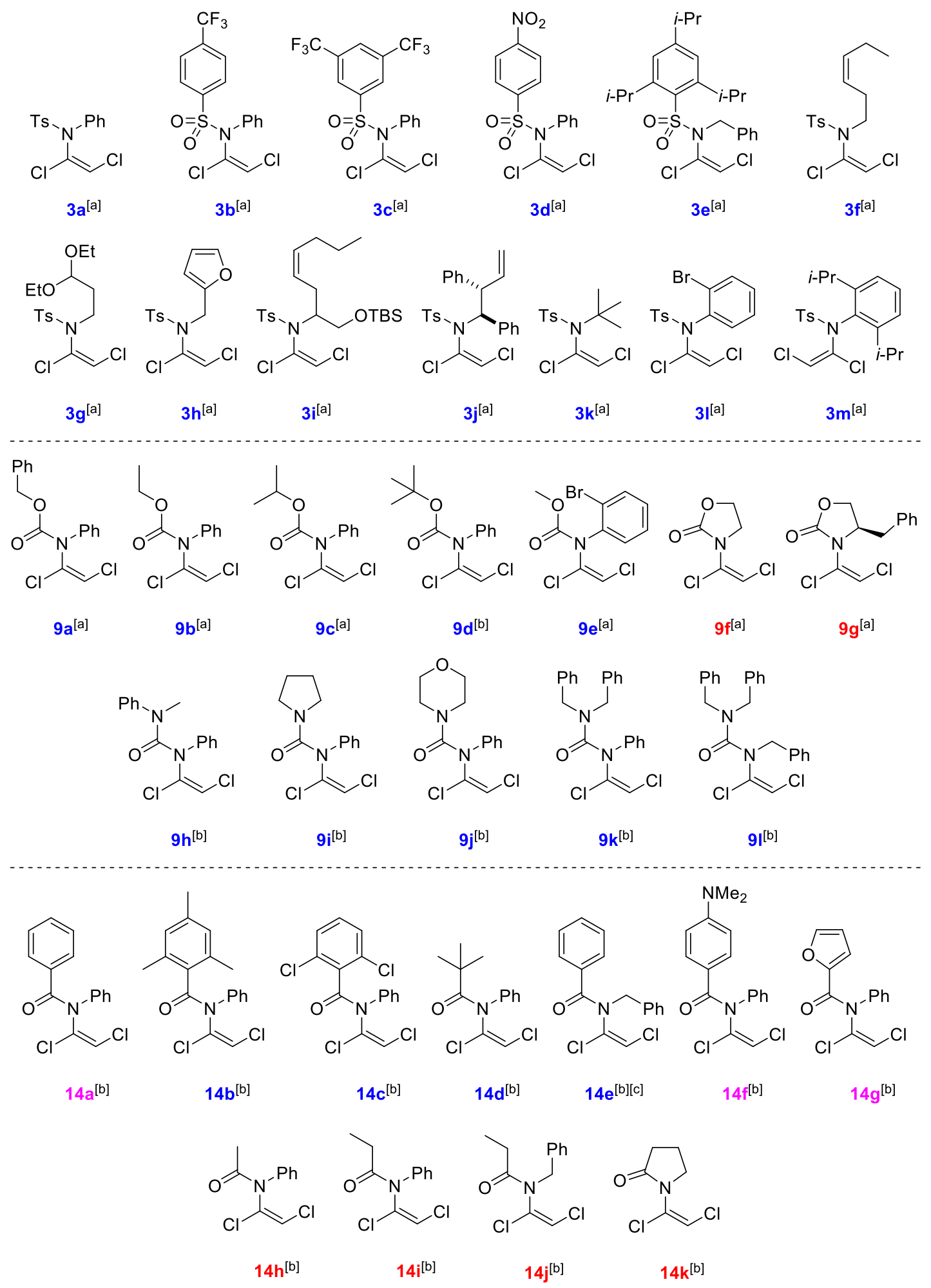

Figure S12: Dichloroenamide formation: Conditions [a] TCE (1.1 equiv.), $\mathrm{Cs}_{2} \mathrm{CO}_{3}$ (1.5 equiv.), DMF, $50{ }^{\circ} \mathrm{C}$; [b] TCE (3.0 equiv.), $n$ - $\mathrm{Bu}_{4} \mathrm{NHSO}_{4}$ (0.25 equiv.), $50 \%$ aq. $\mathrm{KOH}, \mathrm{PhMe}$; [c] TCE (1.5 equiv.), $\mathrm{NaH}$ (2.5 equiv.), $2-\mathrm{MeTHF}, 75^{\circ} \mathrm{C}$. 


\subsection{General information.}

Reagents, solvents and techniques: All reagents, obtained from Acros, Alfa and TCI (Fisher Scientific), Fluorochem, Sigma-Aldrich and Strem fine chemical suppliers, were used directly as supplied. Anhydrous hexamethyldisilazane (HMDS) and $N, N, N^{\prime}, N^{\prime}$-tetramethylethylenediamine (TMEDA) were both obtained by first stirring overnight $(\sim 12 \mathrm{~h})$ with $\mathrm{CaH}_{2}$ under nitrogen, followed by distillation under low vacuum (for HMDS) or at ambient pressure under a nitrogen atmosphere (for TMEDA). They were used either immediately, or stored over $\mathrm{CaH}_{2}$ under a nitrogen atmosphere. The concentrations of the Grignard and organolithium reagents used were determined by iodometric titration, ${ }^{[9]}$ and it is highly recommended to titrate all organometallic solutions prior to use. Solvents were either used as commercially supplied, or as purified by standard techniques. Anhydrous $t$-butyl methyl ether (TBME), THF and toluene were each obtained from solvent dispenser units having been passed through an activated alumina column under argon. Unless otherwise stated, all non-aqueous reactions were performed in oven dried apparatus under a nitrogen atmosphere at room temperature.

Chromatography: Reactions were monitored by thin layer chromatography on pre-coated aluminium-backed plates (Merck Kieselgel 60 with fluorescent indicator UV254). Spots were visualised by quenching of UV fluorescence or by staining with potassium permanganate or vanillin, and retention factors are reported with the solvent system in parentheses. Flash column chromatography was performed on silica gel obtained from Macherey Nagel (MN 60, 230-400 mesh) under a positive pressure of nitrogen, using the stated solvent system.

Melting Points: Melting points were obtained using a Griffin melting point apparatus and are uncorrected.

Infrared Spectroscopy: Infrared spectra were recorded on a Bruker Tensor 27 FT-IR spectrometer equipped with a diamond ATR module, with the sample being prepared as a thin film. Absorption maxima $\left(v_{\max }\right)$ are quoted in wavenumbers $\left(\mathrm{cm}^{-1}\right)$.

NMR Spectroscopy: ${ }^{1} \mathrm{H},{ }^{13} \mathrm{C}$ and ${ }^{19} \mathrm{~F}$ NMR spectra were recorded on Bruker AV400 or Bruker AVII500 spectrometers using TOPSPIN software, with the deuterated solvent acting as the internal deuterium lock. ${ }^{1} \mathrm{H}$ NMR spectra were recorded at 400 or $500 \mathrm{MHz},{ }^{13} \mathrm{C}$ NMR spectra were recorded at 101 or $126 \mathrm{MHz}$ with ${ }^{1} \mathrm{H}$ decoupling, and ${ }^{19} \mathrm{~F}$ NMR spectra were recorded at 376 or $470 \mathrm{MHz}$. ${ }^{1} \mathrm{H}$ NMR spectra were also recorded on a Bruker Avance Neo spectrometer operating at $400 \mathrm{MHz}$ for ${ }^{1} \mathrm{H}$ with the following spectral parameters: acquisition time $=4 \mathrm{~s}$, number of scans $=16$, number of data points $=32 \mathrm{~K}$ and spectral width $=8250 \mathrm{~Hz}$.

The residual protic solvent signal(s) acted as the internal reference for ${ }^{1} \mathrm{H}$ NMR spectra $\left[\mathrm{CDCl}_{3}\right.$ $(\delta 7.26), \mathrm{C}_{6} \mathrm{D}_{6}(\delta 7.16)$ or toluene- $\left.d_{8}(\delta 7.09)\right]$, and the deuterated solvent signal acted as the internal 
reference for ${ }^{13} \mathrm{C}$ NMR spectra $\left[\mathrm{CDCl}_{3}(\delta 77.0), \mathrm{C}_{6} \mathrm{D}_{6}\left(\delta\right.\right.$ 128.1) or toluene- $\left.d_{8}(\delta 137.5)\right] .{ }^{19} \mathrm{~F}$ NMR spectra were not externally referenced.

Chemical shifts $(\delta)$ are quoted in parts per million (ppm) to the nearest $0.01 \mathrm{ppm}$ for ${ }^{1} \mathrm{H}$ and ${ }^{19} \mathrm{~F}$ NMR spectra, and $0.1 \mathrm{ppm}$ for ${ }^{13} \mathrm{C}$ NMR spectra. Only those signals in the ${ }^{13} \mathrm{C}$ NMR spectra that are within $0.1 \mathrm{ppm}$ are reported to the nearest $0.01 \mathrm{ppm}$. Peak multiplicities are defined as: $\mathrm{s}=$ singlet, $\mathrm{d}=$ doublet, $\mathrm{t}=$ triplet, $\mathrm{q}=$ quartet, quin $=$ quintet, $\mathrm{sxt}=$ sextet, $\mathrm{spt}=$ septet, $\mathrm{m}=$ multiplet, $\mathrm{br} .=$ broad, app. $=$ apparent. Coupling constants $(J)$ are reported to the nearest $0.1 \mathrm{~Hz}$. Assignments were determined either on the basis of unambiguous chemical shift or coupling patterns, COSY, HSQC, $\mathrm{HMBC}$, and/or NOESY experiments.

High Resolution Mass Spectrometry: Electrospray ionisation (ESI) HRMS were recorded on a Thermo Exactive orbitrap spectrometer equipped with a Waters Equity LC system, with a flow rate of $0.2 \mathrm{~mL} / \mathrm{min}$ using water:methanol:formic acid (10:89.9:0.1) as eluent. The system uses a heated electrospray ionisation (HESI-II) probe, and has a resolution of 50,000 FWHM under conditions for maximum sensitivity. The mass reported is that containing the most abundant isotopes, with all values reported to 4 decimal places and within a 5 ppm tolerance.

Chemical ionisation (CI) HRMS was performed on an Agilent 7200 Q-ToF instrument equipped with a direct insertion probe supplied by Scientific Instrument Manufacturer (SIM) GmbH. Instrument control and data processing were performed using Agilent MassHunter software, and the reagent gas used was ammonia. All values are reported to 4 decimal places and are within a 5 ppm tolerance.

HPLC: Xbridge C18 column (5 $\mu \mathrm{m}, 100$ x 4.6,), MPA: CAN, MPB: 20 mM Ammonium Hydroxide in water. Gradient starts from $10 \%$ to $100 \%$ CAN over $5 \mathrm{~min}$ and then hold at $100 \%$ CAN for 5 min, at flow rate of $1.0 \mathrm{~mL} / \mathrm{min}\left(\right.$ temp $\left.=40{ }^{\circ} \mathrm{C}\right)$

LCMS: Analytical LCMS was obtained on an Agilent 1260 Series using ACE C18 PFP column (3 $\mu \mathrm{m}, 3.0 \times 50 \mathrm{~mm}, \mathrm{~T}=50{ }^{\circ} \mathrm{C}$ ). MPA: $0.05 \% \mathrm{TFA}$ in water and MPB: $100 \% \mathrm{CAN}$. Gradient method starts from $5 \% \mathrm{~B}$ to $100 \% \mathrm{~B}$ in $1.3 \mathrm{mins}$ at flow rate $2.2 \mathrm{~mL} / \mathrm{min}$. MS detector is an Agilent G6120B ESI-SQD in positive mode.

X-Ray Crystallography: Details of instrumentation and techniques are reported in Section 5. 


\subsection{General procedures.}

\section{3a Example procedure for the synthesis of 1,2-dichloroenamides using $\mathrm{Cs}_{2} \mathrm{CO}_{3}$.}

To a $500 \mathrm{~mL}$ round bottomed flask equipped with a magnetic stirrer bar and a septum, was added $\mathrm{N}$-phenyl tosylamide $\left(50.0 \mathrm{~g}, 202 \mathrm{mmol}, 1.0\right.$ equiv.) and powdered $\mathrm{Cs}_{2} \mathrm{CO}_{3}$ (79.1 g, $243 \mathrm{mmol}$, 1.2 equiv.). Note: In general for most substrates, and particularly on smaller scale ( $<1 \mathrm{~g}$ of amide), 1.5 equivalents of $\mathrm{Cs}_{2} \mathrm{CO}_{3}$ was found to be more effective. The flask was then evacuated under high vacuum for 30 seconds to remove air and backfilled with nitrogen (this vacuum cycle was repeated twice more - see Safety Note). Next was added DMF (150 mL, $0.75 \mathrm{~mL} \mathrm{mmol}^{-1}$ of amide substrate) and the resulting suspension was then stirred vigorously at $50{ }^{\circ} \mathrm{C}$ for 10 minutes. Note: Strictly anhydrous DMF is not required, and reactions performed using DMF straight from the bottle often perform better - this is likely due to trace water increasing $\mathrm{Cs}_{2} \mathrm{CO}_{3}$ solubility.

Safety Note: Extreme care must be taken when working with dichloroacetylene (DCA), generated here in situ from trichloroethylene, as exposure to air (particularly oxygen) may result in sparking. As a general precaution, it is recommended to conduct these reactions under an inert atmosphere (Ar or $\mathrm{N}_{2}$ ), and to add the trichloroethylene dropwise over 2-30 minutes (depending on the scale, also see 1.1c). For most sulfonamides, the generation and consumption of DCA occurs at a comparable rate, and there is minimal to no accumulation of DCA in the reaction vessel. For the carbamate, urea and amide substrates, the rate of consumption is generally slower than generation and DCA can accumulate in the vessel (generally seen as a white vapour that dissipates as the reaction proceeds).

Using a syringe pump, trichloroethylene $(20.0 \mathrm{~mL}, 222 \mathrm{mmol}, 1.1$ equiv.) was added dropwise over 30 minutes to the vigorously stirring reaction mixture, and the resulting mixture was stirred at $50{ }^{\circ} \mathrm{C}$ until reaction completion ( 2 hours), as analysed by TLC $\left(20 \% \mathrm{Et}_{2} \mathrm{O} /\right.$ petroleum ether). Upon cooling to room temperature, the reaction mixture was poured into a $2 \mathrm{~L}$ separating funnel containing EtOAc $(\sim 300 \mathrm{~mL})$ and brine $(\sim 1200 \mathrm{~mL})$. The reaction vessel was thoroughly rinsed with EtOAc and water $(3 \times 50 \mathrm{~mL}$ each, alternately) and these washings were poured into the separating funnel. The organic layer was then separated and further washed with brine $(2 \times 800 \mathrm{~mL})$. At this point, TLC analysis $(20 \%$ $\mathrm{Et}_{2} \mathrm{O} /$ petroleum ether) of both the organic and aqueous layers was conducted to confirm complete separation of the desired product from DMF (stain with $\mathrm{KMnO}_{4}$ or vanillin to visualise). Note: If the separation is not complete, continue extraction as necessary. The organic was then dried $\left(\mathrm{MgSO}_{4}\right)$, filtered and concentrated in vacuo to afford crude (E)- $N$-(1,2-dichlorovinyl)- $N$-phenyltosylamide $(68.3 \mathrm{~g})$ as a yellow solid.

To this solid in a $1 \mathrm{~L}$ round bottomed flask was added TBME $(\sim 500 \mathrm{~mL})$ and a magnetic stirrer bar, and the mixture was stirred at $\sim 50{ }^{\circ} \mathrm{C}$ to dissolve the material. The solution was allowed to cool to 
room temperature and allowed to stand overnight, by which time colourless crystals of $(E)-N-(1,2-$ dichlorovinyl)- $N$-phenyltosylamide, 1a, had grown. This suspension was further cooled to $-10{ }^{\circ} \mathrm{C}$ for $\sim 2$ hours to enable further crystallisation. Once crystallisation had ceased, the remaining pale yellow solution was decanted into a second $1 \mathrm{~L}$ round bottomed flask, and the colourless crystals were washed with ice cold TBME $(2 \times 20 \mathrm{~mL})$. These crystals were then dried under high vacuum for $\sim 5$ hours. The combined decanted solution and washings were concentrated to approximately 150-200 mL, by which time more of the desired compound had precipitated. This mixture was again stirred at $50{ }^{\circ} \mathrm{C}$ to dissolve the material, and the crystallisation proceeded as before.

The colourless crystals obtained from these 2 crops were both determined to be $>98 \%$ pure (by ${ }^{1} \mathrm{H}$ NMR spectroscopic analysis using 1,3,5-trimethoxybenzene as internal standard). These 2 crops of crystals were combined to give $65.2 \mathrm{~g}$ (190 mmol, 94\%) of (E)- $N$-(1,2-dichlorovinyl)- $N$ phenyltosylamide, $\mathbf{3 a}$, as colourless blocks.

The remaining solution from these crystallisations was concentrated to give a dark orange oil that contained residual $(E)-N$-(1,2-dichlorovinyl)- $N$-phenyltosylamide, 1a. Column chromatography (10\% $\mathrm{Et}_{2} \mathrm{O}$ /petroleum ether) afforded a further $890 \mathrm{mg}$ (96\% pure, as determined by ${ }^{1} \mathrm{H}$ NMR spectroscopic analysis) of the desired compound.

\section{3b Example procedure for the synthesis of 1,2-dichloroenamides using $50 \% \mathrm{w} / \mathrm{v}$ aq. $\mathrm{KOH}$.}

To a $100 \mathrm{~mL}$ round bottomed flask, equipped with a magnetic stirrer bar and a septum, was added $t$-butyl phenylcarbamate $(850 \mathrm{mg}, 4.40 \mathrm{mmol}, 1.0$ equiv.) and tetrabutylammonium hydrogensulfate (373 mg, $1.10 \mathrm{mmol}, 0.25$ equiv.). Toluene ( $44 \mathrm{~mL}$ ) was then added and the mixture was stirred to dissolve the material. The flask was then purged with argon using a balloon and outlet needle. (Alternatively, evacuation under high vacuum and backfilling with $\mathrm{Ar}$ or $\mathrm{N}_{2}$ is also effective, see the previous Safety Note).

Next was added a $50 \% \mathrm{w} / \mathrm{v}$ aqueous solution of $\mathrm{KOH}(20 \mathrm{~mL})$, and the reaction was stirred vigorously at $60{ }^{\circ} \mathrm{C}$ for $\sim 10$ minutes. To the vigorously stirring mixture was then added trichloroethylene (1.18 mL, $13.2 \mathrm{mmol}, 3.0$ equiv.) dropwise over 2 minutes and the mixture was stirred vigorously at $60{ }^{\circ} \mathrm{C}$ for 2 hours. Complete conversion was then confirmed by TLC $\left(10 \% \mathrm{Et}_{2} \mathrm{O} /\right.$ petroleum ether). Note: The reaction mixture often turns dark brown.

Upon cooling to room temperature, the mixture was poured into a $100 \mathrm{~mL}$ separating funnel. The reaction flask was thoroughly rinsed with $\mathrm{Et}_{2} \mathrm{O}$ and water $(2 \times 5 \mathrm{~mL}$ each) and these washings were poured into the separating funnel. The organic layer was separated and was washed with brine $(2 \times 20 \mathrm{~mL})$, dried $\left(\mathrm{Na}_{2} \mathrm{SO}_{4}\right)$ and concentrated in vacuo to afford a brown oil. Column chromatography $\left(5 \% \mathrm{Et}_{2} \mathrm{O} /\right.$ pentane) afforded dichloroenamide $9 \mathrm{~d}(1.12 \mathrm{~g}, 3.89 \mathrm{mmol}, 88 \%)$ as a colourless oil. 


\section{$1.3 \mathrm{c}$ Example procedure for the preparation of functionalised organomagnesium reagents. ${ }^{[10]}$}

To an oven dried, nitrogen flushed flask equipped with a magnetic stirrer bar and a septum, was added 4-iodobenzonitrile (402 $\mathrm{mg}, 1.75 \mathrm{mmol}, 1.2$ equiv.) and the flask purged under high vacuum for $\sim 1$ minute. The flask was backfilled with $\mathrm{N}_{2}$, anhydrous THF $(4 \mathrm{~mL})$ was added, and the solution cooled to $-20{ }^{\circ} \mathrm{C}$ whilst stirring. Next, $i$-propylmagnesium chloride $(1.02 \mathrm{~mL}$ of a $2 \mathrm{M}$ solution in THF, 2.05 mmol, 1.4 equiv.) was added dropwise over 10 minutes and the reaction was stirred for a further 30 minutes at $-20{ }^{\circ} \mathrm{C}$. This solution was used directly in the subsequent reaction.

\section{3d Preparation of $\mathrm{CuCN} \cdot 2 \mathrm{P}(\mathrm{OMe})_{3}$ solution $(0.1 \mathrm{M}$ in $\mathrm{THF})$.}

To an oven dried, nitrogen flushed flask equipped with a magnetic stirrer bar and a septum, was added anhydrous $\mathrm{CuCN}$ (100 mg, $1.12 \mathrm{mmol}, 1.0$ equiv.) and the flask purged under high vacuum for 30 minutes. The flask was backfilled with $\mathrm{N}_{2}$ followed by the addition of anhydrous THF $(11.2 \mathrm{~mL})$ and trimethyl phosphite ( $264 \mu \mathrm{L}, 2.23 \mathrm{mmol}, 2.0$ equiv.). Stirring was continued until the salts were dissolved.

\section{3e Example procedure for the synthesis of ynamides from $\mathrm{N}$-sulfonyl-1,2-dichloroenamides.}

To an oven dried, nitrogen flushed flask equipped with a magnetic stirrer bar and a septum, was added anhydrous TBME $(1.5 \mathrm{~mL})$ and freshly distilled hexamethyldisilazane $(0.37 \mathrm{~mL}, 1.75 \mathrm{mmol}$, 1.2 equiv.), and the solution was cooled to $0{ }^{\circ} \mathrm{C}$ whilst stirring. To this solution was added dropwise $n$-butyllithium $(0.70 \mathrm{~mL}$ of a $2.5 \mathrm{M}$ solution in hexanes, $1.75 \mathrm{mmol}, 1.2$ equiv. $)$ and the mixture stirred for 1 hour at $0{ }^{\circ} \mathrm{C}$. Note: The use of good quality $n$-butyllithium - i.e. a colourless, precipitate-free solution in hexanes - is required to obtain high yields. The resulting solution of LiHMDS should then be colourless. Otherwise, the subsequent reactions will be lower yielding.

To a second, oven dried, nitrogen flushed flask equipped with a magnetic stirrer bar and a septum, was added powdered (E)- $N$-phenyl- $N$-(1,2-dichlorovinyl)tosylamide, 3a, (500 mg, $1.46 \mathrm{mmol}$, 1.0 equiv.) and anhydrous TBME $(2.0 \mathrm{~mL})$, and the suspension was cooled to between -5 and $0{ }^{\circ} \mathrm{C}$ whilst stirring. To this suspension was added the previously prepared solution of LiHMDS dropwise over 30 seconds, and the reaction was stirred between -5 and $0{ }^{\circ} \mathrm{C}$ for 30 minutes. The cooling bath was then removed and the reaction stirred for 1 hour at room temperature (approx. $21^{\circ} \mathrm{C}$ ) (see Figure S13). Complete consumption of the dichloroenamide was verified at this point by TLC (10\% $\mathrm{Et}_{2} \mathrm{O} /$ petroleum ether). 


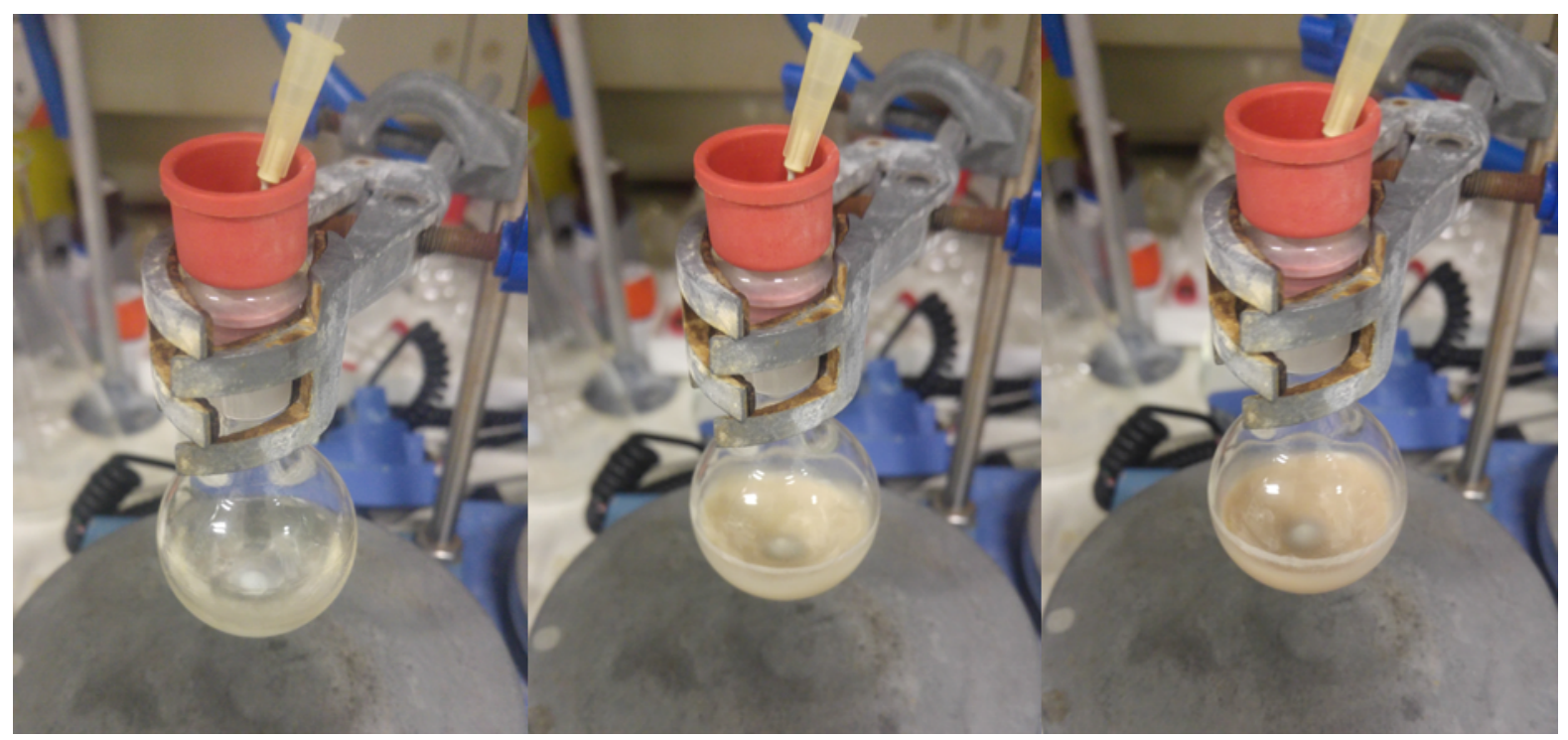

Figure S13: Images showing the expected colour changes for this reaction; (Left) The reaction mixture once a freshly prepared solution of LiHMDS in TBME/hexane has been added to a suspension of $(E)-N$-phenyl- $N-(1,2-$ dichlorovinyl)tosylamide in TBME (cooling bath was removed to obtain the above image); (Centre) The reaction mixture after complete conversion of the dichloroenamide to the corresponding chloroynamide. This is the expected colour for these transformations - a brown or darker reaction mixture generally indicates a lower yield of the chloroynamide; (Right) Reaction mixture after the addition of a solution of $\mathrm{CuCN} \cdot 2 \mathrm{P}(\mathrm{OMe}) 3$.

Next, a solution of $\mathrm{CuCN} \cdot 2 \mathrm{P}(\mathrm{OMe})_{3}(183 \mu \mathrm{L}$ of a $0.1 \mathrm{M}$ solution in THF, $18.3 \mu \mathrm{mol}, 1.25 \mathrm{~mol} \%)$ was added and the reaction stirred for 5 minutes (see Figure S14). A solution of $i$-propylmagnesium chloride (1.50 mL of a 1.0 M solution in THF/TBME (1:1), $1.50 \mathrm{mmol}, 1.03$ equiv.) was then added dropwise over 1 minute, and the reaction was stirred for 30 minutes at room temperature. Reaction completion was then verified by TLC $\left(10 \% \mathrm{Et}_{2} \mathrm{O} /\right.$ petroleum ether). Note: In this case, the reaction mixture turned orange upon reaction completion, but in general, the colour is highly dependent on the Grignard reagent added and the reaction colour may range from pink to dark red, or from yellow to orange to dark brown. The reaction was quenched with aqueous saturated $\mathrm{NH}_{4} \mathrm{Cl}(5 \mathrm{~mL})$, stirred for 10 minutes and then poured into a $250 \mathrm{~mL}$ separating funnel containing $\mathrm{Et}_{2} \mathrm{O}(\sim 50 \mathrm{~mL})$ and aqueous saturated $\mathrm{NH}_{4} \mathrm{Cl}(\sim 50 \mathrm{~mL})$. The reaction vessel was thoroughly rinsed with $\mathrm{Et}_{2} \mathrm{O}$ and water $(2 \times 5 \mathrm{~mL}$ each, alternately) and these washings were poured into the separating funnel. The organic layer was then separated and the aqueous was further extracted with $\mathrm{Et}_{2} \mathrm{O}(2 \times 30 \mathrm{~mL})$. The organic extracts were then combined, dried $\left(\mathrm{MgSO}_{4}\right)$ and concentrated in vacuo. Note: Alternatively, the extractions can be performed using TBME, EtOAc or toluene.

Column chromatography (3\% $\mathrm{Et}_{2} \mathrm{O} / 40-60$ petroleum ether) afforded the ynamide as a pale yellow solid. To this solid was added hexane $(\sim 4 \mathrm{~mL})$ and the mixture heated to $\sim 50{ }^{\circ} \mathrm{C}$ to dissolve the material. The solution was allowed to cool to room temperature and allowed to stand overnight, by which time thin crystalline plates of $N$-(3-methylbut-1-yn-1-yl)- $N$-phenyltosylamide, 1ah, had grown. 
This suspension was further cooled to $-10{ }^{\circ} \mathrm{C}$ for $\sim 2$ hours to enable further crystallisation. Once crystallisation had ceased, the remaining pale yellow solution was decanted and the colourless crystals were washed with ice cold pentane $(2 \times 1 \mathrm{~mL})$. The crystals were then dried under high vacuum for 1 hour. This afforded $390 \mathrm{mg}$ (1.24 mmol, 85\%) of $N$-(3-methylbut-1-yn-1-yl)- $N$-phenyltosylamide, 1ah, as colourless plates.

\section{3f Example procedure for the synthesis of ynamides from $\mathrm{N}$-carbonyl-1,2-dichloroenamides.}

To an oven dried, nitrogen flushed flask equipped with a magnetic stirrer bar and a septum, was added anhydrous TBME $(1.5 \mathrm{~mL})$ and freshly distilled hexamethyldisilazane $(0.39 \mathrm{~mL}, 1.86 \mathrm{mmol}$, 1.2 equiv.), and the solution was cooled to $-5{ }^{\circ} \mathrm{C}$ whilst stirring. To this solution was added dropwise $n$-butyllithium $(0.75 \mathrm{~mL}$ of a $2.5 \mathrm{M}$ solution in hexanes, $1.86 \mathrm{mmol}, 1.2$ equiv. $)$ and the mixture stirred for 1 hour at $21^{\circ} \mathrm{C}$. Note: The use of good quality $n$-butyllithium - i.e. a colourless, precipitate free solution in hexanes - is required to obtain high yields. The resulting solution of LiHMDS should then be colourless. Otherwise, the subsequent reactions will be lower yielding.

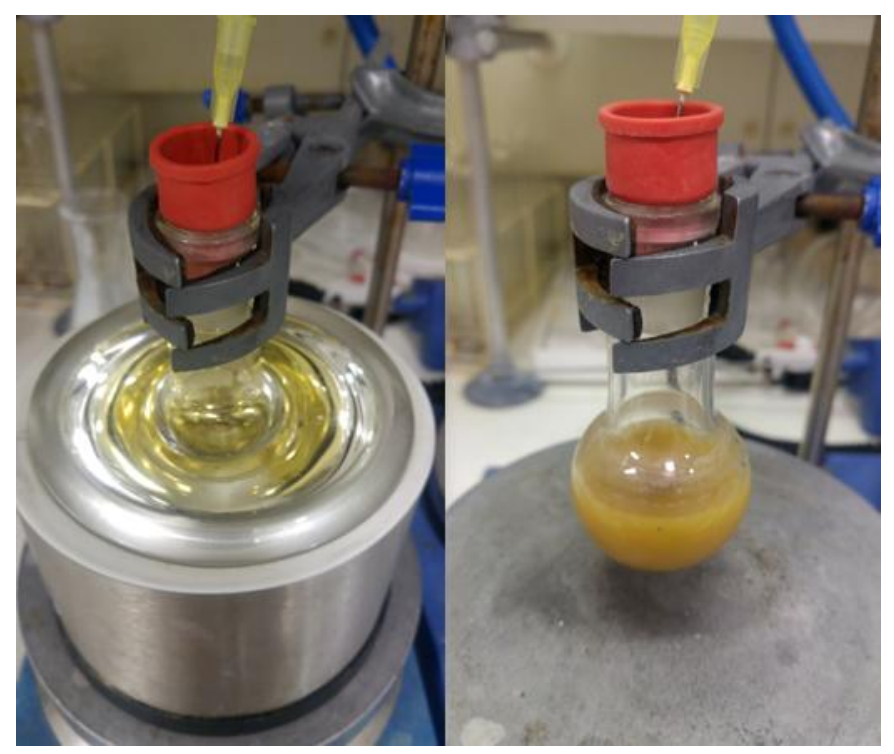

Figure S14: Images showing the expected colour changes for this reaction; (Left) The reaction mixture once a freshly prepared solution of LiHMDS in TBME/hexane has been added to a solution of benzyl $(E)-(1,2-$ dichlorovinyl)(phenyl)carbamate in TBME (cooling bath at $-5^{\circ} \mathrm{C}$ ); (Right) The reaction mixture after complete conversion of the dichloroenamide to the chloroynamide; this (or paler) is the expected colour for these transformations - a brown or darker reaction mixture generally indicates a lower yield of the chloroynamide;

To a second, oven dried, nitrogen flushed flask equipped with a magnetic stirrer bar and a septum, was added benzyl (E)-(1,2-dichlorovinyl)(phenyl)carbamate 9a (500 mg, $1.55 \mathrm{mmol}, 1.0$ equiv.) and anhydrous TBME $(13 \mathrm{~mL})$, and the solution was cooled to $-5{ }^{\circ} \mathrm{C}$ whilst stirring. To this solution was added the previously prepared solution of LiHMDS dropwise over 30 seconds, and the reaction stirred at $0{ }^{\circ} \mathrm{C}$ for 2 hours. This resulted in a heterogeneous yellow solution of the chloroynamide (see Figure 
S14). Complete consumption of the dichloroenamide was verified at this point by TLC (10\% $\mathrm{Et}_{2} \mathrm{O} /$ petroleum ether). The cooling bath was then removed and the reaction mixture was then allowed to warm to room temperature (approx. $21^{\circ} \mathrm{C}$ ) whilst stirring.

To a third, oven dried, nitrogen flushed flask equipped with a magnetic stirrer bar and a septum, was added sequentially anhydrous toluene $(1.0 \mathrm{~mL})$, phenylmagnesium bromide $(0.57 \mathrm{~mL}$ of a $2.8 \mathrm{M}$ solution in $\mathrm{Et}_{2} \mathrm{O}, 1.63 \mathrm{mmol}, 1.05$ equiv.) and zinc(II) chloride $\left(0.82 \mathrm{~mL}\right.$ of a $1.0 \mathrm{M}$ solution in $\mathrm{Et}_{2} \mathrm{O}$, $0.823 \mathrm{mmol}, 0.53$ equiv.) and the mixture stirred for $\sim 1$ minute. Note: There was an exotherm upon the addition of each reagent.

For urea/amide dichloroenamides: To a third, oven dried, nitrogen flushed flask equipped with a magnetic stirrer bar and a septum, was added sequentially anhydrous toluene $\left(\sim 1 \mathrm{~mL} \mathrm{mmol}^{-1}\right.$ of Grignard reagent), 4-chlorophenylmagnesium bromide (1.05-3.0 equiv.) and zinc(II) chloride (0.531.5 equiv.) and the mixture stirred for $\sim 1$ minute. Note: There was an exotherm upon addition of each reagent. To this was added anhydrous TMEDA (10.0 equiv.) dropwise and the reaction stirred for 5 minutes. Note: There was an immediate build up of a white precipitate. The stirring was halted and the precipitates were allowed to settle over 20 minutes. Only the solution was transferred to the subsequent reaction, via syringe, and the remaining precipitate was washed with anhydrous toluene, with these washings also added to the reaction.

To the previously prepared solution of chloroynamide at $21^{\circ} \mathrm{C}$ was added $\mathrm{CuCN} \cdot 2 \mathrm{LiCl}(20 \mu \mathrm{L}$ of a $1.0 \mathrm{M}$ solution in THF, $20 \mu \mathrm{mol}, 1.25 \mathrm{~mol} \%$ ), followed by the previously prepared diarylzinc solution, and the reaction was stirred for 30 minutes at room temperature. Reaction completion was then verified by TLC $\left(10 \% \mathrm{Et}_{2} \mathrm{O} /\right.$ petroleum ether). Note: In this case, the reaction mixture remained yellow upon reaction completion. The reaction was quenched with aqueous saturated $\mathrm{NH}_{4} \mathrm{Cl}(5 \mathrm{~mL})$, stirred for 10 minutes and then poured into a $250 \mathrm{~mL}$ separating funnel containing $\mathrm{Et}_{2} \mathrm{O}(\sim 30 \mathrm{~mL})$ and aqueous saturated $\mathrm{NH}_{4} \mathrm{Cl}(\sim 50 \mathrm{~mL})$. The reaction vessel was thoroughly rinsed with $\mathrm{Et}_{2} \mathrm{O}$ and water $(2 \times 5 \mathrm{~mL}$ each, alternately) and these washings were poured into the separating funnel. The organic layer was then separated and the aqueous was further extracted with $\mathrm{Et}_{2} \mathrm{O}(2 \times 30 \mathrm{~mL})$. The organic extracts were then combined, dried $\left(\mathrm{MgSO}_{4}\right)$ and concentrated in vacuo.

Column chromatography $\left(5 \% \mathrm{Et}_{2} \mathrm{O} / 40-60\right.$ petroleum ether) afforded the ynamide as a pale yellow oil that solidified on standing. To this solid was added hexane $(1.5 \mathrm{~mL})$ and the mixture heated to $\sim 50{ }^{\circ} \mathrm{C}$ to dissolve the material. The solution was allowed to cool to room temperature and left to stand overnight, by which time colourless needles of benzyl phenyl(phenylethynyl) carbamate, 15a, had grown. This suspension was further cooled to $-10{ }^{\circ} \mathrm{C}$ for $\sim 2$ hours to enable further crystallisation. Once crystallisation had ceased, the remaining pale yellow solution was decanted and the colourless crystals were washed with ice cold pentane $(2 \times 1 \mathrm{~mL})$. The crystals were then dried under high vacuum for 1 hour. This afforded $376 \mathrm{mg}(1.15 \mathrm{mmol}, 74 \%)$ of benzyl phenyl(phenylethynyl) carbamate, 13a. 


\subsection{Experimental procedures and characterisation data.}

\section{1a (E)-N-(1,2-Dichlorovinyl)- $N$-phenyltosylamide, 3a}
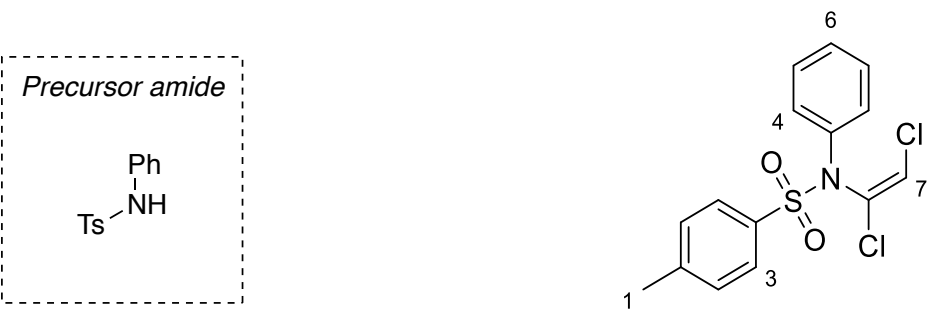

Synthesised according to example procedure 1.3a to give $65.2 \mathrm{~g} \mathrm{(190} \mathrm{mmol,} \mathrm{94 \% )} \mathrm{of} \mathrm{3a.}$

m.p. $120-121^{\circ} \mathrm{C}$;

$\mathbf{R}_{\mathbf{f}} 0.32\left(10 \% \mathrm{Et}_{2} \mathrm{O} / 40-60\right.$ petroleum ether);

IR (thin film, $v_{\max } / \mathrm{cm}^{-1}$ ) 3087, 2315, 1720, 1596, 1490, 1365, 1283, 1169, 1090, 948, 813, 695, 662;

${ }^{1} \mathbf{H}$ NMR $\left(400 \mathrm{MHz}, \mathrm{CDCl}_{3}\right) \delta_{\mathrm{H}} 7.67-7.62(2 \mathrm{H}, \mathrm{m}, H 3), 7.40-7.30(5 \mathrm{H}, \mathrm{m}, H 4, H 5, H 6), 7.24(2 \mathrm{H}, \mathrm{d}$, $J=8.4 \mathrm{~Hz}, H 2), 6.45(1 \mathrm{H}, \mathrm{s}, H 7), 2.42(3 \mathrm{H}, \mathrm{s}, H 1)$;

${ }^{13} \mathrm{C}$ NMR $\left(101 \mathrm{MHz}, \mathrm{CDCl}_{3}\right) \delta_{\mathrm{C}} 144.6,137.6,135.5,130.6,129.4,129.3,129.0,128.7,128.6,120.5$, 21.6. 


\section{1b Organometallic Scope: Ynamides}

\section{$N$-Phenyl- $N$-(phenylethynyl)tosylamide, 1 a}
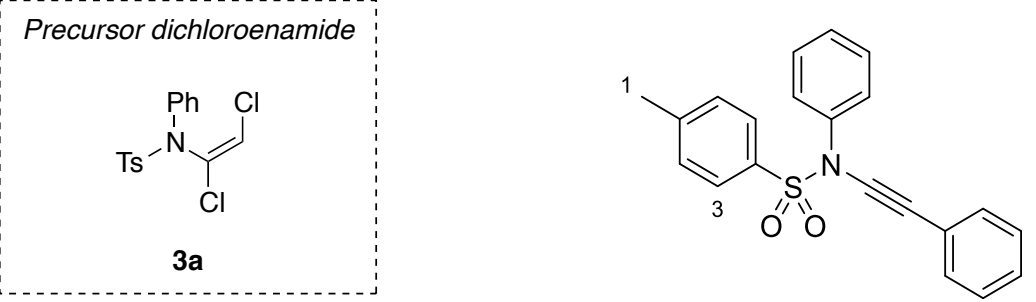

Following example procedure 1.3e: Synthesised from $(E)-N$-phenyl- $N$-(1,2-dichlorovinyl)tosylamide (500 mg, $1.46 \mathrm{mmol}, 1.0$ equiv.) in anhydrous TBME $(2.0 \mathrm{~mL})$ using LiHMDS (freshly prepared according to example procedure 1.3e, 1.2 equiv. $), \mathrm{CuCN} \cdot 2 \mathrm{P}(\mathrm{OMe})_{3}(183 \mu \mathrm{L}$ of a $0.1 \mathrm{M}$ solution in THF, $18.3 \mu \mathrm{mol}, 1.25 \mathrm{~mol} \%)$ and phenylmagnesium bromide $(1.50 \mathrm{~mL}$ of a $1.0 \mathrm{M}$ solution in THF, $1.50 \mathrm{mmol}, 1.03$ equiv.). Upon completion, the reaction was worked up and extracted as for example procedure 1.3e, using EtOAc instead of $\mathrm{Et}_{2} \mathrm{O}$. Column chromatography $\left(6 \% \mathrm{Et}_{2} \mathrm{O} / 40-60\right.$ petroleum ether) afforded the title compound (433 mg, $1.25 \mathrm{mmol}, 85 \%)$ as colourless crystals. This compound can be recrystallised from hexane to give colourless needles, or $\mathrm{Et}_{2} \mathrm{O}$ to give colourless blocks;

m.p. $102{ }^{\circ} \mathrm{C}$ (hexane), $94-95{ }^{\circ} \mathrm{C}\left(\mathrm{Et}_{2} \mathrm{O}\right)$;

$\mathbf{R}_{\mathbf{f}} 0.33\left(10 \% \mathrm{Et}_{2} \mathrm{O} / 40-60\right.$ petroleum ether);

IR (thin film, $v_{\max } / \mathrm{cm}^{-1}$ ) 3063, 2239, 1594, 1490, 1372, 1172, 1089, 1068, 1024, 921, 891, 812, 782 , 754, 689, 653;

${ }^{1} \mathbf{H}$ NMR $\left(400 \mathrm{MHz}, \mathrm{CDCl}_{3}\right) \delta_{\mathrm{H}} 7.63(2 \mathrm{H}, \mathrm{d}, J=8.3 \mathrm{~Hz}, H 3), 7.43-7.27(12 \mathrm{H}, \mathrm{m}, H 2, \mathrm{Ph} H \times 2), 2.45$ $(3 \mathrm{H}, \mathrm{s}, H 1)$;

${ }^{13}$ C NMR $\left(101 \mathrm{MHz}, \mathrm{CDCl}_{3}\right) \delta_{\mathrm{C}} 145.0,138.9,132.9,131.4,129.5,129.1,128.25(2 \mathrm{C}), 128.22,127.9$, $126.2,122.6,82.9,70.5,21.7$;

HRMS (ES+) calc. for $\mathrm{C}_{21} \mathrm{H}_{17} \mathrm{NNaO}_{2} \mathrm{~S}[\mathrm{M}+\mathrm{Na}]^{+} 370.0872$, found 370.0873 .

The above procedure was also demonstrated to be successful using commercially available reagents. Following example procedure 1.3e: Synthesised from $(E)-N$-phenyl- $N$-(1,2-dichlorovinyl)tosylamide (200 mg, $0.58 \mathrm{mmol}, 1.0$ equiv.) in anhydrous TBME (0.85 mL, Sigma Aldrich) using LiHMDS (purchased as $1 \mathrm{M}$ solution in TBME, 1.2 equiv.), $\mathrm{CuCN} \cdot 2 \mathrm{P}(\mathrm{OMe})_{3}(100 \mu \mathrm{L}$ of a $0.1 \mathrm{M}$ solution in THF, $10 \mu \mathrm{mol}, 1.7 \mathrm{~mol} \%)$ and phenylmagnesium bromide $(0.61 \mathrm{~mL}$ of a $1.0 \mathrm{M}$ solution in THF, $0.61 \mathrm{mmol}, 1.05$ equiv.). Upon completion, the reaction was worked up and extracted as for example procedure 1.3e. Following aqueous work-up, the sample was adsorbed onto Celite for flash column chromatography. FCC: 12 g GOLD ISCO, eluent $=0-10 \% \mathrm{Et}_{2} \mathrm{O} /$ hexanes $(20 \mathrm{CV})$ afforded the title compound (160 mg, $0.46 \mathrm{mmol}, 79 \%)$ as a colourless crystalline solid. 
${ }^{1} \mathbf{H}$ NMR $\left(400 \mathrm{MHz}, \mathrm{CDCl}_{3}\right) \delta_{\mathrm{H}} 7.63(2 \mathrm{H}, \mathrm{d}, J=8.3 \mathrm{~Hz}), 7.42-7.27(12 \mathrm{H}, \mathrm{m}), 2.44(3 \mathrm{H}, \mathrm{s})$;

LCMS tR $=1.38$ min, calc. for $\mathrm{C}_{21} \mathrm{H}_{17} \mathrm{NO}_{2} \mathrm{~S}[\mathrm{M}]^{+} 347.4$, found 348.1;

HPLC tR $=6.63 \mathrm{~min}, 100 \%$.

Data File C: \EZXATA 07-18\RCS\RSMITH25_1761_T011-110718-23568.D

Sample Name: rmich25_1761_to

Easy-Access Method: '2min-generic-pos'

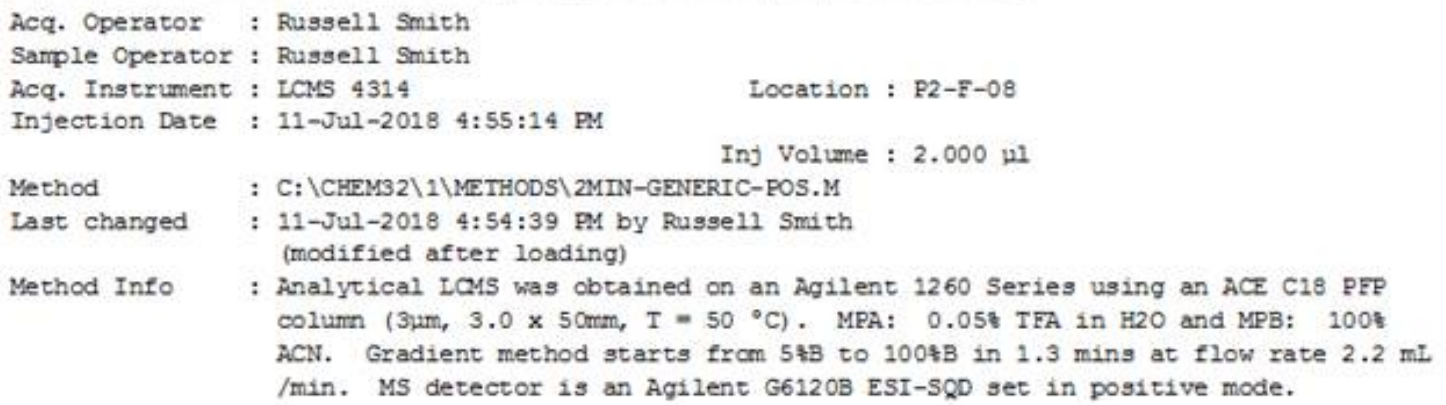

Sarple Info

: Easy-Access Method: '2min-generic-pos'

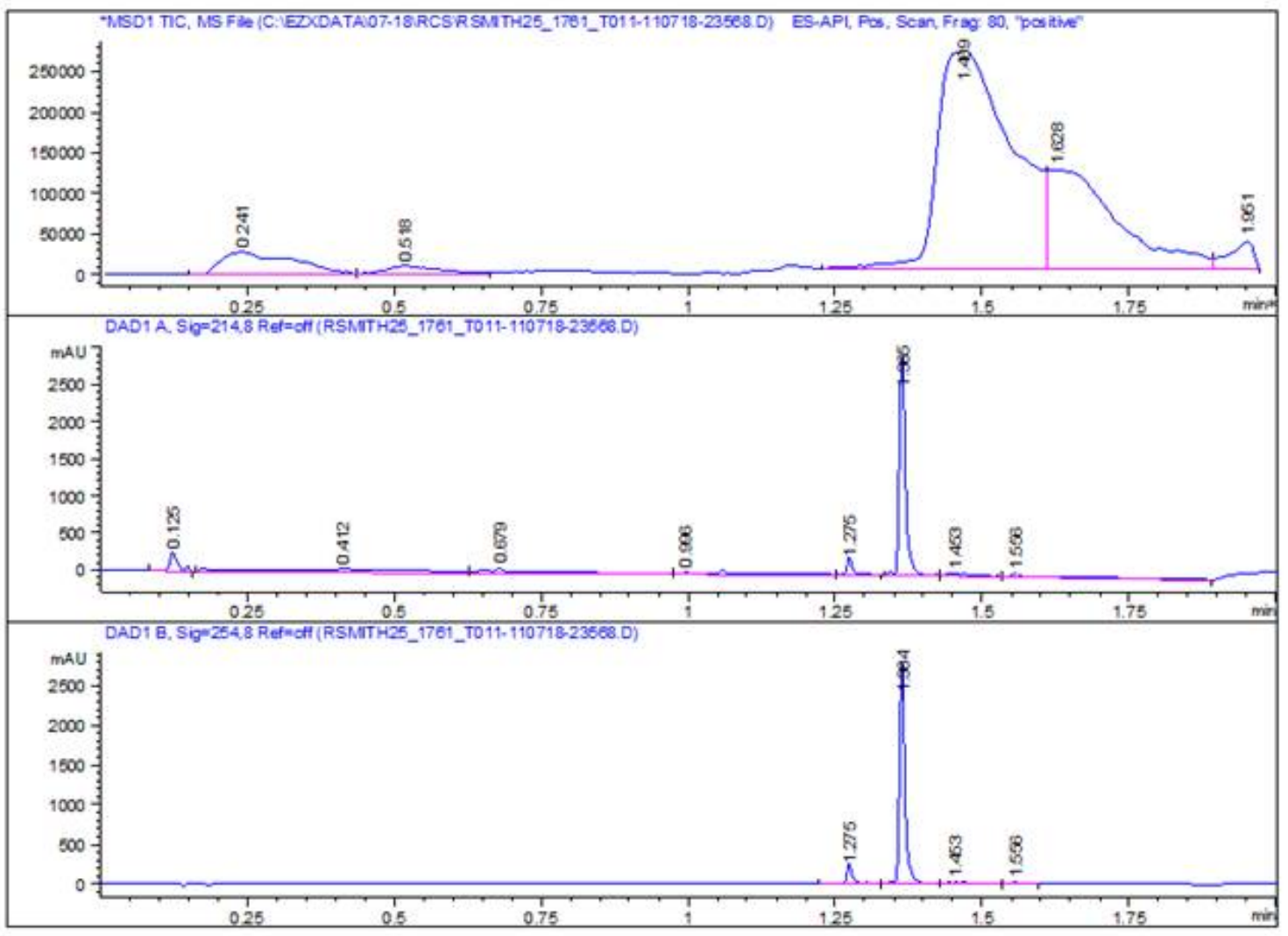


Data File C: \EZXDATA $\backslash 07-18 \backslash$ RCS \RSMITH25_1761_111-160718-06170.D

Sample Name: rsmith25_1761_1

Acq. Operator : Russell Smith

Acq. Instrument : HPLC4314D

Location : Vial 22

Injection Date : 16-Jul-2018 8:26:41 PM

Method : C: \CHEM32\1\METHODS $\backslash$ KIGEN-BASIC.M

Last changed : 16-Jul-2018 8:24:09 PM by Russell Smith

(modified after loading)

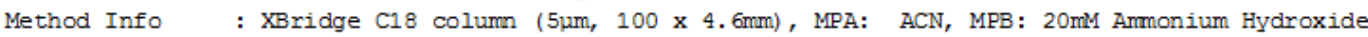
in water. Gradient starts from $10 \%$ to $100 \%$ ACN over $5 \mathrm{mins}$ and then hold at 100 \% $\mathrm{ACN}$ for $5 \mathrm{mins}$, at a flow rate of $1.0 \mathrm{~mL} / \mathrm{min}($ Temp $=40 \mathrm{C}$ )

Sample Info : Easy-Access Method: 'ktgen-basic'

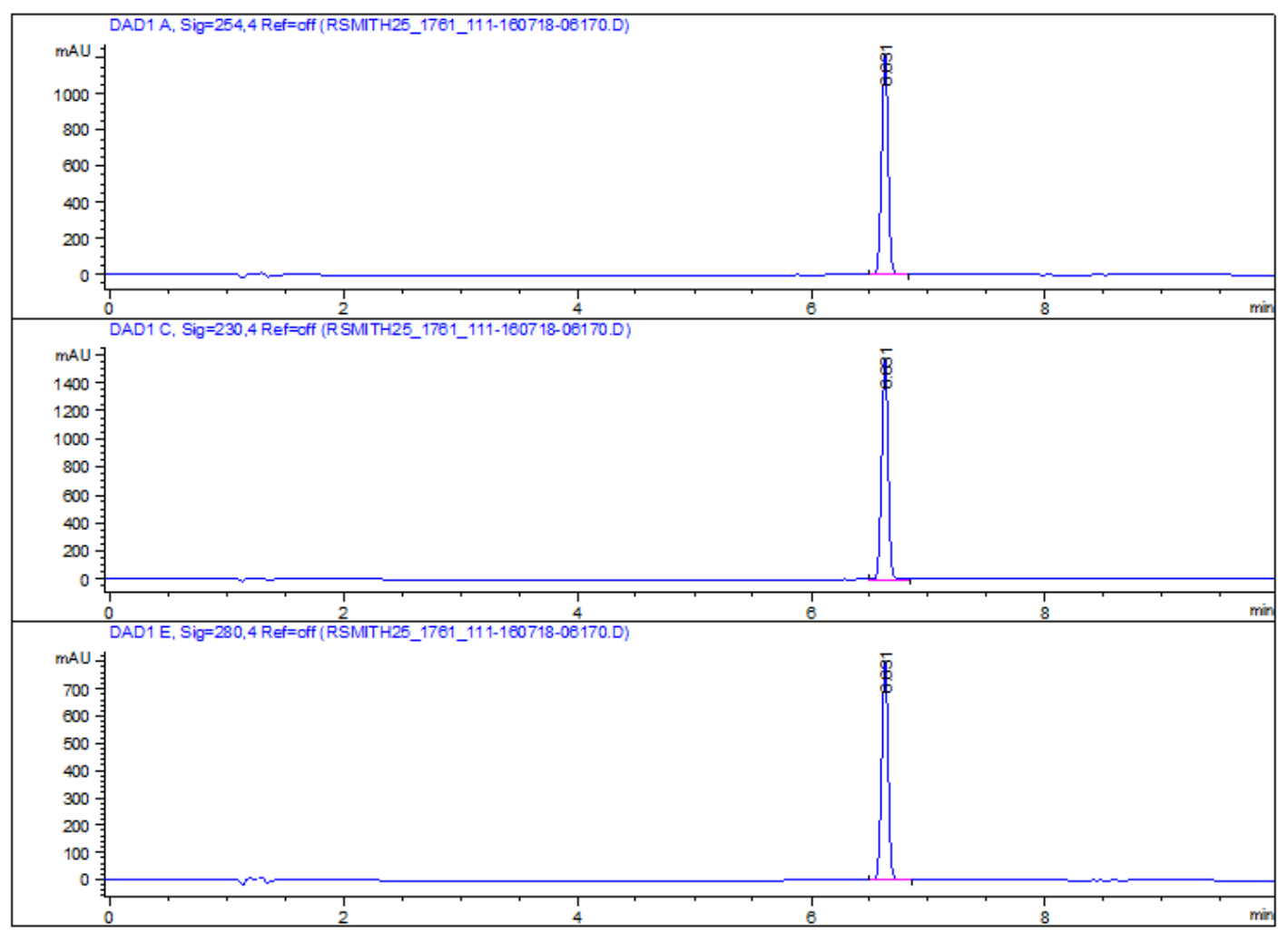




\section{$N$-((4-(Dimethylamino)phenyl)ethynyl)- $N$-phenyltosylamide, 1 b}
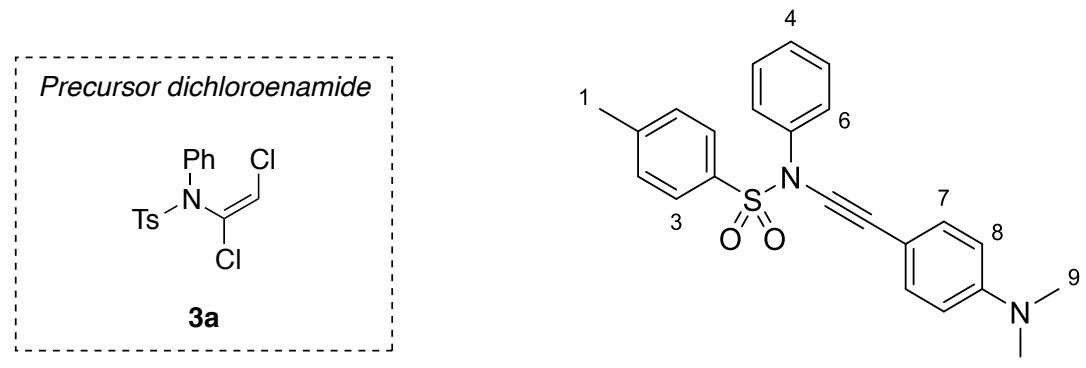

Following example procedure 1.3e: Synthesised from $(E)-N$-phenyl- $N$-(1,2-dichlorovinyl)tosylamide (500 mg, $1.46 \mathrm{mmol}, 1.0$ equiv.) in anhydrous TBME (2.0 mL) using LiHMDS (freshly prepared according to example procedure 1.3e, 1.2 equiv.), $\mathrm{CuCN} \cdot 2 \mathrm{P}(\mathrm{OMe})_{3}(183 \mu \mathrm{L}$ of a $0.1 \mathrm{M}$ solution in THF, $18.3 \mu \mathrm{mol}, 1.25 \mathrm{~mol} \%$ ) and 4-(dimethylamino)phenylmagnesium bromide (3.01 $\mathrm{mL}$ of a $0.5 \mathrm{M}$ solution in THF, $1.50 \mathrm{mmol}, 1.03$ equiv.). Upon completion, the reaction was worked up and extracted as for example procedure 1.3e, using EtOAc instead of $\mathrm{Et}_{2} \mathrm{O}$. Column chromatography (20 $\rightarrow 30 \% \mathrm{Et}_{2} \mathrm{O} / 40-60$ petroleum ether $+5 \% \mathrm{Et}_{3} \mathrm{~N}$ ) afforded the title compound (505 $\mathrm{mg}, 1.29 \mathrm{mmol}$, $88 \%$ ) as colourless crystals. The compound crystallises spontaneously from the column fractions. *Note: This compound is sensitive to prolonged exposure to silica gel, and the material turns green upon melting;

m.p. $136^{\circ} \mathrm{C}$;

$\mathbf{R}_{\mathbf{f}} 0.32\left(30 \% \mathrm{Et}_{2} \mathrm{O} / 40-60\right.$ petroleum ether $)$;

IR (thin film, $v_{\max } / \mathrm{cm}^{-1}$ ) 2892, 2239, 1607, 1523, 1489, 1446, 1367, 1206, 1186, 1172, 1090, 815, $798,758,711,692,663$;

${ }^{1} \mathbf{H}$ NMR $\left(400 \mathrm{MHz}, \mathrm{CDCl}_{3}\right) \delta_{\mathrm{H}} 7.66-7.59(2 \mathrm{H}, \mathrm{d}, J=8.3 \mathrm{~Hz}, H 3)$, 7.37-7.25 (9H, m, H2, H4, H5, $H 6, H 7), 6.65-6.58$ (2H, m, H8), 2.97 (6H, s, H9), 2.45 (3H, s, H1);

${ }^{13} \mathbf{C}$ NMR $\left(101 \mathrm{MHz}, \mathrm{CDCl}_{3}\right) \delta_{\mathrm{C}} 150.2,144.7,139.5,133.4,133.0,129.3,128.9,128.3,127.9,126.1$, 111.7, 109.0, 80.7, 71.3, 40.2, 21.7;

HRMS (ES+) calc. for $\mathrm{C}_{23} \mathrm{H}_{23} \mathrm{NO}_{3} \mathrm{~S}[\mathrm{M}+\mathrm{H}]^{+}$391.1475, found 391.1473 . 


\section{$N$-(4-(((4-Methyl- $N$-phenylphenyl)sulfonamido)ethynyl)phenyl)acetamide, $1 \mathrm{c}$}
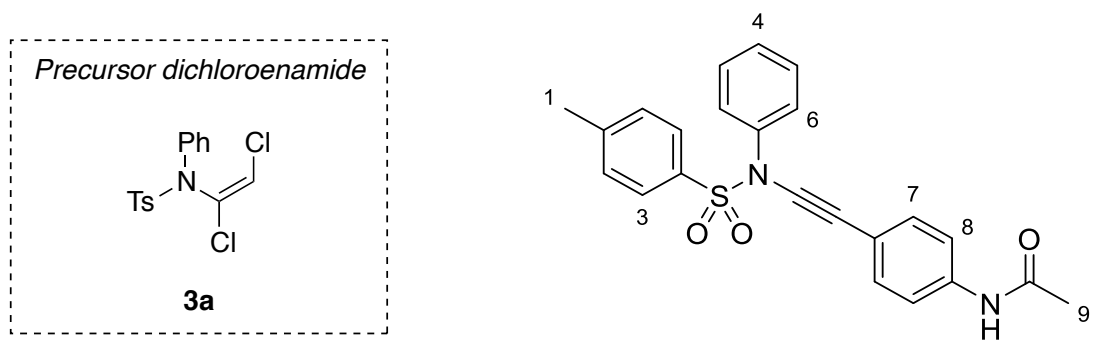

The chloroynamide was synthesised from (E)- $N$-phenyl- $N$-(1,2-dichlorovinyl)tosylamide (500 mg, $1.46 \mathrm{mmol}, 1.0$ equiv.) in anhydrous TBME $(2.0 \mathrm{~mL})$ following example procedure 1.3e. Complete consumption of the dichloroenamide was verified by TLC. The cooling bath was then removed and the reaction mixture was then allowed to warm to room temperature (approx. $21^{\circ} \mathrm{C}$ ) whilst stirring.

$N$-Lithio(4-acetamidophenyl)magnesium chloride/lithium bromide complex was prepared as follows: to an oven dried, nitrogen flushed flask equipped with a magnetic stirrer bar and a septum, was added 4-bromoacetanilide (375 $\mathrm{mg}, 1.75 \mathrm{mmol}, 1.2$ equiv.) and anhydrous THF ( $8 \mathrm{~mL}$ ), and the solution cooled to $-40{ }^{\circ} \mathrm{C}$ whilst stirring. Next, $i$-propylmagnesium chloride $(0.88 \mathrm{~mL}$ of a $2.0 \mathrm{M}$ solution in THF, $1.75 \mathrm{mmol}, 1.2$ equiv.) was added dropwise and the reaction was stirred for a further 5 minutes at $-40{ }^{\circ} \mathrm{C}$. Note: A pale yellow precipitate forms. The suspension was then cooled to $-78{ }^{\circ} \mathrm{C}$, and $t$-BuLi (1.89 $\mathrm{mL}$ of $1.7 \mathrm{M}$ solution in pentanes, $3.21 \mathrm{mmol}, 2.2$ equiv.) was added dropwise over 5 minutes. The resulting yellow suspension was then allowed to warm gradually over 1 hour to $0{ }^{\circ} \mathrm{C}$ whilst stirring, and was used directly in the next step.

To the previously prepared suspension of chloroynamide in TBME was added $\mathrm{CuCN} \cdot 2 \mathrm{P}(\mathrm{OMe})_{3}$ (183 $\mu \mathrm{L}$ of a $0.1 \mathrm{M}$ solution in THF, $18.3 \mu \mathrm{mol}, 1.25 \mathrm{~mol} \%$ ), and the reaction stirred for 5 minutes at room temperature. The suspension of $N$-lithio(4-acetamidophenyl)magnesium chloride/lithium bromide complex was then transferred, by syringe, to this mixture dropwise over 1 minute, and the reaction was stirred for 30 minutes at room temperature. Reaction completion was then verified by TLC. Upon completion, the reaction was worked up and extracted as for example procedure 1.3e, using EtOAc instead of $\mathrm{Et}_{2} \mathrm{O}$. Column chromatography $(50 \rightarrow 60 \%$ EtOAc/40-60 petroleum ether, with the compound loaded as a concentrated solution in $\mathrm{CH}_{2} \mathrm{Cl}_{2}$ ) afforded a pale yellow solid which was recrystallised from EtOAc to give the title compound (394 $\mathrm{mg}, 0.973 \mathrm{mmol}, 67 \%$ ) as colourless plates;

m.p. $>140{ }^{\circ} \mathrm{C}$ (dec.);

$\mathbf{R}_{\mathbf{f}} 0.22$ (60\% EtOAc/40-60 petroleum ether);

IR (thin film, $v_{\max } / \mathrm{cm}^{-1}$ ) 3308, 3040, 2239, 1671, 1593, 1524, 1490, 1404, 1371, 1313, 1293, 1252, $11731089,837,779,689,657$; 
${ }^{1}$ H NMR $\left(400 \mathrm{MHz}, \mathrm{CDCl}_{3}\right) \delta_{\mathrm{H}} 7.69(1 \mathrm{H}$, br. s, NH), $7.60(2 \mathrm{H}, \mathrm{d}, J=8.3 \mathrm{~Hz}, H 3), 7.48(2 \mathrm{H}, \mathrm{d}$, $J=8.3 \mathrm{~Hz}, H 7), 7.36-7.26$ (9H, m, H2, H4, H5, H6, H8), $2.44(3 \mathrm{H}, \mathrm{s}, H 1), 2.16$ (3H, s, H9);

${ }^{13} \mathbf{C}$ NMR $\left(101 \mathrm{MHz}, \mathrm{CDCl}_{3}\right) \delta_{\mathrm{C}} 168.3,145.0,138.9,137.9,132.9,132.5,129.5,129.1,128.3,128.2$, 126.2, 119.3, 118.0, 82.3, 70.2, 24.6, 21.7;

HRMS (ES+) calc. for $\mathrm{C}_{23} \mathrm{H}_{20} \mathrm{~N}_{2} \mathrm{NaO}_{3} \mathrm{~S}[\mathrm{M}+\mathrm{Na}]^{+}$427.1087, found 427.1087. 


\section{$N$-((4-Methoxyphenyl)ethynyl)- $N$-phenyltosylamide, 1d}
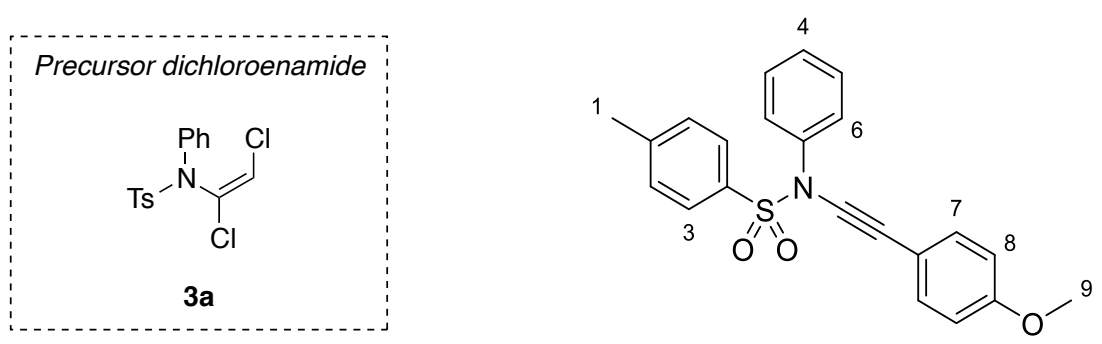

Following example procedure 1.3e: Synthesised from $(E)-N$-phenyl- $N$-(1,2-dichlorovinyl)tosylamide (500 mg, $1.46 \mathrm{mmol}, 1.0$ equiv.) in anhydrous TBME $(2.0 \mathrm{~mL})$ using LiHMDS (freshly prepared according to example procedure 1.3e, 1.2 equiv.), $\mathrm{CuCN} \cdot 2 \mathrm{P}(\mathrm{OMe})_{3}(183 \mu \mathrm{L}$ of a $0.1 \mathrm{M}$ solution in THF, $18.3 \mu \mathrm{mol}, 1.25 \mathrm{~mol} \%)$ and 4-methoxyphenylmagnesium bromide (1.50 $\mathrm{mL}$ of a $1.0 \mathrm{M}$ solution in THF, $1.50 \mathrm{mmol}, 1.03$ equiv.). Upon completion, the reaction was worked up and extracted as for example procedure 1.3e, using EtOAc instead of $\mathrm{Et}_{2} \mathrm{O}$. Column chromatography $\left(6 \% \mathrm{Et}_{2} \mathrm{O} / 40-60\right.$ petroleum ether) afforded a yellow solid which was triturated with hexane, followed by recrystallisation from hexane:TBME (2:1) to give the title compound (457 $\mathrm{mg}, 1.21 \mathrm{mmol}, 83 \%)$ as colourless plates;

m.p. $99-100^{\circ} \mathrm{C}$;

$\mathbf{R}_{\mathbf{f}} 0.16\left(10 \% \mathrm{Et}_{2} \mathrm{O} / 40-60\right.$ petroleum ether $)$;

IR (thin film, $v_{\max } / \mathrm{cm}^{-1}$ ) 2958, 2838, 2241, 1605, 1510, 1489, 1371, 1248, 1172, 1089, 1028, 922, $891,832,812,721,691,668$;

${ }^{1} \mathbf{H}$ NMR $\left(400 \mathrm{MHz}, \mathrm{CDCl}_{3}\right) \delta_{\mathrm{H}} 7.61(2 \mathrm{H}, \mathrm{d}, J=8.3 \mathrm{~Hz}, H 3), 7.38-7.22(9 \mathrm{H}, \mathrm{m}, H 2, H 4, H 5, H 6$, $H 7), 6.86-6.78$ (2H, m, H8), 3.79 (3H, s, H9), 2.43 (3H, s, H1);

${ }^{13} \mathbf{C}$ NMR $\left(101 \mathrm{MHz}, \mathrm{CDCl}_{3}\right) \delta_{\mathrm{C}} 159.6,144.8,139.1,133.4,133.0,129.4,129.0,128.3,128.1,126.2$, $114.5,113.9,81.5,70.2,55.3,21.7$;

HRMS (ES+) calc. for $\mathrm{C}_{22} \mathrm{H}_{19} \mathrm{NNaO}_{3} \mathrm{~S}[\mathrm{M}+\mathrm{Na}]^{+} 400.0978$, found 400.0978 . 


\section{$N$-((2-Methoxyphenyl)ethynyl)- $N$-phenyltosylamide, $1 \mathrm{e}$}
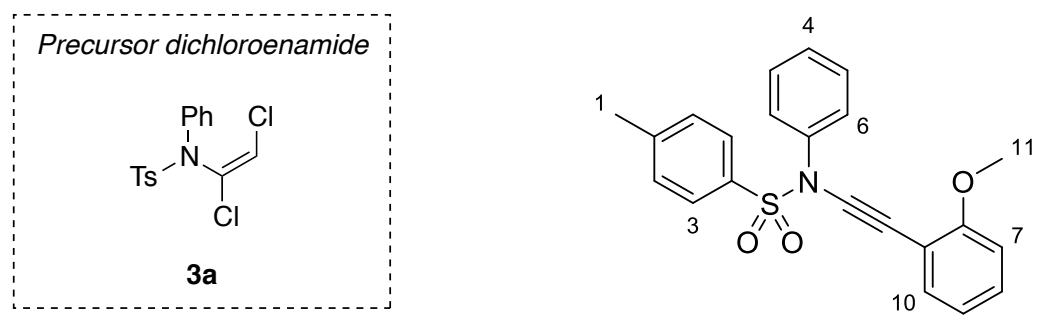

Following example procedure 1.3e: Synthesised from $(E)-N$-phenyl- $N$-(1,2-dichlorovinyl)tosylamide (500 mg, $1.46 \mathrm{mmol}, 1.0$ equiv.) in anhydrous TBME (2.0 mL) using LiHMDS (freshly prepared according to example procedure $1.3 e, 1.2$ equiv.), $\mathrm{CuCN} \cdot 2 \mathrm{P}(\mathrm{OMe})_{3}(183 \mu \mathrm{L}$ of a $0.1 \mathrm{M}$ solution in THF, $18.3 \mu \mathrm{mol}, 1.25 \mathrm{~mol} \%$ ) and 2-methoxyphenylmagnesium chloride (prepared according to example procedure 1.3c from 2-iodoanisole $(0.23 \mathrm{~mL}, 1.75 \mathrm{mmol}, 1.2$ equiv.) in anhydrous THF (4 $\mathrm{mL}$ ) using $i$-propylmagnesium chloride (1.02 $\mathrm{mL}$ of a $2.0 \mathrm{M}$ solution in THF, $2.05 \mathrm{mmol}, 1.4$ equiv.) and stirring for 2 hours at $-20^{\circ} \mathrm{C}$ ). Upon completion, the reaction was worked up and extracted as for example procedure 1.3e, using EtOAc instead of $\mathrm{Et}_{2} \mathrm{O}$. Column chromatography $\left(6 \% \mathrm{Et}_{2} \mathrm{O} / 40-60\right.$ petroleum ether) afforded the title compound (501 mg, $1.33 \mathrm{mmol}, 91 \%)$ as a colourless solid. This compound can be recrystallised from benzene:dibutyl ether (1:1) to give colourless crystals;

m.p. $57^{\circ} \mathrm{C}$;

$\mathbf{R}_{\mathbf{f}} 0.24\left(10 \% \mathrm{Et}_{2} \mathrm{O} / 40-60\right.$ petroleum ether);

IR (thin film, $v_{\max } / \mathrm{cm}^{-1}$ ) 3066, 2938, 2837, 2240, 1595, 1491, 1370, 1247, 1172, 1023, 812, 752, 703, 691, 679, 653;

${ }^{1} \mathbf{H}$ NMR $\left(400 \mathrm{MHz}, \mathrm{CDCl}_{3}\right) \delta_{\mathrm{H}} 7.60(2 \mathrm{H}, \mathrm{d}, J=8.3 \mathrm{~Hz}, H 3), 7.31-7.11(9 \mathrm{H}, \mathrm{m}, H 2, H 4, H 5, H 6, H 8$, $H 10), 6.86-6.70(2 \mathrm{H}, \mathrm{m}, H 7, H 9), 3.79(3 \mathrm{H}, \mathrm{s}, H 11), 2.43$ (3H, s, $H 1)$;

${ }^{13}$ C NMR $\left(101 \mathrm{MHz}, \mathrm{CDCl}_{3}\right) \delta_{\mathrm{C}} 160.0,144.8,139.0,133.0,132.9,129.33,129.30,128.9,128.3$, $128.0,126.1,120.3,111.8,110.6,86.5,67.0,55.7,21.6$;

HRMS (ES+) calc. for $\mathrm{C}_{22} \mathrm{H}_{19} \mathrm{NNaO}_{3} \mathrm{~S}[\mathrm{M}+\mathrm{Na}]^{+} 400.0978$, found 400.0978 . 


\section{$N$-((2-Fluoro-6-methoxyphenyl)ethynyl)- $N$-phenyltosylamide, if}
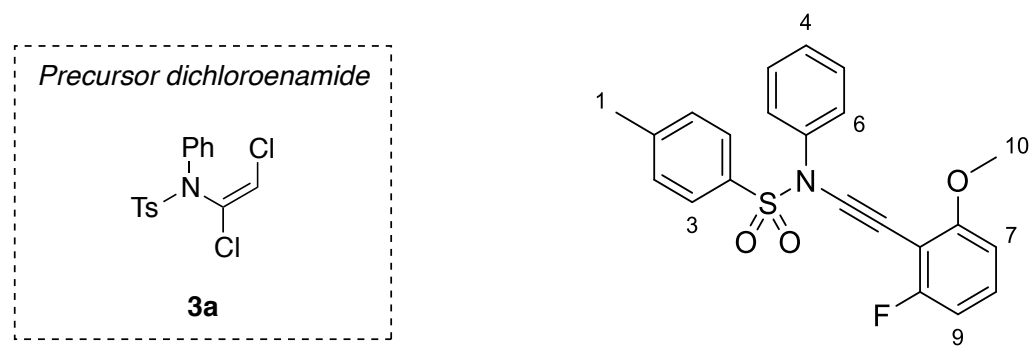

Preparation via arylmagnesium bromide/lithium bromide complex:

The chloroynamide was synthesised from (E)- $N$-phenyl- $N$-(1,2-dichlorovinyl)tosylamide $(500 \mathrm{mg}$, $1.46 \mathrm{mmol}, 1.0$ equiv.) in anhydrous TBME $(2.0 \mathrm{~mL})$ following example procedure 1.3e. Complete consumption of the dichloroenamide was verified by TLC. The cooling bath was then removed and the reaction mixture was then allowed to warm to room temperature (approx. $21^{\circ} \mathrm{C}$ ) whilst stirring.

(2-Fluoro-6-methoxyphenyl)magnesium bromide/lithium chloride complex was prepared as followed: To an oven dried, nitrogen flushed flask equipped with a magnetic stirrer bar and a septum, was added magnesium turnings (53.3 mg, $2.19 \mathrm{mmol}, 1.5$ equiv.), and anhydrous THF ( $6 \mathrm{~mL}$ ), followed by the careful addition of 1,2-dibromoethane (190 $\mu \mathrm{L}, 2.19 \mathrm{mmol}, 1.5$ equiv.) at room temperature. The reaction was then heated at reflux for 2 hours and the solution was then allowed to cool to room temperature.

To a second oven dried, nitrogen flushed flask equipped with a magnetic stirrer bar and a septum, was added anhydrous THF $(1 \mathrm{~mL})$ and di-i-propylamine $(0.25 \mathrm{~mL}, 1.75 \mathrm{mmol}, 1.2$ equiv. $)$, and the solution was cooled to $0{ }^{\circ} \mathrm{C}$ whilst stirring. To this solution was added dropwise $n$-butyllithium $(0.70$ $\mathrm{mL}$ of a $2.5 \mathrm{M}$ solution in hexanes, $1.75 \mathrm{mmol}, 1.2$ equiv.) and the mixture stirred for 1 hour at $0{ }^{\circ} \mathrm{C}$. The mixture was then cooled to $-78{ }^{\circ} \mathrm{C}$. Next, a solution of 3-fluoroanisole $(0.20 \mathrm{~mL}, 1.75 \mathrm{mmol}, 1.2$ equiv.) in anhydrous THF ( $2 \mathrm{~mL})$ was added dropwise and the solution stirred for 1 hour at $-78{ }^{\circ} \mathrm{C}$. To the resulting pale yellow solution was added the previously prepared solution of magnesium bromide in THF. The reaction was stirred for 20 minutes at $-78{ }^{\circ} \mathrm{C}$ and then allowed to warm to $0{ }^{\circ} \mathrm{C}$. This mixture was used directly in the next step.

To the previously prepared suspension of chloroynamide in TBME was added $\mathrm{CuCN} \cdot 2 \mathrm{P}(\mathrm{OMe})_{3}$ (183 $\mu \mathrm{L}$ of a $0.1 \mathrm{M}$ solution in THF, $18.3 \mu \mathrm{mol}, 1.25 \mathrm{~mol} \%$ ), and the reaction stirred for 5 minutes at room temperature. The suspension of (2-fluoro-6-methoxyphenyl)magnesium bromide/lithium bromide complex was then transferred, by syringe, to this mixture and the reaction was stirred for 30 minutes at room temperature. Upon completion, the reaction was worked up and extracted as for example procedure 1.3e, using EtOAc instead of $\mathrm{Et}_{2} \mathrm{O}$. Column chromatography $\left(20 \% \mathrm{Et}_{2} \mathrm{O} / 40-60\right.$ petroleum ether), followed by recrystallisation from hexane:TBME (2:1), afforded the title compound 
(451 mg, $1.14 \mathrm{mmol}, 78 \%$ ) as colourless crystals. These crystals were also suitable for X-ray diffraction.

\section{Preparation via arylzinc chloride/lithium chloride complex:}

(2-Fluoro-6-methoxyphenyl)zinc chloride/lithium chloride complex was prepared as followed: To an oven dried, nitrogen flushed flask equipped with a magnetic stirrer bar and a septum, was added anhydrous THF $(1 \mathrm{~mL})$ and di-i-propylamine $(0.25 \mathrm{~mL}, 1.75 \mathrm{mmol}, 1.2$ equiv. $)$, and the solution was cooled to $0{ }^{\circ} \mathrm{C}$ whilst stirring. To this solution was added dropwise $n$-butyllithium $(0.70 \mathrm{~mL}$ of a 2.5 $\mathrm{M}$ solution in hexanes, $1.75 \mathrm{mmol}, 1.2$ equiv.) and the mixture stirred for 1 hour at $0{ }^{\circ} \mathrm{C}$. The mixture was then cooled to $-78{ }^{\circ} \mathrm{C}$. Next, a solution of 3-fluoroanisole $(0.20 \mathrm{~mL}, 1.75 \mathrm{mmol}, 1.2$ equiv.) in anhydrous THF ( $2 \mathrm{~mL})$ was added dropwise and the solution stirred for 1 hour at $-78{ }^{\circ} \mathrm{C}$. To the resulting pale yellow solution was added a solution of zinc(II) chloride ( $0.92 \mathrm{~mL}$ of a $1.9 \mathrm{M}$ solution in 2-MeTHF, $1.75 \mathrm{mmol}, 1.2$ equiv.). The reaction was stirred for 20 minutes at $-78{ }^{\circ} \mathrm{C}$ and then allowed to warm to room temperature. This solution was then used following the above procedure as for the analogous magnesium bromide/lithium bromide complex, albeit the reaction required heating at $50{ }^{\circ} \mathrm{C}$ overnight to achieve completion. Column chromatography $\left(20 \% \mathrm{Et}_{2} \mathrm{O} / 40\right.$ 60 petroleum ether) afforded a brown oil that was triturated with hexane/ $\mathrm{Et}_{2} \mathrm{O}(5: 1)$ to afford a pale yellow solid. This solid was recrystallised from hexane:TBME (2:1) to afford the title compound (312 mg, $0.79 \mathrm{mmol}, 54 \%$ ) as colourless crystals;

m.p. $89-91{ }^{\circ} \mathrm{C}$;

$\mathbf{R}_{\mathbf{f}} 0.18$ (10\% EtOAc/40-60 petroleum ether);

IR (thin film, $v_{\max } / \mathrm{cm}^{-1}$ ) 3150, 3065, 2241, 1594, 1489, 1469, 1371, 1336, 1173, 1130, 1110, 1090, 1029, 881, 812, 784, 766, 736, 704, 691, 654;

${ }^{1} \mathbf{H}$ NMR $\left(400 \mathrm{MHz}, \mathrm{CDCl}_{3}\right) \delta_{\mathrm{H}} 7.71-7.66(2 \mathrm{H}, \mathrm{m}, H 3), 7.37-7.25(7 \mathrm{H}, \mathrm{m}, H 2, H 4, H 5, H 6), 7.20$ $(1 \mathrm{H}, \mathrm{td}, J=8.4,6.6 \mathrm{~Hz}, H 8), 6.69(1 \mathrm{H}, \mathrm{td}, J=8.4,0.8 \mathrm{~Hz}, H 9), 6.65(1 \mathrm{H}, \mathrm{dt}, J=8.4,0.8 \mathrm{~Hz}, H 7)$, $3.87(3 \mathrm{H}, \mathrm{s}, H 10), 2.43(3 \mathrm{H}, \mathrm{s}, H 1)$;

${ }^{13}$ C NMR $\left(101 \mathrm{MHz}, \mathrm{CDCl}_{3}\right) \delta_{\mathrm{C}} 163.7(1 \mathrm{C}, \mathrm{d}, J=251 \mathrm{~Hz}), 161.4(1 \mathrm{C}, \mathrm{d}, J=5.6 \mathrm{~Hz}), 144.8,138.9$, 132.9, $129.4(1 \mathrm{C}, \mathrm{d}, J=11.1 \mathrm{~Hz}), 129.4,129.0,128.4,128.0,126.1,107.7$ (1C, d, $J=21.5 \mathrm{~Hz}), 106.2$ $(1 \mathrm{C}, \mathrm{d}, J=3.2 \mathrm{~Hz}), 101.3(1 \mathrm{C}, \mathrm{d}, J=18.3 \mathrm{~Hz}), 91.1(1 \mathrm{C}, \mathrm{d}, J=3.2 \mathrm{~Hz}), 60.5(1 \mathrm{C}, \mathrm{d}, J=1.6 \mathrm{~Hz})$, $56.3,21.7$;

${ }^{19}$ F NMR $\left(376 \mathrm{MHz}, \mathrm{CDCl}_{3}\right) \delta_{\mathrm{F}}-108.6(1 \mathrm{~F}, \mathrm{ddd}, J=8.4,6.6,0.8 \mathrm{~Hz})$;

HRMS (ES+) calc. for $\mathrm{C}_{22} \mathrm{H}_{18} \mathrm{FNNaO}_{3} \mathrm{~S}[\mathrm{M}+\mathrm{Na}]^{+} 418.0884$, found 418.0882 . 


\section{$N$-(Mesitylethynyl)- $N$-phenyltosylamide, $1 \mathrm{~g}$}
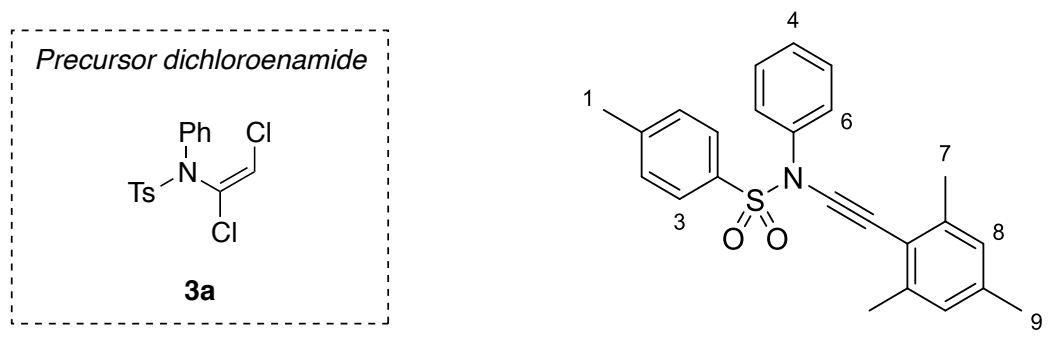

Following example procedure 1.3e: Synthesised from $(E)-N$-phenyl- $N$-(1,2-dichlorovinyl)tosylamide (500 mg, $1.46 \mathrm{mmol}, 1.0$ equiv.) in anhydrous TBME $(2.0 \mathrm{~mL})$ using LiHMDS (freshly prepared according to example procedure 1.3e, 1.2 equiv.), $\mathrm{CuCN} \cdot 2 \mathrm{P}(\mathrm{OMe})_{3}(183 \mu \mathrm{L}$ of a $0.1 \mathrm{M}$ solution in THF, $18.3 \mu \mathrm{mol}, 1.25 \mathrm{~mol} \%)$ and mesitylmagnesium bromide $(1.50 \mathrm{~mL}$ of a $1.0 \mathrm{M}$ solution in THF, $1.50 \mathrm{mmol}, 1.03$ equiv.). Upon completion, the reaction was worked up and extracted as for example procedure 1.3e. Column chromatography $\left(3 \% \mathrm{Et}_{2} \mathrm{O} / 40-60\right.$ petroleum ether) afforded the title compound (352 mg, $1.36 \mathrm{mmol}, 93 \%$ ) as a white powder. This compound can be recrystallised from hexane/TBME (4:1) to give colourless crystals;

m.p. $79-81{ }^{\circ} \mathrm{C}$;

$\mathbf{R}_{\mathbf{f}} 0.43\left(20 \% \mathrm{Et}_{2} \mathrm{O} / 40-60\right.$ petroleum ether);

IR (thin film, $v_{\max } / \mathrm{cm}^{-1}$ ) 2918, 2235, 1594, 1489, 1454, 1372, 1174, 1090, 921, 892, 854, 813, 771, 726, 692, 667;

${ }^{1} \mathbf{H}$ NMR $\left(400 \mathrm{MHz}, \mathrm{CDCl}_{3}\right) \delta_{\mathrm{H}} 7.58(2 \mathrm{H}, \mathrm{d}, J=8.1 \mathrm{~Hz}, H 3), 7.40-7.24(5 \mathrm{H}, \mathrm{m}, H 4, H 5, H 6), 7.20$ $(2 \mathrm{H}, \mathrm{d}, J=8.1 \mathrm{~Hz}, H 2), 6.82(2 \mathrm{H}, \mathrm{s}, H 8), 2.37(3 \mathrm{H}, \mathrm{s}, H 1), 2.33(6 \mathrm{H}, \mathrm{s}, H 7), 2.24(3 \mathrm{H}, \mathrm{s}, H 9)$;

${ }^{13} \mathrm{C}$ NMR $\left(101 \mathrm{MHz}, \mathrm{CDCl}_{3}\right) \delta_{\mathrm{C}} 144.8,139.8,139.2,137.3,132.9,129.3,128.9,128.00,127.96$, $127.4,125.9,119.1,90.0,68.3,21.5,21.1,20.9$;

HRMS (ES+) calc. for $\mathrm{C}_{24} \mathrm{H}_{24} \mathrm{NO}_{2} \mathrm{~S}[\mathrm{M}+\mathrm{H}]^{+}$390.1522, found 390.1523 . 

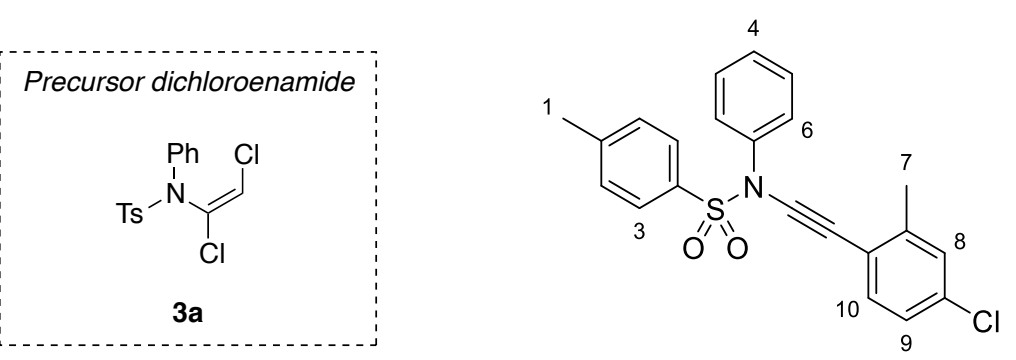

Following example procedure 1.3e: Synthesised from $(E)-N$-phenyl- $N$-(1,2-dichlorovinyl)tosylamide (500 mg, $1.46 \mathrm{mmol}, 1.0$ equiv.) in anhydrous TBME (2.0 mL) using LiHMDS (freshly prepared according to example procedure $1.3 \mathrm{e}, 1.2$ equiv. $), \mathrm{CuCN} \cdot 2 \mathrm{P}(\mathrm{OMe})_{3}(183 \mu \mathrm{L}$ of a $0.1 \mathrm{M}$ solution in THF, $18.3 \mu \mathrm{mol}, 1.25 \mathrm{~mol} \%$ ) and (4-chloro-2-methylphenyl)magnesium chloride (prepared according to example procedure $\mathbf{1 . 3 c}$ from 2-bromo-5-chlorotoluene $(0.23 \mathrm{~mL}, 1.75 \mathrm{mmol}, 1.2$ equiv.) in anhydrous THF $(4 \mathrm{~mL})$ using $i$-propylmagnesium chloride/lithium chloride complex $(1.57 \mathrm{~mL}$ of a 1.3 $\mathrm{M}$ solution in THF, $2.05 \mathrm{mmol}, 1.4$ equiv.), and stirring overnight at room temperature). Upon completion, the reaction was worked up and extracted as for example procedure 1.3e, using EtOAc instead of $\mathrm{Et}_{2} \mathrm{O}$. Column chromatography $\left(3 \% \mathrm{Et}_{2} \mathrm{O} / 40-60\right.$ petroleum ether) afforded the title compound (514 mg, $1.30 \mathrm{mmol}, 89 \%)$ as a white powder. This compound can be recrystallised from hexane/TBME (3:1) to give colourless crystals;

m.p. $93-95^{\circ} \mathrm{C}$;

$\mathbf{R}_{\mathbf{f}} 0.35$ ( $8 \% \mathrm{Et}_{2} \mathrm{O} / 40-60$ petroleum ether);

IR (thin film, $v_{\max } / \mathrm{cm}^{-1}$ ) 3066, 2922, 2238, 1594, 1485, 1454, 1373, 1334, 1210, 1188, 1174, 1092, $1056,922,890,814,771,704,688,658$;

${ }^{1} \mathbf{H}$ NMR $\left(400 \mathrm{MHz}, \mathrm{CDCl}_{3}\right) \delta_{\mathrm{H}} 7.59(2 \mathrm{H}, \mathrm{d}, J=8.1 \mathrm{~Hz}, H 3), 7.39-7.29$ (5H, m, H4, H5, H6), 7.29$7.21(3 \mathrm{H}, \mathrm{m}, H 2, H 10), 7.17(1 \mathrm{H}, \mathrm{s}, H 8), 7.08(1 \mathrm{H}, \mathrm{d}, J=8.1 \mathrm{~Hz}, H 9), 2.43(3 \mathrm{H}, \mathrm{s}, H 1), 2.36(3 \mathrm{H}, \mathrm{s}$, $H 7)$;

${ }^{13}$ C NMR $\left(101 \mathrm{MHz}, \mathrm{CDCl}_{3}\right) \delta_{\mathrm{C}} 145.1,141.6,138.8,133.5,133.0,132.6,129.5,129.4,129.1,128.3$, 128.2, 126.2, 125.8, 121.0, 87.4, 68.5, 21.7, 20.7;

HRMS (ES+) calc. for $\mathrm{C}_{28} \mathrm{H}_{18}{ }^{35} \mathrm{ClNNaO} 2 \mathrm{~S}[\mathrm{M}+\mathrm{Na}]^{+} 418.0639$, found 418.0640. 


\section{$N$-(Ferrocenylethynyl)- $N$-phenyltosylamide, $1 \mathrm{i}$}
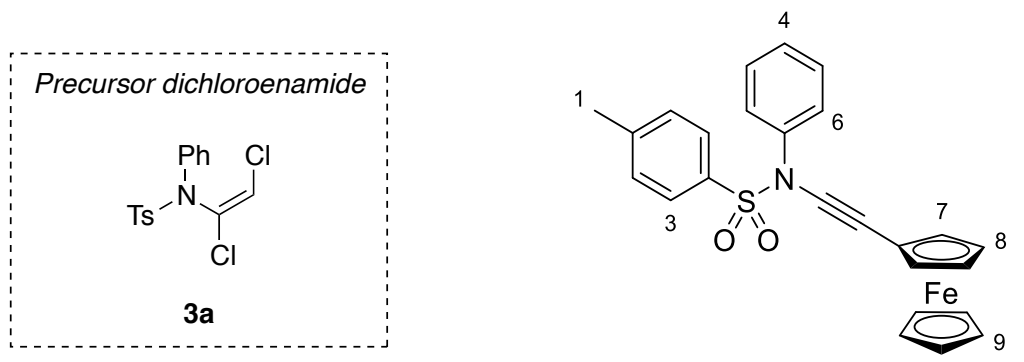

The chloroynamide was synthesised from (E)- $N$-phenyl- $N$-(1,2-dichlorovinyl)tosylamide (500 mg, $1.46 \mathrm{mmol}, 1.0$ equiv.) in anhydrous TBME $(2.0 \mathrm{~mL})$ following example procedure 1.3e. Complete consumption of the dichloroenamide was verified by TLC. The cooling bath was then removed and the reaction mixture was then allowed to warm to room temperature (approx. $21^{\circ} \mathrm{C}$ ) whilst stirring.

(2,2,6,6-Tetramethylpiperidinyl)ferrocenylmagnesium/lithium chloride complex was prepared as followed: to an oven dried, nitrogen flushed flask equipped with a magnetic stirrer bar and a septum, was added bromoferrocene (581 mg, $2.19 \mathrm{mmol}, 1.5$ equiv.) and anhydrous TBME (7 mL), and the solution cooled to $-20{ }^{\circ} \mathrm{C}$ whilst stirring. Next, $n$-butyllithium $(0.88 \mathrm{~mL}$ of a $2.5 \mathrm{M}$ solution in hexanes, 2.19 mmol, 1.5 equiv.) was added dropwise and the reaction was stirred for 2 hours at $-20^{\circ} \mathrm{C}$. Next was added a solution of 2,2,6,6-tetramethylpiperidinylmagnesium chloride/lithium chloride complex (2.19 mL of a $1.0 \mathrm{M}$ solution in toluene/THF (1:1), $2.19 \mathrm{mmol}, 1.5$ equiv.), and the solution stirred at $-20{ }^{\circ} \mathrm{C}$ for 30 minutes. After this, the resulting orange suspension was allowed to warm to room temperature and was used directly in the next step.

To the previously prepared suspension of chloroynamide in TBME was added $\mathrm{CuCN} \cdot 2 \mathrm{LiCl}(18 \mu \mathrm{L}$ of a $1.0 \mathrm{M}$ solution in THF, $18 \mu \mathrm{mol}, 1.25 \mathrm{~mol} \%)$. The suspension of (2,2,6,6-tetramethylpiperidinyl) ferrocenylmagnesium /lithium chloride complex was then transferred, by syringe, to this mixture dropwise over 1 minute, and the reaction was stirred for 30 minutes at room temperature. Reaction completion was then verified by TLC. Upon completion, the reaction was worked up and extracted as for example procedure 1.3e, using EtOAc instead of $\mathrm{Et}_{2} \mathrm{O}$. Column chromatography (10\% $\mathrm{Et}_{2} \mathrm{O} /$ pentane) afforded the title compound (386 $\mathrm{mg}, 0.848 \mathrm{mmol}, 58 \%$ ) as an orange solid. This compound can be recrystallised from heptane/benzene (2:1) to give orange needles;

m.p. $114-115^{\circ} \mathrm{C}$;

$\mathbf{R}_{\mathbf{f}} 0.21\left(10 \% \mathrm{Et}_{2} \mathrm{O} /\right.$ pentane $)$;

IR (thin film, $v_{\max } / \mathrm{cm}^{-1}$ ) 3095, 2245, 1594, 1490, 1455, 1371, 1306, 1209, 1187, 1172, 1106, 1090, $1026,1002,908,814,763,732,710,691,659$;

${ }^{1} \mathbf{H}$ NMR $\left(400 \mathrm{MHz}, \mathrm{CDCl}_{3}\right) \delta_{\mathrm{H}} 7.68-7.61(2 \mathrm{H}, \mathrm{m}, H 3), 7.38-7.27(7 \mathrm{H}, \mathrm{m}, H 2, H 4, H 5, H 6), 4.41$ $(2 \mathrm{H}, \mathrm{t}, J=1.9 \mathrm{~Hz}, H 7), 4.28-4.23(5 \mathrm{H}, \mathrm{m}, H 9), 4.21(2 \mathrm{H}, \mathrm{t}, J=1.9 \mathrm{~Hz}, H 8), 2.47(3 \mathrm{H}, \mathrm{s}, H 1)$; 
${ }^{13} \mathrm{C}$ NMR $\left(101 \mathrm{MHz}, \mathrm{CDCl}_{3}\right) \delta_{\mathrm{C}} 144.8,139.2,133.1,129.4,129.0,128.3,128.0,126.0,78.8,72.1$, 69.7, 69.5, 68.9, 63.9, 21.7;

HRMS (ES+) calc. for $\mathrm{C}_{25} \mathrm{H}_{21}{ }^{56} \mathrm{FeNO}_{2} \mathrm{~S}[\mathrm{M}]^{+}$455.0637, found 455.0636. 


\section{$N$-(Naphthalen-1-ylethynyl)- $N$-phenyltosylamide, $\mathbf{1 j}$}
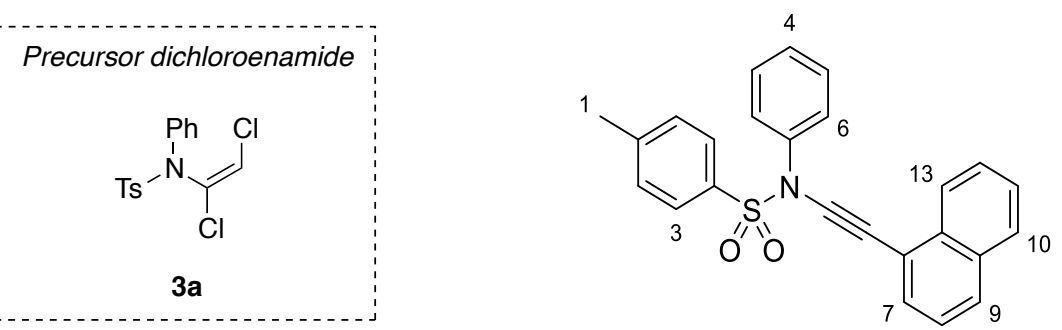

Following example procedure 1.3e: Synthesised from (E)- $N$-phenyl- $N$-(1,2-dichlorovinyl)tosylamide (500 mg, $1.46 \mathrm{mmol}, 1.0$ equiv.) in anhydrous TBME $(2.0 \mathrm{~mL})$ using LiHMDS (freshly prepared according to example procedure 1.3e, 1.2 equiv.), $\mathrm{CuCN} \cdot 2 \mathrm{P}(\mathrm{OMe})_{3}(183 \mu \mathrm{L}$ of a $0.1 \mathrm{M}$ solution in THF, $18.3 \mu \mathrm{mol}, 1.25 \mathrm{~mol} \%)$ and 1-naphthylmagnesium bromide $(3.20 \mathrm{~mL}$ of a $0.5 \mathrm{M}$ solution in 2-MeTHF, $1.50 \mathrm{mmol}, 1.1$ equiv.). Upon completion, the reaction was worked up and extracted as for example procedure 1.3e, using EtOAc instead of $\mathrm{Et}_{2} \mathrm{O}$. Column chromatography $\left(6 \% \mathrm{Et}_{2} \mathrm{O} / 40-60\right.$ petroleum ether), followed by recrystallisation from dibutyl ether afforded the title compound (498 mg, $1.25 \mathrm{mmol}, 86 \%$ ) as colourless crystals.

m.p. $100-101{ }^{\circ} \mathrm{C}$;

$\mathbf{R}_{\mathbf{f}} 0.26$ (50\% toluene/40-60 petroleum ether);

IR (thin film, $v_{\max } / \mathrm{cm}^{-1}$ ) 3058, 2233, 1594, 1489, 1372, 1172, 1089, 800, 773, 713, 691, 674, 653;

${ }^{1} \mathbf{H}$ NMR $\left(400 \mathrm{MHz}, \mathrm{CDCl}_{3}\right) \delta_{\mathrm{H}} 8.34-8.26(1 \mathrm{H}, \mathrm{m}, H 13), 7.89-7.84(1 \mathrm{H}, \mathrm{m}, H 10), 7.81(1 \mathrm{H}, \mathrm{d}, J=$ $8.3 \mathrm{~Hz}, H 9), 7.71(2 \mathrm{H}, \mathrm{d}, J=8.2 \mathrm{~Hz}, H 3), 7.62(1 \mathrm{H}, \mathrm{dd}, J=7.1,1.0 \mathrm{~Hz}, H 7), 7.58(1 \mathrm{H}, \mathrm{ddd}, J=7.8$, 6.8, $1.5 \mathrm{~Hz}, H 12), 7.53$ (1H, ddd, $J=7.8,6.8,1.5 \mathrm{~Hz}, H 11), 7.46-7.36$ (6H, m, H4, H5, H6, H8), 7.29 $(2 \mathrm{H}, 2 \mathrm{H}, \mathrm{d}, J=8.2 \mathrm{~Hz}, H 2), 2.44(3 \mathrm{H}, \mathrm{s}, H 1)$;

${ }^{13} \mathrm{C}$ NMR $\left(101 \mathrm{MHz}, \mathrm{CDCl}_{3}\right) * \delta_{\mathrm{C}} 145.0,138.9,133.2,133.1,133.0,129.8,129.5,129.2,128.3$, $128.23,128.20,126.7,126.3,126.2,126.1,125.2,120.3,87.5,69.0,21.6$; *Note: A single ${ }^{13} \mathrm{C}$ resonance is obscured due to signal overlap.

HRMS (ES+) calc. for $\mathrm{C}_{25} \mathrm{H}_{19} \mathrm{NNaO}_{2} \mathrm{~S}[\mathrm{M}+\mathrm{Na}]^{+} 420.1029$, found 420.1029 . 


\section{$N$-(Naphthalen-2-ylethynyl)- $N$-phenyltosylamide, $1 \mathrm{k}$}
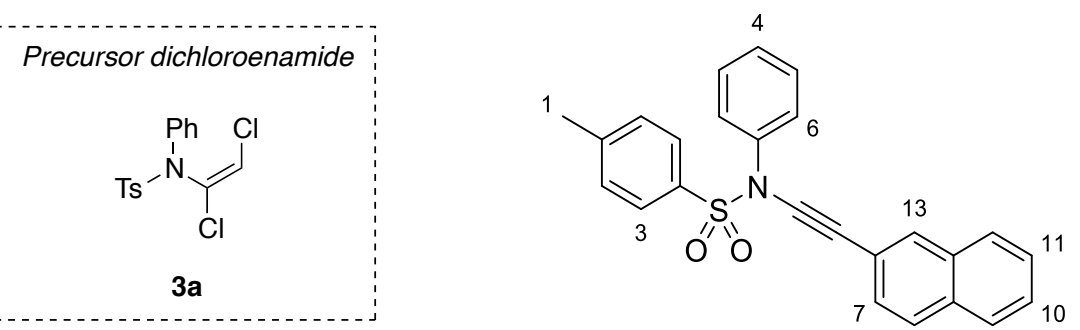

Following example procedure 1.3e: Synthesised from (E)- $N$-phenyl- $N$-(1,2-dichlorovinyl)tosylamide (500 mg, $1.46 \mathrm{mmol}, 1.0$ equiv.) in anhydrous TBME $(2.0 \mathrm{~mL})$ using LiHMDS (freshly prepared according to example procedure 1.3e, 1.2 equiv.), $\mathrm{CuCN} \cdot 2 \mathrm{P}(\mathrm{OMe})_{3}(183 \mu \mathrm{L}$ of a $0.1 \mathrm{M}$ solution in THF, $18.3 \mu \mathrm{mol}, 1.25 \mathrm{~mol} \%)$ and 2-naphthylmagnesium bromide $(6.40 \mathrm{~mL}$ of a $0.25 \mathrm{M}$ solution in 2-MeTHF, $1.50 \mathrm{mmol}, 1.1$ equiv.). Upon completion, the reaction was worked up and extracted as for example procedure 1.3e, using EtOAc instead of $\mathrm{Et}_{2} \mathrm{O}$. Column chromatography (50\% toluene/40-60 petroleum ether) afforded a yellow oil that was triturated with hexane/ $\mathrm{Et}_{2} \mathrm{O}(5: 1)$ to give a pale yellow solid. This solid was recrystallised from dibutyl ether/benzene/hexane $(\sim 2: 1: 4)$ to afford the title compound (502 mg, $1.26 \mathrm{mmol}, 86 \%$ ) as colourless crystals;

m.p. $84-85^{\circ} \mathrm{C}$;

$\mathbf{R}_{\mathbf{f}} 0.17$ (50\% toluene/40-60 petroleum ether);

IR (thin film, $v_{\max } / \mathrm{cm}^{-1}$ ) 3058, 2236, 1595, 1489, 1372, 1174, 1090, 815, 764, 748, 715, 691, 666, 649 ;

${ }^{1} \mathbf{H}$ NMR $\left(400 \mathrm{MHz}, \mathrm{CDCl}_{3}\right) \delta_{\mathrm{H}} 7.91(1 \mathrm{H}$, br. s, H13), 7.85-7.74 (3H, m, H8, H9, H12), $7.67(2 \mathrm{H}, \mathrm{d}$, $J=8.2 \mathrm{~Hz}, H 3), 7.53-7.46(2 \mathrm{H}, \mathrm{m}, H 10, H 11), 7.45(1 \mathrm{H}, \mathrm{dd}, J=8.4,1.3 \mathrm{~Hz}, H 7), 7.41-7.33$ (5H, m, $H 4, H 5, H 6), 7.31(2 \mathrm{H}, \mathrm{d}, J=8.2 \mathrm{~Hz}, H 2), 2.45(3 \mathrm{H}, \mathrm{s}, H 1)$;

${ }^{13}$ C NMR $\left(101 \mathrm{MHz}, \mathrm{CDCl}_{3}\right) \delta_{\mathrm{C}} 145.0,138.9,132.9,132.6,131.0,129.5,129.1,128.28,128.26$, $127.9,127.7,127.6,126.53,126.50,126.3,119.9,83.3,70.9,21.72,21.68$; *Note: Two ${ }^{13} \mathrm{C}$ resonances are obscured due to signal overlap.

HRMS (ES+) calc. for $\mathrm{C}_{25} \mathrm{H}_{19} \mathrm{NNaO}_{2} \mathrm{~S}[\mathrm{M}+\mathrm{Na}]^{+} 420.1029$, found 420.1029 . 

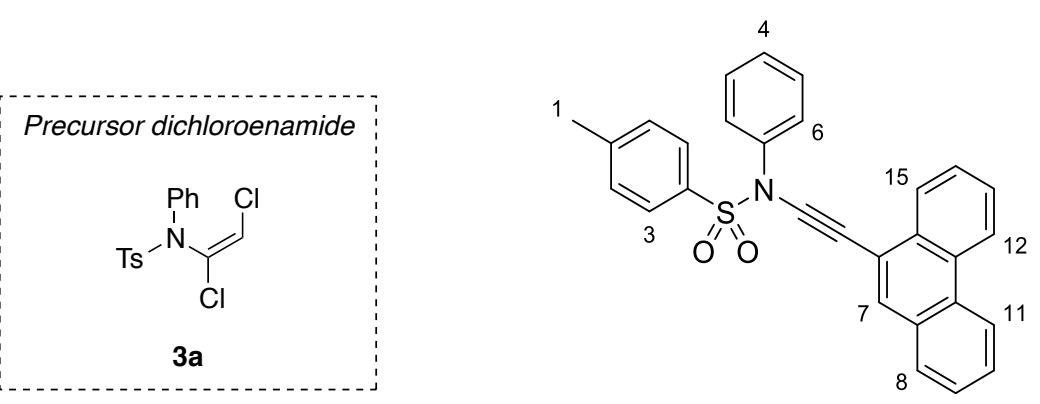

Following example procedure 1.3e: Synthesised from $(E)-N$-phenyl- $N$-(1,2-dichlorovinyl)tosylamide (500 mg, $1.46 \mathrm{mmol}, 1.0$ equiv.) in anhydrous TBME (2.0 mL) using LiHMDS (freshly prepared according to example procedure $1.3 \mathrm{e}, 1.2$ equiv.), $\mathrm{CuCN} \cdot 2 \mathrm{P}(\mathrm{OMe})_{3}(183 \mu \mathrm{L}$ of a $0.1 \mathrm{M}$ solution in THF, $18.3 \mu \mathrm{mol}, 1.25 \mathrm{~mol} \%)$ and 9-phenanthrylmagnesium bromide $(3.20 \mathrm{~mL}$ of a $0.5 \mathrm{M}$ solution in THF, $1.50 \mathrm{mmol}$, 1.1 equiv.). Upon completion, the reaction was worked up and extracted as for example procedure 1.3e, using EtOAc instead of $\mathrm{Et}_{2} \mathrm{O}$. Column chromatography (50\% toluene/40-60 petroleum ether) afforded the title compound (533 $\mathrm{mg}, 1.19 \mathrm{mmol}, 81 \%)$ as a white, semi-crystalline foam. This compound can be crystallised by vapour diffusion of pentane into a concentrated solution of the title compound in benzene to give colourless crystals;

m.p. $120-121^{\circ} \mathrm{C}$;

$\mathbf{R}_{\mathbf{f}} 0.25$ ( $50 \%$ toluene $/ 40-60$ petroleum ether);

IR (thin film, $v_{\max } / \mathrm{cm}^{-1}$ ) 3062, 2232, 1594, 1490, 1451, 1372, 1271, 1214, 1187, 1174, 892, 813, 751, 726, 705, 690, 658;

${ }^{1} \mathbf{H}$ NMR $\left(400 \mathrm{MHz}, \mathrm{CDCl}_{3}\right) \delta_{\mathrm{H}} 8.71-8.66(1 \mathrm{H}, \mathrm{m}, H 12), 8.64(1 \mathrm{H}, \mathrm{d}, J=8.3 \mathrm{~Hz}, H 11), 8.44-8.36$ (1H, m, H15), $7.92(1 \mathrm{H}, \mathrm{s}, H 7), 7.82(1 \mathrm{H}, \mathrm{dd}, J=7.8,1.3 \mathrm{~Hz}, H 8), 7.75-7.70$ (2H, m, H3), 7.73-7.65 (2H, m, H13, H14), 7.65 (1H, ddt, $J=8.3,6.8,1.3 \mathrm{~Hz}, H 10), 7.59$ (1H, ddt, $J=7.8,6.8,1.3 \mathrm{~Hz}, H 9)$, 7.51-7.46 (2H, m, H5), 7.46-7.36 (3H, m, H4, H6), 7.29 (2H, d, $J=8.1 \mathrm{~Hz}, H 2), 2.43$ (3H, s, H1);

${ }^{13} \mathbf{C}$ NMR $\left(101 \mathrm{MHz}, \mathrm{CDCl}_{3}\right) \delta_{\mathrm{C}} 145.1,138.9,133.0,131.2,131.1,130.9,130.02,129.96,129.6$, $129.2,128.33,128.25,128.23,127.2,127.1,127.0,126.91,126.88,126.3,122.7,122.5,119.0,87.2$, 69.2, 21.6;

HRMS (ES+) calc. for $\mathrm{C}_{29} \mathrm{H}_{21} \mathrm{NNaO}_{2} \mathrm{~S}[\mathrm{M}+\mathrm{Na}]^{+} 470.1185$, found 470.1185 . 


\section{$N$-((4-Fluorophenyl)ethynyl)- $N$-phenyltosylamide, $1 \mathrm{~m}$}
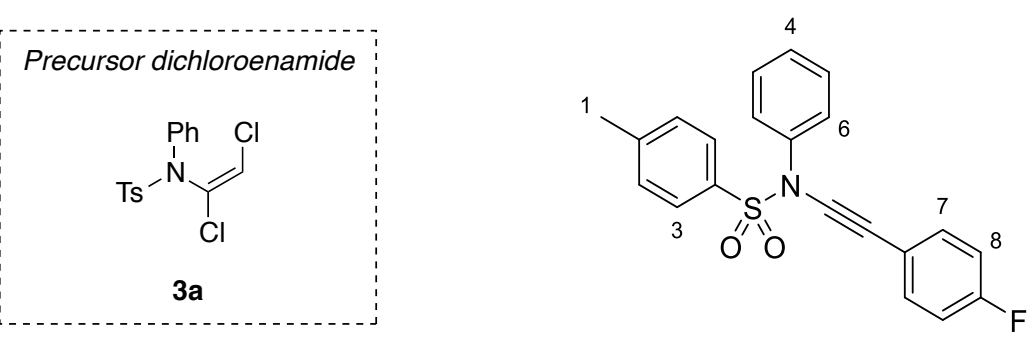

Following example procedure 1.3e: Synthesised from (E)- $N$-phenyl- $N$-(1,2-dichlorovinyl)tosylamide (500 mg, 1.46 mmol, 1.0 equiv.) in anhydrous TBME (2.0 mL) using LiHMDS (freshly prepared according to example procedure 1.3e, 1.2 equiv.), $\mathrm{CuCN} \cdot 2 \mathrm{P}(\mathrm{OMe})_{3}(183 \mu \mathrm{L}$ of a $0.1 \mathrm{M}$ solution in THF, $18.3 \mu \mathrm{mol}, 1.25 \mathrm{~mol} \%)$ and 4-fluorophenylmagnesium bromide $(1.50 \mathrm{~mL}$ of a $1.0 \mathrm{M}$ solution in THF, $1.50 \mathrm{mmol}, 1.03$ equiv.). Upon completion, the reaction was worked up and extracted as for example procedure 1.3e. Column chromatography $\left(3 \% \mathrm{Et}_{2} \mathrm{O} / 40-60\right.$ petroleum ether) afforded a pale yellow solid which was recrystallisated from hexane:TBME (3:1) to give the title compound (451 mg, $1.23 \mathrm{mmol}, 84 \%$ ) as colourless needles;

m.p. $78-79{ }^{\circ} \mathrm{C}$;

$\mathbf{R}_{\mathbf{f}} 0.18\left(6 \% \mathrm{CH}_{2} \mathrm{Cl}_{2} / 4 \%\right.$ EtOAc/40-60 petroleum ether);

IR (thin film, $v_{\max } / \mathrm{cm}^{-1}$ ) 3067, 2243, 1599, 1508, 1489, 1372, 1229, 1174, 1091, 922, 892, 836, 813, $768,723,691,668,649$;

${ }^{1} \mathbf{H}$ NMR $\left(400 \mathrm{MHz}, \mathrm{CDCl}_{3}\right) \delta_{\mathrm{H}} 7.61(2 \mathrm{H}, \mathrm{d}, J=8.1 \mathrm{~Hz}, H 3), 7.42-7.27(9 \mathrm{H}, \mathrm{m}, H 4, H 5, H 6, H 7)$, $7.00(2 \mathrm{H}, \mathrm{t}, J=8.7 \mathrm{~Hz}, H 8), 2.45(3 \mathrm{H}, \mathrm{s}, H 1)$;

${ }^{13}$ C NMR $\left(101 \mathrm{MHz}, \mathrm{CDCl}_{3}\right) \delta_{\mathrm{C}} 162.4(1 \mathrm{C}, \mathrm{d}, J=249 \mathrm{~Hz}), 145.0,138.8,133.5(2 \mathrm{C}, \mathrm{d}, J=7.9 \mathrm{~Hz})$, $132.9,129.5,129.1,128.3,128.2,126.3,118.6(1 \mathrm{C}, \mathrm{d}, J=3.2 \mathrm{~Hz}), 115.6$ (2C, d, $J=22.3 \mathrm{~Hz}), 82.6$, 69.3, 21.7;

${ }^{19}$ F NMR $\left(376 \mathrm{MHz}, \mathrm{CDCl}_{3}\right) \delta_{\mathrm{F}}-111.2(1 \mathrm{~F}, \mathrm{tt}, J=8.7,5.5 \mathrm{~Hz})$;

HRMS (ES+) calc. for $\mathrm{C}_{21} \mathrm{H}_{16} \mathrm{FNNaO}_{2} \mathrm{~S}[\mathrm{M}+\mathrm{Na}]^{+}$388.0778, found 388.0779. 


\section{$N$-((2-Bromophenyl)ethynyl)- $N$-phenyltosylamide, $1 \mathrm{n}$}
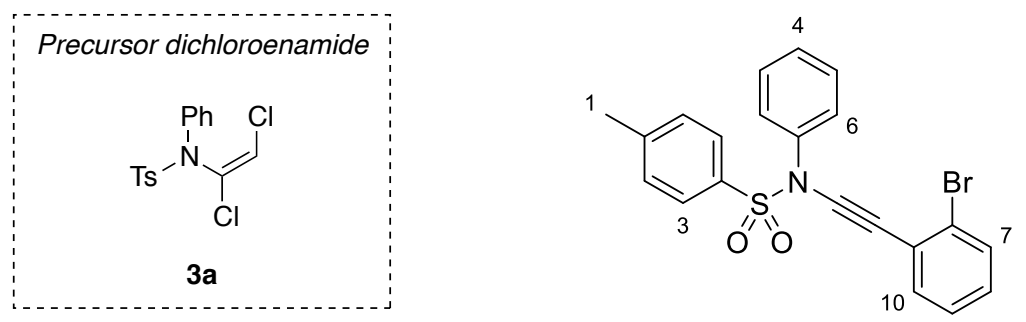

Following example procedure 1.3e: Synthesised from $(E)-N$-phenyl- $N$-(1,2-dichlorovinyl)tosylamide (500 mg, $1.46 \mathrm{mmol}, 1.0$ equiv.) in anhydrous TBME $(2.0 \mathrm{~mL})$ using LiHMDS (freshly prepared according to example procedure $1.3 \mathrm{e}, 1.2$ equiv.), $\mathrm{CuCN} \cdot 2 \mathrm{P}(\mathrm{OMe})_{3}(183 \mu \mathrm{L}$ of a $0.1 \mathrm{M}$ solution in THF, $18.3 \mu \mathrm{mol}, 1.25 \mathrm{~mol} \%$ ) and 2-bromophenylmagnesium chloride/lithium chloride (prepared according to example procedure $\mathbf{1 . 3 c}$ from 2-bromoiodobenzene ( $225 \mu \mathrm{L}, 1.75 \mathrm{mmol}, 1.2$ equiv.) in anhydrous THF $(3 \mathrm{~mL})$ using $i$-propylmagnesium chloride/lithium chloride $(1.57 \mathrm{~mL}$ of a $1.3 \mathrm{M}$ solution in THF, $2.05 \mathrm{mmol}, 1.4$ equiv.) and stirring for 1 hour at $-20{ }^{\circ} \mathrm{C}$ ). Upon completion, the reaction was worked up and extracted as for example procedure 1.3e. Column chromatography (10\% $\mathrm{Et}_{2} \mathrm{O} / 40-60$ petroleum ether) afforded a pale yellow oil that was crystallised from dibutyl ether:hexane (2:1) to afford the title compound (474 mg, $1.11 \mathrm{mmol}, 76 \%)$ as colourless needles;

m.p. $68-69{ }^{\circ} \mathrm{C}$;

$\mathbf{R}_{\mathbf{f}} 0.23\left(10 \% \mathrm{Et}_{2} \mathrm{O} / 40-60\right.$ petroleum ether);

IR (thin film, $v_{\max } / \mathrm{cm}^{-1}$ ) 3065, 2238, 1594, 1490, 1372, 1187, 1172, 1088, 1026, 891, 812, 789, 751, 732, 704, 686, 658;

${ }^{1} \mathbf{H}$ NMR $\left(400 \mathrm{MHz}, \mathrm{CDCl}_{3}\right) \delta_{\mathrm{H}} 7.69-7.63(2 \mathrm{H}, \mathrm{m}, H 3), 7.54(1 \mathrm{H}, \mathrm{dd}, J=8.1,1.1 \mathrm{~Hz}, H 7), 7.43(1 \mathrm{H}$, dd, $J=7.9,1.8 \mathrm{~Hz}, H 10), 7.40-7.31(5 \mathrm{H}, \mathrm{m}, H 4, H 5, H 6), 7.26(2 \mathrm{H}$, br. d, $J=7.8 \mathrm{~Hz}, H 2), 7.24(1 \mathrm{H}$, ddd, $J=7.9,7.6,1.1 \mathrm{~Hz}, H 9), 7.13(1 \mathrm{H}, \mathrm{ddd}, J=8.1,7.6,1.8 \mathrm{~Hz}, H 8), 2.43(3 \mathrm{H}, \mathrm{s}, H 1)$;

${ }^{13} \mathrm{C}$ NMR $\left(101 \mathrm{MHz}, \mathrm{CDCl}_{3}\right) \delta_{\mathrm{C}} 145.0,138.7,133.1,132.9,132.3,129.5,129.1,129.0,128.34$, $128.28,127.0,126.3,125.2,124.9,87.2,69.5,21.7$;

HRMS (ES+) calc. for $\mathrm{C}_{21} \mathrm{H}_{16}{ }^{79} \mathrm{BrNNaO}_{2} \mathrm{~S}[\mathrm{M}+\mathrm{Na}]^{+}$447.9977, found 447.9978. 


\section{$N$-Phenyl- $N$-((4-(trifluoromethyl)phenyl)ethynyl)tosylamide, 10}
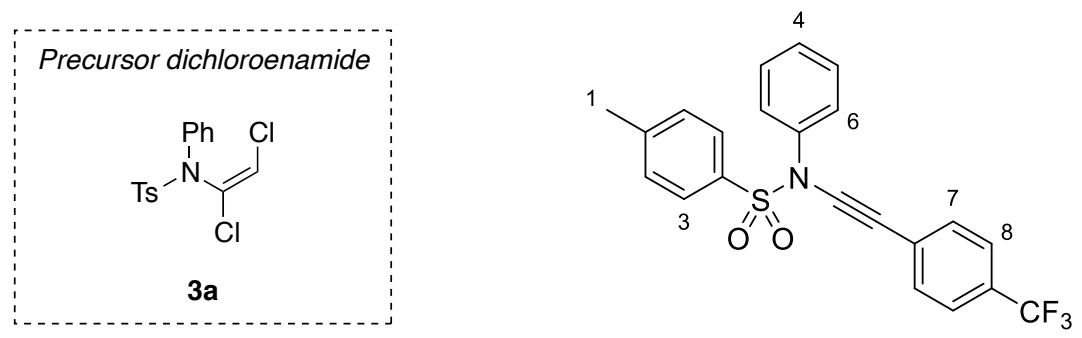

Following example procedure 1.3e: Synthesised from $(E)-N$-phenyl- $N$-(1,2-dichlorovinyl)tosylamide (500 mg, $1.46 \mathrm{mmol}, 1.0$ equiv.) in anhydrous TBME $(2.0 \mathrm{~mL})$ using LiHMDS (freshly prepared according to example procedure $1.3 \mathrm{e}, 1.2$ equiv. $), \mathrm{CuCN} \cdot 2 \mathrm{P}(\mathrm{OMe})_{3}(183 \mu \mathrm{L}$ of a $0.1 \mathrm{M}$ solution in THF, $18.3 \mu \mathrm{mol}, 1.25 \mathrm{~mol} \%$ ) and 4-(trifluoromethyl)phenylmagnesium chloride (prepared according to example procedure 1.3c from 4-iodobenzotrifluoride $(0.26 \mathrm{~mL}, 1.75 \mathrm{mmol}, 1.2$ equiv.) in anhydrous THF $(4 \mathrm{~mL})$, using $i$-propylmagnesium chloride $(1.02 \mathrm{~mL}$ of a $2.0 \mathrm{M}$ solution in THF, 2.05 mmol, 1.4 equiv.) and stirring for 30 minutes at $-20{ }^{\circ} \mathrm{C}$ ). Upon completion, the reaction was worked up and extracted as for example procedure 1.3e, using EtOAc instead of $\mathrm{Et}_{2} \mathrm{O}$. Column chromatography ( $10 \% \mathrm{CH}_{2} \mathrm{Cl}_{2} / 10 \% \mathrm{Et}_{2} \mathrm{O} / 40-60$ petroleum ether) afforded a pale yellow solid which was recrystallised from hexane:TBME (3:1) to give the title compound (545 mg, $1.31 \mathrm{mmol}, 90 \%)$ as colourless needles;

m.p. $139-140{ }^{\circ} \mathrm{C}$;

$\mathbf{R}_{\mathbf{f}} 0.21\left(10 \% \mathrm{Et}_{2} \mathrm{O} / 40-60\right.$ petroleum ether);

IR (thin film, $v_{\max } / \mathrm{cm}^{-1}$ ) 3068, 2237, 1594, 1488, 1375, 1320, 1168, 1124, 1105, 1071, 1017, 812, 684, 655;

${ }^{1} \mathbf{H}$ NMR $\left(400 \mathrm{MHz}, \mathrm{CDCl}_{3}\right) \delta_{\mathrm{H}} 7.62(2 \mathrm{H}, \mathrm{d}, J=8.1 \mathrm{~Hz}, H 3), 7.55(2 \mathrm{H}, \mathrm{d}, J=8.1 \mathrm{~Hz}, H 8), 7.47(2 \mathrm{H}$, d, $J=8.1 \mathrm{~Hz}, H 7), 7.40-7.33$ (3H, m, H5, H4), 7.33-7.27 (4H, m, H2, H6), 2.45 (3H, s, H1);

${ }^{13} \mathrm{C}$ NMR $\left(101 \mathrm{MHz}, \mathrm{CDCl}_{3}\right) \delta_{\mathrm{C}} 145.2,138.5,132.9,131.1,129.6,129.4(2 \mathrm{C}, \mathrm{q}, J=33.4 \mathrm{~Hz}), 129.2$, 128.5, 128.2, 126.6, 126.3, 125.2 (2C, q, $J=3.7 \mathrm{~Hz}), 123.9$ (1C, q, $J=271.8 \mathrm{~Hz}), 85.5,69.6,21.7$;

${ }^{19} \mathbf{F}$ NMR $\left(376 \mathrm{MHz}, \mathrm{CDCl}_{3}\right) \delta_{\mathrm{F}}-62.7$;

HRMS (ES+) calc. for $\mathrm{C}_{22} \mathrm{H}_{16} \mathrm{~F}_{3} \mathrm{NNaO}_{2} \mathrm{~S}[\mathrm{M}+\mathrm{Na}]^{+}$438.0746, found 438.0746. 


\section{Methyl 3-(( $N$-phenyltosylamido)ethynyl)benzoate, 1p}
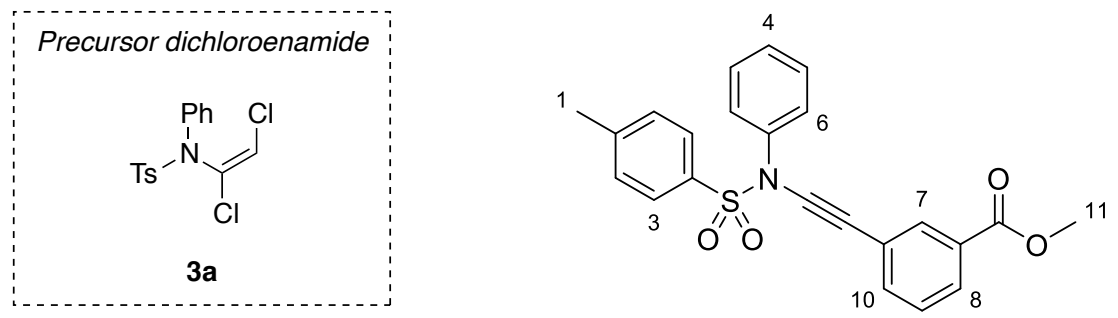

Following example procedure 1.3e: Synthesised from $(E)-N$-phenyl- $N$-(1,2-dichlorovinyl)tosylamide (500 mg, $1.46 \mathrm{mmol}, 1.0$ equiv.) in anhydrous TBME $(2.0 \mathrm{~mL})$ using LiHMDS (freshly prepared according to example procedure $1.3 e, 1.2$ equiv. $), \mathrm{CuCN} \cdot 2 \mathrm{P}(\mathrm{OMe})_{3}(183 \mu \mathrm{L}$ of a $0.1 \mathrm{M}$ solution in THF, $18.3 \mu \mathrm{mol}, 1.25 \mathrm{~mol} \%$ ) and (3-(methoxycarbonyl)phenyl)magnesium chloride (prepared according to example procedure 1.3c from methyl 3-iodobenzoate (459 mg, $1.75 \mathrm{mmol}, 1.2$ equiv.) in anhydrous THF ( $4 \mathrm{~mL})$, using $i$-propylmagnesium chloride $(1.02 \mathrm{~mL}$ of a $2.0 \mathrm{M}$ solution in THF, 2.05 mmol, 1.4 equiv.) and stirring for 1 hour at $-20{ }^{\circ} \mathrm{C}$ ). Upon completion, the reaction was worked up and extracted as for example procedure 1.3e, using EtOAc instead of $\mathrm{Et}_{2} \mathrm{O}$. Column chromatography $\left(10 \% \mathrm{CH}_{2} \mathrm{Cl}_{2} / 10 \% \mathrm{Et}_{2} \mathrm{O} / 40-60\right.$ petroleum ether) afforded a pale yellow solid which was recrystallised from hexane:TBME $(3: 1)$ to give the title compound (545 $\mathrm{mg}, 1.31 \mathrm{mmol}, 90 \%)$ as colourless needles;

m.p. $90-91{ }^{\circ} \mathrm{C}$;

$\mathbf{R}_{\mathbf{f}} 0.21\left(10 \% \mathrm{Et}_{2} \mathrm{O} / 40-60\right.$ petroleum ether $)$;

IR (thin film, $v_{\max } / \mathrm{cm}^{-1}$ ) 2951, 2240, 1722, 1595, 1490, 1439, 1373, 1282, 1259, 1172, 1112, 1088 , $980,894,859,814,784,752,689$;

${ }^{1} \mathbf{H}$ NMR $\left(400 \mathrm{MHz}, \mathrm{CDCl}_{3}\right) \delta_{\mathrm{H}} 8.04(1 \mathrm{H}, \mathrm{s}, H 7), 7.95(1 \mathrm{H}, \mathrm{d}, J=7.3 \mathrm{~Hz}, H 8), 7.62(2 \mathrm{H}, \mathrm{d}, J=8.1$ $\mathrm{Hz}, H 3), 7.57(1 \mathrm{H}, \mathrm{d}, J=7.1 \mathrm{~Hz}, H 10), 7.42-7.27$ (8H, m, H2, H4, H5, H6, H9), 3.92 (3H, s, H11), $2.44(3 \mathrm{H}, \mathrm{s}, H 1)$;

${ }^{13}$ C NMR $\left(101 \mathrm{MHz}, \mathrm{CDCl}_{3}\right) \delta_{\mathrm{C}} 166.4,145.1,138.7,135.4,132.8,132.4,130.3,129.6,129.2,128.8$, $128.41,128.37,128.2,126.3,123.1,83.8,69.6,52.3,21.7$;

HRMS (ES+) calc. for $\mathrm{C}_{23} \mathrm{H}_{19} \mathrm{NNaO}_{4} \mathrm{~S}[\mathrm{M}+\mathrm{Na}]^{+} 428.0927$, found 428.0925 . 

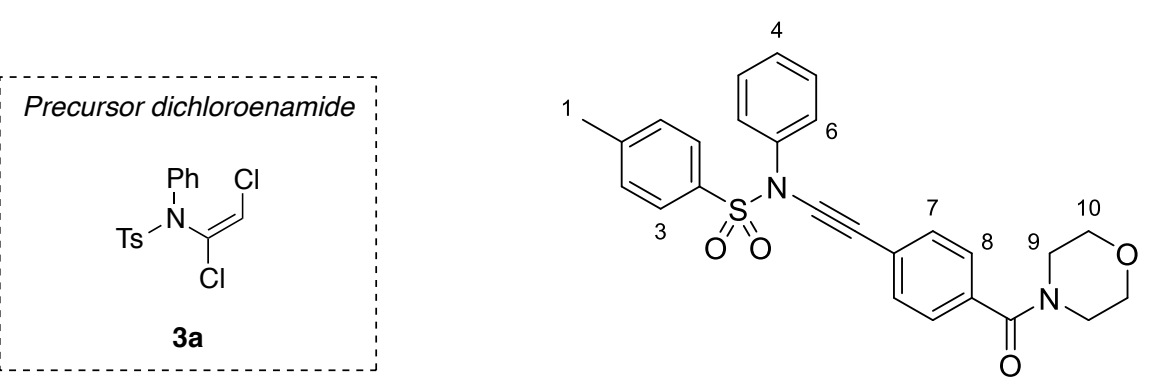

Following example procedure 1.3e: Synthesised from $(E)-N$-phenyl- $N$-(1,2-dichlorovinyl)tosylamide (500 mg, $1.46 \mathrm{mmol}, 1.0$ equiv.) in anhydrous TBME $(2.0 \mathrm{~mL})$ using LiHMDS (freshly prepared according to example procedure $1.3 e, 1.2$ equiv. $), \mathrm{CuCN} \cdot 2 \mathrm{P}(\mathrm{OMe})_{3}(183 \mu \mathrm{L}$ of a $0.1 \mathrm{M}$ solution in THF, $18.3 \mu \mathrm{mol}, 1.25 \mathrm{~mol} \%$ ) and (4-(morpholine-4-carbonyl)phenyl)magnesium chloride/lithium chloride complex (prepared according to example procedure $1.3 \mathrm{c}$ from (4-bromophenyl) (morpholino)methanone (513 mg, $1.90 \mathrm{mmol}, 1.3$ equiv.) in anhydrous THF (4 mL), using $i$-propylmagnesium chloride/lithium chloride complex $(1.69 \mathrm{~mL}$ of a $1.3 \mathrm{M}$ solution in THF, $2.19 \mathrm{mmol}, 1.5$ equiv.) and stirring for 20 hours at $-5^{\circ} \mathrm{C}$ ). Upon completion, the reaction was worked up and extracted as for example procedure 1.3e, using EtOAc instead of $\mathrm{Et}_{2} \mathrm{O}$. Column chromatography ( $20 \rightarrow 30 \%$ acetone/40-60 petroleum ether) afforded the title compound (530 mg, $1.15 \mathrm{mmol}, 79 \%$ ) as a white powder. This compound can be recrystallised by vapour diffusion of pentane into a concentrated solution of the title compound in benzene to give colourless crystals;

m.p. $157-158^{\circ} \mathrm{C}$;

$\mathbf{R}_{\mathbf{f}} 0.11$ (20\% acetone/40-60 petroleum ether);

IR (thin film, $v_{\max } / \mathrm{cm}^{-1}$ ) 2966, 2921, 2857, 2238, 1630, 1429, 1373, 1278, 1258, 1173, 1114, 1065, 1012, 840, 730, 691;

${ }^{1} \mathbf{H}$ NMR $\left(400 \mathrm{MHz}, \mathrm{CDCl}_{3}\right) \delta_{\mathrm{H}}$ 7.64-6.58 (2H, m, H3), 7.44-7.39 (2H, m, H8), 7.39-7.32 (5H, m, $H 4, H 5, H 7), 7.32-7.26$ (4H, m, H2, H6), 4.13-3.18 (8H, br. m, H9, H10), 2.44 (3H, s, H1);

${ }^{13} \mathbf{C}$ NMR $\left(126 \mathrm{MHz}, \mathrm{CDCl}_{3}\right) \delta_{\mathrm{C}} 169.7,145.1,138.6,134.3,132.9,131.2,129.6,129.2,128.4,128.2$, $127.2,126.3,124.5,84.7,69.9,66.8,48.3,42.6,21.7$;

HRMS (ES+) calc. for $\mathrm{C}_{26} \mathrm{H}_{24} \mathrm{~N}_{2} \mathrm{NaO}_{4} \mathrm{~S}[\mathrm{M}+\mathrm{Na}]^{+} 483.1349$, found 483.1350 . 


\section{$N$-((4-Cyanophenyl)ethynyl)- $N$-phenyltosylamide, $1 \mathrm{r}$}
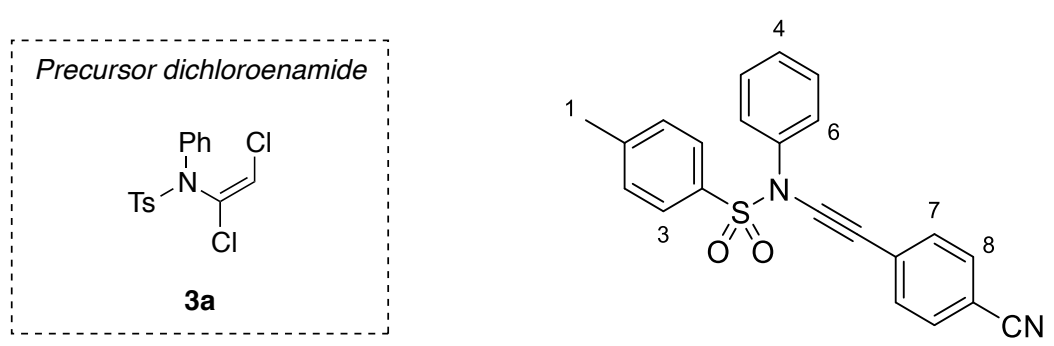

Following example procedure 1.3e: Synthesised from $(E)-N$-phenyl- $N$-(1,2-dichlorovinyl)tosylamide (500 mg, $1.46 \mathrm{mmol}, 1.0$ equiv.) in anhydrous TBME $(2.0 \mathrm{~mL})$ using LiHMDS (freshly prepared according to example procedure 1.3e, 1.2 equiv.), $\mathrm{CuCN} \cdot 2 \mathrm{P}(\mathrm{OMe})_{3}(183 \mu \mathrm{L}$ of a $0.1 \mathrm{M}$ solution in THF, $18.3 \mu \mathrm{mol}, 1.25 \mathrm{~mol} \%$ ) and 4-cyanophenylmagnesium chloride (prepared according to example procedure 1.3c from 4-iodobenzonitrile (402 $\mathrm{mg}, 1.75 \mathrm{mmol}, 1.2$ equiv.) in anhydrous THF (4 mL) using $i$-propylmagnesium chloride (1.02 $\mathrm{mL}$ of a $2.0 \mathrm{M}$ solution in THF, $2.05 \mathrm{mmol}, 1.4$ equiv.)). Upon completion, the reaction was worked up and extracted as for example procedure 1.3e, using EtOAc instead of $\mathrm{Et}_{2} \mathrm{O}$. Column chromatography $\left(5 \% \mathrm{Et}_{2} \mathrm{O} / 40-60\right.$ petroleum ether) afforded a pale yellow solid which was recrystallised from heptane: $\mathrm{Et}_{2} \mathrm{O}(2: 1)$ to give the title compound $(448 \mathrm{mg}$, $1.20 \mathrm{mmol}, 82 \%$ ) as colourless needles;

m.p. $122^{\circ} \mathrm{C}$;

$\mathbf{R}_{\mathbf{f}} 0.11\left(6 \% \mathrm{CH}_{2} \mathrm{Cl}_{2} / 4 \%\right.$ EtOAc/40-60 petroleum ether);

IR (thin film, $v_{\max } / \mathrm{cm}^{-1}$ ) 3066, 2225, 1594, 1488, 1374, 1174, 1065, 923, 892, 838, 812, 761, 710, 691, 661;

${ }^{1} \mathbf{H}$ NMR $\left(400 \mathrm{MHz}, \mathrm{CDCl}_{3}\right) \delta_{\mathrm{H}} 7.60(2 \mathrm{H}, \mathrm{d}, J=8.1 \mathrm{~Hz}, H 3), 7.57(2 \mathrm{H}, \mathrm{d}, J=8.1 \mathrm{~Hz}, H 8), 7.43(2 \mathrm{H}$, d, $J=8.1 \mathrm{~Hz}, H 7), 7.40-7.33$ (3H, m, H5, H4), 7.33-7.24 (4H, m, H2, H6), 2.44 (3H, s, H1);

${ }^{13} \mathbf{C}$ NMR $\left(101 \mathrm{MHz}, \mathrm{CDCl}_{3}\right) \delta_{\mathrm{C}} 145.4,138.2,132.8,131.9,131.1,129.7,129.3,128.6,128.1,127.9$, $126.3,118.5,110.7,87.6,69.7,21.7$;

HRMS (ES+) calc. for $\mathrm{C}_{22} \mathrm{H}_{17} \mathrm{~N}_{2} \mathrm{O}_{2} \mathrm{~S}[\mathrm{M}+\mathrm{H}]^{+} 373.1005$, found 373.0991 . 


\section{$N$-((2,6-Difluoro-3-nitrophenyl)ethynyl)- $N$-phenyltosylamide, $1 \mathrm{~s}$}
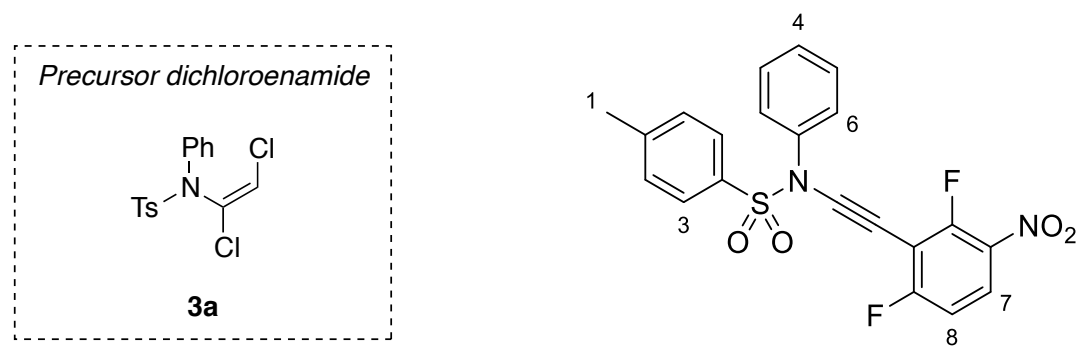

The chloroynamide was synthesised from (E)- $N$-phenyl- $N$-(1,2-dichlorovinyl)tosylamide $(500 \mathrm{mg}$, $1.46 \mathrm{mmol}, 1.0$ equiv.) in anhydrous TBME $(2.0 \mathrm{~mL})$ following example procedure 1.3e. Complete consumption of the dichloroenamide was verified by TLC. The cooling bath was then removed and the reaction mixture was then allowed to warm to room temperature (approx. $21^{\circ} \mathrm{C}$ ) whilst stirring.

(2,6-Difluoro-3-nitrophenyl)zinc chloride/lithium chloride complex was prepared and used as followed: To an oven dried, nitrogen flushed flask equipped with a magnetic stirrer bar and a septum, was added anhydrous THF $(2 \mathrm{~mL})$ and freshly distilled 2,2,6,6-tetramethylpiperidine $(0.32 \mathrm{~mL}$, $1.90 \mathrm{mmol}, 1.3$ equiv.), and the solution was cooled to $-5{ }^{\circ} \mathrm{C}$ whilst stirring. To this solution was added dropwise $n$-butyllithium ( $0.76 \mathrm{~mL}$ of a $2.5 \mathrm{M}$ solution in hexanes, $1.90 \mathrm{mmol}, 1.3$ equiv.) and the mixture stirred for 1 hour at $-5^{\circ} \mathrm{C}$. Next, $\mathrm{ZnCl}_{2}(1.08 \mathrm{~mL}$ of a $1.9 \mathrm{M}$ solution in 2-MeTHF, 2.04 mmol, 1.4 equiv.) was added and the resulting solution was stirred for 30 minutes at room temperature. Note: The resulting solution was yellow. The reaction was cooled to $-20{ }^{\circ} \mathrm{C}$ and 2,4difluoro-1-nitrobenzene (192 $\mu \mathrm{L}, 1.75 \mathrm{mmol}, 1.2$ equiv.) was added dropwise. The reaction was stirred for 30 minutes at $-20{ }^{\circ} \mathrm{C}$ and for 2 hours at room temperature, giving the requisite arylzinc chloride/lithium chloride complex as a red solution. This solution was cooled to $-20{ }^{\circ} \mathrm{C}$ and $\mathrm{CuCN} \cdot 2 \mathrm{LiCl}(73 \mu \mathrm{L}$ of a $1 \mathrm{M}$ solution in THF, $73 \mu \mathrm{mol}, 5 \mathrm{~mol} \%)$ was added. The solution was then stirred for 30 minutes at room temperature and used directly in the next step.

To the previously prepared suspension of chloroynamide in TBME was added the solution of (2,6-difluoro-3-nitrophenyl)copper(I) cyanide/zinc chloride/lithium chloride complex by syringe, and the reaction was stirred overnight at room temperature. Upon completion, the reaction was worked up and extracted as for example procedure 1.3e, using EtOAc instead of $\mathrm{Et}_{2} \mathrm{O}$. Column chromatography (10\% EtOAc/40-60 petroleum ether) afforded the title compound (398 mg, $928 \mu \mathrm{mol}, 64 \%)$ as a white powder;

m.p. $103-105^{\circ} \mathrm{C}$;

$\mathbf{R}_{\mathbf{f}} 0.21$ (10\% EtOAc/40-60 petroleum ether);

IR (thin film, $v_{\max } / \mathrm{cm}^{-1}$ ) 3094, 2244, 1584, 1537, 1487, 1461, 1376, 1353, 1332, 1288, 1188, 1174 , $1089,1026,887,801,758,688,659$; 
${ }^{1} \mathbf{H}$ NMR $\left(400 \mathrm{MHz}, \mathrm{CDCl}_{3}\right) \delta_{\mathrm{H}} 8.02(1 \mathrm{H}, \mathrm{ddd}, J=9.3,8.4,5.6 \mathrm{~Hz}, H 7), 7.63(2 \mathrm{H}, \mathrm{d}, J=8.3 \mathrm{~Hz}, H 3)$, 7.40-7.34 (3H, m, H4, H5), 7.34-7.25 (4H, m, H2, H6), 7.05 (1H, ddd, $J=9.3,7.6,1.7 \mathrm{~Hz}, H 8), 2.45$ $(3 \mathrm{H}, \mathrm{s}, H 1)$;

${ }^{13} \mathbf{C}$ NMR $\left(101 \mathrm{MHz}, \mathrm{CDCl}_{3}\right) \delta_{\mathrm{C}} 165.2(1 \mathrm{C}, \mathrm{dd}, J=263,5.6 \mathrm{~Hz}), 156.5(1 \mathrm{C}, \mathrm{dd}, J=270,5.6 \mathrm{~Hz})$, 145.6, 137.9, 134.2 (1C, m), 132.5, 129.7, 129.3, 128.7, 128.2, 126.2, 125.8 (1C, d, $J=10.3 \mathrm{~Hz})$, $111.6(1 \mathrm{C}, \mathrm{dd}, J=23.0,4.8 \mathrm{~Hz}), 105.0(1 \mathrm{C}, \mathrm{dd}, J=21.5,19.3 \mathrm{~Hz}), 94.8(1 \mathrm{C}, \mathrm{t}, J=3.2 \mathrm{~Hz}), 56.6$, 21.7 ;

${ }^{19}$ F NMR $\left(376 \mathrm{MHz}, \mathrm{CDCl}_{3}\right) \delta_{\mathrm{F}}-95.3(1 \mathrm{~F}, \mathrm{ddd}, J=13.1,8.4,1.7 \mathrm{~Hz}),-109.1(1 \mathrm{~F}, \mathrm{ddd}, J=13.1,7.6$, $5.6 \mathrm{~Hz})$;

HRMS (ES+) calc. for $\mathrm{C}_{21} \mathrm{H}_{14} \mathrm{~F}_{2} \mathrm{~N}_{2} \mathrm{NaO}_{4} \mathrm{~S}[\mathrm{M}+\mathrm{Na}]^{+}$451.0535, found 451.0534. 


\section{$N$-Phenyl- $N$-(thiophen-2-ylethynyl)tosylamide, $1 \mathrm{t}$}
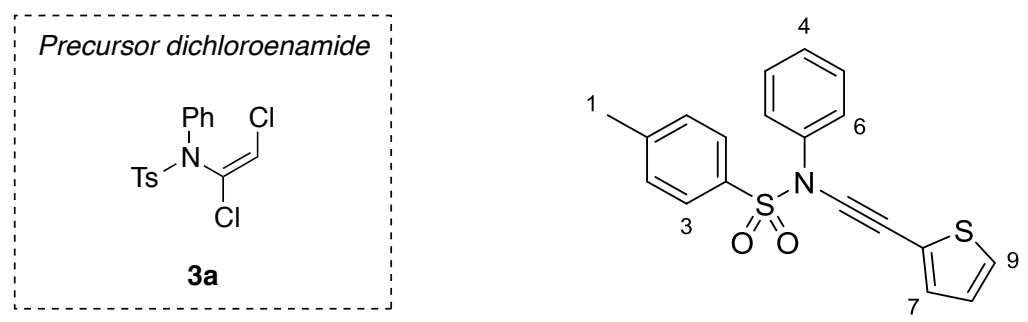

Following example procedure 1.3e: Synthesised from (E)-N-phenyl- $N$-(1,2-dichlorovinyl)tosylamide (500 mg, $1.46 \mathrm{mmol}, 1.0$ equiv.) in anhydrous TBME $(2.0 \mathrm{~mL})$ using LiHMDS (freshly prepared according to example procedure 1.3e, 1.2 equiv.), $\mathrm{CuCN} \cdot 2 \mathrm{P}(\mathrm{OMe})_{3}(183 \mu \mathrm{L}$ of a $0.1 \mathrm{M}$ solution in THF, $18.3 \mu \mathrm{mol}, 1.25 \mathrm{~mol} \%)$ and 2-thienylmagnesium bromide $(1.50 \mathrm{~mL}$ of a $1.0 \mathrm{M}$ solution in THF, $1.50 \mathrm{mmol}, 1.03$ equiv.). Upon completion, the reaction was worked up and extracted as for example procedure 1.3e, using EtOAc instead of $\mathrm{Et}_{2} \mathrm{O}$. Column chromatography $\left(10 \% \mathrm{Et}_{2} \mathrm{O} / 5 \% \mathrm{CH}_{2} \mathrm{Cl}_{2} / 40-60\right.$ petroleum ether) afforded a pale yellow solid which was recrystallised from hexane: $\mathrm{CH}_{2} \mathrm{Cl}_{2}$ :TBME $(\sim 5: 1: 1)$ to give the title compound (464 $\mathrm{mg}, 1.31 \mathrm{mmol}, 90 \%)$ as colourless crystals;

m.p. $129-130{ }^{\circ} \mathrm{C}$ (dec.);

$\mathbf{R}_{\mathbf{f}} 0.41$ (20\% $\mathrm{Et}_{2} \mathrm{O} / 40-60$ petroleum ether);

IR (thin film, $v_{\max } / \mathrm{cm}^{-1}$ ) 3069, 2229, 1595, 1491, 1372, 1172, 1089, 1052, 1017, 921, 890, 851, 813, $765,710,691,666,651$;

${ }^{1} \mathbf{H}$ NMR $\left(400 \mathrm{MHz}, \mathrm{CDCl}_{3}\right) \delta_{\mathrm{H}} 7.62(2 \mathrm{H}, \mathrm{d}, J=8.1 \mathrm{~Hz}, H 3), 7.39-7.24(8 \mathrm{H}, \mathrm{m}, H 2, H 4, H 5, H 6$, $H 7), 7.22-7.17(1 \mathrm{H}, \mathrm{m}, H 9), 6.97(1 \mathrm{H}, \mathrm{m}, H 8), 2.46(3 \mathrm{H}, \mathrm{s}, H 1)$;

${ }^{13} \mathbf{C}$ NMR $\left(101 \mathrm{MHz}, \mathrm{CDCl}_{3}\right) \delta_{\mathrm{C}} 145.1,138.8,133.0,132.9,129.5,129.1,128.33,128.25,127.9$, $127.0,126.3,122.6,86.4,63.9,21.7$;

HRMS (ES+) calc. for $\mathrm{C}_{19} \mathrm{H}_{15} \mathrm{NNaO}_{2} \mathrm{~S}_{2}[\mathrm{M}+\mathrm{Na}]^{+} 376.0436$, found 376.0438 . 


\section{$N$-(Furan-2-ylethynyl)- $N$-phenyltosylamide, 1u}
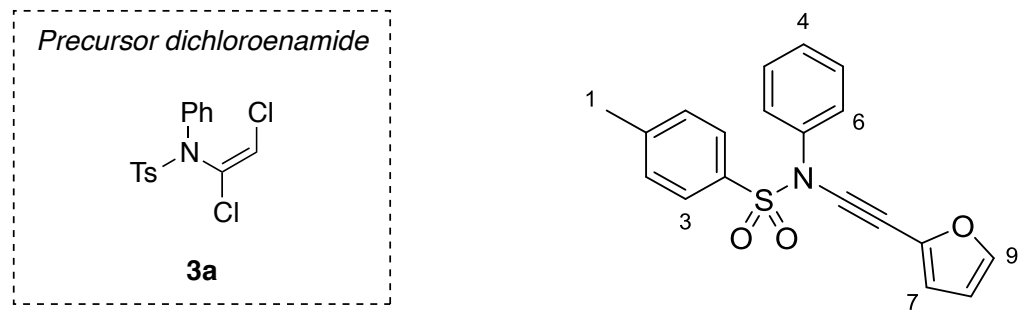

The chloroynamide was synthesised from (E)-N-phenyl- $N$-(1,2-dichlorovinyl)tosylamide (500 mg, $1.46 \mathrm{mmol}, 1.0$ equiv.) in anhydrous TBME $(2.0 \mathrm{~mL})$ following example procedure 1.3e. Complete consumption of the dichloroenamide was verified by TLC. The cooling bath was then removed and the reaction mixture was then allowed to warm to room temperature (approx. $21^{\circ} \mathrm{C}$ ) whilst stirring.

(Furan-2-yl)zinc chloride/lithium chloride complex was prepared as followed: To an oven dried, nitrogen flushed flask equipped with a magnetic stirrer bar and a septum, was added anhydrous THF $(2 \mathrm{~mL})$ and furan $\left(128 \mu \mathrm{L}, 1.75 \mathrm{mmol}, 1.2\right.$ equiv.), and the reaction cooled to $-10{ }^{\circ} \mathrm{C}$. Next, was added dropwise $n$-butyllithium $(0.76 \mathrm{~mL}$ of a $2.5 \mathrm{M}$ solution in hexanes, $1.90 \mathrm{mmol}, 1.3$ equiv. $)$ and the mixture stirred for 2 hours at $-10{ }^{\circ} \mathrm{C} . \mathrm{ZnCl}_{2}(1.08 \mathrm{~mL}$ of a $1.9 \mathrm{M}$ solution in 2-MeTHF, 2.05 mmol, 1.4 equiv.) was then added, followed by anhydrous TMEDA (307 $\mu \mathrm{L}, 2.05 \mathrm{mmol}, 1.3$ equiv.), and the resulting solution was allowed to warm to $0{ }^{\circ} \mathrm{C}$ over 30 minutes whilst stirring. $\mathrm{CuCN} \cdot 2 \mathrm{LiCl}$ (73 $\mu \mathrm{L}$ of a $1 \mathrm{M}$ solution in THF, $73 \mu \mathrm{mol}, 5 \mathrm{~mol} \%$ ) was then added and the resulting solution was then stirred for 5 minutes at $0^{\circ} \mathrm{C}$.

This solution was then transferred to the previously prepared suspension of chloroynamide in TBME by syringe and the reaction was stirred overnight at room temperature. Upon completion, the reaction was worked up and extracted as for example procedure 1.3e, using EtOAc instead of $\mathrm{Et}_{2} \mathrm{O}$. Column chromatography $\left(5 \rightarrow 10 \% \mathrm{Et}_{2} \mathrm{O} / 40-60\right.$ petroleum ether) afforded a pale yellow powder, which was recrystallised from TBME/hexane (1:1) the title compound (415 mg, $1.23 \mathrm{mmol}, 84 \%$ ) as colourless crystals;

m.p. $123-125^{\circ} \mathrm{C}$;

$\mathbf{R}_{\mathbf{f}} 0.26\left(10 \% \mathrm{Et}_{2} \mathrm{O} / 40-60\right.$ petroleum ether);

IR (thin film, $v_{\max } / \mathrm{cm}^{-1}$ ) 3067, 2230, 1593, 1490, 1372, 1173, 1088, 1011, 917, 886, 813, 748, 691, 659 ;

${ }^{1} \mathbf{H}$ NMR $\left(400 \mathrm{MHz}, \mathrm{CDCl}_{3}\right) \delta_{\mathrm{H}} 7.63(2 \mathrm{H}, \mathrm{d}, J=8.3 \mathrm{~Hz}, H 3), 7.40(1 \mathrm{H}, \mathrm{dd}, J=1.9,0.7 \mathrm{~Hz}, H 9)$, 7.37-7.24 (7H, m, H2, H4, H5, H6), $6.63(1 \mathrm{H}, \mathrm{dd}, J=3.4,0.7 \mathrm{~Hz}, H 7), 6.39(1 \mathrm{H}, \mathrm{dd}, J=3.4,1.9 \mathrm{~Hz}$, $H 8), 2.45(3 \mathrm{H}, \mathrm{s}, H 1)$; 
${ }^{13}$ C NMR $\left(101 \mathrm{MHz}, \mathrm{CDCl}_{3}\right) \delta_{\mathrm{C}} 145.1,144.1,138.6,136.6,133.1,129.6,129.2,128.4,128.2,126.3$, 117.2, 111.1, 86.9, 61.2, 21.7;

HRMS (ES+) calc. for $\mathrm{C}_{19} \mathrm{H}_{15} \mathrm{NNaO}_{3} \mathrm{~S}[\mathrm{M}+\mathrm{Na}]^{+} 360.0665$, found 360.0665 . 


\section{$t$-Butyl 2-(((N-phenyltosylamido)ethynyl)-1H-pyrrole-1-carboxylate, $1 \mathrm{v}$}
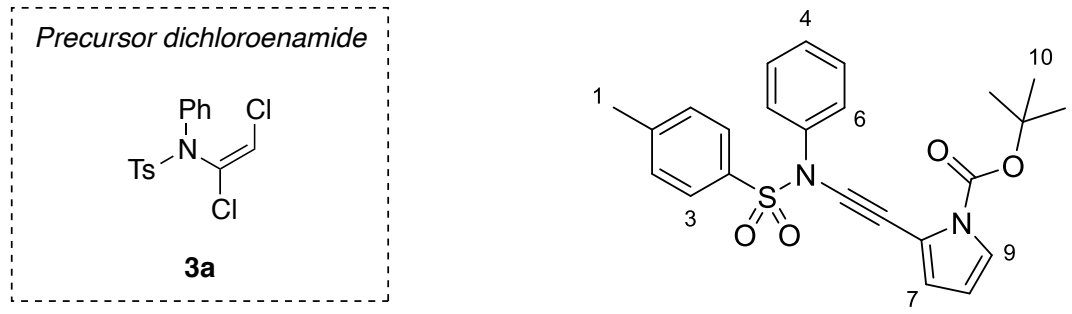

The chloroynamide was synthesised from (E)-N-phenyl- $N$-(1,2-dichlorovinyl)tosylamide (500 mg, $1.46 \mathrm{mmol}, 1.0$ equiv.) in anhydrous TBME $(2.0 \mathrm{~mL})$ following example procedure 1.3e. Complete consumption of the dichloroenamide was verified by TLC. The cooling bath was then removed and the reaction mixture was then allowed to warm to room temperature (approx. $21^{\circ} \mathrm{C}$ ) whilst stirring.

(1-(t-Butoxycarbonyl)-1H-pyrrol-2-yl)zinc chloride/lithium chloride complex was prepared as followed: To an oven dried, nitrogen flushed flask equipped with a magnetic stirrer bar and a septum, was added anhydrous THF $(2 \mathrm{~mL})$ and freshly distilled 2,2,6,6-tetramethylpiperidine $(0.32 \mathrm{~mL}$, $1.90 \mathrm{mmol}, 1.3$ equiv.), and the solution was cooled to $-5{ }^{\circ} \mathrm{C}$ whilst stirring. To this solution was added dropwise $n$-butyllithium $(0.76 \mathrm{~mL}$ of a $2.5 \mathrm{M}$ solution in hexanes, $1.90 \mathrm{mmol}, 1.3$ equiv.) and the mixture stirred for 1 hour at $-5{ }^{\circ} \mathrm{C}$. Next, the reaction was cooled to $-78{ }^{\circ} \mathrm{C}$ and $N$-Boc pyrrole (293 $\mu \mathrm{L}, 1.75 \mathrm{mmol}, 1.2$ equiv.) was added and the reaction stirred at $-78{ }^{\circ} \mathrm{C}$ for 1 hour. $\mathrm{ZnCl}_{2}(1.08$ $\mathrm{mL}$ of a $1.9 \mathrm{M}$ solution in 2-MeTHF, $2.05 \mathrm{mmol}, 1.4$ equiv.) was then added, followed by anhydrous TMEDA ( $307 \mu \mathrm{L}, 2.05 \mathrm{mmol}, 1.3$ equiv.), and the resulting solution was allowed to warm to $0{ }^{\circ} \mathrm{C}$ over 30 minutes whilst stirring. $\mathrm{CuCN} \cdot 2 \mathrm{LiCl}(73 \mu \mathrm{L}$ of a $1 \mathrm{M}$ solution in THF, $73 \mu \mathrm{mol}, 5 \mathrm{~mol} \%$ ) was then added and the resulting solution was then stirred for 5 minutes at $0^{\circ} \mathrm{C}$.

This solution was then transferred to the previously prepared suspension of chloroynamide in TBME by syringe and the reaction was stirred overnight at room temperature. Upon completion, the reaction was worked up and extracted as for example procedure 1.3e, using EtOAc instead of $\mathrm{Et}_{2} \mathrm{O}$. Column chromatography ( $5 \rightarrow 10 \% \mathrm{Et}_{2} \mathrm{O} / 40-60$ petroleum ether) afforded the title compound (493 $\mathrm{mg}$, $1.13 \mathrm{mmol}, 77 \%$ ) as colourless crystals. The compound crystallises spontaneously from the column fractions;

m.p. $130{ }^{\circ} \mathrm{C}$;

$\mathbf{R}_{\mathbf{f}} 0.27\left(10 \% \mathrm{Et}_{2} \mathrm{O} / 40-60\right.$ petroleum ether);

IR (thin film, $v_{\max } / \mathrm{cm}^{-1}$ ) 2981, 2238, 1744, 1594, 1490, 1404, 1371, 1347, 1317, 1288, 1173, 1144, $1089,1054,1002,884,844,814,768,733,712,692,660$;

${ }^{1} \mathbf{H}$ NMR $\left(400 \mathrm{MHz}, \mathrm{CDCl}_{3}\right) \delta_{\mathrm{H}} 7.70-7.63(2 \mathrm{H}, \mathrm{m}, H 3), 7.35-7.24(8 \mathrm{H}, \mathrm{m}, H 2, H 4, H 5, H 6, H 7), 6.51$ $(1 \mathrm{H}, \mathrm{dd}, J=3.4,1.7 \mathrm{~Hz}, H 9), 6.14(1 \mathrm{H}, \mathrm{t}, J=3.4 \mathrm{~Hz}, H 8), 2.43(3 \mathrm{H}, \mathrm{s}, H 1), 1.55(9 \mathrm{H}, \mathrm{s}, H 10)$; 
${ }^{13}$ C NMR $\left(101 \mathrm{MHz}, \mathrm{CDCl}_{3}\right) \delta_{\mathrm{C}} 148.2,144.7,139.1,133.2,129.4,129.0,128.3,128.0,126.2,123.0$, $122.0,114.5,100.8,85.9,84.1,62.8,27.9,21.7$;

HRMS (ES+) calc. for $\mathrm{C}_{24} \mathrm{H}_{24} \mathrm{~N}_{2} \mathrm{NaO}_{4} \mathrm{~S}[\mathrm{M}+\mathrm{Na}]^{+} 459.1349$, found 459.1349 . 


\section{$N$-((1-Methyl-1 $H$-pyrazol-4-yl)ethynyl)- $N$-phenyltosylamide, $1 \mathrm{w}$}
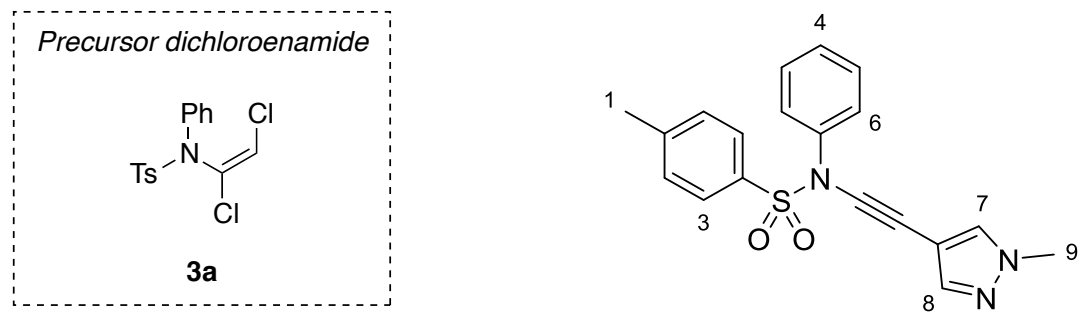

Following example procedure 1.3e: Synthesised from $(E)-N$-phenyl- $N$-(1,2-dichlorovinyl)tosylamide (500 mg, $1.46 \mathrm{mmol}, 1.0$ equiv.) in anhydrous TBME (2.0 mL) using LiHMDS (freshly prepared according to example procedure $1.3 \mathrm{e}, 1.2$ equiv. $), \mathrm{CuCN} \cdot 2 \mathrm{P}(\mathrm{OMe})_{3}(183 \mu \mathrm{L}$ of a $0.1 \mathrm{M}$ solution in THF, $18.3 \mu \mathrm{mol}, 1.25 \mathrm{~mol} \%$ ) and (1-methyl-1H-pyrazol-4-yl)magnesium chloride/lithium chloride complex (prepared according to example procedure 1.3c from 4-iodo-1-methyl-1H-pyrazole $(365 \mathrm{mg}$, $1.75 \mathrm{mmol}, 1.2$ equiv.) in anhydrous THF ( $4 \mathrm{~mL})$, using $i$-propylmagnesium chloride/lithium chloride (1.57 mL of a $1.3 \mathrm{M}$ solution in THF, $2.05 \mathrm{mmol}, 1.4$ equiv.) and stirring for 1 hour at $-20{ }^{\circ} \mathrm{C}$ ). Upon completion, the reaction was worked up and extracted as for example procedure 1.3e, using EtOAc instead of $\mathrm{Et}_{2} \mathrm{O}$. Column chromatography (40\% EtOAc/40-60 petroleum ether) afforded a yellow solid which was recrystallised from hexane:TBME $(\sim 1: 3)$ to give the title compound (403 mg, $1.15 \mathrm{mmol}, 78 \%$ ) as colourless needles;

m.p. $124-125^{\circ} \mathrm{C}$;

$\mathbf{R}_{\mathbf{f}} 0.24$ (40\% EtOAc/40-60 petroleum ether);

IR (thin film, $v_{\max } / \mathrm{cm}^{-1}$ ) 3067, 2945, 2247, 1594, 1558, 1489, 1454, 1368, 1252, 1171, 1090, 981, 922, 893, 813, 769, 704, 688, 656;

${ }^{1} \mathbf{H}$ NMR $\left(400 \mathrm{MHz}, \mathrm{CDCl}_{3}\right) \delta_{\mathrm{H}} 7.63-7.57(2 \mathrm{H}, \mathrm{m}, H 3), 7.52(1 \mathrm{H}, \mathrm{s}, H 8), 7.47(1 \mathrm{H}, \mathrm{s}, H 7), 7.36-7.26$ (7H, m, $H 2, H 4, H 5, H 6), 3.87(3 \mathrm{H}, \mathrm{s}, H 9), 2.44(3 \mathrm{H}, \mathrm{s}, H 1)$;

${ }^{13}$ C NMR $\left(101 \mathrm{MHz}, \mathrm{CDCl}_{3}\right) \delta_{\mathrm{C}} 144.9,142.8,139.1,133.5,133.1,129.5,129.1,128.3,128.2,126.2$, 102.2, 83.3, 61.7, 39.1, 21.7;

HRMS (ES+) calc. for $\mathrm{C}_{19} \mathrm{H}_{17} \mathrm{~N}_{3} \mathrm{NaO}_{2} \mathrm{~S}[\mathrm{M}+\mathrm{Na}]^{+}$374.0934, found 374.0935. 


\section{$N$-(Benzofuran-5-ylethynyl)- $N$-phenyltosylamide, $1 x$}
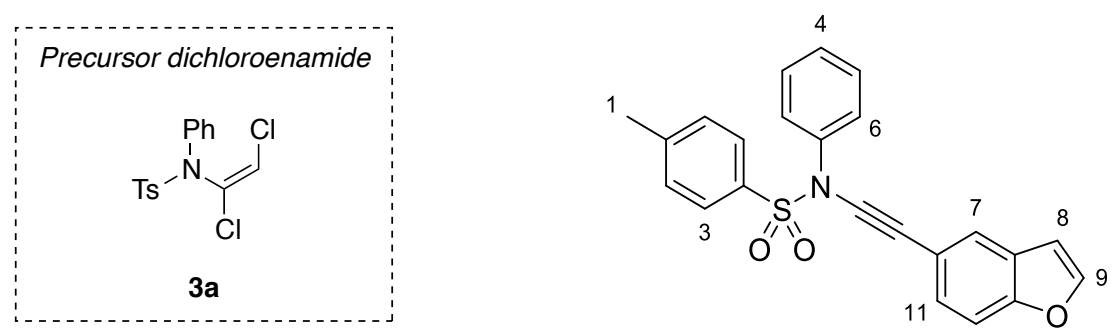

The chloroynamide was synthesised from (E)- $N$-phenyl- $N$-(1,2-dichlorovinyl)tosylamide (500 mg, $1.46 \mathrm{mmol}, 1.0$ equiv.) in anhydrous TBME $(2.0 \mathrm{~mL})$ following example procedure 1.3e. Complete consumption of the dichloroenamide was verified by TLC. The cooling bath was then removed and the reaction mixture was then allowed to warm to room temperature (approx. $21^{\circ} \mathrm{C}$ ) whilst stirring.

Benzofuran-5-ylmagnesium chloride/lithium chloride complex was prepared as followed: To an oven dried, nitrogen flushed flask equipped with a magnetic stirrer bar and a septum, was added magnesium turnings (107 mg, $4.38 \mathrm{mmol}, 3.0$ equiv.), anhydrous lithium chloride (92.9 mg, 2.19 mmol, 1.5 equiv.) and anhydrous THF ( $4 \mathrm{~mL})$, followed by 5-bromobenzofuran ( $220 \mu \mathrm{L}, 1.75 \mathrm{mmol}$, 1.2 equiv.) and the reaction was stirred at room temperature for 3 hours, followed by heating at reflux for 2 hours. The suspension was then allowed to cool to room temperature.

To the previously prepared suspension of chloroynamide in TBME was added $\mathrm{CuCN} \cdot 2 \mathrm{P}(\mathrm{OMe})_{3}$ (183 $\mu \mathrm{L}$ of a $0.1 \mathrm{M}$ solution in THF, $18.3 \mu \mathrm{mol}, 1.25 \mathrm{~mol} \%$ ), and the reaction stirred for 5 minutes at room temperature. The suspension of benzofuran-5-ylmagnesium chloride/lithium chloride complex was then transferred, by syringe, to this mixture and the reaction was stirred for 1 hour at room temperature. Upon completion, the reaction was worked up and extracted as for example procedure 1.3e, using EtOAc instead of $\mathrm{Et}_{2} \mathrm{O}$. Column chromatography $\left(5 \rightarrow 10 \% \mathrm{Et}_{2} \mathrm{O} / 40-60\right.$ petroleum ether $)$ afforded the title compound ( $415 \mathrm{mg}, 1.07 \mathrm{mmol}, 73 \%)$ as a white powder. This compound can be recrystallised from hexane/ $\mathrm{Et}_{2} \mathrm{O}(3: 1)$ to give colourless crystals;

m.p. $90-91^{\circ} \mathrm{C}$;

$\mathbf{R}_{\mathbf{f}} 0.13$ (10\% EtOAc/40-60 petroleum ether);

IR (thin film, $v_{\max } / \mathrm{cm}^{-1}$ ) 3068, 2943, 2841, 2244, 1611, 1594, 1489, 1471, 1438, 1372, 1282, 1246, $1187,1174,1079,1052,922,892,813,799,778,709,691,666,651$;

${ }^{1} \mathbf{H}$ NMR $\left(400 \mathrm{MHz}, \mathrm{CDCl}_{3}\right) \delta_{\mathrm{H}} 7.90-7.67(4 \mathrm{H}, \mathrm{m}, H 3, H 7, H 9), 7.43(1 \mathrm{H}, \mathrm{dt}, J=8.6,0.7 \mathrm{~Hz}, H 11)$, 7.37-7.32 (6H, m, H4, H5, H6, H10), 7.32-7.27 (2H, m, H2), 6.74 (1H, dd, $J=2.2,1.0 \mathrm{~Hz}, H 8), 2.45$ $(3 \mathrm{H}, \mathrm{s}, H 1)$;

${ }^{13}$ C NMR $\left(101 \mathrm{MHz}, \mathrm{CDCl}_{3}\right) * \delta_{\mathrm{C}} 154.5,145.8,144.9,139.1,133.0,129.5,129.1,128.3,128.2,127.5$, 126.2, 124.9, 117.0, 111.4, 106.4, 81.5, 70.7, 21.7; *Note: A single ${ }^{13} \mathrm{C}$ resonance is obscured due to signal overlap.

HRMS (ES+) calc. for $\mathrm{C}_{23} \mathrm{H}_{17} \mathrm{NNaO}_{3} \mathrm{~S}[\mathrm{M}+\mathrm{Na}]^{+} 410.0821$, found 410.0822 . 

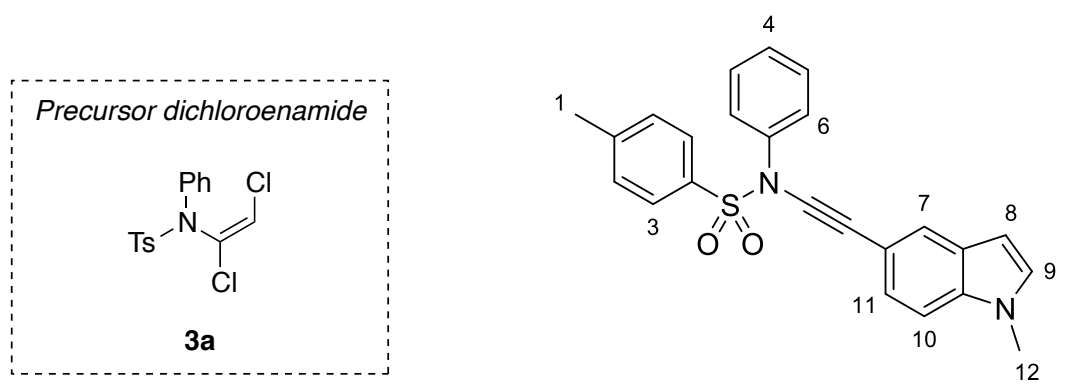

Following example procedure 1.3e: Synthesised from $(E)-N$-phenyl- $N$-(1,2-dichlorovinyl)tosylamide (500 mg, $1.46 \mathrm{mmol}, 1.0$ equiv.) in anhydrous TBME $(2.0 \mathrm{~mL})$ using LiHMDS (freshly prepared according to example procedure $1.3 \mathrm{e}, 1.2$ equiv. $), \mathrm{CuCN} \cdot 2 \mathrm{P}(\mathrm{OMe})_{3}(183 \mu \mathrm{L}$ of a $0.1 \mathrm{M}$ solution in THF, $18.3 \mu \mathrm{mol}, 1.25 \mathrm{~mol} \%$ ) and (1-methyl-1H-indol-5-yl)magnesium chloride (prepared according to example procedure 1.3c from 5-iodo-1-methyl-1H-indole (451 mg, $1.75 \mathrm{mmol}, 1.2$ equiv.) in anhydrous THF ( $4 \mathrm{~mL})$, using $i$-propylmagnesium chloride/lithium chloride complex $(1.57 \mathrm{~mL}$ of a 1.3 M solution in THF, $2.05 \mathrm{mmol}, 1.4$ equiv.) and stirring at $0{ }^{\circ} \mathrm{C}$ for 2 hours). Upon completion, the reaction was worked up and extracted as for example procedure 1.3e, using EtOAc instead of $\mathrm{Et}_{2} \mathrm{O}$. Column chromatography (20\% $\mathrm{Et}_{2} \mathrm{O} / 40-60$ petroleum ether) afforded a brown oil which was triturated with hexane/ $\mathrm{Et}_{2} \mathrm{O}(10: 1)$ to afford a pale yellow solid. Recrystallisation of this solid using hexane/TBME (2:1) gave the title compound (353 mg, $882 \mu \mathrm{mol}, 60 \%$ ) as colourless crystals;

m.p. $111-112^{\circ} \mathrm{C}$;

$\mathbf{R}_{\mathbf{f}} 0.19\left(20 \% \mathrm{Et}_{2} \mathrm{O} / 40-60\right.$ petroleum ether);

IR (thin film, $v_{\max } / \mathrm{cm}^{-1}$ ) 3064, 2945, 2239, 1594, 1488, 1369, 1345, 1173, 1089, 912, 887, 813, 797, 759, 727, 707, 691, 659;

${ }^{1} \mathbf{H}$ NMR $\left(400 \mathrm{MHz}, \mathrm{CDCl}_{3}\right) \delta_{\mathrm{H}} 7.73-7.70(1 \mathrm{H}, \mathrm{m}, H 10), 7.69-7.62(2 \mathrm{H}, \mathrm{m}, H 3), 7.39-7.212(9 \mathrm{H}, \mathrm{m}$, $H 2, H 4, H 5, H 6, H 7, H 11), 7.06(1 \mathrm{H}, \mathrm{d}, J=3.2 \mathrm{~Hz}, H 9), 6.45(1 \mathrm{H}, \mathrm{dd}, J=3.2,0.6 \mathrm{~Hz}, H 8), 3.78(3 \mathrm{H}$, s, $H 12), 2.45$ (3H, s, $H 1)$;

${ }^{13} \mathbf{C}$ NMR $\left(101 \mathrm{MHz}, \mathrm{CDCl}_{3}\right) \delta_{\mathrm{C}} 144.7,139.4,136.3,133.0,129.8,129.4,129.0,128.3,128.2,128.0$, $126.2,125.5,125.2,112.8,109.2,101.1,80.5,71.9,32.9,21.7$;

HRMS (ES+) calc. for $\mathrm{C}_{24} \mathrm{H}_{20} \mathrm{~N}_{2} \mathrm{NaO}_{2} \mathrm{~S}[\mathrm{M}+\mathrm{Na}]^{+} 423.1138$, found 423.1137 . 


\section{$N$-Phenyl- $N$-(pyridin-2-ylethynyl)tosylamide, $1 z$}
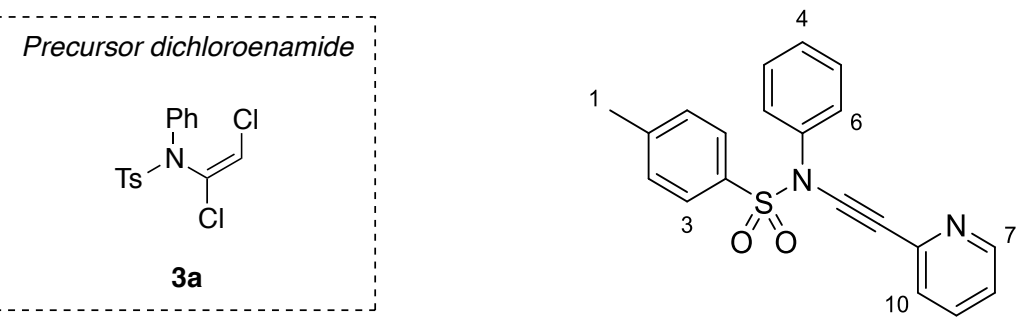

Following example procedure 1.3e: Synthesised from $(E)-N$-phenyl- $N$-(1,2-dichlorovinyl)tosylamide (500 mg, $1.46 \mathrm{mmol}, 1.0$ equiv.) in anhydrous TBME (2.0 mL) using LiHMDS (freshly prepared according to example procedure 1.3e, 1.2 equiv.), $\mathrm{CuCN} \cdot 2 \mathrm{P}(\mathrm{OMe})_{3}(183 \mu \mathrm{L}$ of a $0.1 \mathrm{M}$ solution in THF, $18.3 \mu \mathrm{mol}, 1.25 \mathrm{~mol} \%$ ) and pyridin-2-ylmagnesium chloride (prepared according to example procedure $1.3 \mathrm{c}$ from 2-bromopyridine $(167 \mu \mathrm{L}, 1.75 \mathrm{mmol}, 1.2$ equiv.) in anhydrous THF $(4 \mathrm{~mL})$, using $i$-propylmagnesium chloride $(1.02 \mathrm{~mL}$ of a $2.0 \mathrm{M}$ solution in THF, $2.05 \mathrm{mmol}, 1.4$ equiv.) and stirring at room temperature for 2 hours). Upon completion, the reaction was worked up and extracted as for example procedure 1.3e, using EtOAc instead of $\mathrm{Et}_{2} \mathrm{O}$. Column chromatography $(40 \rightarrow 50 \%$ EtOAc/40-60 petroleum ether) afforded a pink solid which was recrystallised from hexane/TBME (2:1) to give the title compound ( $378 \mathrm{mg}, 1.08 \mathrm{mmol}, 74 \%$ ) as pale yellow needles;

m.p. $100-101{ }^{\circ} \mathrm{C}$;

$\mathbf{R}_{\mathbf{f}} 0.48$ (50\% EtOAc/40-60 petroleum ether);

IR (thin film, $v_{\max } / \mathrm{cm}^{-1}$ ) 3031, 2237, 1583, 1491, 1467, 1372, 1171, 1085, 892, 813, 777, 687, 655;

${ }^{1} \mathbf{H}$ NMR $\left(400 \mathrm{MHz}, \mathrm{CDCl}_{3}\right) \delta_{\mathrm{H}} 8.53(1 \mathrm{H}$, app. dq, $J=4.9,1.1 \mathrm{~Hz}, H 7), 7.66-7.62(2 \mathrm{H}, \mathrm{m}, H 3), 7.62$ (1H, app. ddd, $J=7.8,7.6,2.0 \mathrm{~Hz}, H 9), 7.41(1 \mathrm{H}, \mathrm{dt}, J=7.8,1.1 \mathrm{~Hz}, H 10), 7.36-7.29(5 \mathrm{H}, \mathrm{m}, H 4$, $H 5, H 5), 7.29-7.25$ (2H, m, H2), 7.17 (1H, ddd, $J=7.6,4.9,1.1 \mathrm{~Hz}, H 8), 2.42$ (3H, s, H1);

${ }^{13} \mathbf{C}$ NMR $\left(101 \mathrm{MHz}, \mathrm{CDCl}_{3}\right) \delta_{\mathrm{C}} 149.9,145.2,143.3,138.3,136.0,133.0,129.6,129.2,128.5,128.2$, $126.7,126.5,122.2,83.1,70.5,21.7$;

HRMS (ES+) calc. for $\mathrm{C}_{20} \mathrm{H}_{17} \mathrm{~N}_{2} \mathrm{O}_{2} \mathrm{~S}[\mathrm{M}+\mathrm{H}]^{+} 349.1005$, found 349.1006 . 

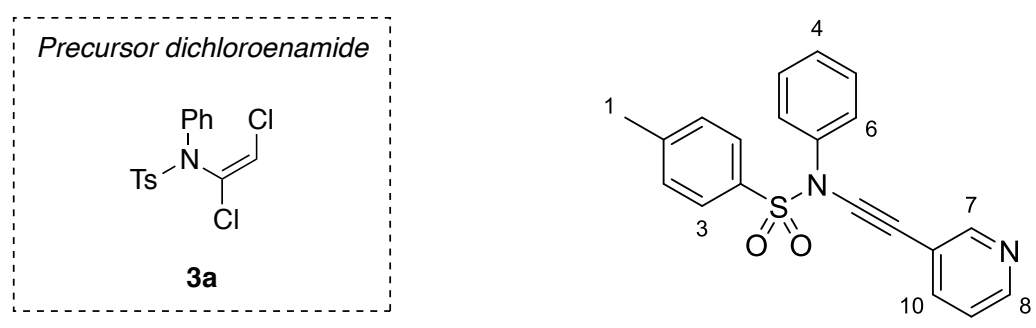

Following example procedure 1.3e: Synthesised from $(E)-N$-phenyl- $N$-(1,2-dichlorovinyl)tosylamide (500 mg, $1.46 \mathrm{mmol}, 1.0$ equiv.) in anhydrous TBME $(2.0 \mathrm{~mL})$ using LiHMDS (freshly prepared according to example procedure $1.3 e, 1.2$ equiv.), $\mathrm{CuCN} \cdot 2 \mathrm{P}(\mathrm{OMe})_{3}(183 \mu \mathrm{L}$ of a $0.1 \mathrm{M}$ solution in THF, $18.3 \mu \mathrm{mol}, 1.25 \mathrm{~mol} \%$ ) and pyridin-3-ylmagnesium chloride (prepared according to example procedure 1.3c from 3-iodopyridine ( $359 \mathrm{mg}, 1.75 \mathrm{mmol}, 1.2$ equiv.) in anhydrous THF (4 mL), using $i$-propylmagnesium chloride (1.02 $\mathrm{mL}$ of a $2.0 \mathrm{M}$ solution in THF, $2.05 \mathrm{mmol}, 1.4$ equiv.) and stirring at $-20{ }^{\circ} \mathrm{C}$ for 1 hour). Upon completion, the reaction was worked up and extracted as for example procedure 1.3e, using EtOAc instead of $\mathrm{Et}_{2} \mathrm{O}$. Recrystallisation from EtOAc gave the title compound (444 $\mathrm{mg}, 1.27 \mathrm{mmol}, 87 \%$ ) as pale yellow crystals;

m.p. $108-109^{\circ} \mathrm{C}$;

$\mathbf{R}_{\mathbf{f}} 0.31$ (40\% EtOAc/40-60 petroleum ether);

IR (thin film, $v_{\max } / \mathrm{cm}^{-1}$ ) 3031, 2240, 1594, 1491, 1373, 1187, 1172, 1085, 1023, 892, 802, 704, 687, 655 ;

${ }^{1} \mathbf{H}$ NMR $\left(400 \mathrm{MHz}, \mathrm{CDCl}_{3}\right) \delta_{\mathrm{H}} 8.60(1 \mathrm{H}, \mathrm{d}, J=1.1 \mathrm{~Hz}, H 7), 8.50(1 \mathrm{H}, \mathrm{dd}, J=4.9,1.1 \mathrm{~Hz}, H 8), 7.67$ $(1 \mathrm{H}, \mathrm{dt}, J=7.8,2.0 \mathrm{~Hz}, H 10), 7.64-7.57$ (2H, m, H3), 7.40-7.33 (3H, m, H4, H5), 7.33-7.27 (4H, m, $H 2, H 6), 7.23(1 \mathrm{H}, \mathrm{ddd}, J=7.8,4.9,0.7 \mathrm{~Hz}, H 9), 2.44(3 \mathrm{H}, \mathrm{s}, H 1)$;

${ }^{13} \mathbf{C}$ NMR $\left(101 \mathrm{MHz}, \mathrm{CDCl}_{3}\right) \delta_{\mathrm{C}} 152.0,148.3,145.2,138.5,138.2,132.8,129.6,129.2,128.5,128.2$, $126.3,122.9,119.9,86.0,67.3,21.7$;

HRMS (ES+) calc. for $\mathrm{C}_{20} \mathrm{H}_{17} \mathrm{~N}_{2} \mathrm{O}_{2} \mathrm{~S}[\mathrm{M}+\mathrm{H}]^{+} 349.1005$, found 349.1006 . 


\section{$N$-((7-Chloroquinolin-4-yl)ethynyl)- $N$-phenyltosylamide, 1ab}
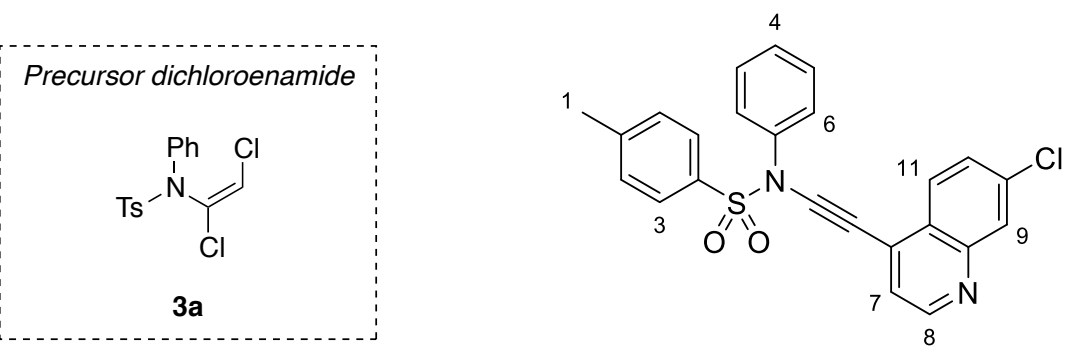

Following example procedure 1.3e: Synthesised from (E)- $N$-phenyl- $N$-(1,2-dichlorovinyl)tosylamide (500 mg, $1.46 \mathrm{mmol}, 1.0$ equiv.) in anhydrous TBME (2.0 mL) using LiHMDS (freshly prepared according to example procedure 1.3e, 1.2 equiv.), $\mathrm{CuCN} \cdot 2 \mathrm{P}(\mathrm{OMe})_{3}(183 \mu \mathrm{L}$ of a $0.1 \mathrm{M}$ solution in THF, $18.3 \mu \mathrm{mol}, 1.25 \mathrm{~mol} \%$ ) and (7-chloroquinolin-4-yl)magnesium chloride (prepared according to example procedure 1.3c from 7-chloro-4-iodoquinoline (508 $\mathrm{mg}, 1.75 \mathrm{mmol}, 1.2$ equiv.) in anhydrous THF $(5 \mathrm{~mL})$, using $i$-propylmagnesium chloride $(1.02 \mathrm{~mL}$ of a $2.0 \mathrm{M}$ solution in THF, $2.05 \mathrm{mmol}$, 1.4 equiv.) and stirring at $-20{ }^{\circ} \mathrm{C}$ for 1 hour). Upon completion, the reaction was worked up and extracted as for example procedure 1.3e, using EtOAc instead of $\mathrm{Et}_{2} \mathrm{O}$. Column chromatography $(20 \%$ EtOAc/40-60 petroleum ether) afforded a dark yellow solid which was recrystallised from EtOAc to give the title compound (563 mg, $1.30 \mathrm{mmol}, 89 \%$ ) as colourless crystals;

m.p. $130-132{ }^{\circ} \mathrm{C}$;

$\mathbf{R}_{\mathbf{f}} 0.13$ (20\% EtOAc/40-60 petroleum ether);

IR (thin film, $v_{\max } / \mathrm{cm}^{-1}$ ) 3064, 2981, 2229, 1576, 1490, 1375, 1174, 1089, 1072, 996, 884, 835, 691;

${ }^{1} \mathbf{H}$ NMR $\left(400 \mathrm{MHz}, \mathrm{CDCl}_{3}\right) \delta_{\mathrm{H}} 8.80(1 \mathrm{H}, \mathrm{d}, J=4.4 \mathrm{~Hz}, H 8), 8.18(1 \mathrm{H}, \mathrm{d}, J=8.8 \mathrm{~Hz}, H 11), 8.08(1 \mathrm{H}$, d, $J=2.1 \mathrm{~Hz}, H 9), 7.68-7.61(2 \mathrm{H}, \mathrm{m}, H 3), 7.55(1 \mathrm{H}, \mathrm{dd}, J=8.8,2.1 \mathrm{~Hz}, H 10), 7.46-7.39(3 \mathrm{H}, \mathrm{m}$, $H 4, H 5), 7.39-7.34(2 \mathrm{H}, \mathrm{m}, H 6), 7.32(1 \mathrm{H}, \mathrm{d}, J=4.4 \mathrm{~Hz}, H 7), 7.31-7.26$ (2H, br. m, H2), 2.42 (3H, s, $H 1)$;

${ }^{13} \mathbf{C}$ NMR $\left(101 \mathrm{MHz}, \mathrm{CDCl}_{3}\right) \delta_{\mathrm{C}} 150.6,148.3,145.6,138.1,135.7,132.9,129.82,129.78,129.4$, $128.9,128.7,128.10,128.08,127.4,126.3,125.8,121.7,93.1,67.8,21.7$;

HRMS (ES+) calc. for $\mathrm{C}_{24} \mathrm{H}_{18}{ }^{35} \mathrm{ClN}_{2} \mathrm{NaO}_{2} \mathrm{~S}[\mathrm{M}+\mathrm{H}]^{+}$433.0772, found 433.0773. 


\section{$N$-((3,6-Dichloropyridazin-4-yl)ethynyl)- $N$-phenyltosylamide, 1ac}
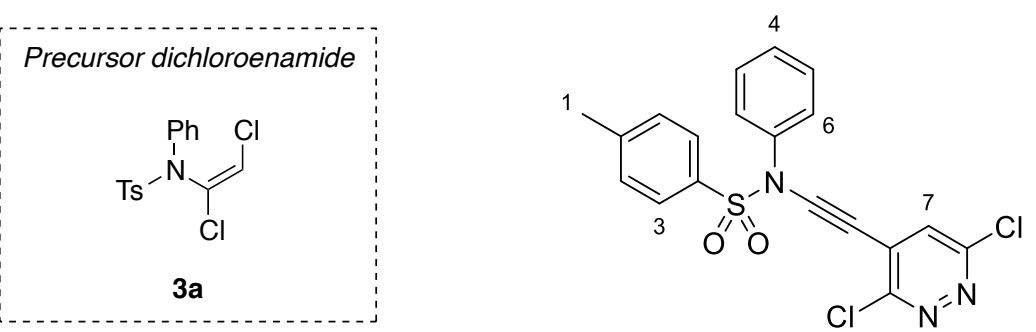

The chloroynamide was synthesised from (E)- $N$-phenyl- $N$-(1,2-dichlorovinyl)tosylamide $(500 \mathrm{mg}$, $1.46 \mathrm{mmol}, 1.0$ equiv.) in anhydrous TBME $(2.0 \mathrm{~mL})$ following example procedure 1.3e. Complete consumption of the dichloroenamide was verified by TLC. The cooling bath was then removed and the reaction mixture was then allowed to warm to room temperature (approx. $21^{\circ} \mathrm{C}$ ) whilst stirring.

(3,6-dichloropyridazin-4-yl)zinc chloride/lithium chloride complex was prepared and used as followed: To an oven dried, nitrogen flushed flask equipped with a magnetic stirrer bar and a septum, was added anhydrous THF $(2 \mathrm{~mL})$ and freshly distilled 2,2,6,6-tetramethylpiperidine $(0.32 \mathrm{~mL}$, $1.90 \mathrm{mmol}, 1.3$ equiv.), and the solution was cooled to $-5{ }^{\circ} \mathrm{C}$ whilst stirring. To this solution was added dropwise $n$-butyllithium $(0.76 \mathrm{~mL}$ of a $2.5 \mathrm{M}$ solution in hexanes, $1.90 \mathrm{mmol}, 1.3$ equiv.) and the mixture stirred for 1 hour at $-5^{\circ} \mathrm{C}$. Next, $\mathrm{ZnCl}_{2}(1.08 \mathrm{~mL}$ of a $1.9 \mathrm{M}$ solution in 2-MeTHF, 2.04 mmol, 1.4 equiv.) was added and the resulting solution was stirred for 30 minutes at room temperature. Note: The resulting solution was yellow. The reaction was cooled to $-20{ }^{\circ} \mathrm{C}$ and a solution of 3,6-dichloropyridazine (261 mg, $1.75 \mathrm{mmol}, 1.2$ equiv.) in anhydrous THF (1 mL) was added dropwise. The reaction was stirred for 30 minutes at $-20{ }^{\circ} \mathrm{C}$ and for 2 hours at room temperature, giving the requisite arylzinc chloride/lithium chloride complex as a dark red solution. This solution was cooled to $-20{ }^{\circ} \mathrm{C}$ and $\mathrm{CuCN} \cdot 2 \mathrm{LiCl}(73 \mu \mathrm{L}$ of a $1 \mathrm{M}$ solution in THF, $73 \mu \mathrm{mol}, 5$ mol\%) was added. The solution was then stirred for 30 minutes at room temperature and used directly in the next step.

To the previously prepared suspension of chloroynamide in TBME was added the solution of $(3,6-$ dichloropyridazin-4-yl)copper(I) cyanide/zinc chloride/lithium chloride complex by syringe, and the reaction was stirred overnight at room temperature. Upon completion, the reaction was worked up and extracted as for example procedure 1.3e, using EtOAc instead of $\mathrm{Et}_{2} \mathrm{O}$. Column chromatography $(10 \rightarrow 20 \%$ EtOAc/40-60 petroleum ether) afforded an orange solid which was recrystallised from heptane/TBME (2:1) to afford the title compound (478 mg, $1.15 \mu \mathrm{mol}, 79 \%)$ as colourless needles. This compound can be recrystallised from TBME/heptane (1:2) to give fine, colourless needles;

m.p. $128^{\circ} \mathrm{C}$;

$\mathbf{R}_{\mathbf{f}} 0.44$ (20\% EtOAc/40-60 petroleum ether); 
IR (thin film, $v_{\max } / \mathrm{cm}^{-1}$ ) 3068, 2224, 1594, 1558, 1489, 1403, 1379, 1330, 1209, 1189, 1176, 1132, 1089, 876, 814, 763, 691, 677, 655;

${ }^{1} \mathbf{H}$ NMR $\left(400 \mathrm{MHz}, \mathrm{CDCl}_{3}\right) \delta_{\mathrm{H}} 7.67-7.59(2 \mathrm{H}, \mathrm{m}, H 3), 7.45-7.35$ (4H, m, H4, H5, H7), 7.34-7.29 $(2 \mathrm{H}, \mathrm{m}, H 2), 7.29-7.04(2 \mathrm{H}, \mathrm{m}, H 6), 2.45(3 \mathrm{H}, \mathrm{s}, H 1)$;

${ }^{13} \mathbf{C}$ NMR $\left(101 \mathrm{MHz}, \mathrm{CDCl}_{3}\right) \delta_{\mathrm{C}} 154.9,154.4,146.0,137.3,132.7,130.0,129.6,129.3,128.3,128.2$, 127.3, 126.3, 98.1, 65.7, 21.8;

HRMS (ES+) calc. for $\mathrm{C}_{19} \mathrm{H}_{14}{ }^{35} \mathrm{Cl}_{2} \mathrm{~N}_{3} \mathrm{NaO}_{2} \mathrm{~S}[\mathrm{M}+\mathrm{H}]^{+} 418.0178$, found 418.0178. 


\section{$N$-(3-Methylbut-3-en-1-yn-1-yl)- $N$-phenyltosylamide, 1ad}
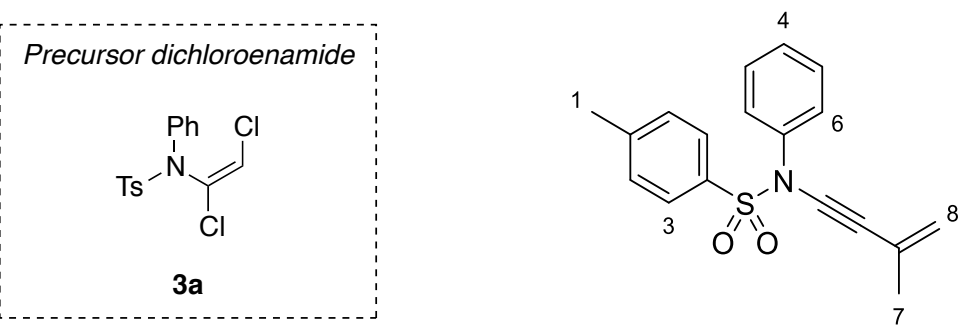

Following example procedure 1.3e: Synthesised from (E)- $N$-phenyl- $N$-(1,2-dichlorovinyl)tosylamide (500 mg, $1.46 \mathrm{mmol}, 1.0$ equiv.) in anhydrous TBME $(2.0 \mathrm{~mL})$ using LiHMDS (freshly prepared according to example procedure 1.3e, 1.2 equiv.), $\mathrm{CuCN} \cdot 2 \mathrm{P}(\mathrm{OMe})_{3}(183 \mu \mathrm{L}$ of a $0.1 \mathrm{M}$ solution in THF, $18.3 \mu \mathrm{mol}, 1.25 \mathrm{~mol} \%$ ) and prop-1-en-2-ylmagnesium bromide (3.01 $\mathrm{mL}$ of a $0.5 \mathrm{M}$ solution in THF, $1.50 \mathrm{mmol}, 1.03$ equiv.). Upon completion, the reaction was worked up and extracted as for example procedure 1.3e. Column chromatography (4\% $\mathrm{Et}_{2} \mathrm{O} / 40-60$ petroleum ether) afforded a yellow solid which was triturated with hexane, followed by recrystallisation from hexane: $\mathrm{Et}_{2} \mathrm{O}(4: 1)$ to give the title compound (319 $\mathrm{mg}, 1.02 \mathrm{mmol}, 70 \%$ ) as colourless crystals;

m.p. $67-68^{\circ} \mathrm{C}$ (decomp.);

$\mathbf{R}_{\mathbf{f}} 0.26\left(4 \% \mathrm{Et}_{2} \mathrm{O} / 40-60\right.$ petroleum ether);

IR (thin film, $v_{\max } / \mathrm{cm}^{-1}$ ) 2912, 2228, 1594, 1487, 1454, 1371, 1223, 1173, 1130, 1089, 1027, 921, 891, 813, 789, 745, 691, 792;

${ }^{1} \mathbf{H}$ NMR $\left(400 \mathrm{MHz}, \mathrm{CDCl}_{3}\right) \delta_{\mathrm{H}} 7.61-7.54(2 \mathrm{H}, \mathrm{m}, H 3), 7.36-7.18$ (7H, m, H2, H4, H5, H6), 5.22$5.12(2 \mathrm{H}, \mathrm{m}, H 8), 2.43(3 \mathrm{H}, \mathrm{s}, H 1), 1.88(3 \mathrm{H}, \mathrm{dd}, J=1.2,0.7 \mathrm{~Hz}, H 7)$;

${ }^{13} \mathbf{C}$ NMR $\left(101 \mathrm{MHz}, \mathrm{CDCl}_{3}\right) \delta_{\mathrm{C}} 144.9,138.9,132.9,129.4,129.0,128.2,128.1,126.2,126.0,120.2$, 82.3, 72.0, 23.4, 21.7;

HRMS (ES+) calc. for $\mathrm{C}_{18} \mathrm{H}_{17} \mathrm{NNaO}_{2} \mathrm{~S}[\mathrm{M}+\mathrm{Na}]^{+} 334.0872$, found 334.0873. 

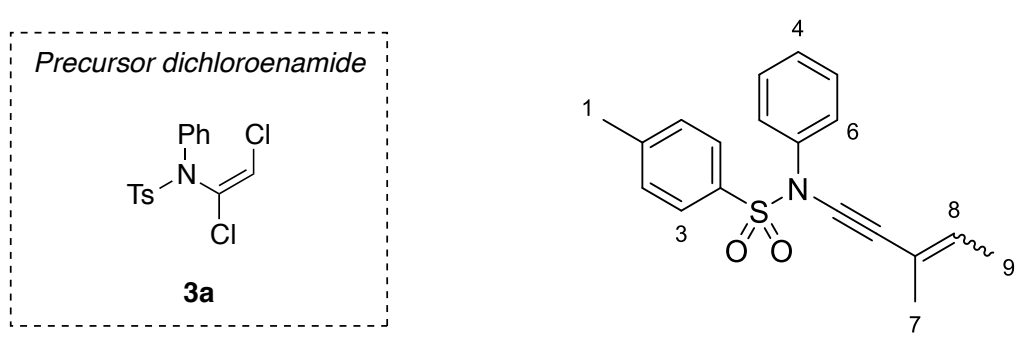

Following example procedure 1.3e: Synthesised from (E)-N-phenyl- $N$-(1,2-dichlorovinyl)tosylamide (500 mg, $1.46 \mathrm{mmol}, 1.0$ equiv.) in anhydrous TBME $(2.0 \mathrm{~mL})$ using LiHMDS (freshly prepared according to example procedure 1.3e, 1.2 equiv.), $\mathrm{CuCN} \cdot 2 \mathrm{P}(\mathrm{OMe})_{3}(183 \mu \mathrm{L}$ of a $0.1 \mathrm{M}$ solution in THF, $18.3 \mu \mathrm{mol}, 1.25 \mathrm{~mol} \%$ ) and 1-methyl-1-propenylmagnesium bromide (3.01 $\mathrm{mL}$ of a $0.5 \mathrm{M}$ solution in THF, $1.50 \mathrm{mmol}, 1.03$ equiv.). Upon completion, the reaction was worked up and extracted as for example procedure 1.3e. Column chromatography (4\% $\mathrm{Et}_{2} \mathrm{O} / 40-60$ petroleum ether) afforded the title compound ( $373 \mathrm{mg}, 1.15 \mathrm{mmol}, 78 \%$ ) as a colourless oil;

$\mathbf{R}_{\mathbf{f}} 0.51\left(10 \% \mathrm{Et}_{2} \mathrm{O} / 40-60\right.$ petroleum ether);

IR (thin film, $v_{\max } / \mathrm{cm}^{-1}$ ) 2921, 2227, 1595, 1488, 1372, 1270, 1173, 1090, 1028, 924, 891, 813, 778, 692, 669;

${ }^{1} \mathbf{H}$ NMR $\left(400 \mathrm{MHz}, \mathrm{CDCl}_{3}\right) \delta_{\mathrm{H}}$ data for $(E)$-isomer: 7.60-7.54 $(2 \mathrm{H}, \mathrm{m}, H 3), 7.37-7.23(7 \mathrm{H}, \mathrm{m}, H 2$, $H 4, H 5, H 6), 5.66(1 \mathrm{H}, \mathrm{qq}, J=6.8,1.5 \mathrm{~Hz}, H 8), 2.42(3 \mathrm{H}, \mathrm{s}, H 1), 1.82(3 \mathrm{H}$, quin, $J=1.5 \mathrm{~Hz}, H 7)$, $1.76(3 \mathrm{H}, \mathrm{dq}, J=6.8,1.5 \mathrm{~Hz}, H 9)$; data for $(Z)$-isomer: 7.60-7.54 (2H, m, H3), 7.37-7.23 (7H, m, $H 2$, $H 4, H 5, H 6), 5.86(1 \mathrm{H}, \mathrm{qq}, J=7.0,1.5 \mathrm{~Hz}, H 8), 2.42(3 \mathrm{H}, \mathrm{s}, H 1), 1.77(3 \mathrm{H}$, quin, $J=1.5 \mathrm{~Hz}, H 7)$, $1.68(3 \mathrm{H}, \mathrm{dq}, J=7.0,1.5 \mathrm{~Hz}, H 9)$;

${ }^{13} \mathbf{C}$ NMR $\left(101 \mathrm{MHz}, \mathrm{CDCl}_{3}\right) \delta_{\mathrm{C}}$ data for $(E)$-isomer: 144.8, 139.18, 132.94, 131.3, 129.4, 129.0, $128.22,128.02,126.1,117.8,86.5,70.0,22.9,21.7,16.2$; data for $(Z)$-isomer: 144.7, 139.22, 132.88, $132.3,129.3,128.9,128.25,127.95,126.1,117.6,79.4,73.4,21.7,17.1,14.1$;

HRMS (ES+) calc. for $\mathrm{C}_{19} \mathrm{H}_{19} \mathrm{NNaO}_{2} \mathrm{~S}[\mathrm{M}+\mathrm{Na}]^{+} 348.1029$, found 348.1029. 


\section{$N$-(Prop-1-yn-1-yl)- $N$-phenyltosylamide, 1af}
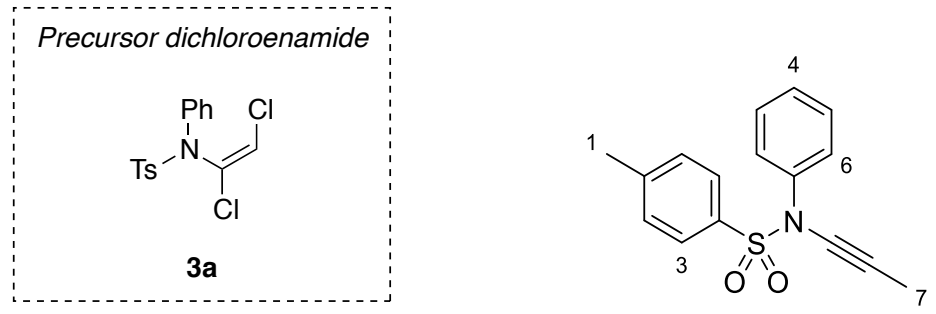

Following example procedure 1.3e: Synthesised from $(E)-N$-phenyl- $N$-(1,2-dichlorovinyl)tosylamide (500 mg, $1.46 \mathrm{mmol}, 1.0$ equiv.) in anhydrous TBME $(2.0 \mathrm{~mL})$ using LiHMDS (freshly prepared according to example procedure 1.3e, 1.2 equiv.), $\mathrm{CuCN} \cdot 2 \mathrm{P}(\mathrm{OMe})_{3}(183 \mu \mathrm{L}$ of a $0.1 \mathrm{M}$ solution in THF, $18.3 \mu \mathrm{mol}, 1.25 \mathrm{~mol} \%)$ and methylmagnesium bromide $\left(0.50 \mathrm{~mL}\right.$ of a $3.0 \mathrm{M}^{2}$ solution in $\mathrm{Et}_{2} \mathrm{O}$ which was further diluted with $1.0 \mathrm{~mL}$ anhydrous TBME, added dropwise over 1 minute, $1.50 \mathrm{mmol}$, 1.03 equiv.). Upon completion, the reaction was worked up and extracted as for example procedure 1.3e, using EtOAc instead of $\mathrm{Et}_{2} \mathrm{O}$. Column chromatography (4\% $\mathrm{Et}_{2} \mathrm{O} / 40-60$ petroleum ether), followed by recrystallisation from hexane/ $\mathrm{Et}_{2} \mathrm{O}$ (3:1) afforded the title compound (365 mg, 1.16 mmol, $80 \%$ ) as colourless needles;

m.p. $103-104{ }^{\circ} \mathrm{C}$;

$\mathbf{R}_{\mathbf{f}} 0.32\left(20 \% \mathrm{Et}_{2} \mathrm{O} / 40-60\right.$ petroleum ether);

IR (thin film, $v_{\max } / \mathrm{cm}^{-1}$ ) 2919, 2262, 1594, 1488, 1455, 1368, 1282, 1174, 1090, 1028, 926, 897, $813,756,705,692,680,652$;

${ }^{1} \mathbf{H}$ NMR $\left(400 \mathrm{MHz}, \mathrm{CDCl}_{3}\right) \delta_{\mathrm{H}} 7.57-7.52(2 \mathrm{H}, \mathrm{m}, H 3), 7.33-7.21(7 \mathrm{H}, \mathrm{m}, H 2, H 4, H 5, H 6), 2.42$ $(3 \mathrm{H}, \mathrm{s}, H 1), 1.91(3 \mathrm{H}, \mathrm{s}, H 7)$;

${ }^{13}$ C NMR $\left(101 \mathrm{MHz}, \mathrm{CDCl}_{3}\right) \delta_{\mathrm{C}} 144.6,139.2,133.0,129.3,128.9,128.1,127.9,126.1,72.7,65.7$, 21.6, 3.3;

HRMS (ES+) calc. for $\mathrm{C}_{16} \mathrm{H}_{15} \mathrm{NNaO}_{2} \mathrm{~S}[\mathrm{M}+\mathrm{Na}]^{+}$308.0716, found 308.0716. 


\section{$N$-(Pent-1-yn-1-yl)- $N$-phenyltosylamide, 1ag}
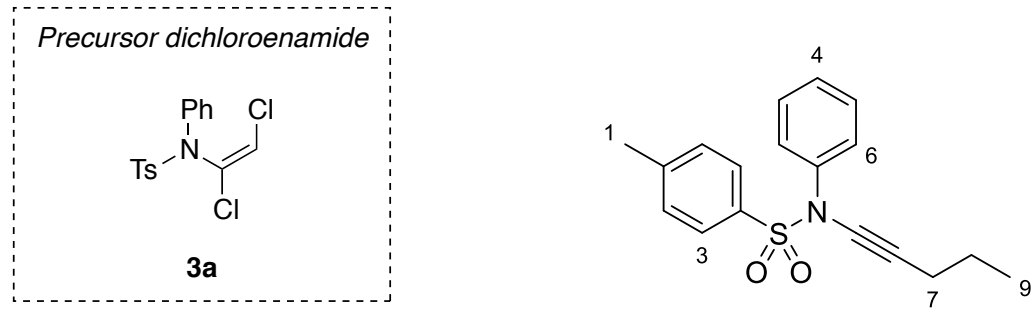

Following example procedure 1.3e: Synthesised from $(E)-N$-phenyl- $N$-(1,2-dichlorovinyl)tosylamide (500 mg, $1.46 \mathrm{mmol}, 1.0$ equiv.) in anhydrous TBME $(2.0 \mathrm{~mL})$ using LiHMDS (freshly prepared according to example procedure $1.3 e, 1.2$ equiv. $), \mathrm{CuCN} \cdot 2 \mathrm{P}(\mathrm{OMe})_{3}(183 \mu \mathrm{L}$ of a $0.1 \mathrm{M}$ solution in THF, $18.3 \mu \mathrm{mol}, 1.25 \mathrm{~mol} \%)$ and propylmagnesium bromide $\left(0.75 \mathrm{~mL}\right.$ of a $2.0 \mathrm{M}^{2}$ solution in $\mathrm{Et}_{2} \mathrm{O}$ which was further diluted with $0.75 \mathrm{~mL}$ anhydrous TBME, added dropwise over 1 minute, $1.50 \mathrm{mmol}, 1.03$ equiv.). Upon completion, the reaction was worked up and extracted as for example procedure 1.3e. Column chromatography $\left(4 \% \mathrm{Et}_{2} \mathrm{O} / 40-60\right.$ petroleum ether) afforded a yellow oil, which was crystallised from hexane/dibutyl ether $(1: 1)$ at $-20{ }^{\circ} \mathrm{C}$ to afford the title compound (365 mg, $1.16 \mathrm{mmol}, 80 \%$ ) as colourless needles;

m.p. $40-41^{\circ} \mathrm{C}$;

$\mathbf{R}_{\mathbf{f}} 0.24$ (4\% Et ${ }_{2} \mathrm{O} / 40-60$ petroleum ether);

IR (thin film, $v_{\max } / \mathrm{cm}^{-1}$ ) 2963, 2254, 1595, 1490, 1371, 1266, 1175, 1091, 1028, 925, 893, 813, 692, 653;

${ }^{1} \mathbf{H}$ NMR $\left(400 \mathrm{MHz}, \mathrm{CDCl}_{3}\right) \delta_{\mathrm{H}} 7.58-7.51(2 \mathrm{H}, \mathrm{m}, H 3), 7.34-7.22(7 \mathrm{H}, \mathrm{m}, H 2, H 4, H 5, H 6), 2.42$ $(3 \mathrm{H}, \mathrm{s}, H 1), 2.27(2 \mathrm{H}, \mathrm{t}, J=7.1 \mathrm{~Hz}, H 7), 1.53(2 \mathrm{H}, \mathrm{sxt}, J=7.1 \mathrm{~Hz}, H 8), 0.95(3 \mathrm{H}, \mathrm{t}, J=7.1 \mathrm{~Hz}, H 9)$;

${ }^{13} \mathbf{C}$ NMR $\left(101 \mathrm{MHz}, \mathrm{CDCl}_{3}\right) \delta_{\mathrm{C}} 144.6,139.4,133.0,129.3,128.9,128.2,127.8,126.1,74.0,70.2$, 22.3, 21.6, 20.5, 13.4;

HRMS (ES+) calc. for $\mathrm{C}_{18} \mathrm{H}_{19} \mathrm{NNaO}_{2} \mathrm{~S}[\mathrm{M}+\mathrm{Na}]^{+} 336.1029$, found 336.1029. 
$N$-(3-Methylbut-1-yn-1-yl)- $N$-phenyltosylamide, 1ah
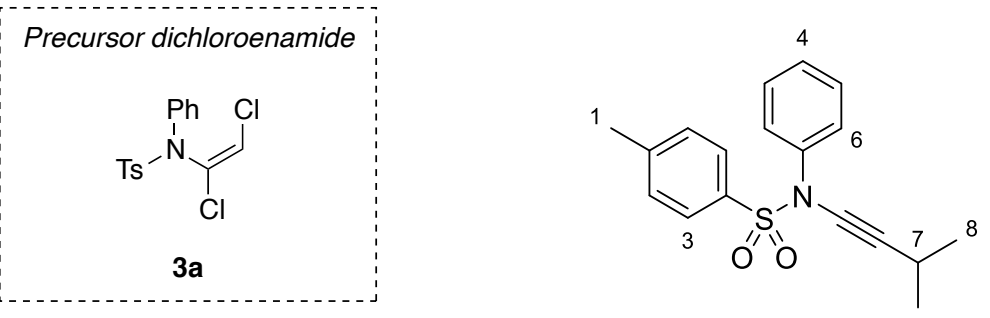

Synthesised according to example procedure 1.3e;

m.p. $56{ }^{\circ} \mathrm{C}$;

$\mathbf{R}_{\mathbf{f}} 0.38$ (10\% Et $2 \mathrm{O} / 40-60$ petroleum ether);

IR (thin film, $v_{\max } / \mathrm{cm}^{-1}$ ) 2980, 2927, 2253, 1596, 1490, 1456, 1371, 1267, 1175, 1090, 908, 813, 788,692 ;

${ }^{1} \mathbf{H}$ NMR $\left(400 \mathrm{MHz}, \mathrm{CDCl}_{3}\right) \delta_{\mathrm{H}} 7.54(2 \mathrm{H}, \mathrm{d}, J=8.1 \mathrm{~Hz}, H 3), 7.33-7.21(7 \mathrm{H}, \mathrm{m}, H 2, H 4, H 5, H 6)$, $2.66(1 \mathrm{H}, \mathrm{spt}, J=6.8 \mathrm{~Hz}, H 7), 2.43(3 \mathrm{H}, \mathrm{s}, H 1), 1.16(6 \mathrm{H}, \mathrm{d}, J=6.8 \mathrm{~Hz}, H 8)$;

${ }^{13} \mathbf{C}$ NMR $\left(101 \mathrm{MHz}, \mathrm{CDCl}_{3}\right) \delta_{\mathrm{C}} 144.6,139.3,132.7,129.2,128.8,128.3,127.8,126.0,75.6,73.4$, 23.0, 21.6, 20.4;

HRMS (ES+) calc. for $\mathrm{C}_{18} \mathrm{H}_{20} \mathrm{NO}_{2} \mathrm{~S}[\mathrm{M}+\mathrm{H}]^{+} 314.1209$, found 314.1211 . 


\section{$N$-(Cyclohexylethynyl)- $N$-phenyltosylamide, 1ai}
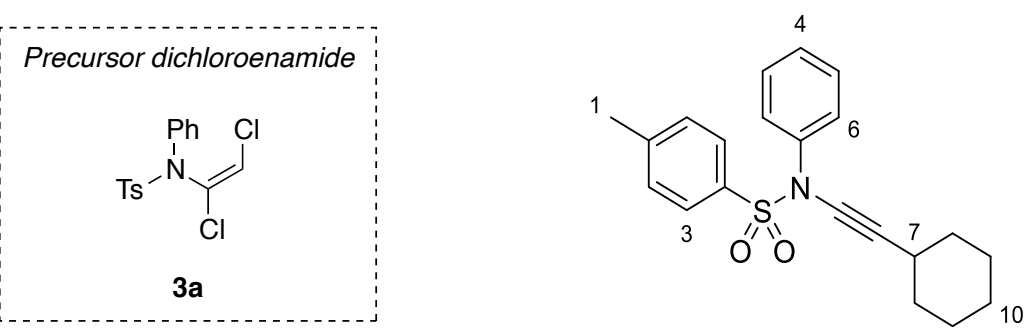

Following example procedure 1.3e: Synthesised from (E)- $N$-phenyl- $N$-(1,2-dichlorovinyl)tosylamide (500 mg, $1.46 \mathrm{mmol}, 1.0$ equiv.) in anhydrous TBME (2.0 mL) using LiHMDS (freshly prepared according to example procedure $1.3 \mathrm{e}, 1.2$ equiv.), $\mathrm{CuCN} \cdot 2 \mathrm{P}(\mathrm{OMe})_{3}(183 \mu \mathrm{L}$ of a $0.1 \mathrm{M}$ solution in THF, $18.3 \mu \mathrm{mol}, 1.25 \mathrm{~mol} \%)$ and cyclohexylmagnesium chloride $(1.16 \mathrm{~mL}$ of a $1.3 \mathrm{M}$ solution in toluene/THF (1:1), added dropwise over 1 minute, $1.50 \mathrm{mmol}, 1.03$ equiv.). Upon completion, the reaction was worked up and extracted as for example procedure 1.3e. Column chromatography (4\% $\mathrm{Et}_{2} \mathrm{O} / 40-60$ petroleum ether) afforded a pale orange solid which was triturated with ice-cold hexane to give the title compound (403 mg, $1.14 \mathrm{mmol}, 78 \%$ ) as colourless crystals. This compound can be recrystallised from hexane to give colourless plates;

m.p. $62{ }^{\circ} \mathrm{C}$;

$\mathbf{R}_{\mathbf{f}} 0.59$ (20\% EtOAc/40-60 petroleum ether);

IR (thin film, $v_{\max } / \mathrm{cm}^{-1}$ ) 2980, 2928, 2853, 2249, 1596, 1489, 1449, 1372, 1257, 1172, 1090, 813, 690;

${ }^{1} \mathbf{H}$ NMR $\left(400 \mathrm{MHz}, \mathrm{CDCl}_{3}\right) \delta_{\mathrm{H}} 7.57-7.50(2 \mathrm{H}, \mathrm{m}, H 3), 7.36-7.21(7 \mathrm{H}, \mathrm{m}, H 2, H 4, H 5, H 6), 2.51$ $(1 \mathrm{H}, \mathrm{tt}, J=8.6,3.7 \mathrm{~Hz}, H 7), 2.43(3 \mathrm{H}, \mathrm{s}, H 1), 1.81-1.71(2 \mathrm{H}, \mathrm{m}, H 8), 1.71-1.60(2 \mathrm{H}, \mathrm{m}, H 9), 1.53-$ $1.38(3 \mathrm{H}, \mathrm{m}, H 8, H 10), 1.36-1.26(3 \mathrm{H}, \mathrm{m}, H 9, H 10)$;

${ }^{13}$ C NMR $\left(101 \mathrm{MHz}, \mathrm{CDCl}_{3}\right) \delta_{\mathrm{C}} 144.6,139.5,132.8,129.2,128.8,128.3,127.7,126.0,74.3,74.2$, 32.7, 28.8, 25.9, 24.7, 21.7;

HRMS (ES+) calc. for $\mathrm{C}_{21} \mathrm{H}_{23} \mathrm{NNaO}_{2} \mathrm{~S}[\mathrm{M}+\mathrm{Na}]^{+} 376.1342$, found 376.1349 . 


\section{$N$-(Cyclopropylethynyl)- $N$-tosylamide, 1aj}
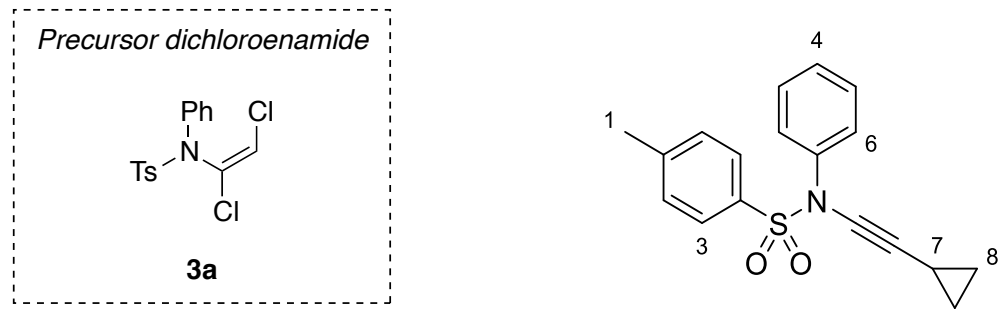

Following example procedure 1.3e: Synthesised from $(E)-N$-phenyl- $N$-(1,2-dichlorovinyl)tosylamide (500 mg, $1.46 \mathrm{mmol}, 1.0$ equiv.) in anhydrous TBME (2.0 mL) using LiHMDS (freshly prepared according to example procedure $1.3 \mathrm{e}, 1.2$ equiv.), $\mathrm{CuCN} \cdot 2 \mathrm{P}(\mathrm{OMe})_{3}(183 \mu \mathrm{L}$ of a $0.1 \mathrm{M}$ solution in THF, $18.3 \mu \mathrm{mol}, 1.25 \mathrm{~mol} \%)$ and cyclopropylmagnesium bromide $(1.75 \mathrm{~mL}$ of a $1.0 \mathrm{M}$ solution in THF, added dropwise over 1.5 minutes, $1.75 \mathrm{mmol}, 1.2$ equiv.). Upon completion, the reaction was worked up and extracted as for example procedure 1.3e. Column chromatography $\left(4 \% \mathrm{Et}_{2} \mathrm{O} / 40-60\right.$ petroleum ether) afforded a pale yellow solid which was recrystallised from hexane:Et $\mathrm{t}_{2} \mathrm{O}$ (4:1) to give the title compound (405 mg, $1.30 \mathrm{mmol}, 89 \%$ ) as colourless crystals;

m.p. $69^{\circ} \mathrm{C}$;

$\mathbf{R}_{\mathbf{f}} 0.47$ (20\% $\mathrm{Et}_{2} \mathrm{O} / 40-60$ petroleum ether);

IR (thin film, $v_{\max } / \mathrm{cm}^{-1}$ ) 3013, 2250, 1595, 1489, 1368, 1271, 1173, 1090, 1028, 924, 892, 812, 773 , 692, 675;

${ }^{1} \mathbf{H}$ NMR $\left(400 \mathrm{MHz}, \mathrm{CDCl}_{3}\right) \delta_{\mathrm{H}} 7.58-7.51(2 \mathrm{H}, \mathrm{m}, H 3), 7.34-7.18(7 \mathrm{H}, \mathrm{m}, \mathrm{H} 2, \mathrm{H} 4, \mathrm{H} 5, \mathrm{H6}), 2.43$ $(3 \mathrm{H}, \mathrm{s}, H 1), 1.32(1 \mathrm{H}, \mathrm{tt}, J=8.1,4.9 \mathrm{~Hz}, H 7), 0.82-0.75$ (2H, m, H8), 0.69-0.62 (2H, m, H8);

${ }^{13} \mathbf{C}$ NMR $\left(101 \mathrm{MHz}, \mathrm{CDCl}_{3}\right) \delta_{\mathrm{C}} 144.6,139.3,133.0,129.3,128.9,128.2,127.8,126.0,74.6,69.3$, 21.6, 8.7, -0.7;

HRMS (ES+) calc. for $\mathrm{C}_{18} \mathrm{H}_{17} \mathrm{NNaO}_{2} \mathrm{~S}[\mathrm{M}+\mathrm{Na}]^{+}$334.0872, found 334.0872. 


\section{$N$-(3,3-Dimethylbut-1-yn-1-yl)- $N$-phenyltosylamide, 1ak}
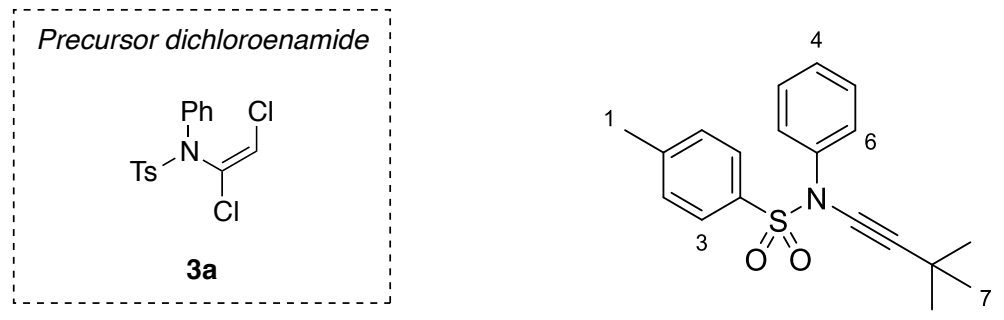

Following example procedure 1.3e: Synthesised from $(E)-N$-phenyl- $N$-(1,2-dichlorovinyl)tosylamide (500 mg, $1.46 \mathrm{mmol}, 1.0$ equiv.) in anhydrous TBME (2.0 mL) using LiHMDS (freshly prepared according to example procedure 1.3e, 1.2 equiv.), $\mathrm{CuCN} \cdot 2 \mathrm{P}(\mathrm{OMe})_{3}(183 \mu \mathrm{L}$ of a $0.1 \mathrm{M}$ solution in THF, $18.3 \mu \mathrm{mol}, 1.25 \mathrm{~mol} \%)$ and $t$-butylmagnesium chloride $(0.89 \mathrm{~mL}$ of a $1.7 \mathrm{M}$ solution in THF which was further diluted with $0.6 \mathrm{~mL}$ of anhydrous TBME, added dropwise over 1 minute, $1.50 \mathrm{mmol}, 1.03$ equiv.). Upon completion, the reaction was worked up and extracted as for example procedure 1.3e. Column chromatography $\left(4 \% \mathrm{Et}_{2} \mathrm{O} / 40-60\right.$ petroleum ether) afforded a pale yellow solid which was recrystallised from hexane to give the title compound (375 $\mathrm{mg}, 1.14 \mathrm{mmol}, 78 \%$ ) as colourless plates;

m.p. $87-88^{\circ} \mathrm{C}$;

$\mathbf{R}_{\mathbf{f}} 0.62$ (20\% EtOAc/40-60 petroleum ether);

IR (thin film, $v_{\max } / \mathrm{cm}^{-1}$ ) 2968, 2256, 1595, 1489, 1455, 1371, 1219, 1174, 1124, 1090, 813, 766, 692,668 ;

${ }^{1} \mathbf{H}$ NMR $\left(400 \mathrm{MHz}, \mathrm{CDCl}_{3}\right) \delta_{\mathrm{H}} 7.56-7.46(2 \mathrm{H}, \mathrm{m}, H 3), 7.34-7.15(7 \mathrm{H}, \mathrm{m}, H 2, H 4, H 5, H 6), 2.40$ $(3 \mathrm{H}, \mathrm{s}, H 1), 1.20(9 \mathrm{H}, \mathrm{s}, H 7)$;

${ }^{13} \mathbf{C}$ NMR $\left(101 \mathrm{MHz}, \mathrm{CDCl}_{3}\right) \delta_{\mathrm{C}} 144.6,139.4,132.5,129.1,128.8,128.3,127.7,125.9,78.4,73.0$, 30.9, 27.4, 21.6;

HRMS (ES+) calc. for $\mathrm{C}_{19} \mathrm{H}_{22} \mathrm{NO}_{2} \mathrm{~S}[\mathrm{M}+\mathrm{H}]^{+} 328.1366$, found 328.1368 . 


\section{$N$-((3-Allylbicyclo[1.1.1]pentan-1-yl)ethynyl)- $N$-phenyltosylamide, 1al}
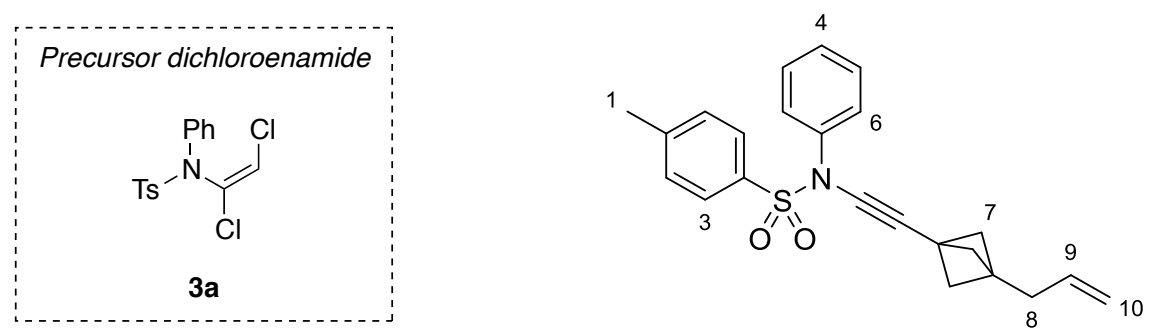

The chloroynamide was synthesised from (E)- $N$-phenyl- $N$-(1,2-dichlorovinyl)tosylamide $(500 \mathrm{mg}$, $1.46 \mathrm{mmol}, 1.0$ equiv.) in anhydrous TBME $(2.0 \mathrm{~mL})$ following example procedure 1.3e. Complete consumption of the dichloroenamide was verified by TLC. The cooling bath was then removed and the reaction mixture was then allowed to warm to room temperature (approx. $21^{\circ} \mathrm{C}$ ) whilst stirring.

(3-Allylbicyclo[1.1.1]pentan-1-yl)magnesium bromide solution was prepared and used as followed: Safety Note: Extreme care should be taken when working with glassware under pressure. This reaction was conducted in a properly equipped fume hood behind a blast shield. To an oven dried, argon flushed Ace pressure vial $(20 \mathrm{~mL})$ equipped with a magnetic stirrer bar, was added allylmagnesium bromide ( $4.0 \mathrm{~mL}$ of a $1 \mathrm{M}$ solution in $\mathrm{Et}_{2} \mathrm{O}, 4.0 \mathrm{mmol}, 2.74$ equiv.) and [1.1.1]propellane (2.47 $\mathrm{mL}$ of a $0.81 \mathrm{M}$ solution in $\mathrm{Et}_{2} \mathrm{O}, 2.0 \mathrm{mmol}, 1.37$ equiv.). The vial was sealed with a screw cap and placed in an oil bath preheated to $100^{\circ} \mathrm{C}$. The reaction was stirred at this temperature for 3 hours, and the vial was then removed from the bath and cooled to room temperature $\left(21^{\circ} \mathrm{C}\right)$.

To the previously prepared suspension of chloroynamide in TBME was added $\mathrm{CuCN} \cdot 2 \mathrm{P}(\mathrm{OMe})_{3}$ (183 $\mu \mathrm{L}$ of a $0.1 \mathrm{M}$ solution in THF, $18.3 \mu \mathrm{mol}, 1.25 \mathrm{~mol} \%$ ), and the reaction stirred for 5 minutes at room temperature. The solution of (3-allylbicyclo[1.1.1]pentan-1-yl)magnesium bromide was then added dropwise over 1 minute by syringe, and the reaction was stirred for 30 minutes at room temperature. Upon completion, the reaction was worked up and extracted as for example procedure 1.3e, using EtOAc instead of $\mathrm{Et}_{2} \mathrm{O}$. Column chromatography $\left(3 \rightarrow 5 \% \mathrm{Et}_{2} \mathrm{O} / 40-60\right.$ petroleum ether) afforded the title compound (298 $\mathrm{mg}, 0.788 \mathrm{mmol}, 54 \%$ ) as a white powder. This compound can be recrystallised from hexane to give colourless needles;

m.p. $100-101{ }^{\circ} \mathrm{C}$

$\mathbf{R}_{\mathbf{f}} 0.44$ (10\% Et ${ }_{2} \mathrm{O} / 40-60$ petroleum ether);

IR (thin film, $v_{\max } / \mathrm{cm}^{-1}$ ) 2971, 2909, 2873, 2245, 1595, 1491, 1374, 1218, 1187, 1174, 1124, 1090, $915,813,764,710,691,658$; 
${ }^{1} \mathbf{H}$ NMR $\left(400 \mathrm{MHz}, \mathrm{CDCl}_{3}\right) \delta_{\mathrm{H}} 7.59-7.51(2 \mathrm{H}, \mathrm{m}, H 3), 7.34-7.24(5 \mathrm{H}, \mathrm{m}, H 2, H 4, H 5), 7.24-7.18$ $(2 \mathrm{H}, \mathrm{m}, H 6), 5.74-5.64(1 \mathrm{H}, \mathrm{m}, H 9), 5.04-4.95(2 \mathrm{H}, \mathrm{m}, H 10), 2.44(3 \mathrm{H}, \mathrm{s}, H 1), 2.19(2 \mathrm{H}, \mathrm{d}$, $J=7.3 \mathrm{~Hz}, H 8), 1.89(6 \mathrm{H}, \mathrm{s}, H 7)$;

${ }^{13} \mathbf{C}$ NMR $\left(101 \mathrm{MHz}, \mathrm{CDCl}_{3}\right) \delta_{\mathrm{C}} 144.7,139.0,134.8,132.9,129.3,128.9,128.3,128.0,126.2,116.2$, 73.0, 69.8, 54.5, 41.4, 36.2, 28.6, 21.7;

HRMS (ES+) calc. for $\mathrm{C}_{23} \mathrm{H}_{24} \mathrm{NO}_{2} \mathrm{~S}[\mathrm{M}+\mathrm{H}]^{+} 378.1522$, found 378.1522 . 


\section{1c Organometallic Scope: Miscellaneous}

(Z)- $N$-(2-Chloro-1-phenylvinyl)- $N$-phenyltosylamide, $4, \&(1 Z, 4 Z)-N^{1}, N^{4}, 1,4-T e t r a p h e n y l b u t-2-$ yne-1,4-diimine, 6
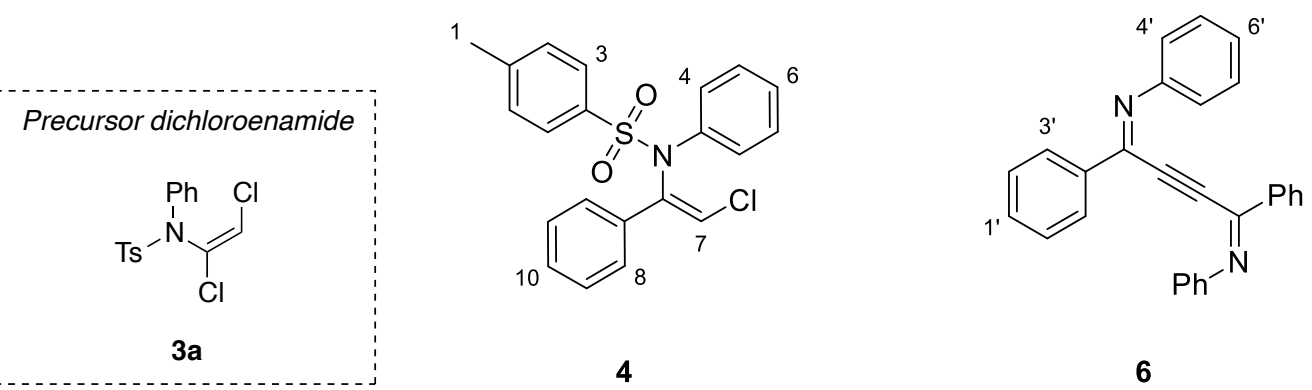

Following example procedure 1.3e: Synthesised from (E)-N-phenyl- $N$-(1,2-dichlorovinyl)tosylamide (500 mg, $1.46 \mathrm{mmol}, 1.0$ equiv.) in anhydrous THF (2.0 mL) using LiHMDS (freshly prepared according to example procedure 1.3e, 1.2 equiv.), $\mathrm{CuCl}_{2}(9.8 \mathrm{mg}, 73 \mu \mathrm{mol}, 5 \mathrm{~mol} \%)$ and phenylmagnesium bromide $(1.75 \mathrm{~mL}$ of a $1.0 \mathrm{M}$ solution in THF, added dropwise over 1 hour, $1.75 \mathrm{mmol}, 1.2$ equiv.). Upon completion, the reaction was worked up and extracted as for example procedure 1.3e, using EtOAc instead of $\mathrm{Et}_{2} \mathrm{O}$. Column chromatography (6\% $\mathrm{Et}_{2} \mathrm{O} / 40-60$ petroleum ether) afforded the title compounds alongside the desired $N$-phenyl- $N$-(phenylethynyl)tosylamide 1a. Recrystallisation of enamide 4 from hexane/ $\mathrm{Et}_{2} \mathrm{O}(3: 1)$ gave $(226 \mathrm{mg}, 0.588 \mathrm{mmol}, 40 \%)$ as colourless crystals and recrystallisation of imine 6 from ice-cold hexane gave (5.5 mg, $14.3 \mu \mathrm{mol}, 2 \%)$ as lemon yellow plates. Both sets of crystals were suitable for X-ray diffraction;

- Data for enamide 4:

m.p. $113^{\circ} \mathrm{C}$;

$\mathbf{R}_{\mathbf{f}} 0.25\left(10 \% \mathrm{Et}_{2} \mathrm{O} / 40-60\right.$ petroleum ether);

IR (thin film, $v_{\max } / \mathrm{cm}^{-1}$ ) 3078, 1735, 1596, 1445, 1352, 1307, 1240, 1220, 1091, 1031, 951, 813, $757,690,669,611$;

${ }^{1} \mathbf{H}$ NMR $\left(400 \mathrm{MHz}, \mathrm{CDCl}_{3}\right) \delta_{\mathrm{H}} 7.66-7.59(2 \mathrm{H}, \mathrm{m}, H 3), 7.55-7.48(2 \mathrm{H}, \mathrm{m}, H 9), 7.44-7.38(2 \mathrm{H}, \mathrm{m}$, H5), 7.36-7.29 (3H, m, H8, H10), 7.27-7.20 (2H, m, H4), 7.20-7.13 (3H, m, H2, H6), $6.67(1 \mathrm{H}, \mathrm{s}$, $H 7), 2.38(3 \mathrm{H}, \mathrm{s}, H 1)$;

${ }^{13} \mathbf{C}$ NMR $\left(101 \mathrm{MHz}, \mathrm{CDCl}_{3}\right) \delta_{\mathrm{C}} 143.8,142.1,139.5,137.1,135.9,129.09,129.06,129.0,128.6$, $128.1,127.0,126.7,125.8,119.9,21.5$;

HRMS (ES+) calc. for $\mathrm{C}_{21} \mathrm{H}_{18}{ }^{35} \mathrm{ClNNaO}_{2} \mathrm{~S}[\mathrm{M}+\mathrm{Na}]^{+}$406.0639, found 406.0639.

- Data for imine 6:

m.p. $>120^{\circ} \mathrm{C}($ dec. $)$;

$\mathbf{R}_{\mathbf{f}} 0.60\left(10 \% \mathrm{Et}_{2} \mathrm{O} / 40-60\right.$ petroleum ether $) ;$ 
IR (thin film, $v_{\max } / \mathrm{cm}^{-1}$ ) 3059, 2922, 1726, 1590, 1572, 1481, 1448, 1322, 1297, 1169, 1096, 1071, 1023, 999, 906, 838, 823, 771, 744, 692, 667;

${ }^{1} \mathbf{H}$ NMR $\left(500 \mathrm{MHz}, \mathrm{CDCl}_{3}\right) \delta_{\mathrm{H}} 7.65-7.58\left(2 \mathrm{H}, \mathrm{m}, H 3^{\prime}\right), 7.48-7.40\left(3 \mathrm{H}, \mathrm{m}, H 5^{\prime}, H 6^{\prime}\right), 7.33-7.27(3 \mathrm{H}$, m, $\left.H 1^{\prime}, H 2^{\prime}\right), 7.06-6.97$ (2H, m, $\left.H 4^{\prime}\right)$;

${ }^{13}$ C NMR $\left(126 \mathrm{MHz}, \mathrm{CDCl}_{3}\right) \delta_{\mathrm{C}} 152.0,149.6,136.0,131.4,129.1,128.4,128.2,125.0,120.0,88.0$;

HRMS (ES+) calc. for $\mathrm{C}_{28} \mathrm{H}_{21} \mathrm{~N}_{2}[\mathrm{M}+\mathrm{H}]^{+} 385.1699$, found 385.1700 . 


\section{$N$-(2,2-Diphenylvinyl)- $N$-phenyltosylamide, 5}
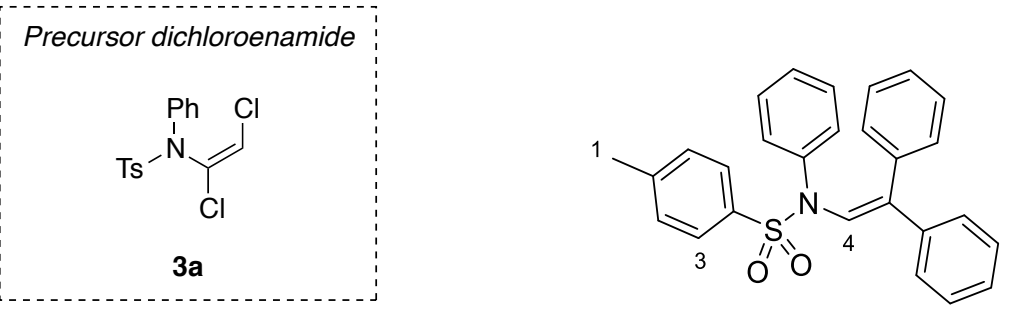

Following example procedure 1.3e: Synthesised from $(E)-N$-phenyl- $N$-(1,2-dichlorovinyl)tosylamide (500 mg, $1.46 \mathrm{mmol}, 1.0$ equiv.) in anhydrous TBME (2.0 mL) using LiHMDS (freshly prepared according to example procedure 1.3e, 1.2 equiv.), $\mathrm{CuCN}(6.5 \mathrm{mg}, 73 \mu \mathrm{mol}, 5 \mathrm{~mol} \%), \mathrm{P}(\mathrm{OMe})_{3}$ (17 $\mu \mathrm{L}, 0.146 \mathrm{mmol}, 10 \mathrm{~mol} \%$ ) and phenylmagnesium bromide $(1.75 \mathrm{~mL}$ of a $1.0 \mathrm{M}$ solution in THF, added dropwise over 1 minute, $1.75 \mathrm{mmol}, 1.2$ equiv.). Upon completion, the reaction was worked up and extracted as for example procedure 1.3e, using EtOAc instead of $\mathrm{Et}_{2} \mathrm{O}$. Column chromatography ( $2 \% \mathrm{Et}_{2} \mathrm{O} / 40-60$ petroleum ether) afforded the title compound (49.6 $\mathrm{mg}, 0.117 \mathrm{mmol}, 8 \%$ ) as a pale yellow powder. Crystals suitable for X-ray diffraction were grown by recrystallisation from $i$-PrOH to give colourless needles;

m.p. $136-138^{\circ} \mathrm{C}$;

$\mathbf{R}_{\mathbf{f}} 0.29\left(10 \% \mathrm{Et}_{2} \mathrm{O} / 40-60\right.$ petroleum ether $)$;

IR (thin film, $v_{\max } / \mathrm{cm}^{-1}$ ) 3057, 3028, 1619, 1593, 1491, 1444, 1399, 1355, 1289, 1248, 1185, 1166, $1089,1075,1027,1004,981,910,828,815,800,776,759,732,693,663,637$;

${ }^{1} \mathbf{H}$ NMR $\left(400 \mathrm{MHz}, \mathrm{CDCl}_{3}\right) \delta_{\mathrm{H}} 7.56-7.49(2 \mathrm{H}, \mathrm{m}, H 3), 7.31-7.23(5 \mathrm{H}, \mathrm{m}, H 2, \mathrm{Ph} H), 7.18-7.11(2 \mathrm{H}$, $\mathrm{m}, \mathrm{Ph} H), 7.10-7.03(3 \mathrm{H}, \mathrm{m}, \mathrm{Ph} H), 7.01(1 \mathrm{H}, \mathrm{s}, H 4), 7.01-6.93(3 \mathrm{H}, \mathrm{m}, \mathrm{Ph} H), 6.91-6.85(2 \mathrm{H}, \mathrm{m}$, $\mathrm{Ph} H), 6.79-6.72(2 \mathrm{H}, \mathrm{m}, \mathrm{Ph} H), 2.45$ (3H, s, H1);

${ }^{13}$ C NMR (101 MHz, $\left.\mathrm{CDCl}_{3}\right) \delta_{\mathrm{C}} 143.9,140.5,140.3,137.6,136.4,134.7,130.0,129.5,128.17$, $128.18,128.15,127.73,127.72,127.69,127.5,127.0,126.7,125.9,21.6$;

HRMS (ES+) calc. for $\mathrm{C}_{27} \mathrm{H}_{24} \mathrm{NO}_{2} \mathrm{~S}[\mathrm{M}+\mathrm{H}]^{+} 426.1522$, found 426.1522 . 

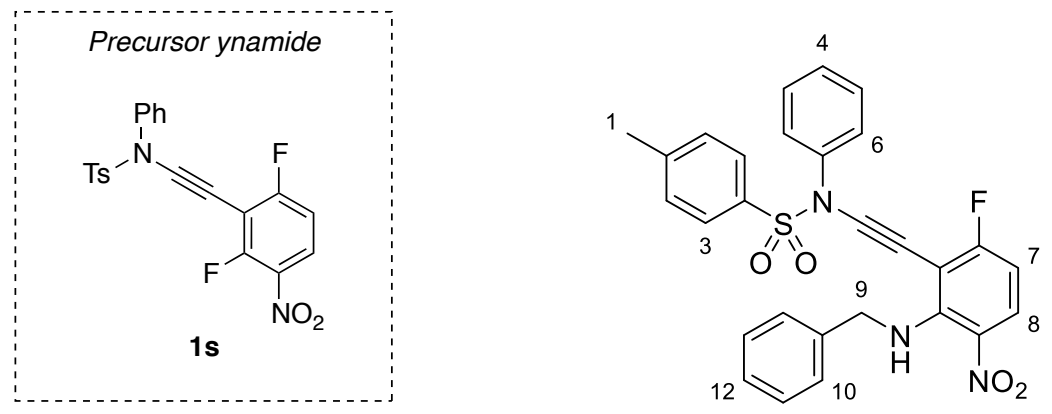

To a $3 \mathrm{~mL}$ vial, equipped with a magnetic stirrer bar, was added sequentially $N$-((2,6-difluoro-3nitrophenyl)ethynyl)- $N$-phenyltosylamide (50.0 mg, $117 \mu$ mol, 1.0 equiv.), anhydrous toluene $(1.0 \mathrm{~mL})$, anhydrous $\mathrm{Et}_{3} \mathrm{~N}(24 \mu \mathrm{L}, 0.18 \mathrm{mmol}, 1.5$ equiv.) and benzylamine (13 $\mu \mathrm{L}, 0.12 \mathrm{mmol}$, 1.0 equiv.). The vial was sealed with a screw cap and stirred for 3 hours. The resulting orange mixture was then poured into a $25 \mathrm{~mL}$ separating funnel containing $\mathrm{Et}_{2} \mathrm{O}(\sim 5 \mathrm{~mL})$ and aqueous saturated $\mathrm{NH}_{4} \mathrm{Cl}(\sim 10 \mathrm{~mL})$. The reaction vessel was thoroughly rinsed with $\mathrm{Et}_{2} \mathrm{O}$ and water $(2 \times 1 \mathrm{~mL}$ each, alternately) and these washings were poured into the separating funnel. The organic layer was then separated and the aqueous was further extracted with $\mathrm{Et}_{2} \mathrm{O}(2 \times 5 \mathrm{~mL})$. The organic extracts were then combined, dried $\left(\mathrm{Na}_{2} \mathrm{SO}_{4}\right)$ and concentrated in vacuo afforded a bright orange solid. Recrystallisation from hexane/Et ${ }_{2} \mathrm{O}$ afforded the title compound $(57.0 \mathrm{mg}, 111 \mu \mathrm{mol}, 95 \%)$ as bright orange needles;

m.p. $110^{\circ} \mathrm{C}$;

$\mathbf{R}_{\mathbf{f}} 0.35$ (15\% EtOAc/40-60 petroleum ether);

IR (thin film, $v_{\max } / \mathrm{cm}^{-1}$ ) 3327, 3066, 2922, 2236, 1605, 1495, 1455, 1374, 1244, 1187, 1173, 1090, $804,761,730,691,661$;

${ }^{1} \mathrm{H}$ NMR $\left(400 \mathrm{MHz}, \mathrm{CDCl}_{3}\right) \delta_{\mathrm{H}} 8.59(1 \mathrm{H}$, br. t, $J=5.6 \mathrm{~Hz}, \mathrm{NH}), 8.07(1 \mathrm{H}, \mathrm{dd}, J=9.5,6.1 \mathrm{~Hz}, H 8)$, $7.47(2 \mathrm{H}, \mathrm{d}, J=8.6 \mathrm{~Hz}, H 3), 7.25-7.10(12 \mathrm{H}, \mathrm{m}, H 2, H 4, H 5, H 6, H 10, H 11, H 12), 6.34(1 \mathrm{H}, \mathrm{dd}$, $J=9.5,7.6 \mathrm{~Hz}, H 7), 5.00(2 \mathrm{H}, \mathrm{d}, J=5.6 \mathrm{~Hz}, H 9), 2.31(3 \mathrm{H}, \mathrm{s}, H 1)$;

${ }^{13} \mathbf{C}$ NMR $\left(101 \mathrm{MHz}, \mathrm{CDCl}_{3}\right) * \delta_{\mathrm{C}} 168.8(1 \mathrm{C}, \mathrm{d}, J=259 \mathrm{~Hz}), 148.2(1 \mathrm{C}, \mathrm{d}, J=5.6 \mathrm{~Hz}), 145.2,138.3$ $(1 \mathrm{C}, \mathrm{d}, J=3.2 \mathrm{~Hz}), 133.2,131.3,129.6,129.20,129.19$ (1C, d, $J=12.7 \mathrm{~Hz}), 128.8,128.4,128.1$, 127.6, 127.3, 126.1, 104.3 (1C, d, $J=25.4 \mathrm{~Hz}), 99.1(1 \mathrm{C}, \mathrm{d}, J=21.5 \mathrm{~Hz}), 93.6(1 \mathrm{C}, \mathrm{d}, J=5.6 \mathrm{~Hz})$, 61.5, 49.7, 21.7; *Note: A single ${ }^{13} \mathrm{C}$ resonance is obscured due to signal overlap

${ }^{19}$ F NMR $\left(376 \mathrm{MHz}, \mathrm{CDCl}_{3}\right) \delta_{\mathrm{F}}-93.0(1 \mathrm{~F}, \mathrm{dd}, J=7.6,6.1 \mathrm{~Hz})$;

HRMS We were unable to obtain an accurate mass (ES+ or $\mathrm{CI}+$ ) due to decomposition upon ionisation. 

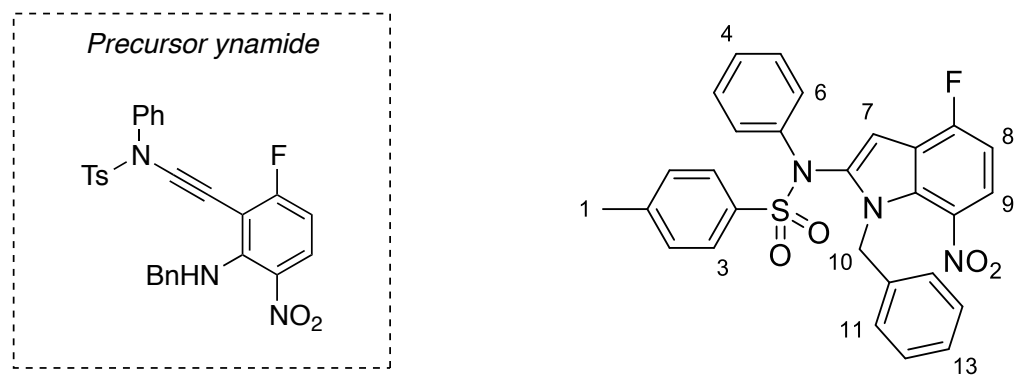

To a $3 \mathrm{~mL}$ vial, equipped with a magnetic stirrer bar, was added sequentially $N$-((2,6-difluoro-3nitrophenyl)ethynyl)- $N$-phenyltosylamide (50.0 mg, $117 \mu \mathrm{mol}, 1.0$ equiv.), anhydrous toluene $(1.0 \mathrm{~mL})$, anhydrous $\mathrm{Et}_{3} \mathrm{~N}(24 \mu \mathrm{L}, 0.18 \mathrm{mmol}, 1.5$ equiv.) and benzylamine (13 $\mu \mathrm{L}, 0.12 \mathrm{mmol}$, 1.0 equiv.). The vial was sealed with a screw cap and stirred for 3 hours. To the resulting orange mixture was added $\mathrm{Cs}_{2} \mathrm{CO}_{3}\left(76.1 \mathrm{mg}, 233 \mu \mathrm{mol}, 2.0\right.$ equiv.) and the mixture stirred at $80{ }^{\circ} \mathrm{C}$ overnight. The mixture was then allowed to cool to room temperature and was then poured into a $25 \mathrm{~mL}$ separating funnel containing $\mathrm{Et}_{2} \mathrm{O}(\sim 5 \mathrm{~mL})$ and aqueous saturated $\mathrm{NH}_{4} \mathrm{Cl}(\sim 10 \mathrm{~mL})$. The reaction vessel was thoroughly rinsed with $\mathrm{Et}_{2} \mathrm{O}$ and water $(2 \times 1 \mathrm{~mL}$ each, alternately) and these washings were poured into the separating funnel. The organic layer was then separated and the aqueous was further extracted with $\mathrm{Et}_{2} \mathrm{O}(2 \times 5 \mathrm{~mL})$. The organic extracts were then combined, dried $\left(\mathrm{Na}_{2} \mathrm{SO}_{4}\right)$ and concentrated in vacuo afforded an orange solid. Recrystallisation from EtOH afforded the title compound ( $43.6 \mathrm{mg}, 84.6 \mu \mathrm{mol}, 72 \%)$ as golden yellow needles. These crystals were suitable for X-ray diffraction;

m.p. $>100{ }^{\circ} \mathrm{C}($ dec. $)$;

$\mathbf{R}_{\mathbf{f}} 0.35$ (15\% EtOAc/40-60 petroleum ether);

IR (thin film, $v_{\max } / \mathrm{cm}^{-1}$ ) 3066, 1522, 1495, 1454, 1359, 1319, 1299, 1246, 1208, 1185, 1167, 1090, 956, 910, 815, 730, 695, 669;

${ }^{1} \mathbf{H}$ NMR $\left(400 \mathrm{MHz}, \mathrm{CDCl}_{3}\right) \delta_{\mathrm{H}} 7.64(1 \mathrm{H}, \mathrm{dd}, J=8.7,5.1 \mathrm{~Hz}, H 9), 7.58(2 \mathrm{H}, \mathrm{d}, J=8.4 \mathrm{~Hz}, H 3), 7.33$ $(2 \mathrm{H}, \mathrm{d}, J=8.2 \mathrm{~Hz}, H 2), 7.31(5 \mathrm{H}, \mathrm{m}, H 11, H 12, H 13), 7.16-7.04(3 \mathrm{H}, \mathrm{m}, H 4, H 5), 6.77(1 \mathrm{H}, \mathrm{t}$, $J=8.7 \mathrm{~Hz}, H 8), 6.69-6.65(2 \mathrm{H}, \mathrm{m}, H 6), 6.62$ (1H, s, H7), 5.68 (2H, br. s, H10), 2.49 (3H, s, H1);

${ }^{13} \mathbf{C}$ NMR $\left(101 \mathrm{MHz}, \mathrm{CDCl}_{3}\right) \delta_{\mathrm{C}} 158.7(1 \mathrm{C}, \mathrm{d}, J=256 \mathrm{~Hz}), 144.9,139.3,138.4,136.1,134.6,134.1$ $(1 \mathrm{C}, \mathrm{d}, J=2.9 \mathrm{~Hz}), 129.7,129.4,128.52,128.49,128.4,128.2,127.8(1 \mathrm{C}, \mathrm{d}, J=11.4 \mathrm{~Hz}), 127.4$, 126.7, 122.7 (1C, d, $J=9.5 \mathrm{~Hz}), 118.8(1 \mathrm{C}, \mathrm{d}, J=22.9 \mathrm{~Hz}), 104.8(1 \mathrm{C}, \mathrm{d}, J=21.0 \mathrm{~Hz}), 97.5,48.6$, 21.7

${ }^{19} \mathbf{F}$ NMR $\left(376 \mathrm{MHz}, \mathrm{CDCl}_{3}\right) \delta_{\mathrm{F}}-111.2(1 \mathrm{~F}, \mathrm{dd}, J=8.7,5.1 \mathrm{~Hz})$;

HRMS (ES+) calc. for $\mathrm{C}_{28} \mathrm{H}_{22} \mathrm{FN}_{3} \mathrm{NaO}_{4} \mathrm{~S}[\mathrm{M}+\mathrm{Na}]^{+}$538.1207, found 538.1205. 


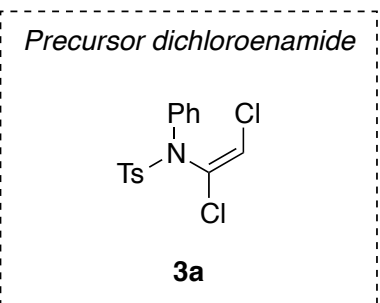

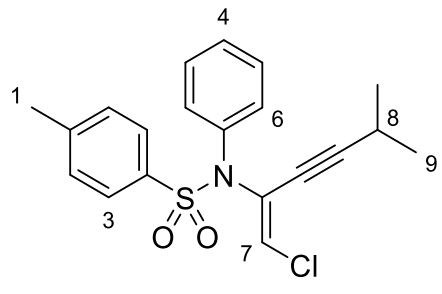

s1a

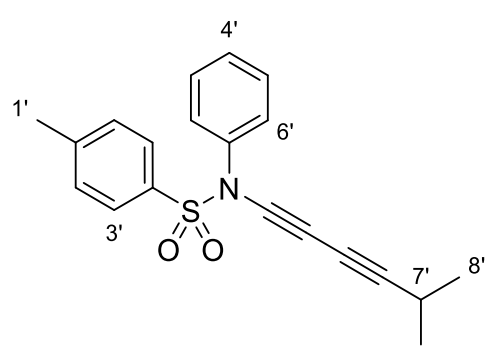

S2a

Following example procedure 1.3e: Synthesised from $(E)-N$-phenyl- $N$-(1,2-dichlorovinyl)tosylamide (500 mg, $1.46 \mathrm{mmol}, 1.0$ equiv.) in anhydrous TBME (2.0 mL) using LiHMDS (freshly prepared according to example procedure 1.3e, 1.2 equiv. $), \mathrm{CuCN} \cdot 2 \mathrm{P}(\mathrm{OMe})_{3}(1.46 \mathrm{~mL}$ of a $0.1 \mathrm{M}$ solution in THF, $146 \mu \mathrm{mol}, 10 \mathrm{~mol} \%$ ) and (3-methylbut-1-yn-1-yl)magnesium chloride (prepared according to example procedure 1.3c from 3-methylbut-1-yne $(0.36 \mathrm{~mL}, 3.51 \mathrm{mmol}, 2.4$ equiv.) in anhydrous THF (4 mL), using ethylmagnesium chloride (1.75 mL of a $2.0 \mathrm{M}$ solution in THF, $3.51 \mathrm{mmol}, 2.4$ equiv.) and stirring at $0{ }^{\circ} \mathrm{C}$ for 1 hour). Upon completion, the reaction was worked up and extracted as for example procedure 1.3e. Column chromatography ( $2 \% \mathrm{Et}_{2} \mathrm{O} / 40-60$ petroleum ether) afforded the compounds S1a and S2a as orange solids, which were both recrystallised from hexane at $-20{ }^{\circ} \mathrm{C}$ overnight. This gave S1a $(76.3 \mathrm{mg}, 0.204 \mathrm{mmol}, 14 \%)$ as colourless plates and S2a (15.5 mg, $45.9 \mu \mathrm{mol}, 3 \%$ ) as colourless needles;

- Data for enyne S1a:

m.p. $97-99^{\circ} \mathrm{C}$;

$\mathbf{R}_{\mathbf{f}} 0.25$ (5\% Et $\mathrm{E}_{2} \mathrm{O} / 40-60$ petroleum ether);

IR (thin film, $v_{\max } / \mathrm{cm}^{-1}$ ) 3084, 2972, 2224, 1595, 1492, 1358, 1322, 1238, 1165, 1091, 1013, 949, $894,832,814,695,665,610$;

${ }^{1} \mathbf{H}$ NMR $\left(400 \mathrm{MHz}, \mathrm{CDCl}_{3}\right) \delta_{\mathrm{H}} 7.65(2 \mathrm{H}, \mathrm{d}, J=8.3 \mathrm{~Hz}, H 3), 7.35-7.21(7 \mathrm{H}, \mathrm{m}, H 2, H 4, H 5, H 6)$, $6.86(1 \mathrm{H}, \mathrm{s}, H 7), 2.58(1 \mathrm{H}, \mathrm{spt}, J=6.9 \mathrm{~Hz}, H 8), 2.42(3 \mathrm{H}, \mathrm{s}, H 1), 1.06(6 \mathrm{H}, \mathrm{d}, J=6.9 \mathrm{~Hz}, H 7)$;

${ }^{13} \mathbf{C}$ NMR $\left(101 \mathrm{MHz}, \mathrm{CDCl}_{3}\right) \delta_{\mathrm{C}} 143.8,139.7,136.3,129.4,129.2,129.1,128.34,128.28,128.2$, 124.9, 105.6, 73.3, 22.1, 21.5, 21.2;

HRMS (ES+) calc. for $\mathrm{C}_{20} \mathrm{H}_{21}{ }^{35} \mathrm{ClNO}_{2} \mathrm{~S}[\mathrm{M}+\mathrm{H}]^{+} 374.0976$, found 374.0978 .

- Data for diyne S2a:

$\mathbf{R}_{\mathbf{f}} 0.30$ ( $5 \% \mathrm{Et}_{2} \mathrm{O} / 40-60$ petroleum ether);

IR (thin film, $v_{\max } / \mathrm{cm}^{-1}$ ) 2973, 2932, 2871, 2254, 2165, 1594, 1490, 1455, 1376, 1187, 1175, 1090, 990, 922, 891, 813, 762; 
${ }^{1} \mathbf{H}$ NMR $\left(400 \mathrm{MHz}, \mathrm{CDCl}_{3}\right) \delta_{\mathrm{H}} 7.61-7.56\left(2 \mathrm{H}, \mathrm{m}, H 3^{\prime}\right), 7.34-7.27\left(5 \mathrm{H}, \mathrm{m}, H 2^{\prime}, H 4^{\prime}, H 5^{\prime}\right), 7.24-7.18$ $\left(2 \mathrm{H}, \mathrm{m}, H 6^{\prime}\right), 2.67\left(1 \mathrm{H}, \mathrm{spt}, J=6.9 \mathrm{~Hz}, H 8^{\prime}\right), 2.44\left(3 \mathrm{H}, \mathrm{s}, H 1^{\prime}\right), 1.19\left(6 \mathrm{H}, \mathrm{d}, J=6.9 \mathrm{~Hz}, H 7^{\prime}\right)$;

${ }^{13} \mathbf{C}$ NMR $\left(101 \mathrm{MHz}, \mathrm{CDCl}_{3}\right) \delta_{\mathrm{C}} 145.2,138.3,133.2,129.7,129.2,128.5,128.2,126.3,89.3,68.4$, 63.7, 57.9, 22.5, 21.7, 21.3;

HRMS (ES+) calc. for $\mathrm{C}_{20} \mathrm{H}_{19} \mathrm{NNaO}_{2} \mathrm{~S}[\mathrm{M}+\mathrm{Na}]^{+} 360.1029$, found 360.1029 . 

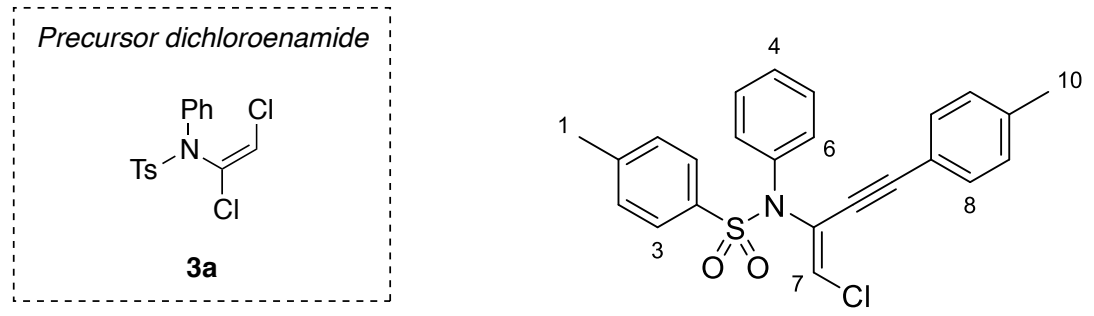

Following example procedure 1.3e: Synthesised from $(E)-N$-phenyl- $N$-(1,2-dichlorovinyl)tosylamide (500 mg, $1.46 \mathrm{mmol}, 1.0$ equiv.) in anhydrous TBME (2.0 mL) using LiHMDS (freshly prepared according to example procedure 1.3e, 1.2 equiv.), $\mathrm{CuCN} \cdot 2 \mathrm{P}(\mathrm{OMe})_{3}(1.46 \mathrm{~mL}$ of a $0.1 \mathrm{M}$ solution in THF, $146 \mu \mathrm{mol}, 10 \mathrm{~mol} \%$ ) and ( $p$-tolylethynyl)magnesium chloride (prepared according to example procedure $1.3 \mathrm{c}$ from 1-ethynyl-4-methylbenzene $(0.45 \mathrm{~mL}, 3.51 \mathrm{mmol}, 2.4$ equiv.) in anhydrous THF (4 mL), using ethylmagnesium chloride (1.75 mL of a $2.0 \mathrm{M}$ solution in THF, $3.51 \mathrm{mmol}, 2.4$ equiv.) and stirring at $0{ }^{\circ} \mathrm{C}$ for 1 hour). Upon completion, the reaction was worked up and extracted as for example procedure 1.3e. Column chromatography $\left(2 \% \mathrm{Et}_{2} \mathrm{O} / 40-60\right.$ petroleum ether) afforded an orange solid that was recrystallised from heptane to give the title compound $(329 \mathrm{mg}, 0.780 \mathrm{mmol}$, $53 \%$ ) as yellow plates;

m.p. $118-119^{\circ} \mathrm{C}$;

$\mathbf{R}_{\mathbf{f}} 0.19\left(5 \% \mathrm{Et}_{2} \mathrm{O} / 40-60\right.$ petroleum ether $)$;

IR (thin film, $v_{\max } / \mathrm{cm}^{-1}$ ) 3078, 2922, 2205, 1595, 1508, 1490, 1458, 1358, 1240, 1166, 1140, 1091, $969,844,815,738,695,665,609$;

${ }^{1} \mathbf{H}$ NMR $\left(400 \mathrm{MHz}, \mathrm{CDCl}_{3}\right) \delta_{\mathrm{H}} 7.70-7.64(2 \mathrm{H}, \mathrm{m}, H 3), 7.38-7.29(5 \mathrm{H}, \mathrm{m}, H 4, H 5, H 6), 7.25-7.20$ (2H, m, H2), 7.16-7.09 (4H, m, H8, H9), 6.96 (1H, s, H7), 2.40 (3H, s, H1), 2.37 (3H, s, H10);

${ }^{13} \mathbf{C}$ NMR $\left(101 \mathrm{MHz}, \mathrm{CDCl}_{3}\right) \delta_{\mathrm{C}} 143.9,139.9,139.7,136.1,131.5,130.5,129.3,129.2,129.1,128.4$, $128.3,128.2,125.0,118.6,98.8,81.9,21.56,21.54$;

HRMS (ES+) calc. for $\mathrm{C}_{24} \mathrm{H}_{21}{ }^{35} \mathrm{ClNO}_{2} \mathrm{~S}[\mathrm{M}+\mathrm{H}]^{+} 422.0976$, found 422.0976 . 


\section{(E)-N-(1-Chloro-4-(trimethylsilyl)but-1-en-3-yn-2-yl)- $N$-phenyltosylamide, S1c}
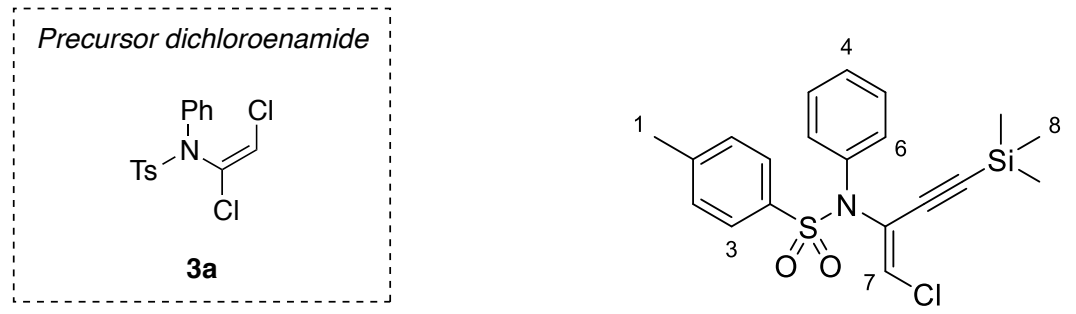

Following example procedure 1.3e: Synthesised from $(E)-N$-phenyl- $N$-(1,2-dichlorovinyl)tosylamide (500 mg, $1.46 \mathrm{mmol}, 1.0$ equiv.) in anhydrous TBME $(2.0 \mathrm{~mL})$ using LiHMDS (freshly prepared according to example procedure $\mathbf{1 . 3 e}, 1.2$ equiv. $), \mathrm{CuCN} \cdot 2 \mathrm{P}(\mathrm{OMe})_{3}(1.46 \mathrm{~mL}$ of a $0.1 \mathrm{M}$ solution in THF, $146 \mu \mathrm{mol}, 10 \mathrm{~mol} \%$ ) and ((trimethylsilyl)ethynyl)magnesium chloride (prepared according to example procedure 1.3c from trimethylsilylacetylene $(0.49 \mathrm{~mL}, 3.51 \mathrm{mmol}, 2.4$ equiv.) in anhydrous THF (4 mL), using ethylmagnesium chloride $(1.75 \mathrm{~mL}$ of a $2.0 \mathrm{M}$ solution in THF, $3.51 \mathrm{mmol}$, 2.4 equiv.) and stirring at $0{ }^{\circ} \mathrm{C}$ for 1 hour). Upon completion, the reaction was worked up and extracted as for example procedure 1.3e. Column chromatography ( $2 \% \mathrm{Et}_{2} \mathrm{O} / 40-60$ petroleum ether) afforded a pale yellow solid which was recrystallised from hexane at $-20{ }^{\circ} \mathrm{C}$ overnight to give the title compound (303 mg, $0.751 \mathrm{mmol}, 51 \%$ ) as colourless plates;

m.p. $120-121^{\circ} \mathrm{C}$;

$\mathbf{R}_{\mathbf{f}} 0.42\left(10 \% \mathrm{Et}_{2} \mathrm{O} / 40-60\right.$ petroleum ether $) ;$

IR (thin film, $v_{\max } / \mathrm{cm}^{-1}$ ) 3080, 2961, 2153, 1596, 1492, 1361, 1251, 1168, 1091, 980, 860, 846, 816, 695, 666, 613;

${ }^{1} \mathbf{H}$ NMR $\left(400 \mathrm{MHz}, \mathrm{CDCl}_{3}\right) \delta_{\mathrm{H}} 7.66(2 \mathrm{H}, \mathrm{m}, H 3), 7.35-7.23(7 \mathrm{H}, \mathrm{m}, H 2, H 4, H 5, H 6), 6.98(1 \mathrm{H}, \mathrm{s}$, $H 7), 2.44$ (3H, s, H1), $0.11(9 \mathrm{H}, \mathrm{s}, H 8)$;

${ }^{13}$ C NMR (101 MHz, $\left.\mathrm{CDCl}_{3}\right) \delta_{\mathrm{C}} 143.9,139.5,136.1,131.6,129.3,129.1,128.41$ (2C), 128.37, 124.5, 105.4, 96.8, 21.6, -0.6;

HRMS (ES+) calc. for $\mathrm{C}_{20} \mathrm{H}_{23} \mathrm{~N}^{35} \mathrm{ClO}_{2} \mathrm{SSi}[\mathrm{M}+\mathrm{H}]^{+}$404.0902, found 404.0901. 


\section{2a Sulfonamide Scope: Dichloroenamides}

(E)-N-(1,2-Dichlorovinyl)- $N$-phenyl-4-(trifluoromethyl)benzenesulfonamide, $3 b$
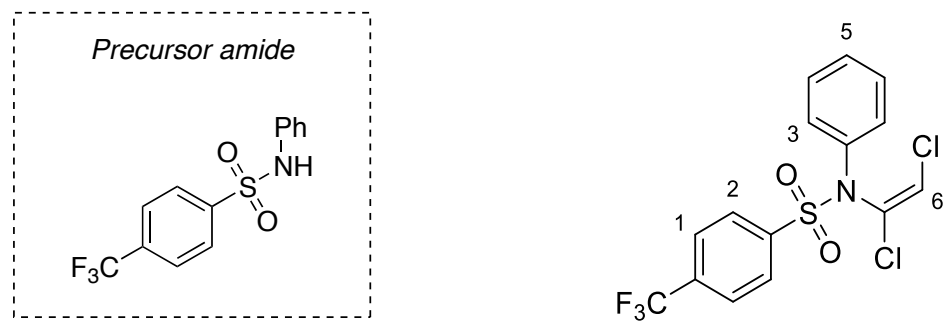

Following example procedure 1.3a: Synthesised from $N$-phenyl-4-(trifluoromethyl) benzenesulfonamide (1.22 g, $4.05 \mathrm{mmol}, 1.0$ equiv.) in DMF (3.04 mL) using trichloroethylene (0.40 mL, $4.45 \mathrm{mmol}, 1.1$ equiv.) and $\mathrm{Cs}_{2} \mathrm{CO}_{3}(1.98 \mathrm{~g}, 6.07 \mathrm{mmol}, 1.5$ equiv.). The reaction takes approximately 2 hours to reach completion. Column chromatography (5\% EtOAc/pentane) afforded the title compound (1.53 g, $3.86 \mathrm{mmol}, 95 \%)$ as a cream solid;

m.p. $90-92{ }^{\circ} \mathrm{C}$;

$\mathbf{R}_{\mathbf{f}} 0.47$ (5\% EtOAc/pentane);

IR (thin film, $v_{\max } / \mathrm{cm}^{-1}$ ) 3088, 1608, 1593, 1489, 1454, 1405, 1372, 1322, 1283, 1225, 1172, 1133 , 1094, 1062, 1018, 951, 911, 843, 815, 759, 734, 714, 695, 679, 617;

${ }^{1} \mathbf{H}$ NMR $\left(400 \mathrm{MHz}, \mathrm{CDCl}_{3}\right) \delta_{\mathrm{H}} 7.90(2 \mathrm{H}, \mathrm{d}, J=8.2 \mathrm{~Hz}, H 1), 7.74(2 \mathrm{H}, \mathrm{d}, J=8.2 \mathrm{~Hz}, H 2), 7.45-7.34$ (5H, m, H3, H4, H5), $6.50(1 \mathrm{H}, \mathrm{d}, H 6)$;

${ }^{13} \mathbf{C}$ NMR $\left(101 \mathrm{MHz}, \mathrm{CDCl}_{3}\right) \delta_{\mathrm{C}} 142.1,137.2,135.1(2 \mathrm{C}, \mathrm{q}, J=33.1 \mathrm{~Hz}), 130.1,129.6,129.5,129.1$, 128.7, 125.9 (2C, q, $J=3.7 \mathrm{~Hz}), 123.1(1 \mathrm{C}, \mathrm{q}, J=272.9 \mathrm{~Hz}), 121.1$;

${ }^{19} \mathbf{F}\left\{{ }^{1} \mathbf{H}\right\}$ NMR $\left(376 \mathrm{MHz}, \mathrm{CDCl}_{3}\right) \delta_{\mathrm{F}}-63.2$;

HRMS We were unable to obtain an accurate mass (ES+ or $\mathrm{CI}+$ ) due to decomposition upon ionisation. 

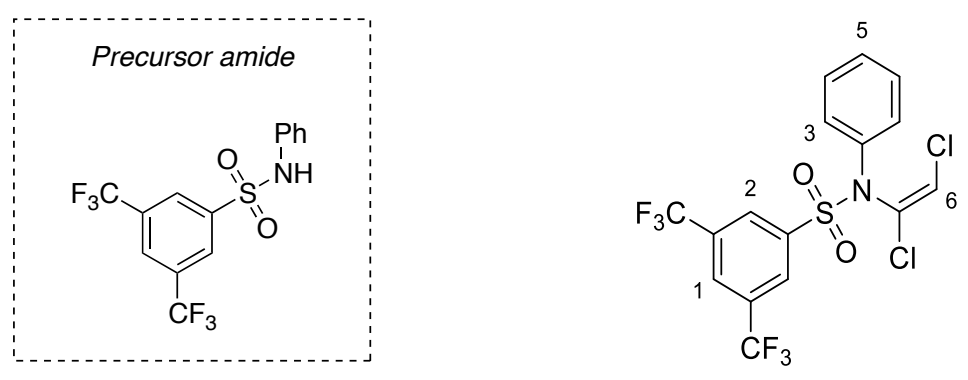

Following example procedure 1.3a: Synthesised from $N$-phenyl-3,5-bis(trifluoromethyl) benzenesulfonamide (1.18 g, $3.20 \mathrm{mmol}, 1.0$ equiv.) in DMF (2.4 mL) using trichloroethylene (0.32 mL, $3.51 \mathrm{mmol}, 1.1$ equiv.) and $\mathrm{Cs}_{2} \mathrm{CO}_{3}$ (1.56 g, $4.79 \mathrm{mmol}, 1.5$ equiv.). The reaction takes approximately 2 hours to reach completion. Column chromatography $\left(10 \% \rightarrow 15 \% \mathrm{Et}_{2} \mathrm{O}\right.$ /pentane $)$ afforded the title compound as a yellow oil, which slowly solidified upon standing to form a yellow powder (1.33 g, $2.87 \mathrm{mmol}, 89 \%)$;

m.p. $64-66^{\circ} \mathrm{C}$;

$\mathbf{R}_{\mathbf{f}} 0.65$ (4\% $\mathrm{Et}_{2} \mathrm{O} /$ pentane);

IR (thin film, $v_{\max } / \mathrm{cm}^{-1}$ ) 3090, 1490, 1382, 1360, 1279, 1172, 1140, 1109, 907, 815, 696, 634;

${ }^{1} \mathbf{H}$ NMR $\left(500 \mathrm{MHz}, \mathrm{CDCl}_{3}\right) \delta_{\mathrm{H}} 8.16(2 \mathrm{H}, \mathrm{s}, H 2), 8.10(1 \mathrm{H}, \mathrm{s}, H 1), 7.48-7.42(1 \mathrm{H}, \mathrm{m}, H 5), 7.42-7.36$ $(2 \mathrm{H}, \mathrm{m}, H 4), 7.35-7.30(2 \mathrm{H}, \mathrm{m}, H 3), 6.52(1 \mathrm{H}, \mathrm{s}, H 6)$;

${ }^{13} \mathbf{C}$ NMR $\left(126 \mathrm{MHz}, \mathrm{CDCl}_{3}\right) \delta_{\mathrm{C}} 141.0,136.7,132.6(2 \mathrm{C}, \mathrm{q}, J=34.7 \mathrm{~Hz}), 130.1,129.8,129.6,128.8$ (2C, q, $J=3.6 \mathrm{~Hz}), 128.7,126.9$ (1C, spt, $J=3.5 \mathrm{~Hz}), 122.2$ (2C, q, $J=273.4 \mathrm{~Hz}), 121.5$;

${ }^{19} \mathbf{F}\left\{{ }^{1} \mathbf{H}\right\}$ NMR $\left(470 \mathrm{MHz}, \mathrm{CDCl}_{3}\right) \delta_{\mathrm{F}}-63.1$;

HRMS (APCI+) calc. for $\mathrm{C}_{16} \mathrm{H}_{10}{ }^{35} \mathrm{Cl}_{2} \mathrm{~F}_{6} \mathrm{NNaO}_{2} \mathrm{~S}[\mathrm{M}+\mathrm{H}]^{+} 463.9708$, found 463.9705 . 

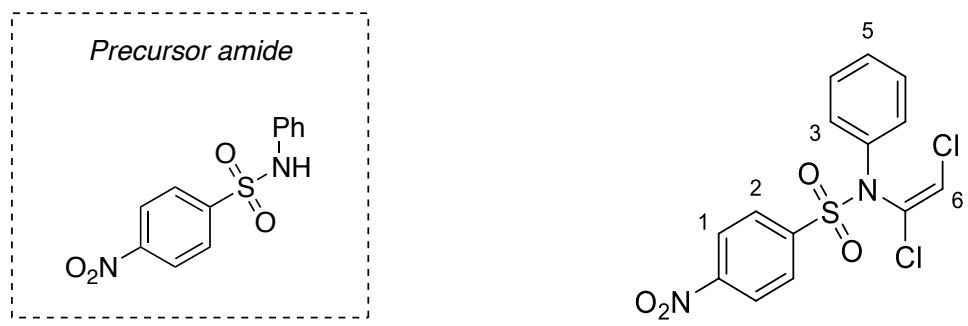

Following example procedure 1.3a: Synthesised from 4-nitro- $N$-phenylbenzenesulfonamide $(850 \mathrm{mg}$, $3.05 \mathrm{mmol}, 1.0$ equiv.) in DMF $(2.29 \mathrm{~mL})$ using trichloroethylene $(0.30 \mathrm{~mL}, 3.36 \mathrm{mmol}, 1.1$ equiv.) and $\mathrm{Cs}_{2} \mathrm{CO}_{3}$ (1.49 g, $4.58 \mathrm{mmol}, 1.5$ equiv.). Note: The reaction was incomplete after 2 hours (as analysed by TLC ( $5 \%$ EtOAc/pentane)) and a further 0.5 equiv. of trichloroethylene was added at this time. The reaction was then stirred for another hour. Recrystallisation (acetone/heptane) afforded the title compound (728 mg, $1.95 \mathrm{mmol}, 64 \%$ ) as yellow crystals;

m.p. $162-163{ }^{\circ} \mathrm{C}$;

$\mathbf{R}_{\mathbf{f}} 0.18$ (5\% EtOAc/pentane);

IR (thin film, $v_{\max } / \mathrm{cm}^{-1}$ ) 3103, 1607, 1531, 1489, 1403, 1373, 1350, 1311, 1283, 1224, 1175, 1094, 1014, 952, 913, 855, 816, 739, 686, 616;

${ }^{1} \mathbf{H}$ NMR $\left(400 \mathrm{MHz}, \mathrm{CDCl}_{3}\right) \delta_{\mathrm{H}} 8.34-8.27(2 \mathrm{H}, \mathrm{m}, H 2), 7.98-7.90(2 \mathrm{H}, \mathrm{m}, H 1), 7.47-7.33$ (5H, m, $H 3, H 4, H 5), 6.51(1 \mathrm{H}, \mathrm{s}, H 6)$;

${ }^{13}$ C NMR $\left(101 \mathrm{MHz}, \mathrm{CDCl}_{3}\right) * \delta_{\mathrm{C}} 150.5,144.1,137.0,129.81,129.76,129.7,128.7,124.0,121.3$; *Note: A single ${ }^{13} \mathrm{C}$ resonance is obscured due to signal overlap.

HRMS We were unable to obtain an accurate mass (ES+ or $\mathrm{CI}+$ ) due to decomposition upon ionisation. 
(E)- $N$-Benzyl- $N$-(1,2-dichlorovinyl)-2,4,6-tri-i-propylbenzenesulfonamide, $3 \mathrm{e}$
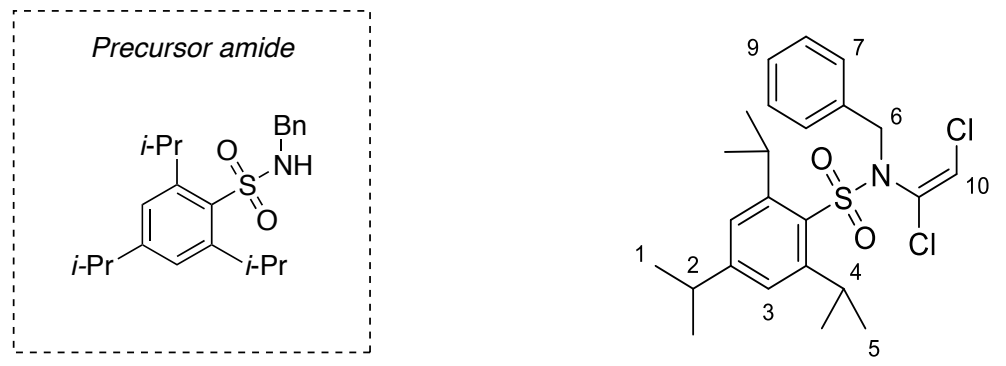

Following example procedure 1.3a: Synthesised from $N$-benzyl-2,4,6-tri-i-propylbenzenesulfonamide (430 mg, $1.15 \mathrm{mmol}, 1.0$ equiv.) in DMF $(0.87 \mathrm{~mL})$ using trichloroethylene (114 $\mu \mathrm{L}, 1.27 \mathrm{mmol}$, 1.1 equiv.) and $\mathrm{Cs}_{2} \mathrm{CO}_{3}(563 \mathrm{mg}, 1.73 \mathrm{mmol}, 1.5$ equiv.). The reaction was stirred overnight for $\sim 15$ hours arbitrarily. Column chromatography (5\% Et $t_{2} \mathrm{O} /$ pentane) afforded the title compound (515 mg, $1.10 \mathrm{mmol}, 96 \%$ ) as a white powder;

m.p. $77-78{ }^{\circ} \mathrm{C}$;

$\mathbf{R}_{\mathbf{f}} 0.63\left(10 \% \mathrm{Et}_{2} \mathrm{O} /\right.$ pentane $)$;

IR (thin film, $v_{\max } / \mathrm{cm}^{-1}$ ) 2959, 2930, 2870, 1600, 1459, 1426, 1370, 1336, 1168, 1104, 1038, 1006, 940, 819, 792, 702, 663;

${ }^{1} \mathbf{H}$ NMR $\left(400 \mathrm{MHz}, \mathrm{CDCl}_{3}\right) \delta_{\mathrm{H}} 7.41-7.28(5 \mathrm{H}, \mathrm{m}, H 7, H 8, H 9), 7.21(2 \mathrm{H}, \mathrm{s}, H 3), 6.18(1 \mathrm{H}, \mathrm{s}, H 10)$, $4.65(2 \mathrm{H}$, br. s, H6), $4.15(2 \mathrm{H}, \mathrm{spt}, J=6.8 \mathrm{~Hz}, H 4), 2.92(1 \mathrm{H}, \mathrm{spt}, J=6.8 \mathrm{~Hz}, H 1), 1.30(12 \mathrm{H}, \mathrm{d}$, $J=6.8 \mathrm{~Hz}, H 5), 1.26(6 \mathrm{H}, \mathrm{d}, J=6.8 \mathrm{~Hz}, H 1)$;

${ }^{13} \mathbf{C}$ NMR $\left(101 \mathrm{MHz}, \mathrm{CDCl}_{3}\right) * \delta_{\mathrm{C}} 154.1,152.3,133.8,131.4,130.6,129.6,128.4,124.2,120.7,51.1$, 34.2, 30.2, 25.0, 23.5; *Note: A single ${ }^{13} \mathrm{C}$ resonance is obscured due to signal overlap.

HRMS (ES+) calc. for $\mathrm{C}_{24} \mathrm{H}_{32}{ }^{35} \mathrm{Cl}_{2} \mathrm{NNaO}_{2} \mathrm{~S}[\mathrm{M}+\mathrm{H}]^{+} 468.1525$, found 468.1525 . 


\section{$N$-((E)-1,2-Dichlorovinyl)- $N$-[(Z)-hex-3-en-1-yl]tosylamide, $3 f$}
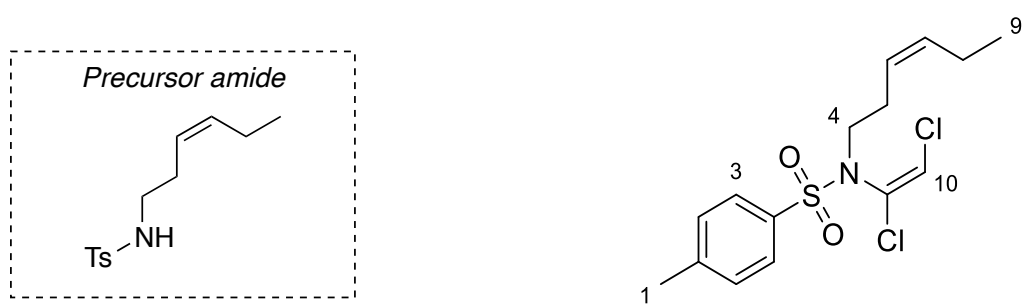

Following example procedure 1.3a: Synthesised from (Z)- $N$-(hex-3-en-1-yl)tosylamide (3.36 g, $13.3 \mathrm{mmol}, 1.0$ equiv.) in DMF (10 mL) using trichloroethylene ( $1.31 \mathrm{~mL}, 14.6 \mathrm{mmol}, 1.1$ equiv.) and $\mathrm{Cs}_{2} \mathrm{CO}_{3}$ (6.48 g, $19.9 \mathrm{mmol}, 1.5$ equiv.). The reaction takes approximately 2 hours to reach completion. Column chromatography $\left(15 \% \mathrm{Et}_{2} \mathrm{O} /\right.$ pentane $)$ afforded the title compound $(4.28 \mathrm{~g}$, $12.3 \mathrm{mmol}, 93 \%$ ) as a colourless oil;

$\mathbf{R}_{\mathbf{f}} 0.45\left(10 \% \mathrm{Et}_{2} \mathrm{O} /\right.$ pentane $)$;

IR (thin film, $v_{\max } / \mathrm{cm}^{-1}$ ) 2964, 1598, 1456, 1362, 1167, 1090, 815, 661;

${ }^{1} \mathbf{H}$ NMR $\left(400 \mathrm{MHz}, \mathrm{CDCl}_{3}\right) \delta_{\mathrm{H}} 7.80(2 \mathrm{H}, \mathrm{d}, J=8.1 \mathrm{~Hz}, H 3), 7.32(2 \mathrm{H}, \mathrm{d}, J=8.1 \mathrm{~Hz}, H 2), 6.51(1 \mathrm{H}$, s, $H 10), 5.46(1 \mathrm{H}, \mathrm{dtt}, J=10.7,7.3,1.6 \mathrm{~Hz}, H 7), 5.26(1 \mathrm{H}, \mathrm{dtt}, 10.7,7.2,1.6 \mathrm{~Hz}, H 6), 3.22(2 \mathrm{H}$, br. s, $H 4), 2.44(3 \mathrm{H}, \mathrm{s}, H 1), 2.28(2 \mathrm{H}, \mathrm{q}, J=7.6 \mathrm{~Hz}, H 5), 2.00$ (2H, quind, $J=7.5,1.6 \mathrm{~Hz}, H 8), 0.94(3 \mathrm{H}, \mathrm{t}$, $J=7.5 \mathrm{~Hz}, H 9)$;

${ }^{13} \mathbf{C}$ NMR $\left(101 \mathrm{MHz}, \mathrm{CDCl}_{3}\right) \delta_{\mathrm{C}} 144.7,135.3,134.9,129.8,129.7,128.5,123.7,121.6,47.8,25.8$, 21.8, 20.7, 14.3;

HRMS $\left(\mathrm{ES}^{+}\right)$calc. for $\mathrm{C}_{15} \mathrm{H}_{19}{ }^{35} \mathrm{Cl}_{2} \mathrm{NNaO}_{2} \mathrm{~S}[\mathrm{M}+\mathrm{Na}]^{+} 370.0406$, found 370.0407 . 


\section{$N$-[(E)-1,2-Dichlorovinyl]- $N$-(3,3-diethoxypropyl)tosylamide, 3g}
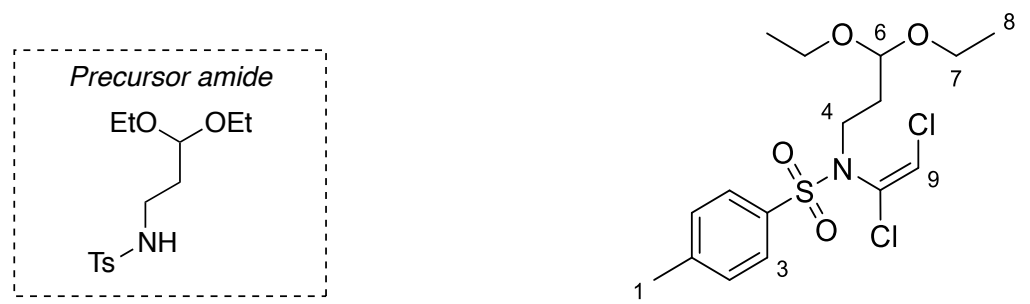

Following example procedure 1.3a: Synthesised from $N$-(3,3-diethoxypropyl)tosylamide (502 $\mathrm{mg}$, $1.67 \mathrm{mmol}, 1.0$ equiv.) in DMF (1.3 mL) using trichloroethylene (165 $\mu \mathrm{L}, 1.83 \mathrm{mmol}, 1.1$ equiv.) and $\mathrm{Cs}_{2} \mathrm{CO}_{3}$ (814 mg, $2.50 \mathrm{mmol}, 1.5$ equiv.). The reaction takes approximately 2 hours to reach completion. Column chromatography ( $20 \rightarrow 30 \%$ EtOAc/pentane) afforded the title compound (556 $\mathrm{mg}, 1.41 \mathrm{mmol}, 85 \%$ ) as a yellow oil which slowly solidified to form a white powder;

m.p. $62-64{ }^{\circ} \mathrm{C}$;

$\mathbf{R}_{\mathbf{f}} 0.30\left(20 \% \mathrm{Et}_{2} \mathrm{O} /\right.$ pentane $)$;

IR (thin film, $v_{\max } / \mathrm{cm}^{-1}$ ) 2976, 2881, 1598, 1449, 1362, 1167, 1121, 1090, 1059, 964, 815, 707, 672;

${ }^{1} \mathbf{H}$ NMR $\left(400 \mathrm{MHz}, \mathrm{CDCl}_{3}\right) \delta_{\mathrm{H}} 7.80(2 \mathrm{H}, \mathrm{d}, J=8.2 \mathrm{~Hz}, H 3), 7.32(2 \mathrm{H}, \mathrm{d}, J=8.2 \mathrm{~Hz}, H 2), 6.51(1 \mathrm{H}$, s, $H 9), 4.62(1 \mathrm{H}, \mathrm{t}, J=5.6 \mathrm{~Hz}, H 6), 3.64(2 \mathrm{H}, \mathrm{dq}, J=9.3,7.0 \mathrm{~Hz}, H 7), 3.49(2 \mathrm{H}, \mathrm{dq}, J=9.3,7.1 \mathrm{~Hz}$, $H 7), 3.32$ (2H, br. s, H4), $2.44(3 \mathrm{H}, \mathrm{s}, H 1), 1.83(2 \mathrm{H}, \mathrm{td}, J=7.0,5.6 \mathrm{~Hz}, H 5), 1.19(6 \mathrm{H}, \mathrm{t}, J=7.1 \mathrm{~Hz}$, $H 8)$;

${ }^{13}$ C NMR $\left(101 \mathrm{MHz}, \mathrm{CDCl}_{3}\right) \delta_{\mathrm{C}} 144.7,135.1,130.0,129.8,128.6,121.5,100.6,62.2,44.2,32.2$, $21.8,15.5$;

HRMS (APCI+) calc. for $\mathrm{C}_{16} \mathrm{H}_{23}{ }^{35} \mathrm{Cl}_{2} \mathrm{NNaO}_{4} \mathrm{~S}[\mathrm{M}+\mathrm{Na}]^{+} 418.0617$, found 418.0621. 
(E)- $N$-(1,2-Dichlorovinyl)- $N$-(furan-2-ylmethyl)tosylamide, $3 \mathrm{~h}$
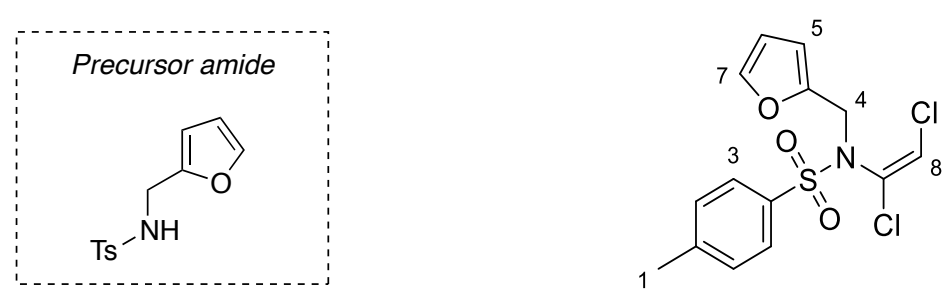

Following example procedure 1.3a: Synthesised from $N$-(furan-2-ylmethyl)tosylamide (279 mg, $1.11 \mathrm{mmol}, 1.0$ equiv.) in DMF (0.83 mL) using trichloroethylene (197 $\mu \mathrm{L}, 1.22 \mathrm{mmol}, 1.1$ equiv.) and $\mathrm{Cs}_{2} \mathrm{CO}_{3}$ (543 mg, $1.67 \mathrm{mmol}, 1.5$ equiv.). The reaction takes approximately 2 hours to reach completion. Column chromatography $(10 \rightarrow 20 \%$ EtOAc/pentane $)$ afforded the title compound (329 $\mathrm{mg}, 0.950 \mathrm{mmol}, 85 \%$ ) as colourless crystals;

m.p. $96-97^{\circ} \mathrm{C}$;

$\mathbf{R}_{\mathbf{f}} 0.28\left(10 \% \mathrm{Et}_{2} \mathrm{O} /\right.$ pentane $)$;

IR (thin film, $v_{\max } / \mathrm{cm}^{-1}$ ) 3088, 1598, 1501, 1361, 1166, 1090, 1010, 942, 814, 661;

${ }^{1} \mathbf{H}$ NMR $\left(400 \mathrm{MHz}, \mathrm{CDCl}_{3}\right) \delta_{\mathrm{H}} 7.87-7.81(2 \mathrm{H}, \mathrm{m}, H 3), 7.37-7.31(3 \mathrm{H}, \mathrm{m}, H 2, H 7), 6.37(1 \mathrm{H}, \mathrm{s}, H 8)$, 6.31-6.27 (2H, m, H5, H6), 4.47 (2H, br. s, H4), 2.46 (3H, s, H1);

${ }^{13} \mathbf{C}$ NMR $\left(101 \mathrm{MHz}, \mathrm{CDCl}_{3}\right) \delta_{\mathrm{C}} 147.2,144.7,143.2,135.4,129.7,129.3,128.4,122.0,110.6,110.5$, 44.4, 21.7;

HRMS (ES+) calc. for $\mathrm{C}_{14} \mathrm{H}_{13}{ }^{35} \mathrm{Cl}_{2} \mathrm{NNaO}_{3} \mathrm{~S}[\mathrm{M}+\mathrm{Na}]^{+}$367.9885, found 367.9886 . 

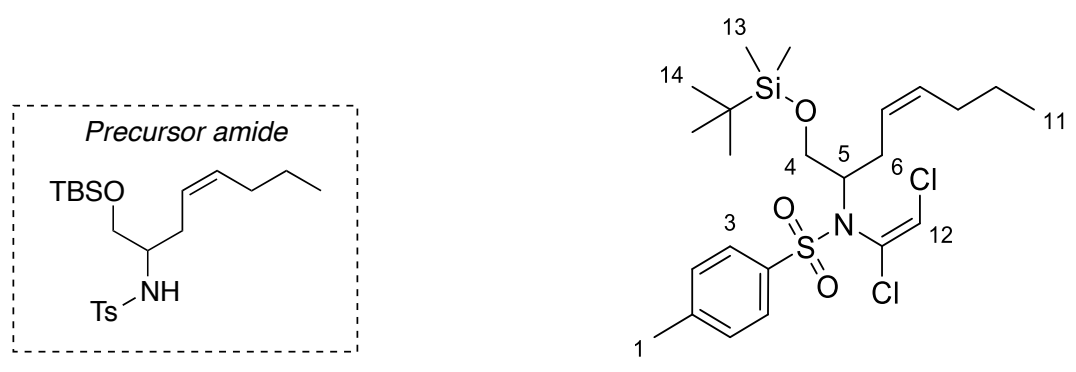

Following example procedure 1.3a: Synthesised from $(Z)-N-(1-((t$-butyldimethylsilyl)oxy)oct-4-en-2yl)tosylamide (359 mg, $0.872 \mathrm{mmol})$ in DMF $(1 \mathrm{~mL})$ using trichloroethylene $(86 \mu \mathrm{L}, 0.959 \mathrm{mmol}$, 1.1 equiv.) and $\mathrm{Cs}_{2} \mathrm{CO}_{3}$ (426 mg, $1.31 \mathrm{mmol}, 1.5$ equiv.). The reaction takes approximately 3 hours to reach completion. Column chromatography ( $0 \rightarrow 10 \%$ EtOAc/pentane) afforded the title compound (335 $\mathrm{mg}, 0.661 \mathrm{mmol}, 76 \%$ ) as a pale yellow oil;

$\mathbf{R}_{\mathbf{f}} 0.55\left(5 \% \mathrm{Et}_{2} \mathrm{O} /\right.$ pentane $)$;

IR (thin film, $v_{\max } / \mathrm{cm}^{-1}$ ) 3088, 2957, 2929, 2858, 1599, 1463, 1360, 1254, 1167, 1091, 836, 814, 667 ;

${ }^{1}$ H NMR $\left(500 \mathrm{MHz}\right.$, toluene- $\left.d_{8}, 363 \mathrm{~K}\right) * \delta_{\mathrm{H}} 7.86(2 \mathrm{H}, \mathrm{d}, J=8.0 \mathrm{~Hz}, H 3), 6.88(2 \mathrm{H}, \mathrm{d}, J=8.0 \mathrm{~Hz}$, $H 2), 6.14$ (1H, s, H12), 5.60-5.20 (2H, m, H7, H8), 4.07-3.94 (1H, m, H5), 3.93-3.86 (1H, m, H4), 3.85-3.77 (1H, m, H4), 2.81-2.69 (1H, m, H6), 2.53-2.41 (1H, m, H6), 2.06-1.93 (5H, m, H1, H9), $1.33(2 \mathrm{H}, \mathrm{sxt}, J=7.2 \mathrm{~Hz}, H 10), 0.97-0.84$ (12H, m, H11,H14), 0.07-0.01 (6H, m, H13); *Note: At room temperature, slow rotation around the $\mathrm{C}^{5}-\mathrm{N}$ single bond leads to peak broadening and splitting in the ${ }^{1} \mathrm{H}$ NMR spectrum.

${ }^{13}$ C NMR (126 MHz, toluene- $\left.d_{8}, 363 \mathrm{~K}\right) \delta_{\mathrm{C}} 143.8,138.3,132.0,129.9,129.5,128.9,126.4,122.6$, 64.7, 64.4, 29.8, 28.6, 26.0, 22.9, 21.0, 18.4, 13.6, -5.5;

HRMS $\left(\mathrm{ES}^{+}\right)$calc. for $\mathrm{C}_{23} \mathrm{H}_{37}{ }^{35} \mathrm{Cl}_{2} \mathrm{NNaO}_{3} \mathrm{SSi}[\mathrm{M}+\mathrm{Na}]^{+}$528.1533, found 528.1533. 

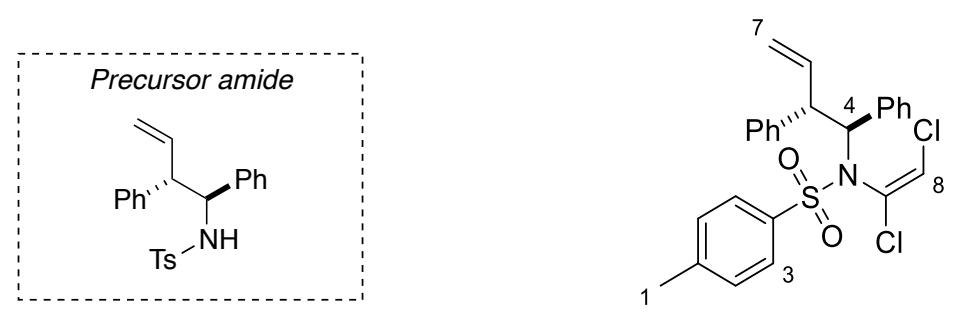

To a stirring solution of $N$-benzylidenetosylamide (500 mg, $1.93 \mathrm{mmol}, 1.0$ equiv.) and cinnamyl bromide (1.14 g, $5.78 \mathrm{mmol}, 3.0$ equiv.) in THF: $\mathrm{H}_{2} \mathrm{O}(8 \mathrm{~mL}$ each) was added indium powder (664 mg, $5.78 \mathrm{mmol}, 3.0$ equiv.) and the reaction stirred overnight. The reaction was quenched with $1 \mathrm{M} \mathrm{HCl}(10 \mathrm{~mL})$ and stirred vigorously for 15 minutes, followed by the addition of $\mathrm{Et}_{2} \mathrm{O}(15 \mathrm{~mL})$. The organic layer was separated, and the aqueous extracted with $\mathrm{Et}_{2} \mathrm{O}(3 \times 10 \mathrm{~mL})$. The combined organic extracts were then washed with aqueous saturated $\mathrm{NaHCO}_{3}(20 \mathrm{~mL})$ and the organic layer separated, dried $\left(\mathrm{Na}_{2} \mathrm{SO}_{4}\right)$ and concentrated in vacuo to afford the crude title product $(657 \mathrm{mg}$, containing $\sim 20 \%$ cinnamyl alcohol and 1,2-diphenylbut-3-en-1-ol) as a white solid. This solid was used directly in the next reaction without purification.

To a nitrogen flushed flask equipped with a magnetic stirrer bar and a septum, was added the crude amide, powdered $\mathrm{Cs}_{2} \mathrm{CO}_{3}$ (777 mg, $2.34 \mathrm{mmol}, \sim 1.7$ equiv.) and DMF (1.25 mL). The resulting suspension was then stirred at $50{ }^{\circ} \mathrm{C}$ for 10 minutes, followed by the addition of trichloroethylene $(0.16 \mathrm{~mL}, 1.75 \mathrm{mmol}, \sim 1.3$ equiv.) dropwise over 10 minutes. The resulting mixture was stirred at $50{ }^{\circ} \mathrm{C}$ until reaction completion, as analysed by TLC ( $\sim 5$ hours). Upon cooling to room temperature, the mixture was partitioned between EtOAc $(10 \mathrm{~mL})$ and brine $(30 \mathrm{~mL})$, the organic layer was separated and further washed with brine $(2 \times 30 \mathrm{~mL})$. The organic layer was then dried $\left(\mathrm{Na}_{2} \mathrm{SO}_{4}\right)$, filtered and concentrated in vacuo. Column chromatography ( $3 \% \mathrm{Et}_{2} \mathrm{O} / 40-60$ petroleum ether), followed by recrystallisation from $i-\mathrm{PrOH}: \mathrm{H}_{2} \mathrm{O}$ (10:1), afforded the title compound (446 mg, $0.943 \mathrm{mmol}, 49 \%$ ) as colourless crystals;

m.p. $99-100{ }^{\circ} \mathrm{C}$;

$\mathbf{R}_{\mathbf{f}} 0.56$ (4\% EtOAc/40-60 petroleum ether);

IR (thin film, $v_{\max } / \mathrm{cm}^{-1}$ ) 3083, 3031, 1598, 1494, 1454, 1353, 1163, 1089, 973, 912, 813, 701, 664;

${ }^{1} \mathbf{H}$ NMR $\left(400 \mathrm{MHz}, \mathrm{CDCl}_{3}\right) \delta_{\mathrm{H}} 7.48-7.05(12 \mathrm{H}, \mathrm{br} . \mathrm{m}, H 3, \mathrm{Ph} H), 7.00(2 \mathrm{H}, \mathrm{d}, J=8.1 \mathrm{~Hz}, H 2), 6.51$ $(1 \mathrm{H}, \mathrm{s}, H 8), 5.79$ (1H, ddd, $J=17.1,10.4,8.6 \mathrm{~Hz}, H 6), 5.47(1 \mathrm{H}$, br. d, $J=7.6 \mathrm{~Hz}, H 4), 4.94(1 \mathrm{H}, \mathrm{d}$, $J=10.4 \mathrm{~Hz}, H 7), 4.90(1 \mathrm{H}$, br. d, $J=17.1 \mathrm{~Hz}, H 7), 4.60-4.22$ (1H, br. m, H5), 2.34 (3H, s, H1);

${ }^{13} \mathbf{C}$ NMR $\left(101 \mathrm{MHz}, \mathrm{CDCl}_{3}\right) * \delta_{\mathrm{C}} 143.5,140.6,137.4,136.8,136.3,134.7,130.7,128.9,128.2,128.0$, 127.5, 126.7, 124.5, 117.4, 68.6, 52.2, 51.6, 21.4; *Note: This compound is rotameric and as a result some ${ }^{13} \mathrm{C}$ resonances are duplicated or obscured due to peak broadening.

HRMS (ES+) calc. for $\mathrm{C}_{25} \mathrm{H}_{23}{ }^{35} \mathrm{Cl}_{2} \mathrm{NNaO}_{2} \mathrm{~S}[\mathrm{M}+\mathrm{Na}]^{+}$494.0719, found 494.0717. 
(E)-N-(t-Butyl)-N-(1,2-dichlorovinyl)tosylamide, 3k
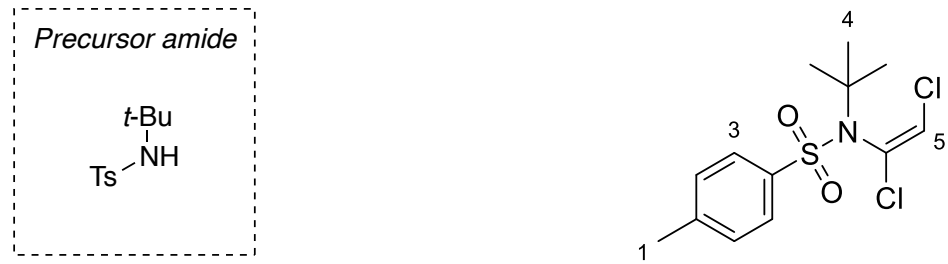

Following example procedure 1.3a: Synthesised from $N$ - $(t$-butyl $)$ tosylamide $(1.00 \mathrm{~g}, 4.40 \mathrm{mmol}$, 1.0 equiv.) in DMF (3.3 mL) using trichloroethylene $\left(0.44 \mathrm{~mL}, 4.84 \mathrm{mmol}, 1.1\right.$ equiv.) and $\mathrm{Cs}_{2} \mathrm{CO}_{3}$ ( $2.15 \mathrm{~g}, 6.60 \mathrm{mmol}, 1.5$ equiv.). The reaction was stirred overnight for $\sim 15$ hours arbitrarily. Column chromatography (10\% $\mathrm{Et}_{2} \mathrm{O} /$ pentane) afforded the title compound $(1.27 \mathrm{~g}, 3.94 \mathrm{mmol}, 90 \%)$ as colourless crystals;

m.p. $92-93{ }^{\circ} \mathrm{C}$;

$\mathbf{R}_{\mathbf{f}} 0.75$ (20\% EtOAc/40-60 petroleum ether);

IR (thin film, $v_{\max } / \mathrm{cm}^{-1}$ ) 3087, 2984, 1598, 1351, 1159, 1107, 1089, 951, 812, 787, 706, 670;

${ }^{1} \mathbf{H}$ NMR $\left(400 \mathrm{MHz}, \mathrm{CDCl}_{3}\right) \delta_{\mathrm{H}} 7.84(2 \mathrm{H}, \mathrm{d}, J=8.2 \mathrm{~Hz}, H 3), 7.26(2 \mathrm{H}, \mathrm{d}, J=8.2 \mathrm{~Hz}, H 2), 6.39(1 \mathrm{H}$, s, $H 5), 2.41(3 \mathrm{H}, \mathrm{s}, H 1), 1.52(9 \mathrm{H}, \mathrm{s}, H 4)$;

${ }^{13} \mathbf{C}$ NMR $\left(101 \mathrm{MHz}, \mathrm{CDCl}_{3}\right) \delta_{\mathrm{C}} 143.9,138.0,131.5,129.2,128.5,121.6,64.3,29.8,21.5$;

HRMS (ES+) calc. for $\mathrm{C}_{13} \mathrm{H}_{17}{ }^{35} \mathrm{Cl}_{2} \mathrm{NNaO}_{2} \mathrm{~S}[\mathrm{M}+\mathrm{Na}]^{+} 344.0249$, found 344.0243 . 
(E)-N-(2-Bromophenyl)- $N$-(1,2-dichlorovinyl)tosylamide, 31
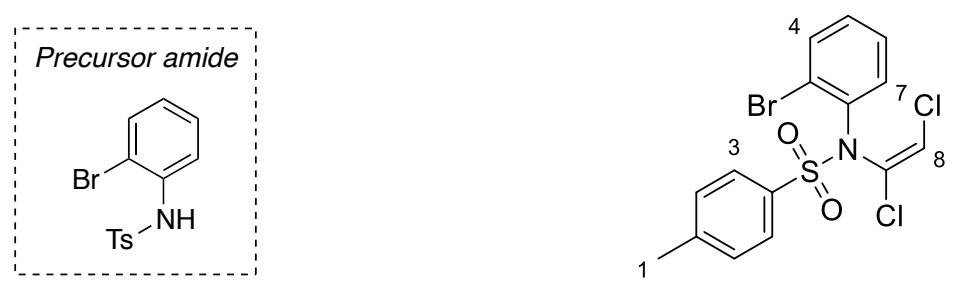

Following example procedure 1.3a: Synthesised from $\mathrm{N}$-(2-bromophenyl)tosylamide (1.00 g, $3.07 \mathrm{mmol}, 1.0$ equiv.) in DMF (2.3 mL) using trichloroethylene (0.30 mL, $3.37 \mathrm{mmol}, 1.1$ equiv.) and $\mathrm{Cs}_{2} \mathrm{CO}_{3}$ (1.50 g, $4.60 \mathrm{mmol}, 1.5$ equiv.). The reaction was stirred overnight for $\sim 15$ hours arbitrarily. Column chromatography $\left(10 \% \mathrm{Et}_{2} \mathrm{O} /\right.$ pentane $)$ afforded the title compound $(1.01 \mathrm{~g}$, $2.40 \mathrm{mmol}, 78 \%$ ) as a white powder. This compound can be recrystallised from $\mathrm{Et}_{2} \mathrm{O} /$ hexane (1:5) to give colourless crystals;

m.p. $133-135^{\circ} \mathrm{C}$;

$\mathbf{R}_{\mathbf{f}} 0.37$ (10\% EtOAc/40-60 petroleum ether);

IR (thin film, $v_{\max } / \mathrm{cm}^{-1}$ ) 3075, 2922, 1597, 1470, 1369, 1289, 1227, 1169, 1088, 1048, 930, 813,757, 707 ;

${ }^{1} \mathbf{H}$ NMR $\left(400 \mathrm{MHz}, \mathrm{CDCl}_{3}\right) \delta_{\mathrm{H}} 7.72-7.66(2 \mathrm{H}, \mathrm{m}, H 3), 7.61(1 \mathrm{H}, \mathrm{dd}, J=7.8,1.6 \mathrm{~Hz}, H 4), 7.59(1 \mathrm{H}$, $\mathrm{dd}, J=7.8,1.6 \mathrm{~Hz}, H 7), 7.31(1 \mathrm{H}, \mathrm{td}, J=7.8,1.6 \mathrm{~Hz}, H 5), 7.26(2 \mathrm{H}, \mathrm{m}, H 2), 7.24(1 \mathrm{H}, \mathrm{td}, J=7.8,1.6$ $\mathrm{Hz}, H 6), 6.43(1 \mathrm{H}, \mathrm{s}, H 8), 2.44(3 \mathrm{H}, \mathrm{s}, H 1)$;

${ }^{13}$ C NMR (101 MHz, $\left.\mathrm{CDCl}_{3}\right) \delta_{\mathrm{C}} 144.9,135.8,135.4,134.3,134.0,130.7,129.42,129.35,129.0$, 127.5, 124.9, 119.4, 21.7;

HRMS (ES+) calc. for $\mathrm{C}_{15} \mathrm{H}_{12}{ }^{79} \mathrm{Br}^{35} \mathrm{Cl}_{2} \mathrm{NNaO}_{2} \mathrm{~S}[\mathrm{M}+\mathrm{Na}]^{+} 441.9041$, found 441.9057 . 

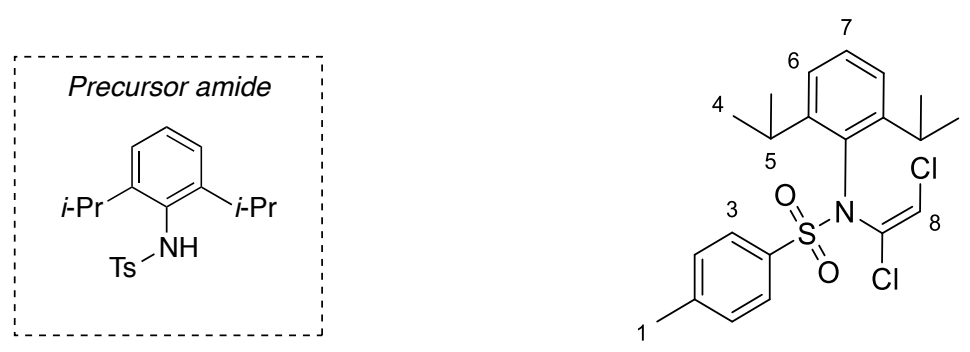

Following example procedure 1.3a: Synthesised from $N$-(2,6-di-i-propylphenyl)tosylamide (300 mg, 0.905 mmol, 1.0 equiv.) in DMF ( $0.70 \mathrm{~mL})$ using trichloroethylene ( $89 \mu \mathrm{L}, 0.996 \mathrm{mmol}, 1.1$ equiv.) and $\mathrm{Cs}_{2} \mathrm{CO}_{3}$ (442 mg, $1.36 \mathrm{mmol}, 1.5$ equiv.). The reaction takes approximately 3 hours to reach completion. Column chromatography $\left(20 \% \mathrm{Et}_{2} \mathrm{O} /\right.$ pentane) afforded the title compound $(361 \mathrm{mg}$, $0.847 \mathrm{mmol}, 94 \%$ ) as a white powder;

m.p. $140{ }^{\circ} \mathrm{C}$;

Rf 0.63 (20\% EtOAc/40-60 petroleum ether);

IR (thin film, $v_{\max } / \mathrm{cm}^{-1}$ ) 2973, 1598, 1466, 1359, 1168, 1075, 932, 809, 666;

${ }^{1} \mathbf{H}$ NMR $\left(400 \mathrm{MHz}, \mathrm{CDCl}_{3}\right) \delta_{\mathrm{H}} 7.67-7.62(2 \mathrm{H}, \mathrm{m}, H 3), 7.43-7.37(1 \mathrm{H}, \mathrm{m}, H 7), 7.27-7.21(4 \mathrm{H}, \mathrm{m}$, $H 2, H 6), 6.19(1 \mathrm{H}, \mathrm{s}, H 8), 3.37(2 \mathrm{H}, \mathrm{spt}, J=6.6 \mathrm{~Hz}, H 5), 2.41(3 \mathrm{H}, \mathrm{s}, H 1), 1.17(6 \mathrm{H}, \mathrm{d}, J=6.6 \mathrm{~Hz}$, $H 4), 1.12(6 \mathrm{H}, \mathrm{d}, J=6.6 \mathrm{~Hz}, H 4)$;

${ }^{13} \mathbf{C}$ NMR $\left(101 \mathrm{MHz}, \mathrm{CDCl}_{3}\right) * \delta_{\mathrm{C}} 150.6,144.4,136.9,132.0,131.7,130.1,129.1,128.9,125.3,113.3$, 28.9, 25.2, 24.0, 21.6; *Note: A single ${ }^{13} \mathrm{C}$ resonance is obscured due to signal overlap.

HRMS (ES+) calc. for $\mathrm{C}_{21} \mathrm{H}_{25}{ }^{35} \mathrm{Cl}_{2} \mathrm{NNaO}_{2} \mathrm{~S}[\mathrm{M}+\mathrm{Na}]^{+} 448.0875$, found 448.0881. 


\section{2b Sulfonamide Scope: Ynamides}

$N$-((4-Chlorophenyl)ethynyl)- $N$-phenyltosylamide, 1am
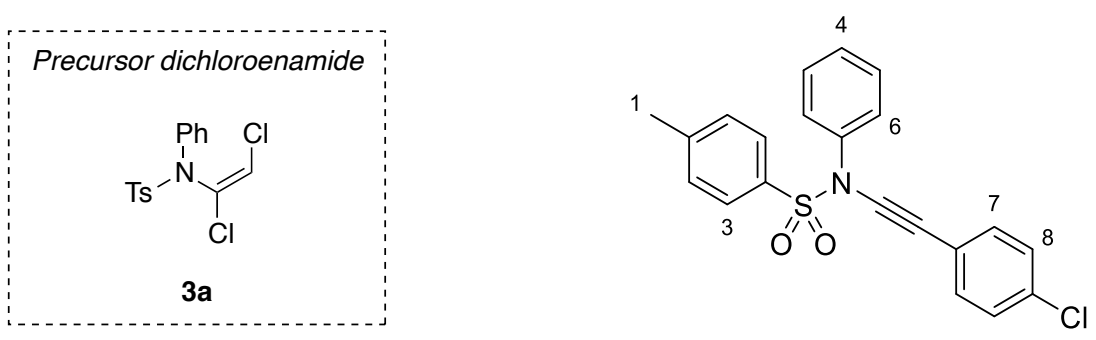

Following example procedure 1.3e: Synthesised from $(E)-N$-phenyl- $N$-(1,2-dichlorovinyl)tosylamide (500 mg, $1.46 \mathrm{mmol}, 1.0$ equiv.) in anhydrous TBME (2.0 mL) using LiHMDS (freshly prepared according to example procedure $1.3 \mathrm{e}, 1.2$ equiv. $), \mathrm{CuCN} \cdot 2 \mathrm{P}(\mathrm{OMe})_{3}(183 \mu \mathrm{L}$ of a $0.1 \mathrm{M}$ solution in THF, $18.3 \mu \mathrm{mol}, 1.25 \mathrm{~mol} \%)$ and 4-chlorophenylmagnesium bromide $(1.50 \mathrm{~mL}$ of a $1.0 \mathrm{M}$ solution in $\mathrm{Et}_{2} \mathrm{O}, 1.50 \mathrm{mmol}, 1.03$ equiv.). Upon completion, the reaction was worked up and extracted as for example procedure 1.3e. Column chromatography (2.5\% EtOAc/pentane) afforded a pale yellow solid which was recrystallised from $i-\mathrm{PrOH} /$ heptane to give the title compound (478 $\mathrm{mg}, 1.25 \mathrm{mmol}, 86 \%$ ) as colourless needles;

m.p. $140-141^{\circ} \mathrm{C}$;

$\mathbf{R}_{\mathbf{f}} 0.24\left(10 \% \mathrm{Et}_{2} \mathrm{O} /\right.$ pentane);

IR (thin film, $v_{\max } / \mathrm{cm}^{-1}$ ) 3066, 2239, 1594, 1488, 1454, 1398, 1373, 1339, 1295, 1187, 1172, 1089 , $1064,1027,1014,922,891,827,814,790,752,705,689,657,610$;

${ }^{1} \mathbf{H}$ NMR $\left(400 \mathrm{MHz}, \mathrm{CDCl}_{3}\right) \delta_{\mathrm{H}} 7.60(2 \mathrm{H}, \mathrm{d}, J=8.3 \mathrm{~Hz}, H 3), 7.39-7.23(11 \mathrm{H}, \mathrm{m}, H 2, H 4, H 5, H 6$, $H 7, H 8), 2.44(3 \mathrm{H}, \mathrm{s}, H 1)$;

${ }^{13} \mathbf{C}$ NMR $\left(101 \mathrm{MHz}, \mathrm{CDCl}_{3}\right) \delta_{\mathrm{C}} 145.1,138.7,133.9,132.9,132.6,129.5,129.1,128.6,128.4,128.2$, 126.3, 121.1, 83.9, 69.5, 21.7;

HRMS (ES+) calc. for $\mathrm{C}_{21} \mathrm{H}_{16}{ }^{35} \mathrm{ClNNaO}_{2} \mathrm{~S}[\mathrm{M}+\mathrm{Na}]^{+}$404.0483, found 404.0483. 


\section{$N$-((4-Chlorophenyl)ethynyl)- $N$-phenyl-4-(trifluoromethyl)benzenesulfonamide, 1an}
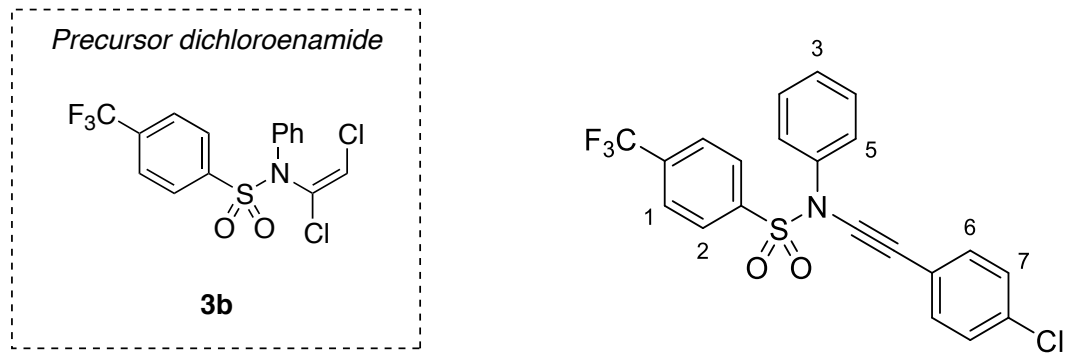

Following example procedure 1.3e: Synthesised from (E)- $N$-(1,2-dichlorovinyl)- $N$-phenyl-4(trifluoromethyl)benzenesulfonamide $(500 \mathrm{mg}, 1.26 \mathrm{mmol}, 1.0$ equiv.) in anhydrous TBME $(2 \mathrm{~mL})$ using LiHMDS (freshly prepared according to example procedure 1.3e, 1.2 equiv.), $\mathrm{CuCN} \cdot 2 \mathrm{LiCl}$ (16 $\mu \mathrm{L}$ of a $1 \mathrm{M}$ solution in THF, $16 \mu \mathrm{mol}, 1.25 \mathrm{~mol} \%)$ and 4-chloromagnesium bromide (1.39 $\mathrm{mL}$ of a $1.0 \mathrm{M}$ solution in $\mathrm{Et}_{2} \mathrm{O}, 1.39 \mathrm{mmol}, 1.1$ equiv.). Upon completion, the reaction was worked up and extracted as for example procedure 1.3e. Filtration through a silica pad (eluting with $20 \%$ $\mathrm{CH}_{2} \mathrm{Cl}_{2} /$ pentane), followed by recrystallisation from TBME/heptane (1:3) afforded the title compound (457 mg, $1.05 \mathrm{mmol}, 83 \%$ ) as colourless crystals;

m.p. $132{ }^{\circ} \mathrm{C}$;

$\mathbf{R}_{\mathbf{f}} 0.31\left(2 \% \mathrm{Et}_{2} \mathrm{O} /\right.$ pentane $)$;

IR (thin film, $v_{\max } / \mathrm{cm}^{-1}$ ) 3071, 2242, 1593, 1489, 1405, 1382, 1321, 1174, 1135, 1108, 1091, 1062, $1016,925,895,828,792,753,734,716,687$;

${ }^{1} \mathbf{H}$ NMR $\left(400 \mathrm{MHz}, \mathrm{CDCl}_{3}\right) \delta_{\mathrm{H}} 7.86(2 \mathrm{H}, \mathrm{d}, J=8.3 \mathrm{~Hz}, H 1), 7.78(2 \mathrm{H}, \mathrm{d}, J=8.3 \mathrm{~Hz}, H 2), 7.43-7.34$ $(3 \mathrm{H}, \mathrm{m}, H 3, H 4), 7.34-7.26(6 \mathrm{H}, \mathrm{m}, H 5, H 6, H 7)$;

${ }^{13}$ C NMR $\left(101 \mathrm{MHz}, \mathrm{CDCl}_{3}\right) \delta_{\mathrm{C}} 139.3,138.3,135.6(1 \mathrm{C}, \mathrm{q}, J=33.4 \mathrm{~Hz}), 134.4,132.7,129.4,128.8$, 128.73, 128.70, 126.2, 126.1 (2C, q, $J=4.0 \mathrm{~Hz}), 123.1$ (1C, q, $J=273 \mathrm{~Hz}), 120.6,83.0,69.9$;

${ }^{19}$ F NMR $\left(376 \mathrm{MHz}, \mathrm{CDCl}_{3}\right) \delta_{\mathrm{F}}-63.2$;

HRMS (ES+) calc. for $\mathrm{C}_{22} \mathrm{H}_{18}{ }^{35} \mathrm{ClF}_{3} \mathrm{NO}_{3} \mathrm{~S}[\mathrm{M}+\mathrm{MeOH}+\mathrm{H}]^{+} 468.0643$, found 468.0642 . 

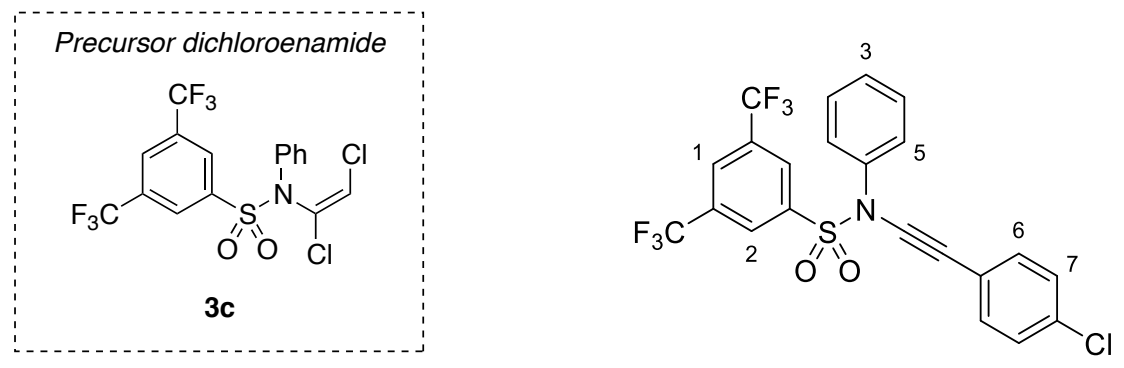

Following example procedure 1.3e: Synthesised from (E)- $N$-phenyl- $N$-(1,2-dichlorovinyl)-3,5bis(trifluoromethyl)benzenesulfonamide (150 mg, $0.323 \mathrm{mmol}, 1.0$ equiv.) in anhydrous TBME (4 mL) using LiHMDS (freshly prepared according to example procedure 1.3e, 1.2 equiv.), $\mathrm{CuCN} \cdot 2 \mathrm{LiCl}(4 \mu \mathrm{L}$ of a $1 \mathrm{M}$ solution in THF, $4 \mu \mathrm{mol}, 1.25 \mathrm{~mol} \%)$ and 4-chloromagnesium bromide ( $0.36 \mathrm{~mL}$ of a $1.0 \mathrm{M}$ solution in $\mathrm{Et}_{2} \mathrm{O}, 0.355 \mathrm{mmol}, 1.1$ equiv.). Upon completion, the reaction was worked up and extracted as for example procedure 1.3e. Column chromatography $(0 \rightarrow 2 \%$ $\mathrm{Et}_{2} \mathrm{O} /$ pentane) afforded the title compound (127 mg, $\left.0.251 \mathrm{mmol}, 78 \%\right)$ as a white powder;

m.p. $108-109^{\circ} \mathrm{C}$;

$\mathbf{R}_{\mathbf{f}} 0.73$ ( $4 \% \mathrm{Et}_{2} \mathrm{O} /$ pentane);

IR (thin film, $v_{\max } / \mathrm{cm}^{-1}$ ) 3087, 2244, 1625, 1593, 1489, 1456, 1391, 1358, 1279, 1179, 1142, 1109 , $1092,1064,1015,927,905,829,790,753,722,691,682,625$;

${ }^{1} \mathbf{H}$ NMR $\left(400 \mathrm{MHz}, \mathrm{CDCl}_{3}\right) \delta_{\mathrm{H}} 8.16(1 \mathrm{H}, \mathrm{s}, H 1), 8.12(2 \mathrm{H}, \mathrm{s}, H 2), 7.44-7.36(3 \mathrm{H}, \mathrm{m}, H 3, H 4), 7.30-$ $7.27(4 \mathrm{H}, \mathrm{m}, H 6, H 7), 7.27-7.21(2 \mathrm{H}, \mathrm{m}, H 5)$;

${ }^{13} \mathbf{C}$ NMR $\left(101 \mathrm{MHz}, \mathrm{CDCl}_{3}\right) * \delta_{\mathrm{C}} 137.9,134.8,132.89(2 \mathrm{C}, \mathrm{q}, J=34.2 \mathrm{~Hz}), 132.88,129.6,129.3$, 128.8, $128.4(2 \mathrm{C}, \mathrm{q}, J=3.4 \mathrm{~Hz}), 127.3(1 \mathrm{C}$, spt, $J=3.5 \mathrm{~Hz}), 126.2,122.3(2 \mathrm{C}, \mathrm{q}, J=273 \mathrm{~Hz}), 120.0$, $82.2,70.5 ; *$ Note: a single ${ }^{13} \mathrm{C}$ resonance is obscured due to signal overlap.

${ }^{19}$ F NMR $\left(376 \mathrm{MHz}, \mathrm{CDCl}_{3}\right) \delta_{\mathrm{F}}-63.0$;

HRMS (ES+) calc. for $\mathrm{C}_{23} \mathrm{H}_{17}{ }^{35} \mathrm{ClF}_{6} \mathrm{NO}_{3} \mathrm{~S}[\mathrm{M}+\mathrm{MeOH}+\mathrm{H}]^{+}$536.0516, found 536.0517. 

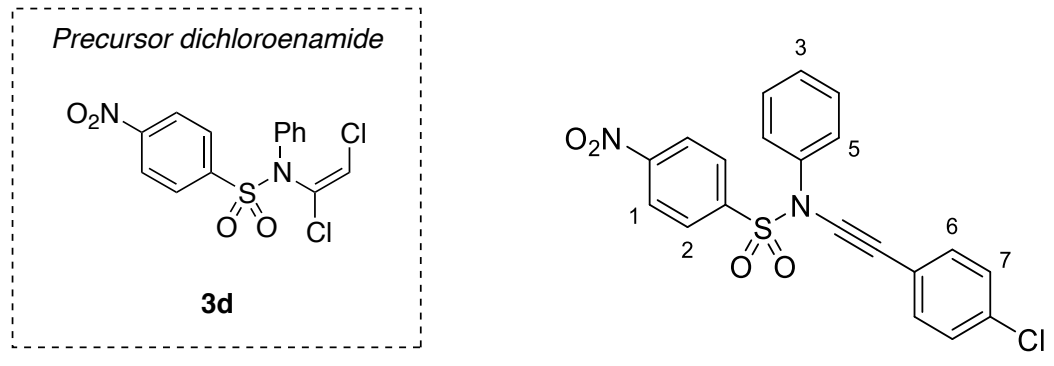

Following example procedure 1.3f: Synthesised from finely powdered $(E)-N$-phenyl- $N-(1,2-$ dichlorovinyl)-4-nitrobenzenesulfonamide (150 mg, $0.402 \mathrm{mmol}, 1.0$ equiv.) in anhydrous TBME ( $5 \mathrm{~mL}$ ) using LiHMDS (freshly prepared according to example procedure 1.3f, 1.2 equiv.). Note: the starting dichloroenamide is poorly soluble in TBME and after the addition of LiHMDS at $0{ }^{\circ} \mathrm{C}$, the reaction was stirred at room temperature $\left(21^{\circ} \mathrm{C}\right)$ for 2 hours. At this time, TLC analysis $(10 \%$ $\mathrm{Et}_{2} \mathrm{O}$ /pentane) indicated incomplete conversion of the starting dichloroenamide, and additional LiHMDS (1.2 equiv.) was added to the reaction at $0{ }^{\circ} \mathrm{C}$. The reaction was then stirred at room temperature for 1 additional hour to achieve complete conversion. The diarylzinc solution was prepared using anhydrous TBME $(1.0 \mathrm{~mL})$, 4-chlorophenylmagnesium bromide $(0.44 \mathrm{~mL}$ of a $1.0 \mathrm{M}$ solution in $\mathrm{Et}_{2} \mathrm{O}, 0.442 \mathrm{mmol}, 1.1$ equiv.), zinc(II) chloride $\left(0.22 \mathrm{~mL}\right.$ of a $1.0 \mathrm{M}$ solution in $\mathrm{Et}_{2} \mathrm{O}$, $0.221 \mathrm{mmol}, 0.55$ equiv.), and the reaction conducted using $\mathrm{CuCN} \cdot 2 \mathrm{LiCl}(5 \mu \mathrm{L}$ of a $1.0 \mathrm{M}$ solution in THF, $5 \mu \mathrm{mol}, 1.25 \mathrm{~mol} \%$ ). Upon completion, the reaction was worked up and extracted as for example procedure 1.3f. Filtration through a silica pad (eluting with $20 \% \mathrm{CH}_{2} \mathrm{Cl}_{2} /$ pentane), followed by recrystallisation from EtOAc/heptane (1:2) afforded the title compound (126 mg, $0.306 \mathrm{mmol}$, $76 \%$ ) as yellow needles;

m.p. $169-170{ }^{\circ} \mathrm{C}$;

$\mathbf{R}_{\mathbf{f}} 0.49\left(10 \% \mathrm{Et}_{2} \mathrm{O} /\right.$ pentane);

IR (thin film, $v_{\max } / \mathrm{cm}^{-1}$ ) 3105, 2242, 1606, 1592, 1531, 1488, 1402, 1382, 1347, 1312, 1180, 1089, 1064, 1014, 925, 900, 855, 829, 791, 738, 690;

${ }^{1} \mathbf{H}$ NMR $\left(400 \mathrm{MHz}, \mathrm{CDCl}_{3}\right) \delta_{\mathrm{H}} 8.39-8.31(2 \mathrm{H}, \mathrm{m}, H 1), 7.96-7.86(2 \mathrm{H}, \mathrm{m}, H 2), 7.44-7.35(3 \mathrm{H}, \mathrm{m}$, $H 3, H 4), 7.35-7.25(6 \mathrm{H}, \mathrm{m}, H 5, H 6, H 7)$;

${ }^{13} \mathbf{C}$ NMR $\left(101 \mathrm{MHz}, \mathrm{CDCl}_{3}\right) \delta_{\mathrm{C}} 150.9,141.1,138.0,134.6,132.8,129.5,129.4,129.0,128.8,126.2$, $124.2,120.4,82.6,70.1$;

HRMS (ES+) calc. for $\mathrm{C}_{20} \mathrm{H}_{17}{ }^{35} \mathrm{ClN}_{3} \mathrm{O}_{4} \mathrm{~S}\left[\mathrm{M}+\mathrm{NH}_{4}\right]^{+} 430.0623$, found 430.0623 . 

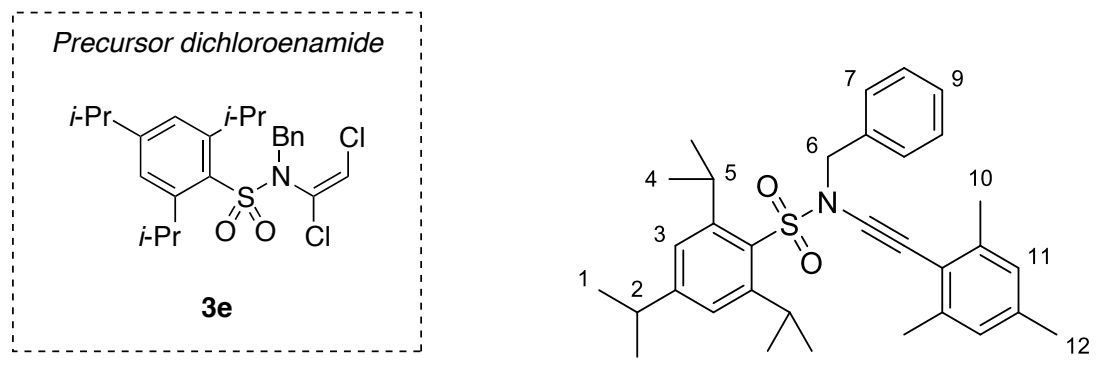

Following example procedure 1.3e: Synthesised from $(E)-N$-benzyl- $N$-(1,2-dichlorovinyl)-2,4,6-tri- $i$ propylbenzenesulfonamide ( $200 \mathrm{mg}, 0.427 \mathrm{mmol}, 1.0$ equiv.) in anhydrous TBME (2.0 mL) using LiHMDS (freshly prepared according to example procedure 1.3e, 1.2 equiv.), $\mathrm{CuCN} \cdot 2 \mathrm{LiCl}$ ( $4 \mu \mathrm{L}, 4$ $\mu \mathrm{mol}, 1.25 \mathrm{~mol} \%)$, and mesitylmagnesium bromide $(0.44 \mathrm{~mL}$ of a $1.0 \mathrm{M}$ solution in THF, $0.440 \mathrm{mmol}, 1.03$ equiv.). Upon completion, the reaction was worked up and extracted as for example procedure 1.3e. Column chromatography $\left(0 \rightarrow 3 \% \mathrm{Et}_{2} \mathrm{O}\right.$ /pentane) afforded an orange oil, which was crystallised using $\mathrm{MeOH}(\sim 1 \mathrm{~mL})$ to afford the title compound $(167 \mathrm{mg}, 0.324 \mathrm{mmol}, 76 \%)$ as colourless plates;

m.p. $89-90{ }^{\circ} \mathrm{C}$;

$\mathbf{R}_{\mathbf{f}} 0.46\left(4 \% \mathrm{Et}_{2} \mathrm{O} /\right.$ pentane);

IR (thin film $v_{\max } / \mathrm{cm}^{-1}$ ) 2960, 2929, 2870, 2231, 1600, 1565, 1497, 1458, 1427, 1370, 1332, 1258, $1168,1103,1075,1060,1038,1004,931,899,852,766,733,697,670,624$;

${ }^{1} \mathbf{H}$ NMR $\left(400 \mathrm{MHz}, \mathrm{CDCl}_{3}\right) \delta_{\mathrm{H}} 7.47-7.37(2 \mathrm{H}, \mathrm{m}, H 8), 7.38-7.28(3 \mathrm{H}, \mathrm{m}, H 7, H 9), 7.20(2 \mathrm{H}, \mathrm{s}, H 3)$, $6.72(2 \mathrm{H}, \mathrm{s}, H 11), 4.74(2 \mathrm{H}, \mathrm{s}, H 8), 4.22(2 \mathrm{H}, \mathrm{spt}, J=6.8 \mathrm{~Hz}, H 5), 2.93(1 \mathrm{H}, \mathrm{spt}, J=6.9 \mathrm{~Hz}, H 2)$, $2.20(3 \mathrm{H}, \mathrm{s}, H 12), 1.90(6 \mathrm{H}, \mathrm{s}, H 10), 1.27(6 \mathrm{H}, \mathrm{d}, J=6.9 \mathrm{~Hz}, H 1), 1.23(12 \mathrm{H}, \mathrm{d}, J=6.8 \mathrm{~Hz}, H 4)$;

${ }^{13} \mathbf{C}$ NMR $\left(101 \mathrm{MHz}, \mathrm{CDCl}_{3}\right) \delta_{\mathrm{C}} 154.1,152.1,140.0,137.0,135.0,130.4,129.2,128.5,128.2,127.3$, 124.0, 119.5, 89.1, 70.4, 53.4, 34.3, 29.7, 24.7, 23.6, 21.2, 20.5;

HRMS (ES+) calc. for $\mathrm{C}_{33} \mathrm{H}_{42} \mathrm{NNaO}_{2} \mathrm{~S}[\mathrm{M}+\mathrm{H}]^{+}$516.2931, found 516.2930. 

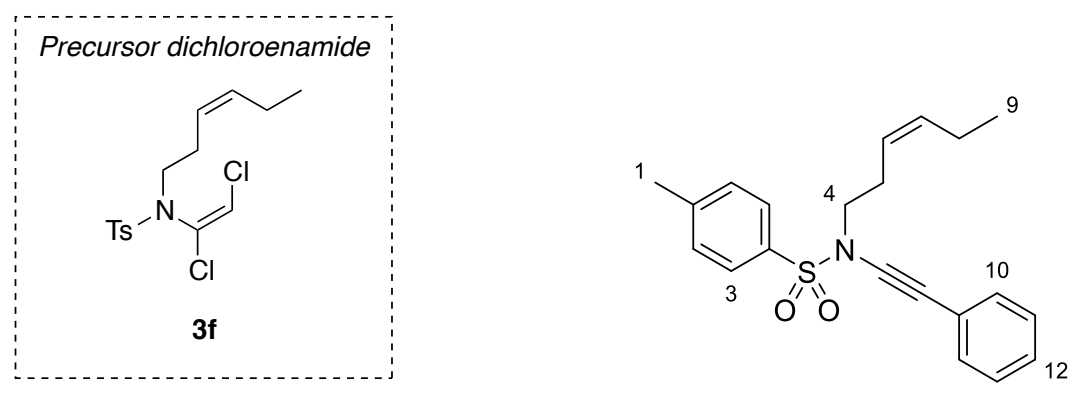

Following example procedure 1.3e: Synthesised from $N-((E)$-1,2-dichlorovinyl)- $N$-[(Z)-hex-3-en-1yl]tosylamide (492 mg, $1.41 \mathrm{mmol}, 1.0$ equiv.) in anhydrous TBME (2.0 mL) using LiHMDS (freshly prepared according to example procedure 1.3e, 1.2 equiv.), $\mathrm{CuCN} \cdot 2 \mathrm{P}(\mathrm{OMe})_{3}(176 \mu \mathrm{L}$ of a $0.1 \mathrm{M}$ solution in THF, $17.6 \mu \mathrm{mol}, 1.25 \mathrm{~mol} \%)$ and phenylmagnesium bromide $(1.45 \mathrm{~mL}$ of a $1.0 \mathrm{M}$ solution in THF, $1.45 \mathrm{mmol}, 1.03$ equiv.). Upon completion, the reaction was worked up and extracted as for example procedure 1.3e. Column chromatography $\left(3 \rightarrow 5 \% \mathrm{Et}_{2} \mathrm{O} /\right.$ pentane) afforded the title compound (430 mg, $1.22 \mathrm{mmol}, 86 \%$ ) as a yellow oil;

$\mathbf{R}_{\mathbf{f}} 0.38\left(10 \% \mathrm{Et}_{2} \mathrm{O} /\right.$ pentane $)$;

IR (thin film, $v_{\max } / \mathrm{cm}^{-1}$ ) 2963, 2234, 1598, 1494, 1364, 1168, 1090, 813, 754, 691, 676;

${ }^{1} \mathbf{H}$ NMR $\left(400 \mathrm{MHz}, \mathrm{CDCl}_{3}\right) \delta_{\mathrm{H}} 7.84(2 \mathrm{H}, \mathrm{d}, J=8.4 \mathrm{~Hz}, H 3), 7.40-7.27(7 \mathrm{H}, \mathrm{m}, H 2, H 10, H 11, H 12)$, $5.48(1 \mathrm{H}, \mathrm{dtt}, J=10.7,7.3,1.5 \mathrm{~Hz}, H 7), 5.27(1 \mathrm{H}, \mathrm{dtt}, J=10.7,7.4,1.6 \mathrm{~Hz}, H 6), 3.42(2 \mathrm{H}, \mathrm{t}$, $J=7.5 \mathrm{~Hz}, H 4), 2.47-2.41(5 \mathrm{H}, \mathrm{m}, H 1, H 5), 2.04(2 \mathrm{H}$, quind, $J=7.5,1.5 \mathrm{~Hz}, H 8), 0.95(3 \mathrm{H}, \mathrm{t}$, $J=7.5 \mathrm{~Hz}, H 9)$;

${ }^{13} \mathbf{C}$ NMR $\left(101 \mathrm{MHz}, \mathrm{CDCl}_{3}\right) \delta_{\mathrm{C}} 144.7,135.2,134.8,131.4,129.9,128.4,127.9,127.8,123.6,123.0$, 82.4, 71.0, 51.4, 26.1, 21.8, 20.8, 14.3;

HRMS (ES+) calc. for $\mathrm{C}_{21} \mathrm{H}_{24} \mathrm{NO}_{2} \mathrm{~S}[\mathrm{M}+\mathrm{H}]^{+}$354.1522, found 354.1521. 

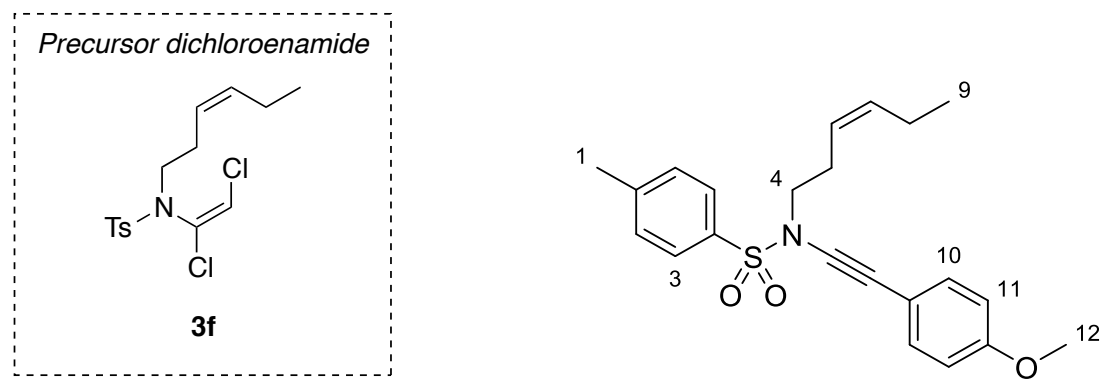

Following example procedure 1.3e: Synthesised from $N-((E)$-1,2-dichlorovinyl)- $N$-[(Z)-hex-3-en-1yl]tosylamide (516 mg, 1.49 mmol, 1.0 equiv.) in anhydrous TBME (2.0 mL) using LiHMDS (freshly prepared according to example procedure 1.3e, 1.2 equiv.), $\mathrm{CuCN} \cdot 2 \mathrm{P}(\mathrm{OMe})_{3}(186 \mu \mathrm{L}$ of a $0.1 \mathrm{M}$ solution in THF, $18.6 \mu \mathrm{mol}, 1.25 \mathrm{~mol} \%)$ and 4-methoxyphenylmagnesium bromide $(1.53 \mathrm{~mL}$ of a $1.0 \mathrm{M}$ solution in THF, $1.53 \mathrm{mmol}, 1.03$ equiv.). Upon completion, the reaction was worked up and extracted as for example procedure 1.3e. Column chromatography ( $3 \rightarrow 8 \% \mathrm{Et}_{2} \mathrm{O} /$ pentane) afforded the title compound (473 $\mathrm{mg}, 1.24 \mathrm{mmol}, 83 \%$ ) as a pale yellow oil;

$\mathbf{R}_{\mathbf{f}} 0.45\left(20 \% \mathrm{Et}_{2} \mathrm{O} /\right.$ pentane $)$;

IR (thin film, $v_{\max } / \mathrm{cm}^{-1}$ ) 2962, 2236, 1605, 1511, 1362, 1247, 1168, 1090, 832, 664;

${ }^{1} \mathbf{H}$ NMR $\left(400 \mathrm{MHz}, \mathrm{CDCl}_{3}\right) \delta_{\mathrm{H}} 7.83(2 \mathrm{H}, \mathrm{d}, J=8.2 \mathrm{~Hz}, H 3), 7.35(2 \mathrm{H}, \mathrm{d}, J=8.2 \mathrm{~Hz}, H 2), 7.32(2 \mathrm{H}$, d, $J=8.8 \mathrm{~Hz}, H 10), 6.83(2 \mathrm{H}, \mathrm{d}, J=8.8 \mathrm{~Hz}, H 11), 5.47(1 \mathrm{H}, \mathrm{dtt}, J=10.8,7.3,1.6 \mathrm{~Hz}, H 7), 5.26(1 \mathrm{H}$, $\mathrm{dtt}, J=10.8,7.3,1.6 \mathrm{~Hz}, H 6), 3.81(3 \mathrm{H}, \mathrm{s}, H 12), 3.39(2 \mathrm{H}, \mathrm{t}, J=7.5 \mathrm{~Hz}, H 4), 2.47-2.38$ (5H, m, $H 1$, $H 5), 2.03(2 \mathrm{H}$, quind, $J=7.5,1.6 \mathrm{~Hz}, H 8), 0.94(3 \mathrm{H}, \mathrm{t}, J=7.5 \mathrm{~Hz}, H 9)$;

${ }^{13} \mathbf{C}$ NMR $\left(101 \mathrm{MHz}, \mathrm{CDCl}_{3}\right) \delta_{\mathrm{C}} 159.6,144.6,135.1,134.9,133.5,129.8,127.8,123.7,114.9,114.0$, 80.9, 70.6, 55.4, 51.5, 26.1, 21.8, 20.8, 14.3;

HRMS (ES+) calc. for $\mathrm{C}_{22} \mathrm{H}_{25} \mathrm{NNaO}_{3} \mathrm{~S}[\mathrm{M}+\mathrm{Na}]^{+} 406.1447$, found 406.1446. 


\section{$N$-[(4-Cyanophenyl)ethynyl]- $N$-[(Z)-hex-3-en-1-yl]tosylamide, 1at}
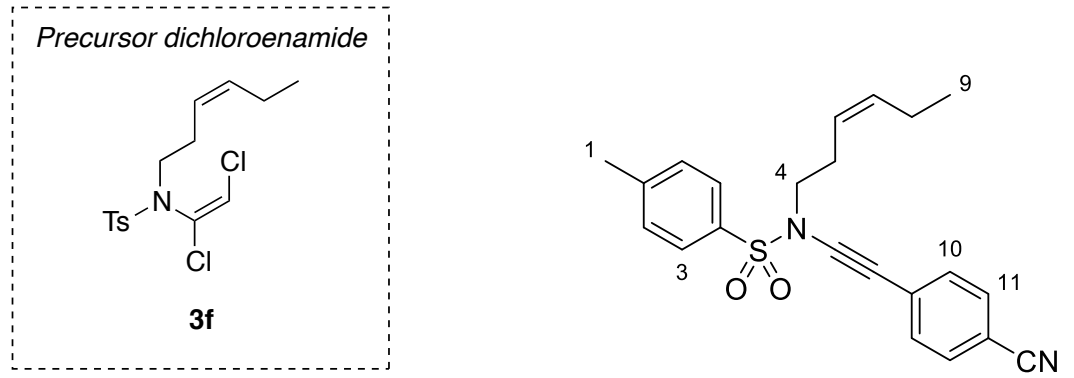

Following example procedure 1.3e: Synthesised from $N-((E)-1,2$-dichlorovinyl)- $N$-[(Z)-hex-3-en-1yl]tosylamide (507 mg, $1.46 \mathrm{mmol} 1.0$ equiv.) in anhydrous TBME (2.0 mL) using LiHMDS (freshly prepared according to example procedure 1.3e, 1.2 equiv.), $\mathrm{CuCN} \cdot 2 \mathrm{P}(\mathrm{OMe})_{3}(146 \mu \mathrm{L}$ of a $0.1 \mathrm{M}$ solution in THF, $14.6 \mu \mathrm{mol}, 1.25 \mathrm{~mol} \%$ ) and 4-cyanophenylmagnesium chloride (prepared according to example procedure $1.3 \mathrm{c}$ from 4-iodobenzonitrile ( $400 \mathrm{mg}, 1.75 \mathrm{mmol}, 1.2$ equiv.) in anhydrous THF (4 mL) using $i$-propylmagnesium chloride $(1.02 \mathrm{~mL}$ of a $2.0 \mathrm{M}$ solution in THF, $2.04 \mathrm{mmol}$, 1.4 equiv.)). Upon completion, the reaction was worked up and extracted as for example procedure 1.3e. Column chromatography ( $5 \rightarrow 17 \% \mathrm{Et}_{2} \mathrm{O}$ in pentane) afforded a viscous yellow oil that solidified on standing, giving the title compound (398 $\mathrm{mg}, 1.05 \mathrm{mmol}, 72 \%$ ) as a white powder. This compound can be recrystallised from toluene/heptane to give colourless needles;

m.p. $54-55^{\circ} \mathrm{C}$ (toluene/heptane);

$\mathbf{R}_{\mathbf{f}} 0.30\left(20 \% \mathrm{Et}_{2} \mathrm{O} /\right.$ pentane $)$;

IR (thin film, $v_{\max } / \mathrm{cm}^{-1}$ ) 2963, 2222, 1603, 1366, 1186, 1169, 1106, 1090, 959, 838, 814, 714, 659;

${ }^{1} \mathbf{H}$ NMR $\left(400 \mathrm{MHz}, \mathrm{CDCl}_{3}\right) \delta_{\mathrm{H}} 7.82(2 \mathrm{H}, \mathrm{d}, J=8.2 \mathrm{~Hz}, H 3), 7.57(2 \mathrm{H}, \mathrm{d}, J=8.5 \mathrm{~Hz}, H 11), 7.40(2 \mathrm{H}$, d, $J=8.5 \mathrm{~Hz}, H 10), 7.36(2 \mathrm{H}, \mathrm{d}, J=8.2 \mathrm{~Hz}, H 2), 5.48(1 \mathrm{H}, \mathrm{dtt}, J=10.8,7.3,1.7 \mathrm{~Hz}, H 7), 5.25(1 \mathrm{H}$, $\mathrm{dtt}, J=10.8,7.3,1.6 \mathrm{~Hz}, H 6), 3.44(2 \mathrm{H}, \mathrm{t}, J=7.4 \mathrm{~Hz}, H 4), 2.49-2.38(5 \mathrm{H}, \mathrm{m}, H 1, H 5), 2.01(2 \mathrm{H}$, quind, $J=7.5,1.6 \mathrm{~Hz}, H 8), 0.93(3 \mathrm{H}, \mathrm{t}, J=7.5 \mathrm{~Hz}, H 9)$;

${ }^{13} \mathbf{C}$ NMR $\left(101 \mathrm{MHz}, \mathrm{CDCl}_{3}\right) \delta_{\mathrm{C}} 145.2,135.4,134.7,132.1,131.0,130.0,128.4,127.8,123.3,118.7$, 110.6, 87.3, 70.7, 51.4, 26.2, 21.8, 20.8, 14.3;

HRMS (ES+) calc. for $\mathrm{C}_{22} \mathrm{H}_{23} \mathrm{~N}_{2} \mathrm{O}_{2} \mathrm{~S}[\mathrm{M}+\mathrm{H}]^{+} 379.1475$, found 379.1474 . 


\section{$N$-[(Z)-Hex-3-en-1-yl]- $N$-(3-methylbut-1-yn-1-yl)tosylamide, 1au}
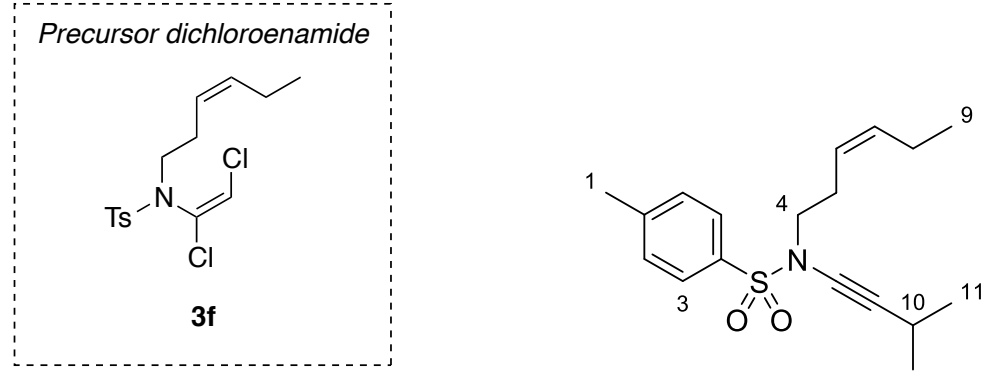

Following example procedure 1.3e: Synthesised from $N-((E)-1,2$-dichlorovinyl)- $N$-[(Z)-hex-3-en-1yl]tosylamide (139 mg, $0.399 \mathrm{mmol}, 1.0$ equiv.) in anhydrous TBME (0.6 mL) using LiHMDS (freshly prepared according to example procedure 1.3e, 1.2 equiv.), $\mathrm{CuCN} \cdot 2 \mathrm{P}(\mathrm{OMe})_{3}(50 \mu \mathrm{L}$ of a $0.1 \mathrm{M}$ solution in THF, $50 \mu \mathrm{mol}, 1.25 \mathrm{~mol} \%)$ and $i$-propylmagnesium bromide $(0.48 \mathrm{~mL}$ of a $1.0 \mathrm{M}$ solution in THF, $0.480 \mathrm{mmol}, 1.2$ equiv.). Note: The Grignard reagent was added at $-5{ }^{\circ} \mathrm{C}$. In this reaction, 1.03 equiv. of $i$-propylmagnesium bromide did not lead to complete consumption of chloroynamide (as analysed by TLC (20\% $\mathrm{CH}_{2} \mathrm{Cl}_{2} /$ pentane)) and 1.2 equiv. was required. Upon completion, the reaction was worked up and extracted as for example procedure 1.3e. Column chromatography $\left(0 \rightarrow 4 \% \mathrm{Et}_{2} \mathrm{O}\right.$ in pentane) afforded the title compound (61 $\left.\mathrm{mg}, 191 \mu \mathrm{mol}, 48 \%\right)$ as a pale yellow oil;

$\mathbf{R}_{\mathbf{f}} 0.45\left(10 \% \mathrm{Et}_{2} \mathrm{O}\right.$ in pentane);

IR (thin film, $v_{\max } / \mathrm{cm}^{-1}$ ) 2967, 2932, 2252, 1598, 1494, 1363, 1168, 1091, 997, 814, 670;

${ }^{1} \mathbf{H}$ NMR $\left(400 \mathrm{MHz}, \mathrm{CDCl}_{3}\right) \delta_{\mathrm{H}} 7.67(2 \mathrm{H}, \mathrm{d}, J=8.2 \mathrm{~Hz}, H 3), 7.22(2 \mathrm{H}, \mathrm{d}, J=8.2 \mathrm{~Hz}, H 2), 5.35(1 \mathrm{H}$, $\mathrm{dtt}, J=10.7,7.4,1.6 \mathrm{~Hz}, H 7), 5.13(1 \mathrm{H}, \mathrm{dtt}, J=10.7,7.4,1.4 \mathrm{~Hz}, H 6), 3.15(2 \mathrm{H}, \mathrm{t}, J=7.5 \mathrm{~Hz}, H 4)$, $2.54(1 \mathrm{H}, \mathrm{spt}, J=6.9 \mathrm{~Hz}, H 10), 2.34(3 \mathrm{H}, \mathrm{s}, H 1), 2.24(2 \mathrm{H}, \mathrm{q}, J=7.4 \mathrm{~Hz}, H 5), 1.91$ (2H, quind, $J=7.5,1.4 \mathrm{~Hz}, H 8), 1.05(6 \mathrm{H}, \mathrm{d}, J=6.9 \mathrm{~Hz}, H 11), 0.84(3 \mathrm{H}, \mathrm{t}, J=7.5 \mathrm{~Hz}, H 9)$;

${ }^{13} \mathbf{C}$ NMR $\left(101 \mathrm{MHz}, \mathrm{CDCl}_{3}\right) \delta_{\mathrm{C}} 144.4,135.0,134.9,129.7,127.9,124.0,76.0,72.8,51.4,26.0,23.4$, 21.8, 20.8, 20.7, 14.4;

HRMS (ES+) calc. for $\mathrm{C}_{18} \mathrm{H}_{26} \mathrm{NO}_{2} \mathrm{~S}[\mathrm{M}+\mathrm{H}]^{+} 320.1679$, found 320.1683 . 


\section{$N$-((4-Chlorophenyl)ethynyl)- $N$-(3,3-diethoxypropyl)tosylamide, 1av}
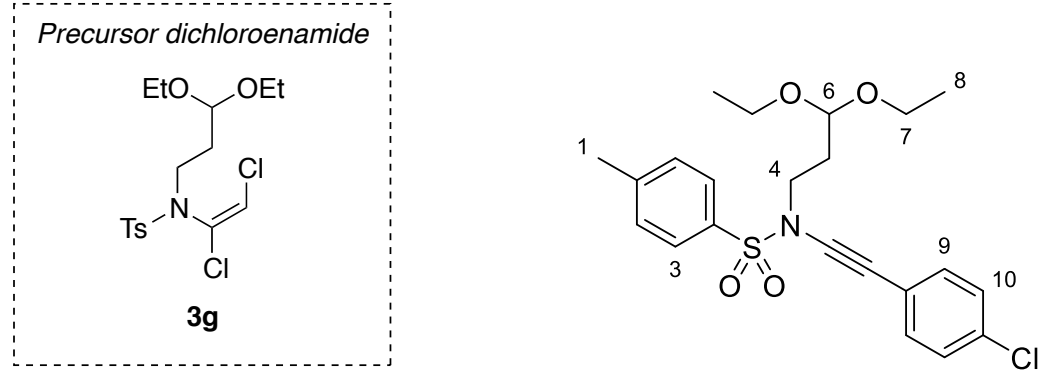

Following example procedure 1.3e: Synthesised from $N$-[(E)-1,2-Dichlorovinyl]- $N-(3,3-$ diethoxypropyl)tosylamide ( $454 \mathrm{mg}, 1.15 \mathrm{mmol}, 1.0$ equiv.) in anhydrous TBME (2.0 mL) using LiHMDS (freshly prepared according to example procedure 1.3e, 1.2 equiv.), $\mathrm{CuCN} \cdot 2 \mathrm{P}(\mathrm{OMe})_{3}$ (143 $\mu \mathrm{L}, 14.3 \mu \mathrm{mol}, 1.25 \mathrm{~mol} \%)$, and 4-chlorophenylmagnesium bromide $(1.18 \mathrm{~mL}$ of a $1.0 \mathrm{M}$ solution in $\mathrm{Et}_{2} \mathrm{O}$, which was further diluted with $1.2 \mathrm{~mL}$ of anhydrous THF, $1.18 \mathrm{mmol}, 1.03$ equiv.). Upon completion, the reaction was worked up and extracted as for example procedure 1.3e. Column chromatography $\left(10 \rightarrow 20 \% \mathrm{Et}_{2} \mathrm{O} /\right.$ pentane) afforded the title compound (420 $\left.\mathrm{mg}, 0.964 \mathrm{mmol}, 84 \%\right)$ as a yellow oil;

$\mathbf{R}_{\mathbf{f}} 0.30\left(20 \% \mathrm{Et}_{2} \mathrm{O} /\right.$ pentane $)$;

IR (thin film, $v_{\max } / \mathrm{cm}^{-1}$ ) 2975, 2879, 2236, 1596, 1492, 1367, 1294, 1170, 1090, 1059, 876, 827, $815,707,657$;

${ }^{1} \mathbf{H}$ NMR $\left(400 \mathrm{MHz}, \mathrm{CDCl}_{3}\right) \delta_{\mathrm{H}} 7.82(2 \mathrm{H}, \mathrm{d}, J=8.2 \mathrm{~Hz}, H 3), 7.35(2 \mathrm{H}, \mathrm{d}, J=8.2 \mathrm{~Hz}, H 2), 7.30-7.23$ $(4 \mathrm{H}, \mathrm{m}, H 9, H 10), 4.60(1 \mathrm{H}, \mathrm{t}, J=5.6 \mathrm{~Hz}, H 6), 3.65(2 \mathrm{H}, \mathrm{dq}, J=9.3,7.0 \mathrm{~Hz}, H 7), 3.55-3.44(4 \mathrm{H}, \mathrm{m}$, $H 4, H 7), 2.45(3 \mathrm{H}, \mathrm{s}, H 1), 2.00(2 \mathrm{H}, \mathrm{dt}, J=5.6,7.1 \mathrm{~Hz}, H 5), 1.20(6 \mathrm{H}, J=7.0 \mathrm{~Hz}, H 8)$;

${ }^{13}$ C NMR $\left(101 \mathrm{MHz}, \mathrm{CDCl}_{3}\right) \delta_{\mathrm{C}} 144.8,134.3,133.8,132.5,129.8,128.6,127.7,121.3,100.4,83.2$, 69.9, 62.8, 47.9, 32.5, 21.6, 15.3;

HRMS (ES+) calc. for $\mathrm{C}_{22} \mathrm{H}_{26}{ }^{35} \mathrm{ClNNaO}_{4} \mathrm{~S}[\mathrm{M}+\mathrm{Na}]^{+} 458.1163$, found 458.1163 . 

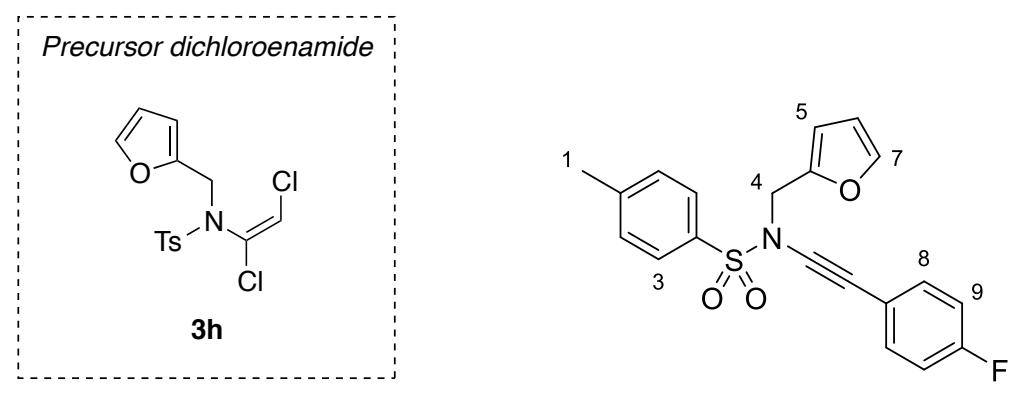

Following example procedure 1.3e: Synthesised from $N$-[(E)-1,2-Dichlorovinyl]- $N-(3,3-$ diethoxypropyl)tosylamide (103 mg, $0.297 \mathrm{mmol}, 1.0$ equiv.) in anhydrous TBME (0.8 mL) using LiHMDS (freshly prepared according to example procedure 1.3e, 1.2 equiv.), $\mathrm{CuCN} \cdot 2 \mathrm{P}(\mathrm{OMe})_{3}$ (30 $\mu \mathrm{L}, 30 \mu \mathrm{mol}, 1 \mathrm{~mol} \%$ ), and 4-fluorophenylmagnesium bromide $(0.18 \mathrm{~mL}$ of a $2.0 \mathrm{M}$ solution in $\mathrm{Et}_{2} \mathrm{O}$, which was further diluted with $0.16 \mathrm{~mL}$ of anhydrous THF, $0.371 \mathrm{mmol}, 1.25$ equiv.). Upon completion, the reaction was worked up and extracted as for example procedure 1.3e. Column chromatography $\left(7.5 \rightarrow 10 \% \mathrm{Et}_{2} \mathrm{O} /\right.$ pentane) afforded the title compound (68.8 $\mathrm{mg}, 0.186 \mathrm{mmol}, 63 \%$ ) as a pale yellow oil;

$\mathbf{R}_{\mathbf{f}} 0.39\left(20 \% \mathrm{Et}_{2} \mathrm{O} /\right.$ pentane $)$;

IR (thin film, $v_{\max } / \mathrm{cm}^{-1}$ ) 2997, 2240, 1599, 1509, 1364, 1227, 1169, 1091, 1006, 933, 836, 717, 664;

${ }^{1} \mathbf{H}$ NMR $\left(500 \mathrm{MHz}, \mathrm{CDCl}_{3}\right) \delta_{\mathrm{H}} 7.78(2 \mathrm{H}, \mathrm{d}, J=8.3 \mathrm{~Hz}, H 3), 7.34-7.29$ (3H, m, H2, H7), 7.29-7.23 $(2 \mathrm{H}, \mathrm{m}, H 8), 6.96(2 \mathrm{H}, \mathrm{m}, H 9), 6.31(1 \mathrm{H}, \mathrm{d}, J=3.2 \mathrm{~Hz}, H 5), 6.28(1 \mathrm{H}, \mathrm{dd}, J=3.2,1.8 \mathrm{~Hz}, H 6), 4.64$ $(2 \mathrm{H}, \mathrm{s}, H 4), 2.44(3 \mathrm{H}, \mathrm{s}, H 1)$;

${ }^{13}$ C NMR $\left(126 \mathrm{MHz}, \mathrm{CDCl}_{3}\right) \delta_{\mathrm{C}} 162.4(1 \mathrm{C}, \mathrm{d}, J=249 \mathrm{~Hz}), 148.0,144.8,143.2,134.7,133.5(2 \mathrm{C}, \mathrm{d}$, $J=8.1 \mathrm{~Hz}), 129.8,128.0,118.9(1 \mathrm{C}, \mathrm{d}, J=3.2 \mathrm{~Hz}), 115.6(2 \mathrm{C}, \mathrm{d}, J=22.3 \mathrm{~Hz}), 110.7,110.6,81.8$, 70.4, 48.4, 21.8;

${ }^{19}$ F NMR $\left(470 \mathrm{MHz}, \mathrm{CDCl}_{3}\right) \delta_{\mathrm{F}}-118.6(1 \mathrm{~F}, \mathrm{tt}, J=8.7,5.2 \mathrm{~Hz})$;

HRMS (ES+) calc. for $\mathrm{C}_{20} \mathrm{H}_{16} \mathrm{FNNaO}_{3} \mathrm{~S}[\mathrm{M}+\mathrm{Na}]^{+}$392.0727, found 392.0727. 

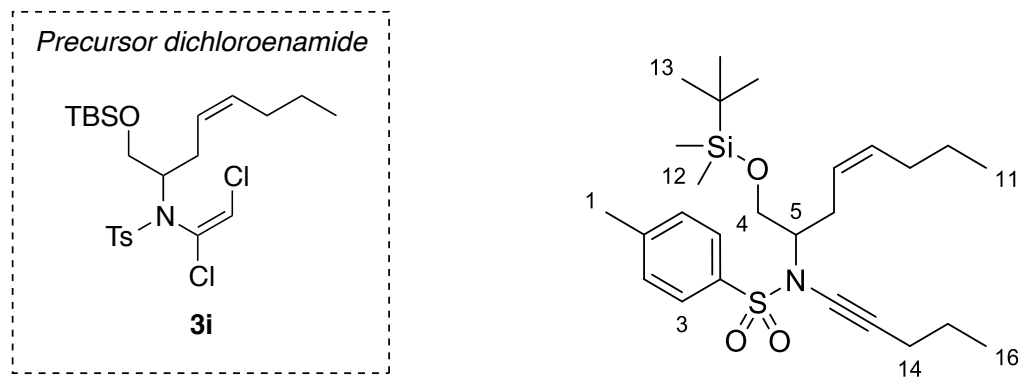

Following example procedure 1.3e: Synthesised from $N-[(Z)-1-\{[t-B u t y 1($ dimethyl)silyl $]$ oxy $\}$ oct-4-en2-yl]- $N$-[(E)-1,2-dichlorovinyl]tosylamide (314 mg, $0.620 \mathrm{mmol}, 1.0$ equiv.) in anhydrous TBME $(0.8 \mathrm{~mL})$ using LiHMDS (freshly prepared according to example procedure 1.3e, 1.2 equiv.), $\mathrm{CuCN} \cdot 2 \mathrm{P}(\mathrm{OMe})_{3}(78 \mu \mathrm{L}$ of a $0.1 \mathrm{M}$ solution in THF, $78 \mu \mathrm{mol}, 1.25 \mathrm{~mol} \%)$ and $n$-propylmagnesium bromide $\left(0.32 \mathrm{~mL}\right.$ of a $2.0 \mathrm{M}$ solution in $\mathrm{Et}_{2} \mathrm{O}$, further diluted with $0.32 \mathrm{~mL}$ of THF, $0.638 \mathrm{mmol}$, 1.03 equiv.). Upon completion, the reaction was worked up and extracted as for example procedure 1.3e. Column chromatography $\left(0 \rightarrow 4 \% \mathrm{Et}_{2} \mathrm{O} /\right.$ pentane $)$ afforded the title compound $(195 \mathrm{mg}$, $0.408 \mathrm{mmol}, 66 \%$ ) as a pale yellow oil;

$\mathbf{R}_{\mathbf{f}} 0.40\left(5 \% \mathrm{Et}_{2} \mathrm{O} /\right.$ pentane $)$;

IR (thin film, $v_{\max } / \mathrm{cm}^{-1}$ ) 2958, 2930, 2858, 2250, 1598, 1463, 1292, 1169, 1118, 1092, 837, 778, 669 ;

${ }^{1} \mathbf{H}$ NMR $\left(500 \mathrm{MHz}, \mathrm{CDCl}_{3}\right) \delta_{\mathrm{H}} 7.78(2 \mathrm{H}, \mathrm{d}, J=8.1 \mathrm{~Hz}, H 3), 7.27(2 \mathrm{H}, \mathrm{d}, J=8.1 \mathrm{~Hz}, H 2), 5.30(1 \mathrm{H}$, $\mathrm{dtt}, J=10.9,7.3,1.6 \mathrm{~Hz}, H 8), 5.13(1 \mathrm{H}, \mathrm{dtt}, J=10.9,7.3,1.6 \mathrm{~Hz}, H 7), 3.89(1 \mathrm{H}, \mathrm{dq}, J=8.9,6.1 \mathrm{~Hz}$, H5), $3.62(1 \mathrm{H}, \mathrm{dd}, J=10.3,6.2 \mathrm{~Hz}, H 4), 3.54(1 \mathrm{H}, \mathrm{dd}, J=10.3,6.2 \mathrm{~Hz}, H 4), 2.42(3 \mathrm{H}, \mathrm{s}, H 1), 2.35$ (1H, dddd, $J=15.1,7.3,5.6,1.7 \mathrm{~Hz}, H 6), 2.25(2 \mathrm{H}, \mathrm{t}, J=6.9 \mathrm{~Hz}, H 14), 2.18$ (1H, dddd, $J=15.1,8.1$, 6.6, $1.5 \mathrm{~Hz}, H 6), 1.93(2 \mathrm{H}, \mathrm{qd}, J=7.4,1.6 \mathrm{~Hz}, H 9), 1.50(2 \mathrm{H}, \mathrm{sxt}, J=7.2 \mathrm{~Hz}, H 15), 1.31$ (2H, sxtd, $J=7.4,1.7 \mathrm{~Hz}, H 10), 0.94(3 \mathrm{H}, \mathrm{t}, J=7.4 \mathrm{~Hz}, H 16), 0.88-0.82(12 \mathrm{H}, \mathrm{m}, H 11, H 13), 0.01(3 \mathrm{H}, \mathrm{s}$, $H 12), 0.00$ (3H, s, H12);

${ }^{13}$ C NMR $\left(126 \mathrm{MHz}, \mathrm{CDCl}_{3}\right) \delta_{\mathrm{C}} 144.0,136.3,132.7,129.4,127.9,124.8,72.0,70.4,63.8,61.8,29.5$, $27.5,26.0,22.8,22.6,21.7,20.8,18.4,13.9,13.6,-5.3,-5.4$;

HRMS (ES+) calc. for $\mathrm{C}_{26} \mathrm{H}_{44} \mathrm{NO}_{3} \mathrm{SSi}[\mathrm{M}+\mathrm{H}]^{+}$478.2806, found 478.2805. 


\section{$N$-((1S,2S)-1,2-Diphenylbut-3-en-1-yl)- $N$-(mesitylethynyl)tosylamide, 1ay}
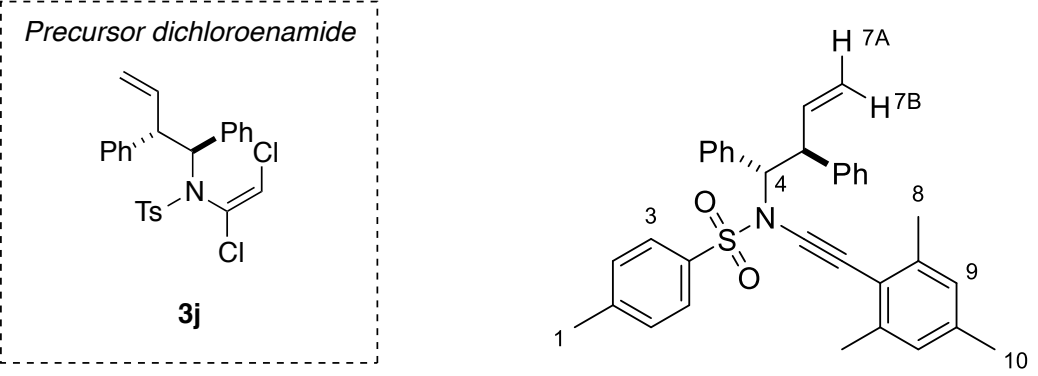

Following example procedure 1.3e: Synthesised from (E)- $N$-benzyl- $N$-(1,2-dichlorovinyl)-2,4,6-tri$i$-propylbenzenesulfonamide $(200 \mathrm{mg}, 0.423 \mathrm{mmol}, 1.0$ equiv.) in anhydrous TBME $(2.0 \mathrm{~mL})$ using LiHMDS (freshly prepared according to example procedure 1.3e, 1.2 equiv.), $\mathrm{CuCN} \cdot 2 \mathrm{LiCl}(5 \mu \mathrm{L}$, $5 \mu \mathrm{mol}, 1.25 \mathrm{~mol} \%)$, and mesitylmagnesium bromide $(0.44 \mathrm{~mL}$ of a $1.0 \mathrm{M}$ solution in THF, $0.436 \mathrm{mmol}, 1.03$ equiv.). Upon completion, the reaction was worked up and extracted as for example procedure 1.3e. Column chromatography $\left(0 \rightarrow 5 \% \mathrm{Et}_{2} \mathrm{O} /\right.$ pentane $)$ afforded the title compound (186 mg, $0.358 \mathrm{mmol}, 84 \%$ ) as a pale yellow oil that solidified on standing. This compound can be recrystallised by vapour diffusion of pentane into a concentrated solution of the title compound in toluene/ $\mathrm{CH}_{2} \mathrm{Cl}_{2}(\sim 5: 1)$, at $0{ }^{\circ} \mathrm{C}$, to give colourless crystals;

m.p. $140-141^{\circ} \mathrm{C}$;

$\mathbf{R}_{\mathbf{f}} 0.29\left(5 \% \mathrm{Et}_{2} \mathrm{O} /\right.$ pentane $)$;

IR (thin film, $v_{\max } / \mathrm{cm}^{-1}$ ) 3063, 3031, 2978, 2917, 2226, 1599, 1495, 1454, 1363, 1306, 1292, 1185, $1167,1089,1032,1019,974,942,915,855,825,811,749,731,699,682,665,615$;

${ }^{1} \mathbf{H}$ NMR $\left(400 \mathrm{MHz}, \mathrm{CDCl}_{3}\right) \delta_{\mathrm{H}} 7.62-7.54(2 \mathrm{H}, \mathrm{m}, \mathrm{Ph} H), 7.47-7.41(2 \mathrm{H}, \mathrm{m}, \mathrm{Ph} H), 7.37-7.25(6 \mathrm{H}, \mathrm{m}$, $\mathrm{Ph} H), 7.18-7.11$ (2H, m, H3), 7.67-7.91 (2H, m, H2), 6.87 (2H, s, H9), 5.75 (1H, ddd, $J=17.1,10.3$, $8.0 \mathrm{~Hz}, H 6), 5.52(1 \mathrm{H}, \mathrm{d}, J=11.7 \mathrm{~Hz}, H 4), 4.88\left(1 \mathrm{H}, \mathrm{dt}, J=10.3,1.2 \mathrm{~Hz}, H 7_{\mathrm{A}}\right), 4.79(1 \mathrm{H}, \mathrm{dt}$, $\left.J=17.1,1.2 \mathrm{~Hz}, H 7_{\mathrm{B}}\right), 4.25(1 \mathrm{H}, \mathrm{dd}, J=11.7,8.0 \mathrm{~Hz}, H 5), 2.30$ (3H, s, H1), 2.29 (3H, s, H10), 2.25 $(6 \mathrm{H}, \mathrm{s}, H 8)$;

${ }^{13}$ C NMR $\left(101 \mathrm{MHz}, \mathrm{CDCl}_{3}\right) \delta_{\mathrm{C}} 143.6,140.63,140.61,138.1,137.8,137.6,135.1,128.9,128.6$, $128.4,128.33,128.28,128.2,127.8,127.6,127.0,119.7,117.7,87.3,71.8,66.0,52.8,21.4,21.2$, 21.1

HRMS (ES+) calc. for $\mathrm{C}_{34} \mathrm{H}_{34} \mathrm{NO}_{2} \mathrm{~S}[\mathrm{M}+\mathrm{H}]^{+}$520.2305, found 520.2304. 

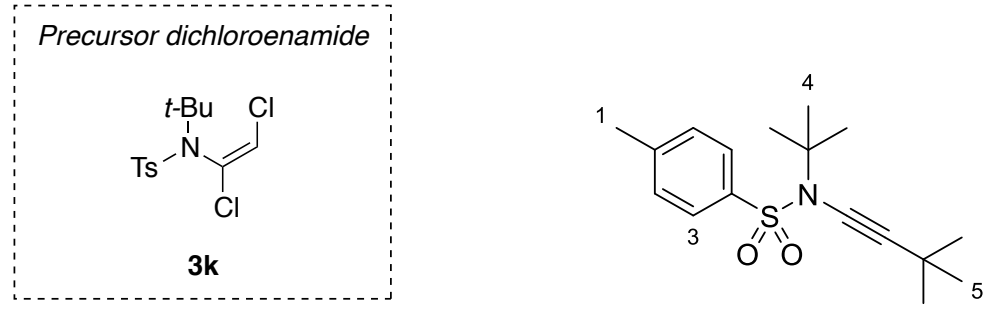

Following example procedure 1.3e: Synthesised from $(E)-N$-( $t$-butyl)- $N$-(1,2-dichlorovinyl)tosylamide (500 mg, $1.55 \mathrm{mmol}, 1.0$ equiv.) in anhydrous TBME $(2.0 \mathrm{~mL})$ using LiHMDS (freshly prepared according to example procedure 1.3e, 1.2 equiv.), $\mathrm{CuCN} \cdot 2 \mathrm{LiCl}(19 \mu \mathrm{L}, 19 \mu \mathrm{mol}, 1.25 \mathrm{~mol} \%)$, $\mathrm{P}(\mathrm{OMe})_{3}(5 \mu \mathrm{L}, 38 \mu \mathrm{mol}, 2.50 \mathrm{~mol} \%)$ and $t$-butylmagnesium bromide $(0.94 \mathrm{~mL}$ of a $1.7 \mathrm{M}$ solution in THF, $1.60 \mathrm{mmol}, 1.03$ equiv.). Upon completion, the reaction was worked up and extracted as for example procedure 1.3e. Column chromatography $\left(0 \rightarrow 3 \% \mathrm{Et}_{2} \mathrm{O} /\right.$ pentane $)$ afforded the title compound (386 mg, $1.26 \mathrm{mmol}, 81 \%$ ) as a yellow oil. *Note: This compound is not stable to prolonged storage.

$\mathbf{R}_{\mathbf{f}} 0.33\left(5 \% \mathrm{Et}_{2} \mathrm{O} /\right.$ pentane $)$;

IR (thin film, $v_{\max } / \mathrm{cm}^{-1}$ ) 2970, 2243, 1599, 1476, 1459, 1357, 1250, 1159, 1089, 943, 867, 813, 718, 663 ;

${ }^{1} \mathbf{H}$ NMR $\left(400 \mathrm{MHz}, \mathrm{CDCl}_{3}\right) \delta_{\mathrm{H}} 7.85-7.80(2 \mathrm{H}, \mathrm{m}, H 3), 7.31-7.27(2 \mathrm{H}, \mathrm{m}, H 2), 2.43(3 \mathrm{H}, \mathrm{s}, H 1)$, $1.41(9 \mathrm{H}, \mathrm{s}, H 5), 1.19(9 \mathrm{H}, \mathrm{s}, H 4)$;

${ }^{13} \mathbf{C}$ NMR $\left(101 \mathrm{MHz}, \mathrm{CDCl}_{3}\right) \delta_{\mathrm{C}} 143.8,137.5,129.1,127.9,79.9,72.4,63.2,31.1,29.2,27.6,21.5$;

HRMS (ES+) calc. for $\mathrm{C}_{17} \mathrm{H}_{25} \mathrm{NNaO}_{2} \mathrm{~S}[\mathrm{M}+\mathrm{Na}]^{+} 330.1498$, found 330.1499 . 


\section{$N$-(2-Bromophenyl)- $N$-((4-chlorophenyl)ethynyl)tosylamide, 1 ba}
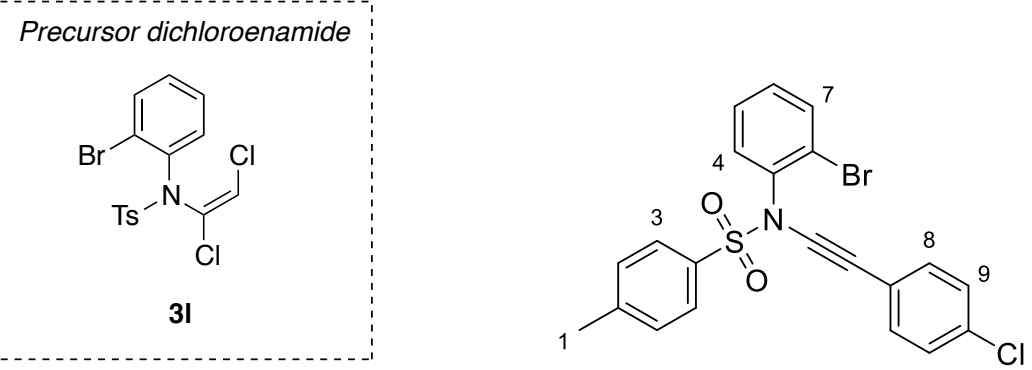

Following example procedure 1.3f: Synthesised from (E)- $N$-(2-bromophenyl)- $N-(1,2-$ dichlorovinyl)tosylamide (500 mg, $1.19 \mathrm{mmol}, 1.0$ equiv.) in anhydrous TBME (2.0 mL) using LiHMDS (freshly prepared according to example procedure 1.3e, 1.2 equiv.), $\mathrm{CuCN} \cdot 2 \mathrm{LiCl}(15 \mu \mathrm{L}$, $15 \mu \mathrm{mol}, 1.25 \mathrm{~mol} \%), \mathrm{P}(\mathrm{OMe})_{3}(4 \mu \mathrm{L}, 30 \mu \mathrm{mol}, 2.50 \mathrm{~mol} \%)$ and 4-chlorophenylmagnesium bromide (1.22 $\mathrm{mL}$ of a $1.0 \mathrm{M}$ solution in $\mathrm{Et}_{2} \mathrm{O}$, further diluted with $1 \mathrm{~mL}$ of anhydrous THF, $1.22 \mathrm{mmol}$, 1.03 equiv.). Upon completion, the reaction was worked up and extracted as for example procedure 1.3f. Column chromatography $\left(10 \% \mathrm{Et}_{2} \mathrm{O} /\right.$ pentane) afforded a yellow oil, which was crystallised from $\mathrm{MeOH} /$ benzene $(\sim 2: 1)$ at $-20{ }^{\circ} \mathrm{C}$ overnight to afford the title compound (452 $\mathrm{mg}, 0.982 \mathrm{mmol}, 83 \%$ ) as colourless needles;

m.p. $78-79{ }^{\circ} \mathrm{C}$;

$\mathbf{R}_{\mathbf{f}} 0.26\left(10 \% \mathrm{Et}_{2} \mathrm{O} / 40-60\right.$ petroleum ether);

IR (thin film, $v_{\max } / \mathrm{cm}^{-1}$ ) 3066, 2980, 2240, 1595, 1492, 1469, 1374, 1187, 1173, 1090, 1043, 1014, 918, 828, 814;

${ }^{1} \mathbf{H}$ NMR $\left(400 \mathrm{MHz}, \mathrm{CDCl}_{3}\right) \delta_{\mathrm{H}} 7.73-7.68(2 \mathrm{H}, \mathrm{m}, H 3), 7.58-7.53(1 \mathrm{H} . \mathrm{m}, H 7), 7.38-7.21(9 \mathrm{H}, H 2$, $H 4, H 5, H 6, H 8, H 9), 2.46$ (3H, s, $H 1)$;

${ }^{13} \mathbf{C}$ NMR $\left(101 \mathrm{MHz}, \mathrm{CDCl}_{3}\right) \delta_{\mathrm{C}} 145.3,137.1,134.4,134.2,133.9,132.7,130.7,130.6,129.7,128.5$ (2C), 128.3, 123.5, 121.2, 82.9, 69.7, 21.7;

HRMS (ES+) calc. for $\mathrm{C}_{21} \mathrm{H}_{16}{ }^{79} \mathrm{Br}^{35} \mathrm{ClNO}_{2} \mathrm{~S}[\mathrm{M}+\mathrm{H}]^{+} 459.9768$, found 459.9769 . 

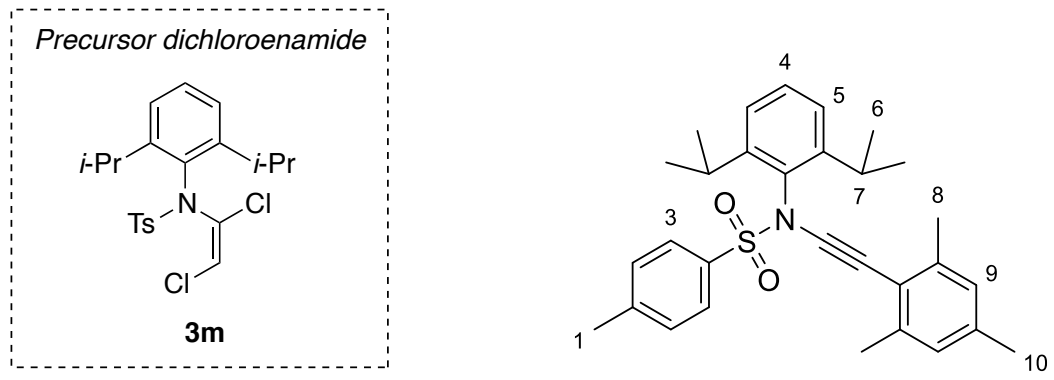

Following example procedure 1.3e: Synthesised from (E)- $N$-(1,2-dichlorovinyl)- $N$-(2,6-di$i$-propylphenyl)tosylamide (150 mg, $0.352 \mathrm{mmol}, 1.0$ equiv.) in anhydrous TBME (2.0 mL) using LiHMDS (freshly prepared according to example procedure 1.3e, 1.2 equiv.), $\mathrm{CuCN} \cdot 2 \mathrm{LiCl}(4 \mu \mathrm{L}$, $4 \mu \mathrm{mol}, 1.25 \mathrm{~mol} \%)$, and mesitylmagnesium bromide $(0.36 \mathrm{~mL}$ of a $1.0 \mathrm{M}$ solution in THF, $0.363 \mathrm{mmol}, 1.03$ equiv.). Upon completion, the reaction was worked up and extracted as for example procedure 1.3e. Column chromatography ( $0 \rightarrow 4 \% \mathrm{Et}_{2} \mathrm{O} /$ pentane) afforded the title compound (135 mg, $0.285 \mathrm{mmol}, 81 \%)$ as a white powder. This compound can be recrystallised from TBME/hexane (1:3) to give colourless crystals;

m.p. $165^{\circ} \mathrm{C}$;

$\mathbf{R}_{\mathbf{f}} 0.27$ ( $4 \% \mathrm{Et}_{2} \mathrm{O} /$ pentane);

IR (thin film, $v_{\max } / \mathrm{cm}^{-1}$ ) 2968, 2869, 2231, 1597, 1461, 1443, 1361, 1337, 1186, 1169, 1090, 1060, 1042, 921, 853, 809, 775, 734, 704, 663, 614;

${ }^{1} \mathbf{H}$ NMR $\left(400 \mathrm{MHz}, \mathrm{CDCl}_{3}\right) \delta_{\mathrm{H}} 7.98-7.89(2 \mathrm{H}, \mathrm{m}, H 3), 7.40-7.32(3 \mathrm{H}, \mathrm{m}, H 4, H 5), 7.23-7.17(2 \mathrm{H}$, m, H2), 6.85 (2H, s, H9), 3.19 (2H, spt, $J=6.7 \mathrm{~Hz}, H 7), 2.48$ (3H, s, H1), 2.31 (6H, s, H8), 2.27 (3H, s, $H 10), 1.21(6 \mathrm{H}, \mathrm{d}, J=6.7 \mathrm{~Hz}, H 6), 1.16(6 \mathrm{H}, \mathrm{d}, J=6.7 \mathrm{~Hz}, H 6)$;

${ }^{13} \mathbf{C}$ NMR $\left(101 \mathrm{MHz}, \mathrm{CDCl}_{3}\right) \delta_{\mathrm{C}} 148.5,144.6,140.5,137.4,135.7,133.9,129.9,129.5,128.3,127.5$, 124.5, 119.6, 90.6, 67.1, 29.0, 25.2, 23.3, 21.7, 21.2, 21.0;

HRMS (ES+) calc. for $\mathrm{C}_{30} \mathrm{H}_{36} \mathrm{NO}_{2} \mathrm{~S}[\mathrm{M}+\mathrm{H}]^{+}$474.2461, found 474.2461. 


\section{3a Carbamate Scope: Dichloroenamides}

\section{Benzyl (E)-(1,2-dichlorovinyl)(phenyl)carbamate, 9a}
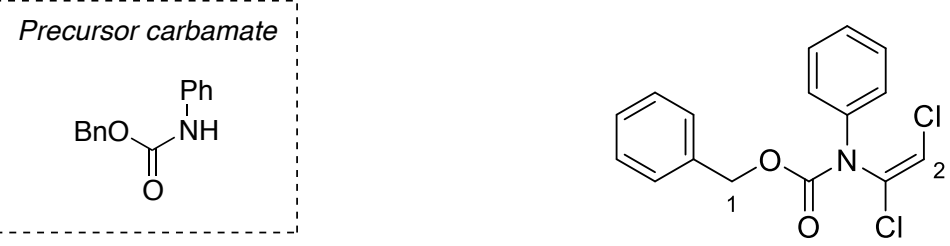

To a $100 \mathrm{~mL}$ round bottomed flask, equipped with a stirrer bar, was added anhydrous $\mathrm{CH}_{2} \mathrm{Cl}_{2}$ $(25 \mathrm{~mL})$, phenyl isocyanate $(4.60 \mathrm{~mL}, 42.0 \mathrm{mmol}, 1.0$ equiv.) and then benzyl alcohol $(4.35 \mathrm{~mL}$, $42.0 \mathrm{mmol}, 1.0$ equiv.), and the reaction was stirred overnight at room temperature. Complete conversion was then confirmed by TLC. The solution was then concentrated in vacuo to afford benzyl phenylcarbamate as a pale yellow solid. This solid was further dried under high vacuum for 1 hour to remove residual $\mathrm{CH}_{2} \mathrm{Cl}_{2}$.

To this solid was added powdered $\mathrm{Cs}_{2} \mathrm{CO}_{3}(20.5 \mathrm{~g}, 63.0 \mathrm{mmol}, 1.5$ equiv.), the flask was capped with a septum and evacuated under high vacuum for $\sim 1$ minute. After backfilling with nitrogen, DMF $(31 \mathrm{~mL})$ was added and the reaction was stirred at $50^{\circ} \mathrm{C}$ for 10 minutes. Trichloroethylene $(4.15 \mathrm{~mL}$, $46.2 \mathrm{mmol}, 1.1$ equiv.) was then added dropwise over 10 minutes, and the resulting mixture was stirred at $50{ }^{\circ} \mathrm{C}$ for 4 hours. Complete conversion was then confirmed by TLC. Upon cooling to room temperature, the mixture was partitioned between $\mathrm{Et}_{2} \mathrm{O}(150 \mathrm{~mL})$ and brine $(500 \mathrm{~mL})$, the organic layer was separated and further washed with brine $(2 \times 200 \mathrm{~mL})$. The organic layer was then dried $\left(\mathrm{MgSO}_{4}\right)$, filtered and concentrated in vacuo.

Column chromatography ( $10 \% \mathrm{Et}_{2} \mathrm{O} / 40-60$ petroleum ether) afforded the title compound as a yellow oil, which was further purified by crystallisation from pentane/ $\mathrm{Et}_{2} \mathrm{O}(2: 1,60 \mathrm{~mL})$ at $0{ }^{\circ} \mathrm{C}$ overnight. Once crystallisation had ceased, the remaining yellow solution was decanted and the colourless crystals were washed with ice cold pentane $(2 \times 20 \mathrm{~mL})$. The crystals were then dried under high vacuum for 1 hour. This afforded $12.0 \mathrm{~g}$ (37.4 mmol, 89\%) of the title compound;

m.p. $46-48^{\circ} \mathrm{C}$;

$\mathbf{R}_{\mathbf{f}} 0.64\left(30 \% \mathrm{Et}_{2} \mathrm{O} / 40-60\right.$ petroleum ether);

IR (thin film, $v_{\max } / \mathrm{cm}^{-1}$ ) 3089, 3034, 1730, 1617, 1596, 1495, 1455, 1382, 1304, 1275, 1231, 1151, $1075,1041,1020,887,821,749,693$;

${ }^{1}$ H NMR $\left(400 \mathrm{MHz}, \mathrm{CDCl}_{3}\right) \delta_{\mathrm{H}} 7.55-7.23(10 \mathrm{H}, \mathrm{m}, \mathrm{Ph} H), 6.37(1 \mathrm{H}, \mathrm{s}, H 2), 5.30(2 \mathrm{H}, \mathrm{s}, H 1)$;

${ }^{13} \mathbf{C}$ NMR $\left(101 \mathrm{MHz}, \mathrm{CDCl}_{3}\right) \delta_{\mathrm{C}} 152.5,138.2,135.5,131.3,129.1,128.5,128.2,127.9,127.5,125.8$, $116.9,88.5$;

HRMS (ES+) calc. for $\mathrm{C}_{16} \mathrm{H}_{13}{ }^{35} \mathrm{Cl}_{2} \mathrm{NNaO}_{2}[\mathrm{M}+\mathrm{Na}]^{+}$344.0216, found 344.0217. 


\section{Ethyl (E)-(1,2-dichlorovinyl)(phenyl)carbamate, 9b}
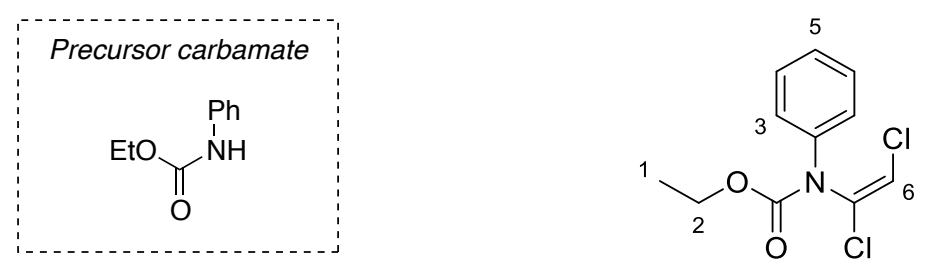

Following example procedure 1.3a: Synthesised from ethyl phenylcarbamate $(500 \mathrm{mg}, 3.03 \mathrm{mmol}$, 1.0 equiv.) in DMF $(2.3 \mathrm{~mL})$ using trichloroethylene $(0.30 \mathrm{~mL}, 3.33 \mathrm{mmol}, 1.1$ equiv. $)$ and $\mathrm{Cs}_{2} \mathrm{CO}_{3}$ (1.48 g, $4.54 \mathrm{mmol}, 1.5$ equiv.). The reaction takes approximately 3 hours to reach completion. Column chromatography $\left(5 \% \mathrm{Et}_{2} \mathrm{O} / 40-60\right.$ petroleum ether) afforded the title compound $(758 \mathrm{mg}$, $2.91 \mathrm{mmol}, 96 \%$ ) as a pale yellow oil;

$\mathbf{R}_{\mathbf{f}} 0.67$ (30\% $\mathrm{Et}_{2} \mathrm{O} / 40-60$ petroleum ether);

IR (thin film, $v_{\max } / \mathrm{cm}^{-1}$ ) 3089, 2983, 1731, 1619, 1597, 1494, 1371, 1309, 1235, 1175, 1149, 1052, 1026, 901, 826, 750, 693;

${ }^{1} \mathbf{H}$ NMR $\left(400 \mathrm{MHz}, \mathrm{CDCl}_{3}\right) \delta_{\mathrm{H}} 7.44-7.35(4 \mathrm{H}, \mathrm{m}, H 3, H 4), 7.35-7.27(1 \mathrm{H}, \mathrm{m}, H 5), 6.36(1 \mathrm{H}, \mathrm{s}, H 6)$, $4.30(2 \mathrm{H}, \mathrm{q}, J=7.1 \mathrm{~Hz}, H 2), 1.32(3 \mathrm{H}, \mathrm{t}, J=7.1 \mathrm{~Hz}, H 1)$;

${ }^{13} \mathbf{C}$ NMR $\left(101 \mathrm{MHz}, \mathrm{CDCl}_{3}\right) \delta_{\mathrm{C}} 152.6,138.3,131.5,129.0,127.3,125.8,116.6,63.1,14.3$;

HRMS (ES+) calc. for $\mathrm{C}_{11} \mathrm{H}_{11}{ }^{35} \mathrm{Cl}_{2} \mathrm{NNaO}_{2}[\mathrm{M}+\mathrm{Na}]^{+} 282.0059$, found 282.0060 . 


\section{i-Propyl (E)-(1,2-dichlorovinyl)(phenyl)carbamate, 9c}
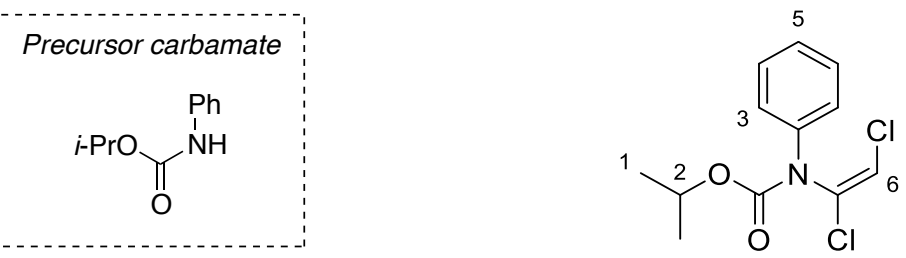

Following example procedure 1.3a: Synthesised from $i$-propyl phenylcarbamate (500 $\mathrm{mg}, 2.79 \mathrm{mmol}$, 1.0 equiv.) in DMF (2.1 mL) using trichloroethylene $\left(0.28 \mathrm{~mL}, 3.07 \mathrm{mmol}, 1.1\right.$ equiv.) and $\mathrm{Cs}_{2} \mathrm{CO}_{3}$ $(1.36 \mathrm{~g}, 4.18 \mathrm{mmol}, 1.5$ equiv.). The reaction takes approximately 3 hours to reach completion. Column chromatography $\left(4 \% \mathrm{Et}_{2} \mathrm{O} / 40-60\right.$ petroleum ether) afforded the title compound $(583 \mathrm{mg}$, $2.13 \mathrm{mmol}, 76 \%$ ) as a pale yellow oil;

$\mathbf{R}_{\mathbf{f}} 0.68$ (30\% EtOAc/40-60 petroleum ether);

IR (thin film, $v_{\max } / \mathrm{cm}^{-1}$ ) 3091, 2982, 1730, 1619, 1598, 1495, 1359, 1307, 1239, 1182, 1156, 1107 , 1016, 931, 822, 751, 693;

${ }^{1} \mathbf{H}$ NMR $\left(400 \mathrm{MHz}, \mathrm{CDCl}_{3}\right) \delta_{\mathrm{H}} 7.43-7.34(4 \mathrm{H}, \mathrm{m}, H 3, H 4), 7.34-7.25(1 \mathrm{H}, \mathrm{m}, H 5), 6.34(1 \mathrm{H}, \mathrm{s}, H 6)$, $5.07(1 \mathrm{H}, \mathrm{spt}, J=6.3 \mathrm{~Hz}, H 2), 1.31(6 \mathrm{H}, \mathrm{d}, J=6.3 \mathrm{~Hz}, H 1)$;

${ }^{13}$ C NMR $\left(101 \mathrm{MHz}, \mathrm{CDCl}_{3}\right) \delta_{\mathrm{C}} 152.1,138.4,131.6,129.0,127.2,125.7,116.4,71.0,21.8 ;$

HRMS (CI+) calc. for $\mathrm{C}_{12} \mathrm{H}_{14}{ }^{35} \mathrm{Cl}_{2} \mathrm{NO}_{2}[\mathrm{M}+\mathrm{H}]^{+} 274.0396$, found 274.0389 . 
(E)-t-Butyl (1,2-dichlorovinyl)(phenyl)carbamate, 9d
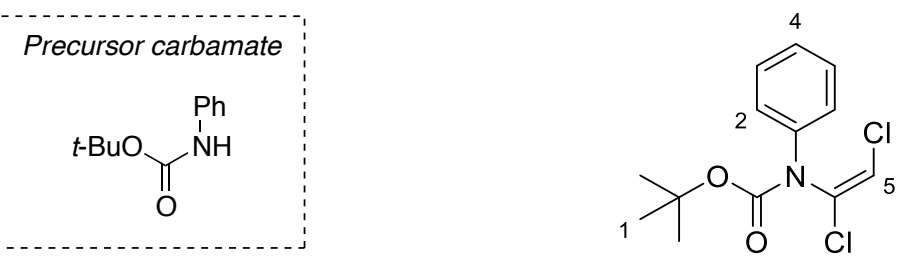

Synthesised according to example procedure 1.3b.

$\mathbf{R}_{\mathbf{f}} 0.67$ (20\% EtOAc/40-60 petroleum ether);

IR (thin film, $v_{\max } / \mathrm{cm}^{-1}$ ) 3081, 2928, 1730, 1598, 1495, 1369, 1315, 1154, 1014, 900, 826,756, 693;

${ }^{1} \mathbf{H}$ NMR $\left(400 \mathrm{MHz}, \mathrm{CDCl}_{3}\right) \delta_{\mathrm{H}} 7.41-7.34(4 \mathrm{H}, \mathrm{m}, H 2, H 3), 7.31-7.24(1 \mathrm{H}, \mathrm{m}, H 4), 6.31(1 \mathrm{H}, \mathrm{s}, H 5)$, $1.52(9 \mathrm{H}, \mathrm{s}, H 1)$;

${ }^{13} \mathbf{C}$ NMR $\left(101 \mathrm{MHz}, \mathrm{CDCl}_{3}\right) \delta_{\mathrm{C}} 151.3,138.5,132.0,128.9,127.0,125.7,115.9,82.8,28.0$. 

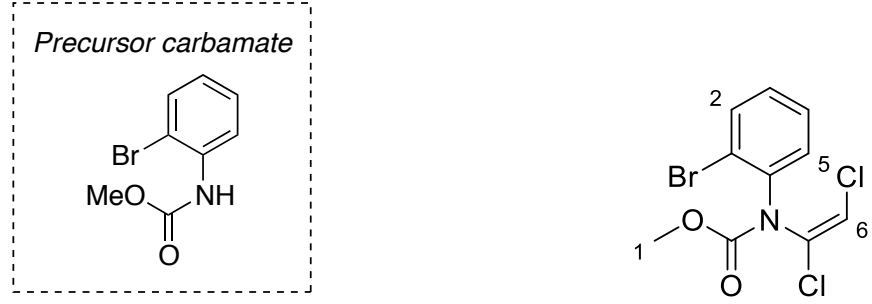

Following example procedure 1.3a: Synthesised from methyl (2-bromophenyl)carbamate (1.00 g, $4.35 \mathrm{mmol}, 1.0$ equiv.) in DMF (3.3 mL) using trichloroethylene (0.59 mL, $4.79 \mathrm{mmol}, 1.1$ equiv.) and $\mathrm{Cs}_{2} \mathrm{CO}_{3}$ (2.12 g, $6.53 \mathrm{mmol}, 1.5$ equiv.). The reaction was stirred overnight for $\sim 15$ hours arbitrarily. Recrystallisation from heptane (plus a few drops of benzene) afforded the title compound $(1.23 \mathrm{~g}, 3.78 \mathrm{mmol}, 87 \%)$ as colourless crystals;

m.p. $80-81^{\circ} \mathrm{C}$;

$\mathbf{R}_{\mathbf{f}} 0.31$ (10\% EtOAc/40-60 petroleum ether);

IR (thin film, $v_{\max } / \mathrm{cm}^{-1}$ ) 3074, 2949, 1740, 1475, 1439, 1309, 1264, 1157, 1070, 1019, 527, 757;

${ }^{1} \mathbf{H}$ NMR $\left(400 \mathrm{MHz}, \mathrm{CDCl}_{3}\right) \delta_{\mathrm{H}} 7.66(1 \mathrm{H}, \mathrm{dd}, J=8.0,1.3 \mathrm{~Hz}, H 2), 7.42(1 \mathrm{H}, \mathrm{dd}, J=8.1,1.7 \mathrm{~Hz}, H 5)$, $7.36(1 \mathrm{H}$, ddd, $J=8.1,7.3,1.3 \mathrm{~Hz}, H 4) H 3, H 4), 7.23(1 \mathrm{H}, \mathrm{ddd}, J=8.0,7.3,1.7 \mathrm{~Hz}, H 3), 6.33(1 \mathrm{H}$, br. s, H6), 3.84 (3H, br. s, $H 1)$;

${ }^{13}$ C NMR $\left(101 \mathrm{MHz}, \mathrm{CDCl}_{3}\right) \delta_{\mathrm{C}} 152.1,137.3,133.8,131.1,129.8,128.8,128.4,123.5,115.6,54.1$;

HRMS (ES+) calc. for $\mathrm{C}_{10} \mathrm{H}_{8}{ }^{79} \mathrm{Br}^{35} \mathrm{Cl}_{2} \mathrm{NNaO}_{2}[\mathrm{M}+\mathrm{Na}]^{+}$345.9008, found 345.9017. 


\section{(E)-3-(1,2-Dichlorovinyl)oxazolidin-2-one, 9 f}
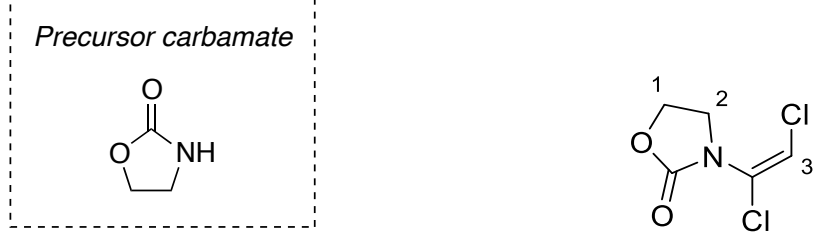

Following example procedure 1.3a: Synthesised from oxazolidin-2-one $(500 \mathrm{mg}, 5.74 \mathrm{mmol}$, 1.0 equiv.) in DMF $(7.7 \mathrm{~mL})$ using trichloroethylene $\left(0.57 \mathrm{~mL}, 6.32 \mathrm{mmol}, 1.1\right.$ equiv.) and $\mathrm{Cs}_{2} \mathrm{CO}_{3}$ $(2.81 \mathrm{~g}, 8.61 \mathrm{mmol}, 1.5$ equiv.). The reaction takes approximately 3 hours to reach completion. Column chromatography ( $25 \%$ EtOAc/40-60 petroleum ether) afforded the title compound ( $855 \mathrm{mg}$, $4.70 \mathrm{mmol}, 82 \%$ ) as a white powder;

$\mathbf{R}_{\mathbf{f}} 0.10$ (10\% EtOAc/40-60 petroleum ether);

IR (thin film, $v_{\max } / \mathrm{cm}^{-1}$ ) 3094, 1757, 1622, 1480, 1395, 1312, 1221, 1100, 1033, 895, 820, 756

${ }^{1} \mathbf{H}$ NMR $\left(400 \mathrm{MHz}, \mathrm{CDCl}_{3}\right) \delta_{\mathrm{H}} 6.34(1 \mathrm{H}, \mathrm{s}, H 3), 4.54-4.43(2 \mathrm{H}, \mathrm{m}, H 1), 3.88-3.78(2 \mathrm{H}, \mathrm{m}, H 2)$;

${ }^{13} \mathbf{C}$ NMR $\left(101 \mathrm{MHz}, \mathrm{CDCl}_{3}\right) \delta_{\mathrm{C}} 153.7,127.0,116.8,62.8,44.0$;

HRMS (ES+) calc. for $\mathrm{C}_{5} \mathrm{H}_{5}{ }^{35} \mathrm{Cl}_{2} \mathrm{NNaO}_{2}[\mathrm{M}+\mathrm{Na}]^{+}$203.9590, found 203.9591 . 

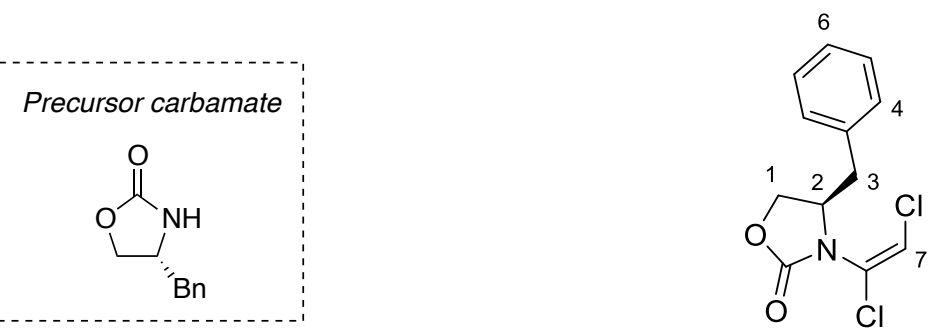

Following example procedure 1.3a: Synthesised from $(S)$-4-benzyloxazolidin-2-one (500 $\mathrm{mg}$, $2.82 \mathrm{mmol}, 1.0$ equiv.) in DMF (2.1 mL) using trichloroethylene $(0.28 \mathrm{~mL}, 3.10 \mathrm{mmol}, 1.1$ equiv.) and $\mathrm{Cs}_{2} \mathrm{CO}_{3}$ (1.38 g, $4.23 \mathrm{mmol}, 1.5$ equiv.). The reaction takes approximately 2 hours to reach completion. Column chromatography (20\% EtOAc/40-60 petroleum ether) afforded the title compound (709 mg, $2.61 \mathrm{mmol}, 92 \%$ ) as a pale yellow oil;

$\mathbf{R}_{\mathbf{f}} 0.36$ (25\% EtOAc/40-60 petroleum ether);

$[\boldsymbol{a}]_{\boldsymbol{D}}^{\mathbf{2 0}}+1.43\left(\mathrm{c} 1, \mathrm{CHCl}_{3}\right)$;

IR (thin film, $v_{\max } / \mathrm{cm}^{-1}$ ) 3089, 2917, 1770, 1623, 1497, 1479, 1455, 1396, 1371, 1307, 1225, 1183, $1106,1029,900,822,756,732,703,653$;

${ }^{1} \mathbf{H}$ NMR $\left(400 \mathrm{MHz}, \mathrm{CDCl}_{3}\right) \delta_{\mathrm{H}} 7.37-7.25(3 \mathrm{H}, \mathrm{m}, H 5, H 6), 7.23-7.16(2 \mathrm{H}, \mathrm{m}, H 4), 6.43(1 \mathrm{H}, \mathrm{s}, H 7)$, $4.42(1 \mathrm{H}$, dddd, $J=9.5,80,7.3,4.4 \mathrm{~Hz}, H 1), 4.35(1 \mathrm{H}, \mathrm{dd}, J=8.6,8.0 \mathrm{~Hz}, H 1), 4.18(1 \mathrm{H}, \mathrm{dd}, J=8.6$, $7.3 \mathrm{~Hz}, H 1), 3.18(1 \mathrm{H}, \mathrm{dd}, J=13.4,4.4 \mathrm{~Hz}, H 3), 2.79(1 \mathrm{H}, \mathrm{dd}, J=13.4,9.5 \mathrm{~Hz}, H 3)$;

${ }^{13} \mathbf{C}$ NMR $\left(101 \mathrm{MHz}, \mathrm{CDCl}_{3}\right) \delta_{\mathrm{C}} 153.3,134.5,129.0,128.9,127.5,126.2,118.2,68.2,56.7,38.8$;

HRMS (ES+) calc. for $\mathrm{C}_{12} \mathrm{H}_{12}{ }^{35} \mathrm{Cl}_{2} \mathrm{NO}_{2}[\mathrm{M}+\mathrm{H}]^{+} 272.0240$, found 272.0241 . 


\section{3b Carbamate Scope: Ynamides}

\section{Benzyl phenyl(phenylethynyl)carbamate, 13a}
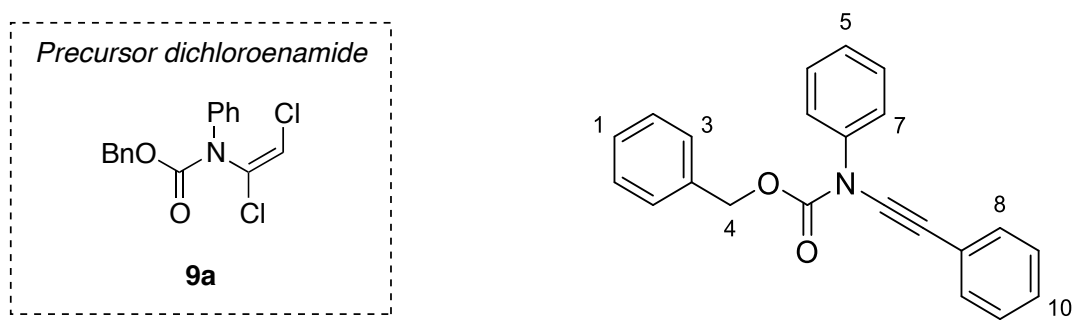

Synthesised according to example procedure $\mathbf{1 . 3 f}$.

m.p. $75-77^{\circ} \mathrm{C}$;

$\mathbf{R}_{\mathbf{f}} 0.38\left(10 \% \mathrm{Et}_{2} \mathrm{O} / 40-60\right.$ petroleum ether);

IR (thin film, $v_{\max } / \mathrm{cm}^{-1}$ ) 3033, 2960, 2251, 1737, 1492, 1383, 1262, 1215, 1017, 947, 910, 753, 692;

${ }^{1} \mathbf{H}$ NMR $\left(400 \mathrm{MHz}, \mathrm{CDCl}_{3}\right) \delta_{\mathrm{H}} 7.62-7.55(2 \mathrm{H}, \mathrm{m}, H 7), 7.53-7.35$ (9H, m, H1, H2, H3, H6, H8), 7.35-7.27 (4H, m, H5, H9, H10), $5.36(2 \mathrm{H}, \mathrm{s}, H 4)$;

${ }^{13} \mathbf{C}$ NMR $\left(101 \mathrm{MHz}, \mathrm{CDCl}_{3}\right) \delta_{\mathrm{C}} 154.1,139.4,135.4,131.2,129.0,128.6,128.3,128.2,127.9,127.7$, $127.0,124.6,122.9,82.8,70.4,68.9$;

HRMS (ES+) calc. for $\mathrm{C}_{22} \mathrm{H}_{17} \mathrm{NNaO}_{2}[\mathrm{M}+\mathrm{Na}]^{+} 350.1152$, found 350.1152 . 


\section{Benzyl ((4-chlorophenyl)ethynyl)(phenyl)carbamate, 13b}
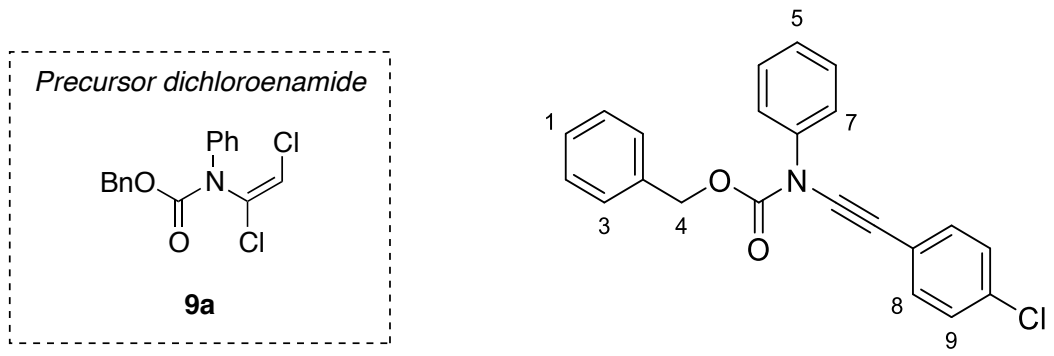

Following example procedure 1.3f: Synthesised from benzyl (E)-(1,2-dichlorovinyl)(phenyl) carbamate (500 mg, $1.55 \mathrm{mmol}, 1.0$ equiv.) in anhydrous TBME (13 mL) using LiHMDS (freshly prepared according to example procedure 1.3f, 1.2 equiv.). The diarylzinc solution was prepared using anhydrous toluene $(1.0 \mathrm{~mL}), 4$-chlorophenylmagnesium bromide $(1.63 \mathrm{~mL}$ of a $1.0 \mathrm{M}$ solution in $\mathrm{Et}_{2} \mathrm{O}, 1.63 \mathrm{mmol}, 1.05$ equiv.), zinc(II) chloride $\left(0.82 \mathrm{~mL}\right.$ of a $1.0 \mathrm{M}$ solution in $\mathrm{Et}_{2} \mathrm{O}, 0.823 \mathrm{mmol}$, 0.53 equiv.), and the reaction conducted using $\mathrm{CuCN} \cdot 2 \mathrm{LiCl}(20 \mu \mathrm{L}$ of a $1.0 \mathrm{M}$ solution in THF, $20 \mu \mathrm{mol}, 1.25 \mathrm{~mol} \%$ ). Upon completion, the reaction was worked up and extracted as for example procedure 1.3f. Column chromatography $\left(5 \% \mathrm{Et}_{2} \mathrm{O} / 40-60\right.$ petroleum ether) afforded a pale yellow solid which was recrystallised from hexane/dibutyl ether (10:1) to give the title compound (410 mg, $1.13 \mathrm{mmol}, 73 \%$ ) as colourless needles;

m.p. $122-123{ }^{\circ} \mathrm{C}$;

$\mathbf{R}_{\mathbf{f}} 0.22\left(5 \% \mathrm{Et}_{2} \mathrm{O} / 40-60\right.$ petroleum ether);

IR (thin film, $v_{\max } / \mathrm{cm}^{-1}$ ) 3035, 2251, 1734, 1594, 1490, 1456, 1381, 1361, 1271, 1212, 1126, 1089 , 1014, 826, 752, 693, 670;

${ }^{1} \mathbf{H}$ NMR $\left(500 \mathrm{MHz}, \mathrm{CDCl}_{3}\right) \delta_{\mathrm{H}} 7.55-7.48(2 \mathrm{H}, \mathrm{m}, H 7)$, 7.45-7.32 (7H, m, H1, H2, H3, H6), 7.327.27 (3H, m, H5, H8), 7.27-7.23 (2H, m, H9), 5.32 (2H, s, H4);

${ }^{13} \mathbf{C}$ NMR $\left(126 \mathrm{MHz}, \mathrm{CDCl}_{3}\right) \delta_{\mathrm{C}} 154.0,139.2,135.3,133.6,132.3,129.0,128.57,128.55,128.4$, $127.9,127.2,124.6,121.5,83.7,69.4,69.0$;

HRMS We were unable to obtain an accurate mass (ES+ or $\mathrm{CI}+$ ) due to decomposition upon ionisation. 


\section{Benzyl phenyl(prop-1-yn-1-yl)carbamate, 13c}
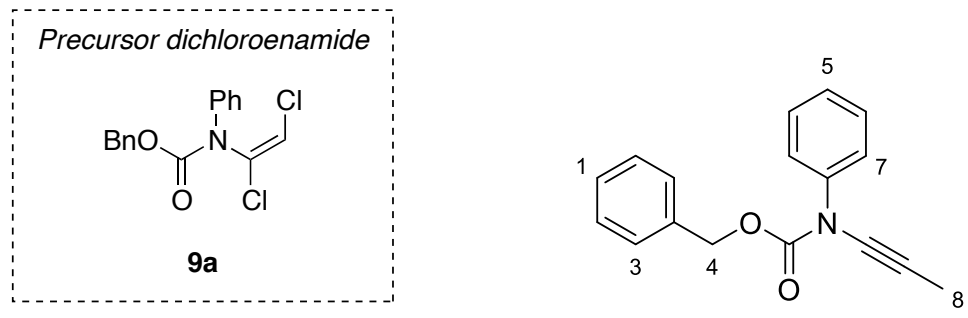

Following example procedure 1.3f: Synthesised from benzyl (E)-(1,2-dichlorovinyl)(phenyl) carbamate (500 mg, $1.55 \mathrm{mmol}, 1.0$ equiv.) in anhydrous TBME (13 mL) using LiHMDS (freshly prepared according to example procedure 1.3f, 1.2 equiv.). The dimethylzinc solution was prepared using anhydrous toluene $(1.0 \mathrm{~mL})$, methylmagnesium iodide $\left(1.09 \mathrm{~mL}\right.$ of a $3.0 \mathrm{M}$ solution in $\mathrm{Et}_{2} \mathrm{O}$, diluted to $1.0 \mathrm{M}$ with anhydrous $\mathrm{Et}_{2} \mathrm{O}, 3.26 \mathrm{mmol}, 2.1$ equiv.), zinc(II) chloride (1.63 mL of a $1.0 \mathrm{M}$ solution in $\mathrm{Et}_{2} \mathrm{O}, 1.63 \mathrm{mmol}, 1.05$ equiv.), and the reaction conducted using $\mathrm{CuCN} \cdot 2 \mathrm{LiCl}(20 \mu \mathrm{L}$ of a $1.0 \mathrm{M}$ solution in THF, $20 \mu \mathrm{mol}, 1.25 \mathrm{~mol} \%$ ). Upon completion, the reaction was worked up and extracted as for example procedure 1.3f. Column chromatography $\left(5 \% \mathrm{Et}_{2} \mathrm{O} / 40-60\right.$ petroleum ether) afforded the title compound (234 $\mathrm{mg}, 0.881 \mathrm{mmol}, 57 \%)$ as a pale yellow oil;

$\mathbf{R}_{\mathbf{f}} 0.22\left(5 \% \mathrm{Et}_{2} \mathrm{O} / 40-60\right.$ petroleum ether);

IR (thin film, $v_{\max } / \mathrm{cm}^{-1}$ ) 3034, 2918, 2271, 1728, 1595, 1492, 1455, 1387, 1340, 1270, 1199, 1044, $1023,750,691,659$;

${ }^{1} \mathbf{H}$ NMR $\left(500 \mathrm{MHz}, \mathrm{CDCl}_{3}\right) \delta_{\mathrm{H}} 7.50-7.45(2 \mathrm{H}, \mathrm{m}, H 7), 7.43-7.31(7 \mathrm{H}, \mathrm{m}, H 1, H 2, H 3, H 6), 7.26$ $(1 \mathrm{H}, \mathrm{tt}, J=7.3,1.3 \mathrm{~Hz}, H 5), 5.29(2 \mathrm{H}, \mathrm{s}, H 4), 1.96(3 \mathrm{H}, \mathrm{s}, H 8)$;

${ }^{13} \mathbf{C}$ NMR $\left(126 \mathrm{MHz}, \mathrm{CDCl}_{3}\right) \delta_{\mathrm{C}} 154.8,139.9,135.6,128.8,128.5,128.2,127.9,126.7,124.6,72.7$, $68.6,65.2,3.24$;

HRMS (ES+) calc. for $\mathrm{C}_{17} \mathrm{H}_{15} \mathrm{NNaO}_{2}[\mathrm{M}+\mathrm{Na}]^{+}$288.0995, found 288.0996 . 


\section{Benzyl (3-methylbut-1-yn-1-yl)(phenyl)carbamate, 13d}
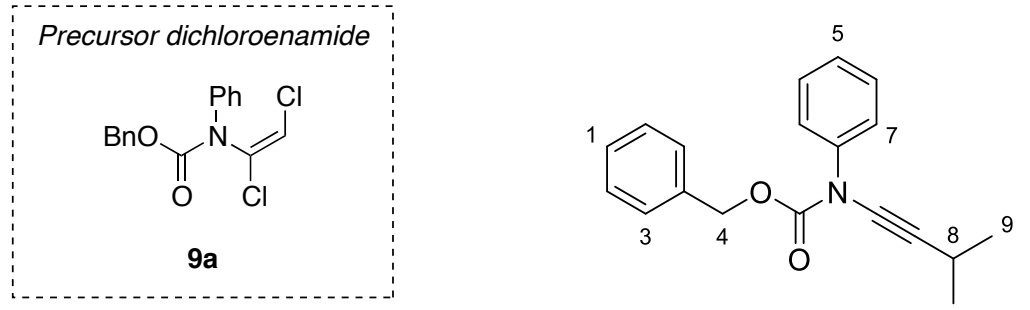

Following example procedure 1.3f: Synthesised from benzyl (E)-(1,2-dichlorovinyl)(phenyl) carbamate (500 mg, $1.55 \mathrm{mmol}, 1.0$ equiv.) in anhydrous TBME (13 mL) using LiHMDS (freshly prepared according to example procedure 1.3f, 1.2 equiv.). The di-i-propylzinc solution was prepared using anhydrous toluene $(1.0 \mathrm{~mL}), i$-propylmagnesium chloride $\left(1.63 \mathrm{~mL}\right.$ of a $2.0 \mathrm{M}$ solution in $\mathrm{Et}_{2} \mathrm{O}$, diluted to $1.0 \mathrm{M}$ with anhydrous $\mathrm{Et}_{2} \mathrm{O}, 3.26 \mathrm{mmol}, 2.1$ equiv.), zinc(II) chloride (1.63 mL of a $1.0 \mathrm{M}$ solution in $\mathrm{Et}_{2} \mathrm{O}, 1.63 \mathrm{mmol}, 1.05$ equiv.), and the reaction conducted using $\mathrm{CuCN} \cdot 2 \mathrm{LiCl}(20 \mu \mathrm{L}$ of a $1.0 \mathrm{M}$ solution in THF, $20 \mu \mathrm{mol}, 1.25 \mathrm{~mol} \%)$. Upon completion, the reaction was worked up and extracted as for example procedure 1.3f. Column chromatography $\left(5 \% \mathrm{Et}_{2} \mathrm{O} / 40-60\right.$ petroleum ether) afforded the title compound $(336.5 \mathrm{mg}, 1.15 \mathrm{mmol}, 74 \%)$ as a pale yellow oil;

$\mathbf{R}_{\mathbf{f}} 0.33$ (5\% Et ${ }_{2} \mathrm{O} / 40-60$ petroleum ether);

IR (thin film, $v_{\max } / \mathrm{cm}^{-1}$ ) 2968, 2262, 1731, 1595, 1493, 1456, 1382, 1264, 1202, 1155, 1095, 1043, 1021, 755, 736, 691, 659;

${ }^{1} \mathbf{H}$ NMR $\left(500 \mathrm{MHz}, \mathrm{CDCl}_{3}\right) \delta_{\mathrm{H}} 7.54-7.49(2 \mathrm{H}, \mathrm{m}, H 7), 7.45-7.31(7 \mathrm{H}, \mathrm{m}, H 1, H 2, H 3, H 6), 7.25$ $(1 \mathrm{H}, \mathrm{tt}, J=7.3,1.3 \mathrm{~Hz}, H 5), 5.30(2 \mathrm{H}, \mathrm{s}, H 4), 2.73(1 \mathrm{H}, \mathrm{spt}, J=6.9 \mathrm{~Hz}, H 8), 1.22(6 \mathrm{H}, \mathrm{d}, J=6.9 \mathrm{~Hz}$, $H 9)$;

${ }^{13}$ C NMR $\left(126 \mathrm{MHz}, \mathrm{CDCl}_{3}\right) \delta_{\mathrm{C}} 154.6,139.9,135.6,128.7,128.4,128.1,127.7,126.5,124.2,75.2$, $73.2,68.5,23.1,20.4$

HRMS (ES+) calc. for $\mathrm{C}_{19} \mathrm{H}_{19} \mathrm{NNaO}_{2}[\mathrm{M}+\mathrm{Na}]^{+}$316.1308, found 316.1309. 


\section{Ethyl ((4-chlorophenyl)ethynyl)(phenyl)carbamate, 13e}
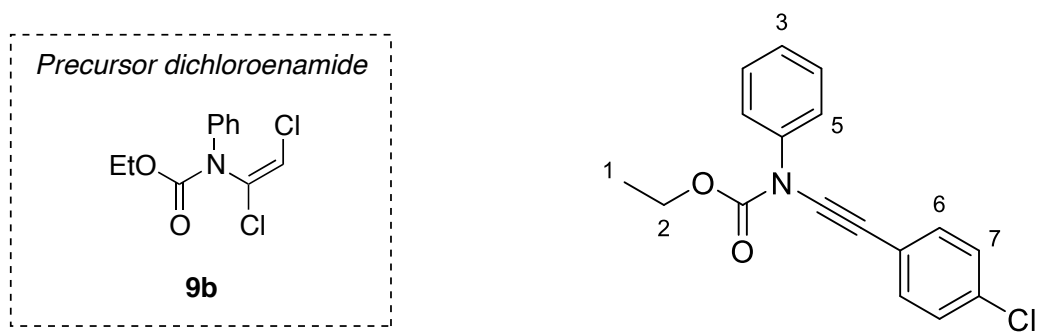

Following example procedure 1.3f: Synthesised from ethyl (E)-(1,2-dichlorovinyl)(phenyl) carbamate (500 mg, $1.92 \mathrm{mmol}, 1.0$ equiv.) in anhydrous TBME (19 mL) using LiHMDS (freshly prepared according to example procedure 1.3f, 1.2 equiv.). The diarylzinc solution was prepared using anhydrous TBME $(2.0 \mathrm{~mL}), 4$-chlorophenylmagnesium bromide $(2.11 \mathrm{~mL}$ of a $1.0 \mathrm{M}$ solution in $\mathrm{Et}_{2} \mathrm{O}, 2.11 \mathrm{mmol}, 1.1$ equiv.), zinc(II) chloride (1.06 $\mathrm{mL}$ of a $1.0 \mathrm{M}$ solution in $\mathrm{Et}_{2} \mathrm{O}, 2.11 \mathrm{mmol}$, 0.55 equiv.), and the reaction conducted using $\mathrm{CuCN} \cdot 2 \mathrm{LiCl}(24 \mu \mathrm{L}$ of a $1.0 \mathrm{M}$ solution in THF, $24 \mu \mathrm{mol}, 1.25 \mathrm{~mol} \%$ ). Upon completion, the reaction was worked up and extracted as for example procedure 1.3f. Column chromatography $\left(0 \rightarrow 3 \% \mathrm{Et}_{2} \mathrm{O} /\right.$ pentane $)$ afforded the title compound (441 mg, $1.47 \mathrm{mmol}, 77 \%$ ) as a colourless oil that solidifies on standing in the freezer $\left(-20^{\circ} \mathrm{C}\right)$. This compound can be crystallised by cooling a concentrated solution of the title compound in pentane to $-20{ }^{\circ} \mathrm{C}$ for 3 months;

$\mathbf{R}_{\mathbf{f}} 0.26\left(5 \% \mathrm{Et}_{2} \mathrm{O} / 40-60\right.$ petroleum ether);

IR (thin film, $v_{\max } / \mathrm{cm}^{-1}$ ) 2981, 2253, 1733, 1594, 1490, 1396, 1370, 1268, 1240, 1214, 1173, 1125 , $1088,1049,1025,1013,825,757,747,692,670$;

${ }^{1} \mathbf{H}$ NMR $\left(400 \mathrm{MHz}, \mathrm{CDCl}_{3}\right) \delta_{\mathrm{H}} 7.58-7.52(2 \mathrm{H}, \mathrm{m}, H 5), 7.46-7.39(2 \mathrm{H}, \mathrm{m}, H 4), 7.39-7.33$ (2H, m, $H 6), 7.31-7.26(2 \mathrm{H}, \mathrm{m}, H 7), 7.28(1 \mathrm{H}, \mathrm{tt}, J=7.4,1.1 \mathrm{~Hz}, H 3), 4.36(2 \mathrm{H}, \mathrm{q}, J=7.2 \mathrm{~Hz}, H 2), 1.39$ (3H, $\mathrm{t}, J=7.2 \mathrm{~Hz}, H 1)$;

${ }^{13} \mathbf{C}$ NMR $\left(101 \mathrm{MHz}, \mathrm{CDCl}_{3}\right) \delta_{\mathrm{C}} 154.0,139.3,133.5,132.3,128.9,128.5,126.9,124.6,121.5,83.9$, 69.1, 63.7, 14.3;

HRMS (ES+) calc. for $\mathrm{C}_{17} \mathrm{H}_{14}{ }^{35} \mathrm{ClNNaO}_{2}[\mathrm{M}+\mathrm{Na}]^{+} 322.0605$, found 322.0607. 


\section{i-Propyl ((4-chlorophenyl)ethynyl)(phenyl)carbamate, $13 f$}
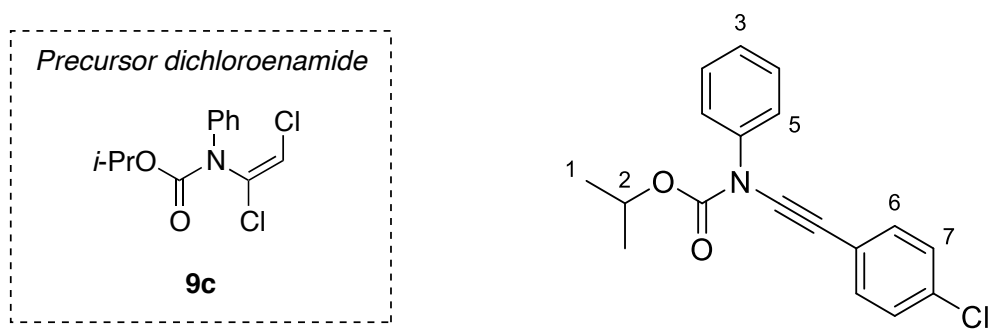

Following example procedure 1.3f: Synthesised from $i$-propyl (E)-(1,2-dichlorovinyl)(phenyl) carbamate (150 mg, $0.547 \mathrm{mmol}, 1.0$ equiv.) in anhydrous TBME (5.5 mL) using LiHMDS (freshly prepared according to example procedure 1.3f, 1.2 equiv.). The diarylzinc solution was prepared using anhydrous TBME $(1.0 \mathrm{~mL})$, 4-chlorophenylmagnesium bromide $(0.60 \mathrm{~mL}$ of a $1.0 \mathrm{M}$ solution in $\mathrm{Et}_{2} \mathrm{O}, 0.602 \mathrm{mmol}, 1.1$ equiv.), zinc(II) chloride $\left(0.30 \mathrm{~mL}\right.$ of a $1.0 \mathrm{M}$ solution in $\mathrm{Et}_{2} \mathrm{O}, 0.300 \mathrm{mmol}$, 0.55 equiv.), and the reaction conducted using $\mathrm{CuCN} \cdot 2 \mathrm{LiCl}(7 \mu \mathrm{L}$ of a $1.0 \mathrm{M}$ solution in THF, $7 \mu \mathrm{mol}, 1.25 \mathrm{~mol} \%)$. Upon completion, the reaction was worked up and extracted as for example procedure 1.3f. Column chromatography $\left(0 \rightarrow 3 \% \mathrm{Et}_{2} \mathrm{O} /\right.$ pentane $)$ afforded the title compound (135 mg, $0.430 \mathrm{mmol}, 79 \%$ ) as a white powder. This compound can be recrystallised by cooling a concentrated solution of the title compound in pentane/dibutyl ether $(4: 1)$ to $-20{ }^{\circ} \mathrm{C}$ overnight to give colourless crystals;

m.p. $165^{\circ} \mathrm{C}$;

$\mathbf{R}_{\mathbf{f}} 0.35\left(5 \% \mathrm{Et}_{2} \mathrm{O} / 40-60\right.$ petroleum ether);

IR (thin film, $v_{\max } / \mathrm{cm}^{-1}$ ) 2981, 2252, 1731, 1490, 1364, 1268, 1219, 1181, 1126, 1103, 1089, 1012, $826,758,749,692$;

${ }^{1} \mathbf{H}$ NMR $\left(400 \mathrm{MHz}, \mathrm{CDCl}_{3}\right) \delta_{\mathrm{H}} 7.57-7.51(2 \mathrm{H}, \mathrm{m}, H 5), 7.45-7.38(2 \mathrm{H}, \mathrm{m}, H 4), 7.37-7.32(2 \mathrm{H}, \mathrm{m}$, $H 6), 7.30-7.25(2 \mathrm{H}, \mathrm{m}, H 7), 7.29$ (1H, tt, $J=7.4,1.2 \mathrm{~Hz}, H 3), 5.10(1 \mathrm{H}, \mathrm{spt}, J=6.3 \mathrm{~Hz}, H 2), 1.38$ $(6 \mathrm{H}, \mathrm{d}, J=6.3 \mathrm{~Hz}, H 1)$;

${ }^{13} \mathbf{C}$ NMR $\left(101 \mathrm{MHz}, \mathrm{CDCl}_{3}\right) \delta_{\mathrm{C}} 153.6,139.4,133.4,132.2,128.9,128.5,126.9,124.6,121.7,84.1$, $71.9,69.2,21.8$

HRMS (ES+) calc. for $\mathrm{C}_{18} \mathrm{H}_{16}{ }^{35} \mathrm{ClNNaO}_{2}[\mathrm{M}+\mathrm{Na}]^{+}$336.0762, found 336.0763. 


\section{t-Butyl ((4-chlorophenyl)ethynyl)(phenyl)carbamate, 13g}
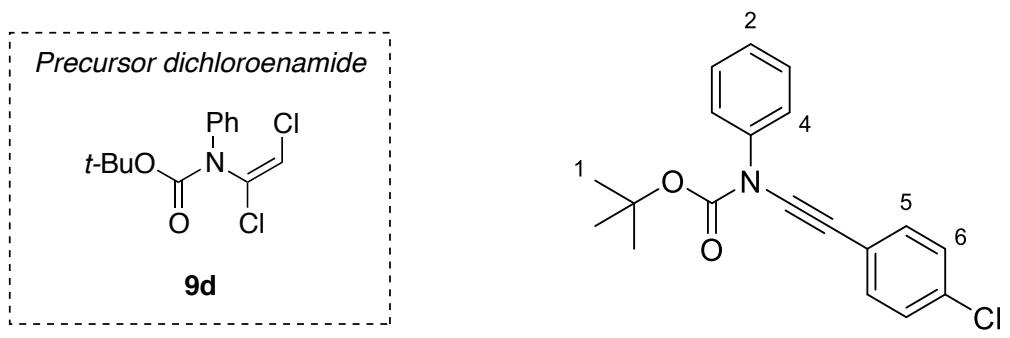

Following example procedure 1.3f: Synthesised from $i$-propyl (E)-(1,2-dichlorovinyl)(phenyl) carbamate (150 mg, $0.521 \mathrm{mmol}, 1.0$ equiv.) in anhydrous TBME (5.2 mL) using LiHMDS (freshly prepared according to example procedure 1.3f, 1.2 equiv.). The diarylzinc solution was prepared using anhydrous TBME $(1.0 \mathrm{~mL})$, 4-chlorophenylmagnesium bromide $(0.57 \mathrm{~mL}$ of a $1.0 \mathrm{M}$ solution in $\mathrm{Et}_{2} \mathrm{O}, 0.573 \mathrm{mmol}, 1.1$ equiv.), zinc(II) chloride $\left(0.29 \mathrm{~mL}\right.$ of a $1.0 \mathrm{M}$ solution in $\mathrm{Et}_{2} \mathrm{O}, 0.287 \mathrm{mmol}$, 0.55 equiv.), and the reaction conducted using $\mathrm{CuCN} \cdot 2 \mathrm{LiCl}(7 \mu \mathrm{L}$ of a $1.0 \mathrm{M}$ solution in THF, $7 \mu \mathrm{mol}, 1.25 \mathrm{~mol} \%$ ). Upon completion, the reaction was worked up and extracted as for example procedure 1.3f. Column chromatography $\left(0 \rightarrow 2 \% \mathrm{Et}_{2} \mathrm{O} /\right.$ pentane $)$ afforded the title compound (125 mg, $0.381 \mathrm{mmol}, 73 \%$ ) as a colourless oil that solidified on standing. This compound can be recrystallised by cooling a concentrated solution of the title compound in pentane to $\sim 2{ }^{\circ} \mathrm{C}$ in a fridge for 1 week to give colourless needles;

m.p. $71{ }^{\circ} \mathrm{C}$;

$\mathbf{R}_{\mathbf{f}} 0.36\left(2.5 \% \mathrm{Et}_{2} \mathrm{O} / 40-60\right.$ petroleum ether);

IR (thin film, $v_{\max } / \mathrm{cm}^{-1}$ ) 2980, 2252, 1731, 1594, 1491, 1394, 1367, 1279, 1252, 1149, 1126, 1088, $1012,859,825,758,742,692,677$;

${ }^{1} \mathbf{H}$ NMR $\left(400 \mathrm{MHz}, \mathrm{CDCl}_{3}\right) \delta_{\mathrm{H}} 7.55-7.50(2 \mathrm{H}, \mathrm{m}, H 4), 7.43-7.36(2 \mathrm{H}, \mathrm{m}, H 3), 7.34-7.29(2 \mathrm{H}, \mathrm{m}$, $H 5), 7.28-7.24$ (2H, m, H6), $7.26(1 \mathrm{H}, \mathrm{tt}, J=7.4,1.2 \mathrm{~Hz}, H 2), 1.57$ (9H, s, $H 1)$;

${ }^{13} \mathbf{C}$ NMR $\left(101 \mathrm{MHz}, \mathrm{CDCl}_{3}\right) \delta_{\mathrm{C}} 152.7,139.5,133.2,132.0,128.8,128.5,126.7,124.7,121.9,84.6$, 83.5, 69.1, 27.9;

HRMS (ES+) calc. for $\mathrm{C}_{19} \mathrm{H}_{18}{ }^{35} \mathrm{ClNNaO}_{2}[\mathrm{M}+\mathrm{Na}]^{+} 350.0918$, found 350.0919 . 

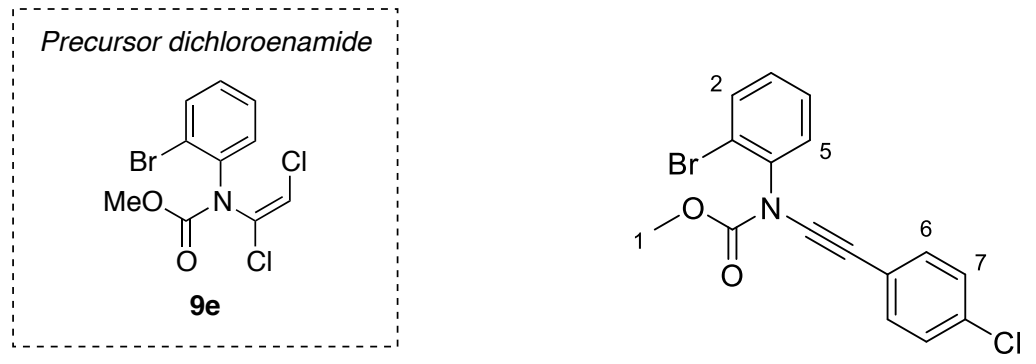

Following example procedure 1.3f: Synthesised from methyl (E)-(1,2-dichlorovinyl)(2-bromophenyl) carbamate (500 mg, $1.54 \mathrm{mmol}, 1.0$ equiv.) in anhydrous TBME (15 mL) using LiHMDS (freshly prepared according to example procedure 1.3f, 1.2 equiv.). The diarylzinc solution was prepared using anhydrous TBME $(2.0 \mathrm{~mL})$, 4-chlorophenylmagnesium bromide $(3.23 \mathrm{~mL}$ of a $1.0 \mathrm{M}$ solution in $\mathrm{Et}_{2} \mathrm{O}, 3.23 \mathrm{mmol}, 2.1$ equiv.), zinc(II) chloride (1.62 $\mathrm{mL}$ of a $1.0 \mathrm{M}$ solution in $\mathrm{Et}_{2} \mathrm{O}, 1.62 \mathrm{mmol}$, 1.05 equiv.), and the reaction conducted using $\mathrm{CuCN} \cdot 2 \mathrm{LiCl}(19 \mu \mathrm{L}$ of a $1.0 \mathrm{M}$ solution in THF, $19 \mu \mathrm{mol}, 1.25 \mathrm{~mol} \%$ ). Upon completion, the reaction was worked up and extracted as for example procedure 1.3f. Column chromatography $\left(10 \% \mathrm{Et}_{2} \mathrm{O} /\right.$ pentane $)$ afforded a pale yellow oil, which was crystallised from heptane $(\sim 2 \mathrm{~mL})$ plus a couple of drops of $i$-PrOH to give the title compound (421 mg, $1.15 \mathrm{mmol}, 75 \%)$ as colourless crystals;

m.p. $103-104{ }^{\circ} \mathrm{C}$;

$\mathbf{R}_{\mathbf{f}} 0.28$ ( $10 \% \mathrm{Et}_{2} \mathrm{O} / 40-60$ petroleum ether);

IR (thin film, $v_{\max } / \mathrm{cm}^{-1}$ ) 2955, 2253, 1740, 1493, 1474, 1438, 1366, 1293, 1258, 1229, 1090, 1069, $1029,1012,828,752$;

${ }^{1} \mathbf{H}$ NMR $\left(400 \mathrm{MHz}, \mathrm{CDCl}_{3}\right) \delta_{\mathrm{H}} 7.68(1 \mathrm{H}, \mathrm{dd}, J=7.8,1.5 \mathrm{~Hz}, H 2), 7.48(1 \mathrm{H}, \mathrm{dd}, J=7.8,1.6 \mathrm{~Hz}, H 5)$, $7.39(1 \mathrm{H}, \mathrm{td}, J=7.8,1.6 \mathrm{~Hz}, H 4), 7.36-7.30(2 \mathrm{H}, \mathrm{m}, H 6), 7.26(1 \mathrm{H}, \mathrm{td}, \mathrm{J}=7.8,1.5 \mathrm{~Hz}, H 3), 7.26-$ $7.21(2 \mathrm{H}, \mathrm{m}, H 7), 3.88(3 \mathrm{H}, \mathrm{s}, H 1)$;

${ }^{13} \mathrm{C}$ NMR $\left(101 \mathrm{MHz}, \mathrm{CDCl}_{3}\right) \delta_{\mathrm{C}} 154.3,138.1,133.8,132.7,130.2,129.2,128.6,128.5$ (2C), 122.4, 121.3, 83.0, 68.8, 54.7;

HRMS (ES+) calc. for $\mathrm{C}_{16} \mathrm{H}_{11}{ }^{79} \mathrm{~B}^{35} \mathrm{ClNNaO}_{2}[\mathrm{M}+\mathrm{Na}]^{+}$385.9554, found 385.9554. 


\section{3c Carbamate Scope: Miscellaneous}

\section{Benzyl (Z)-(2-chloro-1-phenylvinyl)(phenyl)carbamate, (Z)-11}
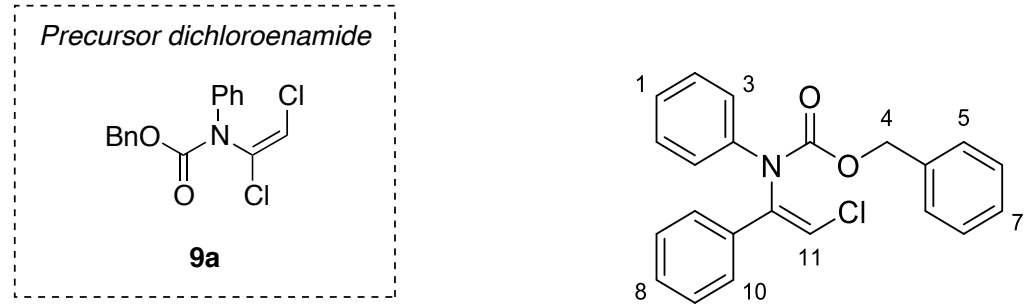

Following example procedure 1.3e: Synthesised from benzyl (E)-(1,2-dichlorovinyl)(phenyl) carbamate (500 mg, $1.55 \mathrm{mmol}, 1.0$ equiv.) in anhydrous TBME (2.0 mL) using LiHMDS (freshly prepared according to example procedure 1.3e, 1.2 equiv.), phenylmagnesium bromide $(1.60 \mathrm{~mL}$ of a 1.0 M solution in THF, $1.60 \mathrm{mmol}, 1.03$ equiv.), $\mathrm{CuCN} \cdot 2 \mathrm{LiCl}(19 \mu \mathrm{L}$ of a $1.0 \mathrm{M}$ solution in THF, $19 \mu \mathrm{mol}, 1.25 \mathrm{~mol} \%)$ and $\mathrm{P}(\mathrm{OMe})_{3}(5 \mu \mathrm{L}, 40 \mu \mathrm{mol}, 2.5 \mathrm{~mol} \%)$ at $21{ }^{\circ} \mathrm{C}$. The reaction was stirred for $2 \mathrm{~h}$ at $21{ }^{\circ} \mathrm{C}$ and was quenched with aqueous saturated $\mathrm{NH}_{4} \mathrm{Cl}(15 \mathrm{~mL})$, followed by the addition of EtOAc $(10 \mathrm{~mL})$, and the layers separated. The aqueous was further extracted with EtOAc $(2 \times 10 \mathrm{~mL})$, the organic extracts combined, dried $\left(\mathrm{MgSO}_{4}\right)$ and concentrated in vacuo. Column chromatography $\left(5 \rightarrow 10 \% \mathrm{Et}_{2} \mathrm{O} / 40-60\right.$ petroleum ether) afforded ynamide 13a (125 $\mathrm{mg}, 0.382 \mathrm{mmol}, 25 \%$ ), an inseparable mixture of $(Z)-\mathbf{1 1}$ and $(E)-\mathbf{1 1}(198 \mathrm{mg}, 0.544 \mathrm{mmol}, 35 \%)$, (E)-ester 12 (48.8 mg, $0.134 \mathrm{mmol}, 9 \%)$ and oxazolone S5 ( $\sim 5 \mathrm{mg}, \sim 20 \mu \mathrm{mol}, 1 \%)$.

- See before for ynamide 13a data;

- Data for carbamate $(Z)-\mathbf{1 1}$ :

$\mathbf{R}_{\mathbf{f}} 0.21$ ( $10 \% \mathrm{Et}_{2} \mathrm{O} / 40-60$ petroleum ether);

${ }^{1} \mathbf{H}$ NMR (400 MHz, $\left.\mathrm{CDCl}_{3}\right) \delta_{\mathrm{H}} 7.37-7.47(5 \mathrm{H}, \mathrm{m}, \mathrm{Ph} H)$, 7.36-7.24 (8H, m, PhH), 7.24-7.18 (2H, br. m, $\mathrm{Ph} H), 7.13-7.08(1 \mathrm{H}, \mathrm{m}, \mathrm{Ph} H), 6.64(1 \mathrm{H}, \mathrm{s}, H 11), 5.22(2 \mathrm{H}$, br. s, $H 4)$;

${ }^{13} \mathbf{C}$ NMR $\left(101 \mathrm{MHz}, \mathrm{CDCl}_{3}\right) \delta_{\mathrm{C}} 154.0,140.0,135.8,135.4,128.9,128.8,128.7$ (2C), 128.3, 127.9 (2C), 125.9, 125.6, 124.3, 117.1, 68.0;

HRMS (ES+) calc. for $\mathrm{C}_{22} \mathrm{H}_{19}{ }^{35} \mathrm{ClNO}_{2}[\mathrm{M}+\mathrm{H}]^{+} 364.1099$, found 364.1100 .

- See next for carbamate $(E)-\mathbf{1 1},(E)$-ester 12 and oxazolone $\mathbf{S 5}$ data. 
Benzyl (E)-(2-chloro-1-phenylvinyl)(phenyl)carbamate, $(E)-11$ \& Benzyl (E)-2-chloro-3-phenyl3-(phenylamino)acrylate, 12

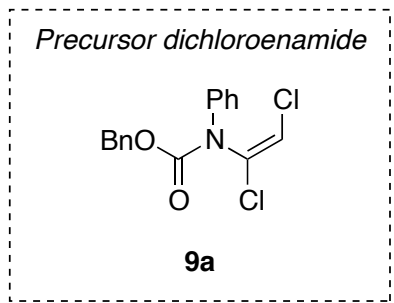

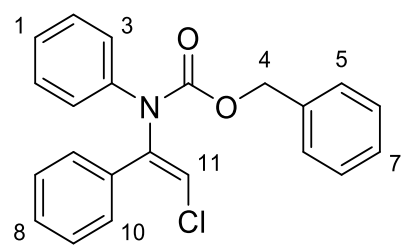

(E)-11<smiles>O=C(OCc1ccccc1)/C(Cl)=C(\Nc1ccccc1)c1ccccc1</smiles>

12

Following example procedure 1.3e: Synthesised from benzyl (E)-(1,2-dichlorovinyl)(phenyl) carbamate (250 mg, $0.776 \mathrm{mmol}, 1.0$ equiv.) in anhydrous TBME (2.0 mL) using LiHMDS (freshly prepared according to example procedure 1.3e, 1.2 equiv.) and phenylmagnesium bromide $(1.75 \mathrm{~mL}$ of a $1.0 \mathrm{M}$ solution in THF, $1.75 \mathrm{mmol}, 1.2$ equiv.) at $0{ }^{\circ} \mathrm{C}$ (Note: no $\mathrm{CuCN}$ was added). The reaction was stirred for $2 \mathrm{~h}$ at $21^{\circ} \mathrm{C}$ and was quenched with aqueous saturated $\mathrm{NH}_{4} \mathrm{Cl}(15 \mathrm{~mL})$, followed by the addition of EtOAc $(10 \mathrm{~mL})$, and the layers separated. The aqueous was further extracted with EtOAc $(2 \times 10 \mathrm{~mL})$, the organic extracts combined, dried $\left(\mathrm{MgSO}_{4}\right)$ and concentrated in vacuo. Column chromatography ( $5 \rightarrow 10 \% \mathrm{Et}_{2} \mathrm{O} / 40-60$ petroleum ether) afforded the title compounds as yellow oils. Carbamate $(E)-\mathbf{1 3}$ was crystallised from benzene/hexane (1:5) to afford (88.2 mg, $0.242 \mathrm{mmol}, 31 \%)$ as colourless crystals, and ester 14 was crystallised from hexane to give $(63.0 \mathrm{mg}, 0.173 \mathrm{mmol}, 22 \%)$ as colourless crystals. Both sets of crystals were suitable for X-ray diffraction.

- Data for carbamate $(E)-\mathbf{1 3}$ :

m.p. $96-97^{\circ} \mathrm{C}$;

$\mathbf{R}_{\mathbf{f}} 0.21$ (10\% Et ${ }_{2} \mathrm{O} / 40-60$ petroleum ether);

IR (thin film, $v_{\max } / \mathrm{cm}^{-1}$ ) 3067, 1714, 1597, 1493, 1382, 1295, 1250, 1202, 1139, 1045, 1020, 762, 733, 696;

${ }^{1} \mathbf{H}$ NMR $\left(400 \mathrm{MHz}, \mathrm{CDCl}_{3}\right) \delta_{\mathrm{H}} 7.66-7.53\left(2 \mathrm{H}, \mathrm{m}, H 10^{\prime}\right), 7.43-7.22\left(10 \mathrm{H}, \mathrm{m}, H 2^{\prime}, H 5^{\prime}, H 6^{\prime}, H 7^{\prime}, H 8^{\prime}\right.$, $\left.H 9^{\prime}\right), 7.22-7.09\left(3 \mathrm{H}, \mathrm{m}, H 1^{\prime}, H 3^{\prime}\right), 6.42\left(1 \mathrm{H}, \mathrm{s}, H 11^{\prime}\right), 5.15$ (2H, s, $\left.H 4^{\prime}\right)$;

${ }^{13} \mathbf{C}$ NMR $\left(101 \mathrm{MHz}, \mathrm{CDCl}_{3}\right) \delta_{\mathrm{C}} 154.5,141.6,141.1,135.7,134.1,128.9,128.8,128.6,128.4,128.2$, $128.0,127.9,126.0,125.2,119.1,67.9$;

HRMS (ES+) calc. for $\mathrm{C}_{22} \mathrm{H}_{19}{ }^{35} \mathrm{ClNO}_{2}[\mathrm{M}+\mathrm{H}]^{+}$364.1099, found 364.1100.

- Data for ester 14:

m.p. $78-80{ }^{\circ} \mathrm{C}$;

$\mathbf{R}_{\mathbf{f}} 0.46\left(10 \% \mathrm{Et}_{2} \mathrm{O} / 40-60\right.$ petroleum ether);

IR (thin film, $v_{\max } / \mathrm{cm}^{-1}$ ) 3232, 3064, 3034, 1650, 1594, 1567, 1499, 1421, 1254, 1225, 1132, 1049, $781,765,754,696$; 
${ }^{1} \mathbf{H}$ NMR $\left(400 \mathrm{MHz}, \mathrm{CDCl}_{3}\right) \delta_{\mathrm{H}} 10.8(1 \mathrm{H}, \mathrm{s}, \mathrm{N} H), 7.52-7.44\left(2 \mathrm{H}, \mathrm{m}, H 10^{\prime}\right), 7.44-7.38\left(2 \mathrm{H}, \mathrm{m}, H 9^{\prime}\right)$, 7.38-7.29 (6H, m, $\left.H 5^{\prime}, H 6^{\prime}, H 7^{\prime}, H 8^{\prime}\right), 7.09-7.00\left(2 \mathrm{H}, \mathrm{m}, H 2^{\prime}\right), 6.94-6.88\left(1 \mathrm{H}, \mathrm{m}, H 1^{\prime}\right), 6.64-6.58$ $\left(2 \mathrm{H}, \mathrm{m}, H 3^{\prime}\right), 5.34\left(2 \mathrm{H}, \mathrm{s}, H 4^{\prime}\right)$;

${ }^{13} \mathbf{C}$ NMR $\left(101 \mathrm{MHz}, \mathrm{CDCl}_{3}\right) \delta_{\mathrm{C}} 167.5,157.4,139.6,136.2,133.6,129.5,129.3,128.6,128.5,128.3$, 128.0, 127.8, 123.7, 122.7, 93.5, 66.5;

HRMS (ES+) calc. for $\mathrm{C}_{22} \mathrm{H}_{19}{ }^{35} \mathrm{ClNO}_{2}[\mathrm{M}+\mathrm{H}]^{+}$364.1099, found 364.1100. 


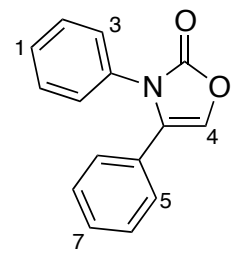

S5

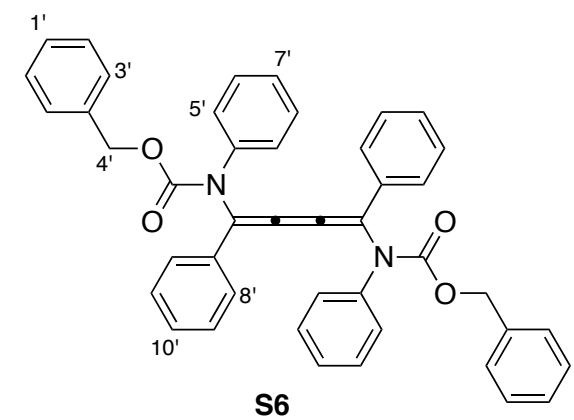

Following example procedure 1.3f: Synthesised from benzyl (E)-(1,2-dichlorovinyl)(phenyl) carbamate (500 mg, $1.55 \mathrm{mmol}, 1.0$ equiv.) in anhydrous toluene (4 mL) using LiHMDS (freshly prepared according to example procedure 1.3f, 1.2 equiv. using anhydrous toluene $(1.5 \mathrm{~mL})$ and anhydrous $\mathrm{Et}_{3} \mathrm{~N}(2.60 \mathrm{~mL}, 15.5 \mathrm{mmol}, 10$ equiv.)). The diarylzinc solution was prepared using anhydrous toluene $(1.0 \mathrm{~mL})$, phenylmagnesium bromide $\left(0.57 \mathrm{~mL}\right.$ of a $2.8 \mathrm{M}$ solution in $\mathrm{Et}_{2} \mathrm{O}$, $1.63 \mathrm{mmol}, 1.05$ equiv.), zinc(II) chloride (0.43 mL of a $1.9 \mathrm{M}$ solution in 2-MeTHF, $0.823 \mathrm{mmol}$, 0.53 equiv.), and the reaction conducted using $\mathrm{CuCN} \cdot 2 \mathrm{LiCl}(20 \mu \mathrm{L}$ of a $1.0 \mathrm{M}$ solution in THF, 20 $\mu \mathrm{mol}, 1.25 \mathrm{~mol} \%)$. Upon completion, the reaction was worked up and extracted as for example procedure 1.3f. Column chromatography $\left(5 \% \rightarrow 50 \% \mathrm{Et}_{2} \mathrm{O} / 40-60\right.$ petroleum ether) afforded the desired ynamide 13a (254 mg, $0.775 \mathrm{mmol}, 50 \%$ ) as a pale yellow powder, and a mixed fraction containing both title compounds $(71.6 \mathrm{mg})$ as a brown foam. Crystallisation of the foam (MeOH/benzene) afforded the cumulene S5 ( $\sim 5 \mathrm{mg}, 8 \mu \mathrm{mol}, 1 \%)$ as lemon yellow microcrystals, and the oxazolone $\mathbf{S 6}$ remained in solution. The microcrystals were too small for X-ray diffraction studies. The remaining solution was concentrated and recolumned (10\% EtOAc/pentane) to afford the oxazolone as an off-white powder, which was recrystallised from heptane plus 2 drops each of benzene and ethanol to give S5 (43.1 mg, $0.182 \mathrm{mmol}, 12 \%)$ as colourless plates. These plates were suitable for X-ray diffraction.

- Data for oxazolone S5:

m.p. $129-130{ }^{\circ} \mathrm{C}$;

$\mathbf{R}_{\mathbf{f}} 0.08\left(10 \% \mathrm{Et}_{2} \mathrm{O} / 40-60\right.$ petroleum ether);

IR (thin film, $v_{\max } / \mathrm{cm}^{-1}$ ) 3063, 2919, 1757, 1597, 1499, 1448, 1381, 1308, 1261, 1176, 1081, 975, $761,729,694,656$;

${ }^{1} \mathbf{H}$ NMR $\left(400 \mathrm{MHz}, \mathrm{CDCl}_{3}\right) \delta_{\mathrm{H}} 7.37-7.23(6 \mathrm{H}, \mathrm{m}, H 1, H 2, H 6, H 7), 7.21-7.16(2 \mathrm{H}, \mathrm{m}, H 3), 7.09-$ $7.04(2 \mathrm{H}, \mathrm{m}, H 5), 7.01(1 \mathrm{H}, \mathrm{s}, H 4)$;

${ }^{13} \mathbf{C}$ NMR $\left(101 \mathrm{MHz}, \mathrm{CDCl}_{3}\right) \delta_{\mathrm{C}} 154.9,133.9,129.5,129.1,129.0,128.7,127.9,127.5,126.6,126.4$, 124.8 ;

HRMS (ES+) calc. for $\mathrm{C}_{15} \mathrm{H}_{12} \mathrm{NO}_{2}[\mathrm{M}+\mathrm{H}]^{+}$238.0863, found 238.0864 . 
- Data for cumulene S6:

$\mathbf{R}_{\mathbf{f}} 0.08$ ( $10 \% \mathrm{Et}_{2} \mathrm{O} / 40-60$ petroleum ether);

IR (thin film, $v_{\max } / \mathrm{cm}^{-1}$ ) 3059, 2953, 1765, 1718, 1595, 1490, 1446, 1382, 1318, 1273, 1225, 1082, 1045, 1021, 761, 693;

${ }^{1}$ H NMR $\left(400 \mathrm{MHz}, \mathrm{CDCl}_{3}\right) * \delta_{\mathrm{H}} 7.41-7.33\left(5 \mathrm{H}, \mathrm{m}, \mathrm{Ph} H^{\prime}\right), 7.25-7.11\left(6 \mathrm{H}, \mathrm{m}, \mathrm{Ph} H^{\prime}\right), 7.10-7.05(2 \mathrm{H}$, m, $\left.H 7^{\prime}\right), 7.04-6.98\left(2 \mathrm{H}, \mathrm{m}, H 4^{\prime}\right), 5.10\left(2 \mathrm{H}, \mathrm{s}, H 3^{\prime}\right)$;

${ }^{13}$ C NMR $\left(101 \mathrm{MHz}, \mathrm{CDCl}_{3}\right) * \delta_{\mathrm{C}} 154.9(\mathrm{~m}), 154.4,149.2(\mathrm{~m}), 148.4,141.7,141.5(\mathrm{~m}), 136.3(\mathrm{~m})$, 136.2, 135.7 (m), 135.5, 133.9, 129.2, 129.0, 128.8, 128.73, 128.71, 128.6, 128.5, 128.3, 127.94, $127.90,127.8,127.5,126.6,126.5,126.4,126.0,125.9,125.7,124.8,121.7,68.1,67.9(\mathrm{~m})$;

HRMS (ES+) calc. for $\mathrm{C}_{44} \mathrm{H}_{34} \mathrm{~N}_{2} \mathrm{NaO}_{4}[\mathrm{M}+\mathrm{Na}]^{+}$677.2411, found 677.2409.

*Note: The data includes peaks for both $(E)$ - and $(Z)$ - isomers, which for the most part were indistinguishable. The label $(\mathrm{m})$ indicates peaks that clearly belong to the minor isomer. This compound was found to undergo slow isomerisation whilst in $\mathrm{CDCl}_{3}$ solution. 


\section{4a Urea Scope: Dichloroenamides}

\section{(E)-1-(1,2-Dichlorovinyl)-3-methyl-1,3-diphenylurea, 9h}
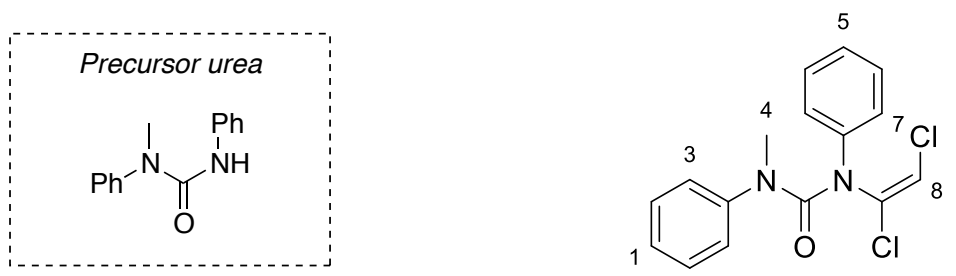

Following example procedure 1.3b: Synthesised from 1-methyl-1,3-diphenylurea (1.00 g, $4.42 \mathrm{mmol}$, 1.0 equiv.) and tetrabutylammonium hydrogensulfate $(375 \mathrm{mg}, 1.11 \mathrm{mmol}, 0.25$ equiv.) in toluene $(44 \mathrm{~mL})$ using $50 \% \mathrm{w} / \mathrm{v}$ aqueous solution of $\mathrm{KOH}(20 \mathrm{~mL})$ and trichloroethylene $(1.19 \mathrm{~mL}$, $13.3 \mathrm{mmol}, 3.0$ equiv.) added dropwise over 2 minutes at $60{ }^{\circ} \mathrm{C}$. The reaction takes approximately 2 hours to reach completion. Recrystallisation from heptane (a hot filtration was required to remove tarry residues) afforded the title compound $(1.24 \mathrm{~g}, 3.85 \mathrm{mmol}, 87 \%)$ as colourless crystals. ${ }^{*}$ Note: This compound is found to be unstable upon prolonged storage and should be used within a couple of days.

m.p. $113-114{ }^{\circ} \mathrm{C}$;

$\mathbf{R}_{\mathbf{f}} 0.25$ (10\% EtOAc/pentane);

IR (thin film, $v_{\max } / \mathrm{cm}^{-1}$ ) 3090, 1675, 1595, 1493, 1420, 1354, 1294, 1274, 1174, 1126, 906, 831, 798, 754, 731, 692, 664;

${ }^{1} \mathbf{H}$ NMR $\left(400 \mathrm{MHz}, \mathrm{CDCl}_{3}\right) \delta_{\mathrm{H}} 7.24-7.16(4 \mathrm{H}, \mathrm{m}, H 2, H 6), 7.15-7.06(4 \mathrm{H}, \mathrm{m}, H 3, H 7), 7.05-6.99$ (2H, m, H1, H5), $6.01(1 \mathrm{H}, \mathrm{s}, H 8), 3.34(3 \mathrm{H}, \mathrm{s}, H 4)$;

${ }^{13}$ C NMR $\left(101 \mathrm{MHz}, \mathrm{CDCl}_{3}\right) \delta_{\mathrm{C}} 156.4,143.6,140.1,133.0,129.0,128.8,126.3,126.19,126.17$, 125.6, 113.4, 39.7;

HRMS (ES+) calc. for $\mathrm{C}_{16} \mathrm{H}_{15}{ }^{35} \mathrm{Cl}_{2} \mathrm{~N}_{2} \mathrm{O}[\mathrm{M}+\mathrm{H}]^{+} 321.0556$, found 321.0557 . 
(E)-N-(1,2-Dichlorovinyl)- $N$-phenylpyrrolidine-1-carboxamide, $9 \mathrm{i}$
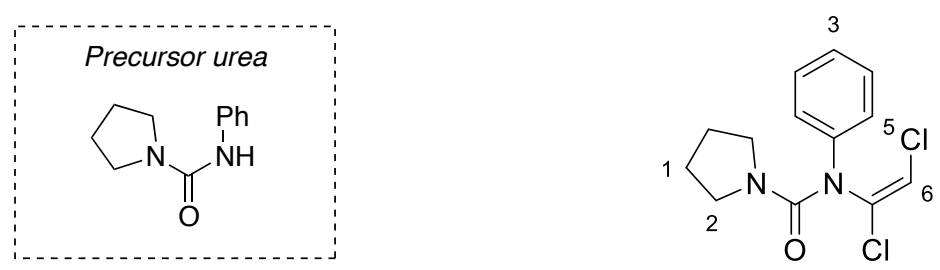

Following example procedure 1.3b: Synthesised from $N$-phenylpyrrolidine-1-carboxamide $(1.00 \mathrm{~g}$, $5.26 \mathrm{mmol}, 1.0$ equiv.) and tetrabutylammonium hydrogensulfate (446 mg, $1.32 \mathrm{mmol}, 0.25$ equiv.) in toluene $(50 \mathrm{~mL})$ using $50 \% \mathrm{w} / \mathrm{v}$ aqueous solution of $\mathrm{KOH}(25 \mathrm{~mL})$ and trichloroethylene $(1.42 \mathrm{~mL}$, $15.8 \mathrm{mmol}, 3.0$ equiv.) added dropwise over 2 minutes at $60{ }^{\circ} \mathrm{C}$. The reaction takes approximately 2 hours to reach completion. Recrystallisation from heptane (a hot filtration was required to remove tarry residues) afforded the title compound (1.31 g, $4.72 \mathrm{mmol}, 87 \%)$ as pale yellow needles. *Note: This compound is found to be unstable upon prolonged storage and should be used within a couple of days;

m.p. $74-76^{\circ} \mathrm{C}$;

$\mathbf{R}_{\mathbf{f}} 0.44$ (30\% EtOAc/40-60 petroleum ether);

IR (thin film, $v_{\max } / \mathrm{cm}^{-1}$ ) 3066, 2974, 2880, 1672, 1594, 1491, 1395, 1342, 1261, 1228, 1192, 755, 698 ;

${ }^{1} \mathbf{H}$ NMR $\left(400 \mathrm{MHz}, \mathrm{CDCl}_{3}\right) \delta_{\mathrm{H}} 7.40-7.31(2 \mathrm{H}, \mathrm{m}, H 4), 7.24-7.18(1 \mathrm{H}, \mathrm{m}, H 3), 7.17-7.11(2 \mathrm{H}, \mathrm{m}$, $H 5), 6.26$ (1H, s, H6), 3.56-3.06 (4H, br. m, H2), 1.90-1.75 (4H, m, H1);

${ }^{13}$ C NMR $\left(101 \mathrm{MHz}, \mathrm{CDCl}_{3}\right) \delta_{\mathrm{C}} 154.8,140.0,132.8,129.3,125.9,124.4,113.3,47.7,25.3$;

HRMS (ES+) calc. for $\mathrm{C}_{13} \mathrm{H}_{15}{ }^{35} \mathrm{Cl}_{2} \mathrm{~N}_{2} \mathrm{O}[\mathrm{M}+\mathrm{H}]^{+}$285.0556, found 285.0557. 


\section{(E)- $N$-(1,2-Dichlorovinyl)- $N$-phenylmorpholine-4-carboxamide, 9 j}
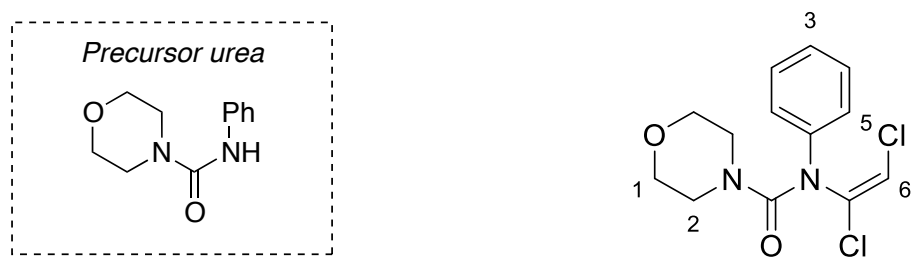

Following example procedure 1.3b: Synthesised from $N$-phenylmorpholine-4-carboxamide $(1.00 \mathrm{~g}$, $4.85 \mathrm{mmol}, 1.0$ equiv.) and tetrabutylammonium hydrogensulfate (412 mg, $1.21 \mathrm{mmol}, 0.25$ equiv.) in toluene $(50 \mathrm{~mL})$ using $50 \% \mathrm{w} / \mathrm{v}$ aqueous solution of $\mathrm{KOH}(25 \mathrm{~mL})$ and trichloroethylene $(1.31 \mathrm{~mL}$, $14.6 \mathrm{mmol}, 3.0$ equiv.) added dropwise over 2 minutes at $60^{\circ} \mathrm{C}$. The reaction takes approximately 1.5 hours to reach completion. Recrystallisation from heptane (a hot filtration was required to remove tarry residues) afforded the title compound (1.26 g, $4.18 \mathrm{mmol}, 86 \%)$ as pale yellow crystals. ${ }^{*}$ Note: This compound is found to be unstable upon prolonged storage and should be used within a couple of days;

m.p. $116-118^{\circ} \mathrm{C}$;

$\mathbf{R}_{\mathbf{f}} 0.44$ (50\% EtOAc/pentane);

IR (thin film, $v_{\max } / \mathrm{cm}^{-1}$ ) 2,967, 2,922, 2,858, 1,677, 1,594, 1,492, 1,452, 1,421, 1,338, 1,300, 1,270, $1,236,1,114,754,696$;

${ }^{1} \mathbf{H}$ NMR $\left(400 \mathrm{MHz}, \mathrm{CDCl}_{3}\right) \delta_{\mathrm{H}} 7.42-7.34(2 \mathrm{H}, \mathrm{m}, H 4), 7.25-7.19(1 \mathrm{H}, \mathrm{m}, H 3), 7.14-7.07(2 \mathrm{H}, \mathrm{m}$, H5), 6.28 (1H, s, H6), 3.64-3.55 (4H, m, H1), 3.43-3.35 (4H, m, H2);

${ }^{13} \mathbf{C}$ NMR $\left(101 \mathrm{MHz}, \mathrm{CDCl}_{3}\right) \delta_{\mathrm{C}} 155.9,140.2,133.0,129.6,126.2,123.5,113.6,66.4,46.0$;

HRMS (ES+) calc. for $\mathrm{C}_{13} \mathrm{H}_{14}{ }^{35} \mathrm{Cl}_{2} \mathrm{~N}_{2} \mathrm{NaO}_{2}[\mathrm{M}+\mathrm{Na}]^{+} 323.0325$, found 323.0325 . 
(E)-1,1-Dibenzyl-3-(1,2-dichlorovinyl)-3-phenylurea, 9k
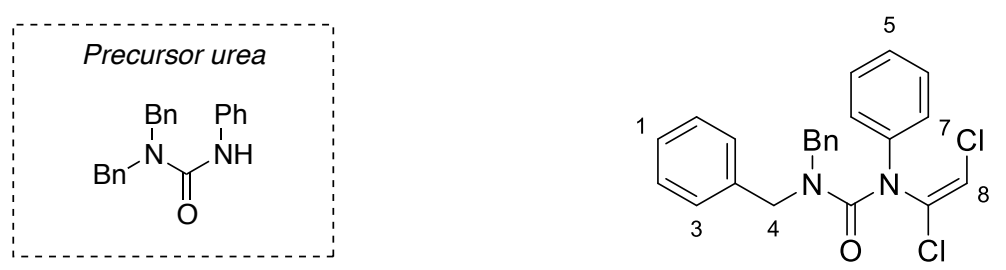

Following example procedure 1.3b: Synthesised from $N, N$-dibenzyl- $N$ '-phenylurea $(1.00 \mathrm{~g}$, $3.16 \mathrm{mmol}, 1.0$ equiv.) and tetrabutylammonium hydrogensulfate (268 mg, $0.790 \mathrm{mmol}, 0.25$ equiv.) in toluene $(30 \mathrm{~mL})$ using $50 \% \mathrm{w} / \mathrm{v}$ aqueous solution of $\mathrm{KOH}(15 \mathrm{~mL})$ and trichloroethylene $(0.85 \mathrm{~mL}$, $9.48 \mathrm{mmol}, 3.0$ equiv.) added dropwise over 2 minutes at $60{ }^{\circ} \mathrm{C}$. The reaction takes approximately 2 hours to reach completion. Recrystallisation from heptane (a hot filtration was required to remove tarry residues) afforded the title compound (1.23 g, $2.98 \mathrm{mmol}, 94 \%)$ as pale yellow needles. ${ }^{*}$ Note: This compound is found to be unstable upon prolonged storage and should be used within a couple of days.

m.p. $104-105^{\circ} \mathrm{C}$;

$\mathbf{R}_{\mathbf{f}}$ 0.65(20\% EtOAc/40-60 petroleum ether);

IR (thin film, $v_{\max } / \mathrm{cm}^{-1}$ ) 2909, 1669, 1595, 1494, 1455, 1404, 1227, 1142, 1079, 908, 814, 731, 694;

${ }^{1} \mathbf{H}$ NMR $\left(400 \mathrm{MHz}, \mathrm{CDCl}_{3}\right) \delta_{\mathrm{H}} 7.36-7.26(8 \mathrm{H}, \mathrm{m}, H 1, H 2, H 6), 7.21(1 \mathrm{H}, \mathrm{tt}, J=7.3,1.2 \mathrm{~Hz}, H 5)$, 7.20-7.15 (4H, m, H3), 7.13-7.07 (2H, m, H7), 6.29 (1H, s, H8), 4.35 (4H, s, H4);

${ }^{13} \mathbf{C}$ NMR $\left(101 \mathrm{MHz}, \mathrm{CDCl}_{3}\right) \delta_{\mathrm{C}} 157.9,140.7,136.1,133.6,129.5,128.5,128.4,127.6,126.2,124.1$, 113.9, 50.4;

HRMS (ES+) calc. for $\mathrm{C}_{23} \mathrm{H}_{20}{ }^{35} \mathrm{Cl}_{2} \mathrm{~N}_{2} \mathrm{NaO}[\mathrm{M}+\mathrm{Na}]^{+} 433.0845$, found 433.0842 . 
(E)-1,1,3-Tribenzyl-3-(1,2-dichlorovinyl)urea, 91
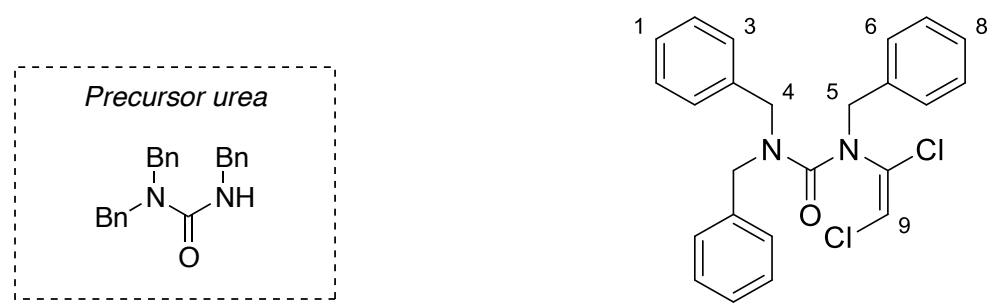

Following example procedure 1.3b: Synthesised from 1,1,3-tribenzylurea (500 mg, $1.51 \mathrm{mmol}$, 1.0 equiv.) and tetrabutylammonium hydrogensulfate (128 $\mathrm{mg}, 0.378 \mathrm{mmol}, 0.25$ equiv.) in toluene $(15 \mathrm{~mL})$ using $50 \% \mathrm{w} / \mathrm{v}$ aqueous solution of $\mathrm{KOH}(7.5 \mathrm{~mL})$ and trichloroethylene $(0.41 \mathrm{~mL}$, $4.54 \mathrm{mmol}, 3.0$ equiv.) added dropwise over 2 minutes at $60{ }^{\circ} \mathrm{C}$. The reaction was halted after 48 hours. Column chromatography $\left(4 \% \mathrm{Et}_{2} \mathrm{O} /\right.$ pentane) gave a yellow oil which was crystallised from heptane $(\sim 1 \mathrm{~mL})$ plus 2 drops of benzene. This afforded the title compound (126 mg, $0.296 \mathrm{mmol}$, $20 \%$ ) as colourless crystals;

m.p. $73-75^{\circ} \mathrm{C}$;

$\mathbf{R}_{\mathbf{f}} 0.64$ (10\% EtOAc/pentane);

IR (thin film, $v_{\max } / \mathrm{cm}^{-1}$ ) 3088, 3030, 2927, 1667, 1495, 1454, 1407, 1363, 1313, 1275, 1223, 1134, 1076, 1029, 948, 815, 736, 698, 670;

${ }^{1} \mathbf{H}$ NMR $\left(400 \mathrm{MHz}, \mathrm{CDCl}_{3}\right) \delta_{\mathrm{H}} 7.55-7.47(2 \mathrm{H}, \mathrm{m}, \mathrm{H6}), 7.36-7.28(3 \mathrm{H}, \mathrm{m}, H 7, H 8), 7.28-7.18(6 \mathrm{H}$, m, H1, H2), 7.13-7.00 (4H, m, H3), $5.86(1 \mathrm{H}, \mathrm{s}, H 9), 4.65(2 \mathrm{H}, \mathrm{s}, H 5), 4.40(4 \mathrm{H}, \mathrm{s}, H 4)$;

${ }^{13} \mathrm{C}$ NMR $\left(101 \mathrm{MHz}, \mathrm{CDCl}_{3}\right) \delta_{\mathrm{C}} 159.3,136.3,136.2,134.1,129.4,128.4,128.2,128.0,127.7,127.3$, 112.4, 52.7, 50.1;

HRMS (ES+) calc. for $\mathrm{C}_{24} \mathrm{H}_{23}{ }^{35} \mathrm{Cl}_{2} \mathrm{~N}_{2} \mathrm{O}[\mathrm{M}+\mathrm{H}]^{+}$425.1182, found 425.1181 . 


\section{4b Urea Scope: Ynamides}

1-((4-Chlorophenyl)ethynyl)-3-methyl-1,3-diphenylurea, 13i \& (E)-1,1'-(1,4-Bis(4-chlorophenyl) buta-1,2,3-triene-1,4-diyl)bis(3-methyl-1,3-diphenylurea), S8

Precursor dichloroenamide<smiles>CN(C(=O)N(/C(Cl)=C\Cl)c1ccccc1)c1ccccc1</smiles>

9h

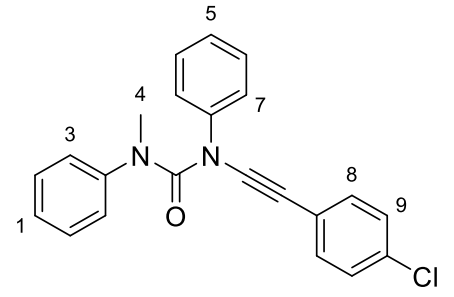

$13 \mathbf{i}$

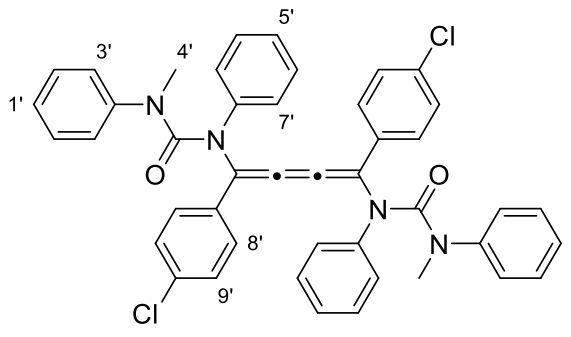

S8

Following example procedure 1.3f: Synthesised from (E)-1-(1,2-dichlorovinyl)-3-methyl-1,3diphenylurea (500 mg, $1.56 \mathrm{mmol}, 1.0$ equiv.) in anhydrous TBME (16 mL) using LiHMDS (freshly prepared according to example procedure 1.3f, 1.2 equiv.). The diarylzinc solution was prepared using anhydrous toluene $(5 \mathrm{~mL})$, 4-chlorophenylmagnesium bromide $\left(4.67 \mathrm{~mL}\right.$ of a $1.0 \mathrm{M}$ solution in $\mathrm{Et}_{2} \mathrm{O}$, $4.67 \mathrm{mmol}, 3.0$ equiv.), zinc(II) chloride (1.23 mL of a $1.9 \mathrm{M}$ solution in 2-MeTHF, $2.33 \mathrm{mmol}$, 1.5 equiv.) and TMEDA (2.33 mL, $15.6 \mathrm{mmol}, 10.0$ equiv.), and the reaction conducted using $\mathrm{CuCN} \cdot 2 \mathrm{LiCl}(20 \mu \mathrm{L}$ of a $1.0 \mathrm{M}$ solution in THF, $20 \mu \mathrm{mol}, 1.25 \mathrm{~mol} \%)$. Upon completion, the reaction was worked up and extracted as for example procedure 1.3f. Column chromatography $(0 \rightarrow 40 \%$ EtOAc/pentane) afforded yne-urea $\mathbf{1 3 i}$ as a pale yellow solid and the cumulene $\mathbf{S 6}$ as an intense yellow solid. Recrystallisation of the yne-urea from heptane/ $\mathrm{Et}_{2} \mathrm{O}(\sim 4: 1)$ afforded $395 \mathrm{mg}$ $(1.09 \mathrm{mmol}, 70 \%)$ as colourless needles. Recrystallisation of the cumulene from heptane/ $\mathrm{Et}_{2} \mathrm{O}(\sim 4: 1)$ afforded $31 \mathrm{mg}(42 \mu \mathrm{mol}, 5 \%)$ as golden yellow crystals. These crystals were suitable for X-ray diffraction;

- Data for yne-urea 13i:

m.p. $96-97^{\circ} \mathrm{C}$;

$\mathbf{R}_{\mathbf{f}} 0.35$ (10\% EtOAc/40-60 petroleum ether);

IR (thin film, $v_{\max } / \mathrm{cm}^{-1}$ ) 3065, 2243, 1686, 1595, 1492, 1420, 1351, 1274, 1239, 1141, 1115, 1090, 1014, 908, 827, 741, 693, 659;

${ }^{1} \mathbf{H}$ NMR $\left(400 \mathrm{MHz}, \mathrm{CDCl}_{3}\right) \delta_{\mathrm{H}} 7.40-7.27(6 \mathrm{H}, \mathrm{m}, \mathrm{Ph} H), 7.24-7.14(6 \mathrm{H}, \mathrm{m}, \mathrm{Ph} H(\times 4), H 8), 7.02-6.96$ (2H, m, H9), 3.43 (3H, m, H4);

${ }^{13} \mathbf{C}$ NMR $\left(101 \mathrm{MHz}, \mathrm{CDCl}_{3}\right) \delta_{\mathrm{C}} 156.8,144.2,140.9,133.2,132.4,129.3,128.9,128.3,126.3,125.7$, 125.4, 122.8, 121.6, 84.8, 70.5, 39.9;

HRMS (ES+) calc. for $\mathrm{C}_{22} \mathrm{H}_{18}{ }^{35} \mathrm{ClN}_{2} \mathrm{O}[\mathrm{M}+\mathrm{H}]^{+} 361.1102$, found 361.1103 . 
- Data for cumulene S8:

m.p. $>150{ }^{\circ} \mathrm{C}($ dec. $)$;

$\mathbf{R}_{\mathbf{f}} 0.07$ (10\% EtOAc/40-60 petroleum ether);

IR (thin film, $v_{\max } / \mathrm{cm}^{-1}$ ) 3063, 2938, 1669, 1595, 1494, 1486, 1455, 1419, 1352, 1273, 1159, 1108 , 1090, 1010, 830, 750, 731, 695;

${ }^{1} \mathbf{H}$ NMR $\left(400 \mathrm{MHz}, \mathrm{CDCl}_{3}\right) \delta_{\mathrm{H}} 7.33-7.26\left(2 \mathrm{H}, \mathrm{m}, H 6^{\prime}\right), 7.22-7.15\left(1 \mathrm{H}, \mathrm{m}, H 5^{\prime}\right), 7.08-7.04(2 \mathrm{H}, \mathrm{m}$, $\left.H 8^{\prime}\right), 7.04-7.96\left(5 \mathrm{H}, \mathrm{m}, H 1^{\prime}, H 2^{\prime}, H 3^{\prime}\right), 6.83-6.78\left(2 \mathrm{H}, \mathrm{m}, H 7^{\prime}\right), 6.69-6.63\left(2 \mathrm{H}, \mathrm{m}, H 9^{\prime}\right), 3.14$ (3H, m, $\left.H 4^{\prime}\right)$;

${ }^{13}$ C NMR $\left(101 \mathrm{MHz}, \mathrm{CDCl}_{3}\right) \delta_{\mathrm{C}} 158.3,145.3,143.5,143.4,134.6,133.8,129.1,128.8,128.3,126.9$, $126.0,125.8,125.3,125.1,121.4,39.1$;

HRMS (ES+) calc. for $\mathrm{C}_{44} \mathrm{H}_{35}{ }^{35} \mathrm{Cl}_{2} \mathrm{~N}_{4} \mathrm{O}_{2}[\mathrm{M}+\mathrm{H}]^{+} 721.2132$, found 721.2132 . 

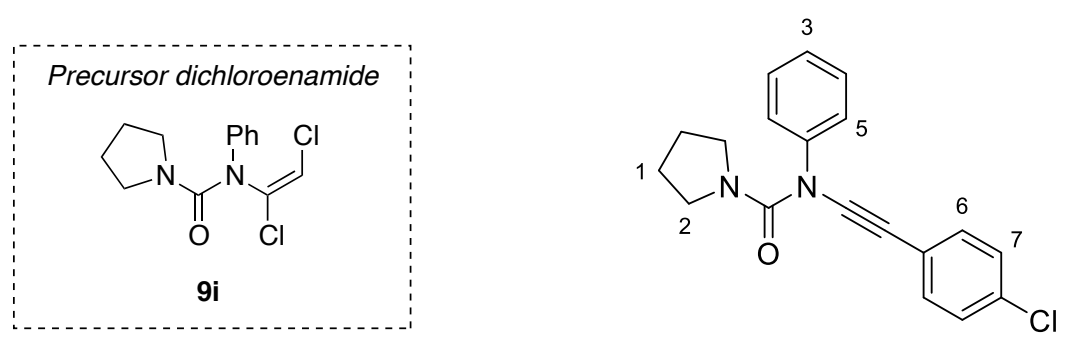

Following example procedure 1.3f: Synthesised from (E)- $N$-(1,2-dichlorovinyl)- $N$-phenylpyrrolidine1-carboxamide (200 mg, $0.701 \mathrm{mmol}, 1.0$ equiv.) in anhydrous TBME (7 mL) using LiHMDS (freshly prepared according to example procedure 1.3f, 1.2 equiv.). The diarylzinc solution was prepared using anhydrous toluene $(2 \mathrm{~mL})$, 4-chlorophenylmagnesium bromide $(2.10 \mathrm{~mL}$ of a $1.0 \mathrm{M}$ solution in $\mathrm{Et}_{2} \mathrm{O}, 2.10 \mathrm{mmol}, 3.0$ equiv.), zinc(II) chloride (0.55 mL of a $1.9 \mathrm{M}$ solution in 2-MeTHF, $1.05 \mathrm{mmol}, 1.5$ equiv.) and anhydrous TMEDA (1.05 mL, $7.01 \mathrm{mmol}, 10.0$ equiv.), and the reaction conducted using $\mathrm{CuCN} \cdot 2 \mathrm{LiCl}(9 \mu \mathrm{L}$ of a $1.0 \mathrm{M}$ solution in THF, $9 \mu \mathrm{mol}, 1.25 \mathrm{~mol} \%)$. Upon completion, the reaction was worked up and extracted as for example procedure 1.3f. Column chromatography ( $20 \% \mathrm{CH}_{2} \mathrm{Cl}_{2} / 10 \%$ EtOAc/pentane $\rightarrow 20 \% \mathrm{CH}_{2} \mathrm{Cl}_{2} / 15 \%$ EtOAc/pentane) afforded a pale yellow oil that was crystallised by flash freezing a concentrated solution of the title compound in heptane $(\sim 1 \mathrm{~mL})$, plus two drops of toluene, at $-78{ }^{\circ} \mathrm{C}$, and allowing the frozen mixture to warm gradually to $-20{ }^{\circ} \mathrm{C}$ in a freezer overnight. This afforded the title compound $(163 \mathrm{mg}, 0.501 \mathrm{mmol}$, $71 \%$ ) as colourless crystals;

m.p. $46-47^{\circ} \mathrm{C}$;

$\mathbf{R}_{\mathbf{f}} 0.28$ (20\% EtOAc/pentane);

IR (thin film, $v_{\max } / \mathrm{cm}^{-1}$ ) 2973, 2881, 2237, 1681, 1595, 1490, 1377, 1230, 1189, 1123, 1089, 1013, $827,753,692$;

${ }^{1} \mathbf{H}$ NMR $\left(400 \mathrm{MHz}, \mathrm{CDCl}_{3}\right) \delta_{\mathrm{H}} 7.43-7.36(4 \mathrm{H}, \mathrm{m}, \mathrm{H4}, \mathrm{H5}), 7.36-7.32(2 \mathrm{H}, \mathrm{m}, \mathrm{H6}), 7.31-7.25(2 \mathrm{H}$, m, H7), $7.18(1 \mathrm{H}, \mathrm{tt}, J=6.7,1.9 \mathrm{~Hz}, H 3), 4.67-4.65(4 \mathrm{H}, \mathrm{m}, H 2), 1.98-1.88(4 \mathrm{H}, \mathrm{m}, H 1)$;

${ }^{13} \mathbf{C}$ NMR $\left(101 \mathrm{MHz}, \mathrm{CDCl}_{3}\right) \delta_{\mathrm{C}} 155.0,140.8,133.3,132.2,129.0,128.6,125.2,122.2,122.0,85.2$, $70.1,48.3,25.5$;

HRMS (ES+) calc. for $\mathrm{C}_{19} \mathrm{H}_{18}{ }^{35} \mathrm{ClN}_{2} \mathrm{O}[\mathrm{M}+\mathrm{H}]^{+} 325.1102$, found 325.1103 . 


\section{$N$-((4-Chlorophenyl)ethynyl)- $N$-phenylmorpholine-4-carboxamide, 13k}
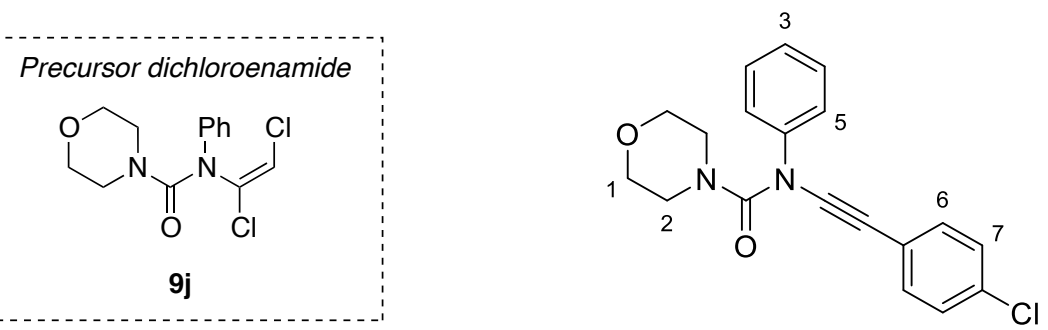

Following example procedure 1.3f: Synthesised from $(E)-N$-(1,2-dichlorovinyl)- $N$-phenylmorpholine1-carboxamide (300 mg, $0.996 \mathrm{mmol}, 1.0$ equiv.) in anhydrous TBME (10 mL) using LiHMDS (freshly prepared according to example procedure 1.3f, 1.2 equiv.). The diarylzinc solution was prepared using anhydrous toluene $(3 \mathrm{~mL})$, 4-chlorophenylmagnesium bromide $(2.99 \mathrm{~mL}$ of a $1.0 \mathrm{M}$ solution in $\mathrm{Et}_{2} \mathrm{O}, 2.99 \mathrm{mmol}, 3.0$ equiv.), zinc(II) chloride (0.79 $\mathrm{mL}$ of a $1.9 \mathrm{M}$ solution in 2-MeTHF, $1.49 \mathrm{mmol}, 1.5$ equiv.) and anhydrous TMEDA (1.49 mL, $4.86 \mathrm{mmol}, 10.0$ equiv.), and the reaction conducted using $\mathrm{CuCN} \cdot 2 \mathrm{LiCl}(12 \mu \mathrm{L}$ of a $1.0 \mathrm{M}$ solution in THF, $12 \mu \mathrm{mol}, 1.25 \mathrm{~mol} \%)$. Upon completion, the reaction was worked up and extracted as for example procedure 1.3f. Column chromatography $\left(20 \% \mathrm{CH}_{2} \mathrm{Cl}_{2} / 10 \%\right.$ EtOAc/pentane $\rightarrow 20 \% \mathrm{CH}_{2} \mathrm{Cl}_{2} / 15 \%$ EtOAc/pentane) afforded the title compound (163 $\mathrm{mg}, 0.501 \mathrm{mmol}, 71 \%$ ) as a colourless solid. This compound can be recrystallised from heptane $(\sim 1 \mathrm{~mL})$ plus a few drops of toluene to give colourless crystals;

m.p. $122-123{ }^{\circ} \mathrm{C}$;

$\mathbf{R}_{\mathbf{f}} 0.35$ (30\% EtOAc/pentane);

IR (thin film, $v_{\max } / \mathrm{cm}^{-1}$ ) 2965, 2919, 2856, 2240, 1686, 1596, 1491, 1451, 1413, 1360, 1300, 1271, $1237,1114,1089,1071,1056,1013,984,828,752,691,647$;

${ }^{1} \mathbf{H}$ NMR $\left(400 \mathrm{MHz}, \mathrm{CDCl}_{3}\right) \delta_{\mathrm{H}} 7.43-7.35(4 \mathrm{H}, \mathrm{m}, H 4, H 5), 7.35-7.31(2 \mathrm{H}, \mathrm{m}, H 6), 7.31-7.27(2 \mathrm{H}$, m, H7), $7.20(1 \mathrm{H}, \mathrm{tt}, J=6.4,2.2 \mathrm{~Hz}, H 3), 4.79-4.71$ (4H, m, H2), 4.71-4.64 (4H, m, H1);

${ }^{13} \mathbf{C}$ NMR $\left(101 \mathrm{MHz}, \mathrm{CDCl}_{3}\right) \delta_{\mathrm{C}} 156.6,140.7,133.6,132.2,129.1,128.7,125.4,121.6,121.5,84.8$, 70.3, 66.6, 46.5;

HRMS (ES+) calc. for $\mathrm{C}_{19} \mathrm{H}_{18}{ }^{35} \mathrm{ClN}_{2} \mathrm{O}_{2}[\mathrm{M}+\mathrm{H}]^{+}$341.1051, found 341.1052. 


\section{1,1-Dibenzyl-3-((4-chlorophenyl)ethynyl)-3-phenylurea, 131}
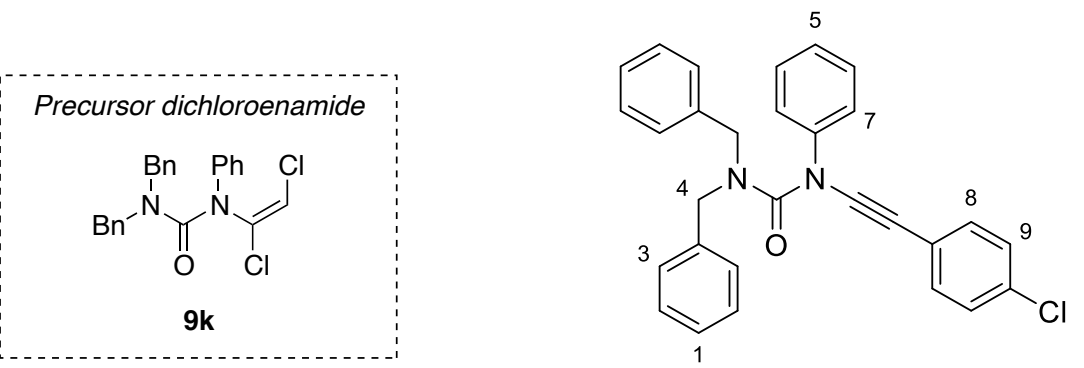

Following example procedure 1.3f: Synthesised from (E)-1,1-dibenzyl-3-(1,2-dichlorovinyl)-3phenylurea (500 mg, $1.22 \mathrm{mmol}, 1.0$ equiv.) in anhydrous TBME (12 mL) using LiHMDS (freshly prepared according to example procedure 1.3f, 1.2 equiv.). The diarylzinc solution was prepared using anhydrous toluene $(4 \mathrm{~mL})$, 4-chlorophenylmagnesium bromide $\left(3.65 \mathrm{~mL}\right.$ of a $1.0 \mathrm{M}$ solution in $\mathrm{Et}_{2} \mathrm{O}$, $3.65 \mathrm{mmol}, 3.0$ equiv.), zinc(II) chloride (0.96 mL of a $1.9 \mathrm{M}$ solution in 2-MeTHF, $1.82 \mathrm{mmol}$, 1.5 equiv.) and anhydrous TMEDA (1.82 mL, $12.2 \mathrm{mmol}, 10.0$ equiv.), and the reaction conducted using $\mathrm{CuCN} \cdot 2 \mathrm{LiCl}(15 \mu \mathrm{L}$ of a $1.0 \mathrm{M}$ solution in THF, $15 \mu \mathrm{mol}, 1.25 \mathrm{~mol} \%)$. Upon completion, the reaction was worked up and extracted as for example procedure 1.3f. Column chromatography (10\% $\mathrm{CH}_{2} \mathrm{Cl}_{2} / 2 \%$ EtOAc/pentane $\rightarrow 10 \% \mathrm{CH}_{2} \mathrm{Cl}_{2} / 4 \%$ EtOAc/pentane) afforded the title compound (397 $\mathrm{mg}, 0.880 \mathrm{mmol}, 72 \%$ ) as a thick, pale yellow oil.

Crystallisation was accomplished using the following procedure: This material was dissolved in ethanol $(\sim 2 \mathrm{~mL})$ with a couple of drops of benzene, and the solution was flash frozen at $-78{ }^{\circ} \mathrm{C}$. After allowing the frozen mixture to warm gradually to room temperature $\left(\sim 21^{\circ} \mathrm{C}\right)$, this was repeated twice more to initiate seed formation. Once a seed had grown, the solution was left at room temperature for 1 week to afford $444 \mathrm{mg}(0.839 \mathrm{mmol}, 69 \%)$ of the title compound as colourless crystals. Note: An equimolar amount of benzene co-crystallised with the compound;

m.p. $60-63{ }^{\circ} \mathrm{C}$;

$\mathbf{R}_{\mathbf{f}} 0.48$ (10\% EtOAc/pentane);

IR (thin film, $v_{\max } / \mathrm{cm}^{-1}$ ) 3031, 2240, 1687, 1596, 1492, 1454, 1407, 1359, 1234, 1119, 1089, 961, $826,752,693,661,607$;

${ }^{1} \mathbf{H}$ NMR $\left(400 \mathrm{MHz}, \mathrm{CDCl}_{3}\right) \delta_{\mathrm{H}} 7.41-7.23(14 \mathrm{H}, \mathrm{m}, H 1, H 2, H 3, H 6, H 7), 7.22-7.13(3 \mathrm{H}, \mathrm{m}, H 5$, H8), 7.11-7.05 (2H, m, H9), 4.65 (4H, s, H4);

${ }^{13} \mathbf{C}$ NMR $\left(101 \mathrm{MHz}, \mathrm{CDCl}_{3}\right) \delta_{\mathrm{C}} 157.9,140.9,136.4,133.3,132.0,129.0,128.7,128.5,128.0,127.7$, 125.2, 121.5, 84.8, 71.1, 50.7;

HRMS (ES+) calc. for $\mathrm{C}_{29} \mathrm{H}_{23}{ }^{35} \mathrm{ClN}_{2} \mathrm{NaO}[\mathrm{M}+\mathrm{Na}]^{+} 473.1391$, found 473.1392 . 


\section{1,1,3-Tribenzyl-3-((4-chlorophenyl)ethynyl)urea, $13 \mathrm{~m}$}
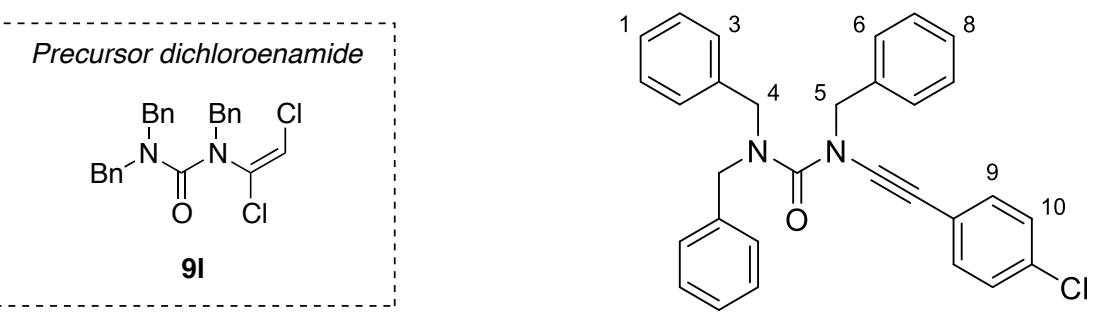

Following example procedure 1.3f: Synthesised from (E)-1,1,3-tribenzyl-3-(1,2-dichlorovinyl)urea (100 mg, $0.235 \mathrm{mmol}, 1.0$ equiv.) in anhydrous TBME (4 mL) using LiHMDS (freshly prepared according to example procedure 1.3f, 1.2 equiv.). The diarylzinc solution was prepared using anhydrous toluene $(2 \mathrm{~mL}), 4$-chlorophenylmagnesium bromide $\left(0.71 \mathrm{~mL}\right.$ of a $1.0 \mathrm{M}$ solution in $\mathrm{Et}_{2} \mathrm{O}$, $0.705 \mathrm{mmol}, 3.0$ equiv.), zinc(II) chloride $\left(0.19 \mathrm{~mL}\right.$ of a $1.0 \mathrm{M}$ solution in $\mathrm{Et}_{2} \mathrm{O}, 0.35 \mathrm{mmol}$, 1.5 equiv.) and anhydrous TMEDA ( $0.35 \mathrm{~mL}, 2.35 \mathrm{mmol}, 10.0$ equiv.), and the reaction conducted using $\mathrm{CuCN} \cdot 2 \mathrm{LiCl}$ ( $3 \mu \mathrm{L}$ of a $1.0 \mathrm{M}$ solution in THF, $3 \mu \mathrm{mol}, 1.25 \mathrm{~mol} \%$ ). Upon completion, the reaction was worked up and extracted as for example procedure 1.3f. Column chromatography $(2 \%$ $\rightarrow 5 \% \mathrm{Et}_{2} \mathrm{O} /$ pentane) afforded the title compound $(60.9 \mathrm{mg}, 0.131 \mathrm{mmol}, 56 \%)$ as a pale yellow oil. Crystallisation by slow evaporation of a solution of the title compound in heptane $(\sim 1 \mathrm{~mL})$ plus 3 drops of ethanol gave the title compound as colourless crystals.

m.p. $45-48{ }^{\circ} \mathrm{C}$;

$\mathbf{R}_{\mathbf{f}} 0.40\left(10 \% \mathrm{Et}_{2} \mathrm{O} /\right.$ pentane);

IR (thin film, $v_{\max } / \mathrm{cm}^{-1}$ ) 3064, 3031, 2928, 2236, 1666, 1494, 1453, 1433, 1410, 1263, 1224, 1116, 1089, 1076, 826, 733, 698;

${ }^{1} \mathbf{H}$ NMR $\left(400 \mathrm{MHz}, \mathrm{CDCl}_{3}\right) \delta_{\mathrm{H}} 7.45-7.37(2 \mathrm{H}, \mathrm{m}, \mathrm{Ph} H), 7.37-7.15(13 \mathrm{H}, \mathrm{m}, \mathrm{PhH}), 7.09-7.03$ (2H, m, H9), 6.69-6.63 (2H, m, H10), $4.76(2 \mathrm{H}, \mathrm{s}, H 5), 4.61$ (4H, s, H4);

${ }^{13} \mathbf{C}$ NMR $\left(101 \mathrm{MHz}, \mathrm{CDCl}_{3}\right) \delta_{\mathrm{C}} 158.9,136.7,136.4,132.7,131.3,129.0,128.6,128.4,128.3,127.9$, $127.8,127.4,121.8,86.8,71.2,55.1,50.8$

HRMS (ES+) calc. for $\mathrm{C}_{30} \mathrm{H}_{26}{ }^{35} \mathrm{ClN}_{2} \mathrm{O}[\mathrm{M}+\mathrm{H}]^{+} 465.1728$, found 465.1730 . 


\section{4c Urea Scope: Miscellaneous}

1-((4-Chlorophenyl)ethynyl)-3-methyl-1,3-diphenylurea, $13 i \quad \& \quad$ (Z)-1-(2-Chloro-1-(4-chloro phenyl)vinyl)-3-methyl-1,3-diphenylurea, S7

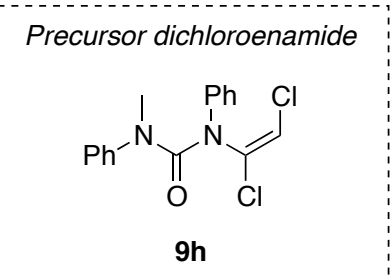

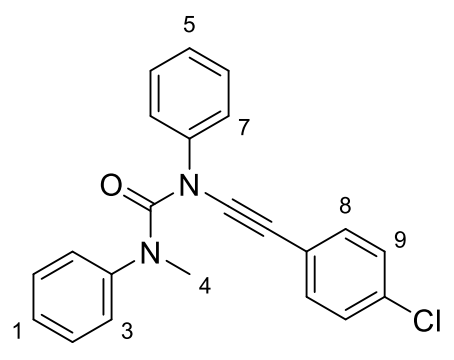

$13 \mathbf{i}$

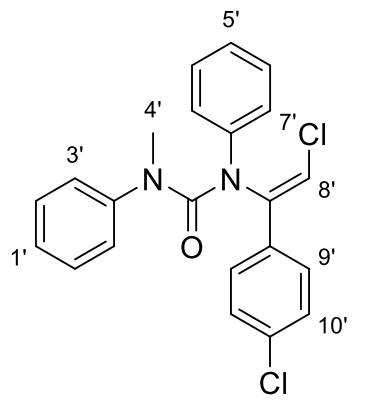

S7

Following example procedure 1.3f: Synthesised from (E)-1-(1,2-dichlorovinyl)-3-methyl-1,3diphenylurea (300 mg, $0.934 \mathrm{mmol}, 1.0$ equiv.) in anhydrous TBME (10 mL) using LiHMDS (freshly prepared according to example procedure 1.3f, 1.2 equiv.). The diarylzinc solution was prepared using anhydrous toluene $(4.0 \mathrm{~mL})$, 4-chlorophenylmagnesium bromide $(2.80 \mathrm{~mL}$ of a $1.0 \mathrm{M}$ solution in $\mathrm{Et}_{2} \mathrm{O}, 2.80 \mathrm{mmol}, 3.0$ equiv.), zinc(II) chloride (0.74 mL of a $1.9 \mathrm{M}$ solution in 2-MeTHF, $1.40 \mathrm{mmol}$, 1.5 equiv.), and the reaction conducted using $\mathrm{CuCN} \cdot 2 \mathrm{LiCl}(12 \mu \mathrm{L}$ of a $1.0 \mathrm{M}$ solution in THF, $12 \mu \mathrm{mol}, 1.25 \mathrm{~mol} \%$ ). Upon completion, the reaction was worked up and extracted as for example procedure 1.3f. Column chromatography ( $0 \rightarrow 10 \%$ EtOAc/pentane) afforded yne-urea 13i as a yellow solid and chloroenamide $\mathbf{S 7}$ as a colourless oil. Recrystallisation of yne-urea 13i from heptane/ $\mathrm{Et}_{2} \mathrm{O}(\sim 4: 1)$ afforded $244 \mathrm{mg}(0.650 \mathrm{mmol}, 70 \%)$ as colourless needles. Crystallisation of chloroenamide $\mathbf{S} 7$ from heptane plus a couple of drops of $\mathrm{Et}_{2} \mathrm{O}$ afforded $58.8 \mathrm{mg}(0.148 \mathrm{mmol}, 16 \%)$ as colourless crystals;

- Data for yne-urea 13i as before.

- Data for chloroenamide $\mathbf{S 7}$ :

m.p. $118-120^{\circ} \mathrm{C}$;

$\mathbf{R}_{\mathbf{f}} 0.28$ (10\% EtOAc/40-60 petroleum ether);

IR (thin film, $v_{\max } / \mathrm{cm}^{-1}$ ) 3080, 1666, 1596, 1493, 1456, 1420, 1400, 1357, 1297, 1278, 1164, 1112 , 1092, 1012, 909, 851, 816, 753, 731, 695;

${ }^{1}$ H NMR $\left(400 \mathrm{MHz}, \mathrm{CDCl}_{3}\right) \delta_{\mathrm{H}} 7.27-7.18\left(6 \mathrm{H}, \mathrm{m}, H 9^{\prime}, \mathrm{Ph} H^{\prime}(\times 4)\right)$, 7.16-7.11 (2H, m, H10'), 7.11$7.02\left(6 \mathrm{H}, \mathrm{m}, \mathrm{Ph} H^{\prime}\right), 5.87\left(1 \mathrm{H}, \mathrm{s}, H 8^{\prime}\right), 3.13\left(3 \mathrm{H}, \mathrm{s}, H 4^{\prime}\right)$;

${ }^{13} \mathbf{C}$ NMR $\left(101 \mathrm{MHz}, \mathrm{CDCl}_{3}\right) \delta_{\mathrm{C}} 158.3,143.7,142.2,141.7,135.0,134.6,128.9,128.8,128.7,127.6$, 125.7, 125.4, 124.9, 124.4, 113.7, 39.3;

HRMS (ES+) calc. for $\mathrm{C}_{22} \mathrm{H}_{19}{ }^{35} \mathrm{Cl}_{2} \mathrm{~N}_{2} \mathrm{O}[\mathrm{M}+\mathrm{H}]^{+}$397.0869, found 397.0868 . 


\section{5a Amide Scope: Dichloroenamides}

(E)- $N$-(1,2-Dichlorovinyl)- $N$-phenylbenzamide, 14a
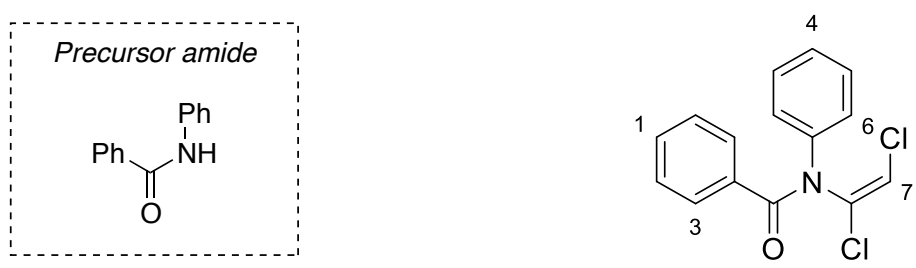

Following example procedure 1.3b: Synthesised from $N$-phenylbenzamide (1.00 g, $5.07 \mathrm{mmol}$, 1.0 equiv.) and tetrabutylammonium hydrogensulfate ( $430 \mathrm{mg}, 1.27 \mathrm{mmol}, 0.25$ equiv.) in toluene $(50 \mathrm{~mL})$ using $50 \% \mathrm{w} / \mathrm{v}$ aqueous solution of $\mathrm{KOH}(20 \mathrm{~mL})$ and trichloroethylene $(1.37 \mathrm{~mL}$, $15.2 \mathrm{mmol}, 3.0$ equiv.) added dropwise over 2 minutes at $21^{\circ} \mathrm{C}$. The reaction takes approximately 2 hours to reach completion. After extraction/concentration in vacuo, the resulting brown solid was recrystallised from ethanol, and once the mixture had cooled to room temperature and crystals had grown, the suspension was further cooled to $-20{ }^{\circ} \mathrm{C}$ for $\sim 2$ hours to enable further crystallisation. This afforded the title compound ( $1.31 \mathrm{~g}, 4.48 \mathrm{mmol}, 88 \%$ ) as pale yellow crystals;

m.p. $107-108^{\circ} \mathrm{C}$;

$\mathbf{R}_{\mathbf{f}} 0.37\left(10 \% \mathrm{Et}_{2} \mathrm{O} /\right.$ pentane);

IR (thin film, $v_{\max } / \mathrm{cm}^{-1}$ ) 3086, 1681, 1595, 1491, 1448, 1317, 1277, 1151, 1075, 889, 851, 817, 782, $758,717,696,666,645$;

${ }^{1} \mathbf{H}$ NMR $\left(400 \mathrm{MHz}, \mathrm{CDCl}_{3}\right) \delta_{\mathrm{H}} 7.67(2 \mathrm{H}, \mathrm{d}, J=7.3 \mathrm{~Hz}, H 3), 7.44(1 \mathrm{H}, \mathrm{t}, J=7.3,1.2 \mathrm{~Hz}, H 1), 7.41-$ $7.22(7 \mathrm{H}, \mathrm{m}, H 2, H 4, H 5, H 6), 6.27(1 \mathrm{H}, \mathrm{s}, H 7)$;

${ }^{13}$ C NMR $\left(101 \mathrm{MHz}, \mathrm{CDCl}_{3}\right) \delta_{\mathrm{C}} 169.4,139.0,134.4,132.9,131.4,129.3,128.5,128.0,127.7,126.4$, 116.2;

HRMS (ES+) calc. for $\mathrm{C}_{15} \mathrm{H}_{12}{ }^{35} \mathrm{Cl}_{2} \mathrm{NO}[\mathrm{M}+\mathrm{H}]^{+}$292.0291, found 292.0292 . 

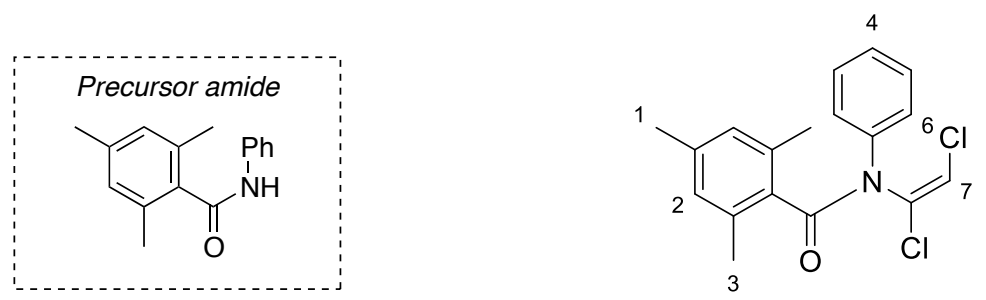

Following example procedure 1.3b: Synthesised from 2,4,6-trimethyl- $N$-phenylbenzamide $(1.00 \mathrm{~g}$, $4.18 \mathrm{mmol}, 1.0$ equiv.) and tetrabutylammonium hydrogensulfate (355 mg, $1.05 \mathrm{mmol}, 0.25$ equiv.) in toluene $(30 \mathrm{~mL})$ using $25 \% \mathrm{w} / \mathrm{v}$ aqueous solution of $\mathrm{KOH}(15 \mathrm{~mL})$ and trichloroethylene $(1.13 \mathrm{~mL}$, $12.5 \mathrm{mmol}, 3.0$ equiv.) added dropwise over 2 minutes at $21{ }^{\circ} \mathrm{C}$. The reaction takes approximately 3 hours to reach completion. Recrystallisation from heptane afforded the title compound $(1.16 \mathrm{~g}$, $3.47 \mathrm{mmol}, 83 \%$ ) as colourless crystals;

m.p. $142-144{ }^{\circ} \mathrm{C}$;

$\mathbf{R}_{\mathbf{f}} 0.54$ (10\% EtOAc/pentane);

IR (thin film, $v_{\max } / \mathrm{cm}^{-1}$ ) 3085, 2952, 2921, 2860, 1682, 1611, 1595, 1493, 1454, 1318, 1274, 1178 , $1123,853,834,811,756,696,614$;

${ }^{1} \mathbf{H}$ NMR $\left(400 \mathrm{MHz}, \mathrm{CDCl}_{3}\right) \delta_{\mathrm{H}}$ data for major rotamer: 7.25-7.11 $(5 \mathrm{H}, \mathrm{m}, H 4, H 5, H 6), 6.67(2 \mathrm{H}, \mathrm{s}$, $H 2), 6.48(1 \mathrm{H}, \mathrm{s}, H 7), 2.29(6 \mathrm{H}$, br. s, $H 3), 2.17(3 \mathrm{H}, \mathrm{s}, H 1)$; data for minor rotamer: 7.58-7.51 $(2 \mathrm{H}$, m, H6), 7.50-7.43 (2H, m, H5), 7.38-7.33 (1H, m, H4), $6.87(2 \mathrm{H}, \mathrm{s}, H 2), 6.10(1 \mathrm{H}, \mathrm{s}, H 7), 2.42(6 \mathrm{H}$, s, $H 3), 2.30(3 \mathrm{H}, \mathrm{s}, H 1)$;

${ }^{13} \mathbf{C}$ NMR $\left(101 \mathrm{MHz}, \mathrm{CDCl}_{3}\right) \delta_{\mathrm{C}}$ combined data: $169.8,138.89,138.86,135.4,134.3,131.8,131.6$, $129.1 *, 128.7,128.2^{*}, 128.1,127.8,127.7^{*}, 126.5^{*}, 126.1,117.1,116.5^{*}, 21.2^{*}, 21.0,20.1 *, 19.6$; *Note: Those ${ }^{13} \mathrm{C}$ resonances indicated by * belong to the minor rotamer, but due to signal overlap, not all of these resonances can be discerned.

HRMS (ES+) calc. for $\mathrm{C}_{18} \mathrm{H}_{18}{ }^{35} \mathrm{Cl}_{2} \mathrm{NO}[\mathrm{M}+\mathrm{H}]^{+} 334.0760$, found 334.0760 . 

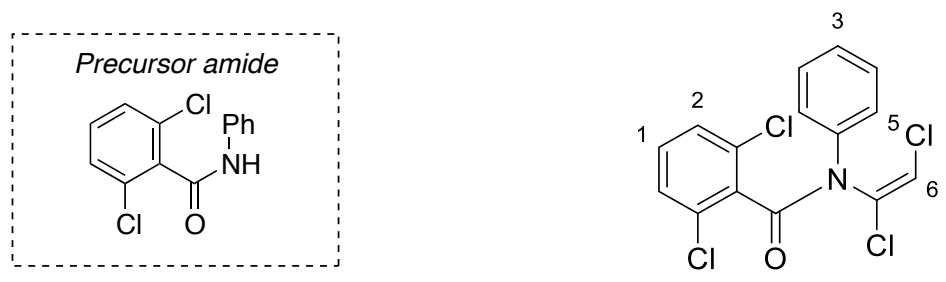

Following example procedure 1.3b: Synthesised from 2,6-dichloro- $N$-phenylbenzamide (1.00 g, $3.76 \mathrm{mmol}, 1.0$ equiv.) and tetrabutylammonium hydrogensulfate $(319 \mathrm{mg}, 0.940 \mathrm{mmol}, 0.25$ equiv.) in toluene $(30 \mathrm{~mL})$ using $25 \% \mathrm{w} / \mathrm{v}$ aqueous solution of $\mathrm{KOH}(15 \mathrm{~mL})$ and trichloroethylene $(1.01 \mathrm{~mL}$, $11.3 \mathrm{mmol}, 3.0$ equiv.) added dropwise over 2 minutes at $21^{\circ} \mathrm{C}$. The reaction takes approximately 3 hours to reach completion. Recrystallisation from heptane (a hot filtration was required to remove tarry residues) afforded the title compound (1.08 g, $2.99 \mathrm{mmol}, 80 \%)$ as colourless crystals;

m.p. $135-137^{\circ} \mathrm{C}$;

$\mathbf{R}_{\mathbf{f}} 0.41$ (10\% EtOAc/pentane);

IR (thin film, $v_{\max } / \mathrm{cm}^{-1}$ ) 3085, 1691, 1594, 1562, 1492, 1432, 1323, 1304, 1281, 1262, 1196, 1166, $1071,842,818,797,781,761,748,731,697,681$;

${ }^{1} \mathbf{H}$ NMR $\left(400 \mathrm{MHz}, \mathrm{CDCl}_{3}\right) * \delta_{\mathrm{H}} 7.65-7.50(2 \mathrm{H}, \mathrm{m}, H 5), 7.31-19(3 \mathrm{H}, \mathrm{m}, H 1, H 4), 7.18-6.95(3 \mathrm{H}$, $\mathrm{m}, H 2, H 3), 6.49(1 \mathrm{H}, \mathrm{s}, H 6) ;{ }^{*}$ Note: The compound is rotameric with many overlapping peaks.

${ }^{13}$ C NMR $\left(101 \mathrm{MHz}, \mathrm{CDCl}_{3}\right) * \delta_{\mathrm{C}} 163.5,138.0,136.2,134.1,132.1,130.8,130.2,129.8,129.2,129.1$, $129.0,128.9,128.1,128.0,127.9,127.8,127.6,127.0,126.6,118.4,117.8$;

HRMS (ES+) calc. for $\mathrm{C}_{15} \mathrm{H}_{10}{ }^{35} \mathrm{Cl}_{4} \mathrm{NO}[\mathrm{M}+\mathrm{H}]^{+} 359.9511$, found 359.9513 .

*Note: It was not possible to categorically assign peaks to each rotamer $\left({ }^{1} \mathrm{H} \&{ }^{13} \mathrm{C}\right)$ 
(E)-N-(1,2-Dichlorovinyl)- $N$-phenylpivalamide, 14d
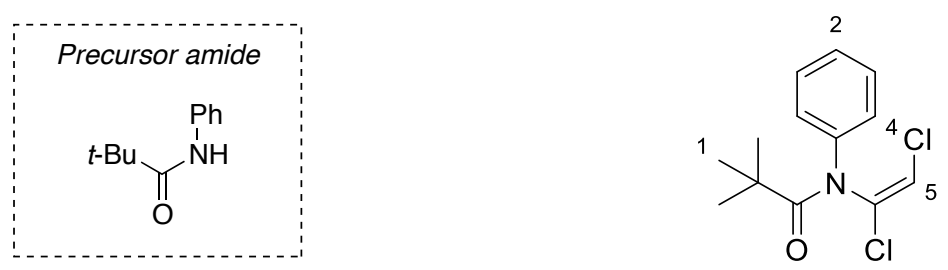

Synthesised from $N$-phenylpivalamide $(1.00 \mathrm{~g}, 5.64 \mathrm{mmol}, 1.0$ equiv. $)$ and tetrabutylammonium hydrogensulfate ( $479 \mathrm{mg}, 1.41 \mathrm{mmol}, 0.25$ equiv.) in toluene $(50 \mathrm{~mL})$ using $50 \% \mathrm{w} / \mathrm{v}$ aqueous solution of $\mathrm{KOH}(20 \mathrm{~mL})$ and trichloroethylene $(1.52 \mathrm{~mL}, 16.9 \mathrm{mmol}, 3.0$ equiv.) added dropwise over 5 minutes at $60{ }^{\circ} \mathrm{C}$, following example procedure $1.3 \mathrm{~b}$. The reaction was stirred overnight to reach completion. Column chromatography $\left(5 \% \mathrm{Et}_{2} \mathrm{O} /\right.$ pentane) afforded the title compound $(1.10 \mathrm{~g}$, $4.04 \mathrm{mmol}, 72 \%$ ) as a pale yellow wax. This compound can be recrystallised from $\mathrm{MeOH} / \mathrm{H}_{2} \mathrm{O}$ to give colourless crystals;

m.p. $65-67{ }^{\circ} \mathrm{C}\left(\mathrm{MeOH} / \mathrm{H}_{2} \mathrm{O}\right)$;

$\mathbf{R}_{\mathbf{f}} 0.50\left(10 \% \mathrm{Et}_{2} \mathrm{O} /\right.$ pentane $)$;

IR (thin film, $v_{\max } / \mathrm{cm}^{-1}$ ) 3088, 2968, 1677, 1594, 1492, 1480, 1397, 1366, 1274, 1220, 1179, 1063 , $1028,852,821,797,760,701$;

${ }^{1} \mathbf{H}$ NMR $\left(400 \mathrm{MHz}, \mathrm{CDCl}_{3}\right) \delta_{\mathrm{H}} 7.48-7.35(5 \mathrm{H}, \mathrm{m}, H 2, H 3, H 4), 6.25(1 \mathrm{H}, \mathrm{s}, H 5), 1.17(9 \mathrm{H}, \mathrm{s}, H 1)$;

${ }^{13} \mathbf{C}$ NMR $\left(101 \mathrm{MHz}, \mathrm{CDCl}_{3}\right) \delta_{\mathrm{C}} 177.9,139.9,133.9,129.2,129.0,128.8,115.1,41.8,28.9$;

HRMS (ES+) calc. for $\mathrm{C}_{13} \mathrm{H}_{16}{ }^{35} \mathrm{Cl}_{2} \mathrm{NO}[\mathrm{M}+\mathrm{H}]^{+} 272.0604$, found 272.0605 . 

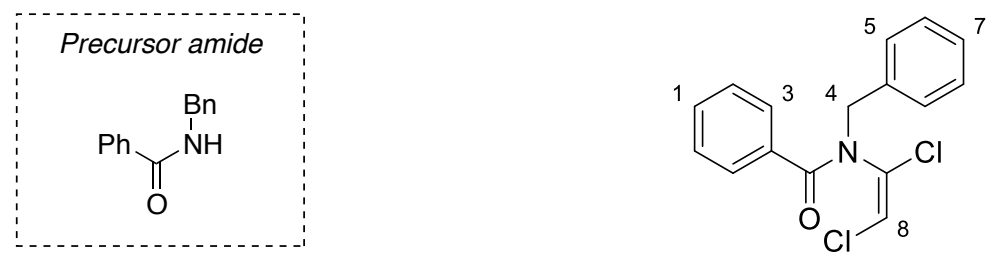

\section{Preparation using $\mathrm{KOH}$ in toluene:}

Following example procedure 1.3b: Synthesised from $N$-benzylbenzamide $(500 \mathrm{mg}, 2.37 \mathrm{mmol}$, 1.0 equiv.) and tetrabutylammonium hydrogensulfate (201 $\mathrm{mg}, 0.593 \mathrm{mmol}, 0.25$ equiv.) in toluene $(24 \mathrm{~mL})$ using $50 \% \mathrm{w} / \mathrm{v}$ aqueous solution of $\mathrm{KOH}(12 \mathrm{~mL})$ and trichloroethylene $(0.64 \mathrm{~mL}$, $7.11 \mathrm{mmol}, 3.0$ equiv.) added dropwise over 2 minutes at $60{ }^{\circ} \mathrm{C}$, following example procedure $\mathbf{1 . 3 \mathbf { b }}$. The reaction takes approximately 2 hours to reach completion. Column chromatography $(5 \rightarrow 10 \%$ $\mathrm{Et}_{2} \mathrm{O} /$ pentane) afforded the title compound $(553 \mathrm{mg}, 1.81 \mathrm{mmol}, 76 \%$ ) as a colourless oil that solidifies on standing at $-20{ }^{\circ} \mathrm{C}$ in the freezer. Recrystallisation can be achieved from heptane plus a few drops of toluene at $-20{ }^{\circ} \mathrm{C}$ for 4 days, but the mass recovery was poor owing to facile dissolution upon slight warming above $-20^{\circ} \mathrm{C}$.

\section{Preparation using NaH in 2-MeTHF:}

To an oven dried, nitrogen-flushed $25 \mathrm{~mL}$ two-necked round bottomed flask, equipped with a magnetic stirrer bar, a reflux condenser and two septa, was added sodium hydride (240 $\mathrm{mg}$ of a $60 \%$ dispersion in mineral oil, $5.9 \mathrm{mmol}, 2.5$ equiv.). The flask was then evacuated under high vacuum for 30 seconds to remove air and backfilled with nitrogen (this vacuum cycle was repeated twice more see Safety Note in procedure 1.3a). After backfilling with nitrogen, anhydrous 2-MeTHF (2.4 mL) was added and the resulting grey suspension was heated to $75^{\circ} \mathrm{C}$ whilst stirring. Next, a solution of $\mathrm{N}$-benzylbenzamide (500 mg, $2.37 \mathrm{mmol}, 1.0$ equiv.) in anhydrous 2-MeTHF (2.4 mL) was added dropwise over 5 minutes and the resulting mixture was stirred at $75^{\circ} \mathrm{C}$ for 1.5 hours. During this time the reaction solution gained a yellow hue.

Next a solution of trichloroethylene $(0.32 \mathrm{~mL}, 3.55 \mathrm{mmol}, 1.5$ equiv. $)$ in anhydrous 2-MeTHF $(1 \mathrm{~mL})$ was added dropwise over 4 minutes, and the mixture was stirred at $75{ }^{\circ} \mathrm{C}$ for 1 hour. Complete conversion was then confirmed by $\mathrm{TLC}\left(10 \% \mathrm{Et}_{2} \mathrm{O} /\right.$ petroleum ether). Upon cooling to room temperature, the reaction was quenched by the slow addition of "wet" 2-MeTHF ( $5 \mathrm{~mL}$ ), followed by $\mathrm{NH}_{4} \mathrm{Cl}(20 \mathrm{~mL})$ and the mixture stirred for 30 minutes. The mixture was poured into a $250 \mathrm{~mL}$ separating funnel and the organic layer was separated. The aqueous layer was then extracted with $\mathrm{Et}_{2} \mathrm{O}(3 \times 40 \mathrm{~mL})$, the organic extracts combined, dried $\left(\mathrm{Na}_{2} \mathrm{SO}_{4}\right)$ and concentrated in vacuo to afford a brown oil. Column chromatography $\left(5 \rightarrow 10 \% \mathrm{Et}_{2} \mathrm{O} /\right.$ pentane) afforded $498 \mathrm{mg}(1.63 \mathrm{mmol}, 69 \%)$ of the title compound; 
m.p. $55^{\circ} \mathrm{C}$;

$\mathbf{R}_{\mathbf{f}} 0.67$ (20\% Et $\mathrm{E}_{2} \mathrm{O} /$ pentane);

IR (thin film, $v_{\max } / \mathrm{cm}^{-1}$ ) 3087, 3032, 1668, 1615, 1447, 1357, 1317, 1295, 1243, 1139, 1075, 1028, 944, 816, 785, 759, 718, 698, 652;

${ }^{1} \mathbf{H}$ NMR $\left(500 \mathrm{MHz}, \mathrm{CDCl}_{3}\right) \delta_{\mathrm{H}} 7.79-7.69(2 \mathrm{H}, \mathrm{m}, H 3), 7.54-7.44(3 \mathrm{H}, \mathrm{m}, H 1, H 6), 7.43-7.28(5 \mathrm{H}$, m, H2, H5, H7), $5.84(1 \mathrm{H}, \mathrm{s}, H 8), 5.22(1 \mathrm{H}$, br. d, $J=14.2 \mathrm{~Hz}, H 4), 4.61(1 \mathrm{H}$, br. d, $J=14.2 \mathrm{~Hz}, H 4)$; ${ }^{13}$ C NMR $\left(126 \mathrm{MHz}, \mathrm{CDCl}_{3}\right) \delta_{\mathrm{C}} 169.9,135.3,134.8,132.7,131.1,129.5,128.3,127.9,127.8,127.5$, 116.2, 49.3;

HRMS (ES+) calc. for $\mathrm{C}_{16} \mathrm{H}_{14}{ }^{35} \mathrm{Cl}_{2} \mathrm{NO}[\mathrm{M}+\mathrm{H}]^{+} 306.0447$, found 306.0448 . 

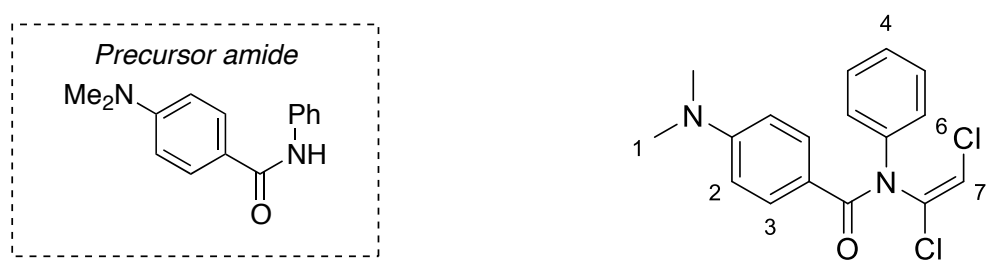

Following example procedure 1.3b: Synthesised from 4-(dimethylamino)- $N$-phenylbenzamide (720 mg, $3.00 \mathrm{mmol}, 1.0$ equiv.) and tetrabutylammonium hydrogensulfate $(254 \mathrm{mg}, 0.75 \mathrm{mmol}$, 0.25 equiv.) in toluene $(30 \mathrm{~mL})$ using $50 \%$ w/v aqueous solution of $\mathrm{KOH}(15 \mathrm{~mL})$ and trichloroethylene $\left(0.81 \mathrm{~mL}, 9.00 \mathrm{mmol}, 3.0\right.$ equiv.) added dropwise over 2 minutes at $60{ }^{\circ} \mathrm{C}$. The reaction takes approximately 2 hours to reach completion. After extraction/concentration in vacuo, the resulting brown solid was recrystallised from methanol, and once the mixture had cooled to room temperature and crystals had grown, the suspension was further cooled to $-20{ }^{\circ} \mathrm{C}$ for $\sim 2$ hours to enable further crystallisation. This afforded the title compound (818 $\mathrm{mg}, 2.54 \mathrm{mmol}, 82 \%$ ) as pale yellow needles;

m.p. $168-170{ }^{\circ} \mathrm{C}$;

$\mathbf{R}_{\mathbf{f}} 0.39$ (20\% EtOAc/pentane);

IR (thin film, $v_{\max } / \mathrm{cm}^{-1}$ ) 3086, 2900, 1666, 1602, 1528, 1492, 1368, 1316, 1274, 1231, 1190, 1172 , 946, 811, 756, 695;

${ }^{1} \mathbf{H}$ NMR $\left(400 \mathrm{MHz}, \mathrm{CDCl}_{3}\right) \delta_{\mathrm{H}} 7.63-7.54(2 \mathrm{H}, \mathrm{m}, H 3), 7.39-7.31(2 \mathrm{H}, \mathrm{m}, H 5), 7.29-7.20(3 \mathrm{H}, \mathrm{m}$, $H 4, H 6), 6.59-6.51(2 \mathrm{H}, \mathrm{m}, H 2), 6.26(1 \mathrm{H}, \mathrm{s}, H 7), 3.00(6 \mathrm{H}, \mathrm{s}, H 1)$;

${ }^{13}$ C NMR $\left(101 \mathrm{MHz}, \mathrm{CDCl}_{3}\right) \delta_{\mathrm{C}} 169.3,152.4,140.1,133.4,131.0,129.2,127.0,126.1,120.4,115.2$, 110.4, 39.9;

HRMS (ES+) calc. for $\mathrm{C}_{17} \mathrm{H}_{17}{ }^{35} \mathrm{Cl}_{2} \mathrm{~N}_{2} \mathrm{O}[\mathrm{M}+\mathrm{H}]^{+}$335.0713, found 335.0711. 

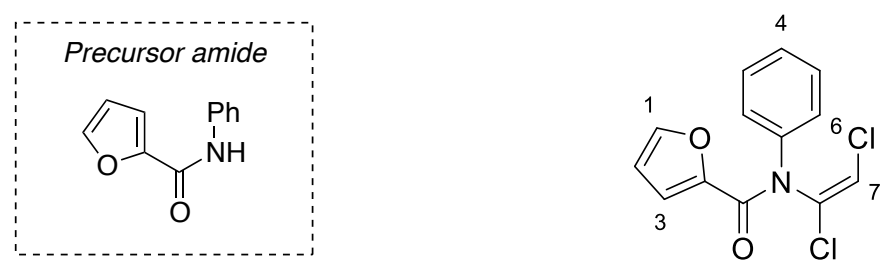

Following example procedure 1.3b: Synthesised from $N$-phenylfuran-2-carboxamide (500 mg, $2.67 \mathrm{mmol}, 1.0$ equiv.) and tetrabutylammonium hydrogensulfate (227 $\mathrm{mg}, 0.668 \mathrm{mmol}, 0.25$ equiv.) in toluene $(27 \mathrm{~mL})$ using $50 \% \mathrm{w} / \mathrm{v}$ aqueous solution of $\mathrm{KOH}(13 \mathrm{~mL})$ and trichloroethylene $(0.72 \mathrm{~mL}$, $8.01 \mathrm{mmol}, 3.0$ equiv.) added dropwise over 2 minutes at $21^{\circ} \mathrm{C}$. The reaction takes approximately 2 hours to reach completion. Column chromatography ( $6 \% \mathrm{Et}_{2} \mathrm{O} /$ pentane) afforded the title compound (457 mg, $1.62 \mathrm{mmol}, 61 \%$ ) as a yellow solid;

m.p. $60-63{ }^{\circ} \mathrm{C}$;

$\mathbf{R}_{\mathbf{f}} 0.73$ (20\% EtOAc/pentane);

IR (thin film, $v_{\max } / \mathrm{cm}^{-1}$ ) 3086, 1670, 1615, 1594, 1572, 1492, 1468, 1388, 1320, 1231, 1187, 1149, 1092, 1014, 886, 827, 756, 695, 660;

${ }^{1} \mathbf{H}$ NMR $\left(400 \mathrm{MHz}, \mathrm{CDCl}_{3}\right) \delta_{\mathrm{H}} 7.51-7.46(1 \mathrm{H}, \mathrm{m}, H 3), 7.46-7.34(5 \mathrm{H}, \mathrm{m}, H 4, H 5, H 6), 6.62(1 \mathrm{H}, \mathrm{br}$. s, $H 1), 6.40(1 \mathrm{H}, \mathrm{s}, H 7), 6.39(1 \mathrm{H}, \mathrm{dd}, J=3.7,1.7 \mathrm{~Hz}, H 2)$;

${ }^{13}$ C NMR $\left(101 \mathrm{MHz}, \mathrm{CDCl}_{3}\right) \delta_{\mathrm{C}} 157.7,146.1,145.6,138.7,131.8,129.5,128.4,127.1,118.4,116.5$, 111.6;

HRMS (ES+) calc. for $\mathrm{C}_{13} \mathrm{H}_{9}{ }^{35} \mathrm{Cl}_{2} \mathrm{NNaO}_{2}[\mathrm{M}+\mathrm{Na}]^{+}$303.9903, found 303.9904. 


\section{(E)-N-(1,2-Dichlorovinyl)- $N$-phenylacetamide, $14 \mathrm{~h}$}
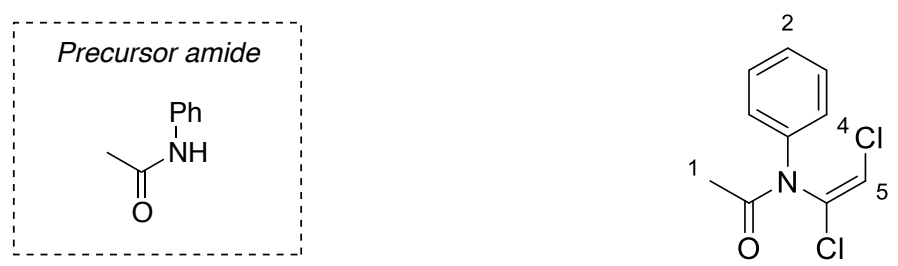

Synthesised from $N$-phenylacetamide $(500 \mathrm{mg}, 3.70 \mathrm{mmol}, 1.0$ equiv.) and tetrabutylammonium hydrogensulfate $(314 \mathrm{mg}, 0.925 \mathrm{mmol}, 0.25$ equiv.) in toluene $(40 \mathrm{~mL})$ using $50 \% \mathrm{w} / \mathrm{v}$ aqueous solution of $\mathrm{KOH}(20 \mathrm{~mL})$ and trichloroethylene $(0.50 \mathrm{~mL}, 5.55 \mathrm{mmol}, 1.5$ equiv.) added dropwise over 2 minutes at $40{ }^{\circ} \mathrm{C}$, following example procedure 1.3b. The reaction takes approximately 2 hours to reach completion. Column chromatography $\left(0 \rightarrow 5 \% \mathrm{Et}_{2} \mathrm{O} /\right.$ pentane $)$ afforded the title compound (431 mg, $1.87 \mathrm{mmol}, 51 \%$ ) as a yellow solid;

${ }^{1} \mathbf{H}$ NMR $\left(500 \mathrm{MHz}, \mathrm{CDCl}_{3}\right) \delta_{\mathrm{H}} 7.69-7.14(5 \mathrm{H}, \mathrm{m}, H 2, H 3, H 4), 6.42(1 \mathrm{H}$, br. s, H5), 2.79-1.75 (3H, br. $\mathrm{m}, H 1)$;

${ }^{13}$ C NMR $\left(126 \mathrm{MHz}, \mathrm{CDCl}_{3}\right) \delta_{\mathrm{C}} 169.3,139.4,138.1,133.2,131.1,129.4,128.0,126.7,117.4,116.4$, 22.1. *Note: This compound is rotameric and as a result some ${ }^{13} \mathrm{C}$ resonances are duplicated and/or broadened. 
(E)- $N$-(1,2-Dichlorovinyl)- $N$-phenylpropionamide, 14i
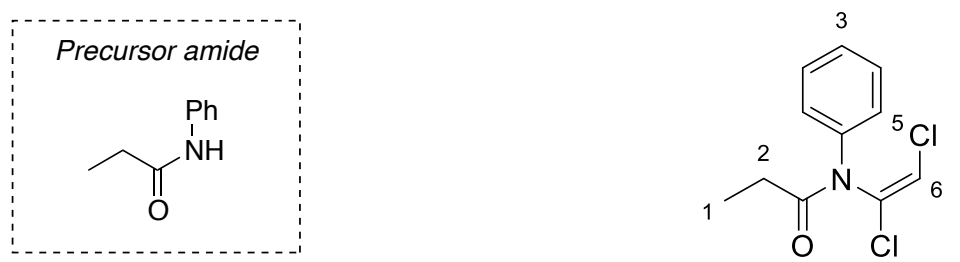

Synthesised from $N$-phenylpropionamide $(1.00 \mathrm{~g}, 6.70 \mathrm{mmol}, 1.0$ equiv.) and tetrabutylammonium hydrogensulfate $(569 \mathrm{mg}, 1.68 \mathrm{mmol}, 0.25$ equiv.) in toluene $(60 \mathrm{~mL})$ using $50 \% \mathrm{w} / \mathrm{v}$ aqueous solution of $\mathrm{KOH}(30 \mathrm{~mL})$ and trichloroethylene $(0.90 \mathrm{~mL}, 10.1 \mathrm{mmol}, 1.5$ equiv.) added dropwise over 2 minutes at $40{ }^{\circ} \mathrm{C}$, following example procedure 1.3b. The reaction takes approximately 1 hour to reach completion. Column chromatography $\left(0 \rightarrow 4 \% \mathrm{Et}_{2} \mathrm{O} /\right.$ pentane $)$ afforded the title compound (859 $\mathrm{mg}, 3.52 \mathrm{mmol}, 53 \%$ ) as a yellow oil;

$\mathbf{R}_{\mathbf{f}} 0.29\left(4 \% \mathrm{Et}_{2} \mathrm{O} /\right.$ pentane $)$;

IR (thin film, $v_{\max } / \mathrm{cm}^{-1}$ ) 3083, 2940, 1699, 1613, 1595, 1492, 1460, 1362, 1290, 1257, 1220, 1198 , $1127,1074,1049,882,811,760,717,694,659$;

${ }^{1} \mathbf{H}$ NMR $\left(400 \mathrm{MHz}, \mathrm{CDCl}_{3}\right) \delta_{\mathrm{H}} 7.52-7.29(5 \mathrm{H}, \mathrm{m}, H 3, H 4, H 5), 6.40$ (1H, br. s, H6), 2.43 (2H, br. s, $H 2), 1.17(3 \mathrm{H}$, br. t, $J=6.8 \mathrm{~Hz}, H 1)$;

${ }^{13}$ C NMR $\left(101 \mathrm{MHz}, \mathrm{CDCl}_{3}\right) \delta_{\mathrm{C}} 172.7,138.7,132.4,129.5,128.4,127.4,116.9,27.4,9.02$;

HRMS (ES+) calc. for $\mathrm{C}_{11} \mathrm{H}_{12}{ }^{35} \mathrm{Cl}_{2} \mathrm{NO}[\mathrm{M}+\mathrm{H}]^{+} 244.0291$, found 244.0292 . 

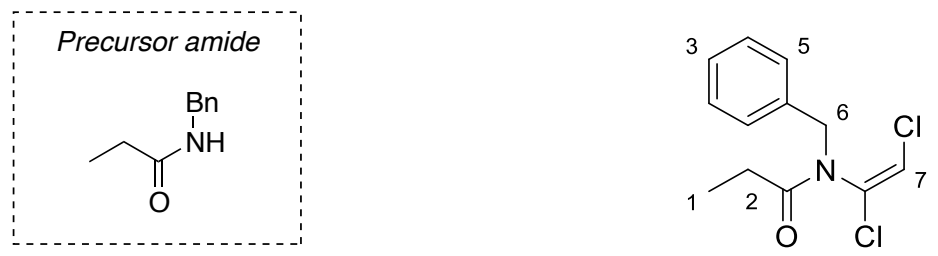

Following example procedure 1.3b: Synthesised from $N$-benzylpropionamide (200 mg, $1.22 \mathrm{mmol}$, 1.0 equiv.) and tetrabutylammonium hydrogensulfate $(104 \mathrm{mg}, 0.306 \mathrm{mmol}, 0.25$ equiv.) in toluene $(12 \mathrm{~mL})$ using $50 \% \mathrm{w} / \mathrm{v}$ aqueous solution of $\mathrm{KOH}(6 \mathrm{~mL})$ and trichloroethylene $(0.33 \mathrm{~mL}, 3.63 \mathrm{mmol}$, 3.0 equiv.) added dropwise over 10 minutes at $60{ }^{\circ} \mathrm{C}$. The reaction was halted after 48 hours. Column chromatography (4\% $\mathrm{Et}_{2} \mathrm{O} /$ pentane) afforded the title compound (153 $\mathrm{mg}, 0.593 \mathrm{mmol}, 48 \%$ ) as a colourless solid;

m.p. $74{ }^{\circ} \mathrm{C}$;

$\mathbf{R}_{\mathbf{f}} 0.72(20 \%$ EtOAc/pentane);

IR (thin film, $v_{\max } / \mathrm{cm}^{-1}$ ) 3081, 3032, 2983, 2929, 2880, 1672, 1638, 1495, 1456, 1412, 1372, 1274 , 1203, 1159, 1074, 1016, 966, 947, 860, 813, 764, 705, 677;

${ }^{1} \mathbf{H}$ NMR $\left(400 \mathrm{MHz}, \mathrm{CDCl}_{3}\right) \delta_{\mathrm{H}} 7.40-7.33(2 \mathrm{H}, \mathrm{m}, H 4), 7.33-7.27(3 \mathrm{H}, \mathrm{m}, H 3, H 5), 6.25(1 \mathrm{H}, \mathrm{s}, H 7)$, $5.02\left(1 \mathrm{H}, \mathrm{AB} \mathrm{d}, J_{\mathrm{AB}}=14.3 \mathrm{~Hz}, H 6\right), 4.42\left(1 \mathrm{H}, \mathrm{AB} \mathrm{d}, J_{\mathrm{BA}}=14.3 \mathrm{~Hz}, H 6\right), 2.47(2 \mathrm{H}, \mathrm{q}, J=7.4 \mathrm{~Hz}, H 2)$, $1.19(3 \mathrm{H}, \mathrm{t}, J=7.4 \mathrm{~Hz}, H 1)$;

${ }^{13} \mathbf{C}$ NMR $\left(101 \mathrm{MHz}, \mathrm{CDCl}_{3}\right) \delta_{\mathrm{C}} 172.9,135.4,132.5,129.5,128.3,127.9,117.6,48.9,26.7,9.0$;

HRMS (ES+) calc. for $\mathrm{C}_{12} \mathrm{H}_{13}{ }^{35} \mathrm{Cl}_{2} \mathrm{NNaO}[\mathrm{M}+\mathrm{Na}]^{+} 280.0266$, found 280.0268 . 


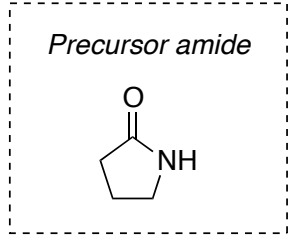<smiles>O=C1CCCN1C(Cl)=CCl</smiles>

Following example procedure 1.3b: Synthesised from anhydrous pyrrolidinone (1.00 g, $11.8 \mathrm{mmol}$, 1.0 equiv.) and tetrabutylammonium hydrogensulfate $(997 \mathrm{mg}, 2.94 \mathrm{mmol}, 0.25$ equiv.) in toluene $(20 \mathrm{~mL})$ using $50 \% \mathrm{w} / \mathrm{v}$ aqueous solution of $\mathrm{KOH}(20 \mathrm{~mL})$ and trichloroethylene $(3.17 \mathrm{~mL}$, $35.3 \mathrm{mmol}, 3.0$ equiv.) added dropwise over 1 hour at $40{ }^{\circ} \mathrm{C}$. The reaction was halted after 48 hours. Column chromatography (30\% EtOAc/pentane) afforded the title compound (193 mg, $1.07 \mathrm{mmol}$, $9 \%)$ as pale yellow oil;

$\mathbf{R}_{\mathbf{f}} 0.44$ (30\% EtOAc/pentane);

IR (thin film, $v_{\max } / \mathrm{cm}^{-1}$ ) 3084, 2892, 1717, 1624, 1379, 1301, 1244, 1200, 813, 652;

${ }^{1} \mathbf{H}$ NMR $\left(500 \mathrm{MHz}, \mathrm{CDCl}_{3}\right) \delta_{\mathrm{H}} 6.27(1 \mathrm{H}, \mathrm{s}, H 4), 3.60(2 \mathrm{H}, \mathrm{t}, J=7.1 \mathrm{~Hz}, H 3), 2.44(2 \mathrm{H}, \mathrm{t}, J=7.9 \mathrm{~Hz}$, $H 1), 2.15(2 \mathrm{H}, \mathrm{tt}, J=7.9,7.1 \mathrm{~Hz}, H 2)$;

${ }^{13}$ C NMR $\left(126 \mathrm{MHz}, \mathrm{CDCl}_{3}\right) \delta_{\mathrm{C}} 173.1,127.7,115.3,46.7,30.4,18.6$;

HRMS (ES+) calc. for $\mathrm{C}_{6} \mathrm{H}_{7}{ }^{35} \mathrm{Cl}_{2} \mathrm{NNaO}[\mathrm{M}+\mathrm{Na}]^{+}$201.9797, found 201.9799. 


\section{5b Amide Scope: Ynamides}

\section{$N$-((4-Chlorophenyl)ethynyl)-2,4,6-trimethyl- $N$-phenylbenzamide, $17 \mathrm{~b}$}
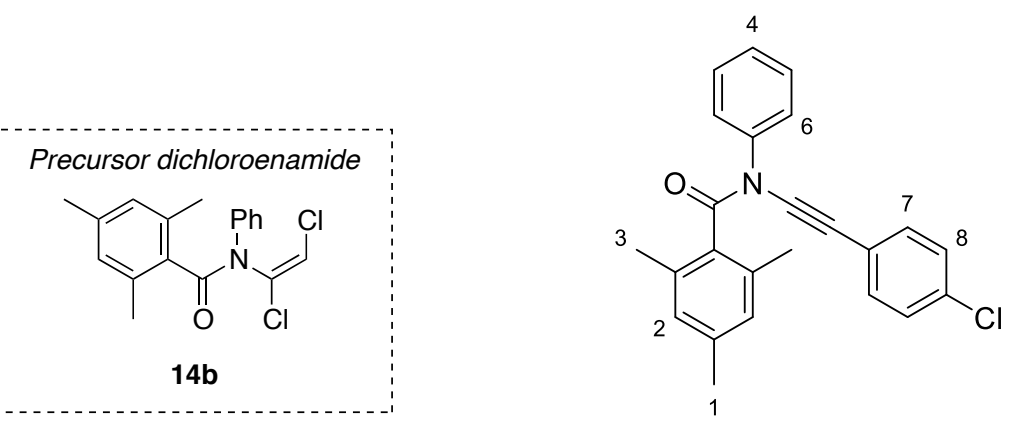

Following example procedure 1.3f: Synthesised from $(E)-N$-(1,2-dichlorovinyl)-2,4,6-trimethyl- $N$ phenylbenzamide (500 mg, $1.50 \mathrm{mmol}, 1.0$ equiv.) in anhydrous TBME (15 mL) using LiHMDS (freshly prepared according to example procedure 1.3f, 1.2 equiv.). Note: The elimination step was conducted at room temperature $\left(\sim 21{ }^{\circ} \mathrm{C}\right)$. The diarylzinc solution was prepared using anhydrous toluene $(4.5 \mathrm{~mL})$, 4-chlorophenylmagnesium bromide $\left(4.49 \mathrm{~mL}\right.$ of a $1.0 \mathrm{M}$ solution in $\mathrm{Et}_{2} \mathrm{O}$, $4.49 \mathrm{mmol}, 3.0$ equiv.), zinc(II) chloride (1.18 mL of a $1.9 \mathrm{M}$ solution in 2-MeTHF, $2.24 \mathrm{mmol}$, 1.5 equiv.) and anhydrous TMEDA (2.24 mL, $15.0 \mathrm{mmol}, 10.0$ equiv.), and the reaction conducted using $\mathrm{CuCN} \cdot 2 \mathrm{LiCl}(19 \mu \mathrm{L}$ of a $1.0 \mathrm{M}$ solution in THF, $19 \mu \mathrm{mol}, 1.25 \mathrm{~mol} \%)$. Upon completion, the reaction was worked up and extracted as for example procedure 1.3f. Column chromatography (5\% $\mathrm{Et}_{2} \mathrm{O} /$ pentane) afforded the title compound (386 mg, $1.03 \mathrm{mmol}, 69 \%$ ) as a colourless oil that yellows on standing. Note: This compound was stored as a frozen matrix in benzene.

$\mathbf{R}_{\mathbf{f}} 0.45\left(10 \% \mathrm{Et}_{2} \mathrm{O} /\right.$ pentane $)$;

IR (thin film, $v_{\max } / \mathrm{cm}^{-1}$ ) 3038, 2951, 2919, 2859, 2247, 1700, 1612, 1594, 1489, 1456, 1357, 1266, $1214,1162,1121,1088,1054,1014,854,826,755,694,686,634,607$;

${ }^{1} \mathbf{H}$ NMR $\left(400 \mathrm{MHz}, \mathrm{C}_{6} \mathrm{D}_{6}\right) \delta_{\mathrm{H}} 7.72(2 \mathrm{H}, \mathrm{d}, J=7.8 \mathrm{~Hz}, H 6), 7.12-7.18(2 \mathrm{H}, \mathrm{dd}, J=7.8,7.4 \mathrm{~Hz}, H 5)$, $7.03(1 \mathrm{H}, \mathrm{t}, J=7.4 \mathrm{~Hz}, H 4), 6.80(2 \mathrm{H}, \mathrm{d}, J=8.3 \mathrm{~Hz}, H 7), 6.68(2 \mathrm{H}, \mathrm{s}, H 2) 6.61(2 \mathrm{H}, \mathrm{d}, J=8.3 \mathrm{~Hz}$, $H 8), 2.37$ (6H, s, H3), 2.09 (3H, s, H1);

${ }^{13}$ C NMR $\left(101 \mathrm{MHz}, \mathrm{C}_{6} \mathrm{D}_{6}\right) \delta_{\mathrm{C}} 171.6,139.3,139.1,134.7,134.1,133.5,131.8,129.4,128.7,128.3$, $128.1,127.8,127.5,125.1,121.7,85.6,71.4,21.2,19.1$;

HRMS (ES+) calc. for $\mathrm{C}_{24} \mathrm{H}_{21}{ }^{35} \mathrm{Cl} \mathrm{NO}[\mathrm{M}+\mathrm{H}]^{+} 374.1306$, found 374.1309 . 

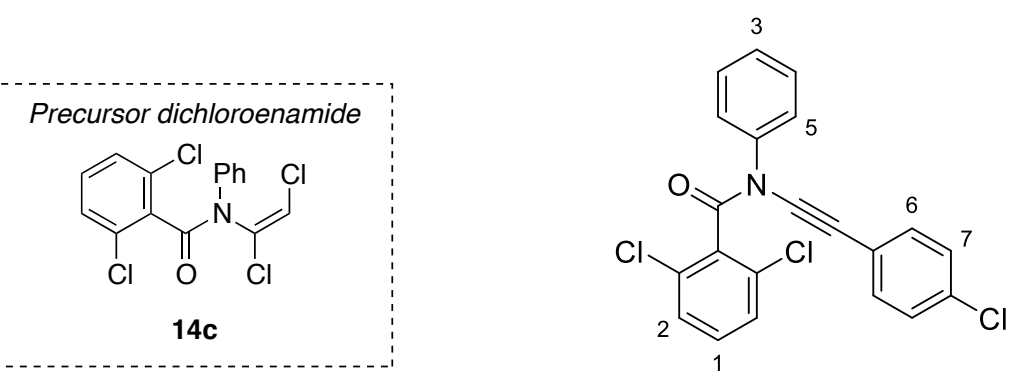

Following example procedure 1.3f: Synthesised from (E)-2,6-dichloro- $N$-(1,2-dichlorovinyl)- $N$ phenylbenzamide (500 mg, $1.38 \mathrm{mmol}, 1.0$ equiv.) in anhydrous TBME (14 mL) using LiHMDS (freshly prepared according to example procedure 1.3f, 1.2 equiv.). Note: The elimination step was conducted at room temperature $\left(\sim 21{ }^{\circ} \mathrm{C}\right)$. The diarylzinc solution was prepared using anhydrous toluene (4 mL), 4-chlorophenylmagnesium bromide ( $4.15 \mathrm{~mL}$ of a $1.0 \mathrm{M}$ solution in $\mathrm{Et}_{2} \mathrm{O}, 4.15 \mathrm{mmol}$, 3.0 equiv.), zinc(II) chloride (1.09 $\mathrm{mL}$ of a $1.9 \mathrm{M}$ solution in 2-MeTHF, $2.08 \mathrm{mmol}, 1.5$ equiv.) and anhydrous TMEDA (2.08 mL, $13.9 \mathrm{mmol}, 10.0$ equiv.), and the reaction conducted using $\mathrm{CuCN} \cdot 2 \mathrm{LiCl}(17 \mu \mathrm{L}$ of a $1.0 \mathrm{M}$ solution in THF, $17 \mu \mathrm{mol}, 1.25 \mathrm{~mol} \%)$. Upon completion, the reaction was worked up and extracted as for example procedure 1.3f. Column chromatography (5\% $\mathrm{Et}_{2} \mathrm{O} /$ pentane) afforded the title compound (361 mg, $\left.0.901 \mathrm{mmol}, 65 \%\right)$ as a colourless oil. Note: This compound was stored as a frozen matrix in benzene;

$\mathbf{R}_{\mathbf{f}} 0.46\left(10 \% \mathrm{Et}_{2} \mathrm{O} /\right.$ pentane $)$;

IR (thin film, $v_{\max } / \mathrm{cm}^{-1}$ ) 3069, 2249, 1709, 1593, 1577, 1562, 1490, 1433, 1356, 1282, 1196, 1143 , 1106, 1089, 1076, 1014, 850, 826, 796, 779, 755, 724, 706, 692, 626;

${ }^{1} \mathbf{H}$ NMR $\left(400 \mathrm{MHz}, \mathrm{C}_{6} \mathrm{D}_{6}\right) \delta_{\mathrm{H}}$ data for major rotamer: 7.80-7.70 (2H, m, H5), 7.19-7.10 (2H, m, H4), 7.03-6.97 (1H, m, H3), 6.83 (2H, d, $J=8.1 \mathrm{~Hz}, H 2), 6.82-6.78$ (2H, m, H6), 6.70-6.64 (2H, m, H7), $6.50(1 \mathrm{H}, \mathrm{t}, J=8.1 \mathrm{~Hz}, H 1)$; data for minor rotamer: 7.52-7.46 $(2 \mathrm{H}, \mathrm{m}, H 5), 7.13-7.08(2 \mathrm{H}, \mathrm{m}, H 6)$, 6.90-6.85 (2H, m, H7), 6.83-6.79 (2H, m, H4), 6.78-6.72 (1H, m, H3), 6.51 (2H, d, $J=8.1 \mathrm{~Hz}, H 2)$, $6.21(1 \mathrm{H}, \mathrm{t}, J=8.1 \mathrm{~Hz}, H 1)$;

${ }^{13} \mathbf{C}$ NMR $\left(101 \mathrm{MHz}, \mathrm{C}_{6} \mathrm{DC}_{6}\right) \delta_{\mathrm{C}}$ data for major rotamer: $165.5,138.6,135.7,134.1,133.0,132.4$, $132.3,131.1,129.5,128.8,127.8,125.2,121.1,84.5,71.6$; data for minor rotamer: 165.4, 139.6, 134.7, 134.2, 132.2, 131.0, 129.3, 129.0, 128.9, 128.0, 127.8, 126.4, 121.6, 84.7, 72.2;

HRMS (ES+) calc. for $\mathrm{C}_{21} \mathrm{H}_{13}{ }^{35} \mathrm{Cl}_{3} \mathrm{NO}[\mathrm{M}+\mathrm{H}]^{+} 400.0057$, found 400.0057 . 


\section{$N$-((4-Chlorophenyl)ethynyl)- $N$-phenylpivalamide, $17 \mathrm{~d}$}
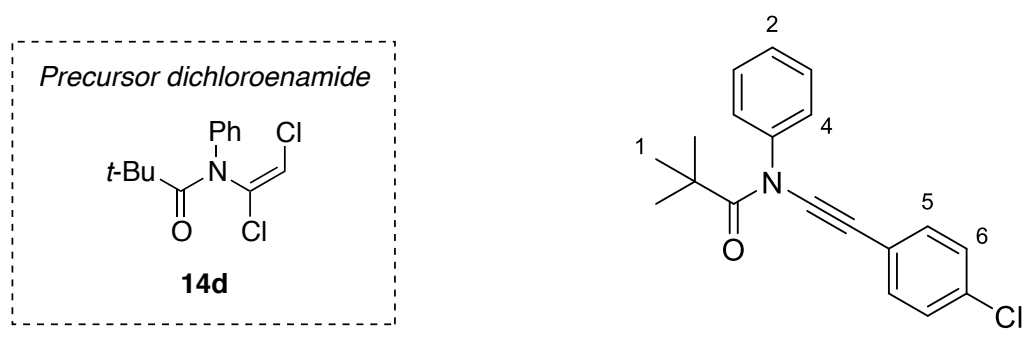

Following example procedure 1.3f: Synthesised from $(E)-N$-(1,2-dichlorovinyl)- $N$-phenylpivalamide (200 mg, $0.735 \mathrm{mmol}, 1.0$ equiv.) in anhydrous TBME (7.4 mL) using LiHMDS (freshly prepared according to example procedure 1.3f, 1.2 equiv.). Note: The elimination step was conducted at $0{ }^{\circ} \mathrm{C}$. The diarylzinc solution was prepared using anhydrous toluene $(2 \mathrm{~mL})$, 4-chlorophenylmagnesium bromide (2.20 mL of a 1.0 M solution in $\mathrm{Et}_{2} \mathrm{O}, 2.20 \mathrm{mmol}, 3.0$ equiv.), zinc(II) chloride ( $0.58 \mathrm{~mL}$ of a 1.9 M solution in 2-MeTHF, $1.10 \mathrm{mmol}, 1.5$ equiv.) and anhydrous TMEDA (1.10 mL, $7.35 \mathrm{mmol}$, 10.0 equiv.), and the reaction conducted using $\mathrm{CuCN} \cdot 2 \mathrm{LiCl}(9 \mu \mathrm{L}$ of a $1.0 \mathrm{M}$ solution in THF, 9 $\mu \mathrm{mol}, 1.25 \mathrm{~mol} \%)$. Upon completion, the reaction was worked up and extracted as for example procedure 1.3f. Column chromatography $\left(5 \% \mathrm{Et}_{2} \mathrm{O} /\right.$ pentane) afforded the title compound $(165 \mathrm{mg}$, $0.528 \mathrm{mmol}, 72 \%)$ as a colourless solid. This compound can be recrystallised from heptane $(\sim 1 \mathrm{~mL})$ to give colourless crystals. Note: This compound begins to decompose within hours in $\mathrm{CDCl}_{3}$ and $\mathrm{C}_{6} \mathrm{D}_{6}$, but the crystals were found to be stable for at least a week on the bench.

m.p. $104-105^{\circ} \mathrm{C}$;

$\mathbf{R}_{\mathbf{f}} 0.27$ ( $5 \% \mathrm{Et}_{2} \mathrm{O} /$ pentane);

IR (thin film, $v_{\max } / \mathrm{cm}^{-1}$ ) 2977, 2243, 1696, 1594, 1490, 1398, 1359, 1272, 1213, 1143, 1087, 1013, $826,753,695$;

${ }^{1}$ H NMR $\left(400 \mathrm{MHz}, \mathrm{C}_{6} \mathrm{D}_{6}\right) \delta_{\mathrm{H}} 7.40-7.30(2 \mathrm{H}, \mathrm{m}, H 4), 7.12-7.05(2 \mathrm{H}, \mathrm{m}, H 3), 6.99-6.94(1 \mathrm{H}, \mathrm{m}$, $H 2), 6.92(4 \mathrm{H}, \mathrm{s}, H 5, H 6), 1.50(9 \mathrm{H}, \mathrm{s}, H 1)$;

${ }^{13}$ C NMR $\left(101 \mathrm{MHz}, \mathrm{C}_{6} \mathrm{D}_{6}\right) \delta_{\mathrm{C}} 177.5,141.9,133.9,132.1,129.3,129.0,127.6,126.6,122.0,87.5$, $72.5,41.1,27.2$;

HRMS (ES+) calc. for $\mathrm{C}_{19} \mathrm{H}_{19}{ }^{35} \mathrm{ClNO}[\mathrm{M}+\mathrm{H}]^{+} 312.1150$, found 312.1150 . 


\section{$N$-Benzyl- $N$-((4-chlorophenyl)ethynyl)benzamide, 17e}
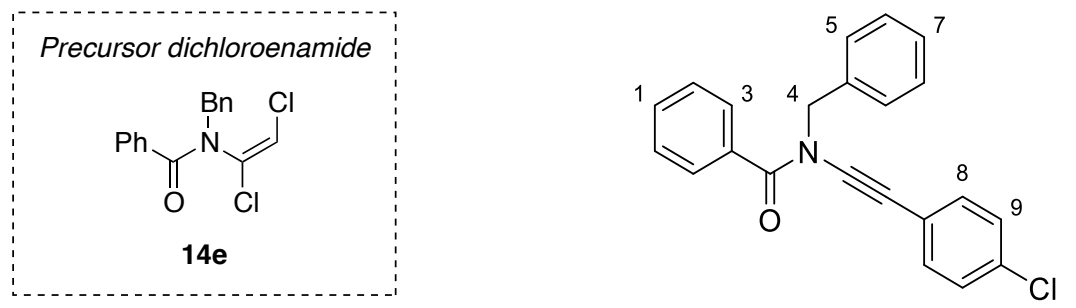

Following example procedure 1.3f: Synthesised from $(E)-N$-benzyl- $N$-(1,2-dichlorovinyl)benzamide (250 mg, $0.817 \mathrm{mmol}, 1.0$ equiv.) in anhydrous TBME (8.2 mL) using LiHMDS (freshly prepared according to example procedure $\mathbf{1 . 3 f}, 1.2$ equiv.). Note: This elimination reaction was conducted at room temperature $\left(\sim 21^{\circ} \mathrm{C}\right)$. The diarylzinc solution was prepared using anhydrous toluene $(2.5 \mathrm{~mL})$, 4-chlorophenylmagnesium bromide (2.45 $\mathrm{mL}$ of a $1.0 \mathrm{M}$ solution in $\mathrm{Et}_{2} \mathrm{O}, 2.45 \mathrm{mmol}, 3.0$ equiv.), zinc(II) chloride ( $0.65 \mathrm{~mL}$ of a $1.9 \mathrm{M}$ solution in 2-MeTHF, $1.22 \mathrm{mmol}, 1.5$ equiv.) and anhydrous TMEDA (1.22 mL, $8.17 \mathrm{mmol}, 10.0$ equiv.), and the reaction conducted using $\mathrm{CuCN} \cdot 2 \mathrm{LiCl}(10 \mu \mathrm{L}$ of a $1.0 \mathrm{M}$ solution in THF, $10 \mu \mathrm{mol}, 1.25 \mathrm{~mol} \%)$. Upon completion, the reaction was worked up and extracted as for example procedure 1.3f. Column chromatography ( $5 \% \mathrm{Et}_{2} \mathrm{O} /$ pentane) afforded a pale yellow oil, which was crystallised at $-20^{\circ} \mathrm{C}$ overnight from heptane $(\sim 2 \mathrm{~mL})$ plus a couple of drops of benzene to give the title compound (193 mg, $0.558 \mathrm{mmol}, 68 \%$ ) as colourless crystals. Note: This compound begins to decompose within hours in $\mathrm{C}_{6} \mathrm{D}_{6}$, but the crystals were found to be stable.

m.p. $53-54{ }^{\circ} \mathrm{C}$;

$\mathbf{R}_{\mathbf{f}} 0.49\left(10 \% \mathrm{Et}_{2} \mathrm{O} /\right.$ pentane $)$;

IR (thin film, $v_{\max } / \mathrm{cm}^{-1}$ ) 3064, 3032, 2242, 1672, 1493, 1447, 1389, 1356, 1289, 1244, 1123, 1089 , $1075,1014,962,826,700$;

${ }^{1}$ H NMR $\left(400 \mathrm{MHz}, \mathrm{C}_{6} \mathrm{D}_{6}\right) \delta_{\mathrm{H}} 7.84-7.77(2 \mathrm{H}, \mathrm{m}, H 3), 7.45-7.37(2 \mathrm{H}, H 5), 7.16-7.11(2 \mathrm{H}, \mathrm{m}, H 6)$, 7.11-7.06 (1H, m, H7), 7.06-7.02 (1H, m, H1), 7.02-6.96 (2H, m, H2), 6.87-6.81 (2H, m, H8), 6.77$6.72(2 \mathrm{H}, \mathrm{m}, H 9), 4.79(2 \mathrm{H}, \mathrm{s}, H 4)$;

${ }^{13}$ C NMR $\left(101 \mathrm{MHz}, \mathrm{C}_{6} \mathrm{D}_{6}\right) \delta_{\mathrm{C}} 169.9,136.6,134.2,133.5,131.8,131.5,129.2(2 \mathrm{C}), 128.9,128.8$, $128.3,127.9,122.0,87.2,72.8,52.9$;

HRMS We were unable to obtain an accurate mass (ES+ or $\mathrm{CI}+$ ) due to decomposition upon ionisation. 


\section{5c Amide Scope: Miscellaneous}

$N$-Phenyl- $N$-((1E,3E)-1,2,4-trichloro-5-oxo-3-phenyl-5-(phenylamino)penta-1,3-dien-1yl)benzamide, $16 \& N$-(2-(4-Chlorophenyl)-2-oxoethyl)- $N$-phenylbenzamide, 18a
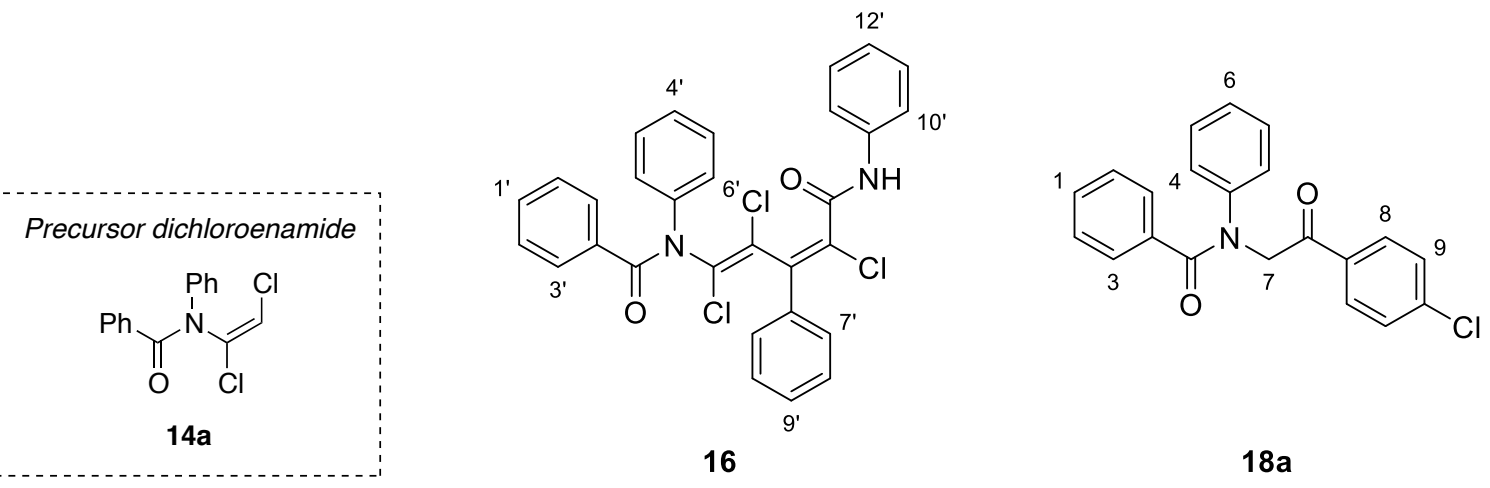

$18 \mathrm{a}$

Following example procedure 1.3f: Synthesised from (E)-N-(1,2-dichlorovinyl)- $N$-phenylbenzamide (200 mg, $0.685 \mathrm{mmol}, 1.0$ equiv.) in anhydrous TBME (6.9 mL) using LiHMDS (freshly prepared according to example procedure 1.3f, 1.2 equiv.) at $0{ }^{\circ} \mathrm{C}$. The diarylzinc solution was prepared using anhydrous toluene $(2.0 \mathrm{~mL})$, 4-chlorophenylmagnesium bromide $(2.05 \mathrm{~mL}$ of a $1.0 \mathrm{M}$ solution in $\mathrm{Et}_{2} \mathrm{O}, 2.05 \mathrm{mmol}, 3.0$ equiv.), zinc(II) chloride (0.54 mL of a $1.9 \mathrm{M}$ solution in 2-MeTHF, $1.03 \mathrm{mmol}$, 1.5 equiv.) and anhydrous TMEDA (1.03 mL, $8.56 \mathrm{mmol}, 10$ equiv.), and the reaction conducted using $\mathrm{CuCN} \cdot 2 \mathrm{LiCl}(9 \mu \mathrm{L}$ of a $1.0 \mathrm{M}$ solution in THF, $9 \mu \mathrm{mol}, 1.25 \mathrm{~mol} \%)$. Upon completion, the reaction was worked up and extracted as for example procedure 1.3f. Column chromatography (20\% $\rightarrow 30 \%$ EtOAc/pentane) afforded trichloroenamide $\mathbf{1 6}$ as a yellow oil and $\delta$-ketoamide 18a as a white powder and. Crystallisation of trichloroenamide $\mathbf{1 6}$ from heptane plus a couple of drops of $\mathrm{Et}_{2} \mathrm{O}$ afforded $40.2 \mathrm{mg}(73.4 \mu \mathrm{mol}, 21 \%)$ as colourless crystals. Recrystallisation of $\delta$-ketoamide 18a from $\mathrm{MeOH} / \mathrm{H}_{2} \mathrm{O}(\sim 5: 1)$ afforded $117 \mathrm{mg}(0.334 \mathrm{mmol}, 49 \%)$ as colourless needles. Both sets of crystals were suitable for X-ray diffraction;

- Data for trichloroenamide 16:

m.p. $138-140{ }^{\circ} \mathrm{C}$;

$\mathbf{R}_{\mathbf{f}} 0.29$ (30\% EtOAc/40-60 petroleum ether);

IR (thin film, $v_{\max } / \mathrm{cm}^{-1}$ ) 3305, 2981, 2888, 1668, 1599, 1533, 1492, 1443, 1383, 1319, 1270, 1157 , $1075,953,909,817,782,755,732,694,644$;

${ }^{1} \mathrm{H}$ NMR $\left(400 \mathrm{MHz}, \mathrm{CDCl}_{3}\right) \delta_{\mathrm{H}} 8.00(1 \mathrm{H}, \mathrm{s}, \mathrm{NH}), 7.58\left(2 \mathrm{H}\right.$, br. d, $\left.J=7.5 \mathrm{~Hz}, H 3^{\prime}\right), 7.54(2 \mathrm{H}, \mathrm{d}, J=$ $\left.7.8 \mathrm{~Hz}, H 10^{\prime}\right), 7.41-7.31$ (3H, m, $\left.H 1^{\prime}, H 11^{\prime}\right), 7.25-7.15$ (3H, m, $\left.H 2^{\prime}, H 12^{\prime}\right), 7.89-6.89$ (10H, br. m, $\left.H 4^{\prime}, H 5^{\prime}, H 6^{\prime}, H 7^{\prime}, H 8^{\prime}, H 9^{\prime}\right)$;

${ }^{13} \mathbf{C}$ NMR $\left(101 \mathrm{MHz}, \mathrm{CDCl}_{3}\right) * \delta_{\mathrm{C}} 169.8,159.8,139.6,136.9,133.7,131.3,129.4,129.3,129.10$, $129.06,128.8,128.5,126.6,128.1,127.9,126.2,125.2,120.2 . *$ Note: Due to significant broadening of peaks, four ${ }^{13} \mathrm{C}$ resonances are obscured;

HRMS (ES+) calc. for $\mathrm{C}_{30} \mathrm{H}_{22}{ }^{35} \mathrm{Cl}_{3} \mathrm{~N}_{2} \mathrm{O}_{2}[\mathrm{M}+\mathrm{H}]^{+}$547.0741, found 547.0739. 
- Data for $\delta$-ketoamide 18a:

m.p. $184{ }^{\circ} \mathrm{C}$;

$\mathbf{R}_{\mathbf{f}} 0.20$ (30\% EtOAc/40-60 petroleum ether);

IR (thin film, $v_{\max } / \mathrm{cm}^{-1}$ ) 2980, 1698, 1643, 1591, 1493, 1447, 1402, 1379, 1322, 1307, 1284, 1222, 1163, 1091, 995, 976, 821, 791, 730, 698;

${ }^{1} \mathbf{H}$ NMR $\left(400 \mathrm{MHz}, \mathrm{CDCl}_{3}\right) \delta_{\mathrm{H}} 7.99-7.89(2 \mathrm{H}, \mathrm{m}, H 8), 7.50-7.42(2 \mathrm{H}, \mathrm{m}, H 9), 7.42-7.33(2 \mathrm{H}, \mathrm{m}$, $H 3), 7.28-7.23$ (1H, m, H1), 7.23-7.10 (7H, m, H2, H4, H5, H6), 5.29 (2H, s, H7);

${ }^{13} \mathbf{C}$ NMR $\left(101 \mathrm{MHz}, \mathrm{CDCl}_{3}\right) \delta_{\mathrm{C}} 192.5,170.3,143.9,140.1,135.1,133.6,129.9,129.4,129.12$, $129.09,128.9,127.7,127.5,126.9,57.0$;

HRMS (ES+) calc. for $\mathrm{C}_{21} \mathrm{H}_{16}{ }^{35} \mathrm{ClNNaO}_{2}[\mathrm{M}+\mathrm{Na}]^{+} 372.0762$, found 372.0763 . 

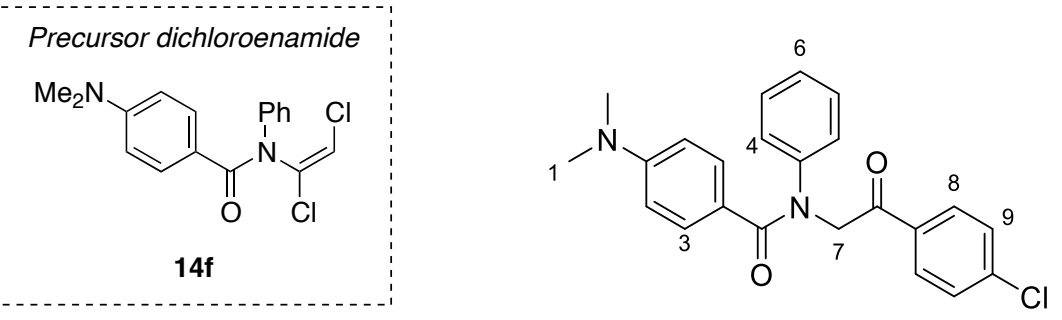

Following example procedure 1.3f: Synthesised from $(E)-N-(1,2$-dichlorovinyl)-4-(dimethylamino)$\mathrm{N}$-phenylbenzamide (100 mg, $0.298 \mathrm{mmol}, 1.0$ equiv.) in anhydrous TBME (3 mL) using LiHMDS (freshly prepared according to example procedure 1.3f, 1.2 equiv.). Note: This elimination reaction was conducted at room temperature $\left(\sim 21^{\circ} \mathrm{C}\right)$. The diarylzinc solution was prepared using anhydrous toluene $(1.0 \mathrm{~mL})$, 4-chlorophenylmagnesium bromide $\left(0.89 \mathrm{~mL}\right.$ of a $1.0 \mathrm{M}$ solution in $\mathrm{Et}_{2} \mathrm{O}$, $0.894 \mathrm{mmol}, 3.0$ equiv.), zinc(II) chloride (0.24 mL of a 1.9 M solution in 2-MeTHF, $0.447 \mathrm{mmol}, 1.5$ equiv.) and anhydrous TMEDA ( $0.45 \mathrm{~mL}, 2.98 \mathrm{mmol}, 10$ equiv.), and the reaction conducted using $\mathrm{CuCN} \cdot 2 \mathrm{LiCl}(4 \mu \mathrm{L}$ of a $1.0 \mathrm{M}$ solution in THF, $4 \mu \mathrm{mol}, 1.25 \mathrm{~mol} \%)$. Upon completion, the reaction was worked up and extracted as for example procedure 1.3f. Column chromatography $(20 \% \rightarrow 30 \%$ EtOAc/pentane) afforded the title compound as a yellow solid. Vapour diffusion of pentane into a concentrated solution of this material in toluene/EtOAc (1:1) afforded the title compound (32.4 mg, $86.4 \mu \mathrm{mol}, 29 \%$ ) as colourless needles;

m.p. $175-177^{\circ} \mathrm{C}$;

$\mathbf{R}_{\mathbf{f}} 0.13$ (20\% EtOAc/40-60 petroleum ether);

IR (thin film, $v_{\max } / \mathrm{cm}^{-1}$ ) 3062, 2924, 2811, 1699, 1631, 1603, 1525, 1494, 1405, 1362, 1322, 1306, 1283, 1221, 1196, 1176, 1091, 977, 910, 823, 759, 728, 698;

${ }^{1} \mathbf{H}$ NMR $\left(400 \mathrm{MHz}, \mathrm{CDCl}_{3}\right) \delta_{\mathrm{H}} 7.99-7.89(2 \mathrm{H}, \mathrm{m}, H 8), 7.48-7.39$ (2H, m, H9), 7.33-7.27 (2H, m, $H 3), 7.27-7.18$ (4H, m, H4, H5), 7.17-7.11 (1H, m, H6), 6.47-6.38 (2H, m, H2), $5.26(2 \mathrm{H}, \mathrm{s}, H 7)$, $2.91(6 \mathrm{H}, \mathrm{s}, H 1)$;

${ }^{13} \mathbf{C}$ NMR $\left(101 \mathrm{MHz}, \mathrm{CDCl}_{3}\right) \delta_{\mathrm{C}} 193.1,170.3,151.3,145.0,139.8,133.7,131.3,131.2,129.4,129.1$, $129.0,127.4,126.3,121.2,110.3,110.2,57.3,40.0,39.9$;

HRMS (ES+) calc. for $\mathrm{C}_{23} \mathrm{H}_{22}{ }^{35} \mathrm{ClN}_{2} \mathrm{O}_{2}[\mathrm{M}+\mathrm{H}]^{+}$393.1364, found 393.1366. 


\section{References.}

[1] G. Cahiez, O. Gager, J. Buendia, Angew. Chem. Int. Ed., 2010, 49, 1278-1281;

[2] A. Basheer, I. Marek, Beilstein J. Org. Chem., 2010, 6, 77;

[3] W. Dohle, D. M. Lindsay, P. Knochel, Org. Lett., 2001, 3, 2871-2873;

[4] P. Knochel, N. Millot, A. L. Rodriguez "Preparation \& Applications of Functionalized Organozinc Compounds", 2001 Organic Reactions, Volume 58, 420-448;

[5] P. Zhao, D. B. Collum, J. Am. Chem. Soc., 2003, 125, 4008-4009;

[6] B. Darses, A. Milet, C. Philouze, A. E. Greene, J.-F. Poisson, Org. Lett., 2008, 10, 4445-4447;

[7] S. J. Mansfield, C. D. Campbell, M. W. Jones, E. A. Anderson Chem. Commun., 2015, 51, 3316; T. Wezeman, S. Zhong, M. Nieger S. Bräse, Angew. Chem. Int. Ed., 2016, 55, 3823-3827; M. Lecomte, G. Evano, Angew. Chem. Int. Ed. 2016, 55, 4547-4551;

[8] J. M. McCabe Dunn, A. Duran-Capece, B. Meehan, J. Ulis, T. Iwama, G. Gloor, G. Wong, E. Bekos, Org. Process Res. Dev., 2011, 15, 1442-1446;

[9] A. Krasovskiy, P. Knochel, Synthesis, 2006, 5, 890-891;

[10] E. J. Rayment, N. Summerhill, E. A. Anderson, J. Org. Chem., 2012, 77, 7052-7060; 


\section{NMR Spectra.}

4.1a (E)-N-(1,2-Dichlorovinyl)- $N$-phenyltosylamide, 3a

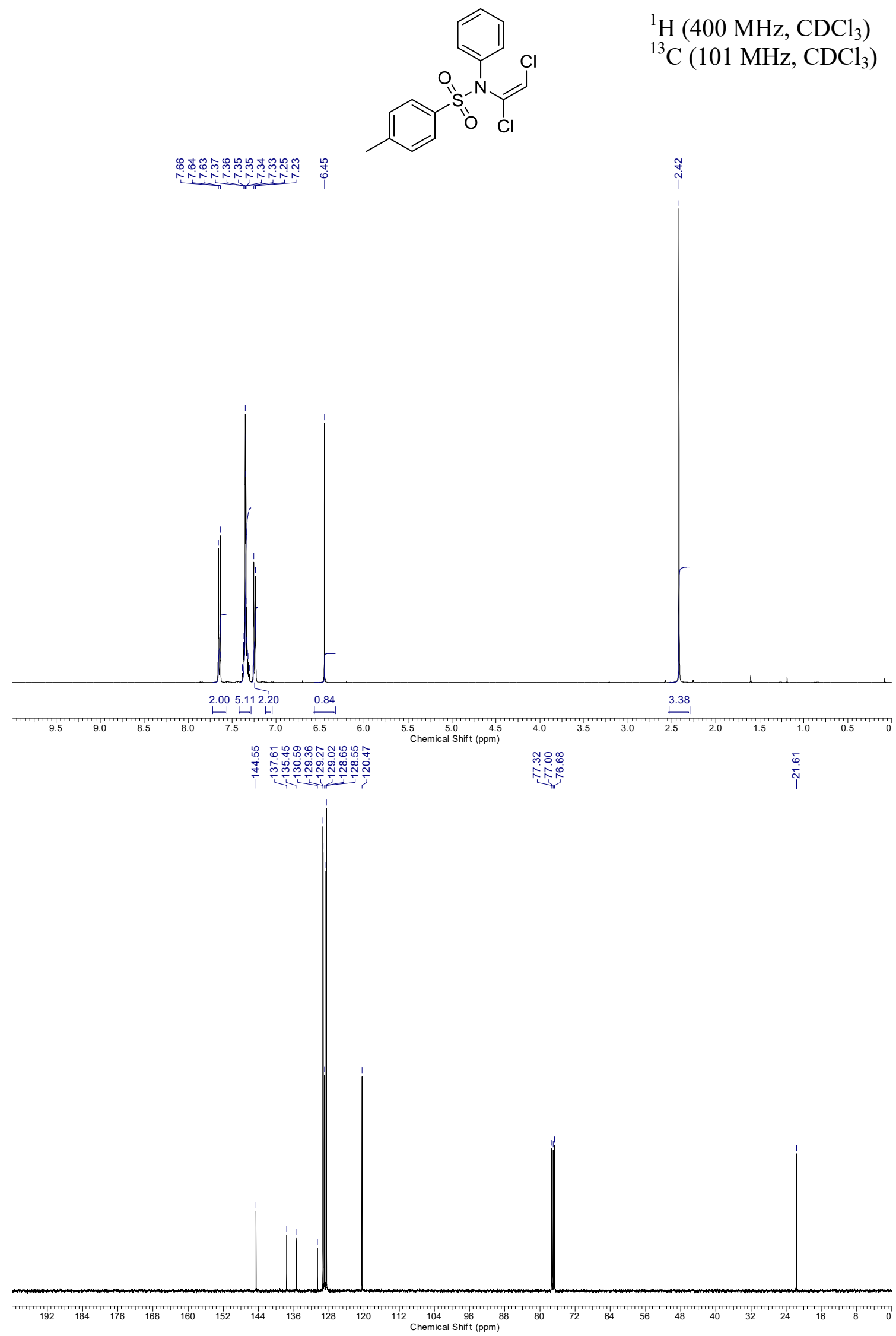




\section{1b Organometallic Scope: Ynamides}

$\mathrm{N}$-Phenyl- $\mathrm{N}$-(phenylethynyl)tosylamide, $1 \mathrm{a}$
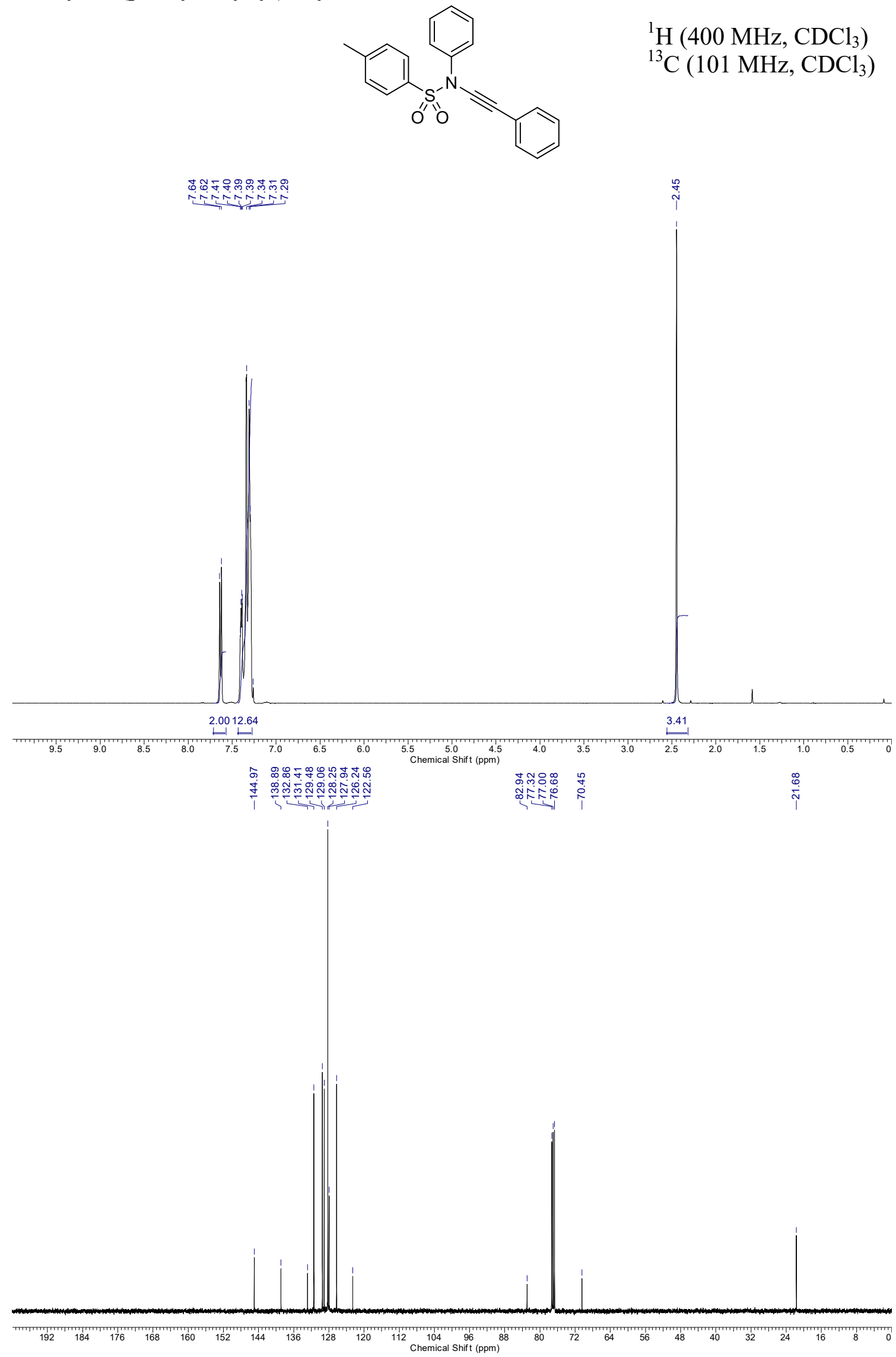
$N$-((4-(Dimethylamino)phenyl)ethynyl)- $N$-phenyltosylamide, $1 \mathrm{~b}$

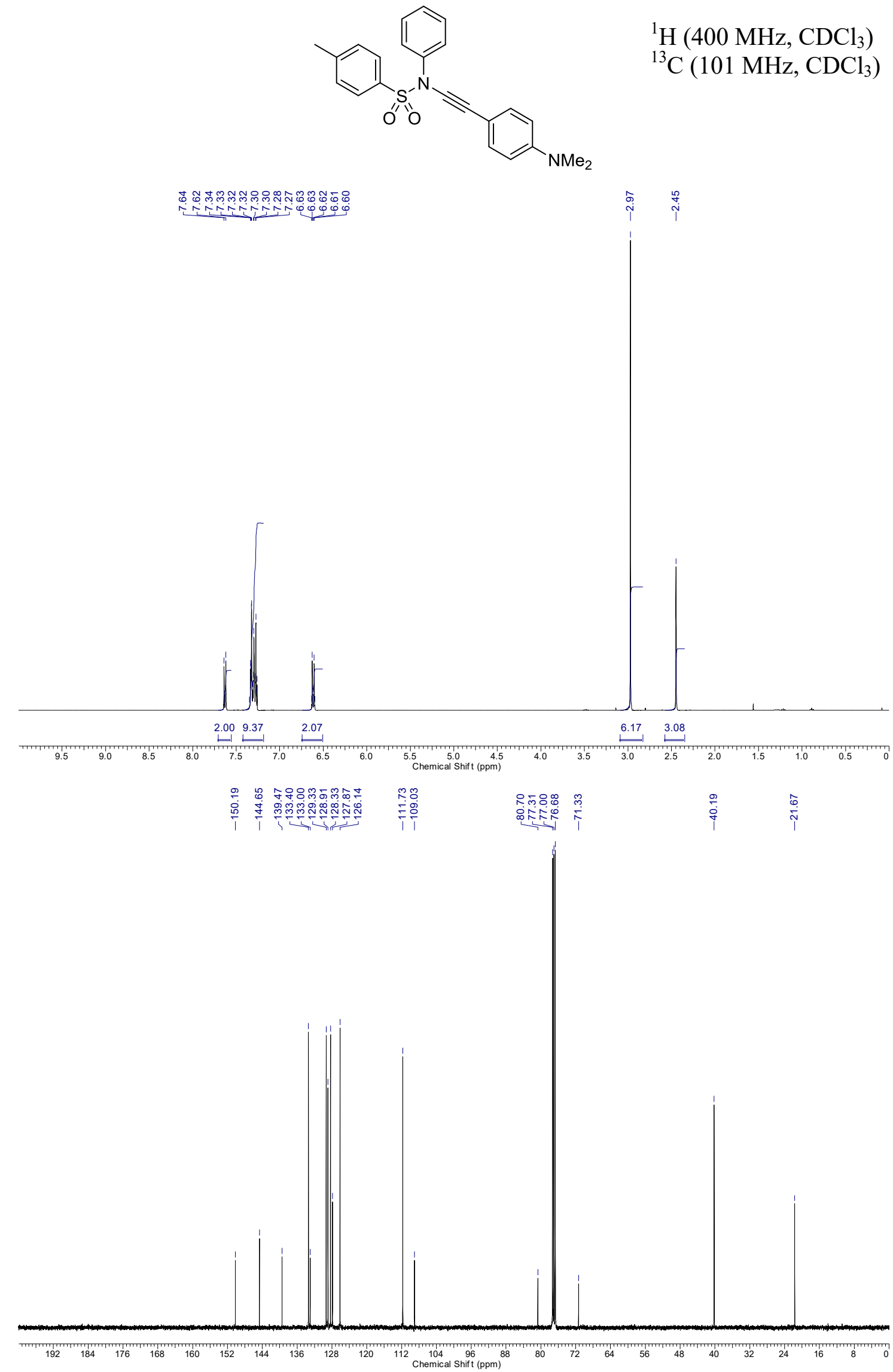


$N$-(4-(((4-Methyl- $N$-phenylphenyl)sulfonamido)ethynyl)phenyl)acetamide, 1c
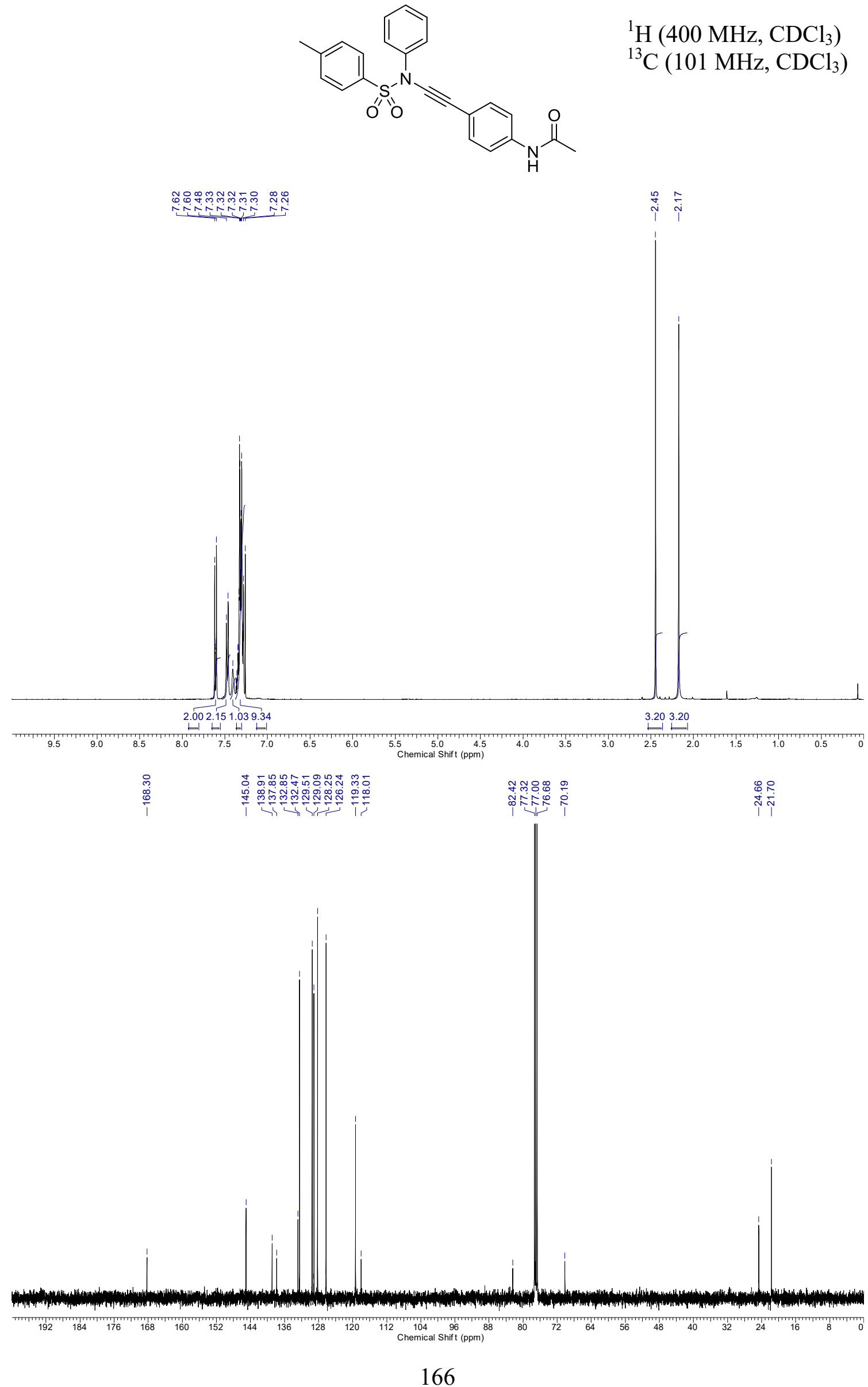
$N$-((4-Methoxyphenyl)ethynyl)- $N$-phenyltosylamide, 1d

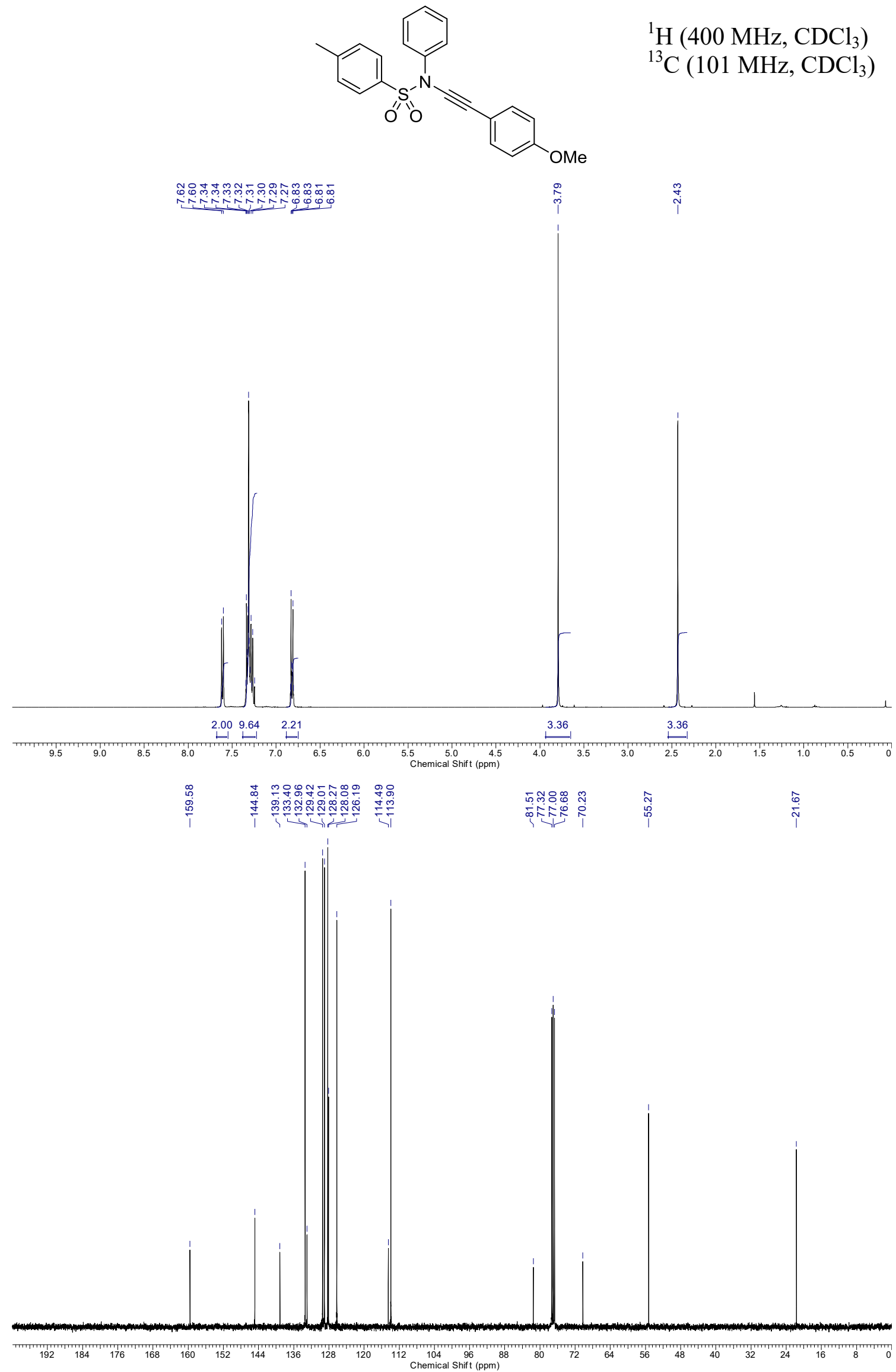


$N$-((2-Methoxyphenyl)ethynyl)- $N$-phenyltosylamide, $1 \mathrm{e}$

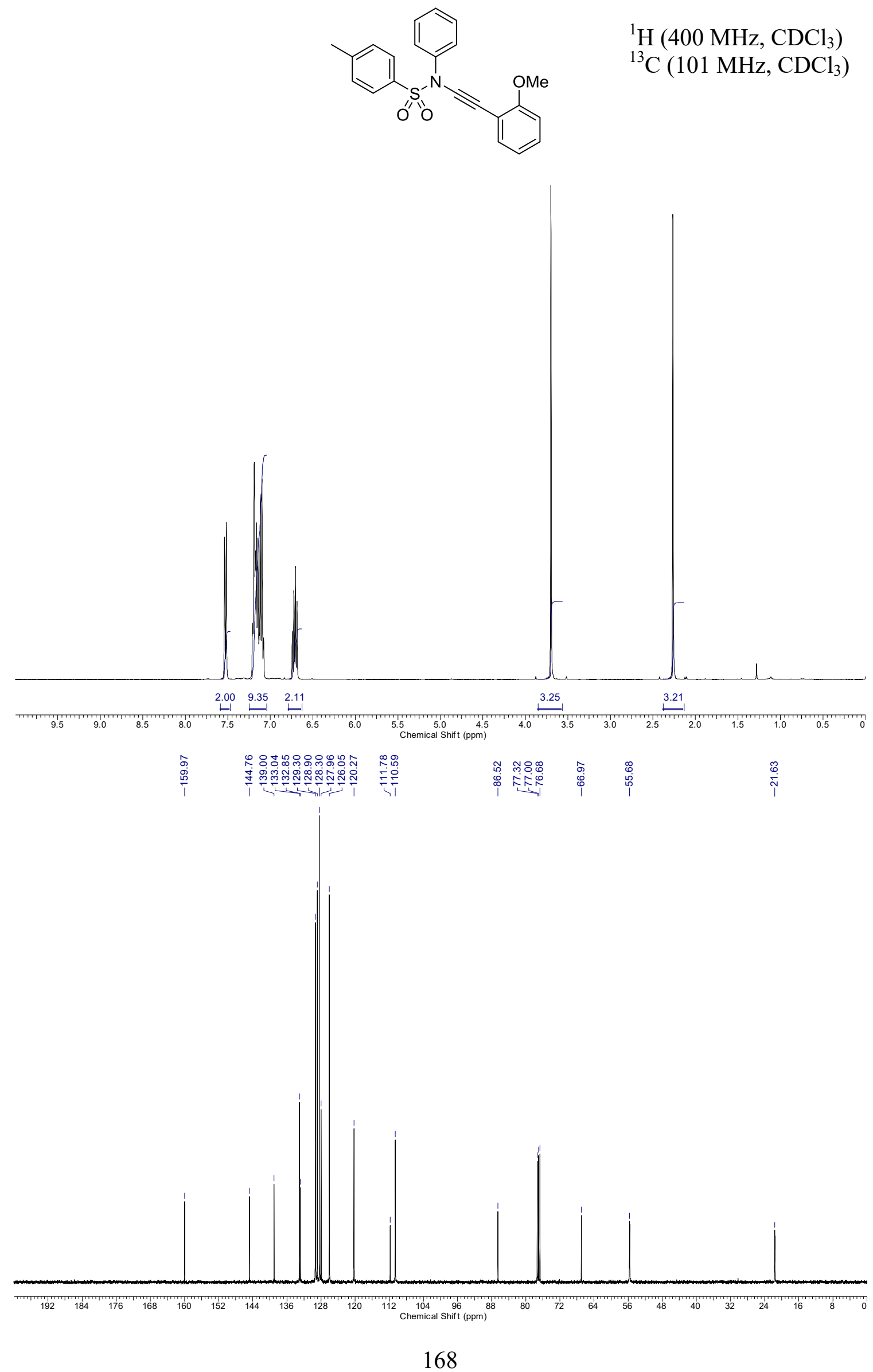


$N$-((2-Fluoro-6-methoxyphenyl)ethynyl)- $N$-phenyltosylamide, $1 \mathrm{f}$<smiles>COc1cccc(F)c1C#CN(c1ccccc1)S(=O)(=O)c1ccc(C)cc1</smiles>

${ }^{1} \mathrm{H}\left(400 \mathrm{MHz}, \mathrm{CDCl}_{3}\right)$

${ }^{13} \mathrm{C}\left(101 \mathrm{MHz}, \mathrm{CDCl}_{3}\right)$
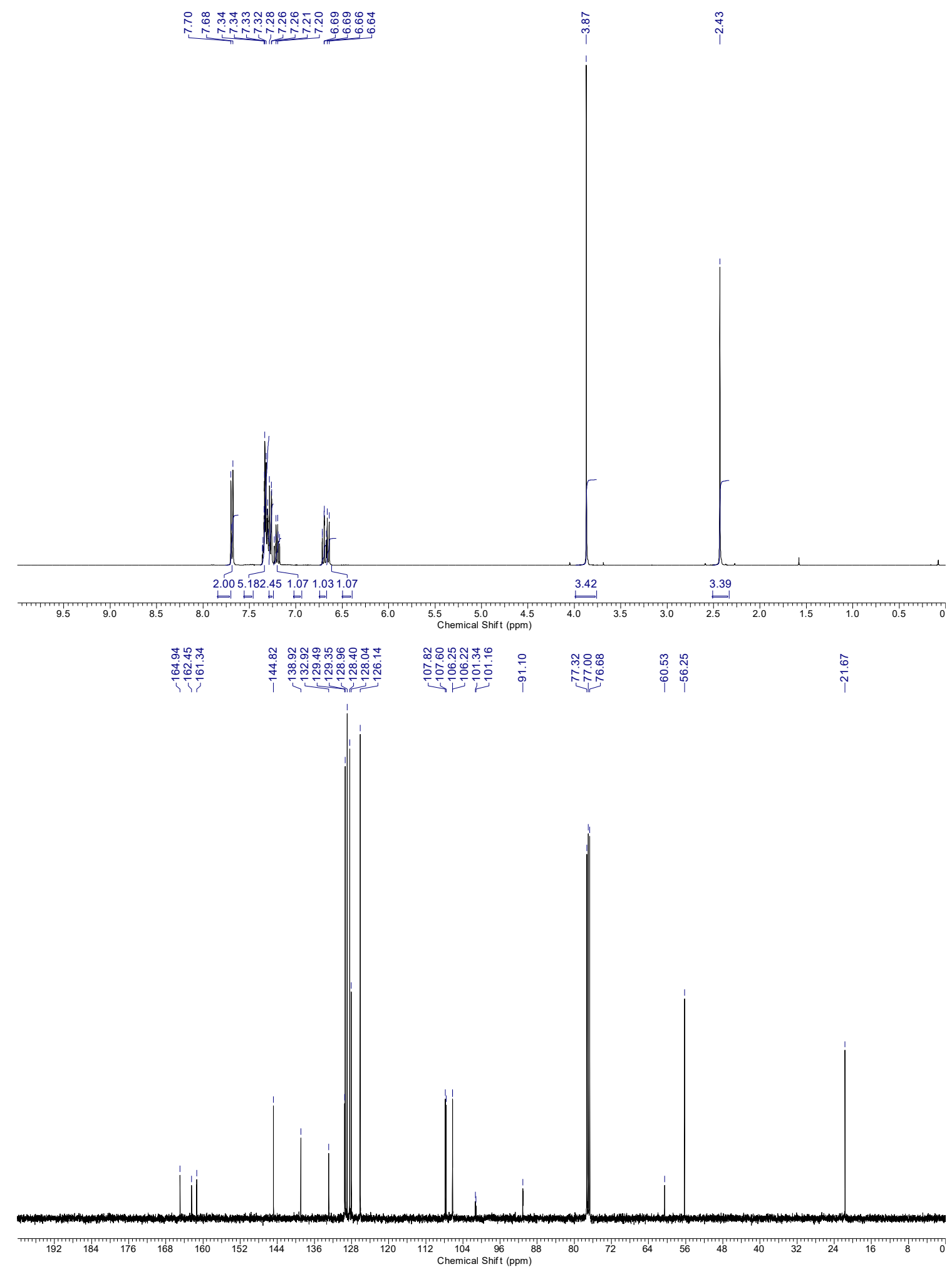
${ }^{19} \mathrm{~F}\left(376 \mathrm{MHz}, \mathrm{CDCl}_{3}\right)$

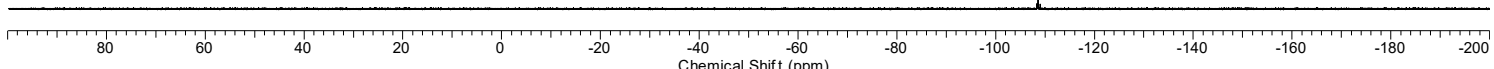


$N$-(Mesitylethynyl)- $N$-phenyltosylamide, $1 \mathrm{~g}$
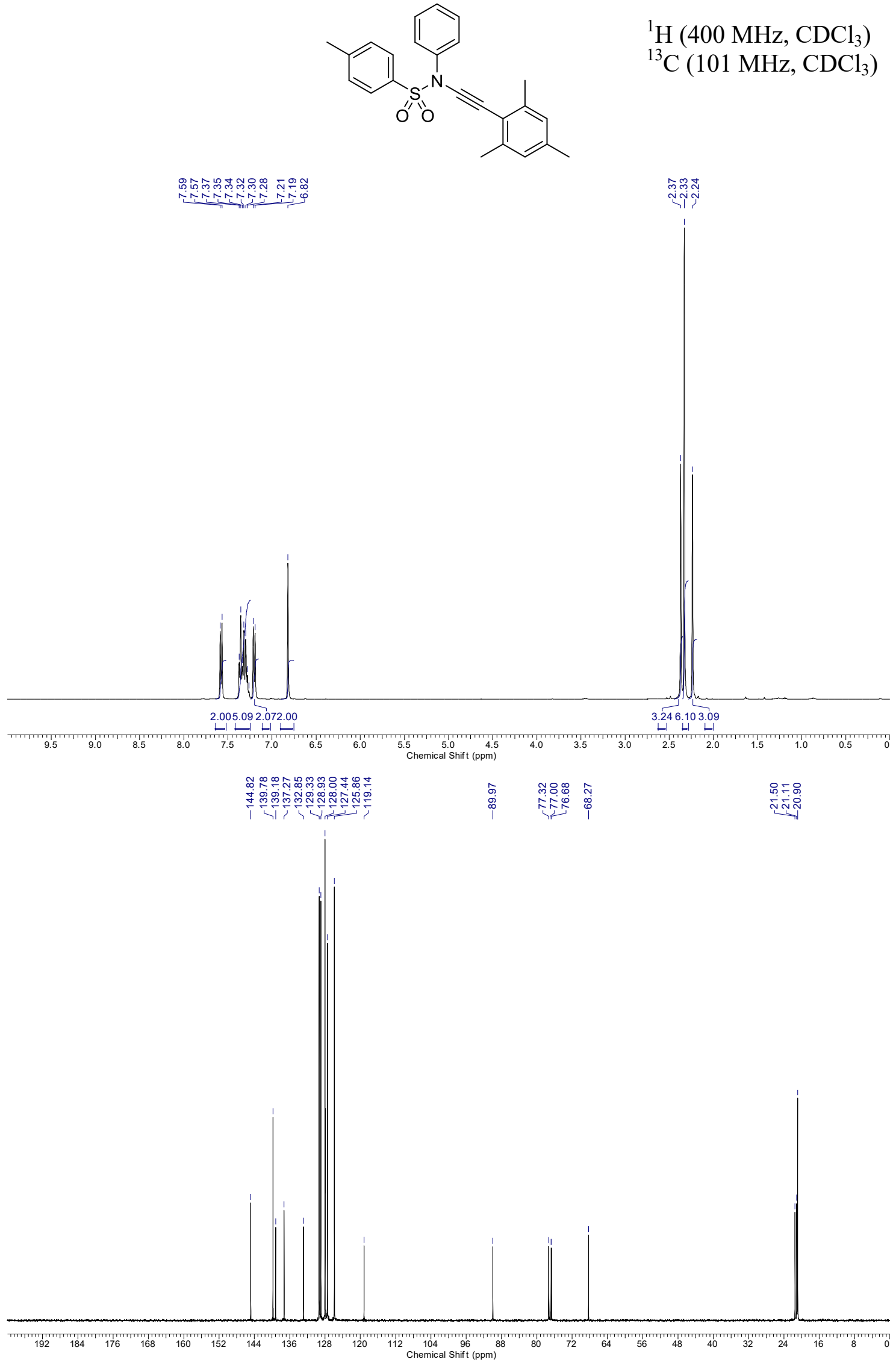
$N$-((4-Chloro-2-methylphenyl)ethynyl)- $N$-phenyltosylamide, $1 \mathrm{~h}$
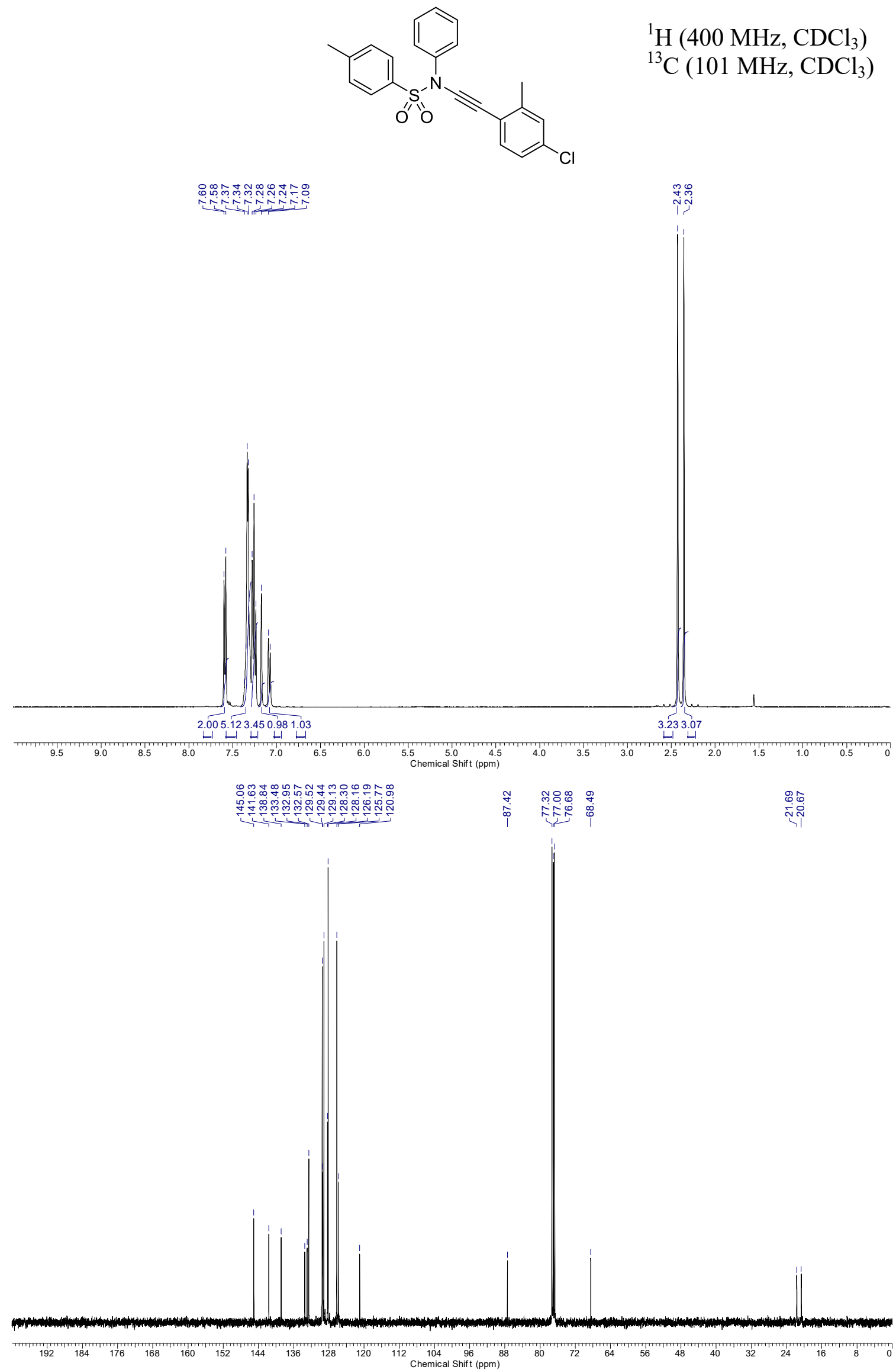
$N$-(Ferrocenylethynyl)- $N$-phenyltosylamide, $1 \mathrm{i}$

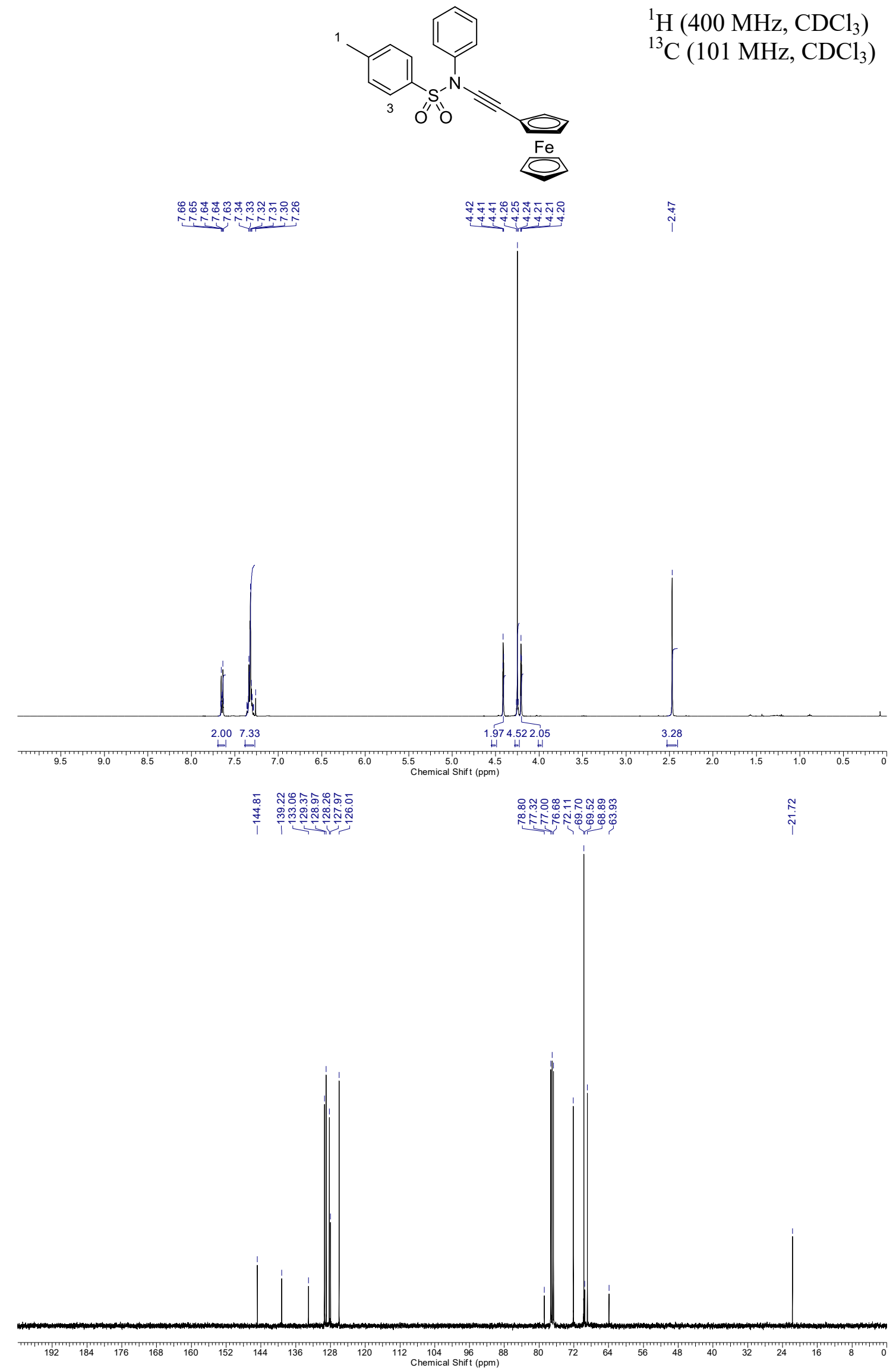


$N$-(Naphthalen-1-ylethynyl)- $N$-phenyltosylamide, $1 \mathbf{j}$
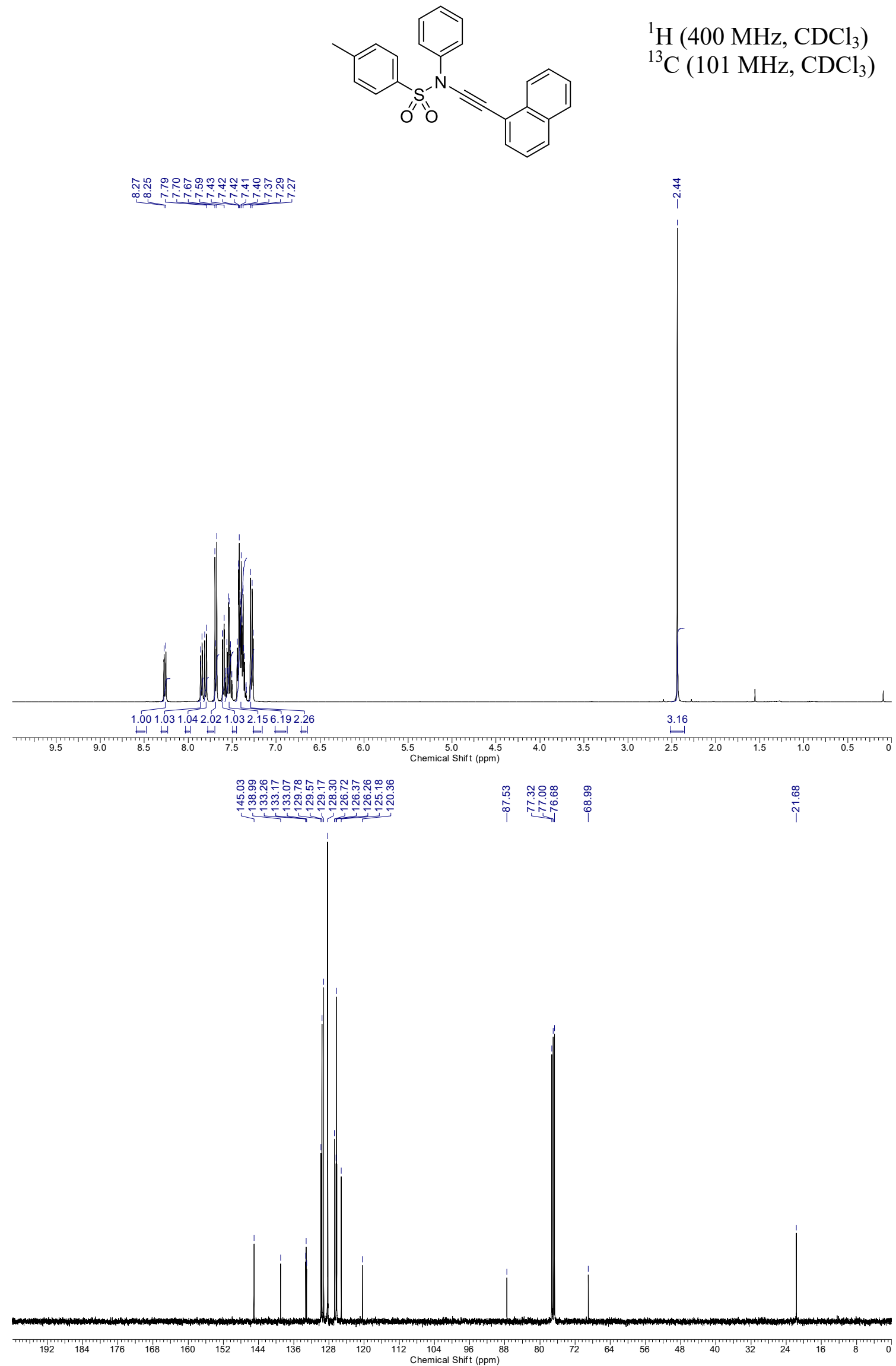
$N$-(Naphthalen-2-ylethynyl)- $N$-phenyltosylamide, $1 \mathrm{k}$

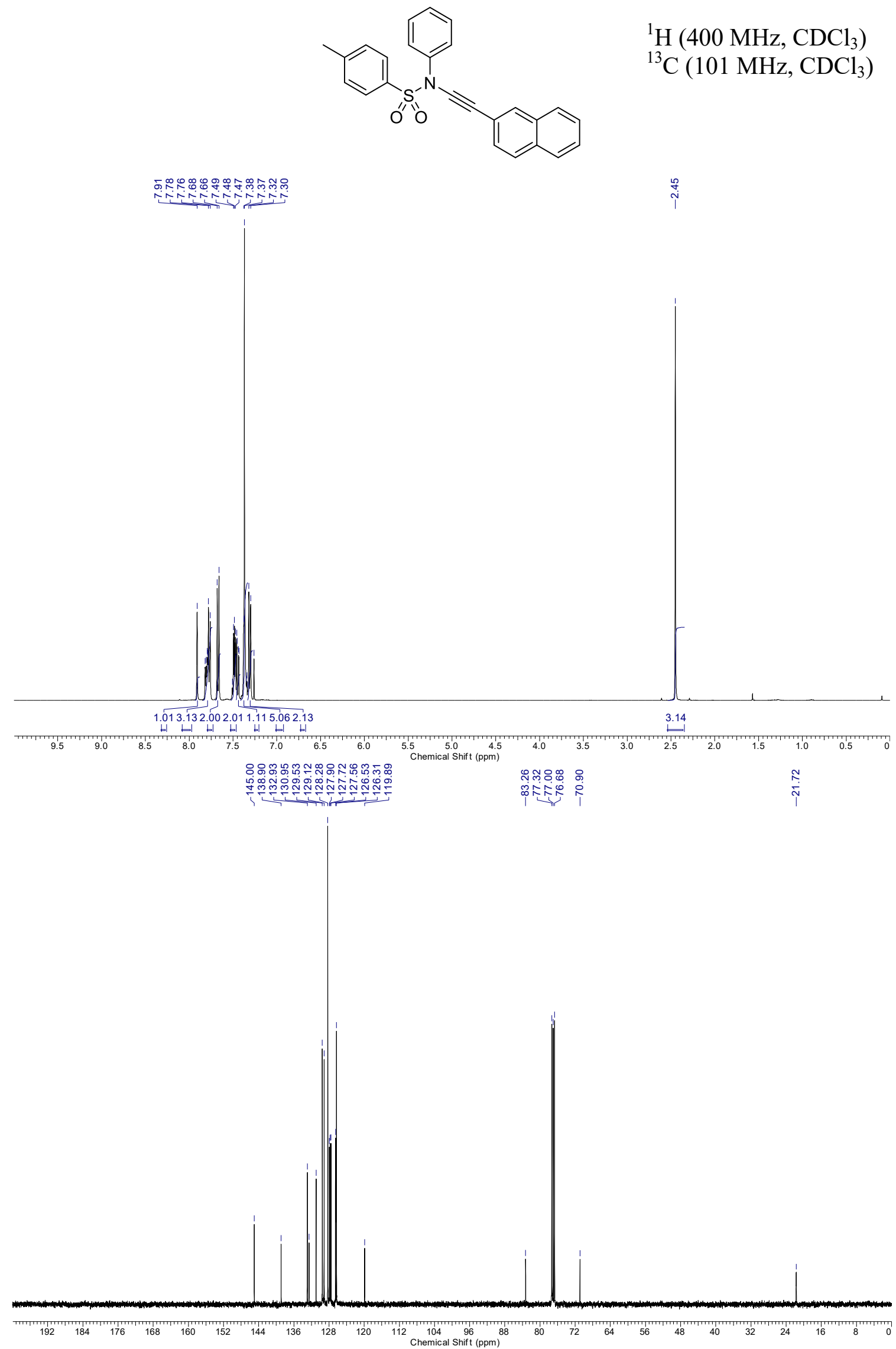


$N$-(Phenanthren-9-ylethynyl)- $N$-phenyltosylamide, 1 l
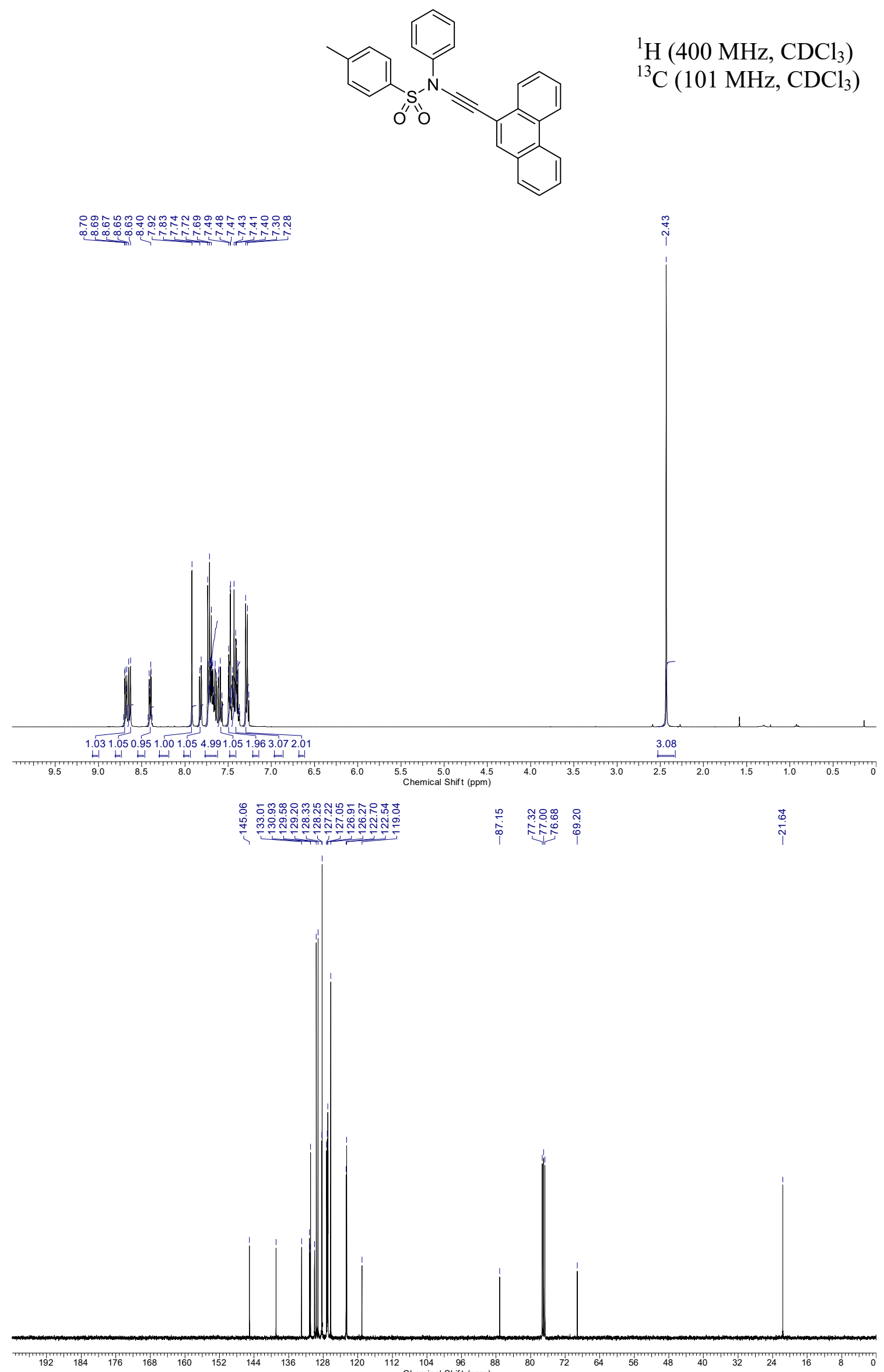
$N$-((4-Fluorophenyl)ethynyl)- $N$-phenyltosylamide, 1 m
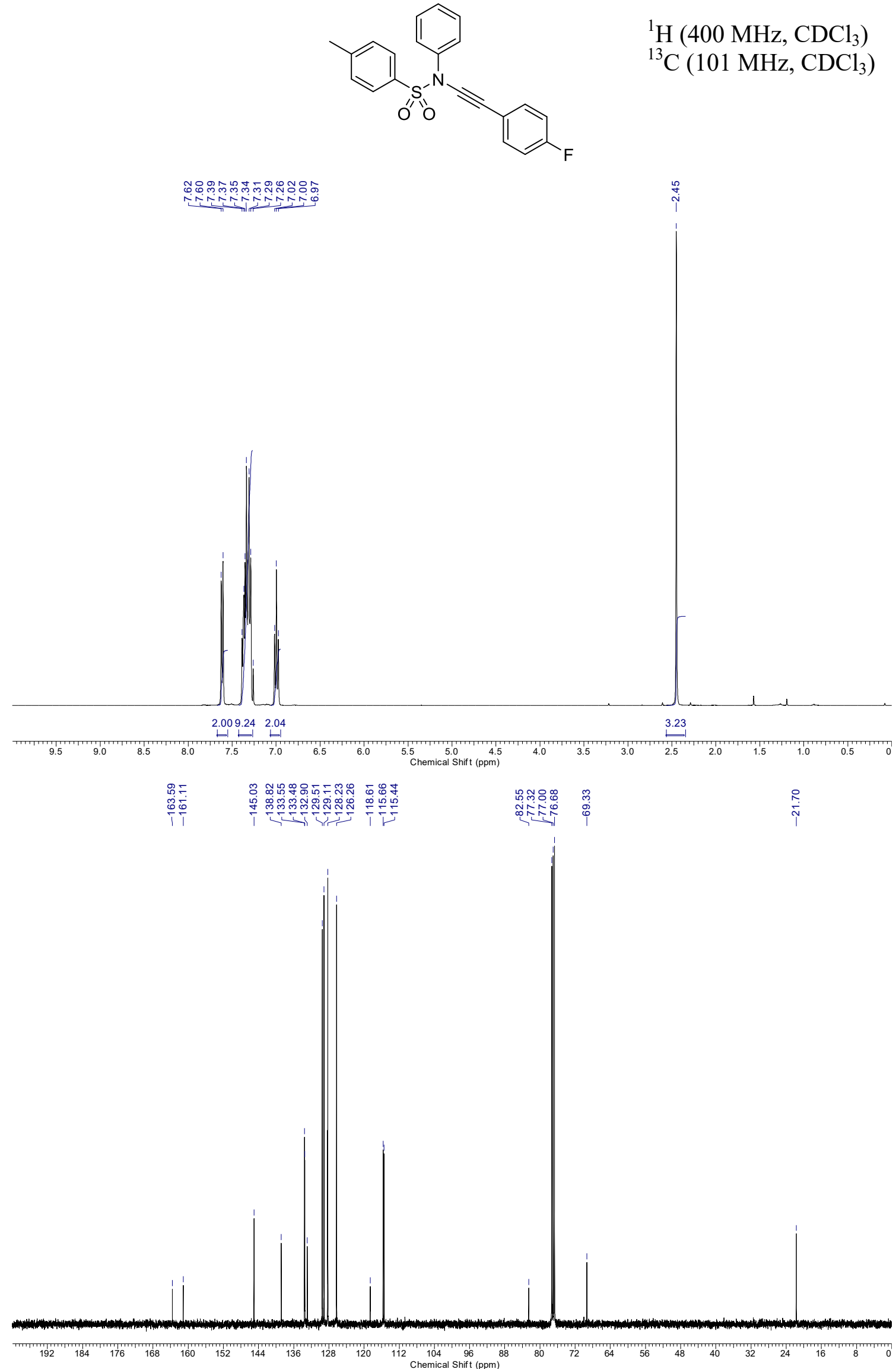


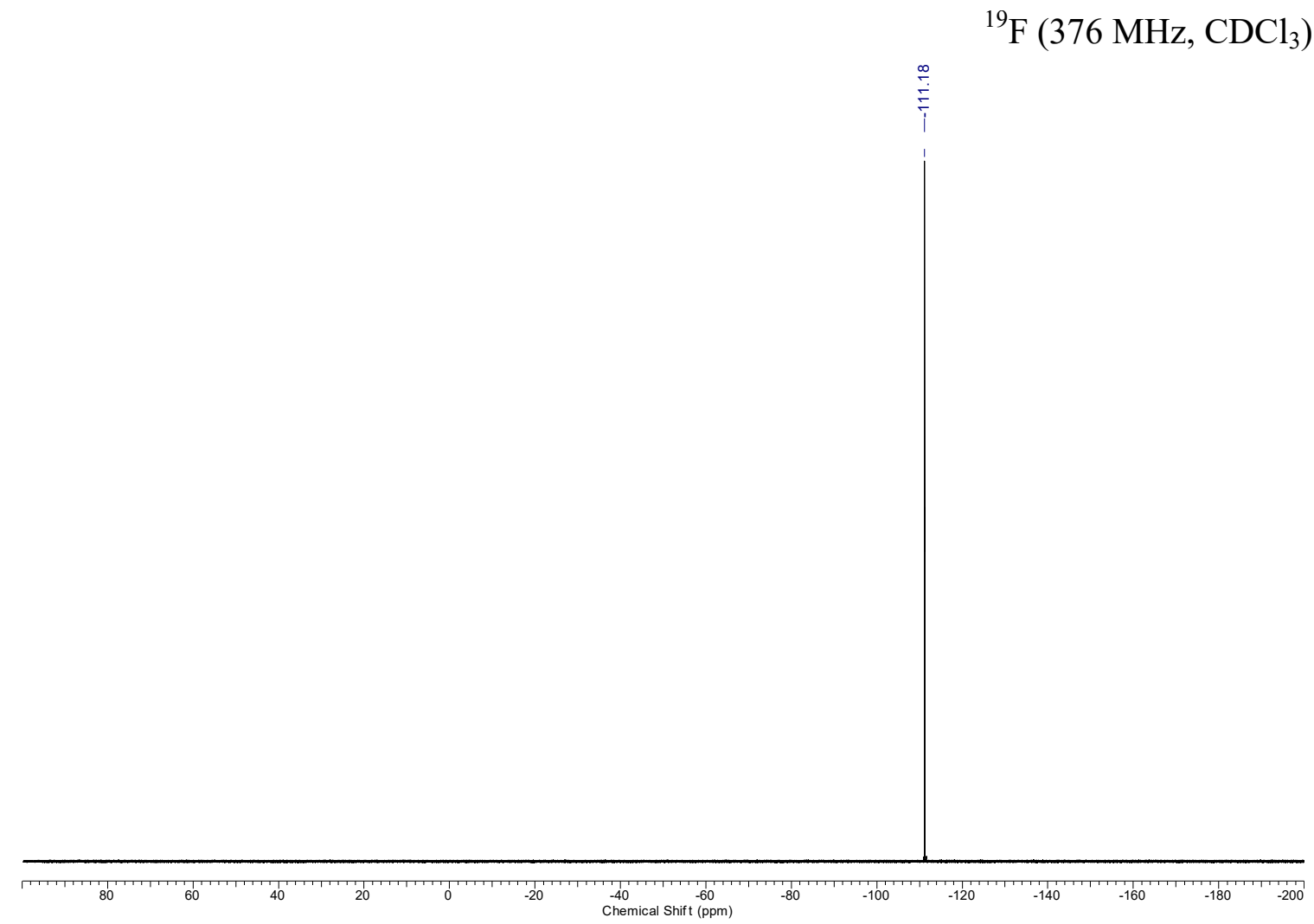


$N$-((2-Bromophenyl)ethynyl)- $N$-phenyltosylamide, 1 n
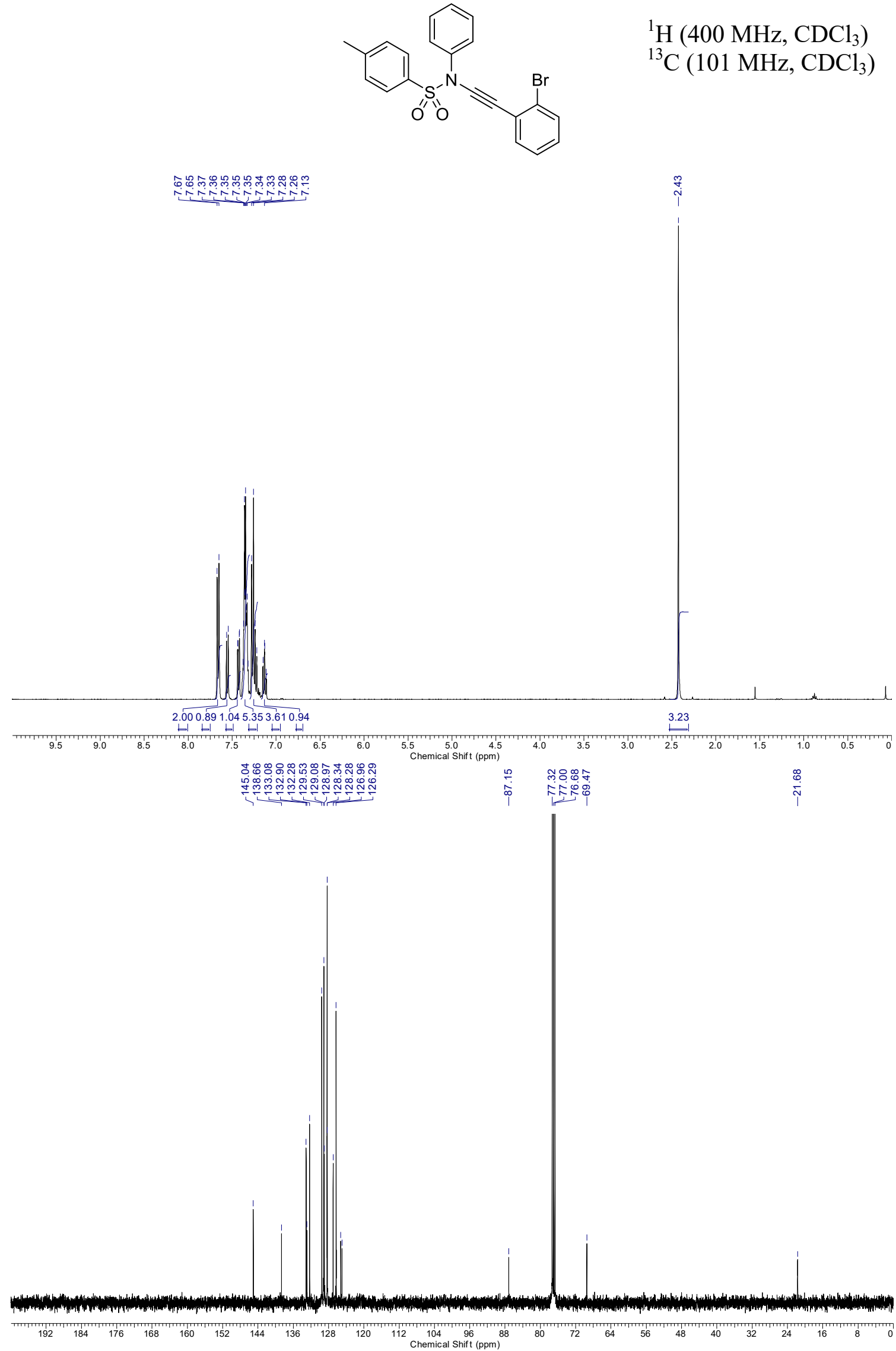
$N$-Phenyl- $N$-((4-(trifluoromethyl)phenyl)ethynyl)tosylamide, 10
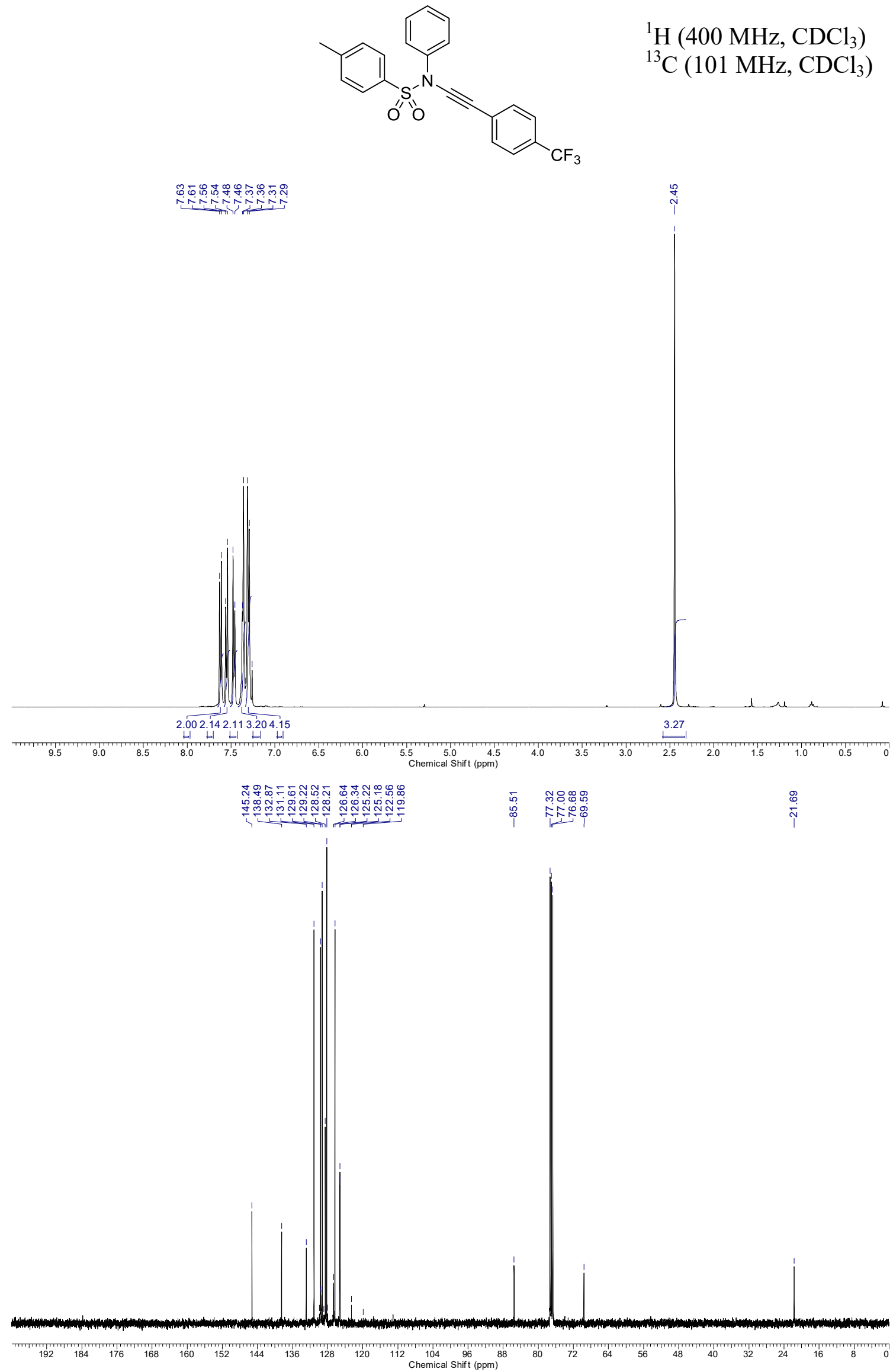
${ }^{19} \mathrm{~F}\left(376 \mathrm{MHz}, \mathrm{CDCl}_{3}\right)$

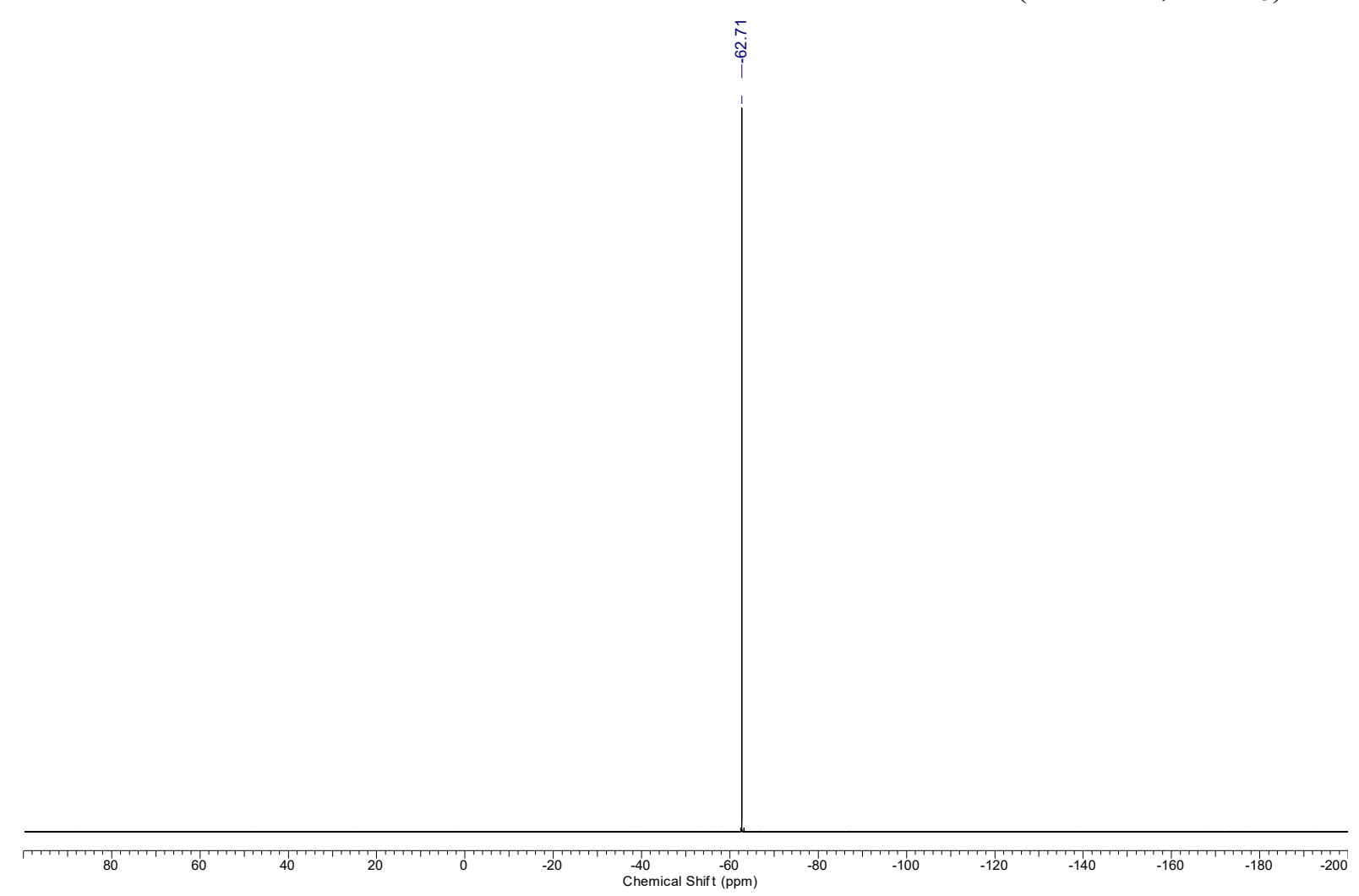


Methyl 3-(( $N$-phenyltosylamido)ethynyl)benzoate, 1p

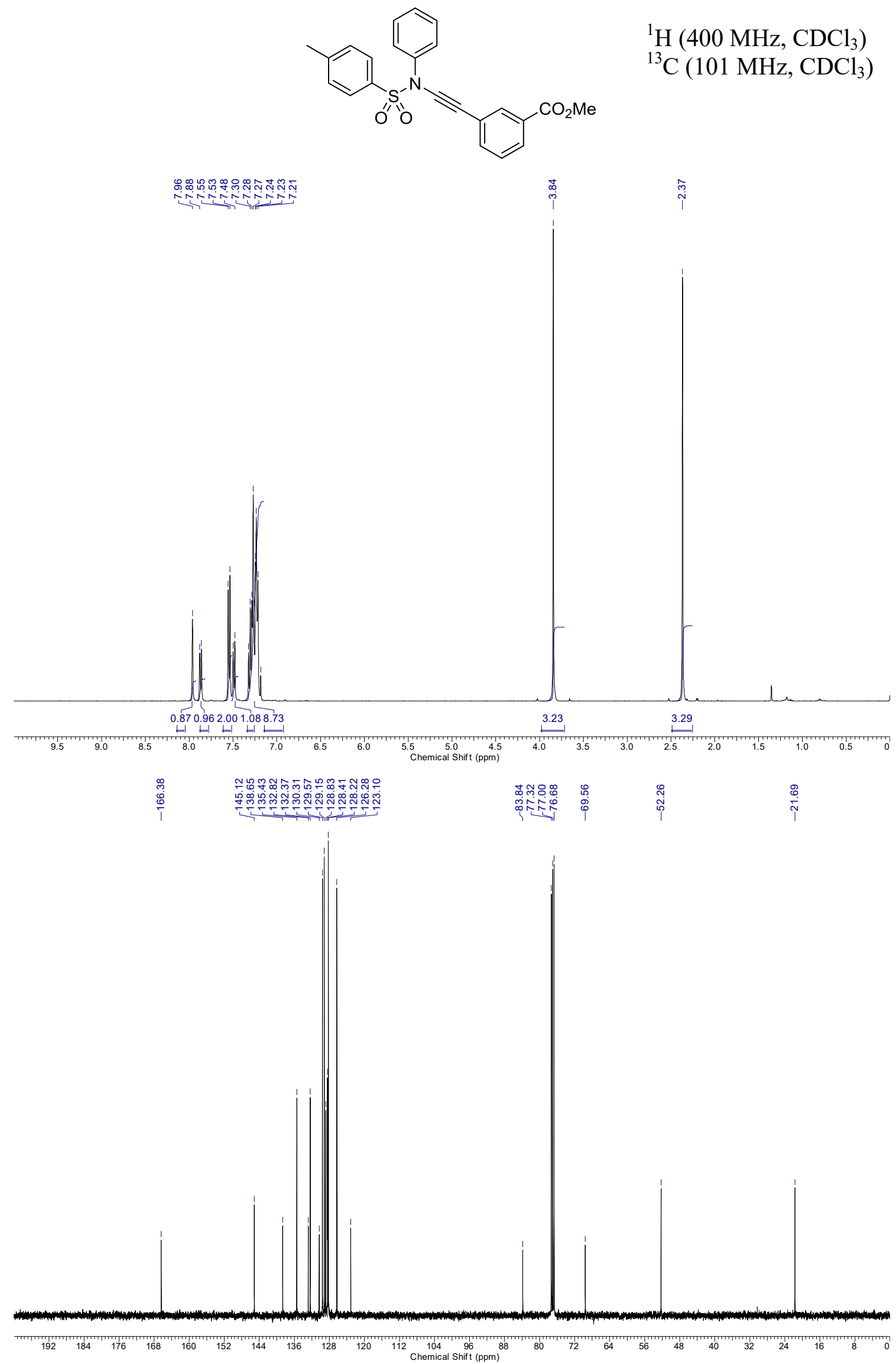


$N$-((4-(Morpholine-4-carbonyl)phenyl)ethynyl)- $N$-phenyltosylamide, 1 q
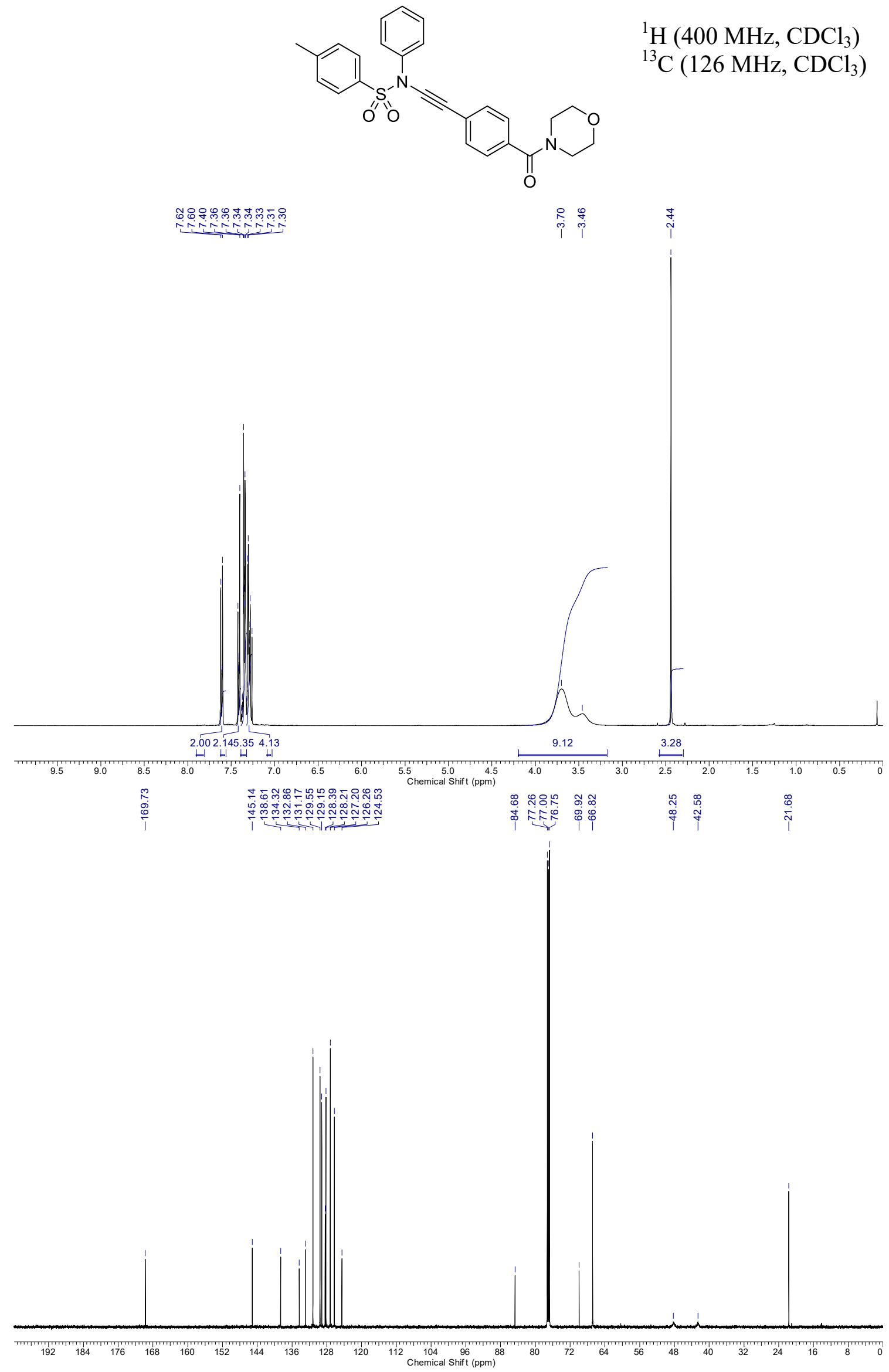
$N$-((4-Cyanophenyl)ethynyl)- $N$-phenyltosylamide, 1 r
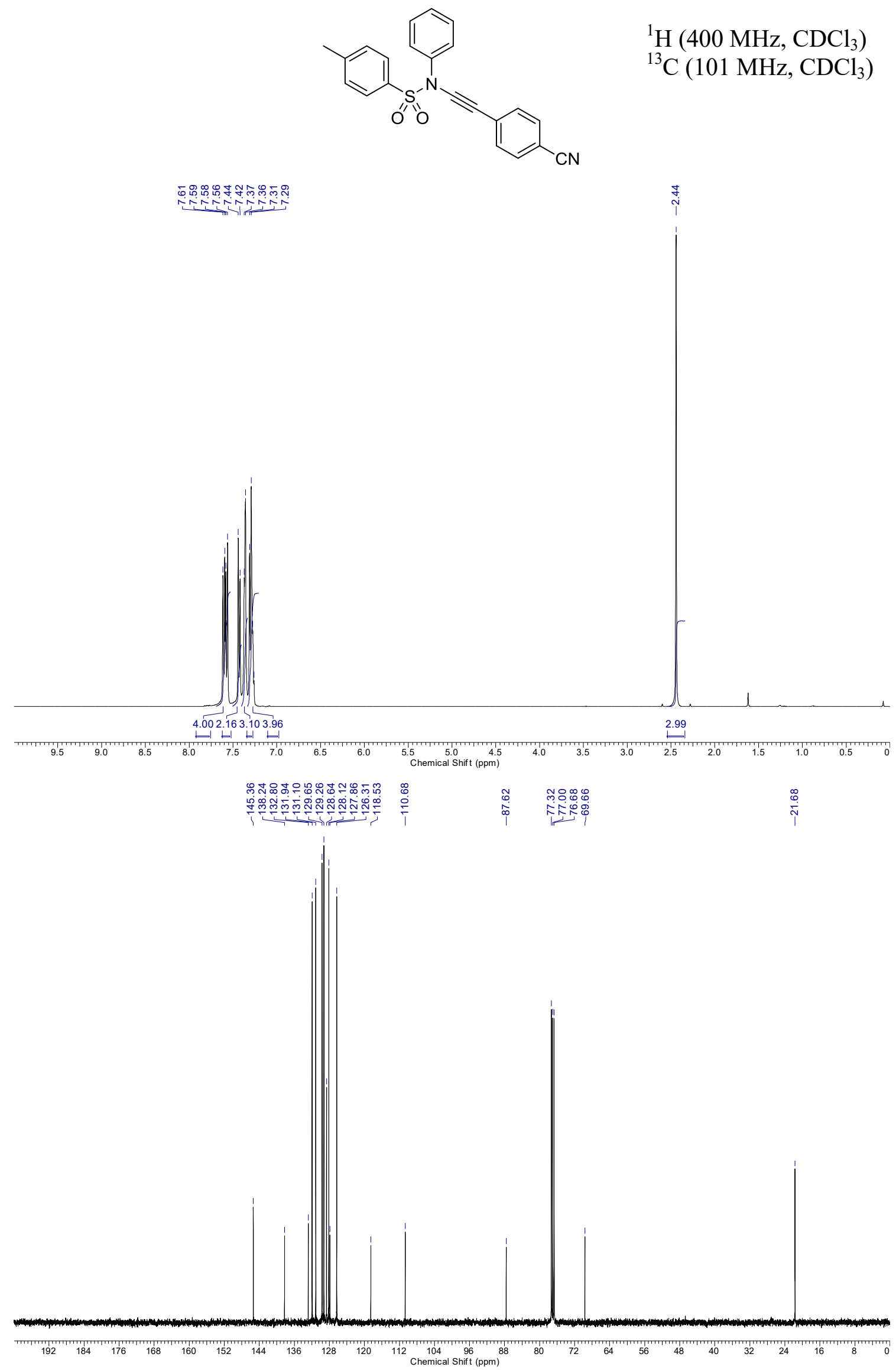
$N$-((2,6-Difluoro-3-nitrophenyl)ethynyl)- $N$-phenyltosylamide, $1 \mathrm{~s}$<smiles>Cc1ccc(S(=O)(=O)N(C#Cc2c(F)ccc([N+](=O)[O-])c2F)c2ccccc2)cc1</smiles>

${ }^{1} \mathrm{H}\left(400 \mathrm{MHz}, \mathrm{CDCl}_{3}\right)$

${ }^{13} \mathrm{C}\left(126 \mathrm{MHz}, \mathrm{CDCl}_{3}\right)$
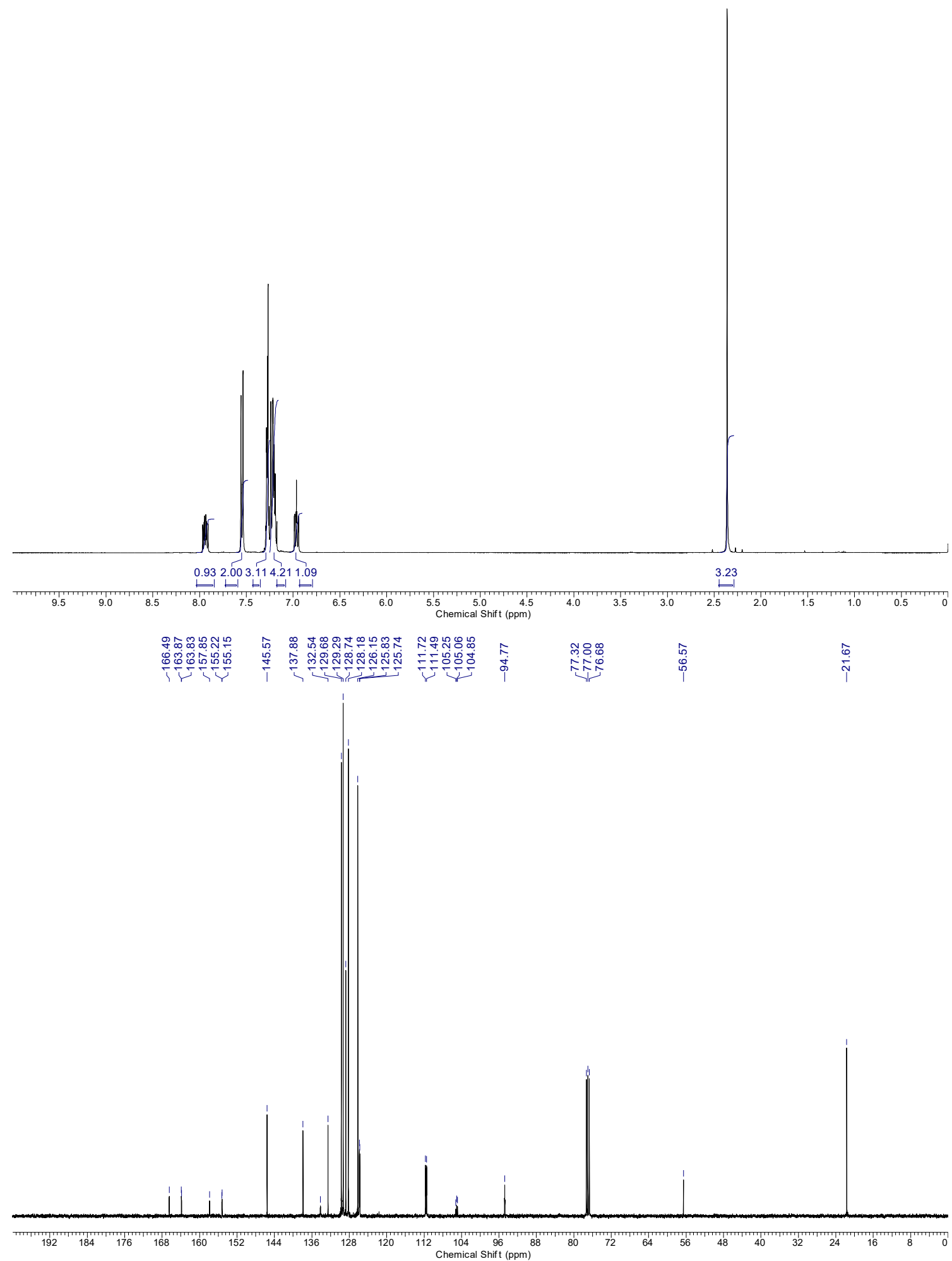


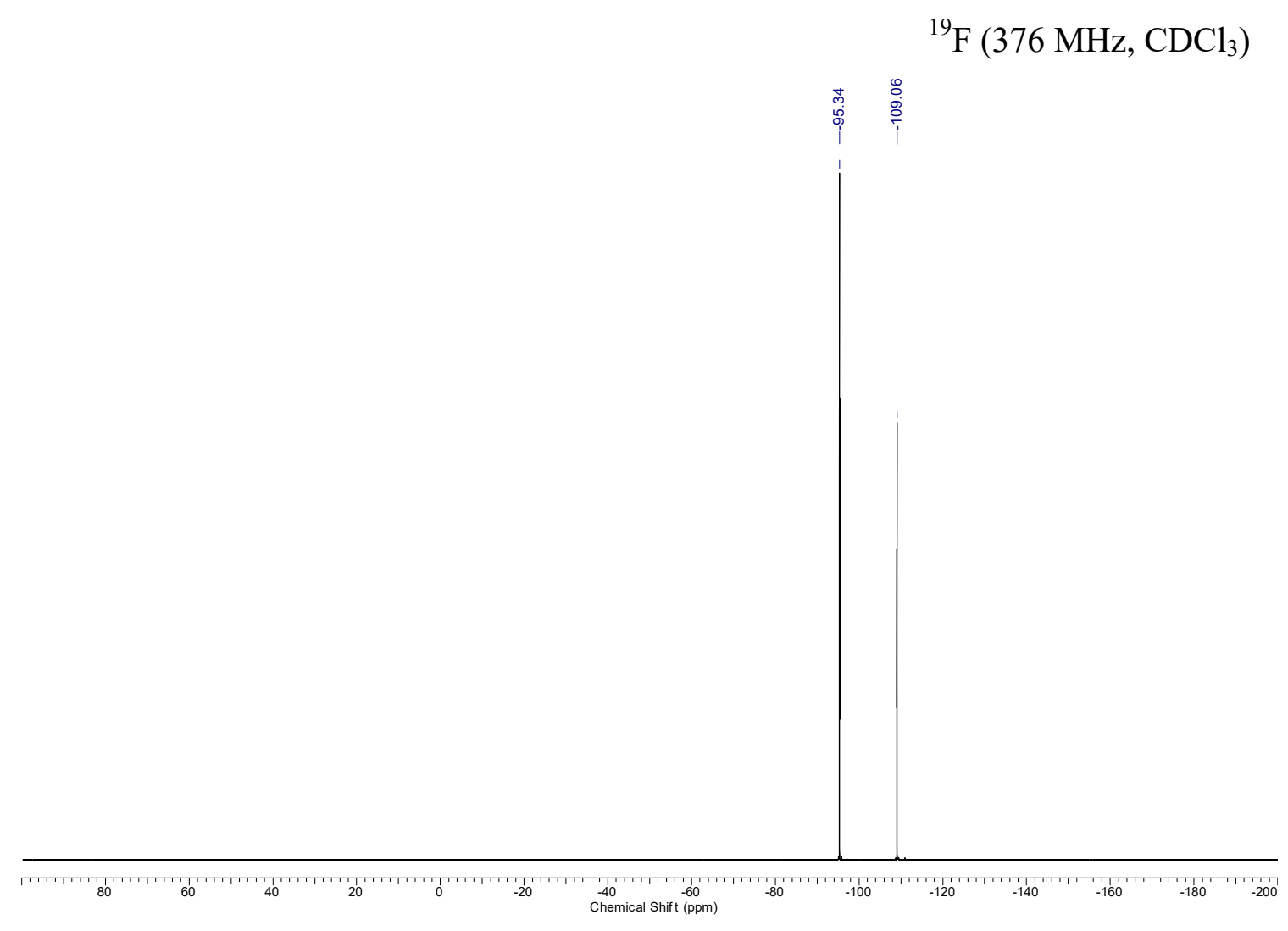


$N$-Phenyl- $N$-(thiophen-2-ylethynyl)tosylamide, 1 t
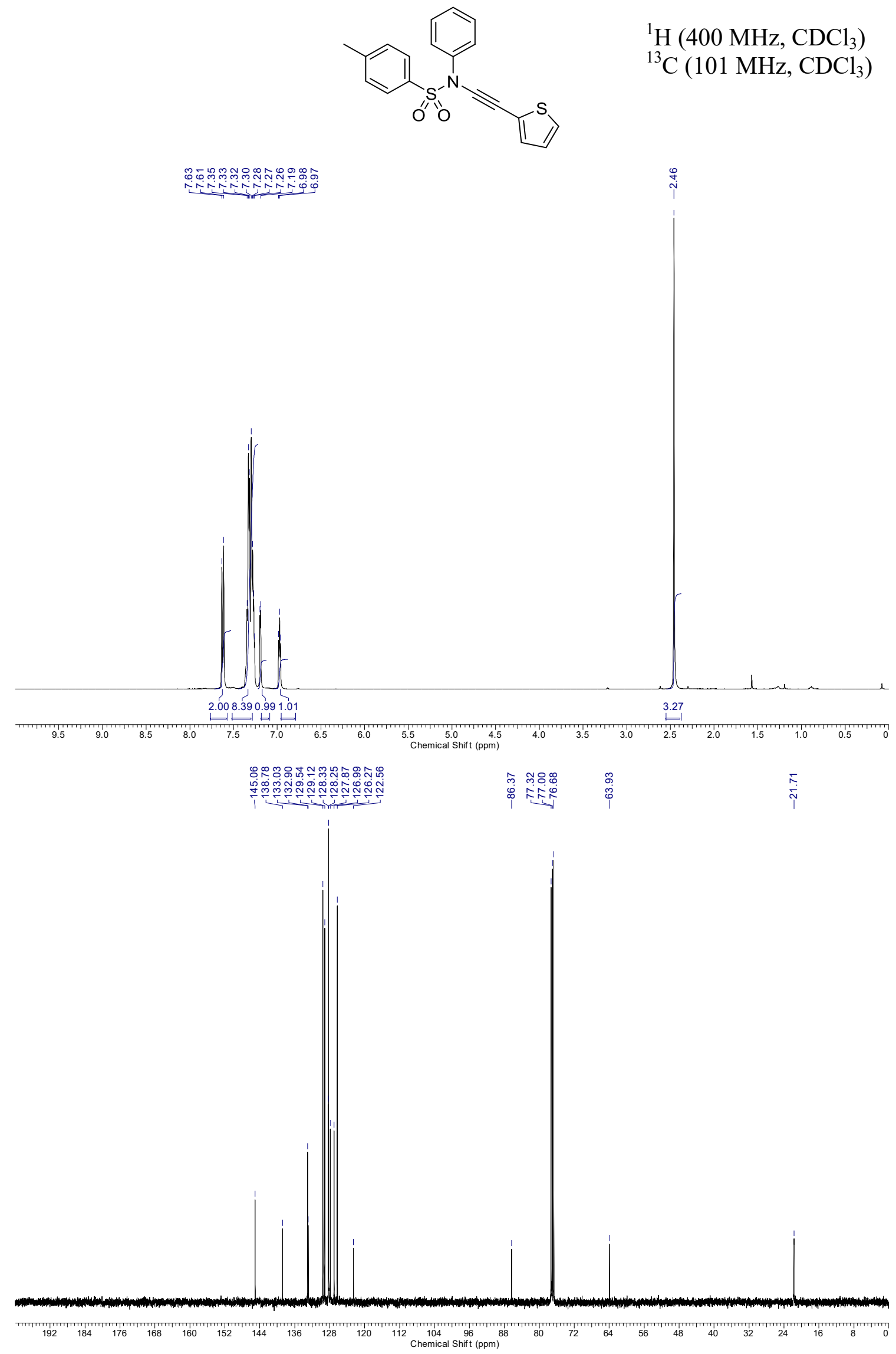
$N$-(Furan-2-ylethynyl)- $N$-phenyltosylamide, 1 u
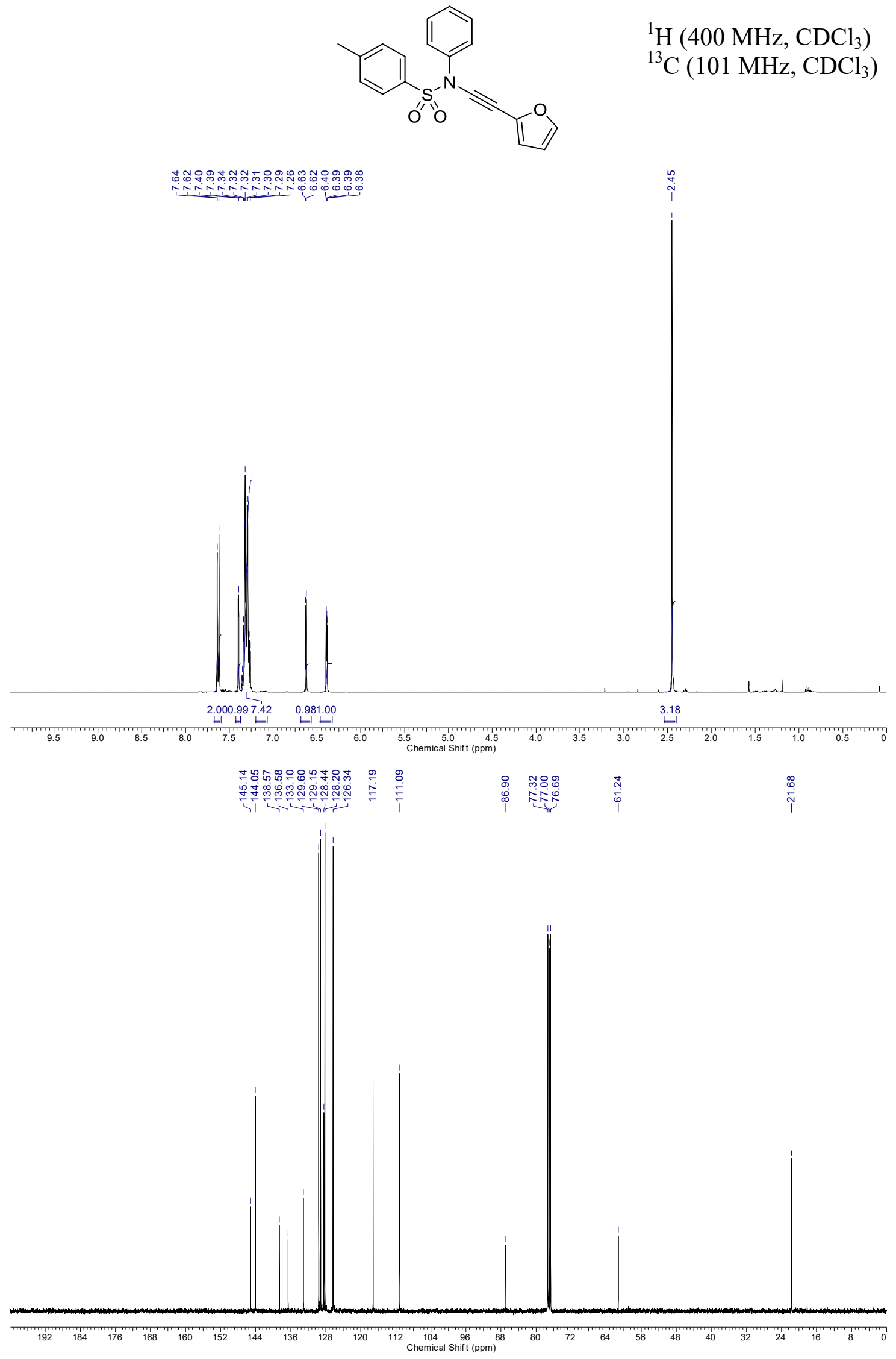
$t$-Butyl 2-(((N-phenyltosylamido)ethynyl)-1H-pyrrole-1-carboxylate, $1 \mathrm{v}$

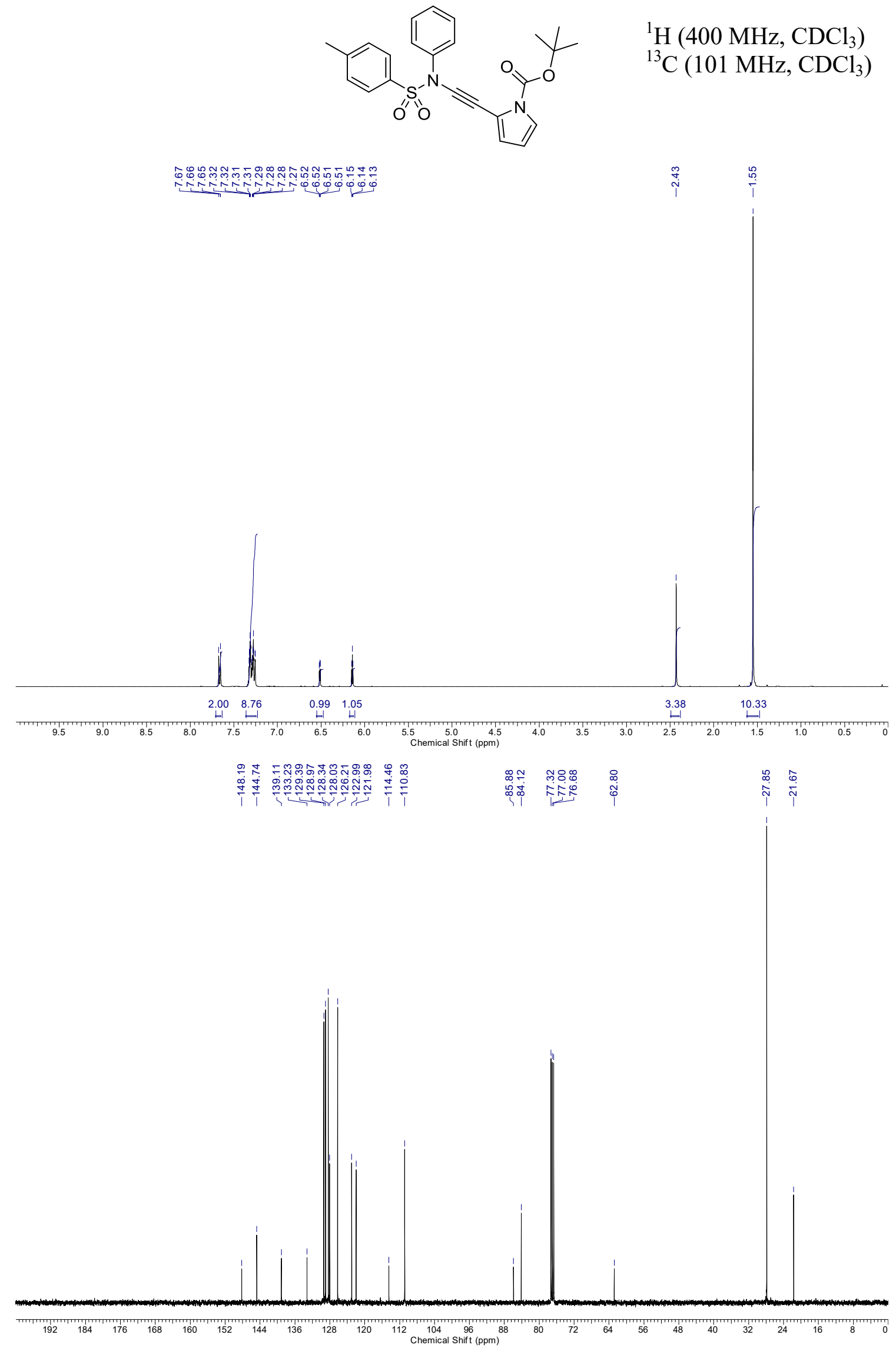


$N$-((1-Methyl-1H-pyrazol-4-yl)ethynyl)- $N$-phenyltosylamide, 1 w
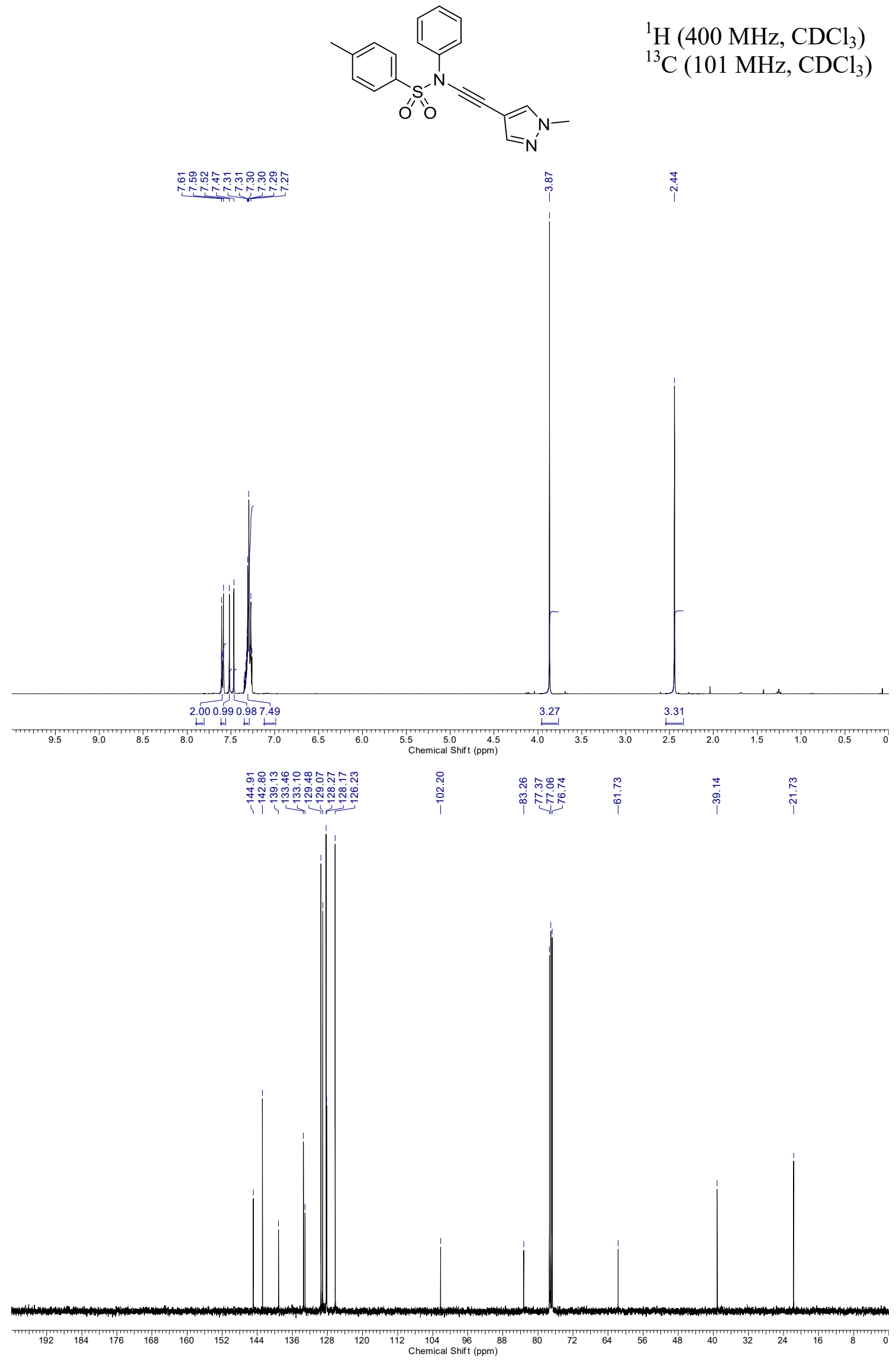
$N$-(Benzofuran-5-ylethynyl)- $N$-phenyltosylamide, $1 \mathbf{x}$
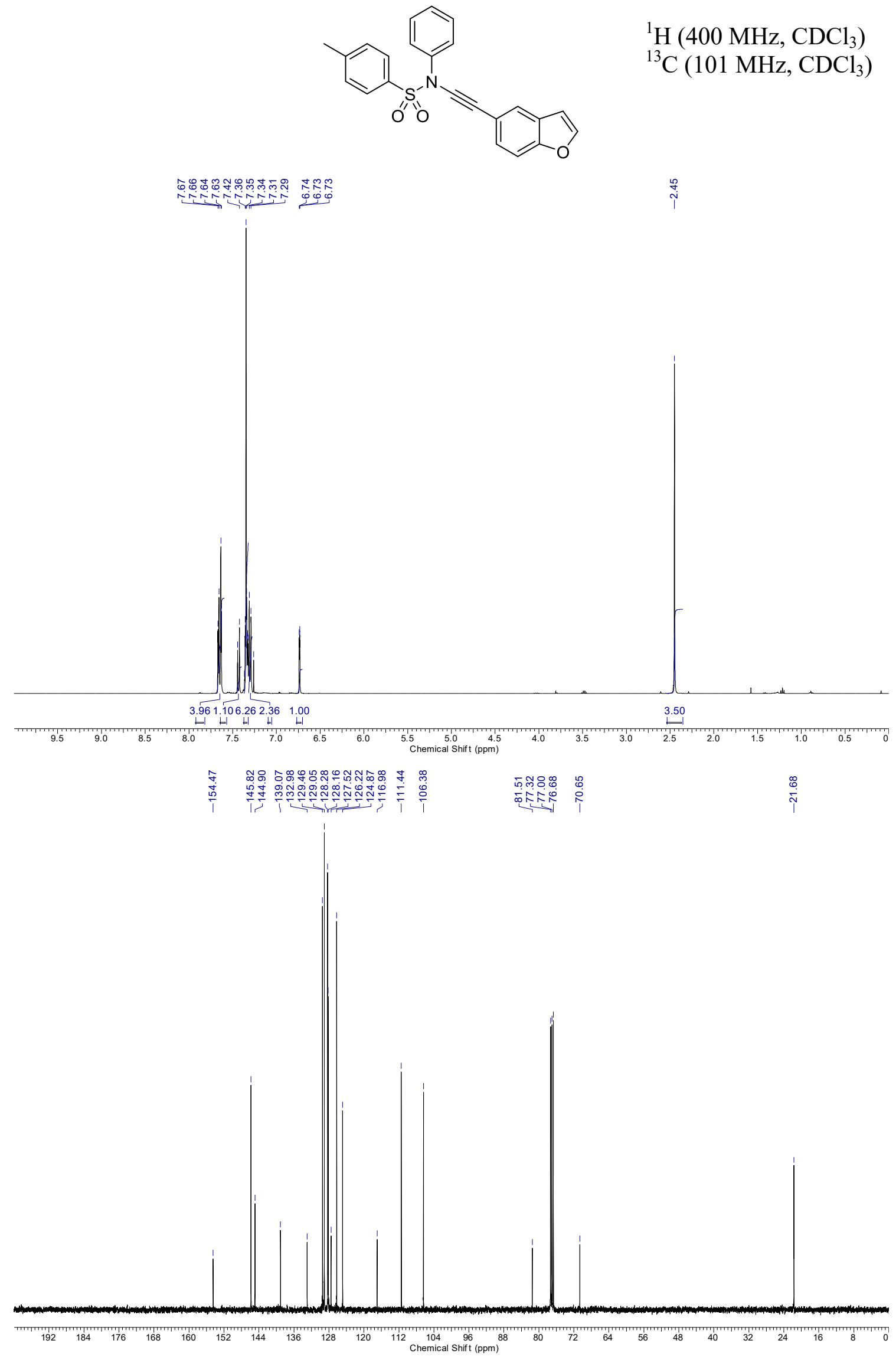
$N$-((1-Methyl-1H-indol-5-yl)ethynyl)- $N$-phenyltosylamide, $1 y$

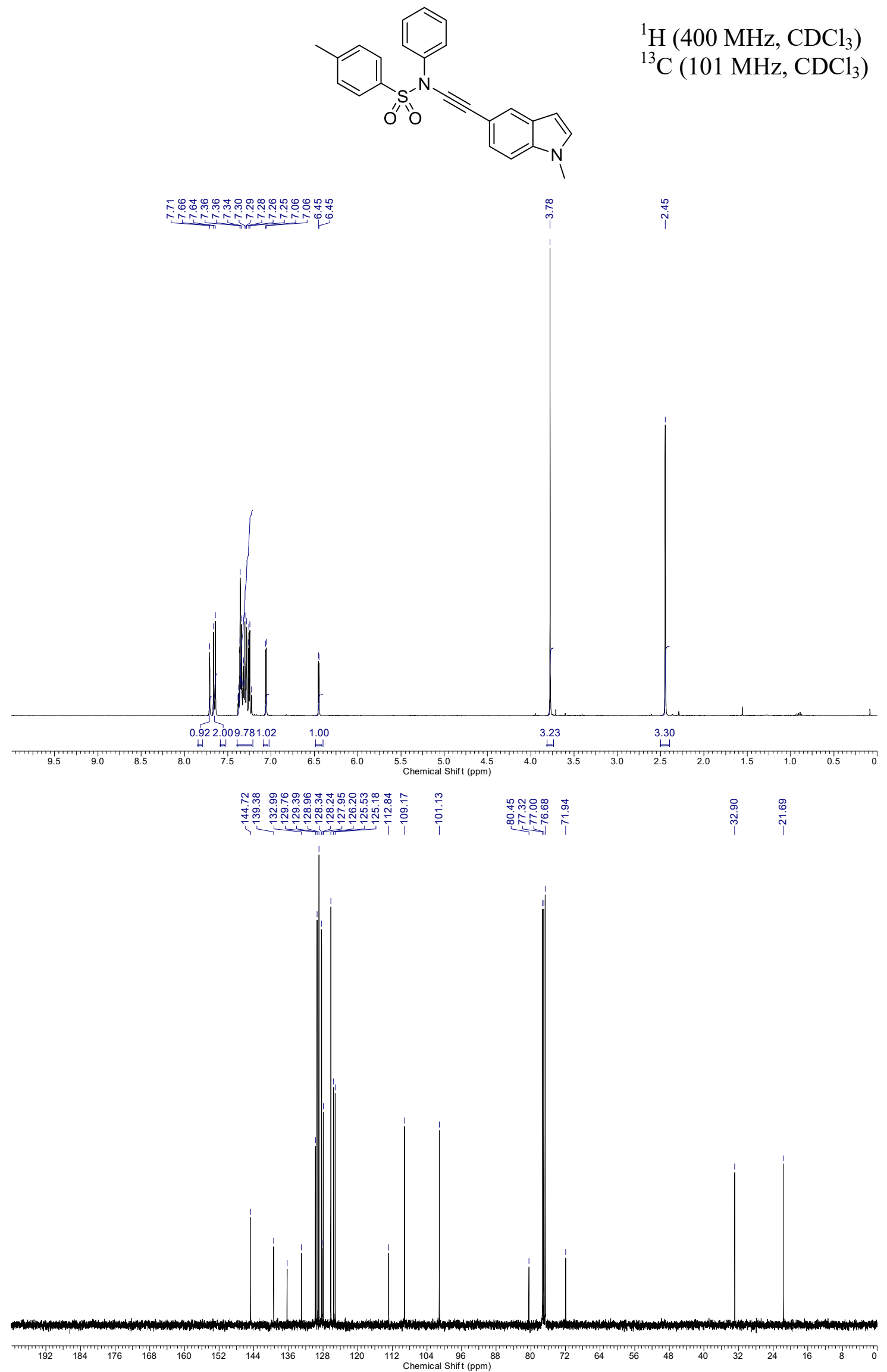


$N$-Phenyl- $N$-(pyridin-2-ylethynyl)tosylamide, $1 z$
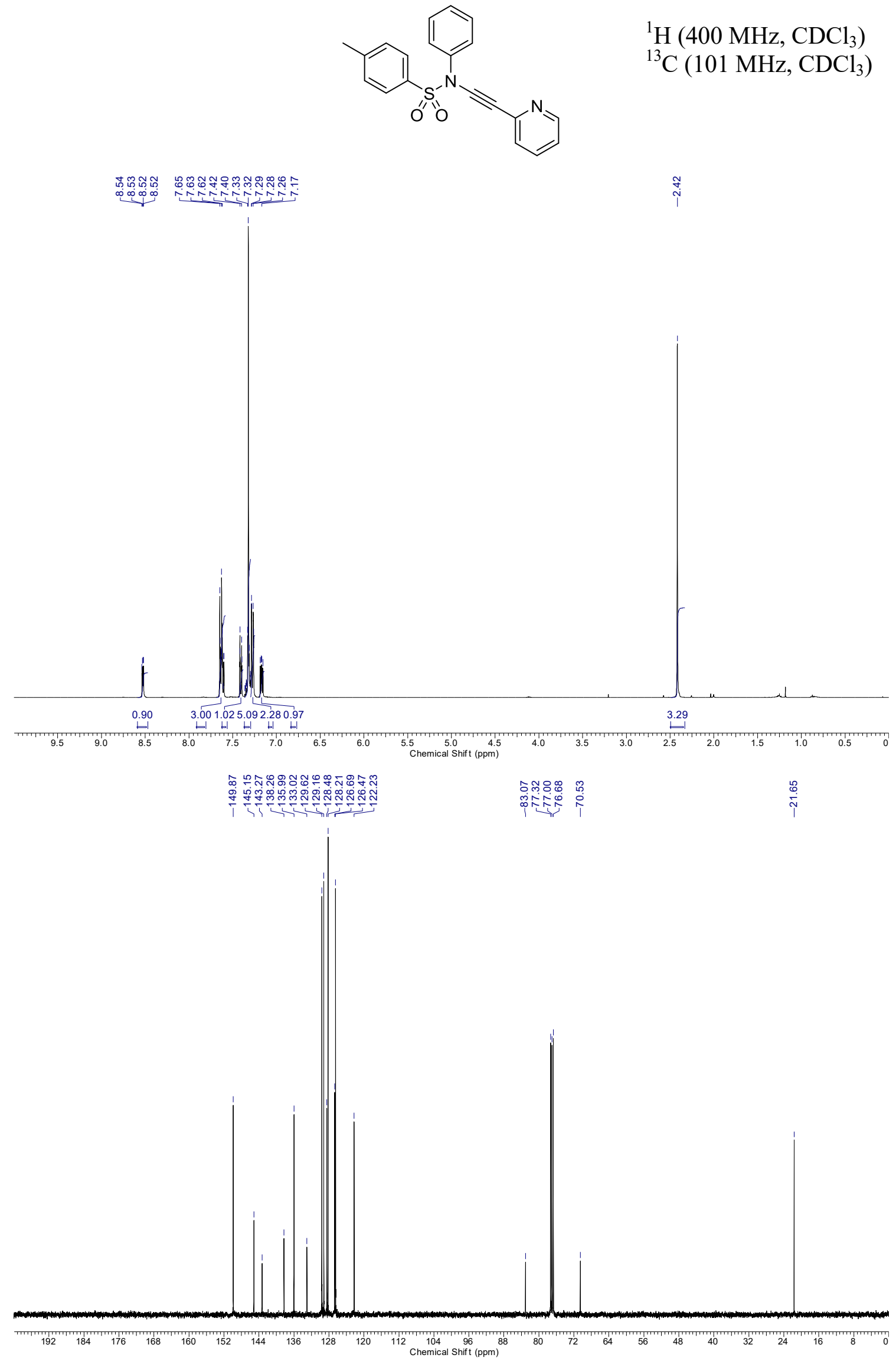
$N$-Phenyl- $N$-(pyridin-3-ylethynyl)tosylamide, 1 aa
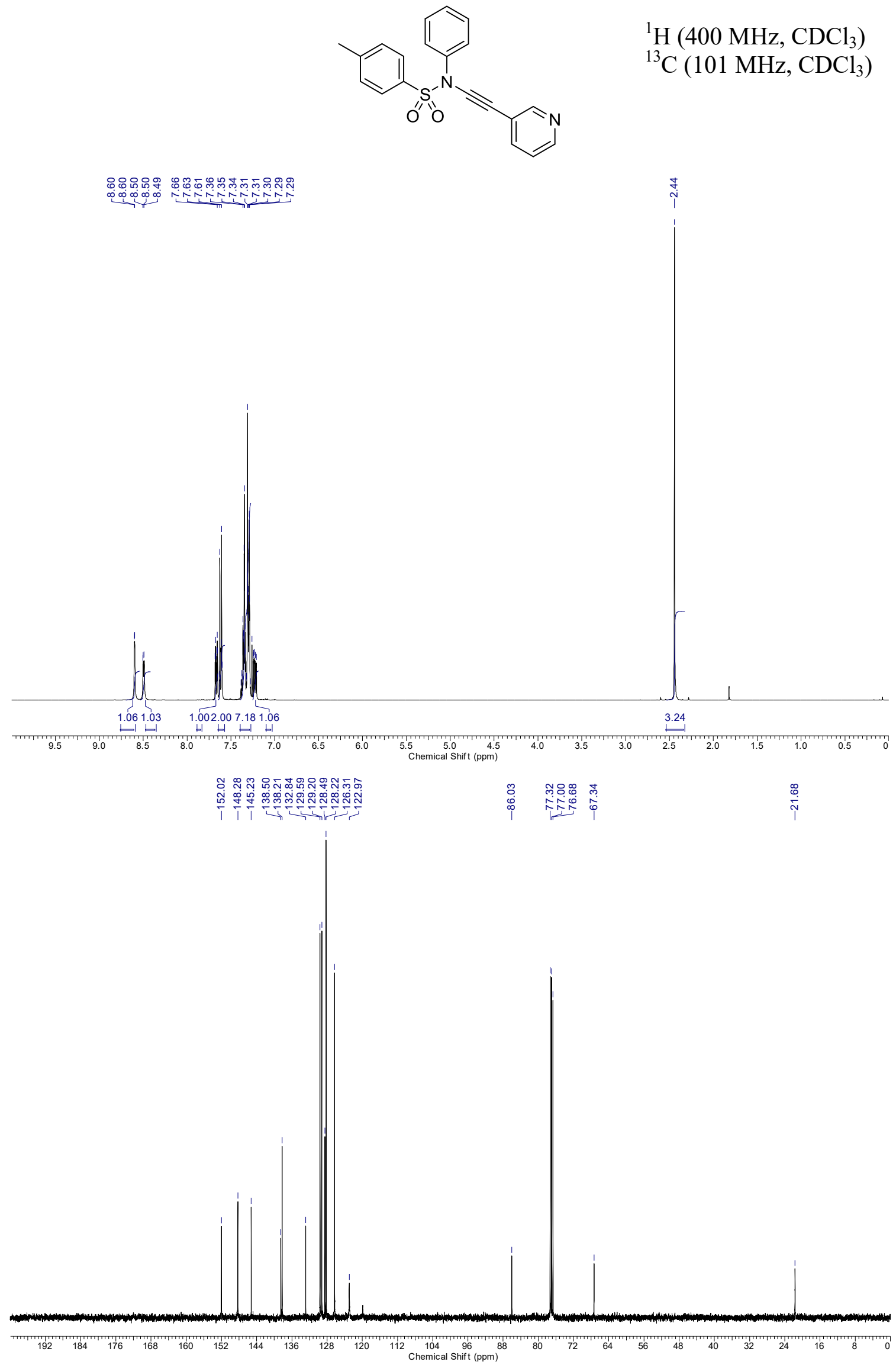
$N$-((7-Chloroquinolin-4-yl)ethynyl)- $N$-phenyltosylamide, 1 ab
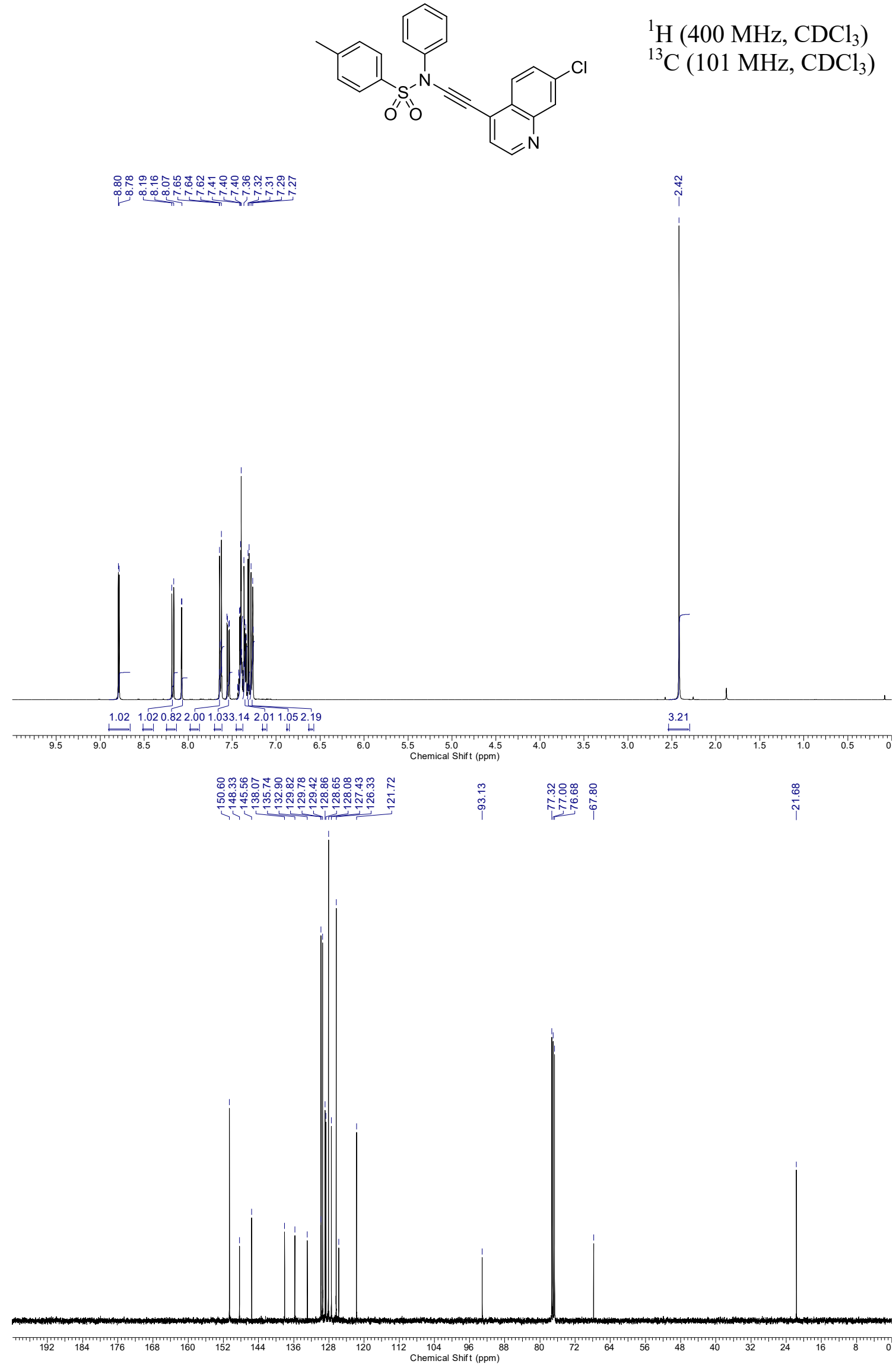
$N$-((3,6-Dichloropyridazin-4-yl)ethynyl)- $N$-phenyltosylamide, 1ac

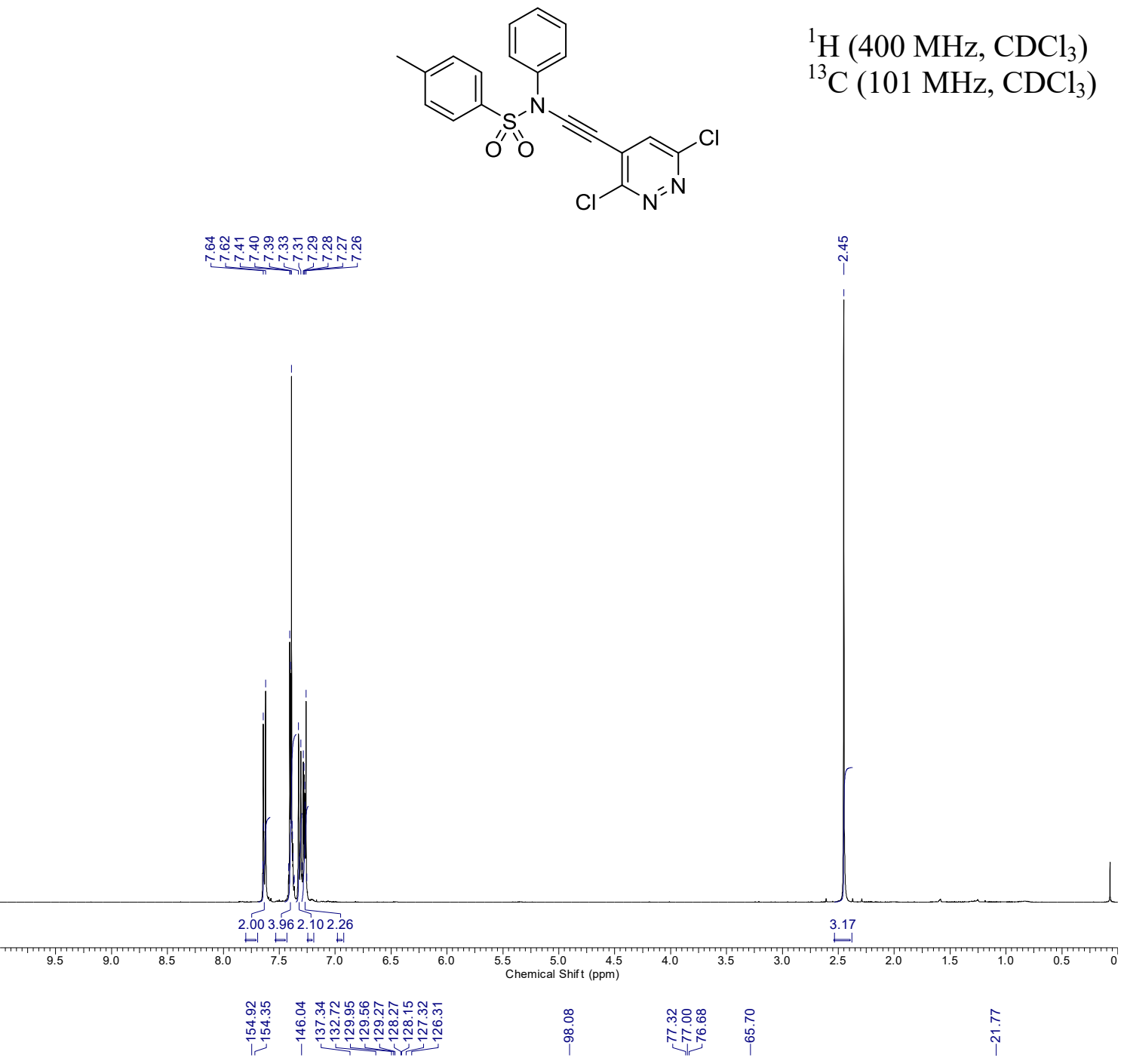

${ }^{1} \mathrm{H}\left(400 \mathrm{MHz}, \mathrm{CDCl}_{3}\right)$

${ }^{13} \mathrm{C}\left(101 \mathrm{MHz}, \mathrm{CDCl}_{3}\right)$

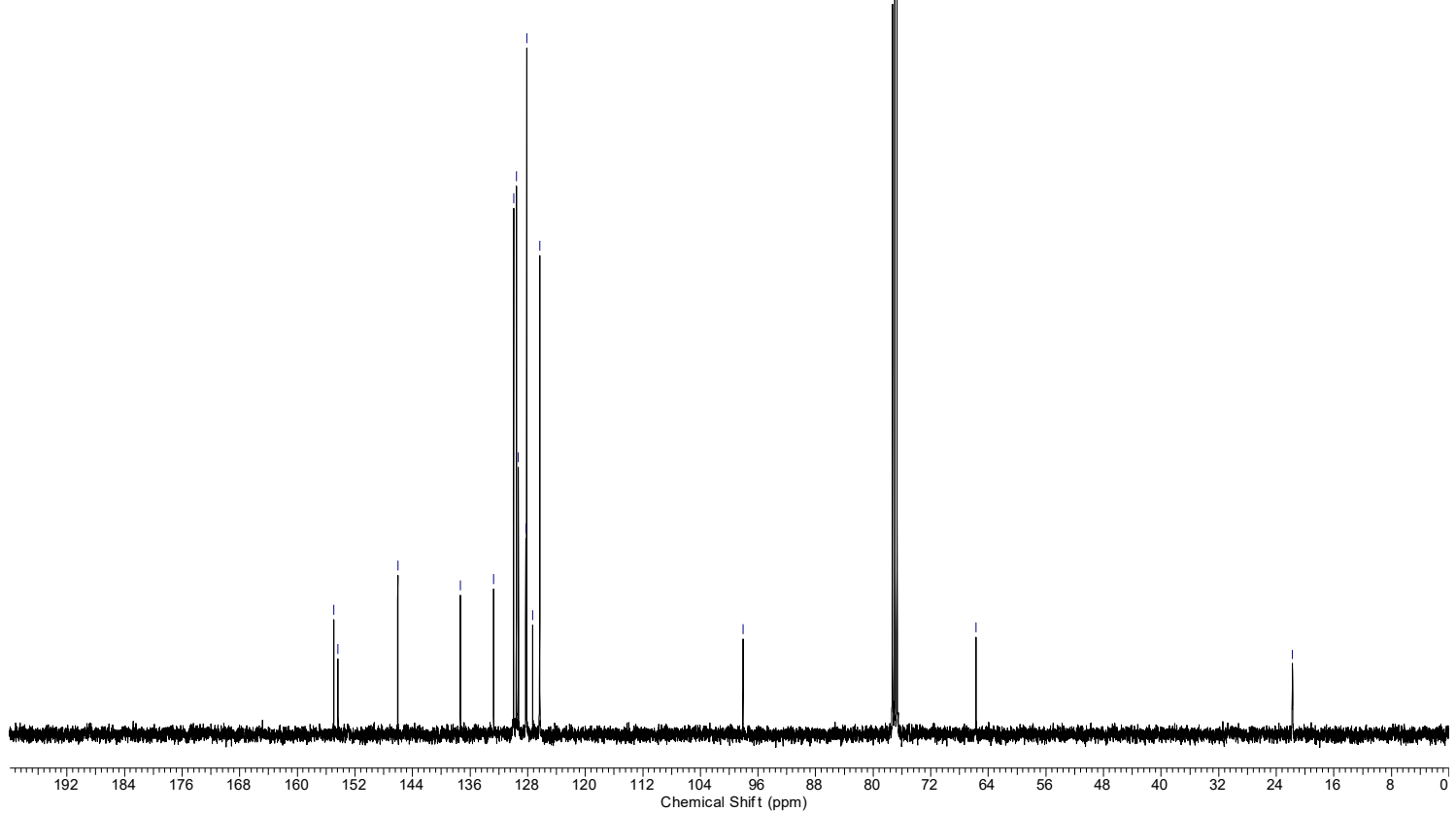


$N$-(3-Methylbut-3-en-1-yn-1-yl)- $N$-phenyltosylamide, 1ad

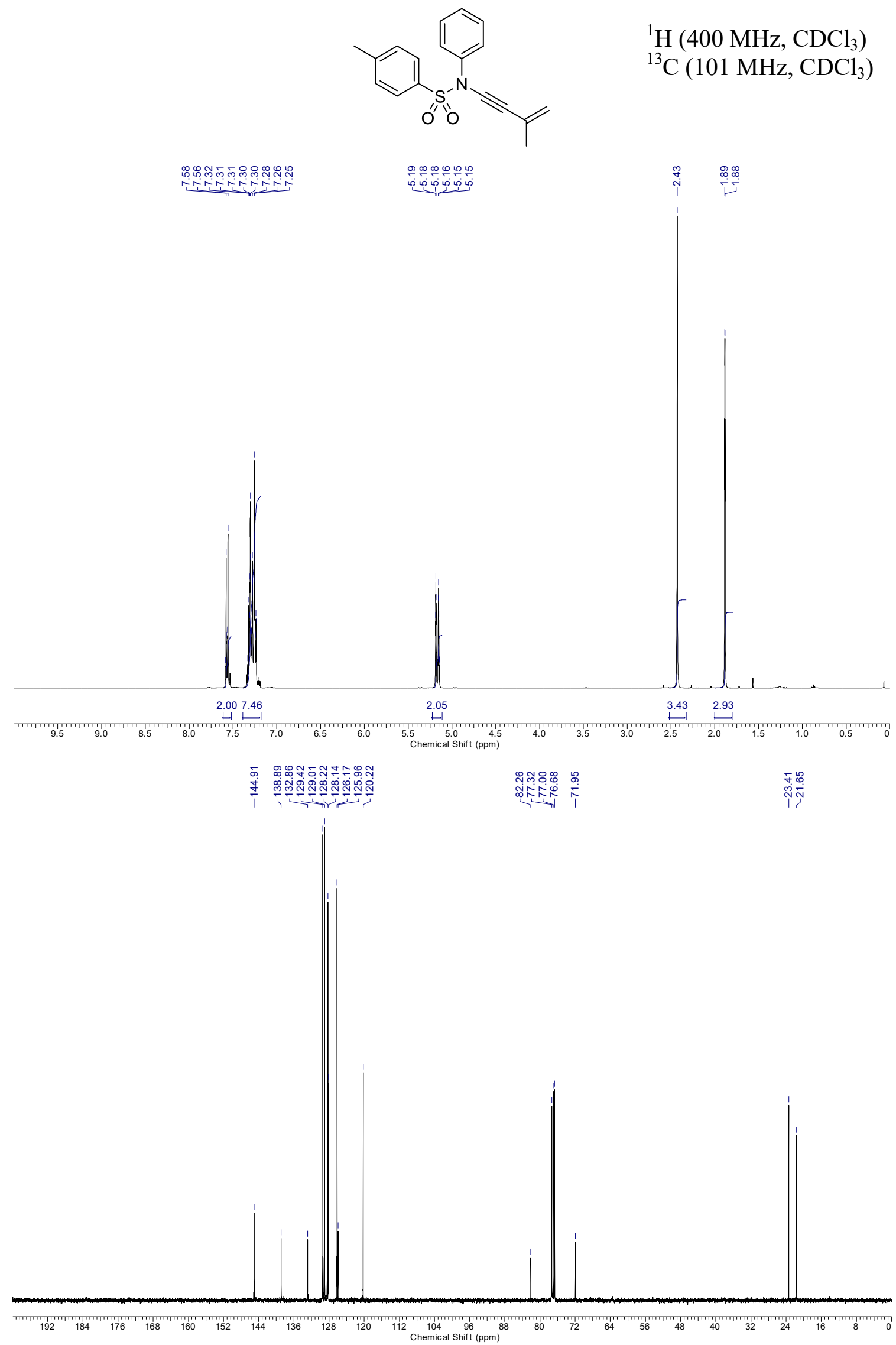


$(E)-/(Z)-N-(3-m e t h y l p e n t-3-e n-1-y n-1-y l)-N$-phenyltosylamide, 1ae

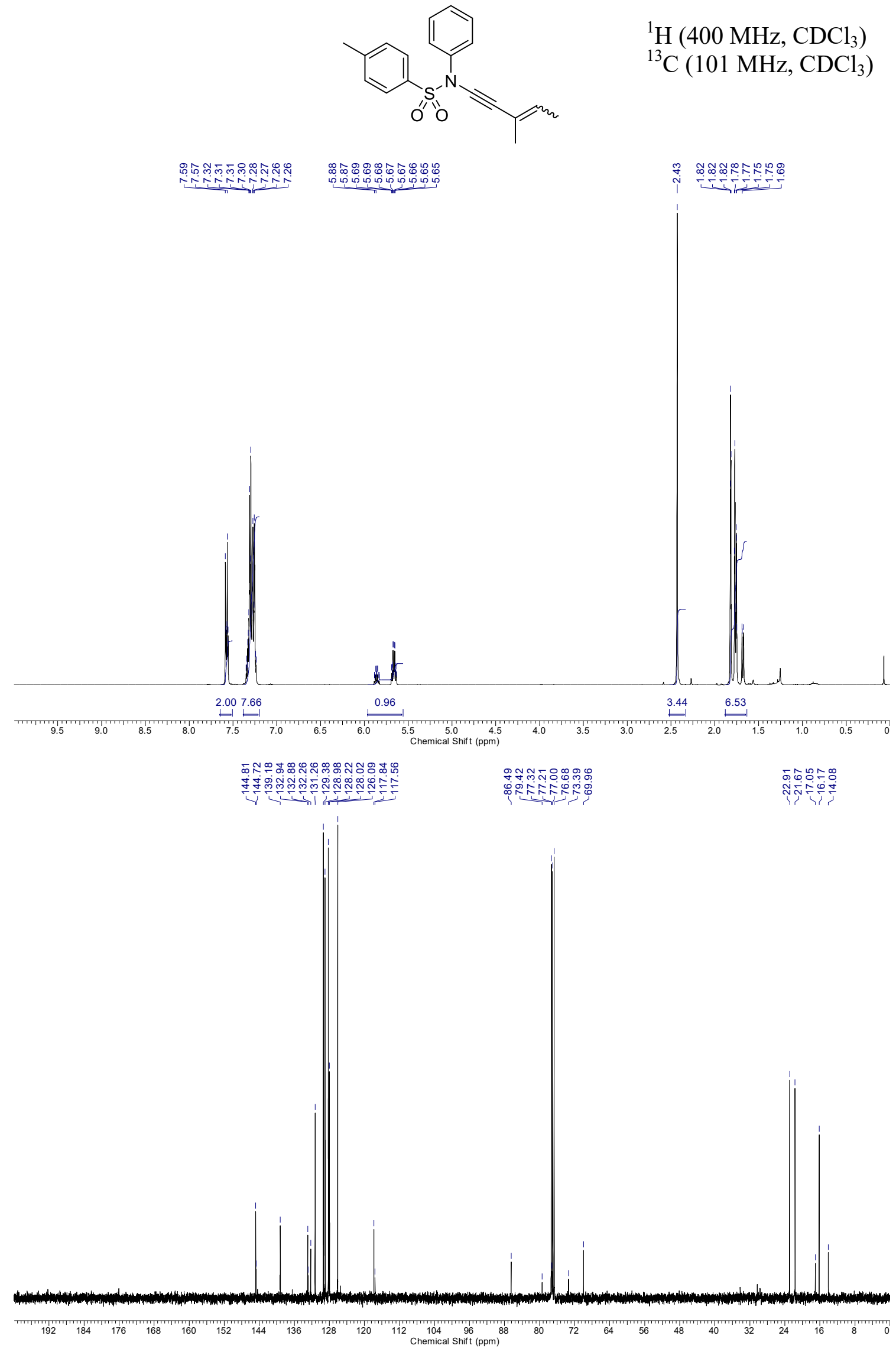


$N$-(Prop-1-yn-1-yl)- $N$-phenyltosylamide, 1af

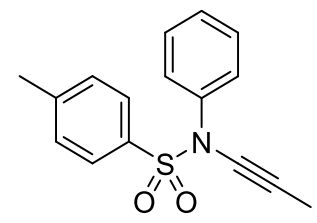

${ }^{1} \mathrm{H}\left(400 \mathrm{MHz}, \mathrm{CDCl}_{3}\right)$

${ }^{13} \mathrm{C}\left(101 \mathrm{MHz}, \mathrm{CDCl}_{3}\right)$

กุ.

hitivitivit

‡ึ
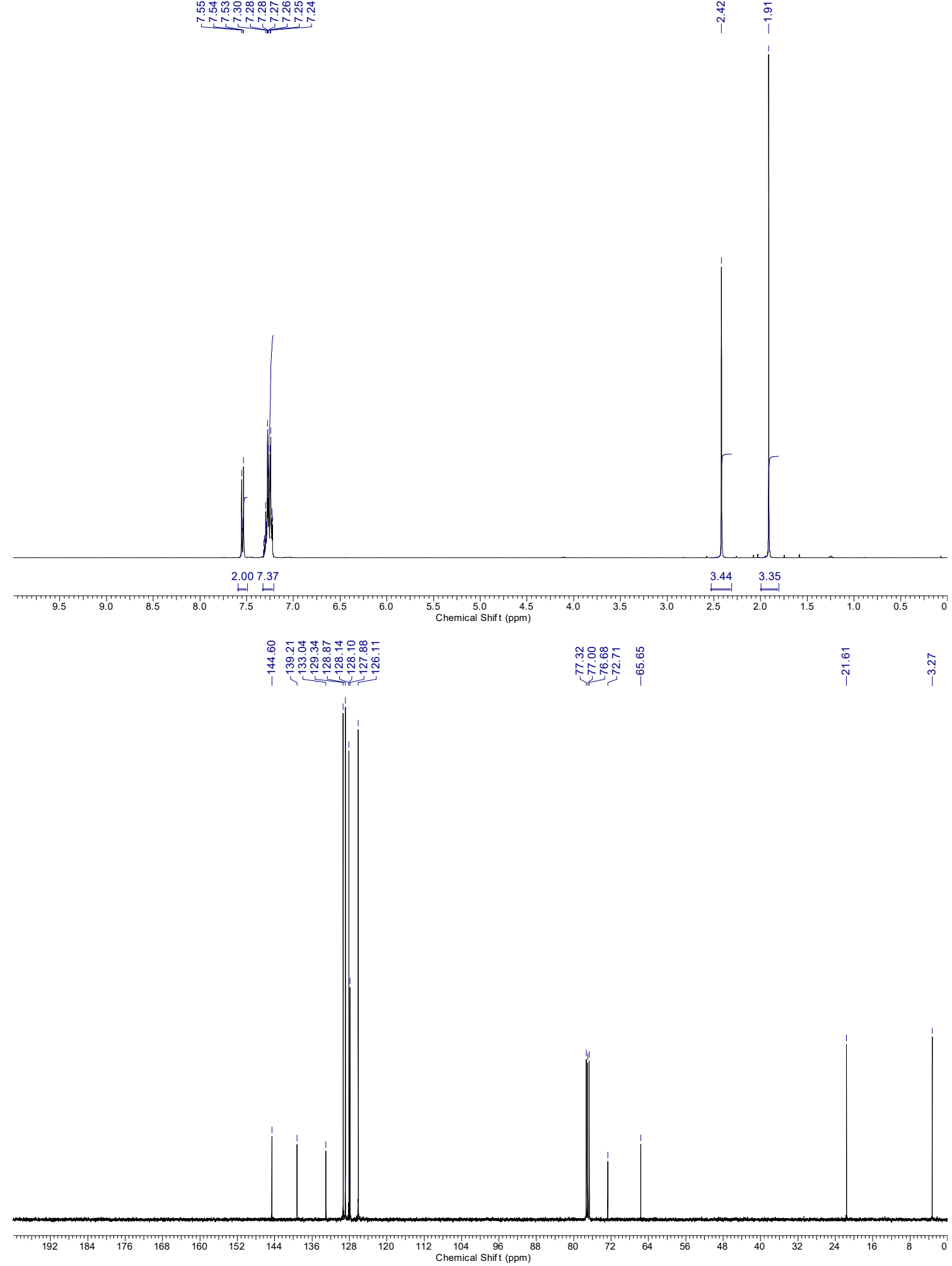
$N$-(Pent-1-yn-1-yl)- $N$-phenyltosylamide, 1 ag

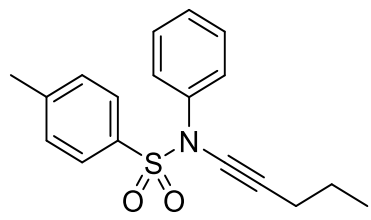

${ }^{1} \mathrm{H}\left(400 \mathrm{MHz}, \mathrm{CDCl}_{3}\right)$

${ }^{13} \mathrm{C}\left(101 \mathrm{MHz}, \mathrm{CDCl}_{3}\right)$

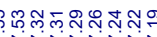

binknititi

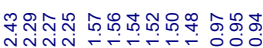

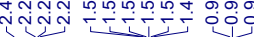
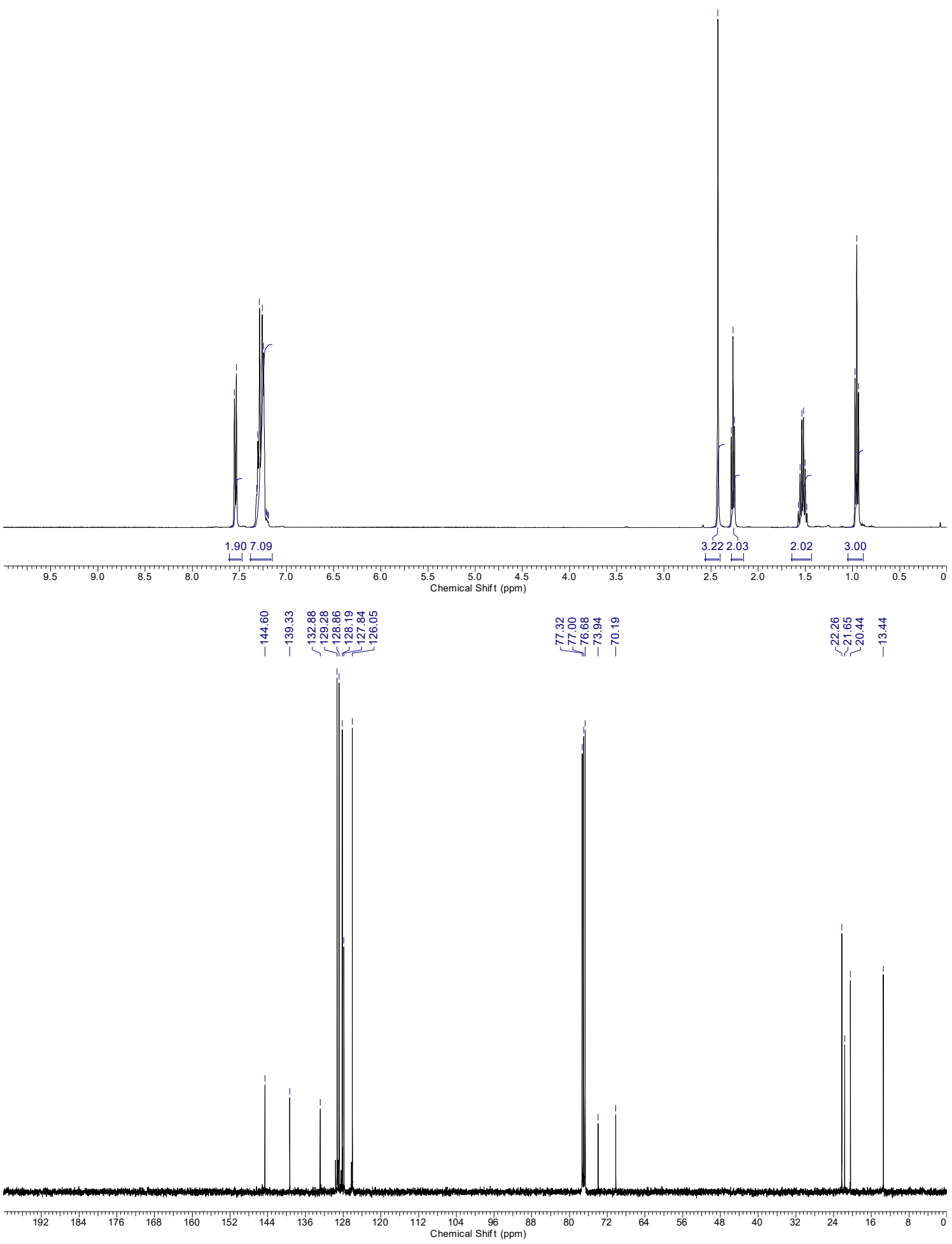
$N$-(3-Methylbut-1-yn-1-yl)- $N$-phenyltosylamide, 1ah

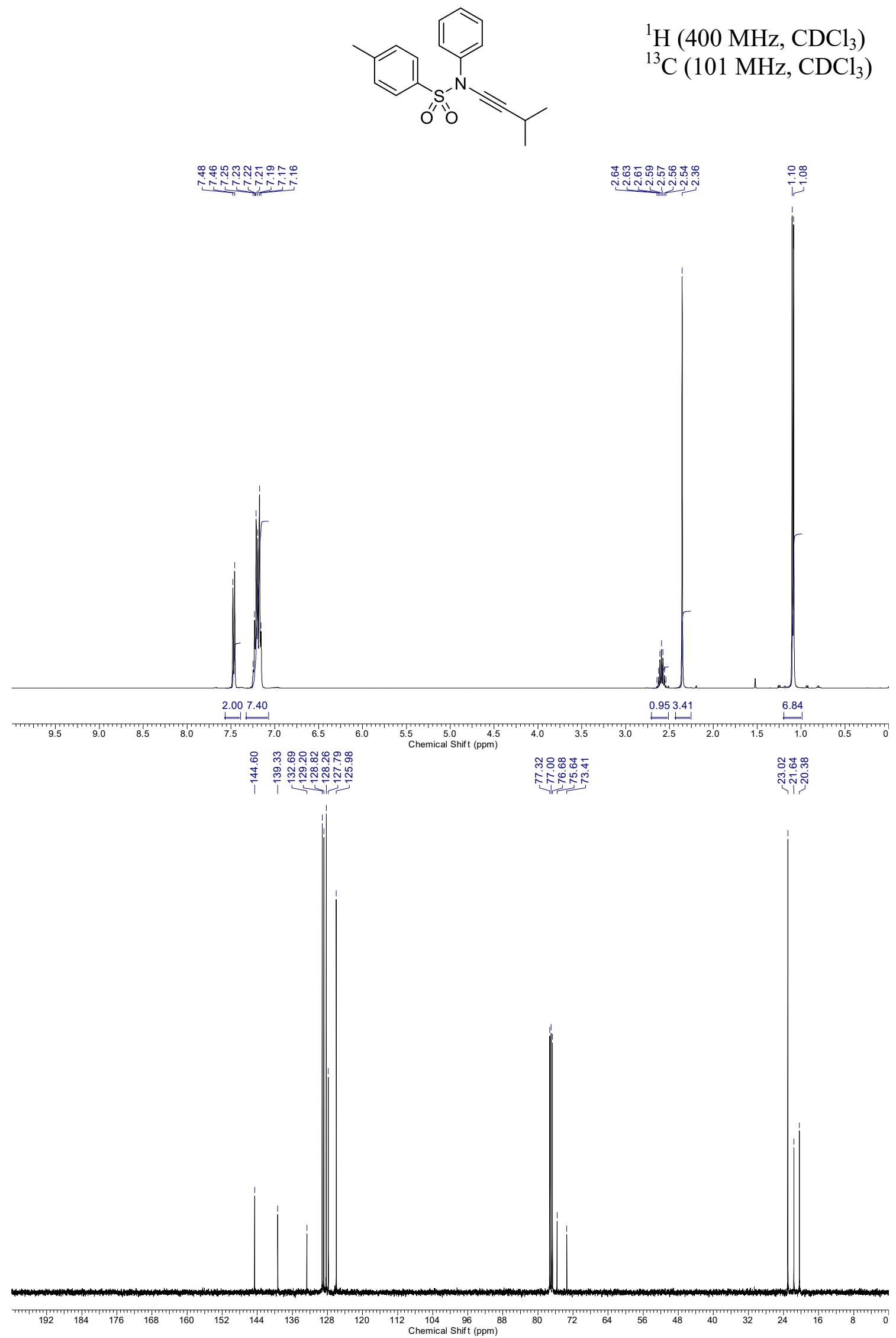


$N$-(Cyclohexylethynyl)- $N$-phenyltosylamide, 1 ai

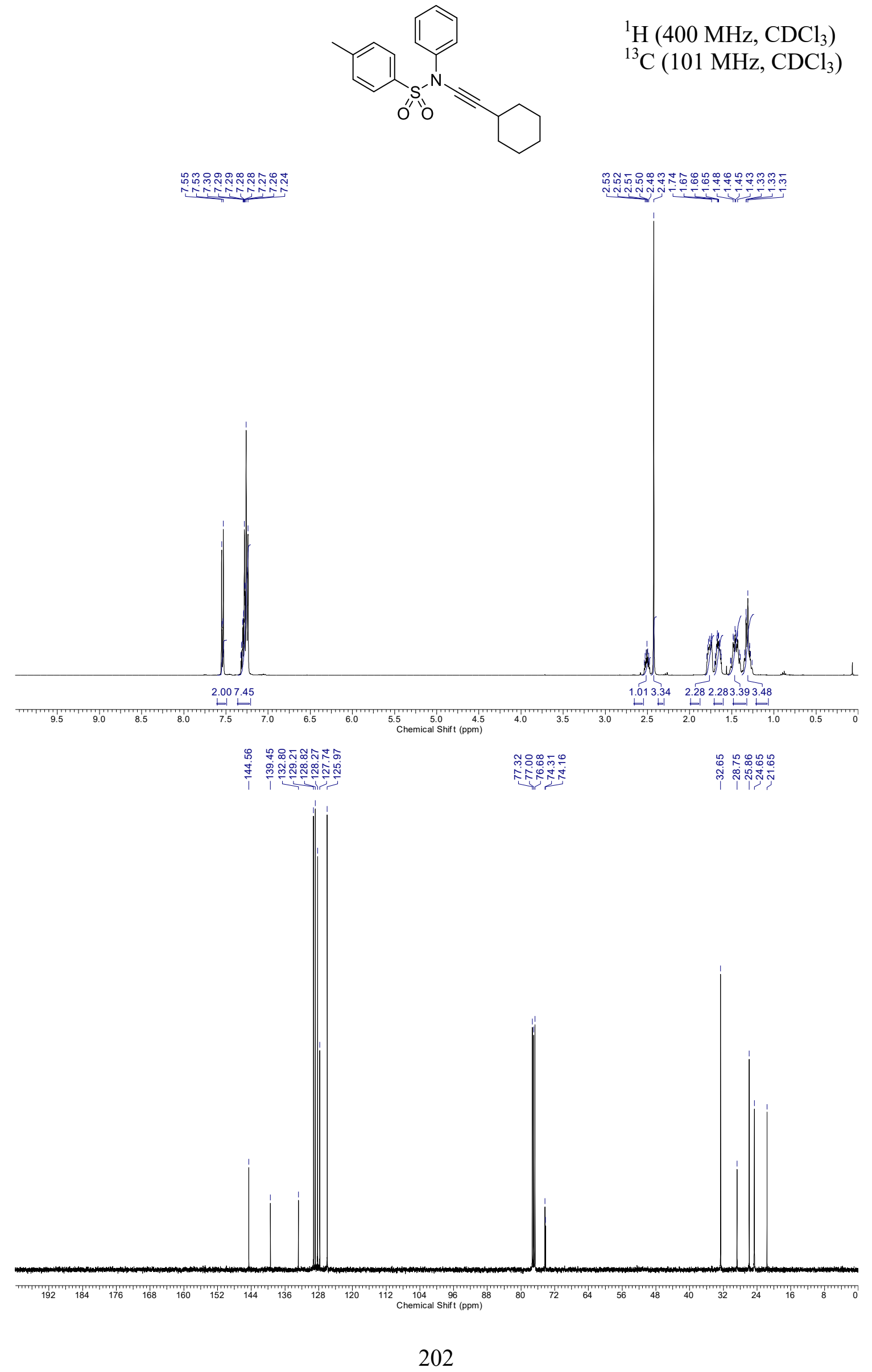


$N$-(Cyclopropylethynyl)- $N$-tosylamide, 1aj

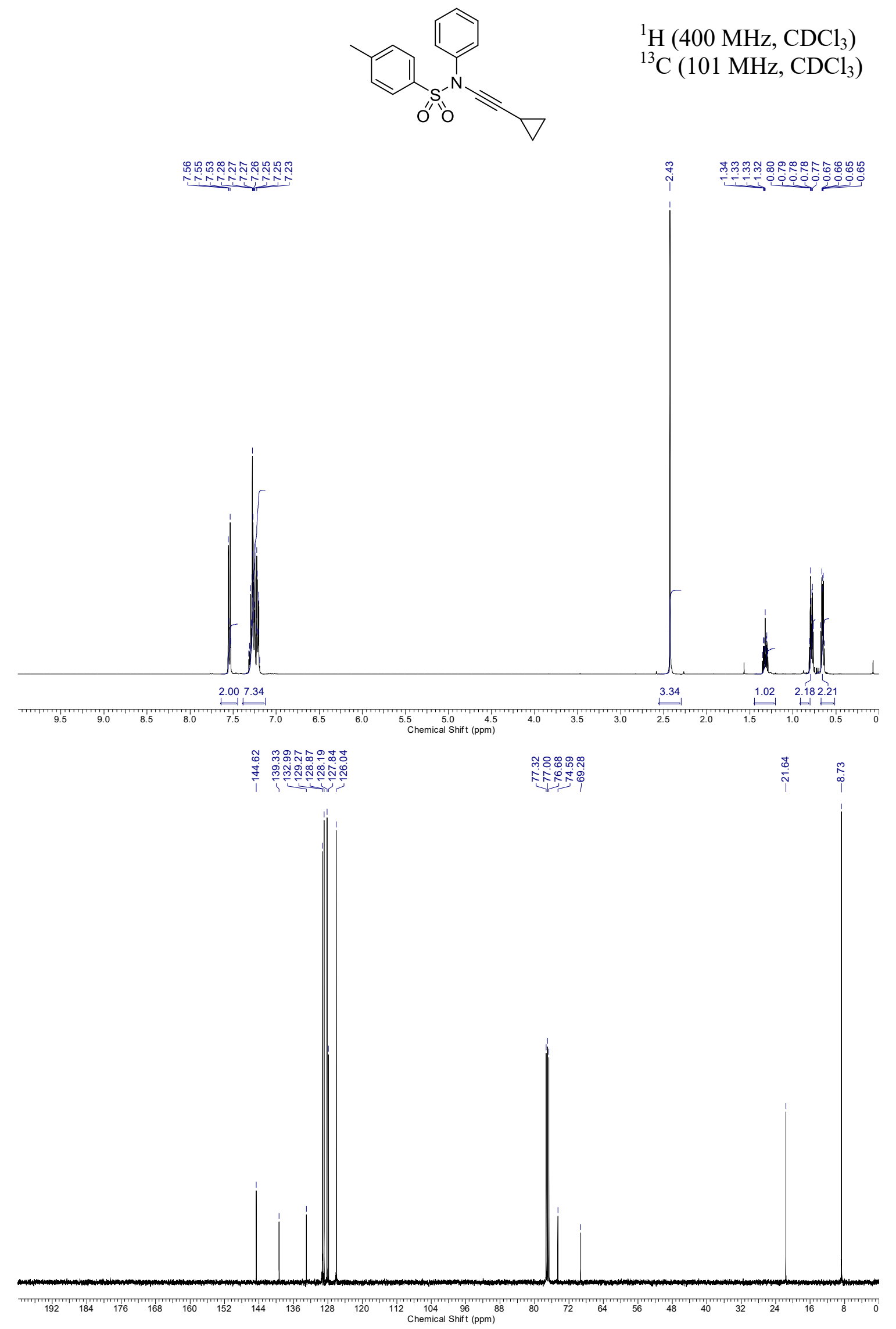


$N$-(3,3-Dimethylbut-1-yn-1-yl)- $N$-phenyltosylamide, 1ak

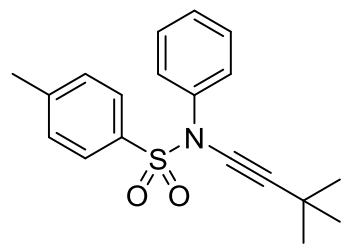

${ }^{1} \mathrm{H}\left(400 \mathrm{MHz}, \mathrm{CDCl}_{3}\right)$

${ }^{13} \mathrm{C}\left(101 \mathrm{MHz}, \mathrm{CDCl}_{3}\right)$

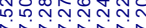

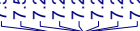

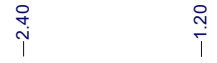
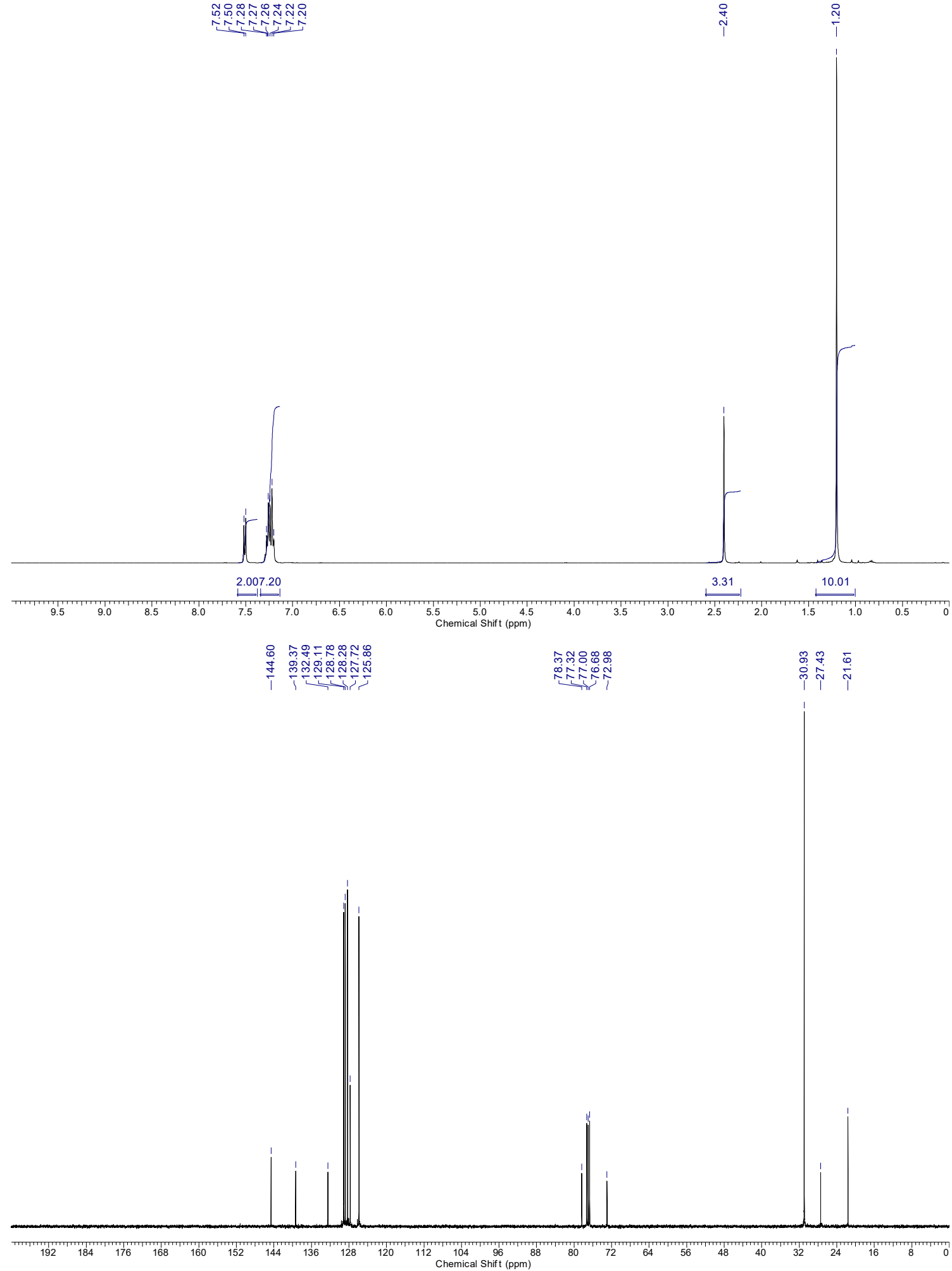
$N$-((3-Allylbicyclo[1.1.1]pentan-1-yl)ethynyl)- $N$-phenyltosylamide, 1al

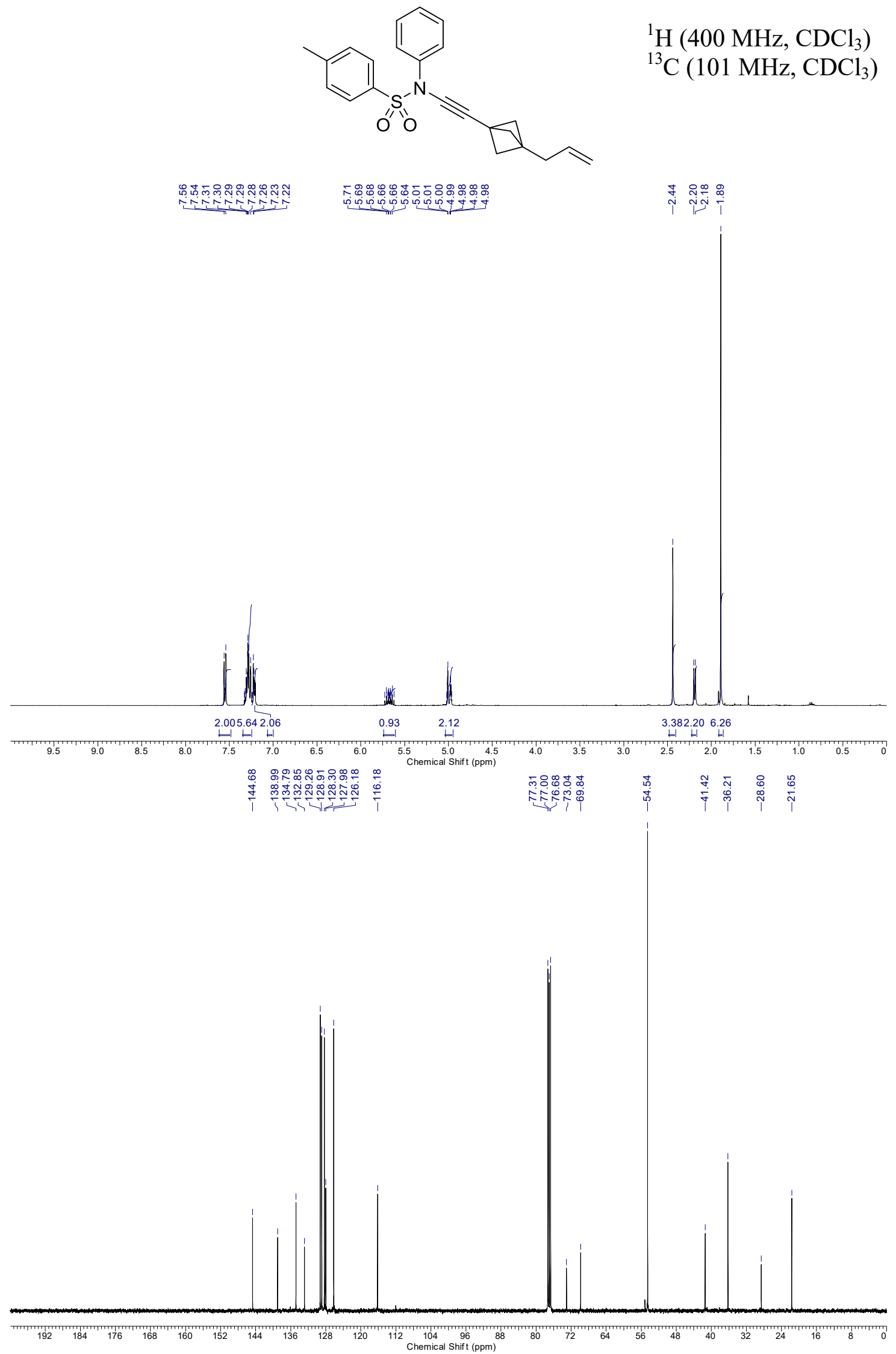




\section{1c Organometallic Scope: Miscellaneous}

(Z)-N-(2-Chloro-1-phenylvinyl)- $N$-phenyltosylamide, 4

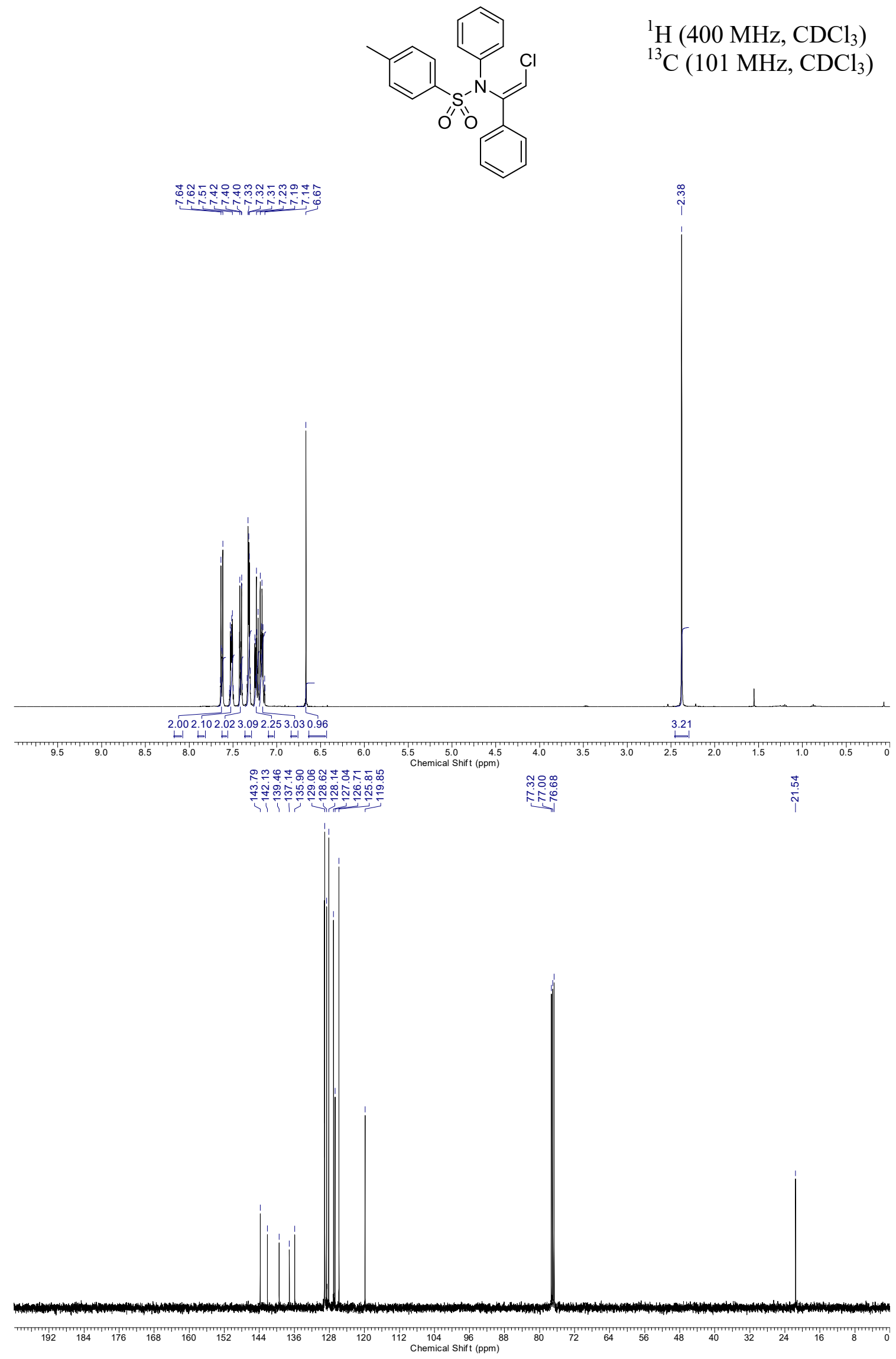


$N$-(2,2-Diphenylvinyl)- $N$-phenyltosylamide, 5<smiles>Cc1ccc(S(=O)(=O)N(C=C(c2ccccc2)c2ccccc2)c2ccccc2)cc1</smiles>

${ }^{1} \mathrm{H}\left(400 \mathrm{MHz}, \mathrm{CDCl}_{3}\right)$

${ }^{13} \mathrm{C}\left(101 \mathrm{MHz}, \mathrm{CDCl}_{3}\right)$

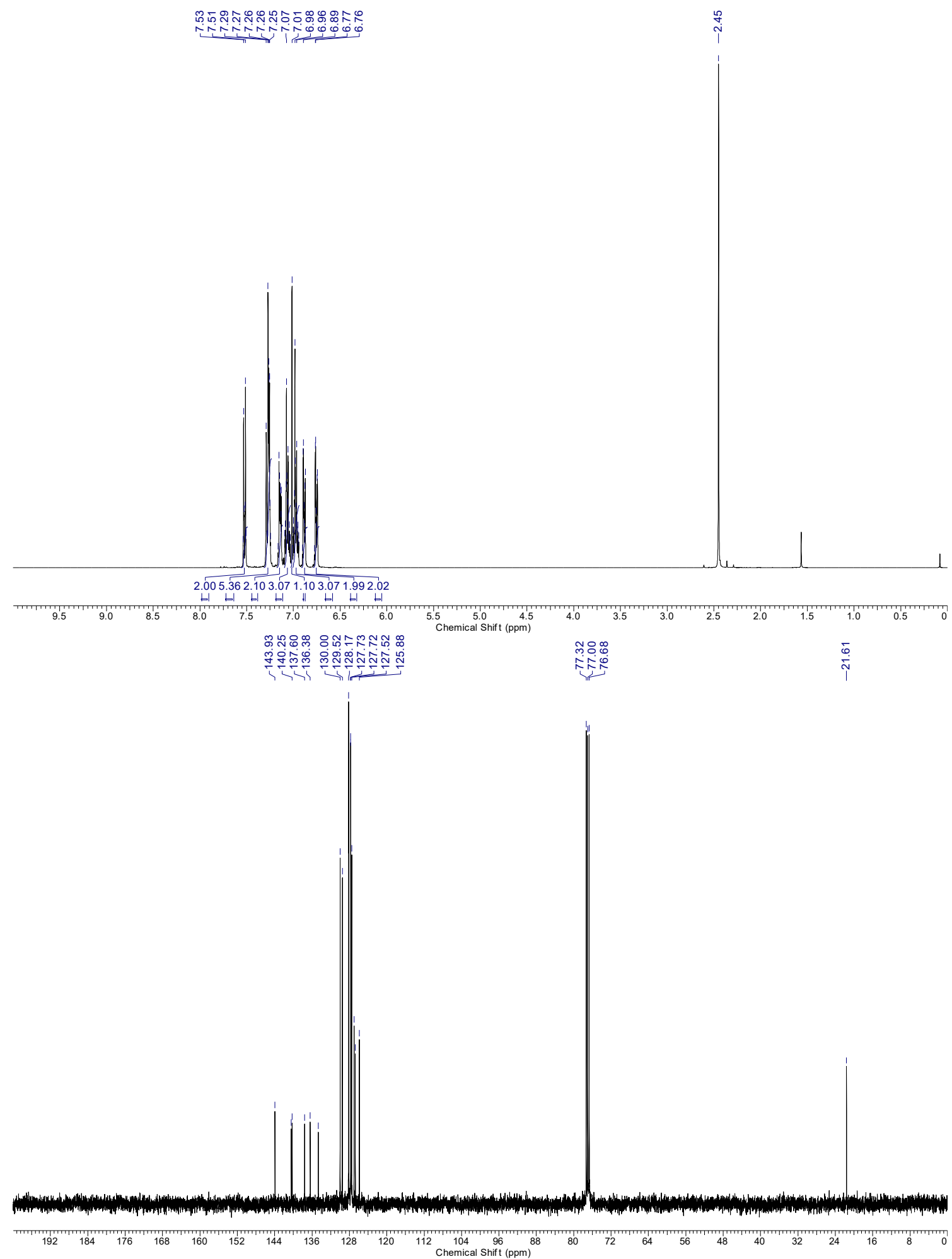


$(1 Z, 4 Z)-N^{1}, N^{4}, 1,4-t e t r a p h e n y l b u t-2-y n e-1,4-d i i m i n e, 6$<smiles>C(#Cc1ccccc1)/C(=N/c1ccccc1)c1ccccc1</smiles>

${ }^{1} \mathrm{H}\left(500 \mathrm{MHz}, \mathrm{CDCl}_{3}\right)$

${ }^{13} \mathrm{C}\left(126 \mathrm{MHz}, \mathrm{CDCl}_{3}\right)$

ஜேேே

$\mathrm{Ph}^{-\mathrm{N}}$
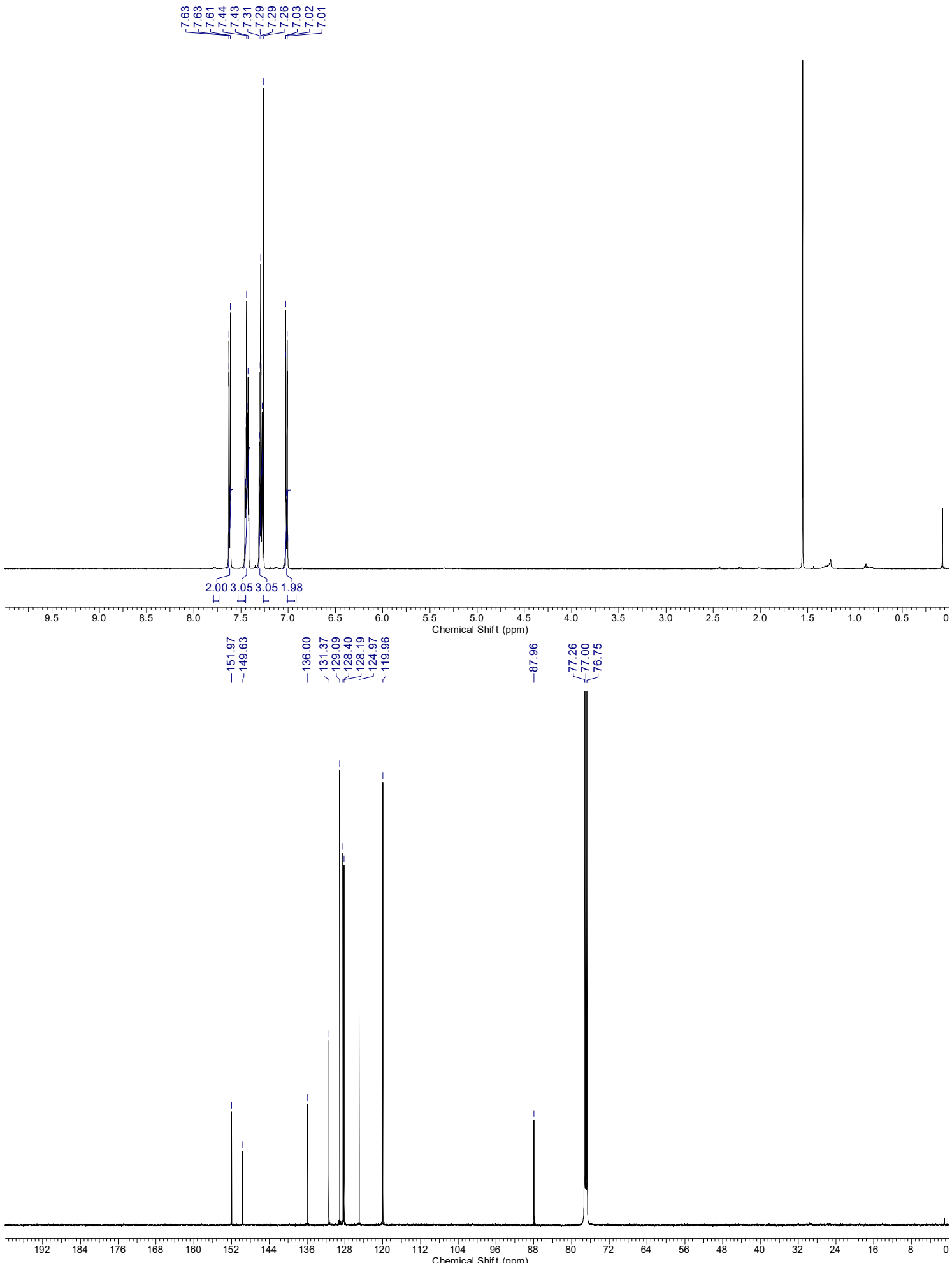
$N$-((2-(Benzylamino)-6-fluoro-3-nitrophenyl)ethynyl)- $N$-phenyltosylamide,

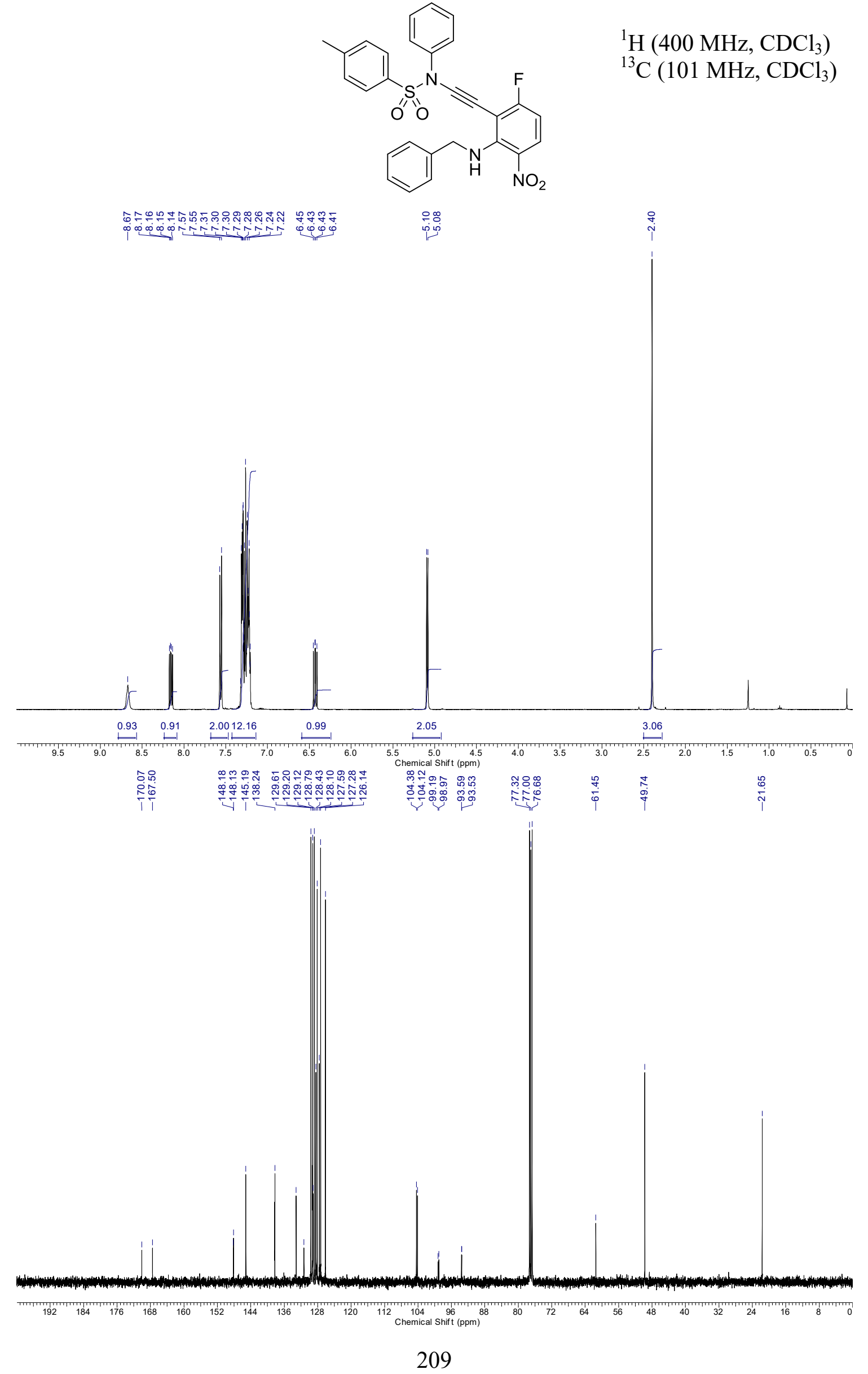


${ }^{19} \mathrm{~F}\left(376 \mathrm{MHz}, \mathrm{CDCl}_{3}\right)$

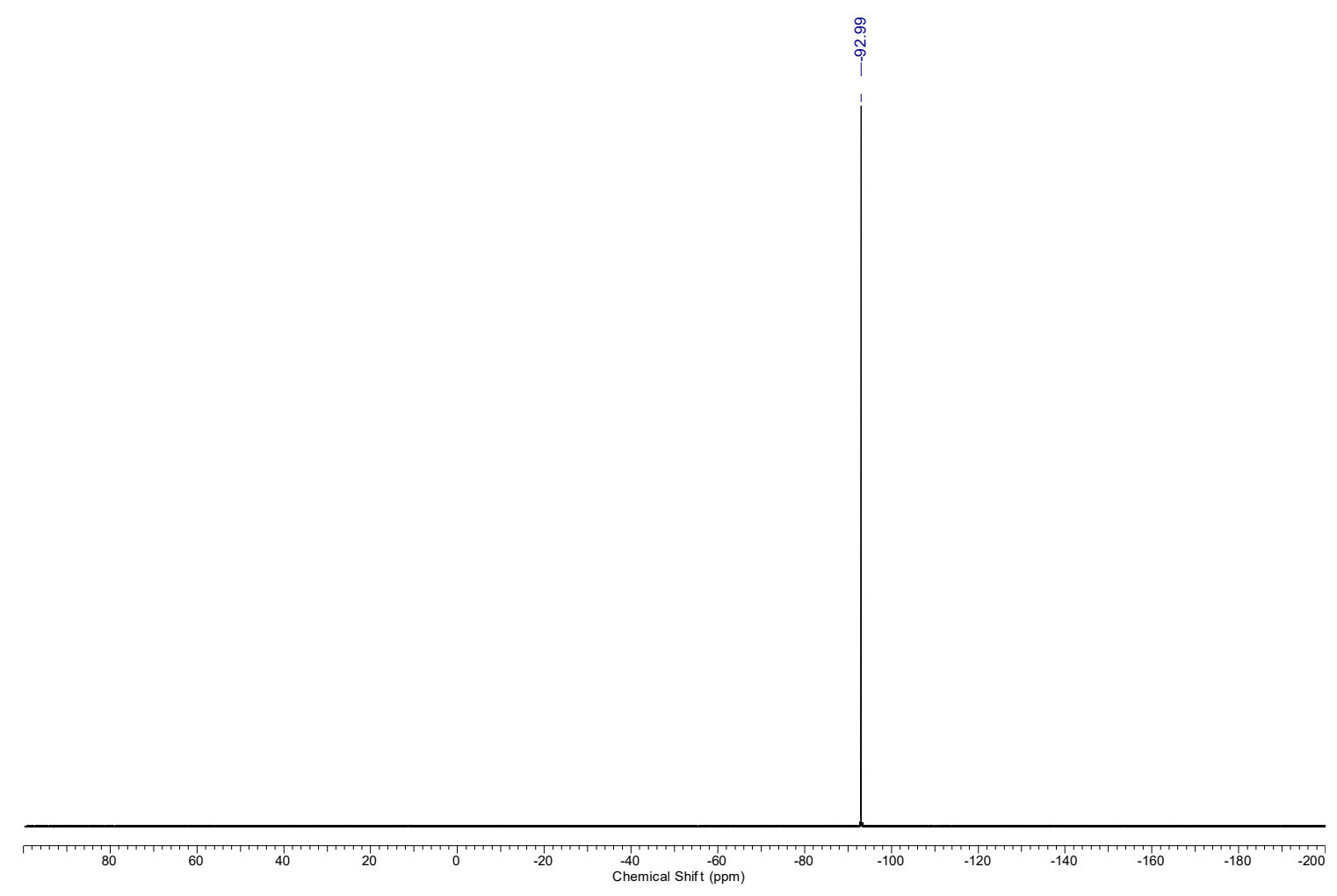


$N$-(1-Benzyl-4-fluoro-7-nitro-1 $H$-indol-2-yl)- $N$-phenyltosylamide, 8

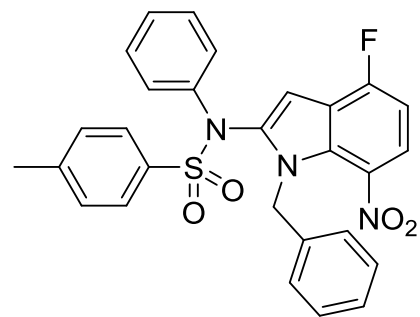

${ }^{1} \mathrm{H}\left(500 \mathrm{MHz}, \mathrm{CDCl}_{3}\right)$

${ }^{13} \mathrm{C}\left(126 \mathrm{MHz}, \mathrm{CDCl}_{3}\right)$

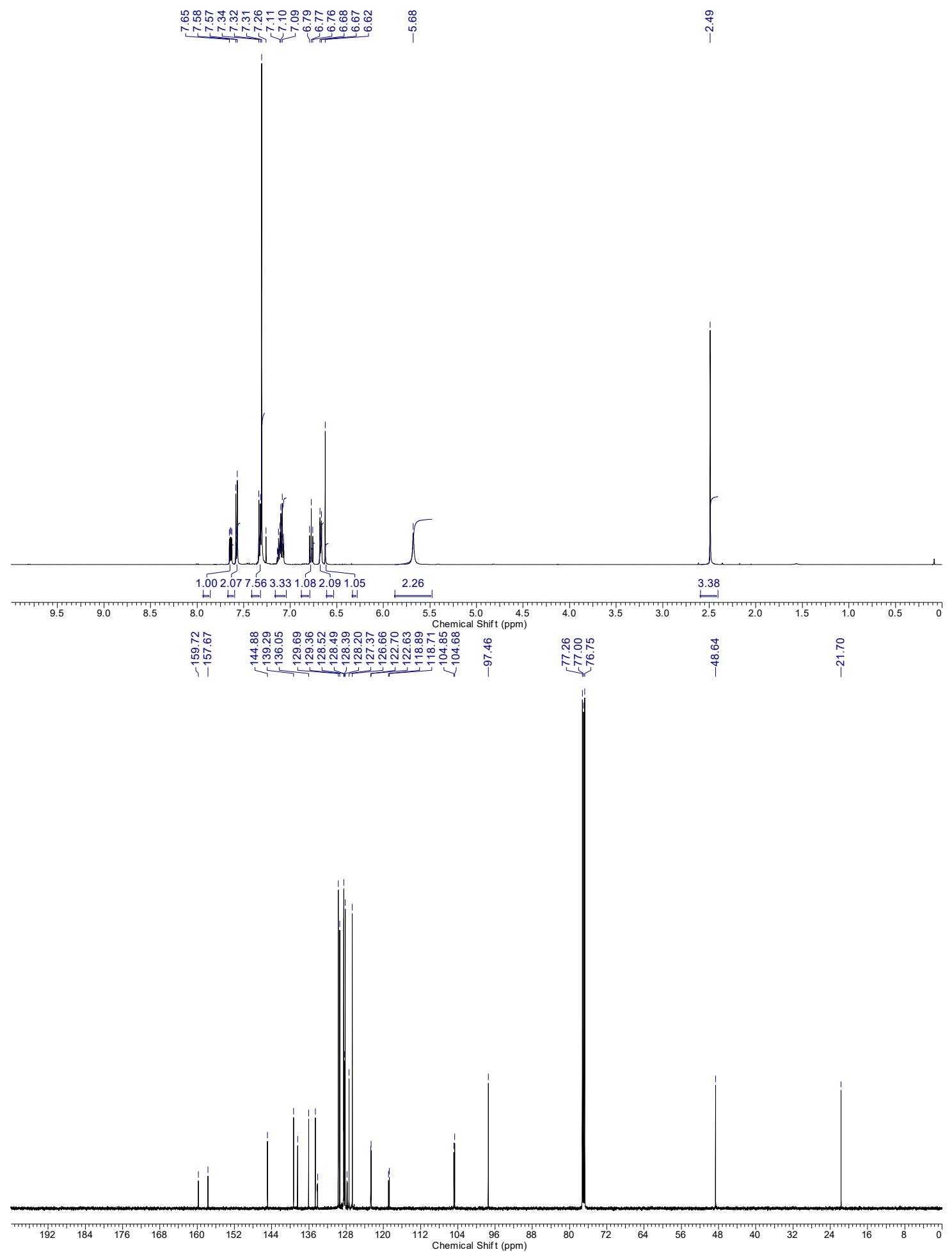


${ }^{19} \mathrm{~F}\left(470 \mathrm{MHz}, \mathrm{CDCl}_{3}\right)$

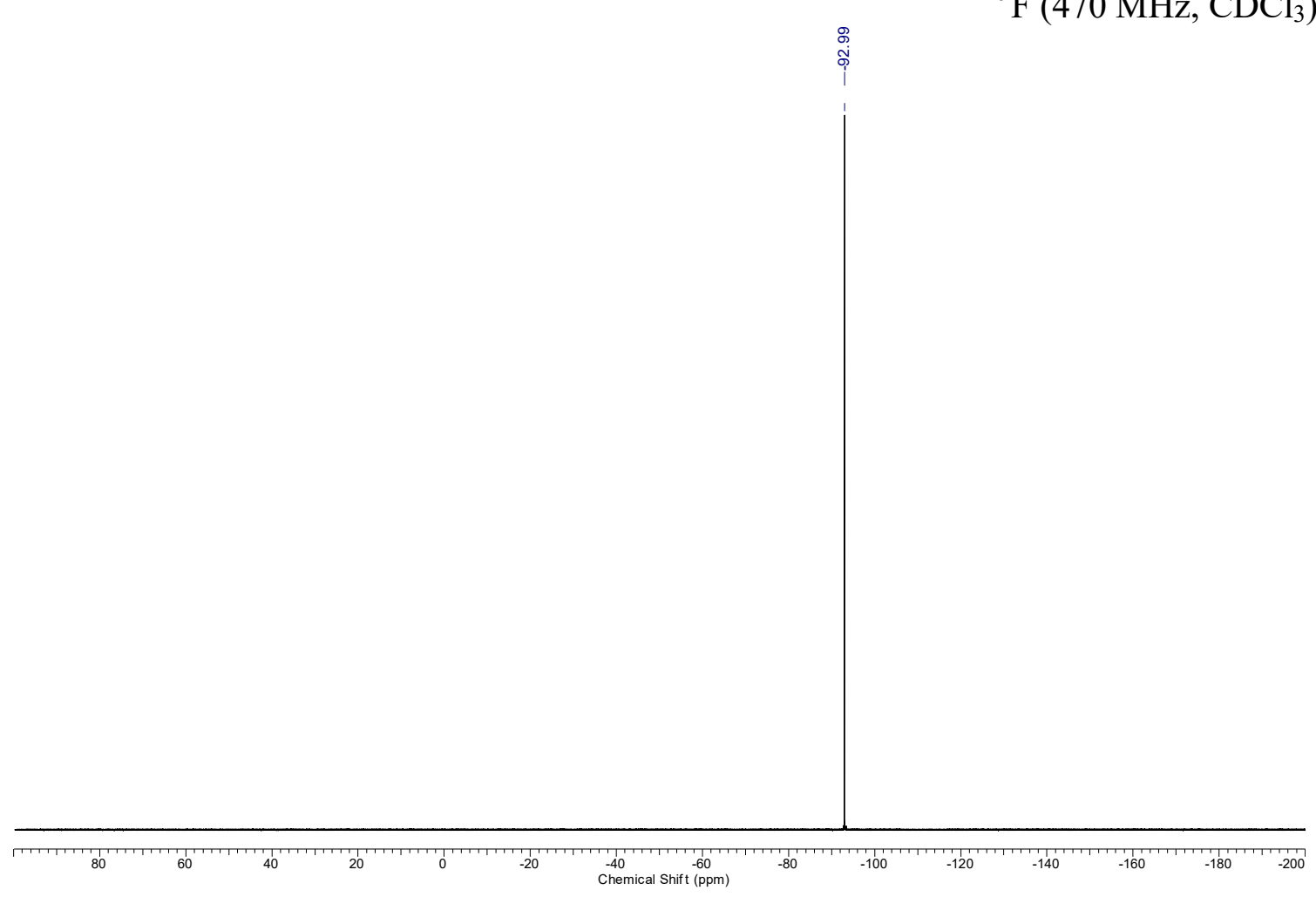


(E)-N-(1-chloro-5-methylhex-1-en-3-yn-2-yl)- $N$-phenyltosylamide, S1a<smiles>Cc1ccc(S(=O)(=O)N(C(C#CC(C)C)=CCl)c2ccccc2)cc1</smiles>

${ }^{1} \mathrm{H}\left(400 \mathrm{MHz}, \mathrm{CDCl}_{3}\right)$

${ }^{13} \mathrm{C}\left(101 \mathrm{MHz}, \mathrm{CDCl}_{3}\right)$

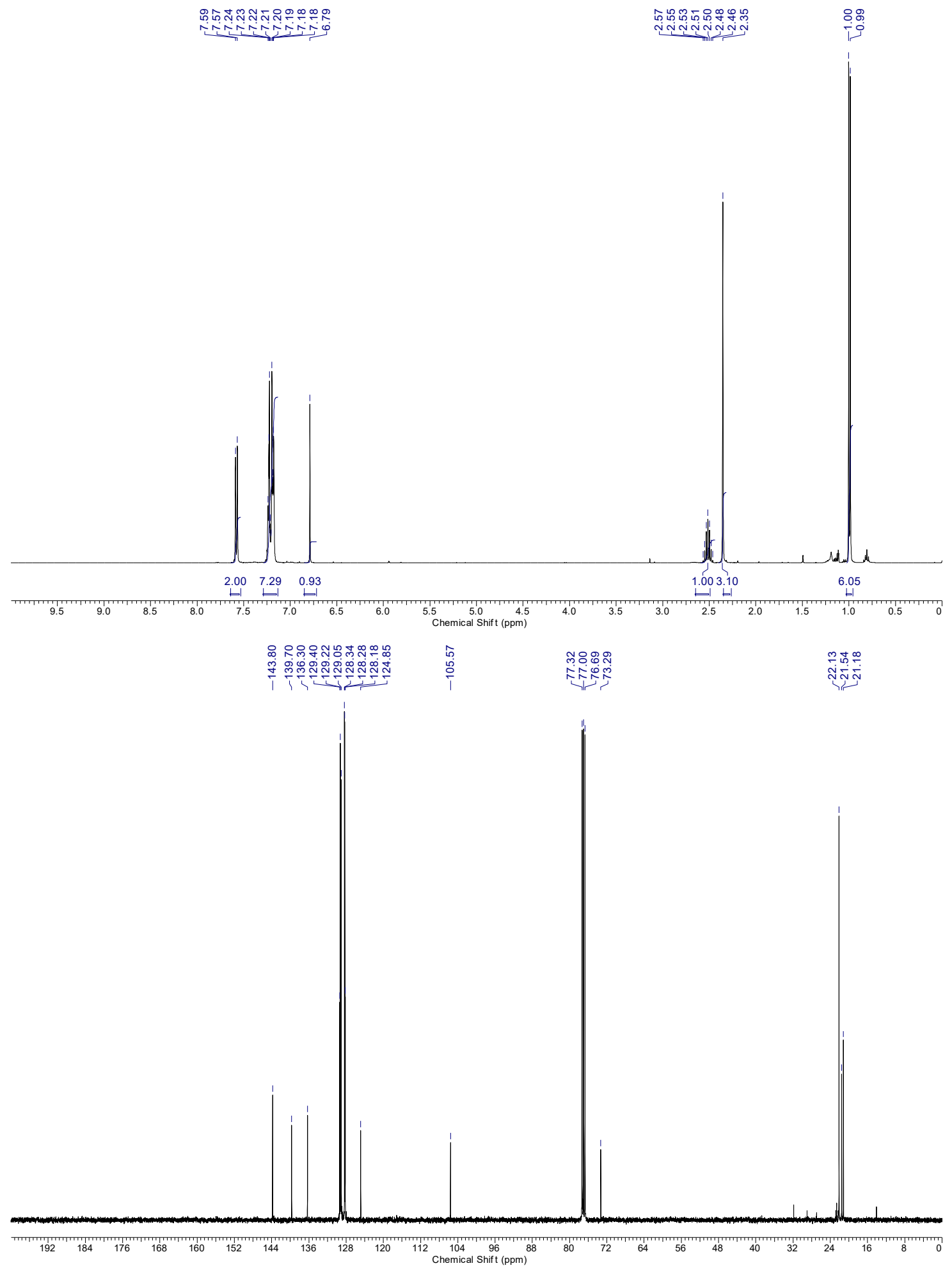


(E)- $N$-(1-Chloro-4-(p-tolyl)but-1-en-3-yn-2-yl)- $N$-phenyltosylamide, S1b

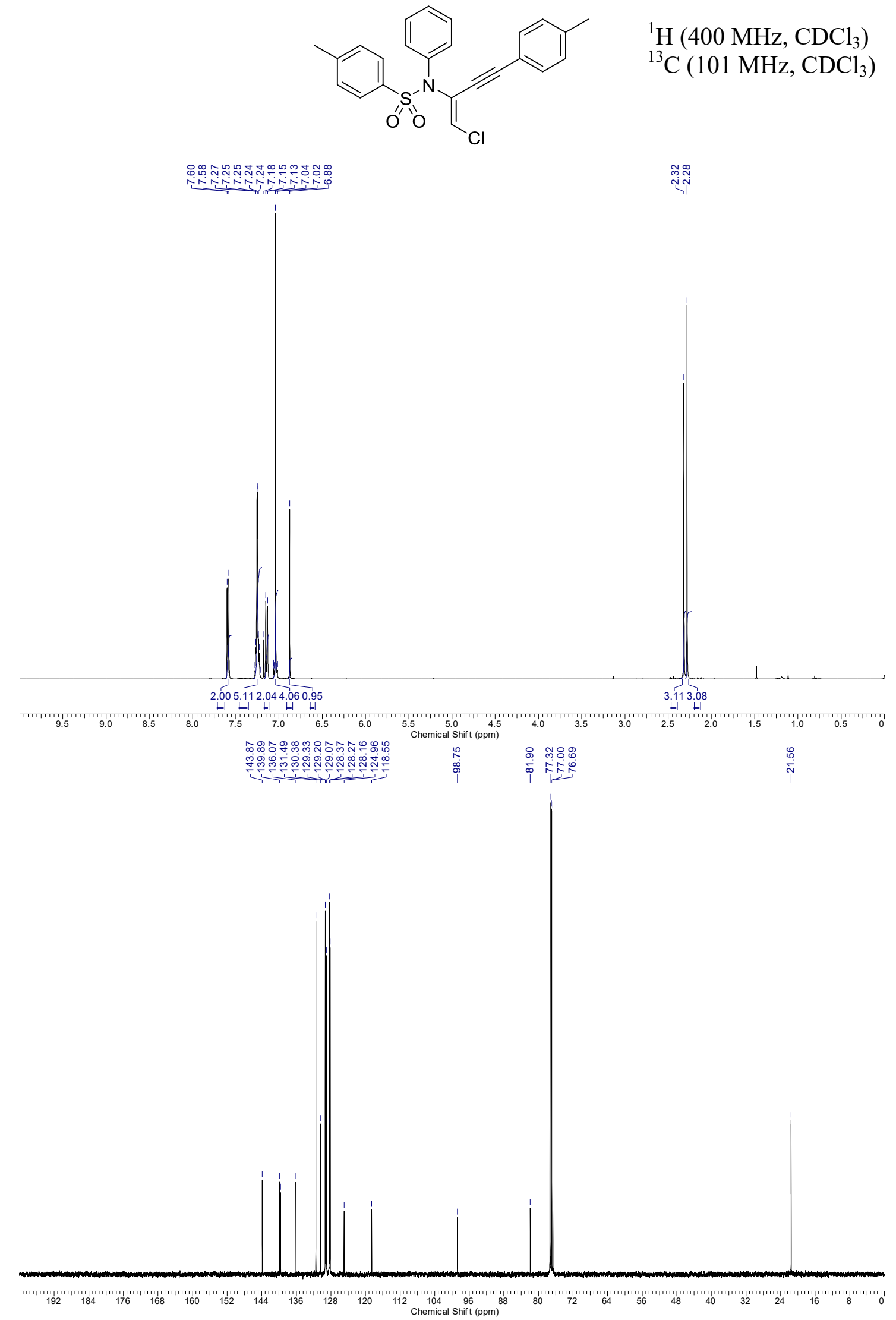


(E)- $N$-(1-Chloro-4-(trimethylsilyl)but-1-en-3-yn-2-yl)- $N$-phenyltosylamide, S1c
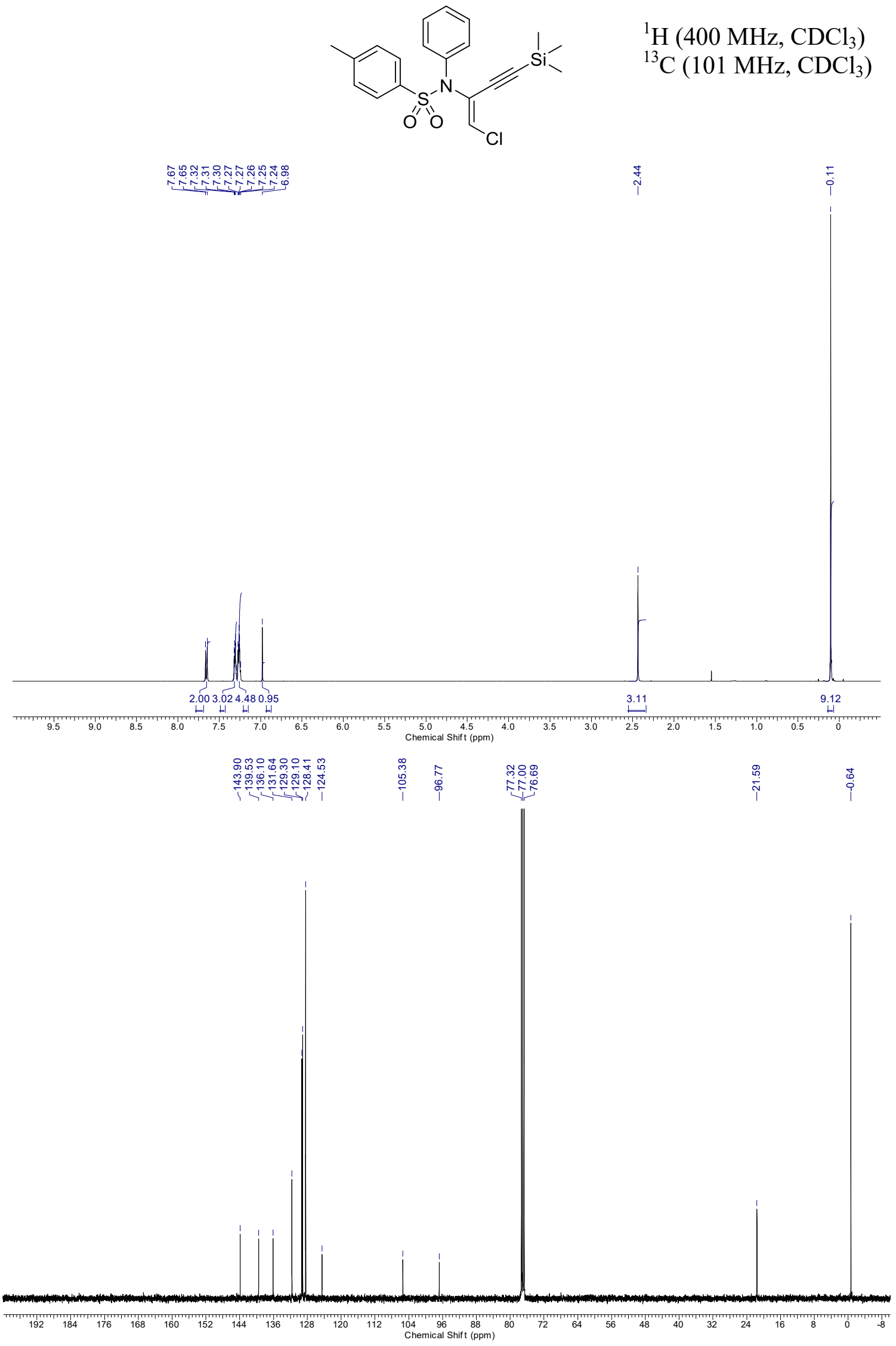
$N$-(5-Methylhexa-1,3-diyn-1-yl)- $N$-phenyltosylamide, S2a

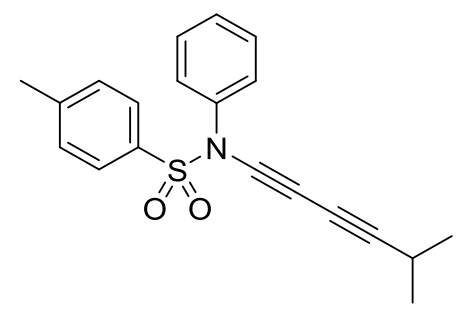

${ }^{1} \mathrm{H}\left(400 \mathrm{MHz}, \mathrm{CDCl}_{3}\right)$

${ }^{13} \mathrm{C}\left(101 \mathrm{MHz}, \mathrm{CDCl}_{3}\right)$

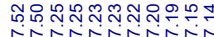

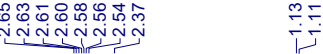

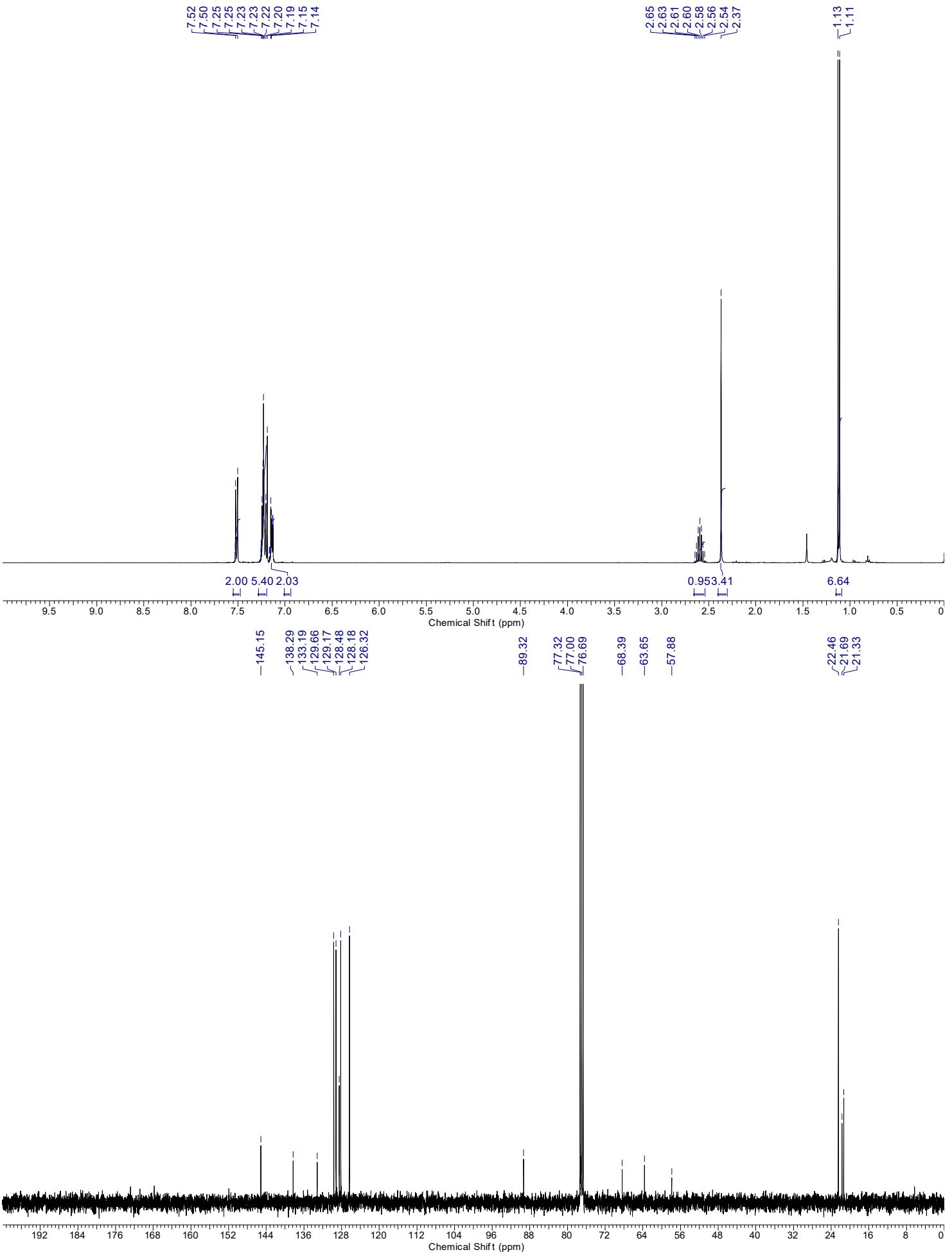




\section{2a Sulfonamide Scope: Dichloroenamides}

(E)- $N$-(1,2-Dichlorovinyl)- $N$-phenyl-4-(trifluoro methyl)benzenesulfonamide, $3 \mathrm{~b}$<smiles>O=S(=O)(c1ccc(C(F)(F)F)cc1)N(/C(Cl)=C\Cl)c1ccccc1</smiles>

${ }^{1} \mathrm{H}\left(400 \mathrm{MHz}, \mathrm{CDCl}_{3}\right)$

${ }^{13} \mathrm{C}\left(101 \mathrm{MHz}, \mathrm{CDCl}_{3}\right)$

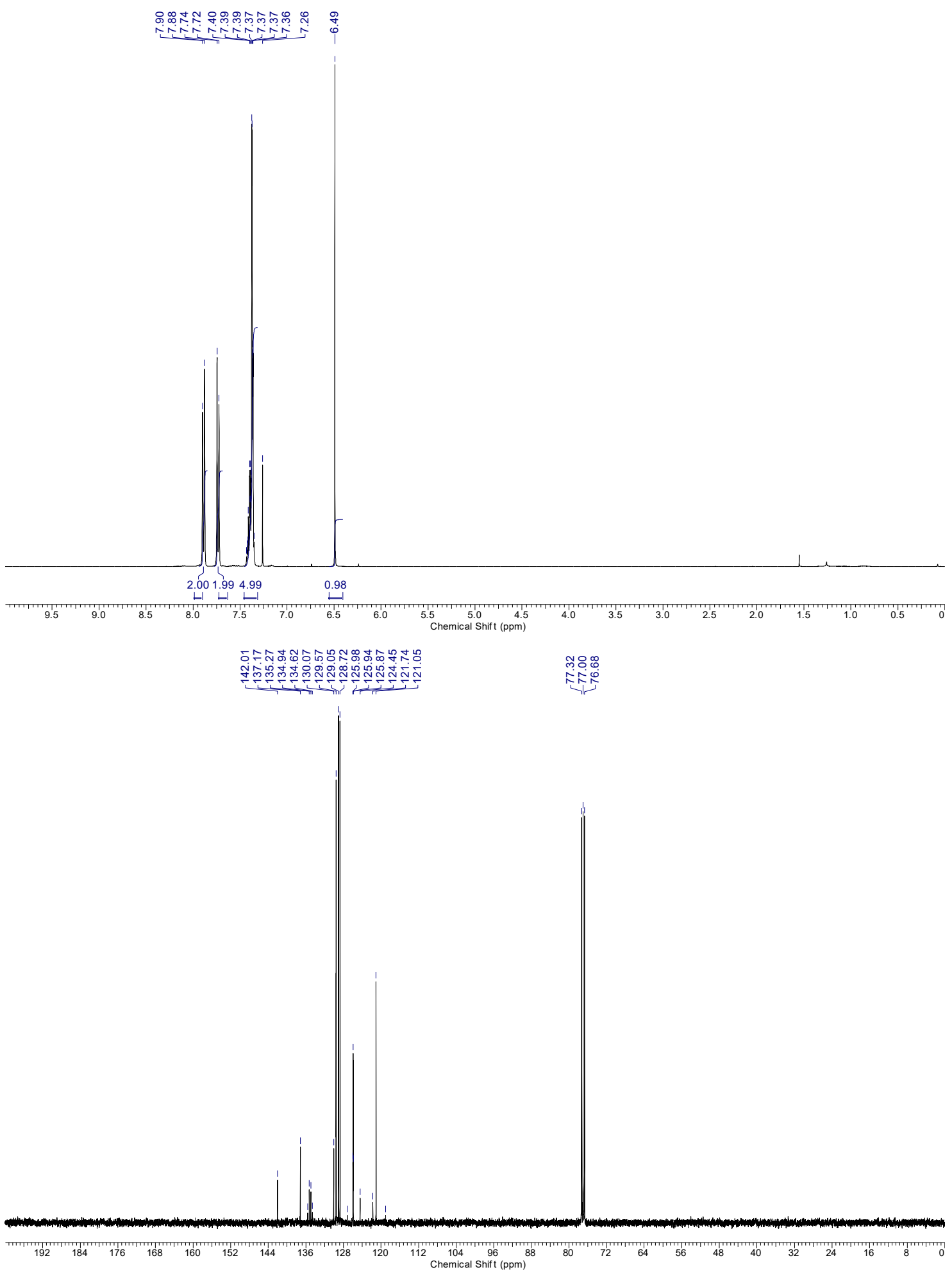


${ }^{19} \mathrm{~F}\left(376 \mathrm{MHz}, \mathrm{CDCl}_{3}\right)$

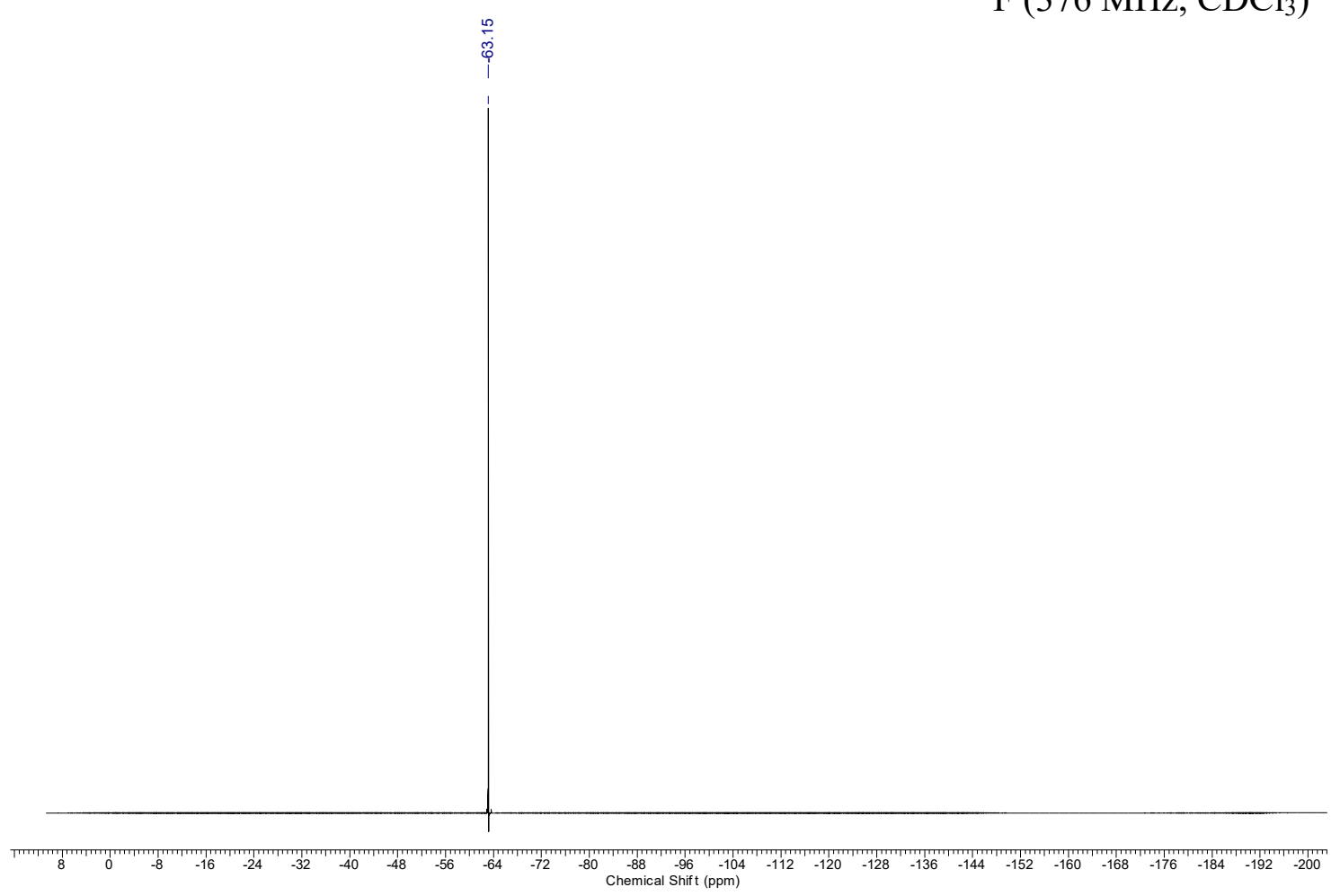


(E)- $N$-Phenyl- $N$-(1,2-dichlorovinyl)-3,5-bis(trifluoromethyl)benzenesulfonamide, 3c

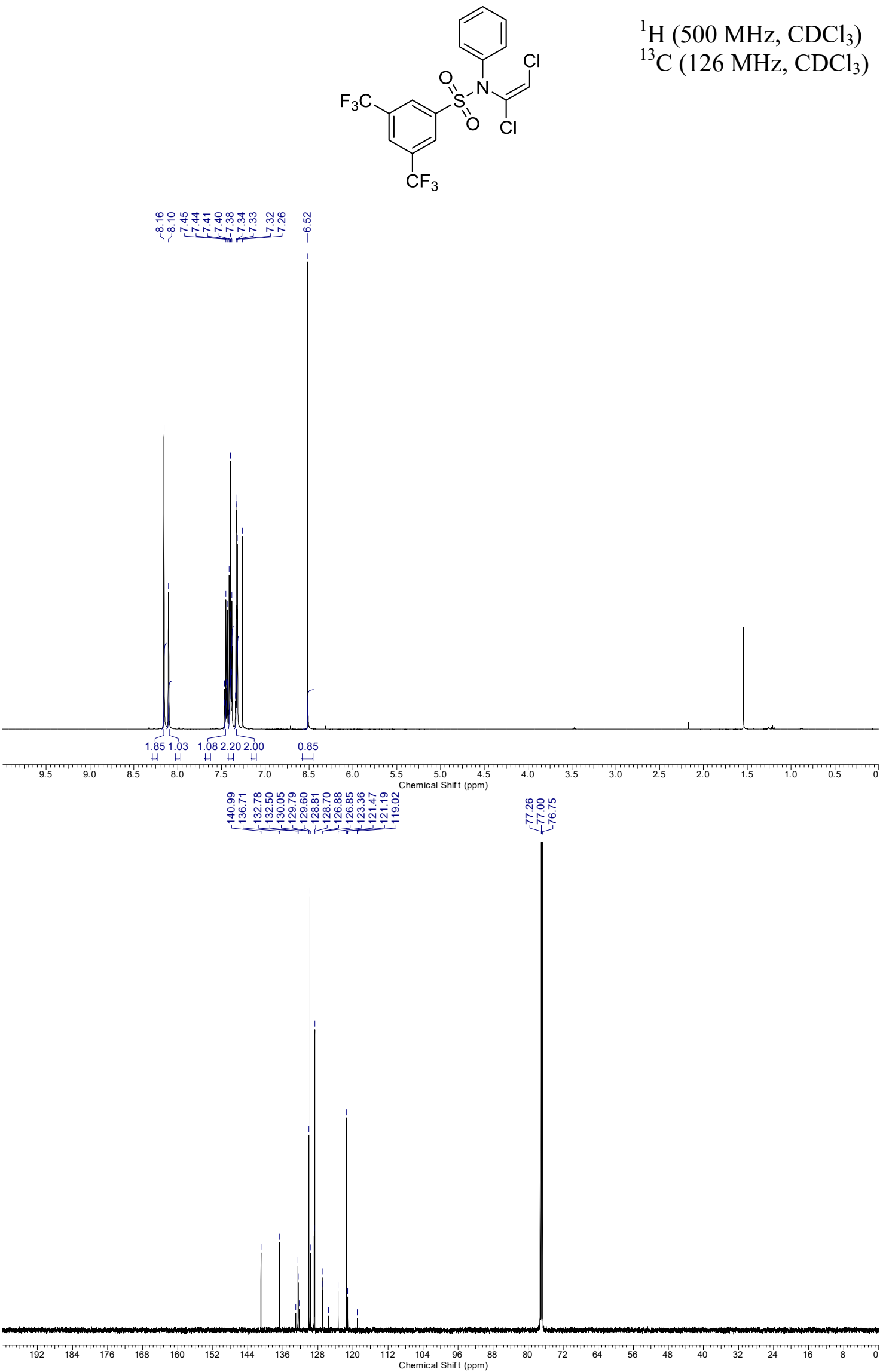

${ }^{1} \mathrm{H}\left(500 \mathrm{MHz}, \mathrm{CDCl}_{3}\right)$

${ }^{13} \mathrm{C}\left(126 \mathrm{MHz}, \mathrm{CDCl}_{3}\right)$ 
${ }^{19} \mathrm{~F}\left(470 \mathrm{MHz}, \mathrm{CDCl}_{3}\right)$

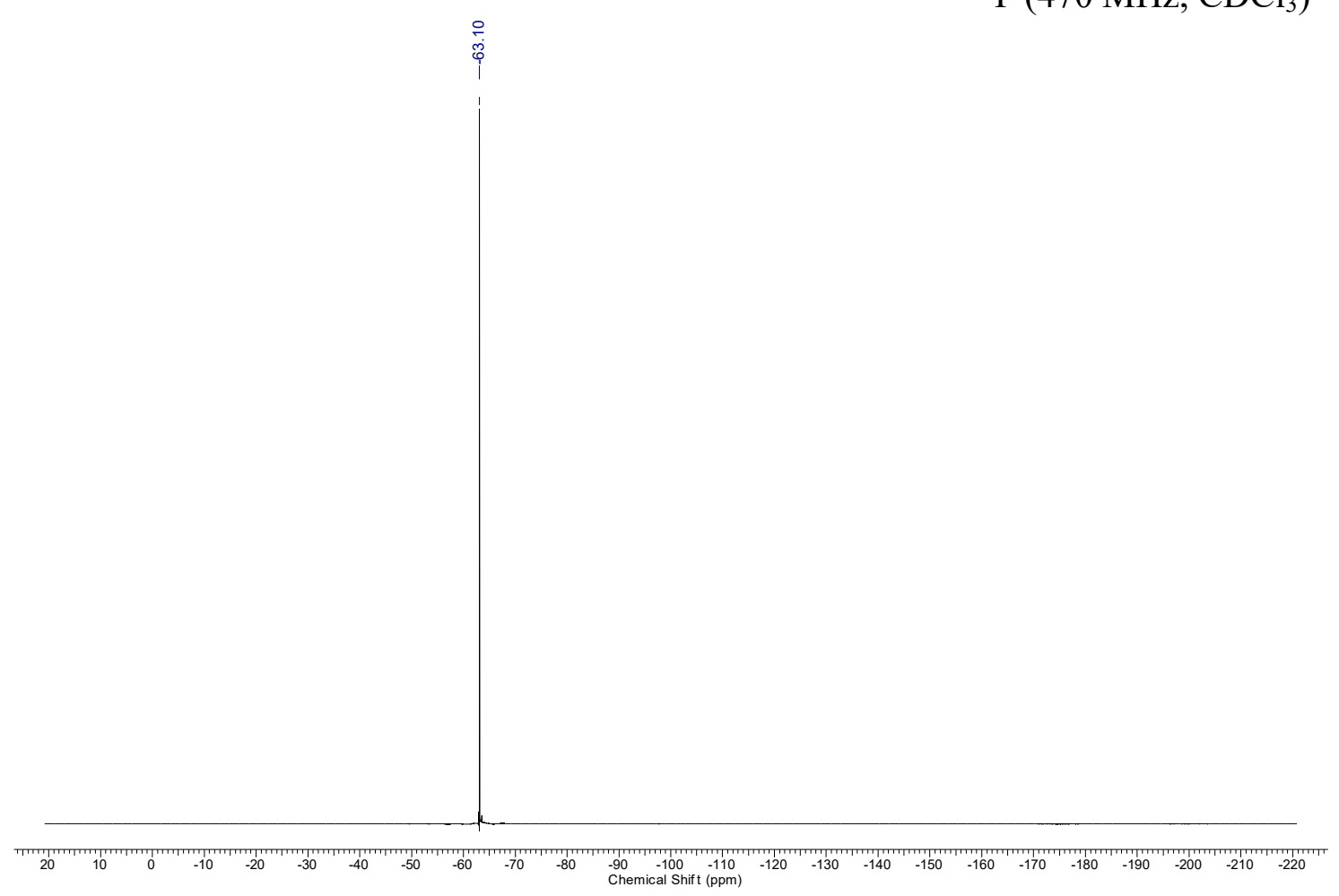


(E)- $N$-Phenyl- $N$-(1,2-dichlorovinyl)-4-nitrobenzenesulfonamide, $3 d$

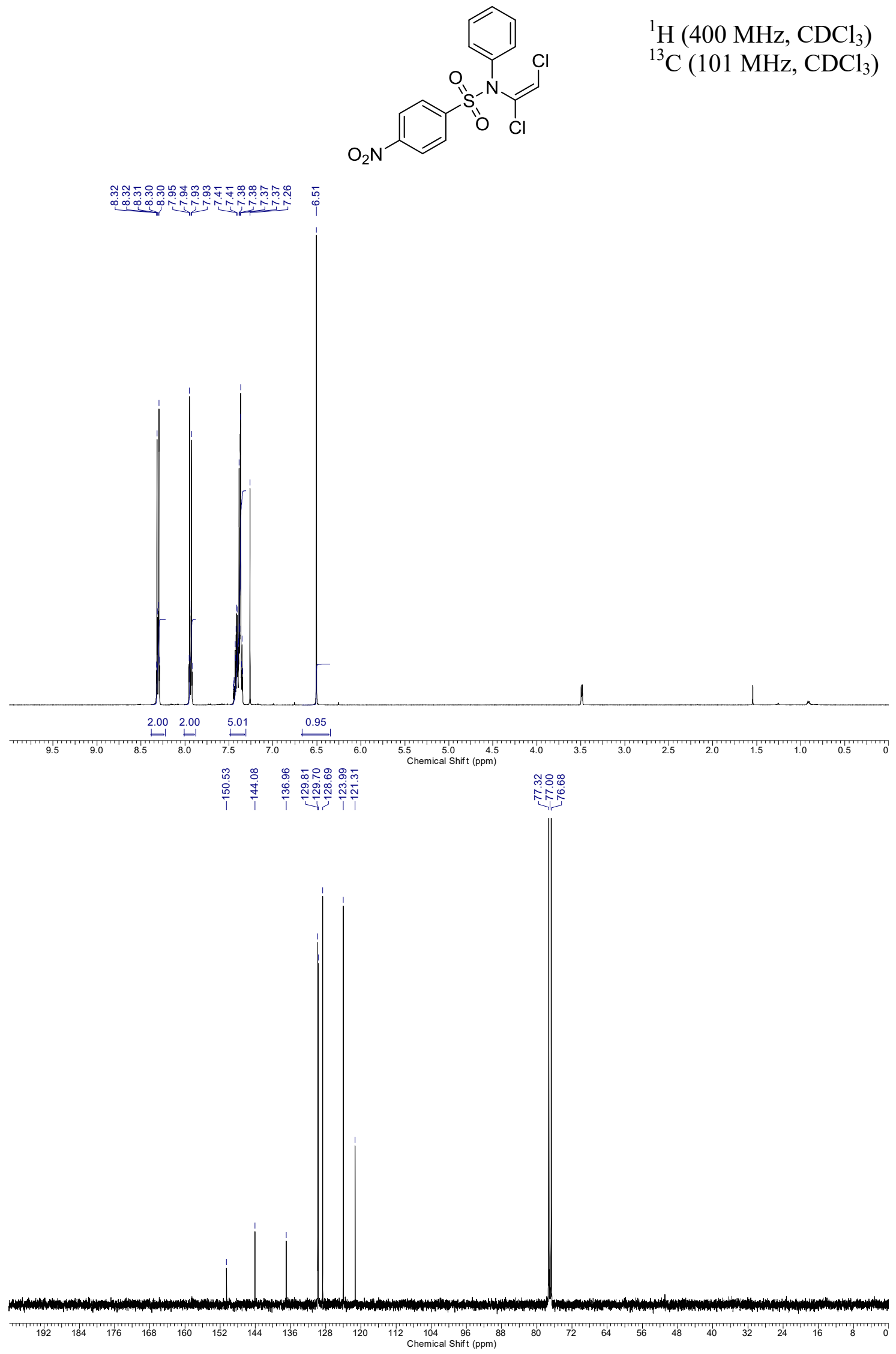


(E)-N-Benzyl- $N$-(1,2-dichlorovinyl)-2,4,6-triisopropylbenzenesulfonamide, $3 \mathrm{e}$

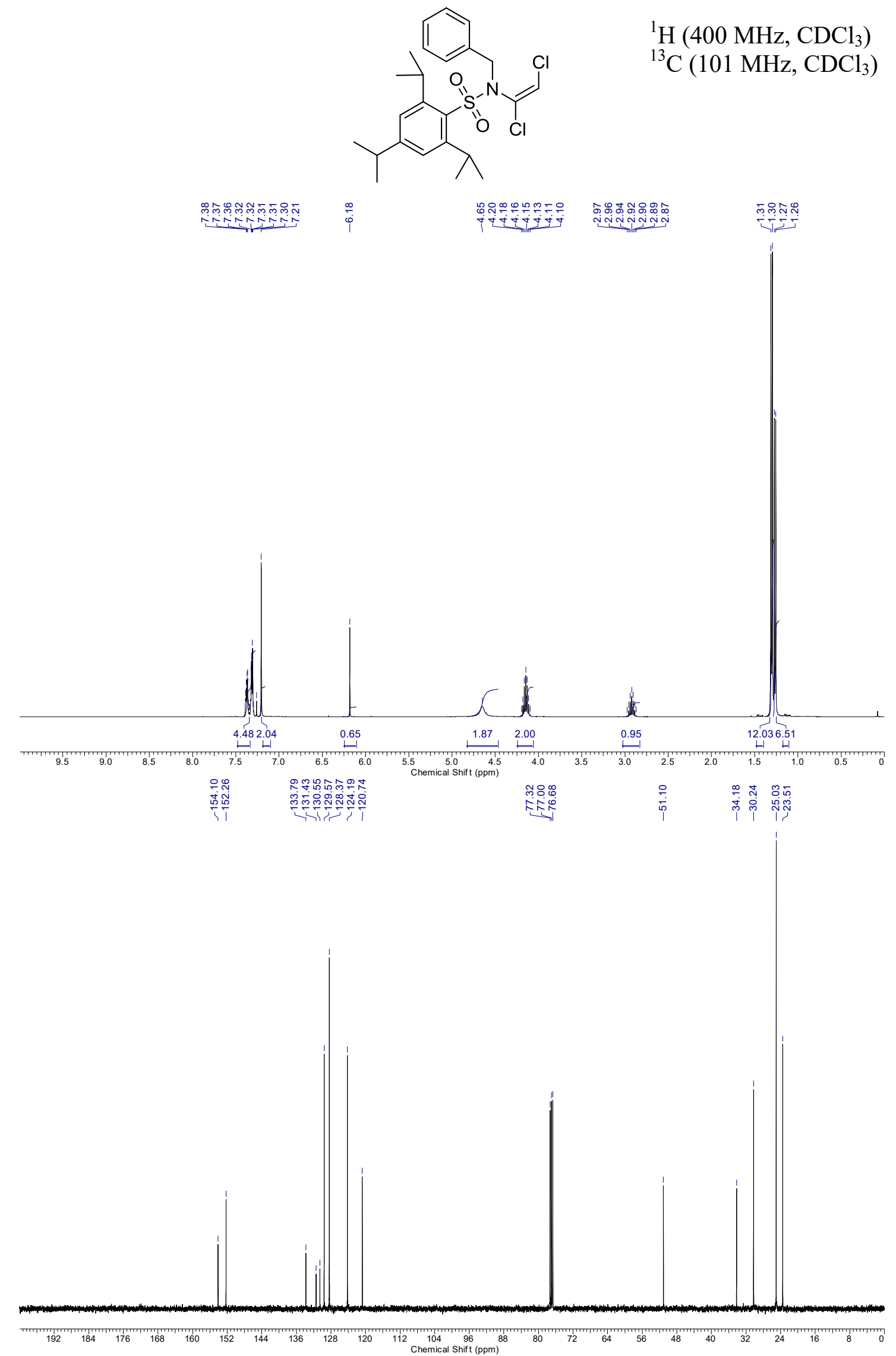


$N$-((E)-1,2-Dichlorovinyl)- $N$-[(Z)-hex-3-en-1-yl]tosylamide, $3 f$

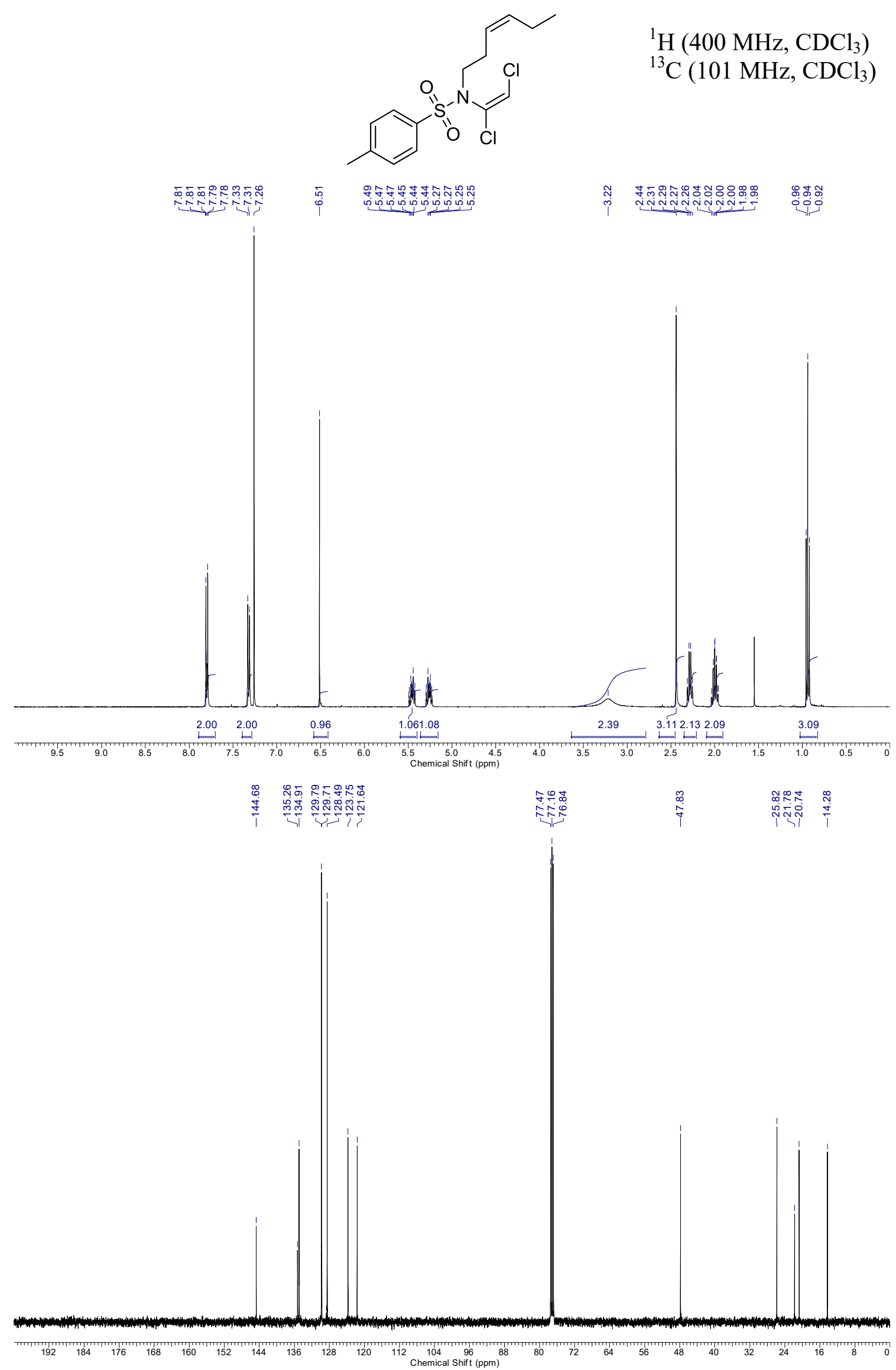


$N$-[(E)-1,2-Dichlorovinyl]- $N$-(3,3-diethoxypropyl)tosylamide, $3 \mathrm{~g}$

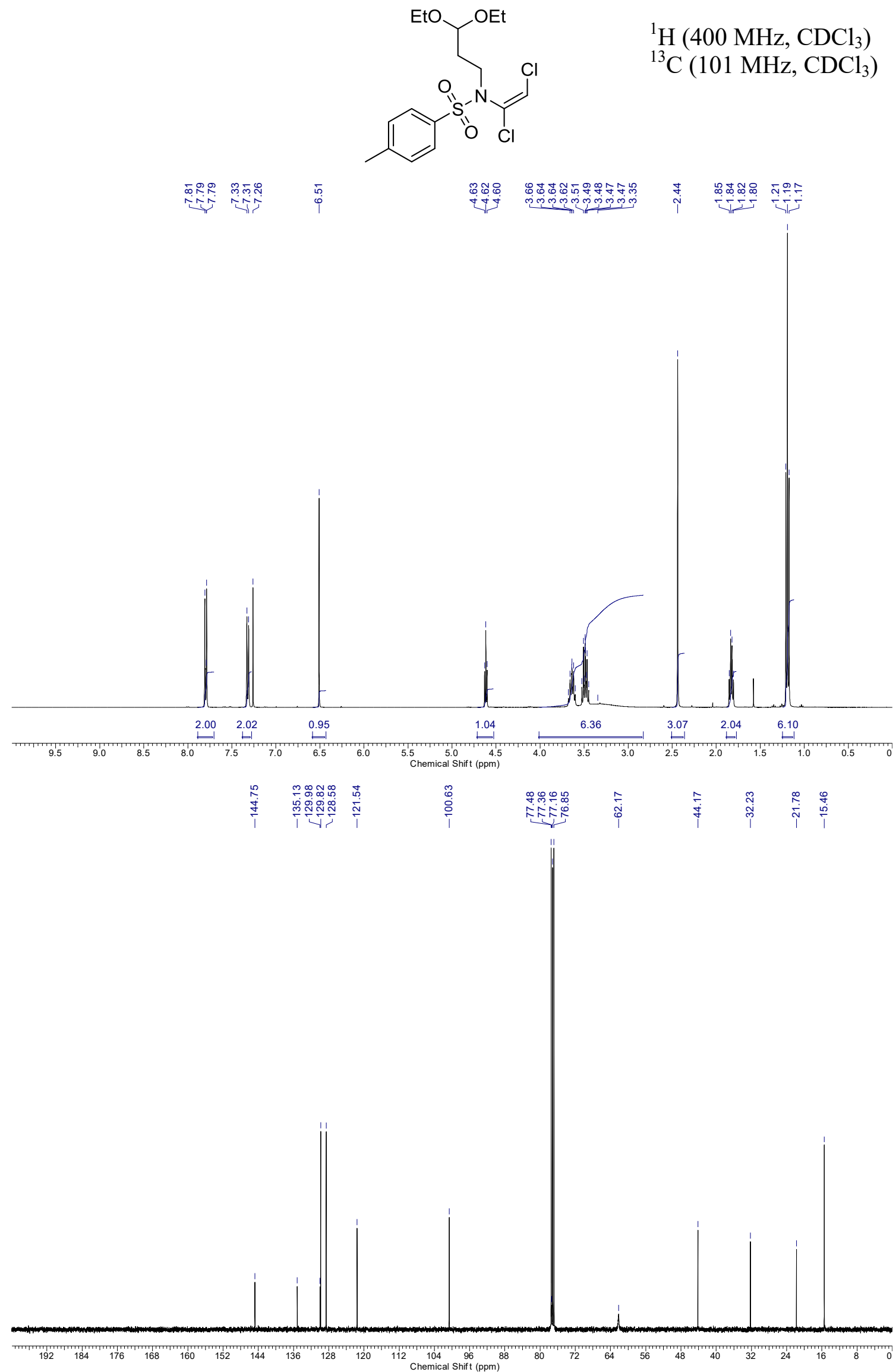


(E)-N-(1,2-Dichlorovinyl)- $N$-(furan-2-ylmethyl)tosylamide, $3 \mathrm{~h}$

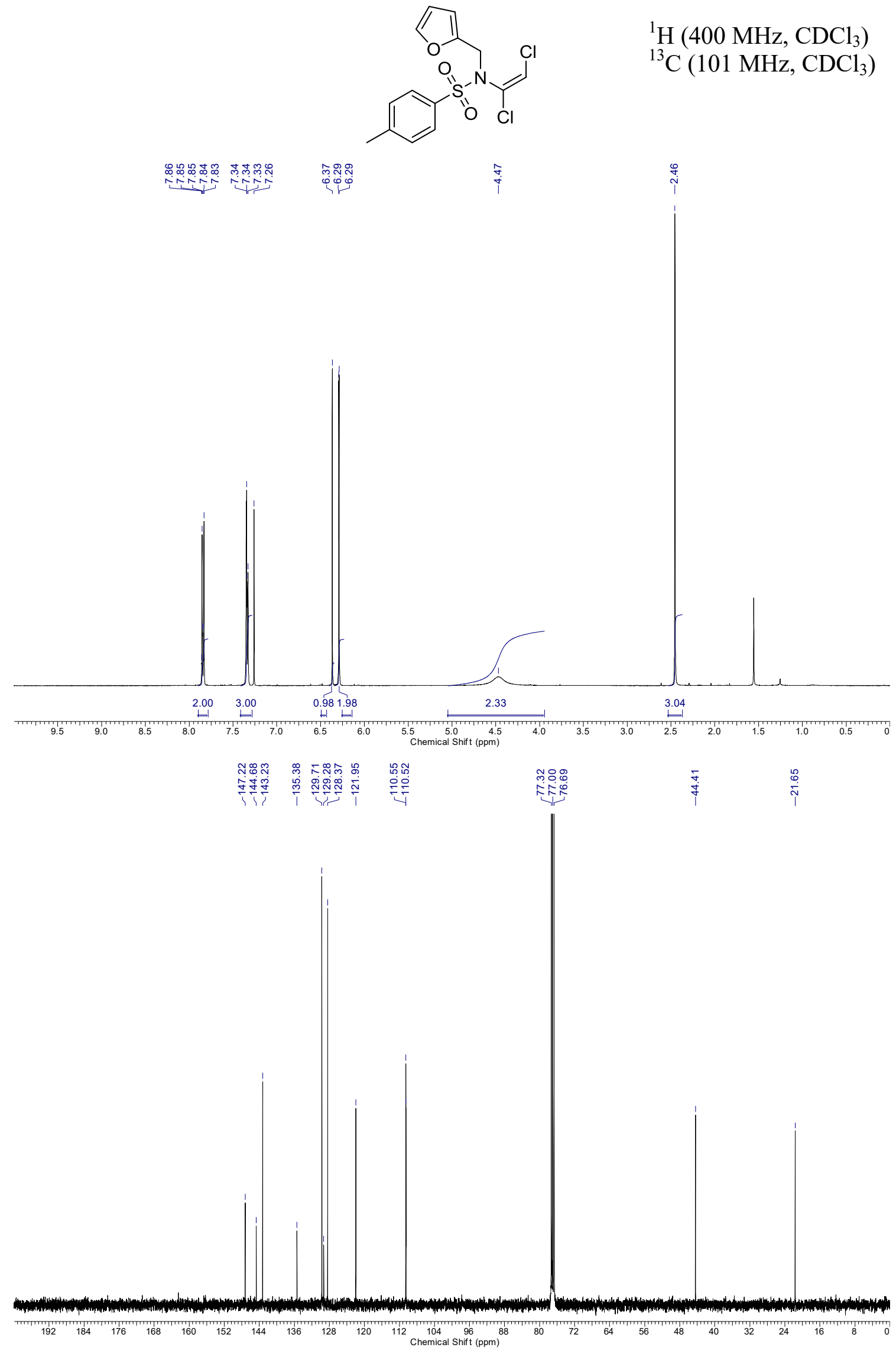


$N-[(Z)-1-\{[t-B u t y l(d i m e t h y l)$ silyl] $]$ xy $\}$ oct-4-en-2-yl]- $N-[(E)-1,2-$ dichlorovinyl $]$ tosylamide, $3 \mathbf{i}$

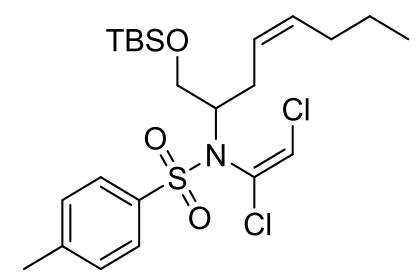

${ }^{1} \mathrm{H}(500 \mathrm{MHz}$, toluene$\mathrm{d} 8,363 \mathrm{~K})$

${ }^{13} \mathrm{C}(126 \mathrm{MHz}$, toluene$\mathrm{d} 8,363 \mathrm{~K})$
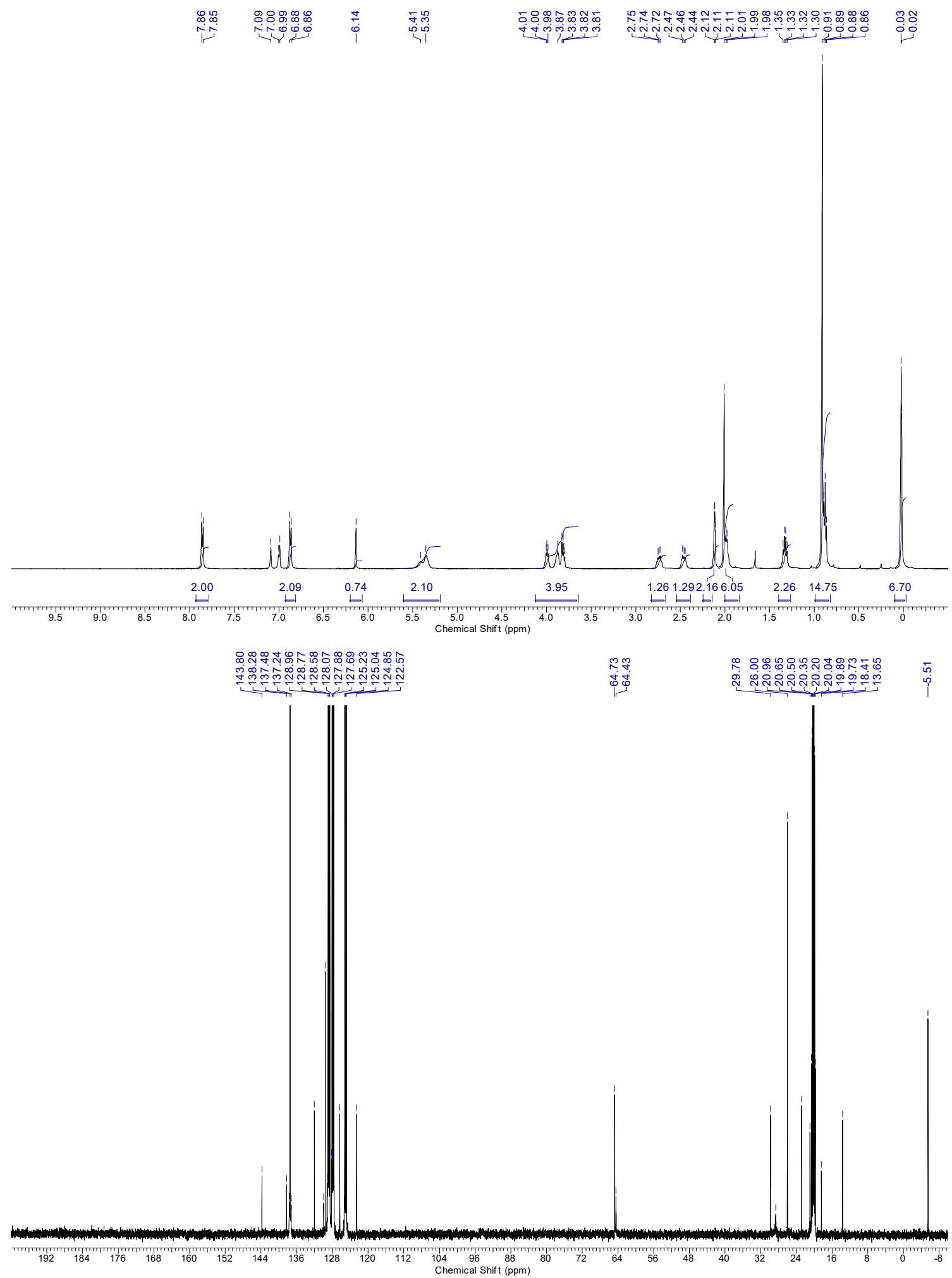
$N$-((E)-1,2-Dichlorovinyl)- $N-((1 s, 2 s)-1,2-$ diphenylbut-3-en-1-yl) tosylamide, $3 \mathrm{j}$

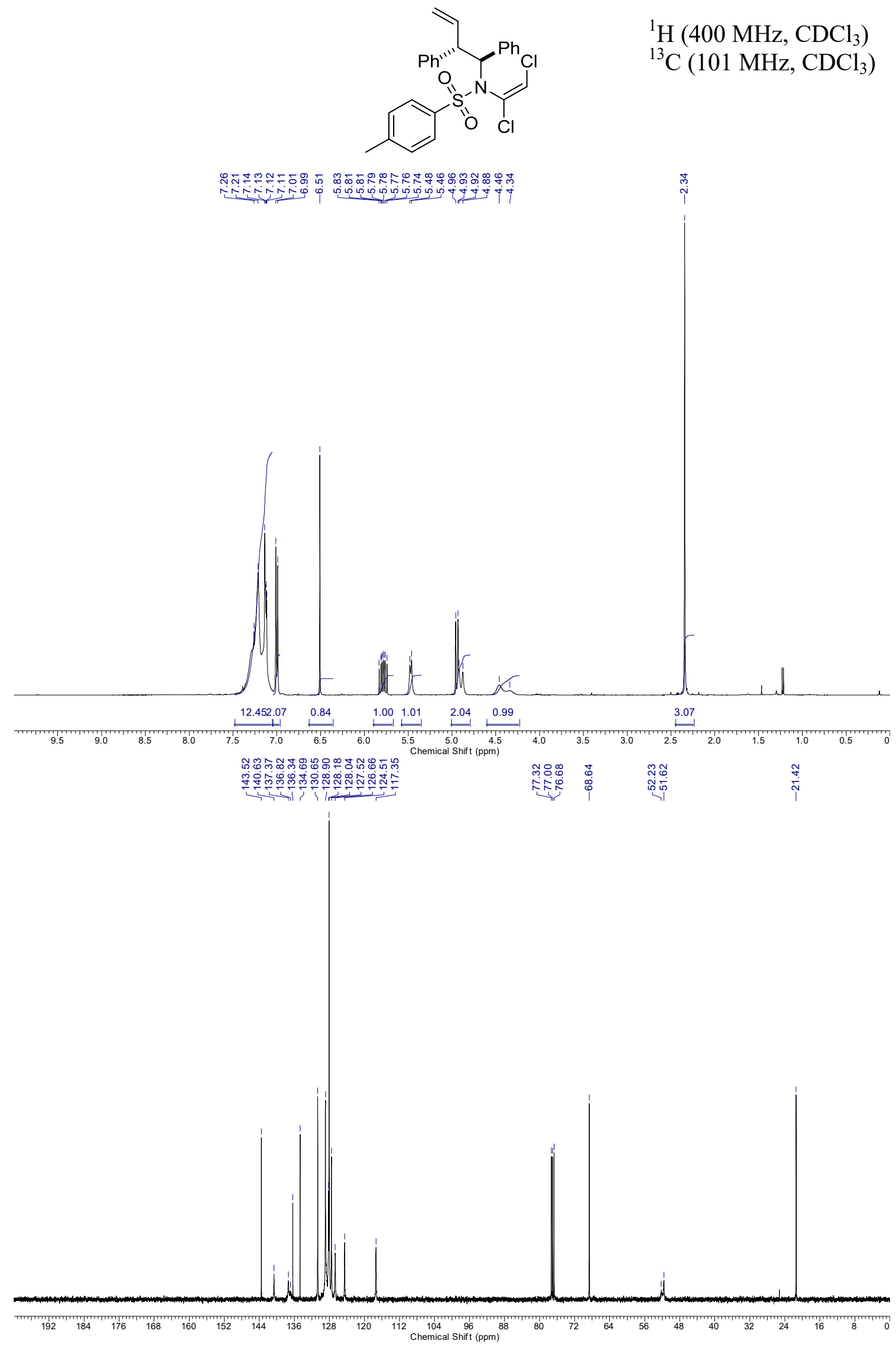


(E)-N-(t-Butyl)-N-(1,2-dichlorovinyl)tosylamide, $3 \mathrm{k}$

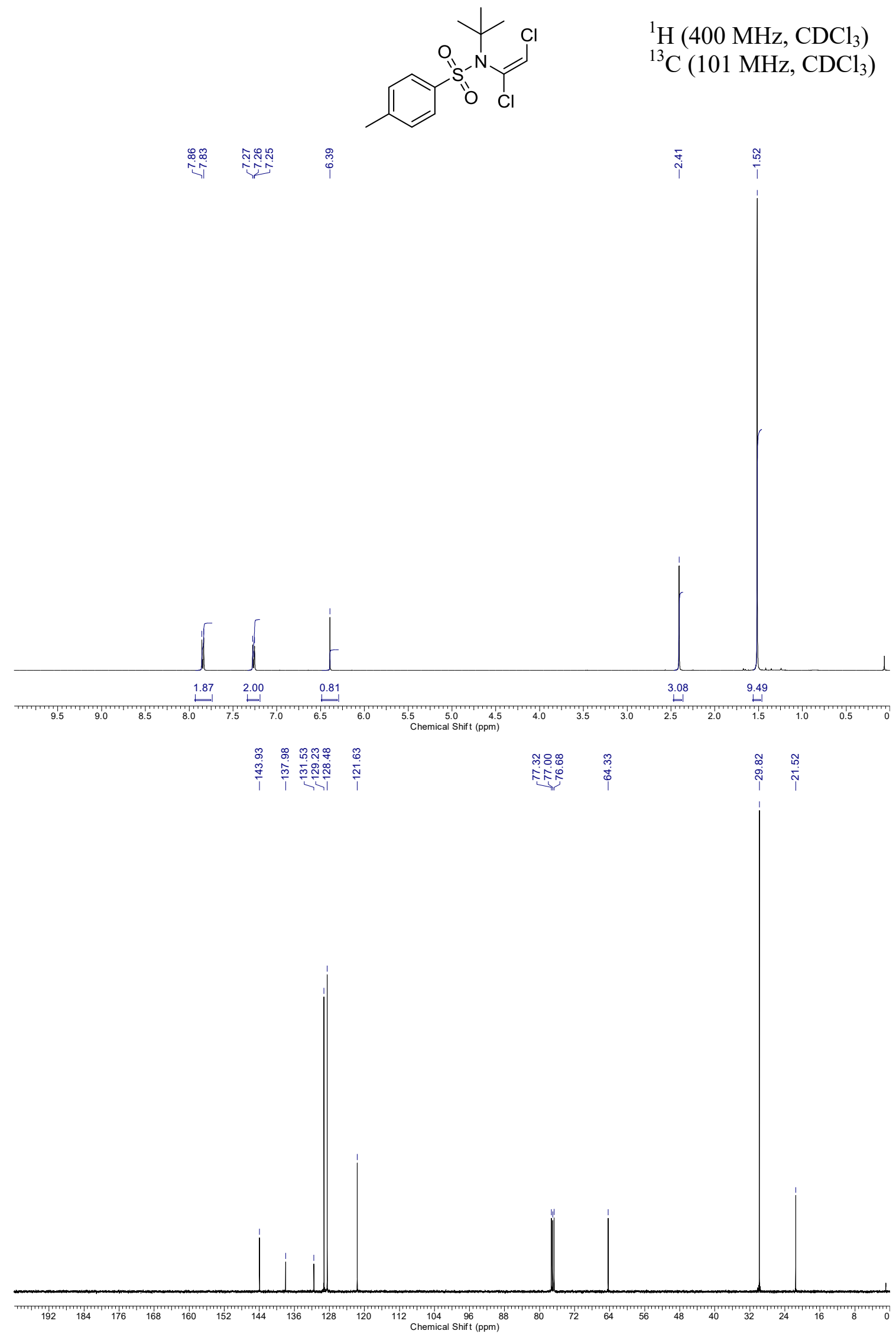


(E)-N-(2-Bromophenyl)- $N$-(1,2-dichlorovinyl)tosylamide, 31

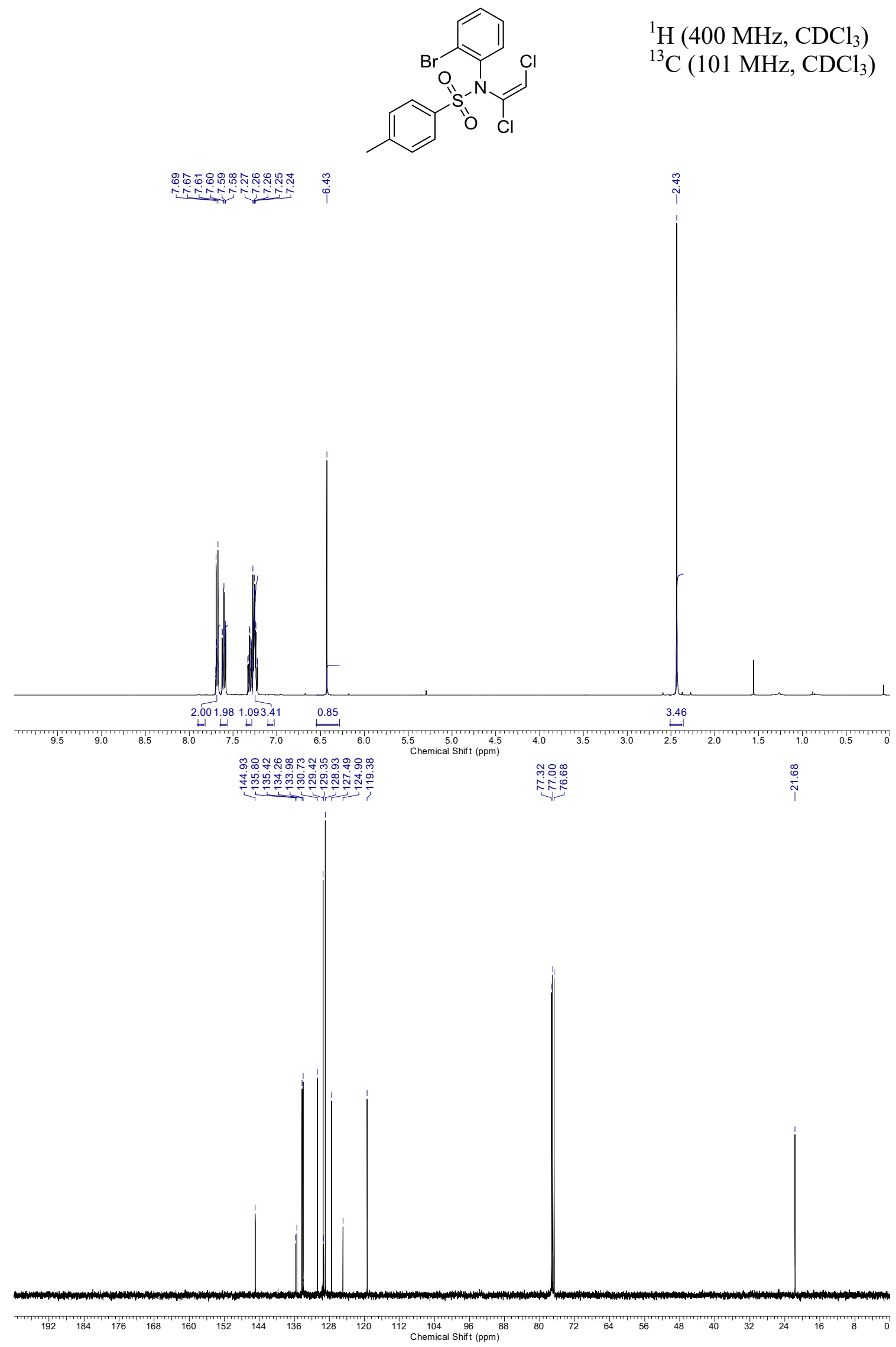


(E)-N-(1,2-Dichlorovinyl)- $N$-(2,6-diisopropylphenyl)tosylamide, $3 \mathrm{~m}$

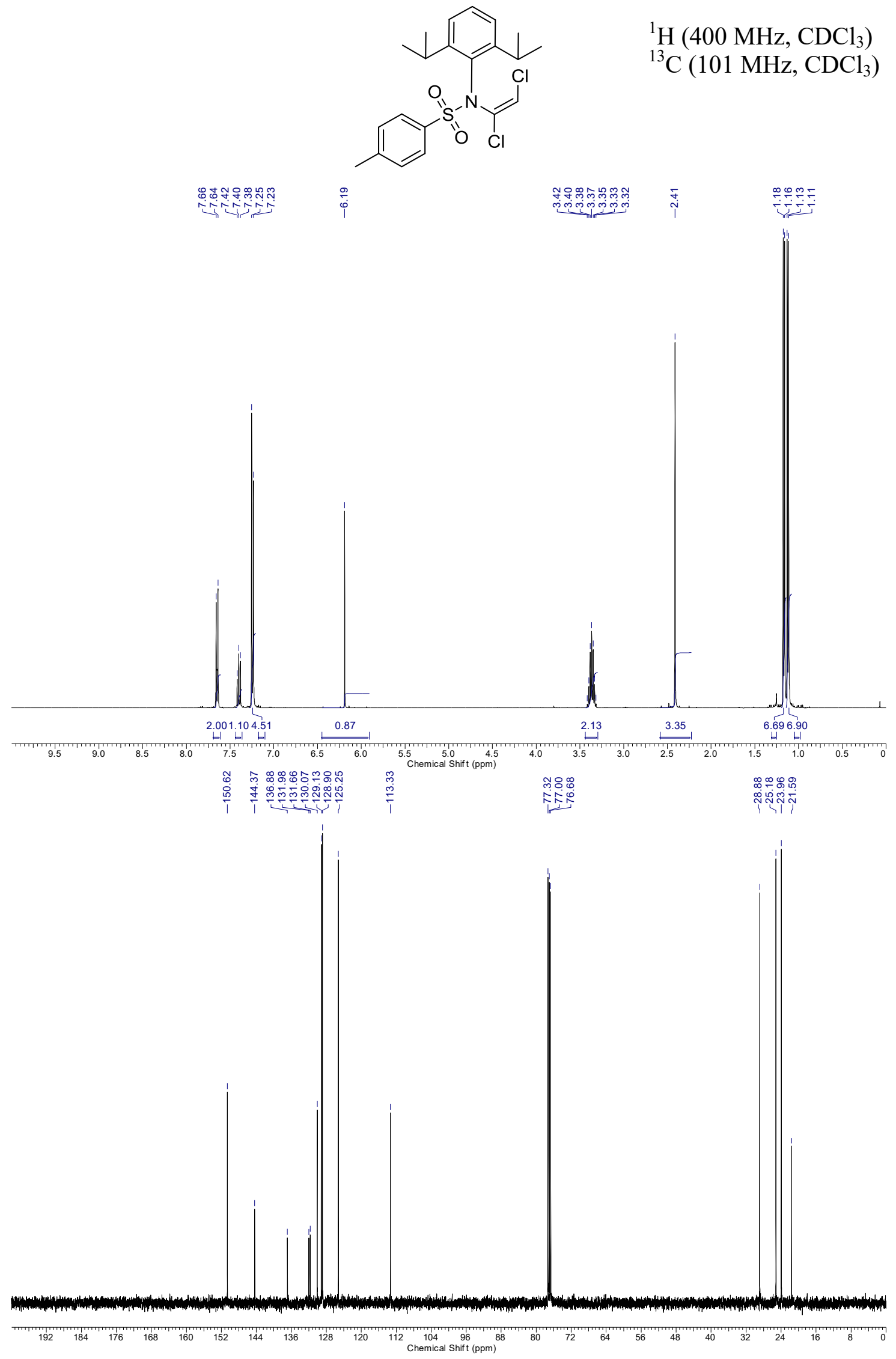




\section{2b Sulfonamide Scope: Ynamides}

$\mathrm{N}$-((4-Chlorophenyl)ethynyl)- $\mathrm{N}$-phenyltosylamide, 1am

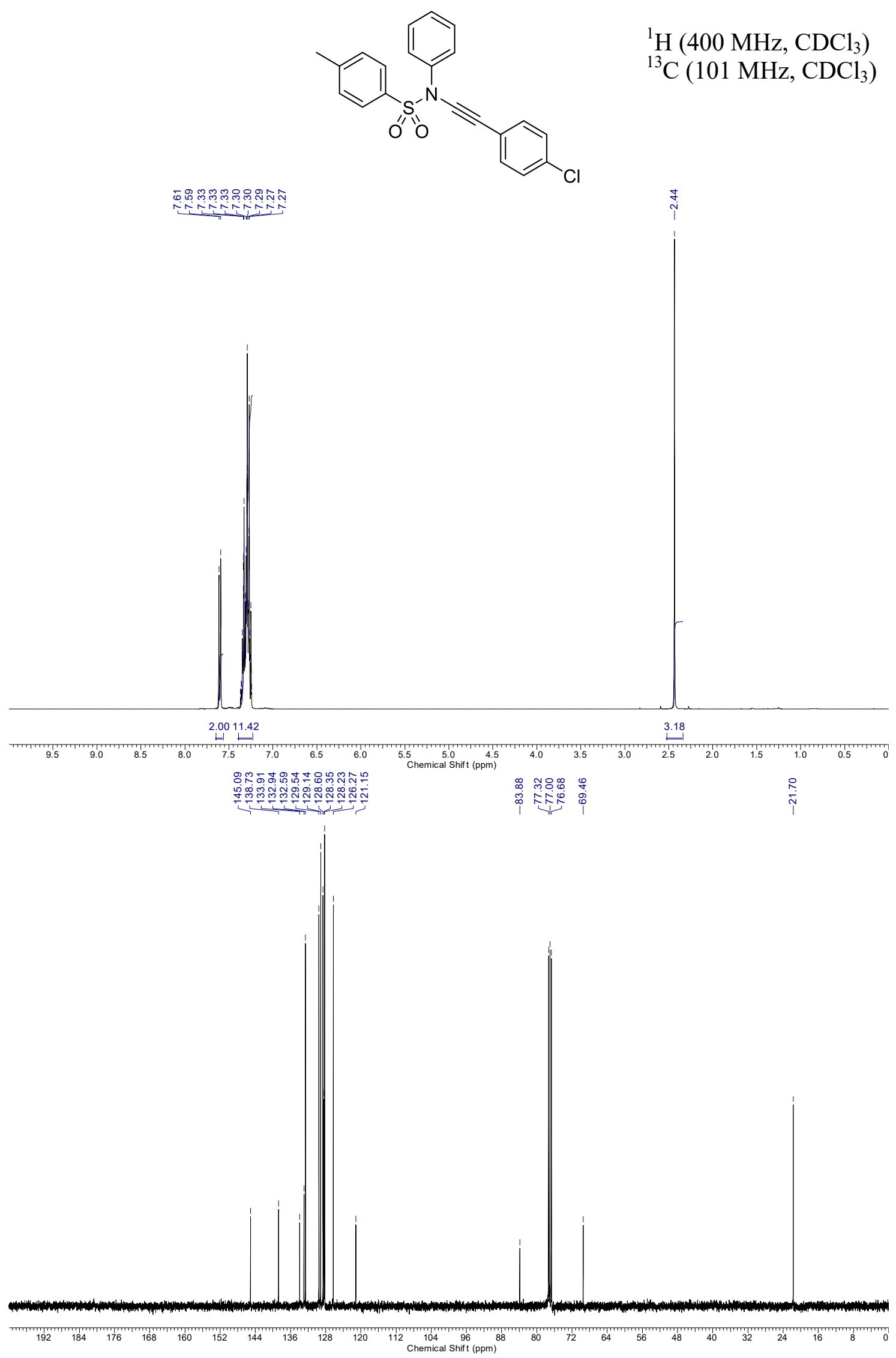


$N$-((4-Chlorophenyl)ethynyl)- $N$-phenyl-4-(trifluoromethyl)benzenesulfonamide, 1an<smiles>O=S(=O)(c1ccc(C(F)(F)F)cc1)N(C#Cc1ccc(Cl)cc1)c1ccccc1</smiles>

${ }^{1} \mathrm{H}\left(400 \mathrm{MHz}, \mathrm{CDCl}_{3}\right)$

${ }^{13} \mathrm{C}\left(101 \mathrm{MHz}, \mathrm{CDCl}_{3}\right)$
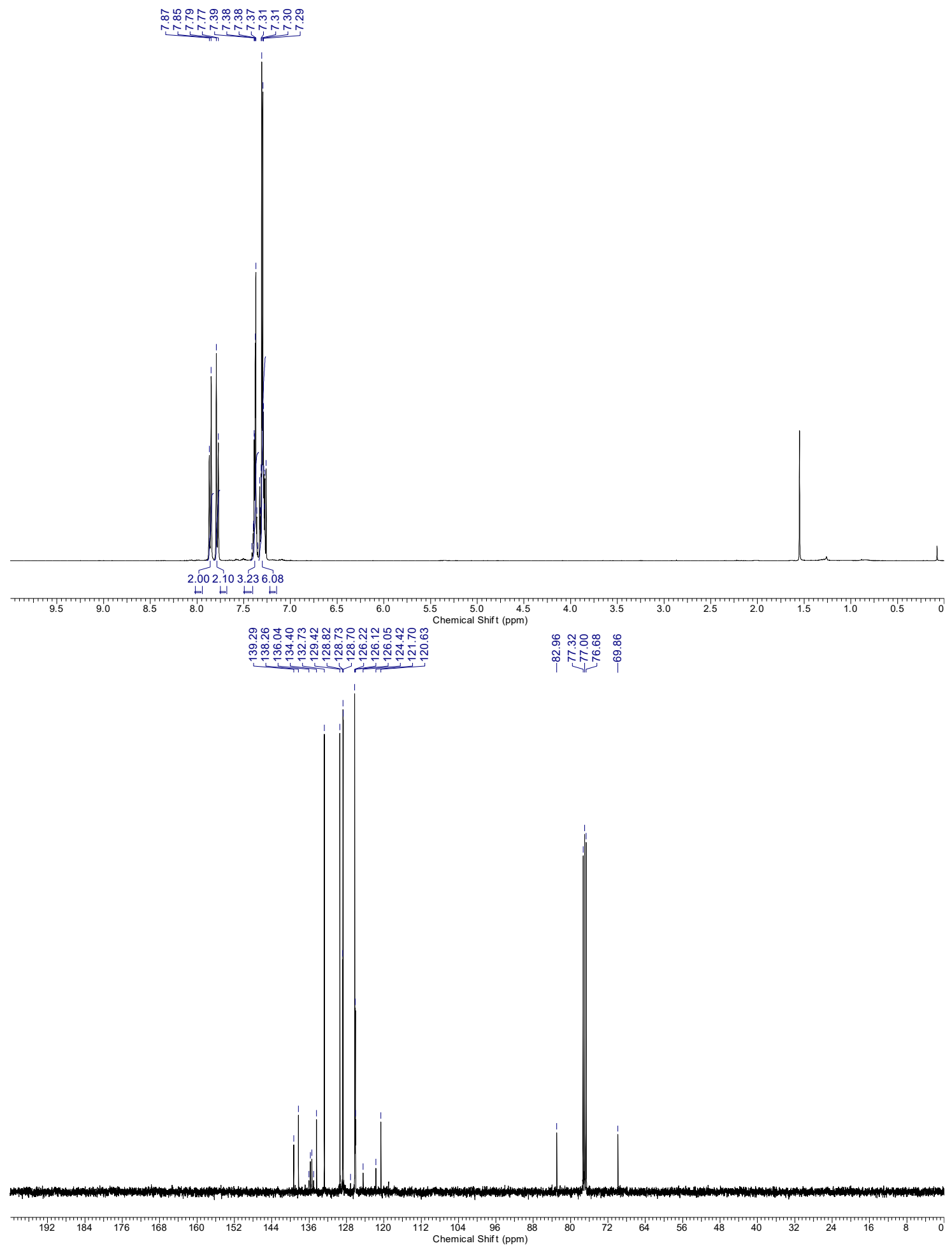
${ }^{19} \mathrm{~F}\left(376 \mathrm{MHz}, \mathrm{CDCl}_{3}\right)$

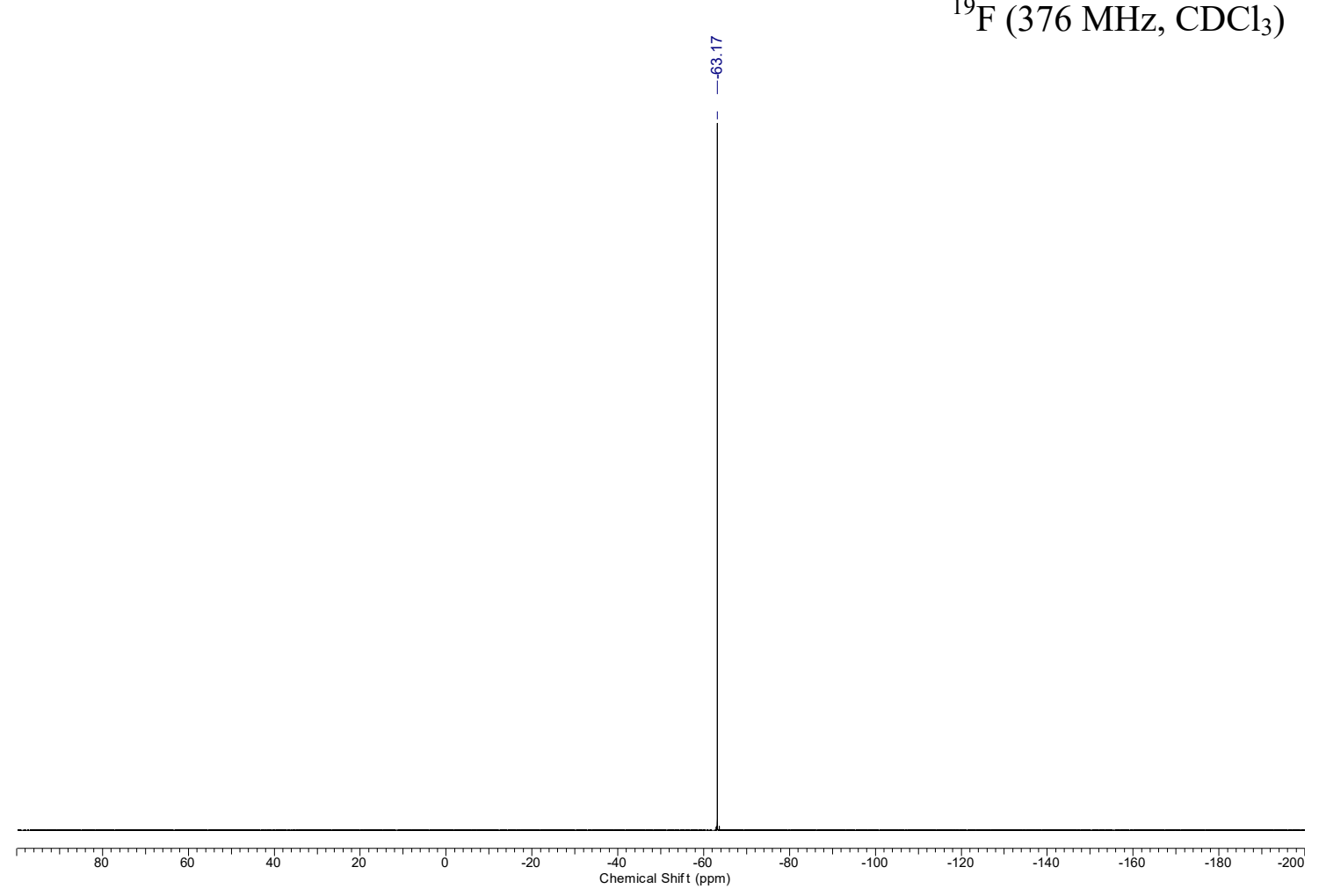


$N$-((4-Chlorophenyl)ethynyl)- $N$-phenyl-3,5-bis(trifluoromethyl)benzenesulfonamide, 1 ao
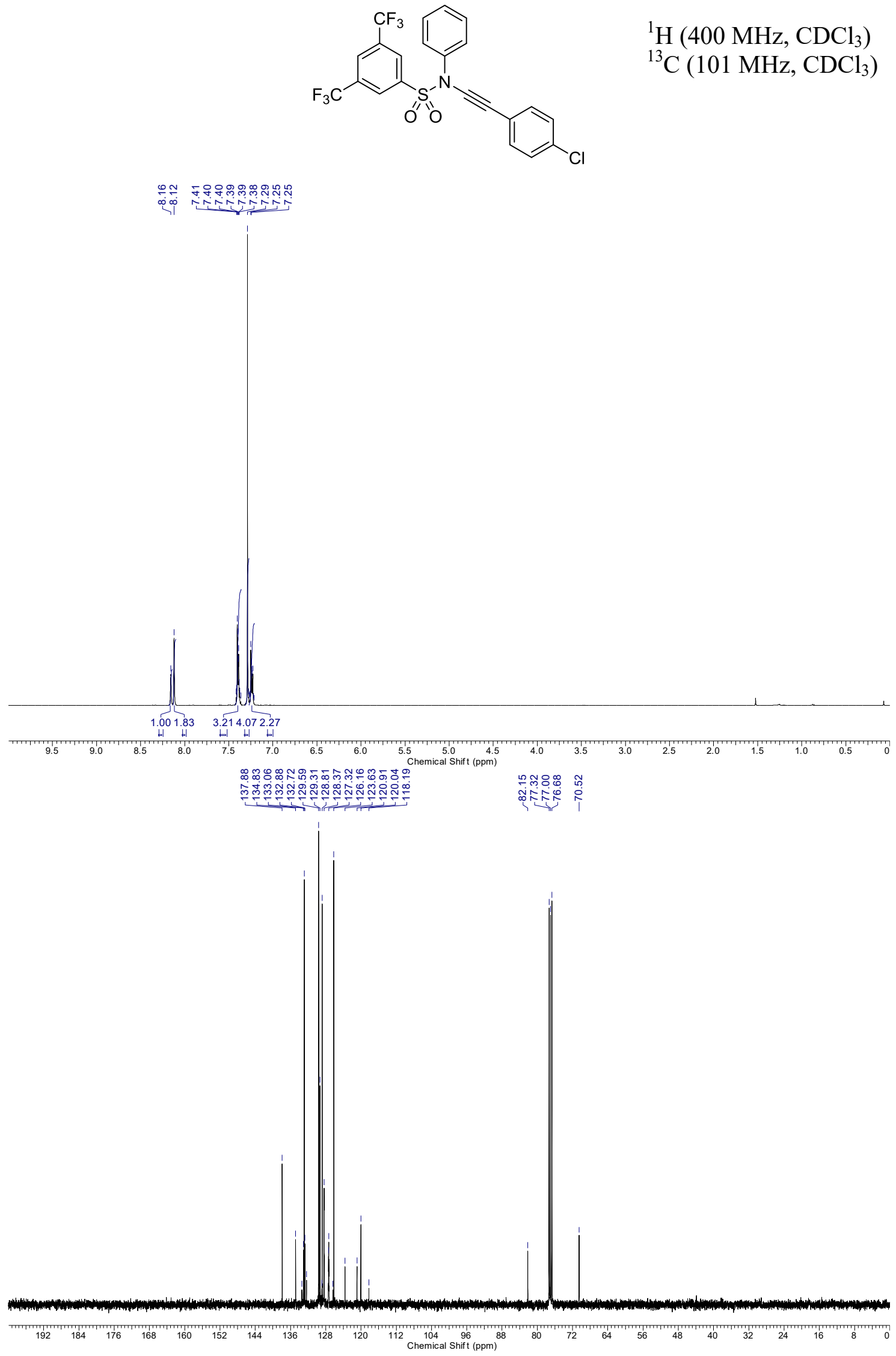
${ }^{19} \mathrm{~F}\left(376 \mathrm{MHz}, \mathrm{CDCl}_{3}\right)$

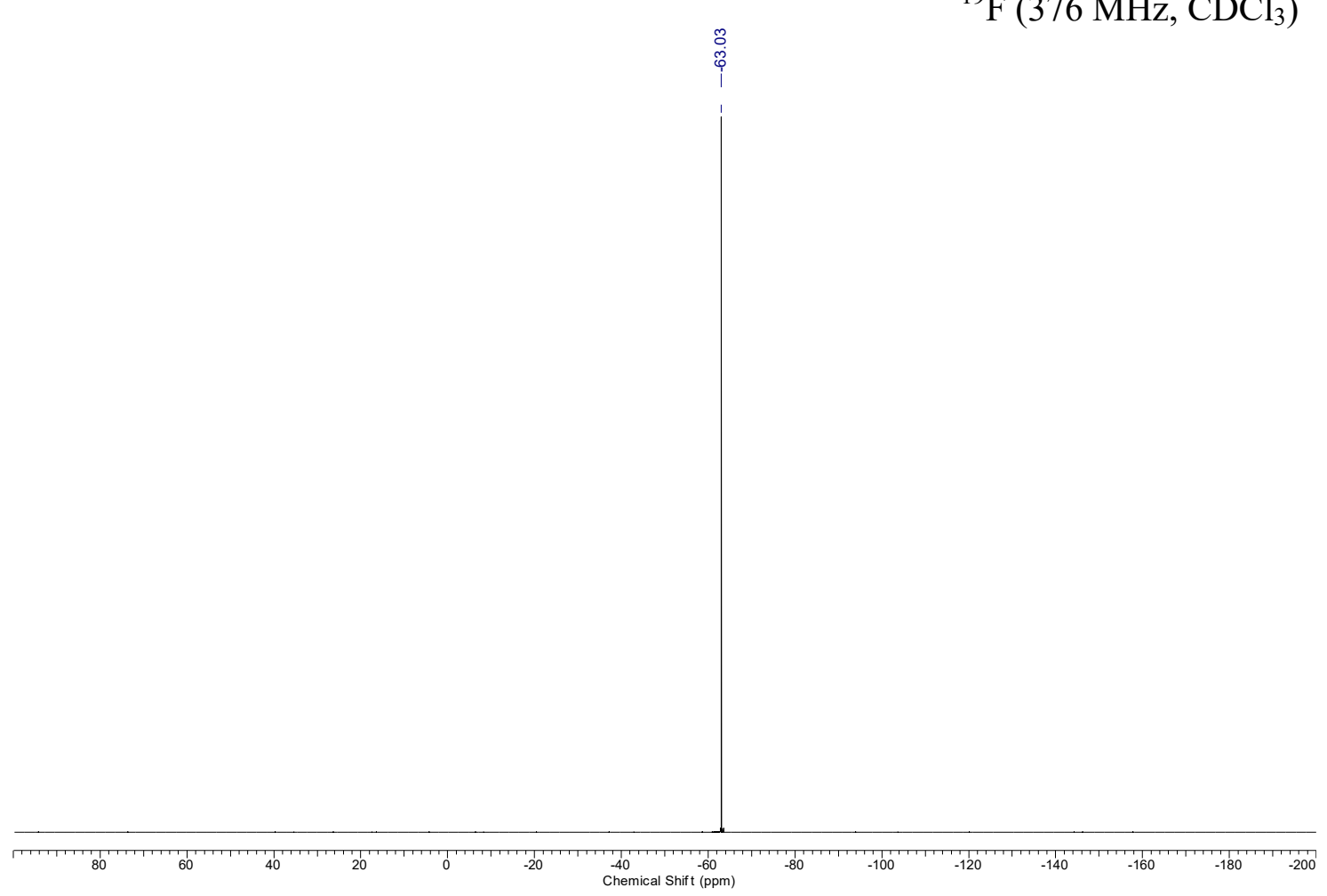


$N$-((4-Chlorophenyl)ethynyl)-4-nitro- $N$-phenylbenzenesulfonamide, 1ap<smiles>O=[N+]([O-])c1ccc(S(=O)(=O)N(C#Cc2ccc(Cl)cc2)c2ccccc2)cc1</smiles>

${ }^{1} \mathrm{H}\left(400 \mathrm{MHz}, \mathrm{CDCl}_{3}\right)$

${ }^{13} \mathrm{C}\left(101 \mathrm{MHz}, \mathrm{CDCl}_{3}\right)$

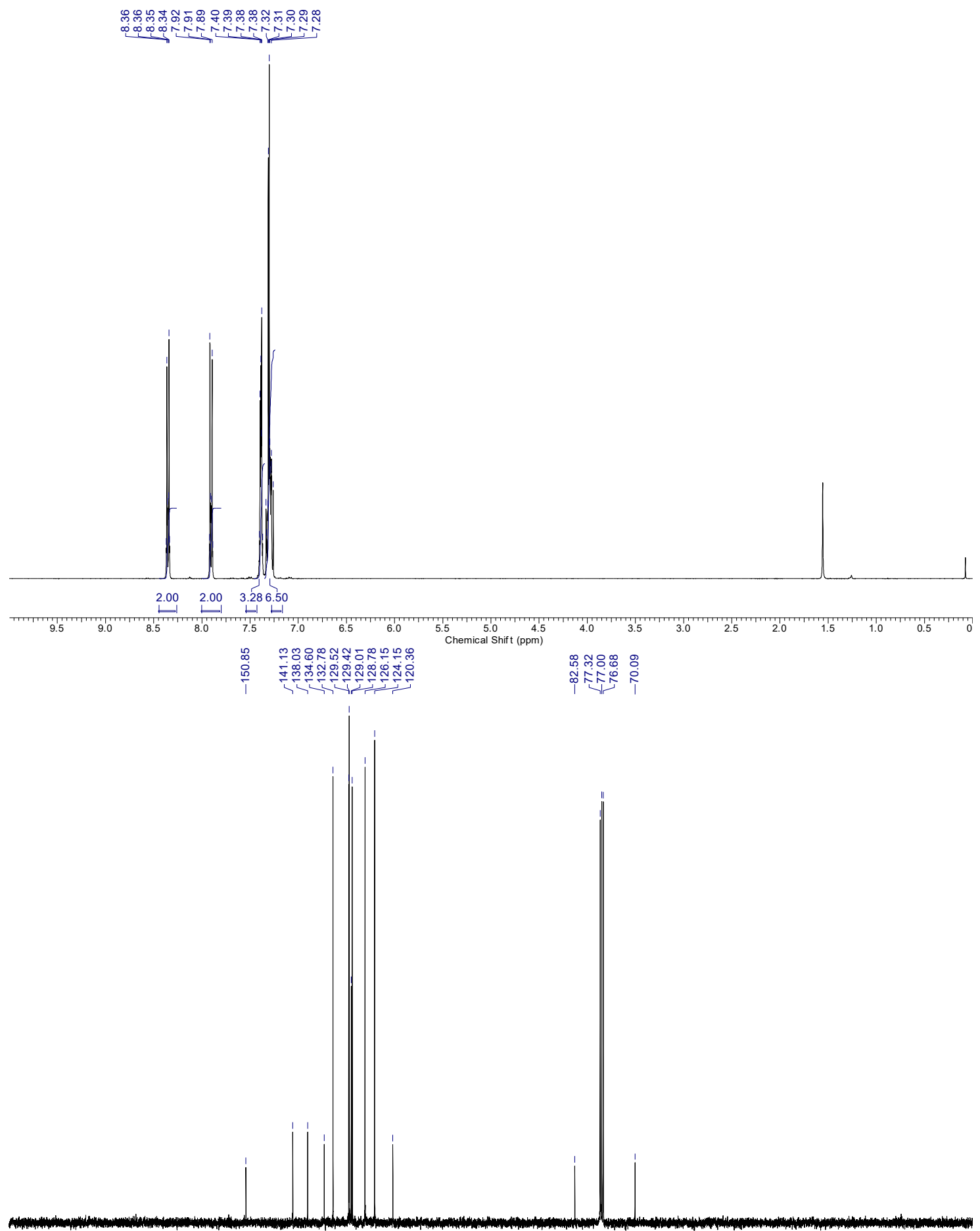

$\begin{array}{lllllllll}192 & 184\end{array}$ 
$N$-Benzyl-2,4,6-tri-i-propyl- $N$-(mesitylethynyl)benzenesulfonamide, 1 aq

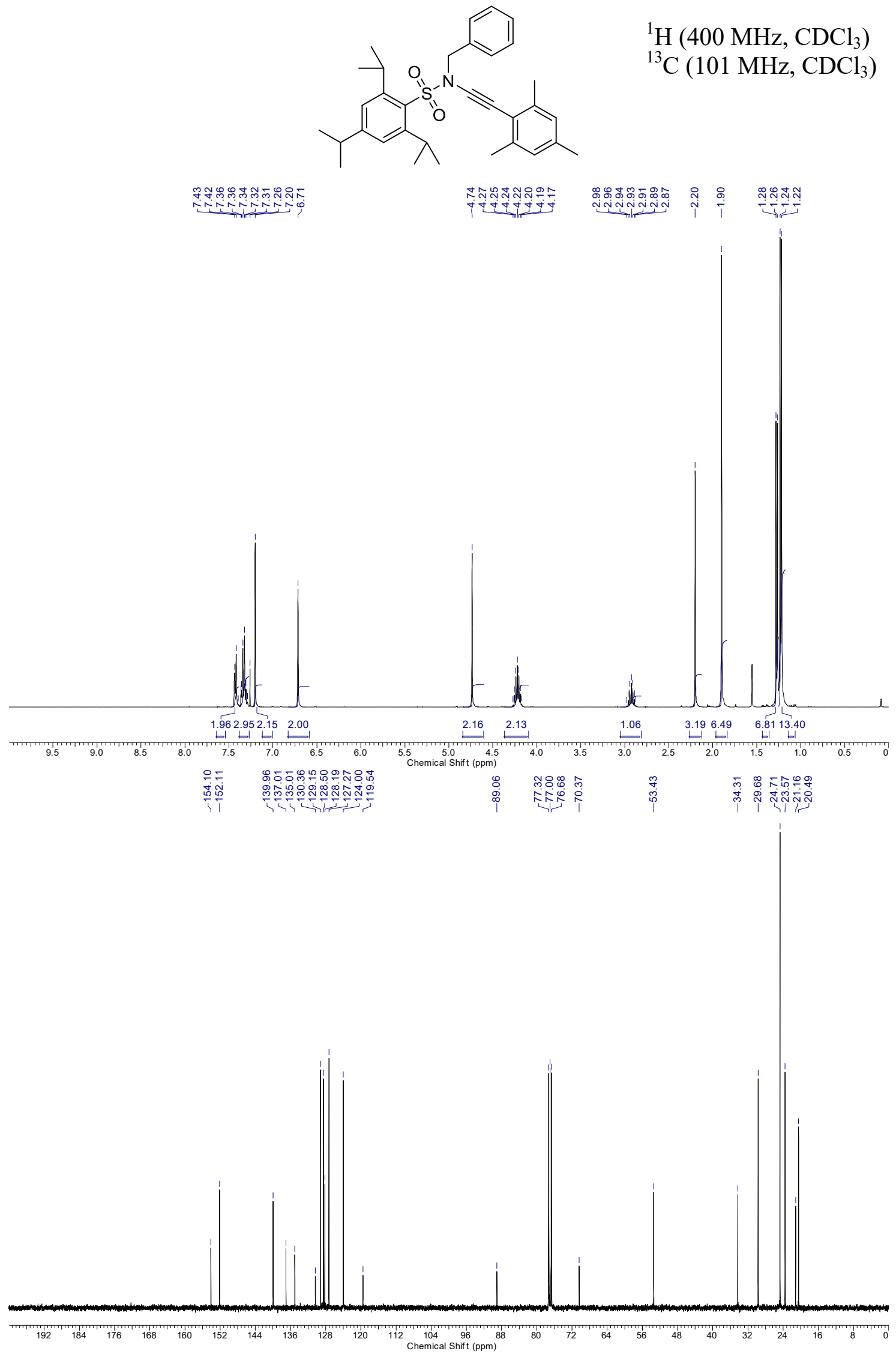


$N$-[(Z)-Hex-3-en-1-yl]- $N$-(phenylethynyl)tosylamide, 1ar

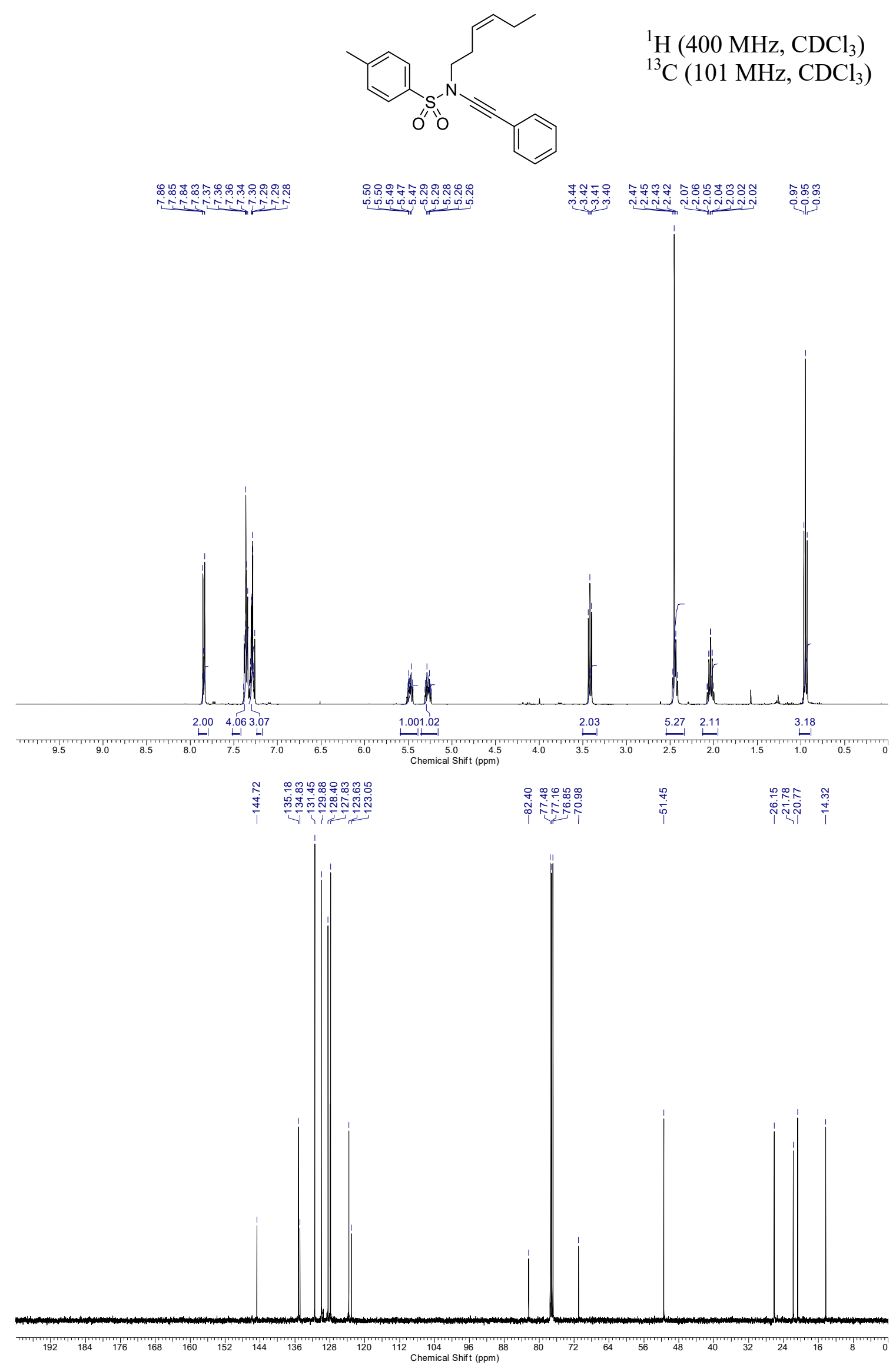


$N$-[(Z)-Hex-3-en-1-yl]- $N$-[(4-methoxyphenyl)ethynyl]tosylamide, 1as

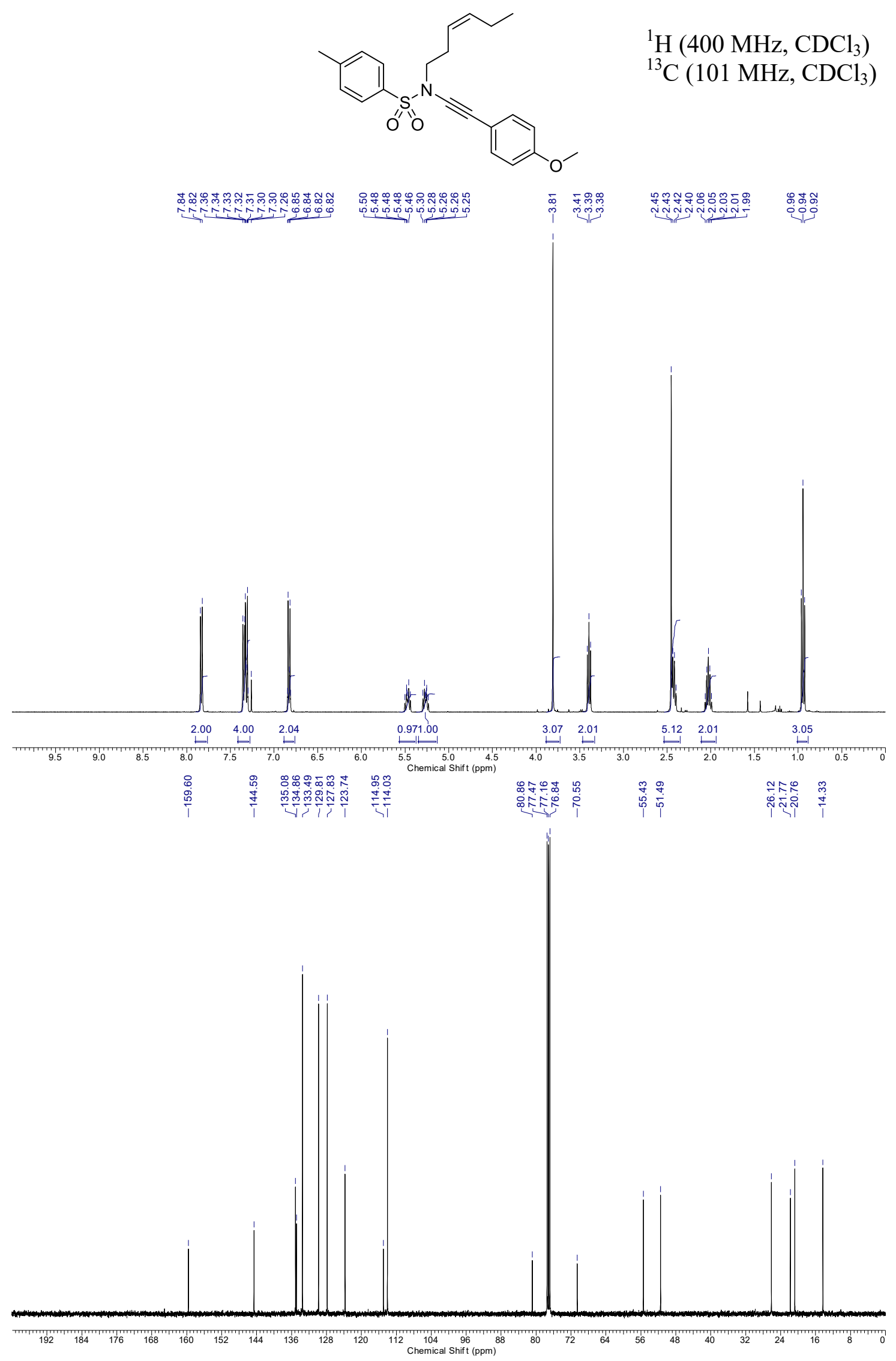


$N$-[(4-Cyanophenyl)ethynyl]- $N$-(phenylethynyl)tosylamide, 1at
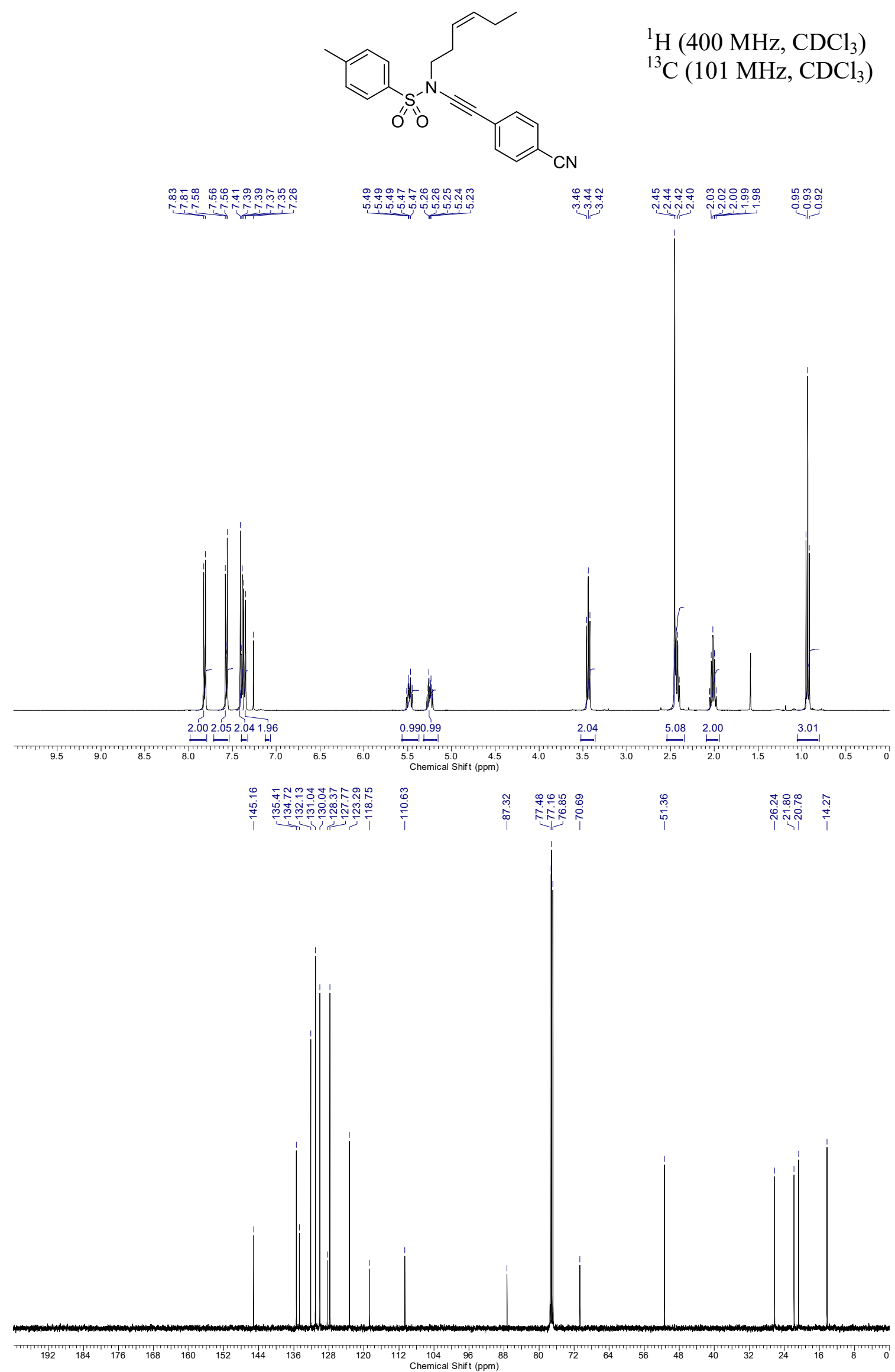
$N$-[(Z)-Hex-3-en-1-yl]- $N$-(3-methylbut-1-yn-1-yl)tosylamide, 1au

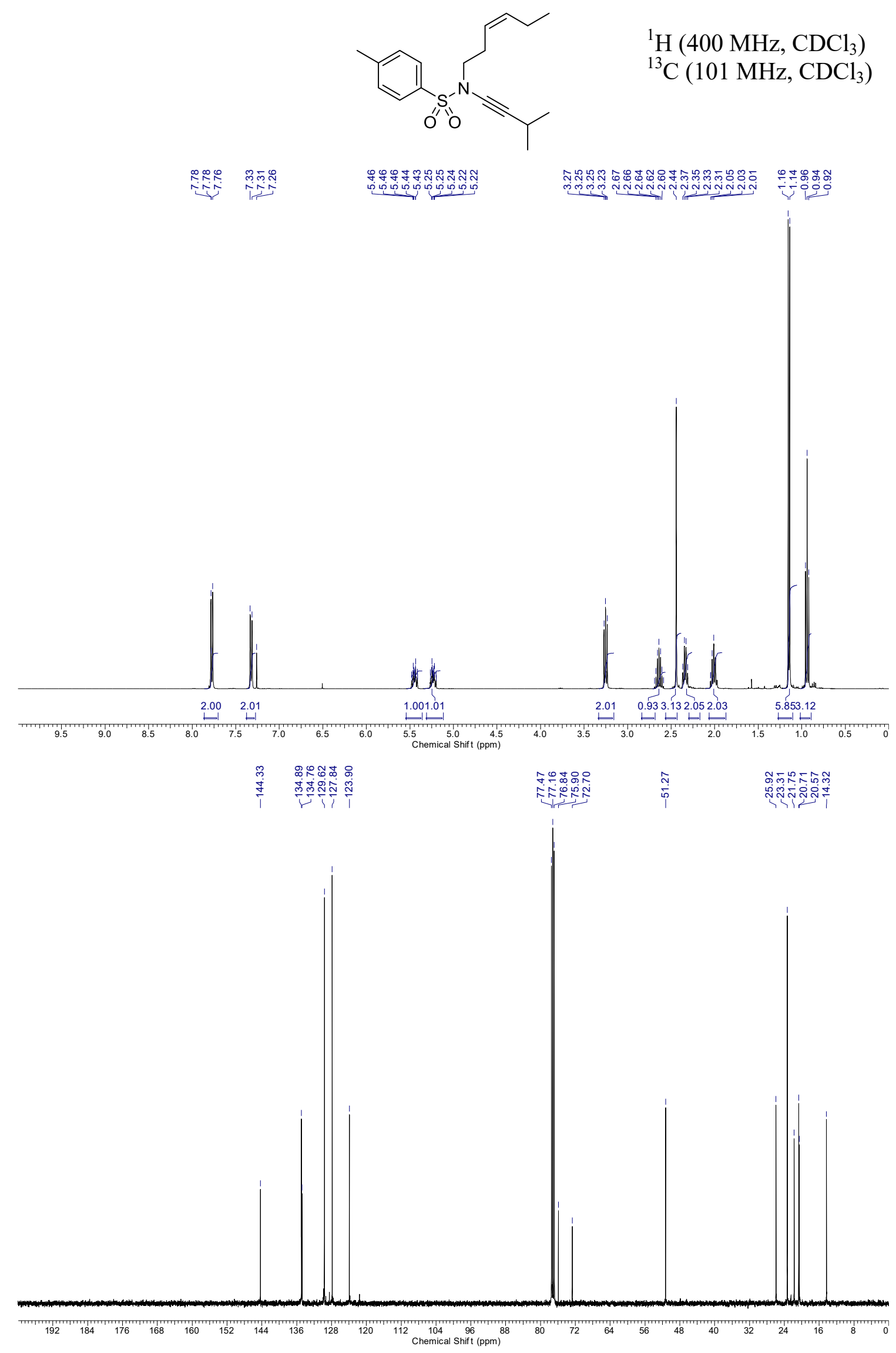


$N$-((4-Chlorophenyl)ethynyl)- $N$-(3,3-diethoxypropyl)tosylamide, 1 av
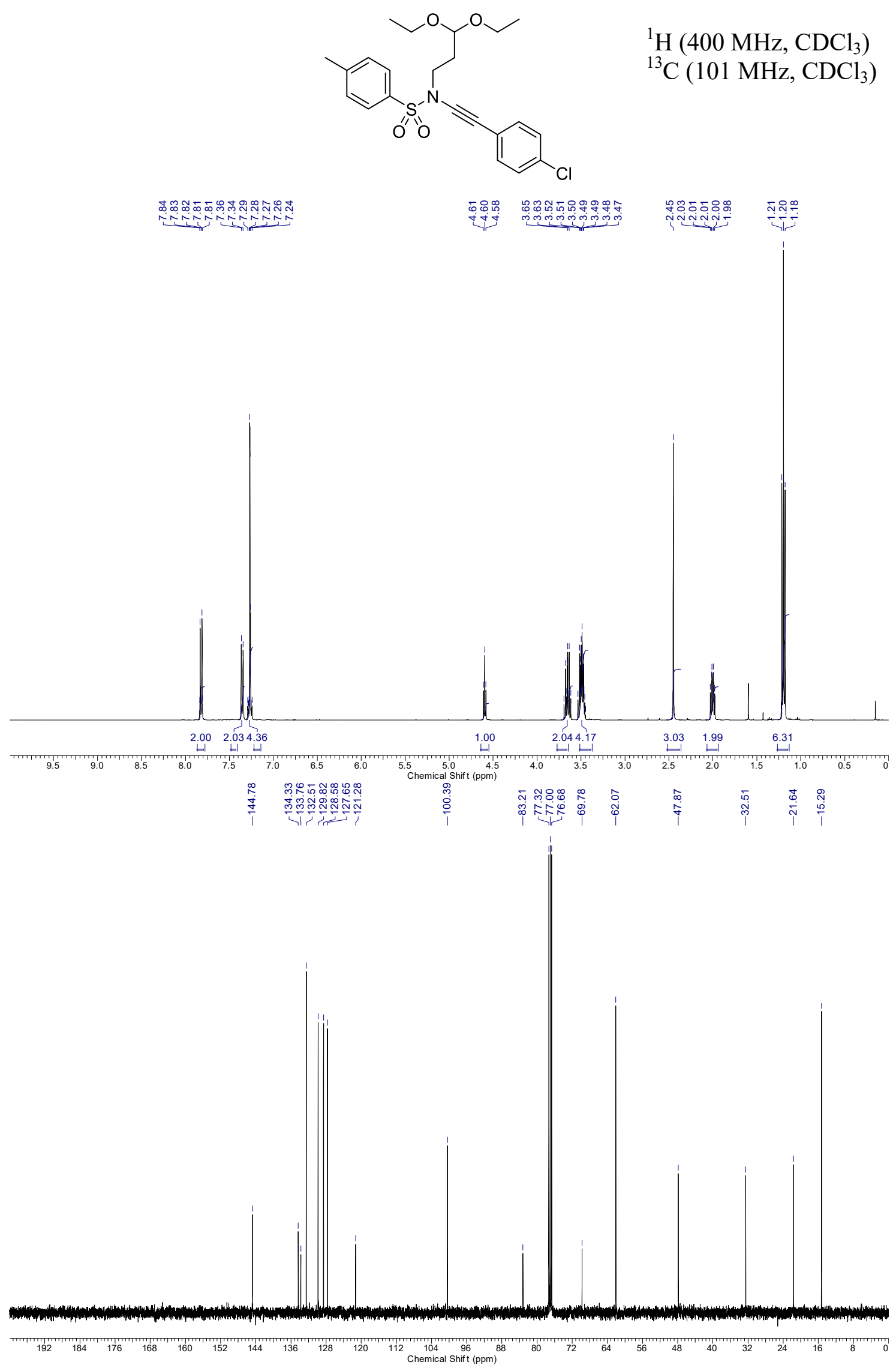
$N$-((4-Fluorophenyl)ethynyl)- $N$-(furan-2-ylmethyl)tosylamide, 1aw<smiles>Cc1ccc(S(=O)(=O)N(C#Cc2ccc(F)cc2)Cc2ccco2)cc1</smiles>

${ }^{1} \mathrm{H}\left(400 \mathrm{MHz}, \mathrm{CDCl}_{3}\right)$

${ }^{13} \mathrm{C}\left(101 \mathrm{MHz}, \mathrm{CDCl}_{3}\right)$

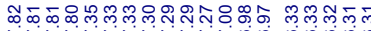

1.00 00000

$\stackrel{\hat{o}}{\mathfrak{j}}$

$\stackrel{\text { ì }}{i}$
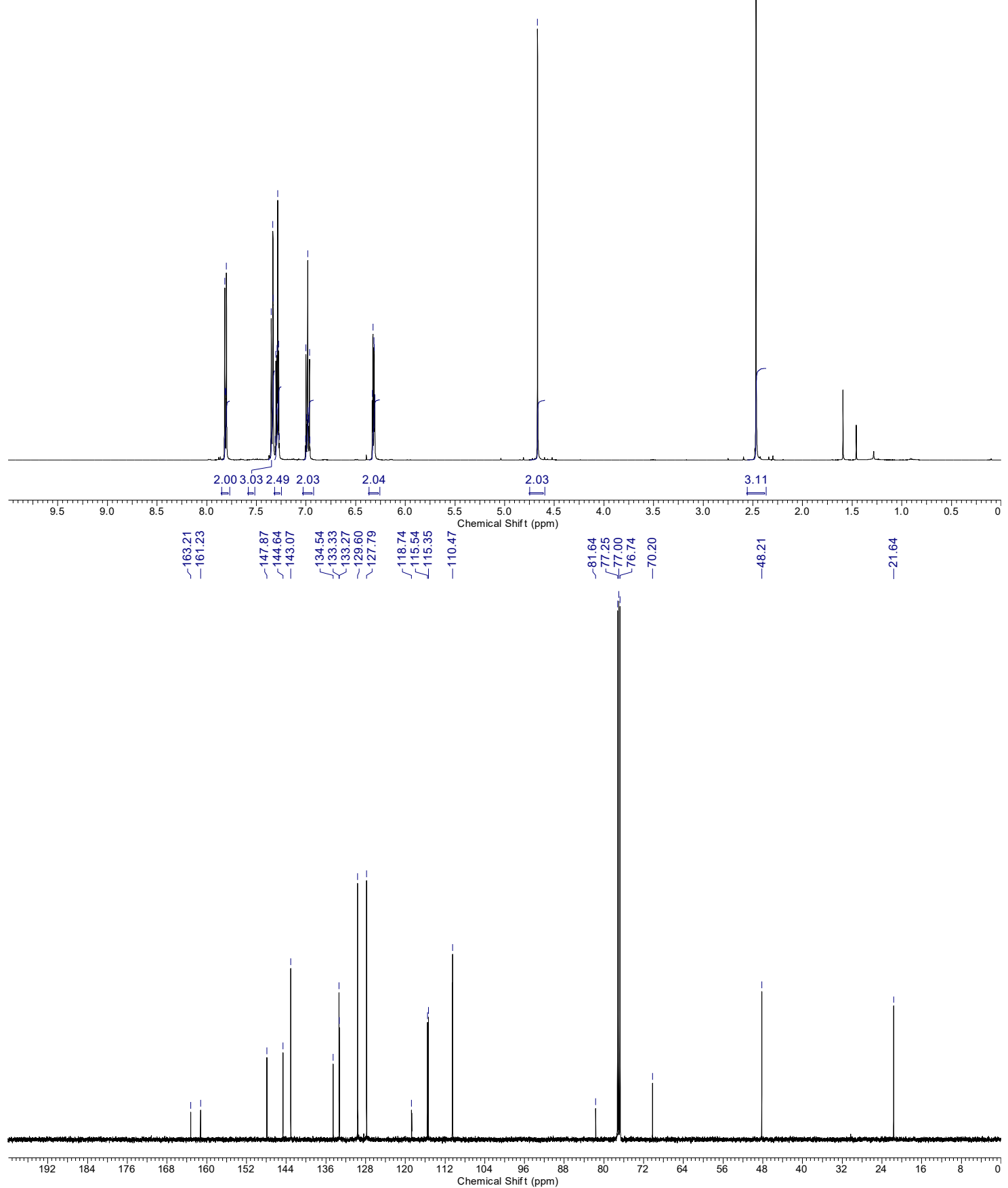
${ }^{19} \mathrm{~F}\left(470 \mathrm{MHz}, \mathrm{CDCl}_{3}\right)$

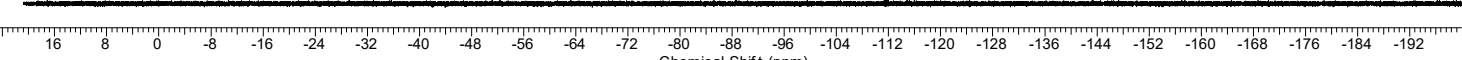


$N$-[(Z)-Hex-3-en-1-yl]- $N$-(3-methylbut-1-yn-1-yl)tosylamide, 1ax
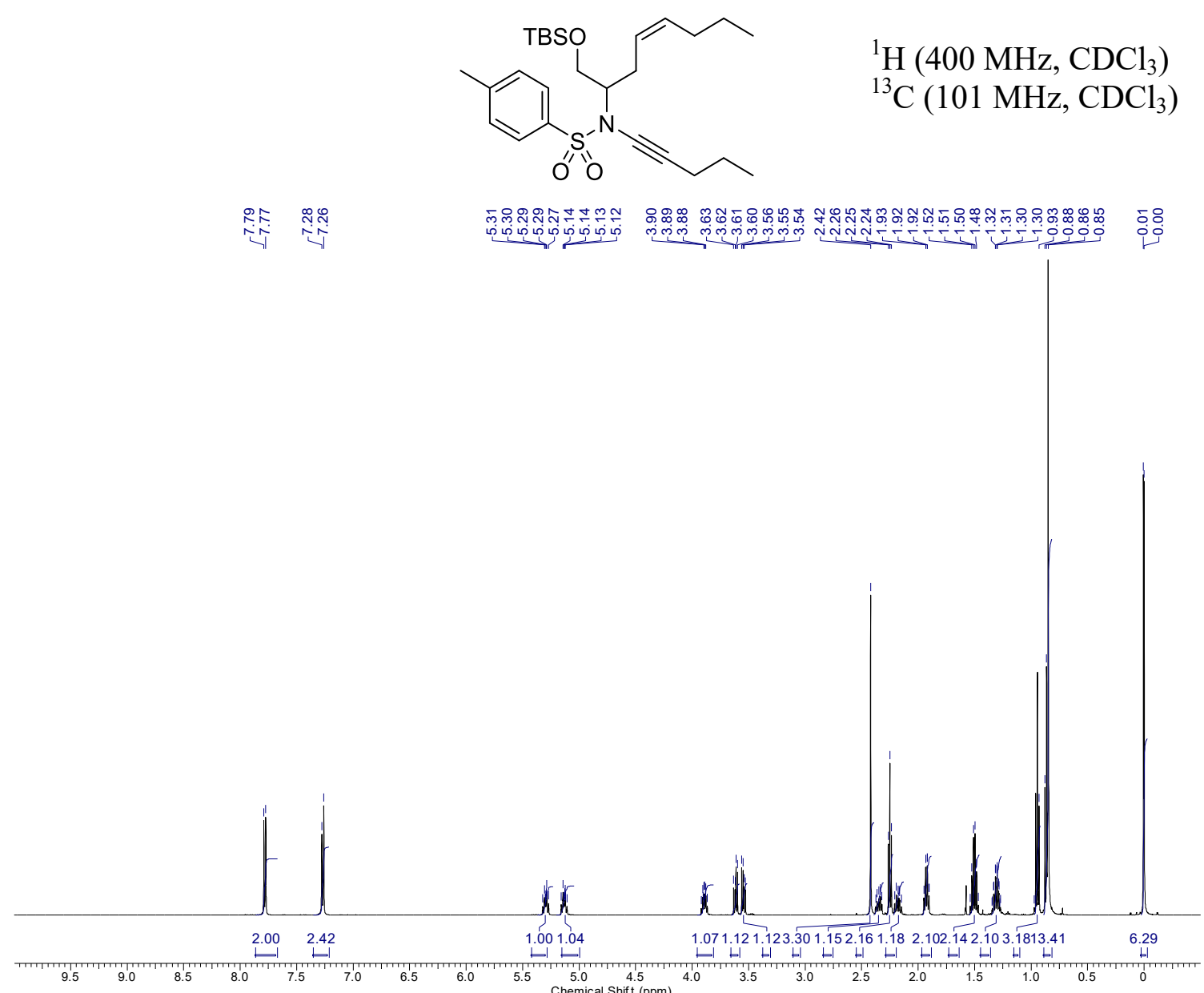

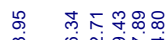

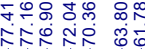

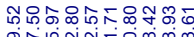

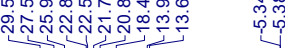

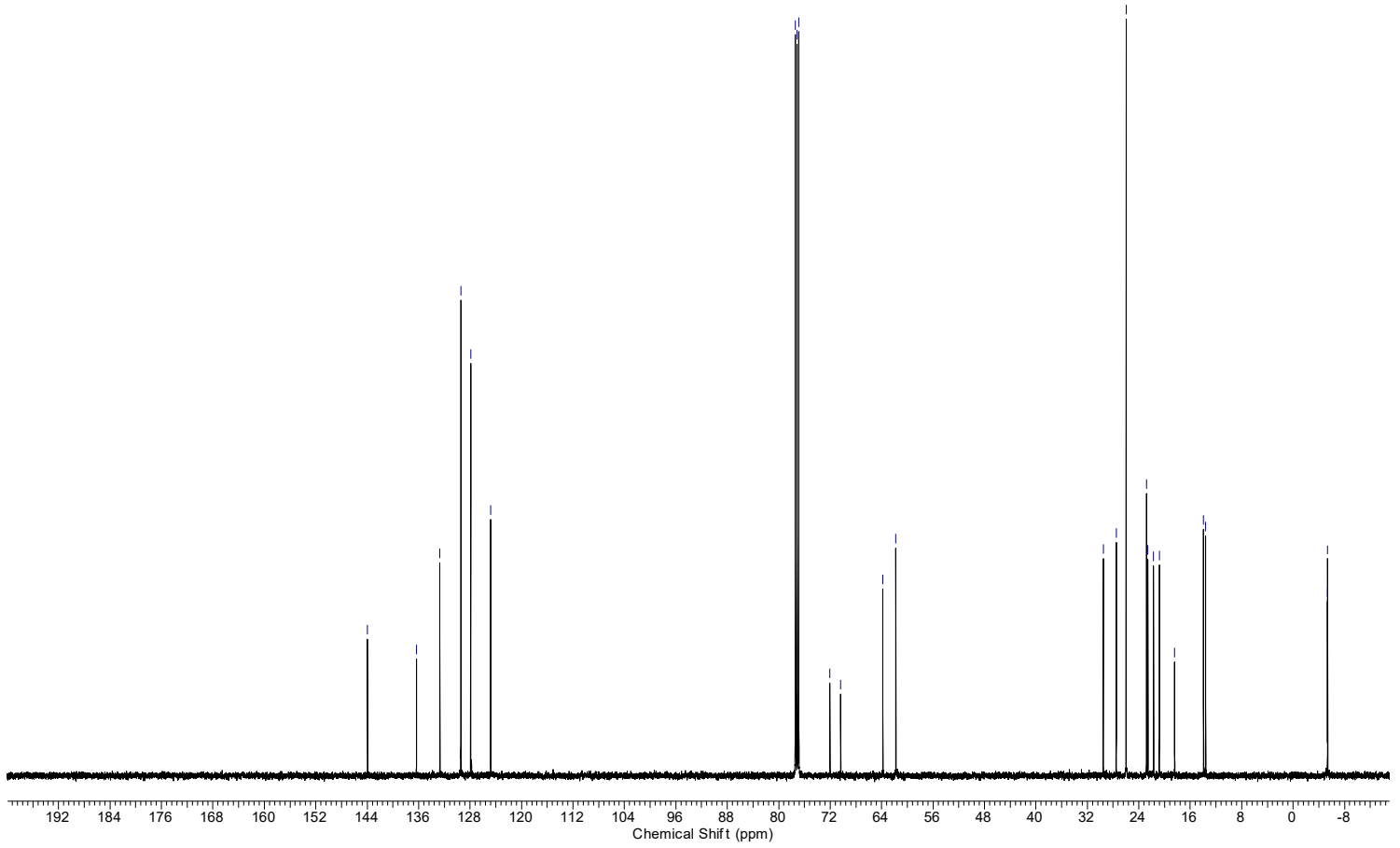


$N-((1 s, 2 s)-1,2-D i p h e n y l b u t-3-e n-1-y l)-N$-(mesitylethynyl)tosylamide, 1ay

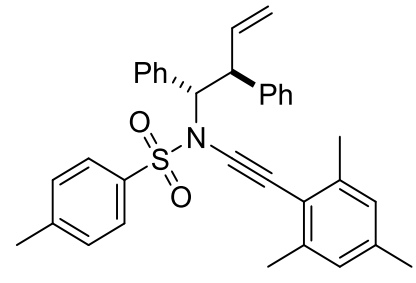

${ }^{1} \mathrm{H}\left(400 \mathrm{MHz}, \mathrm{CDCl}_{3}\right)$

${ }^{13} \mathrm{C}\left(101 \mathrm{MHz}, \mathrm{CDCl}_{3}\right)$

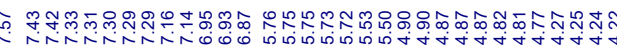

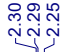

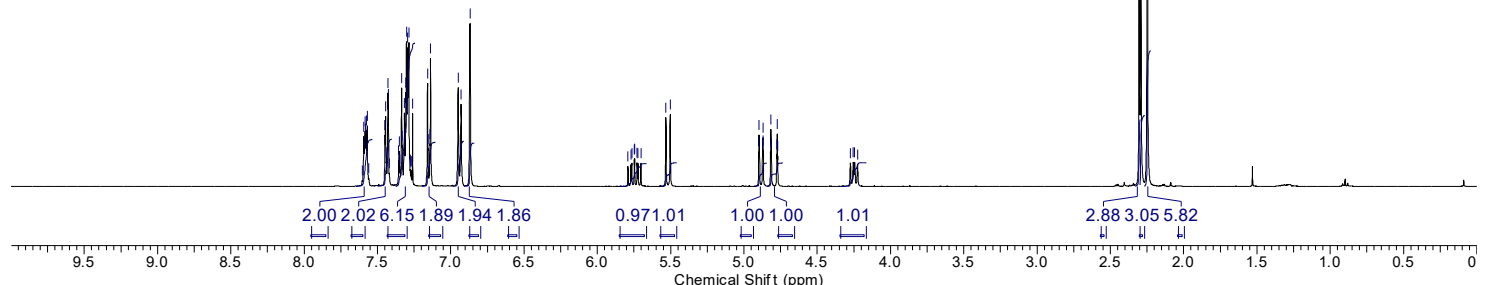

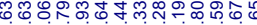

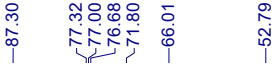

ำ

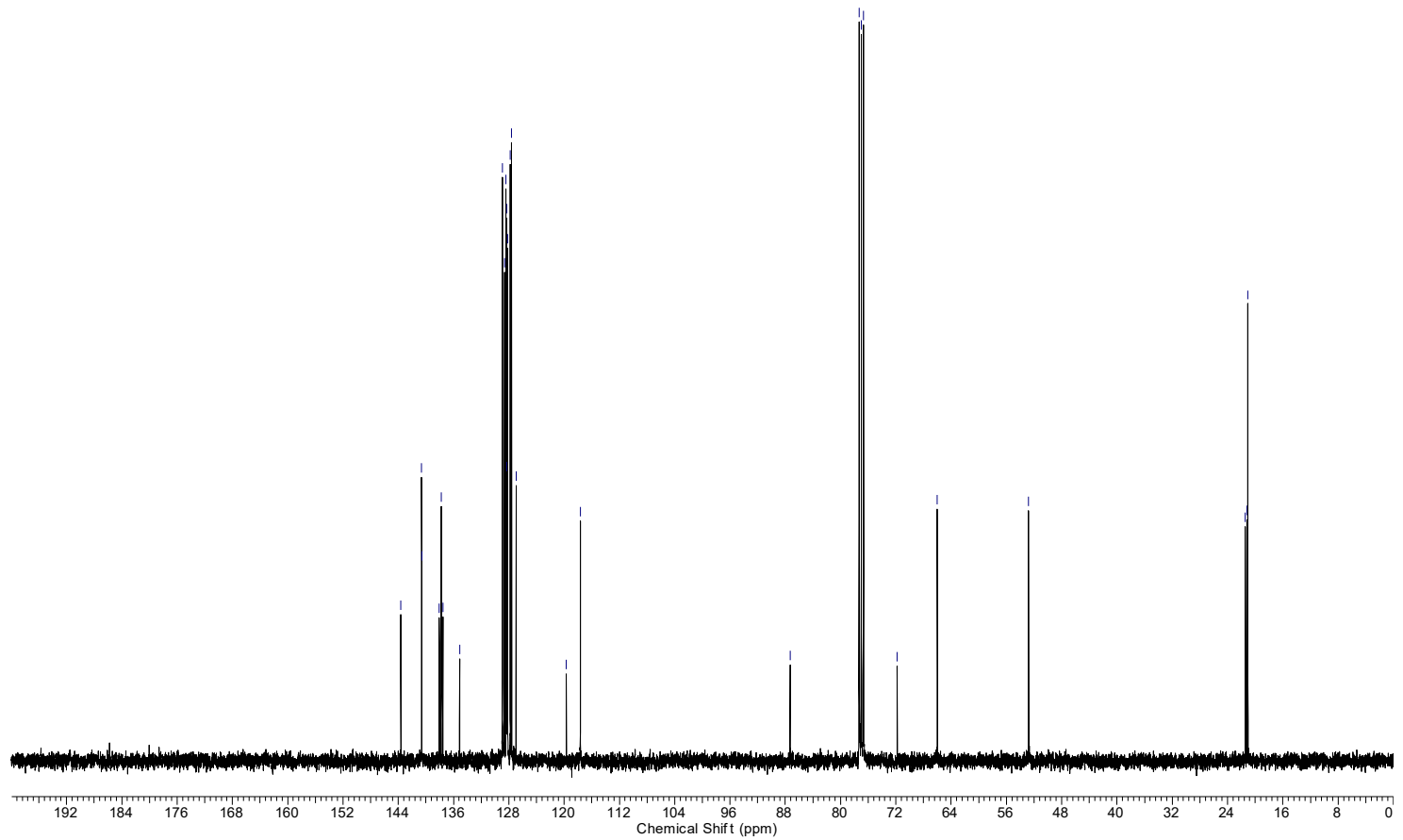


$N$-(t-Butyl)- $N$-(3,3-dimethylbut-1-yn-1-yl)tosylamide, 1 az

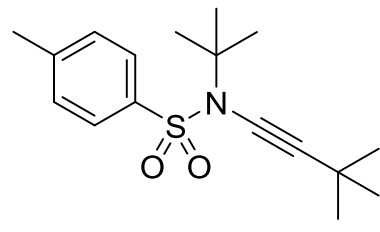

${ }^{1} \mathrm{H}\left(400 \mathrm{MHz}, \mathrm{CDCl}_{3}\right)$

${ }^{13} \mathrm{C}\left(101 \mathrm{MHz}, \mathrm{CDCl}_{3}\right)$

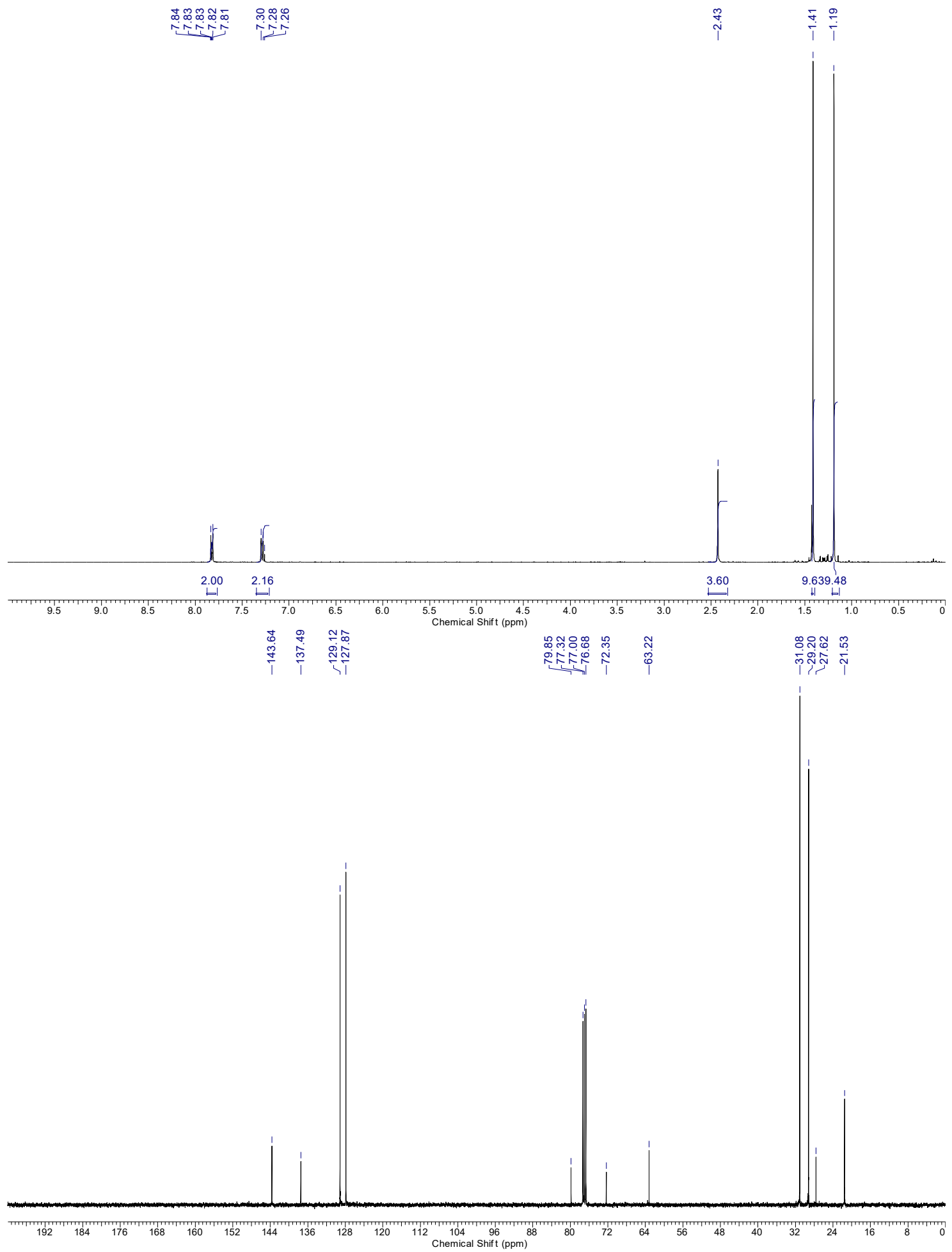


$N$-(2-Bromophenyl)- $N$-((4-chlorophenyl)ethynyl)tosylamide, 1ba
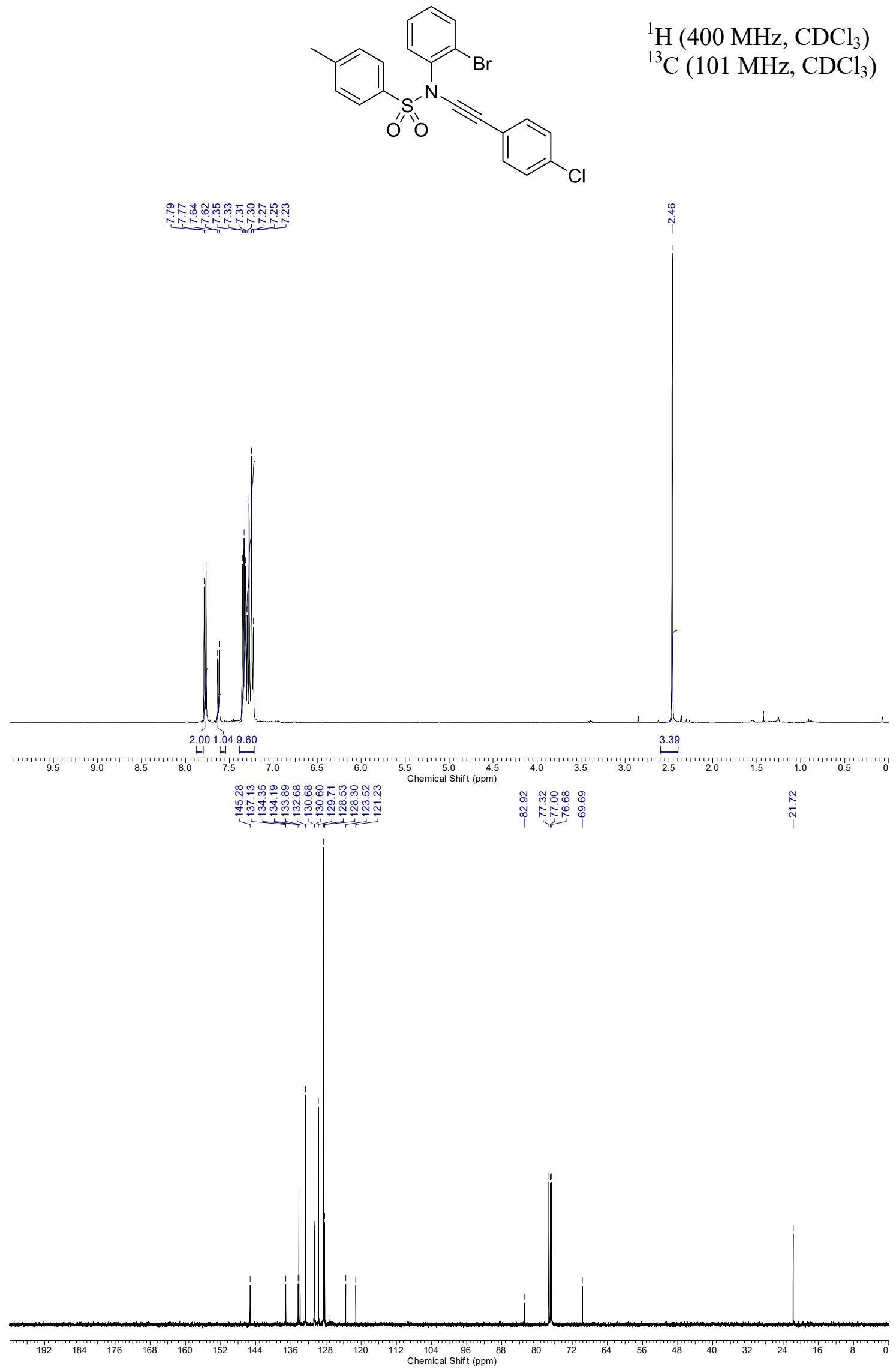
$N$-(2,6-Di-i-propylphenyl)- $N$-(mesitylethynyl)tosylamide, 1 bb

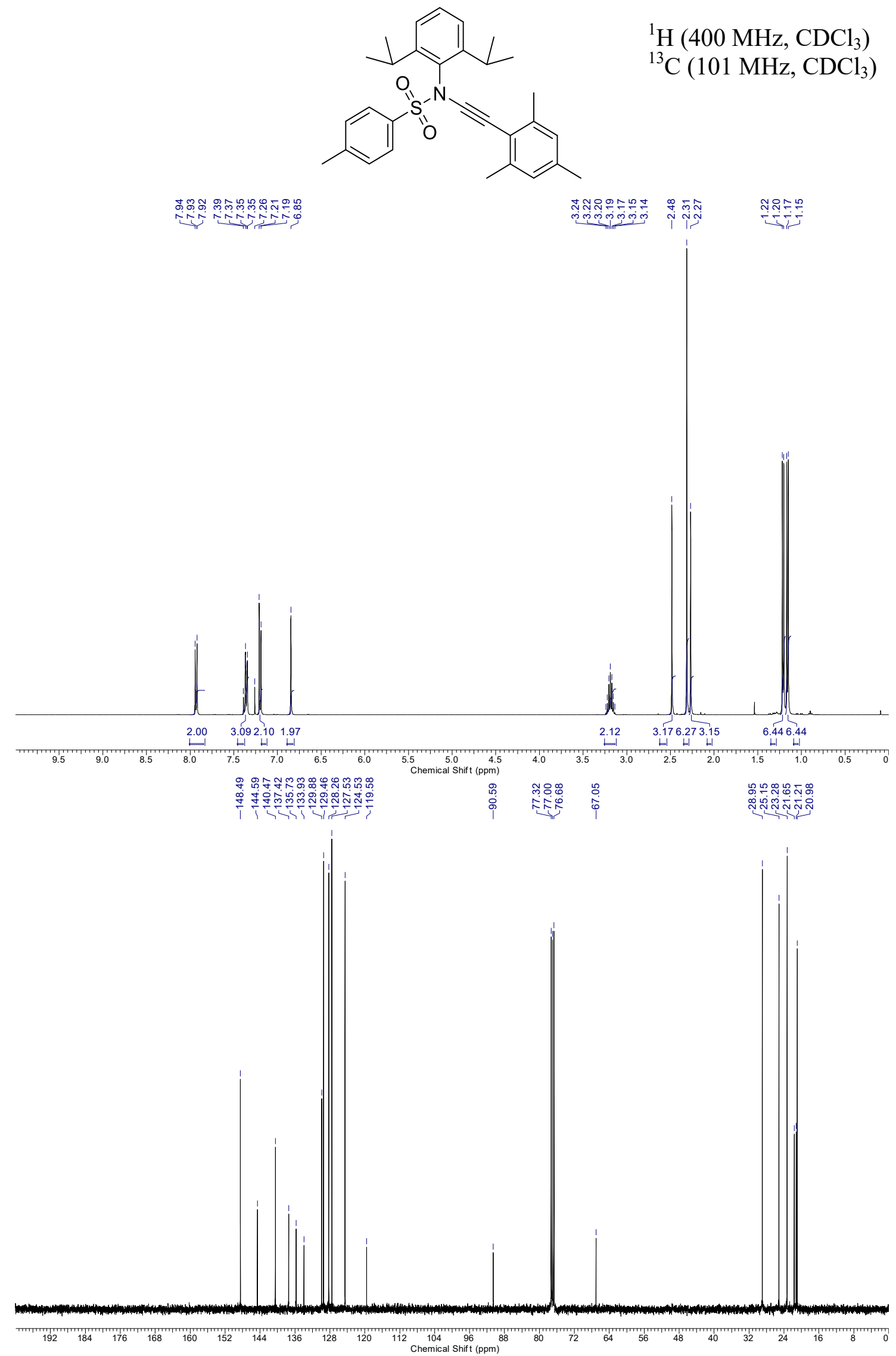




\section{3a Carbamate Scope: Dichloroenamides}

Benzyl (E)-(1,2-dichlorovinyl)(phenyl)carbamate, 9a

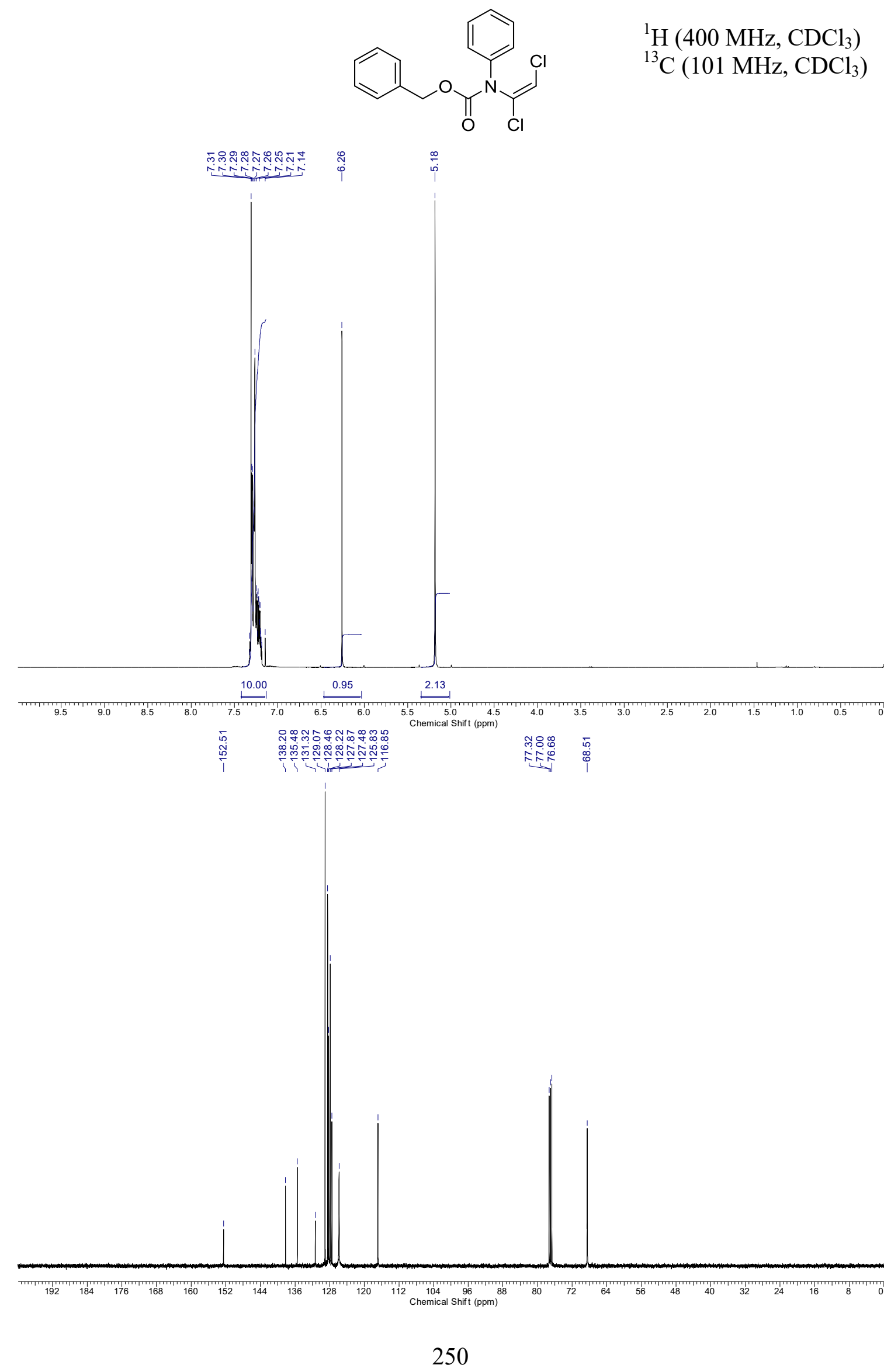


Ethyl (E)-(1,2-dichlorovinyl)(phenyl)carbamate, 9b

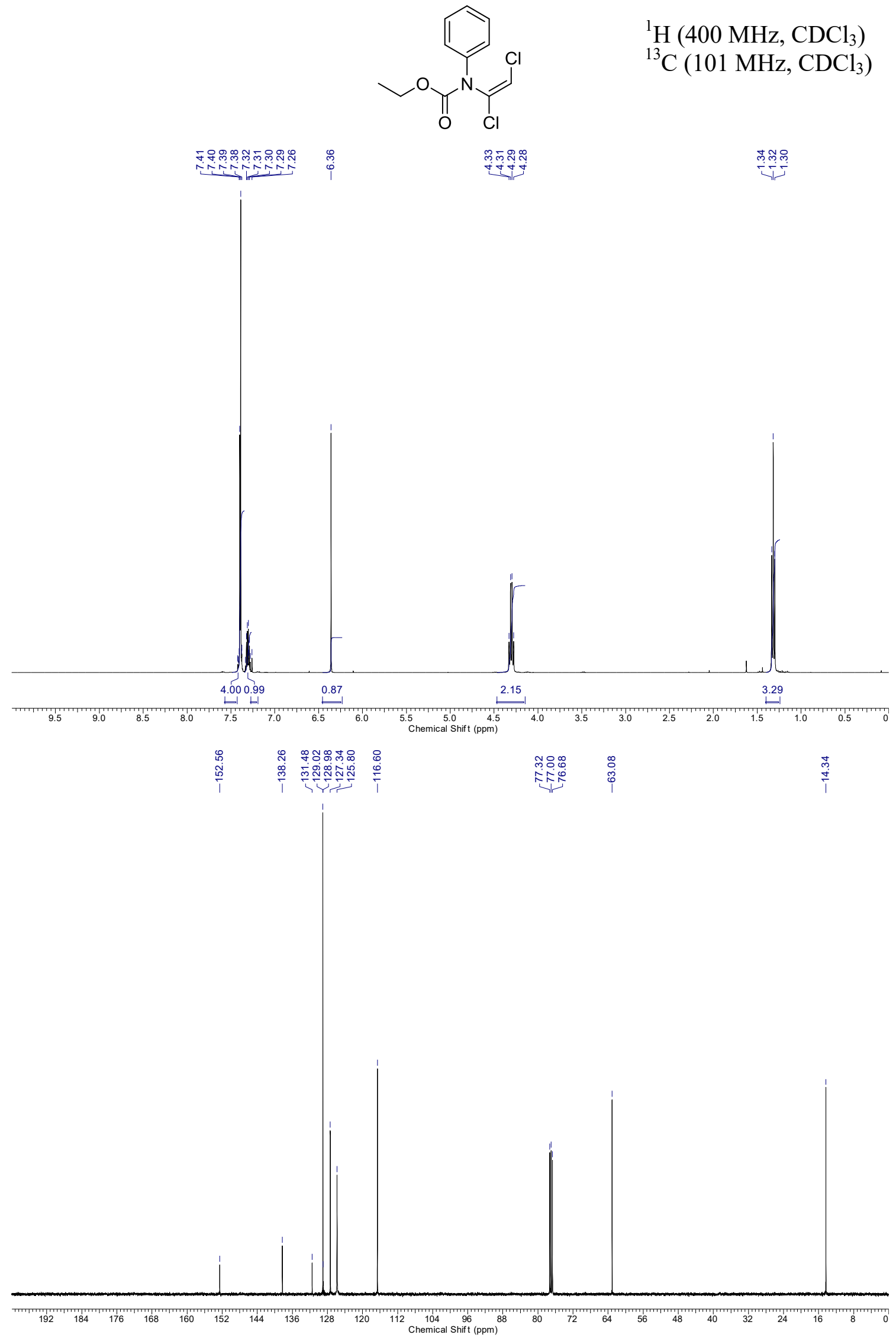


i-Propyl (E)-(1,2-dichlorovinyl)(phenyl)carbamate, 9c<smiles>CC(C)OC(=O)N(/C(Cl)=C\Cl)c1ccccc1</smiles>

${ }^{1} \mathrm{H}\left(400 \mathrm{MHz}, \mathrm{CDCl}_{3}\right)$

${ }^{13} \mathrm{C}\left(101 \mathrm{MHz}, \mathrm{CDCl}_{3}\right)$

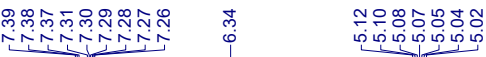

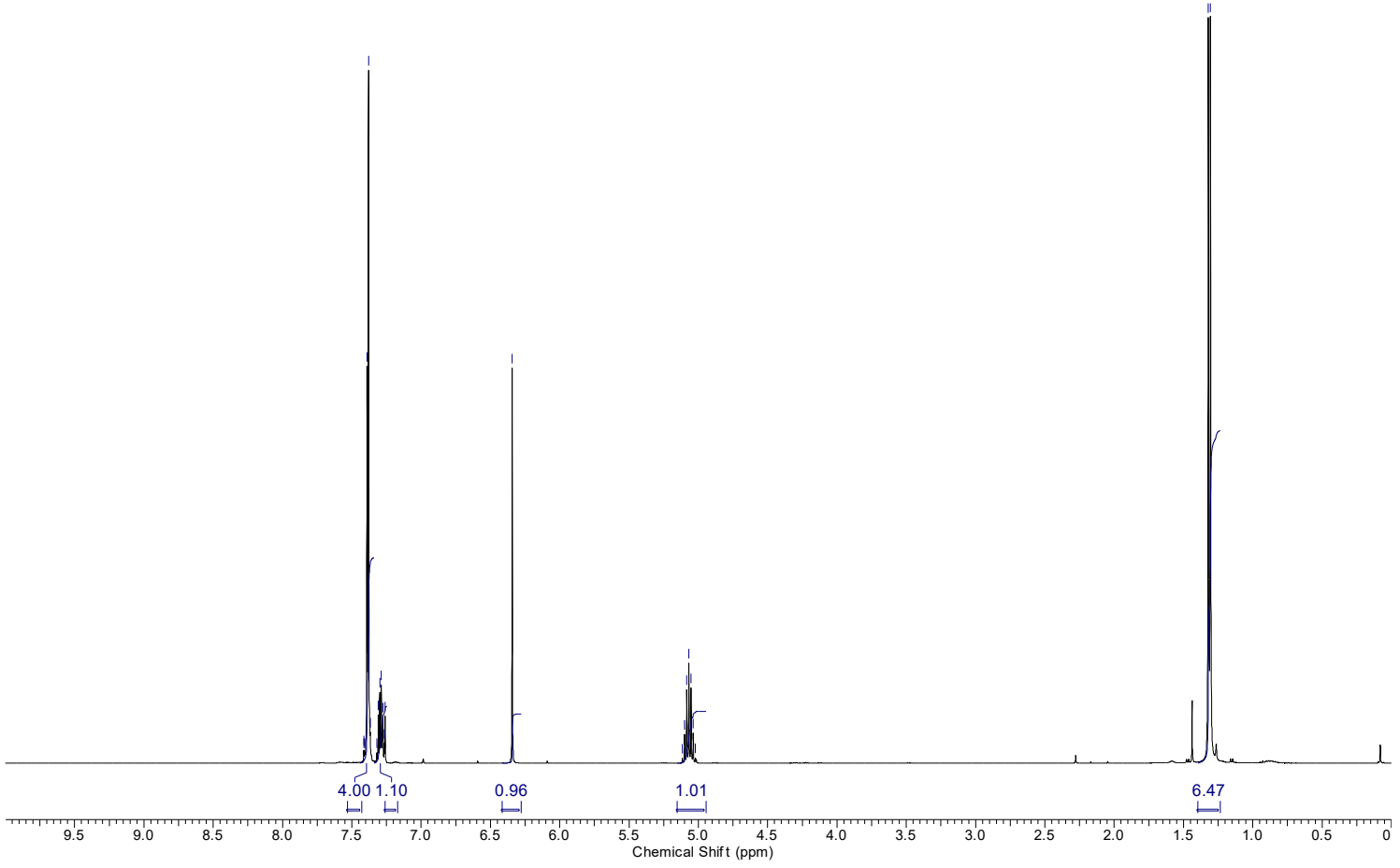

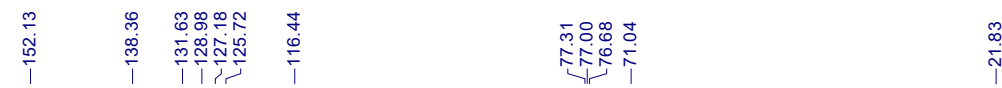

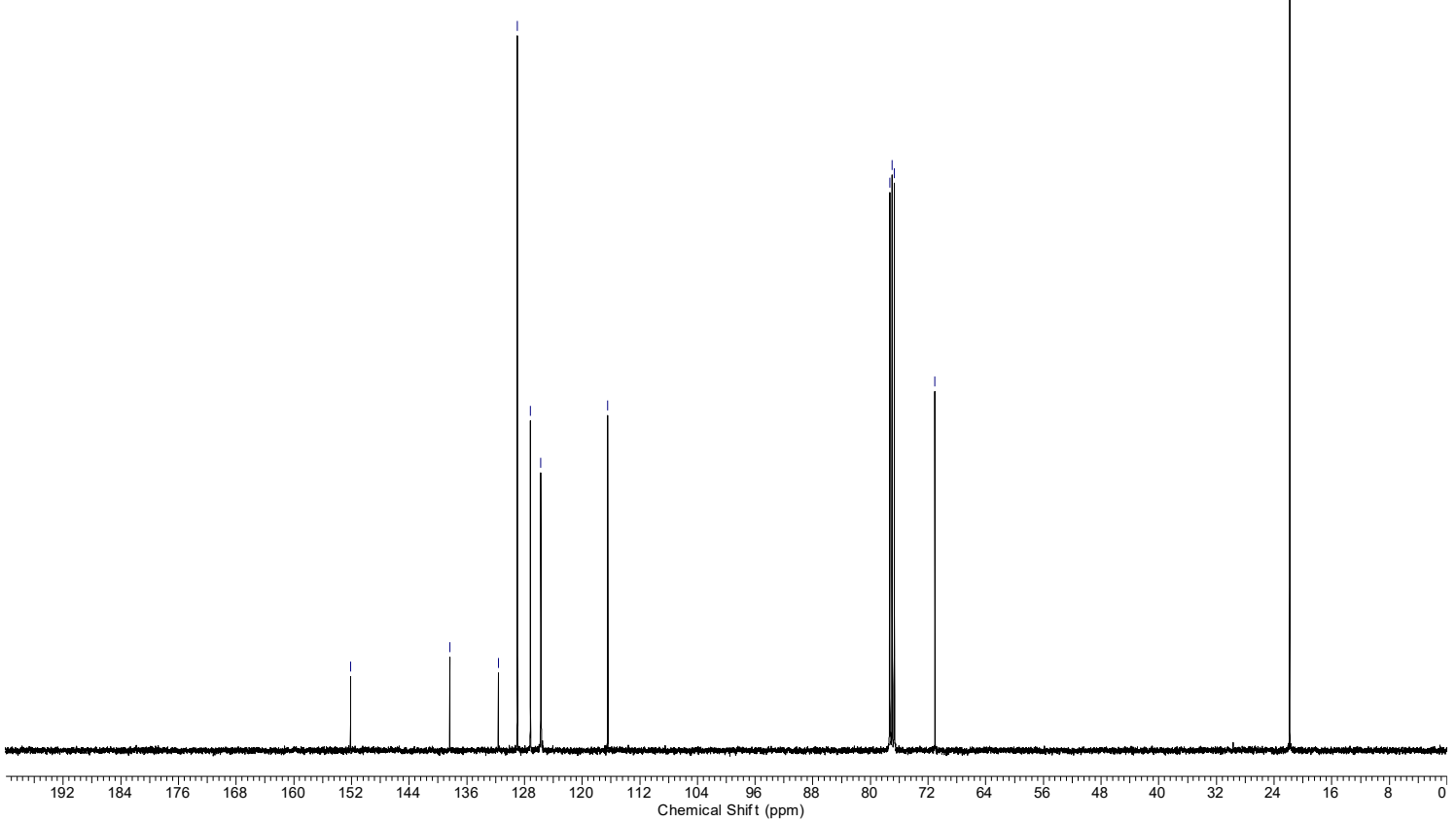


t-Butyl (E)-(1,2-dichlorovinyl)(phenyl)carbamate, 9d
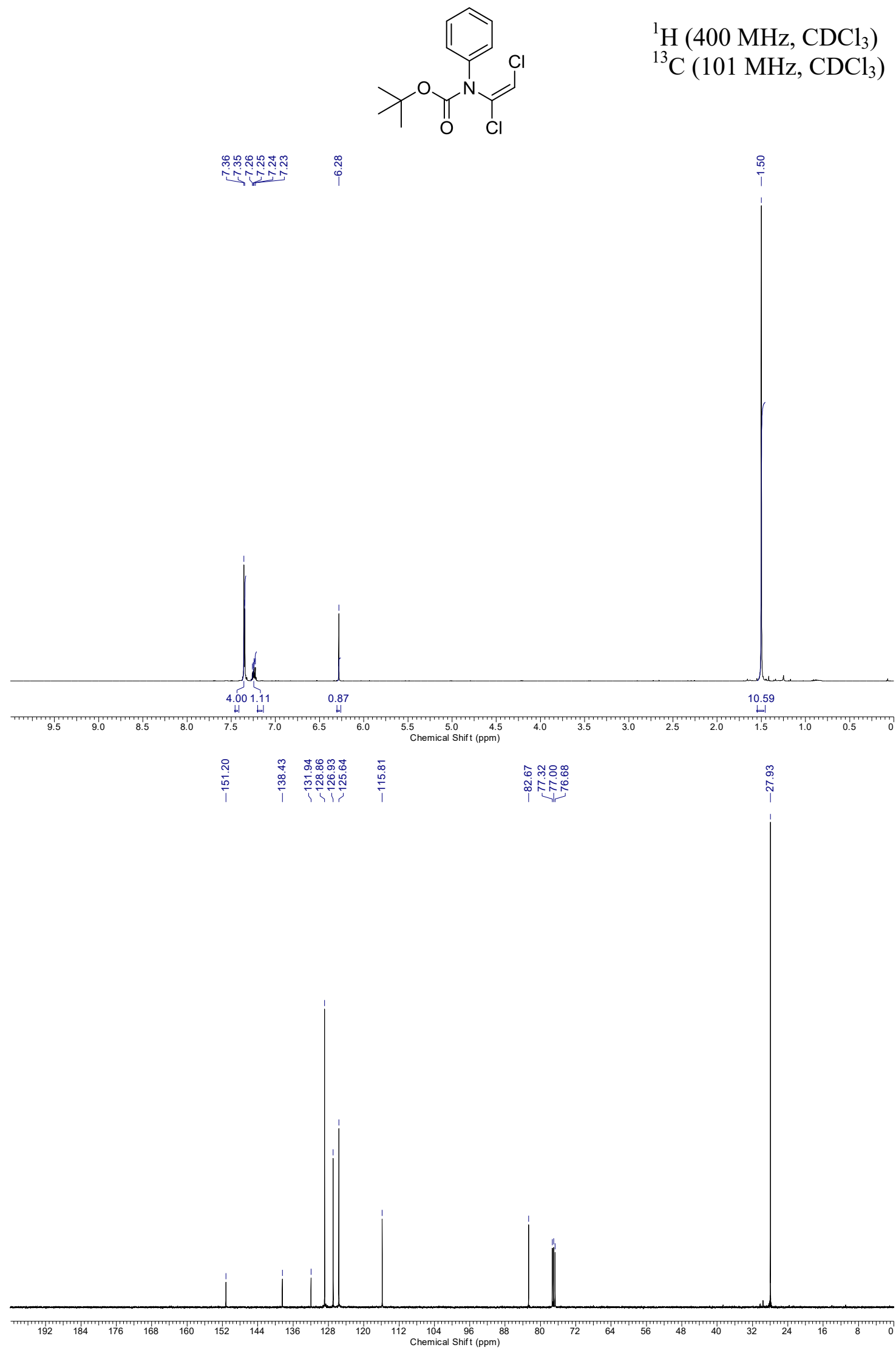
Methyl (E)-(2-bromophenyl)(1,2-dichlorovinyl)carbamate, 9e

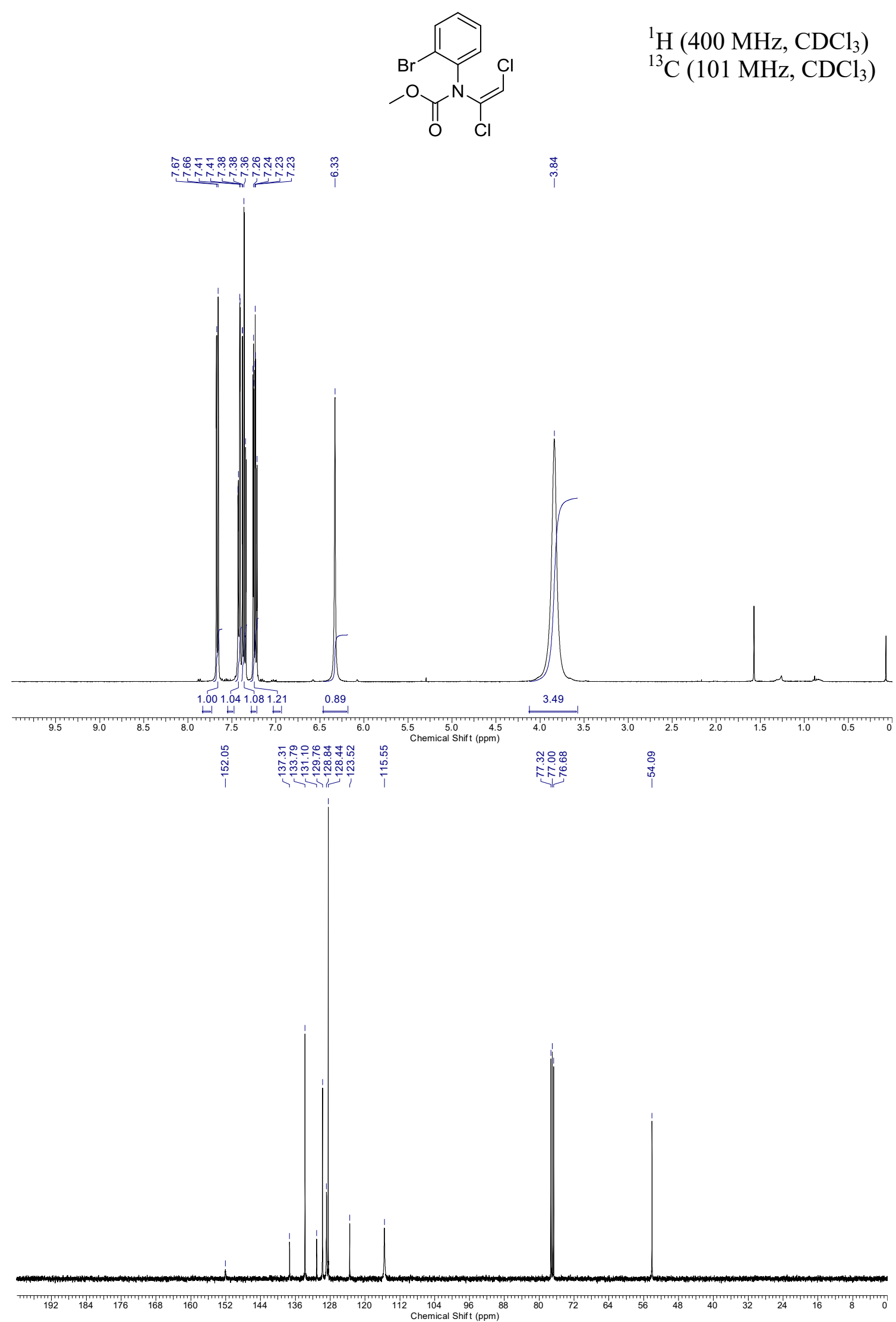

${ }^{1} \mathrm{H}\left(400 \mathrm{MHz}, \mathrm{CDCl}_{3}\right)$

${ }^{13} \mathrm{C}\left(101 \mathrm{MHz}, \mathrm{CDCl}_{3}\right)$ 
(E)-3-(1,2-Dichlorovinyl)oxazolidin-2-one, $9 f$<smiles>O=C1OCCN1C(Cl)=CCl</smiles>

${ }^{1} \mathrm{H}\left(400 \mathrm{MHz}, \mathrm{CDCl}_{3}\right)$

${ }^{13} \mathrm{C}\left(101 \mathrm{MHz}, \mathrm{CDCl}_{3}\right)$

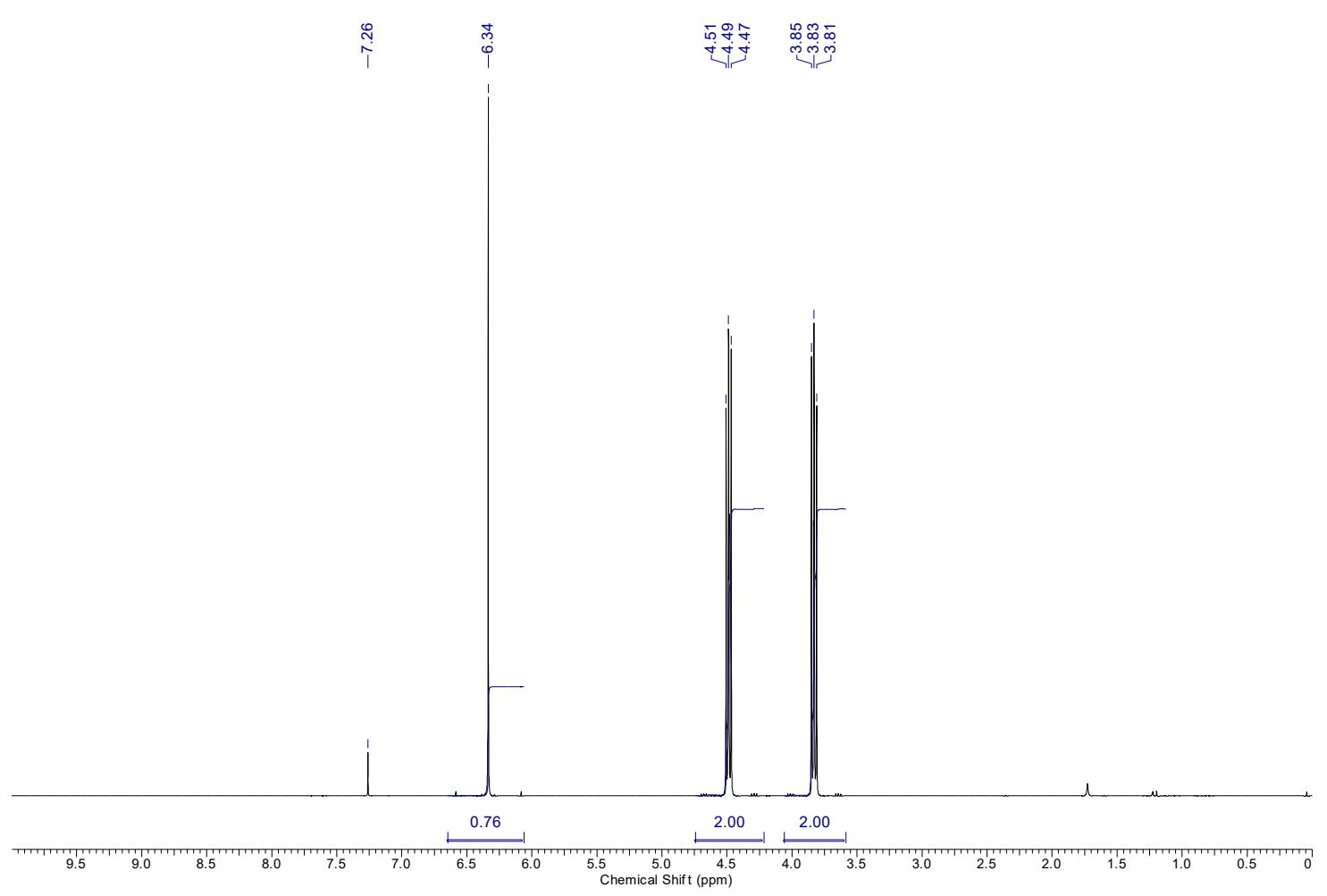

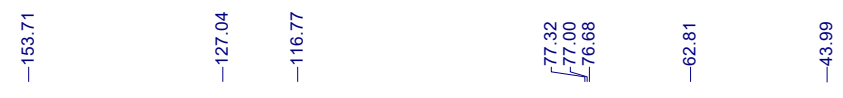

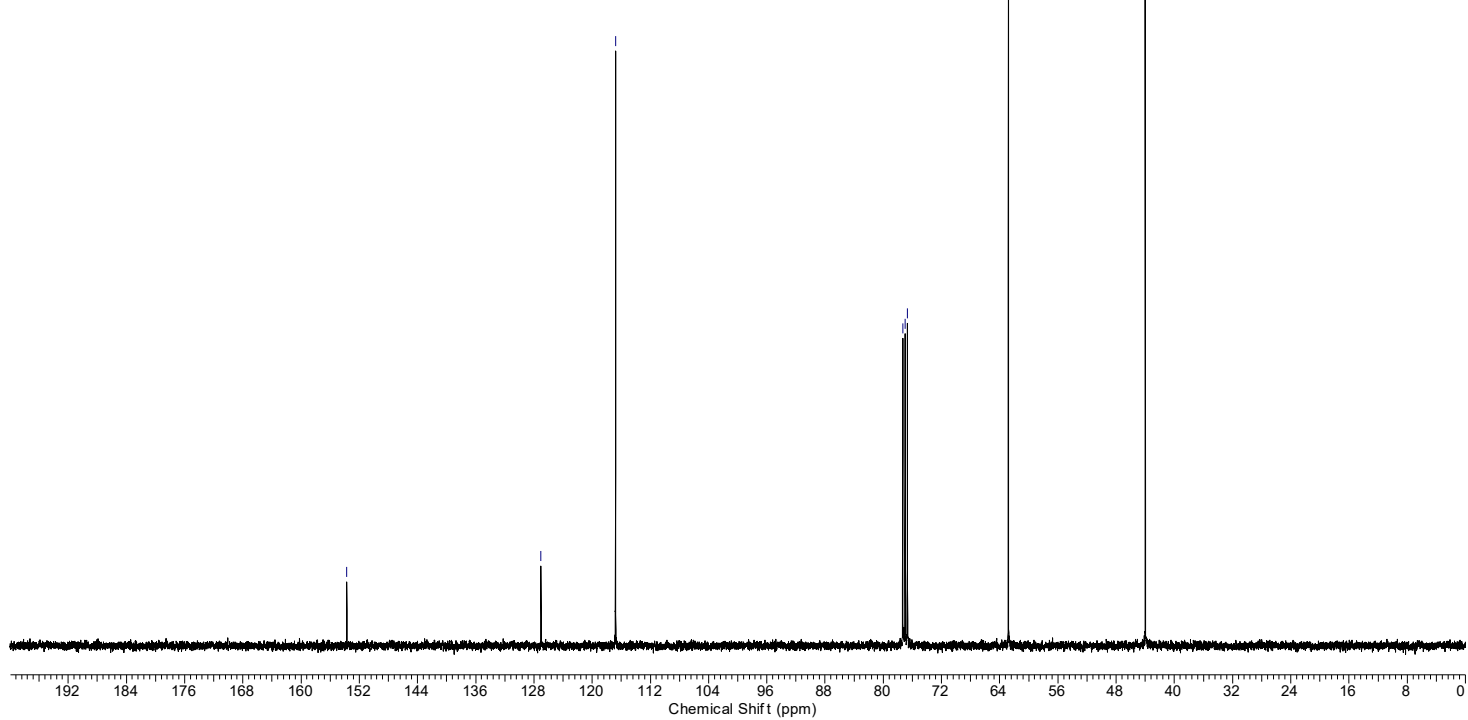


(S,E)-4-Benzyl-3-(1,2-dichlorovinyl)oxazolidin-2-one, 9g

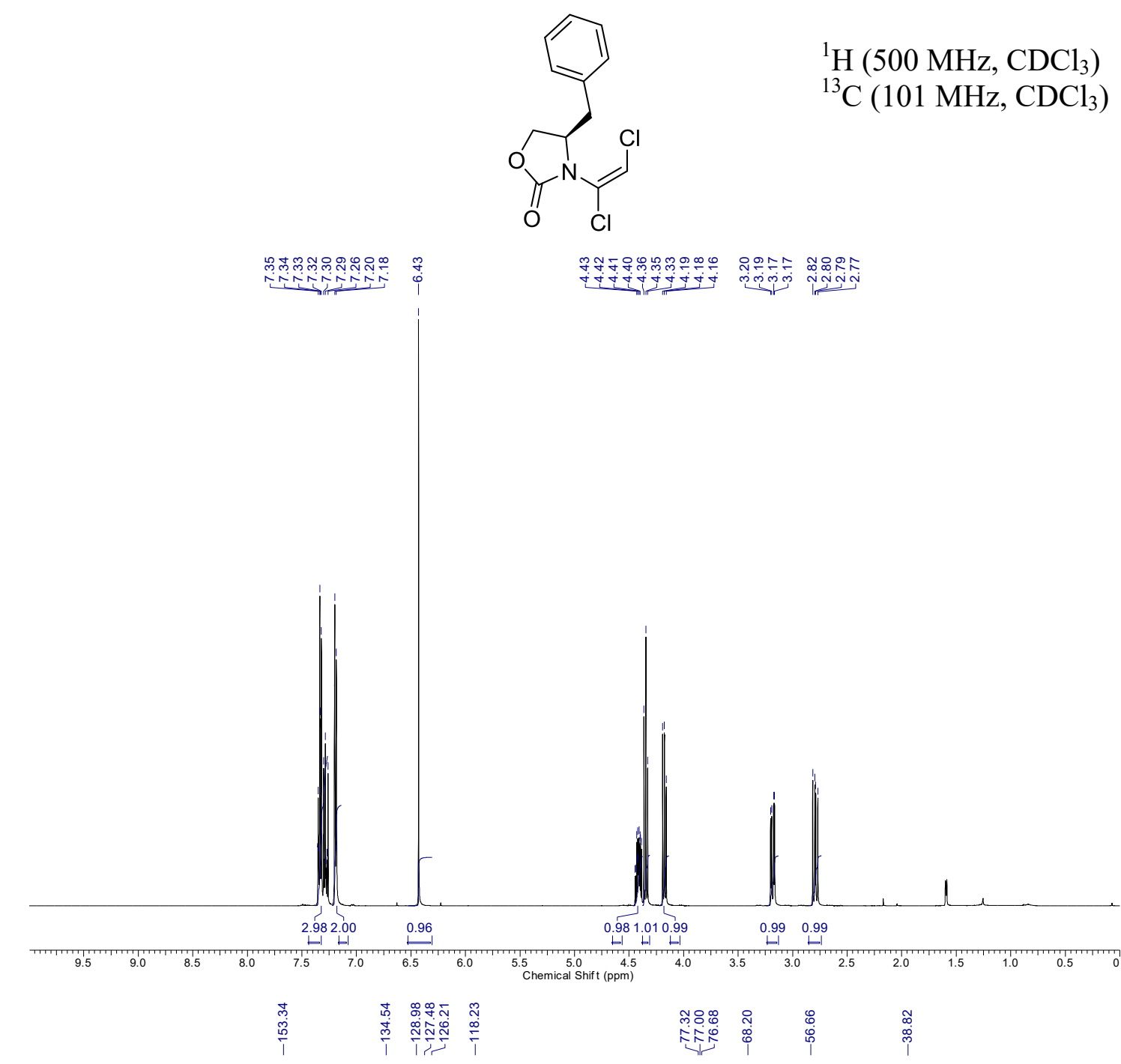

${ }^{1} \mathrm{H}\left(500 \mathrm{MHz}, \mathrm{CDCl}_{3}\right)$

${ }^{13} \mathrm{C}\left(101 \mathrm{MHz}, \mathrm{CDCl}_{3}\right)$

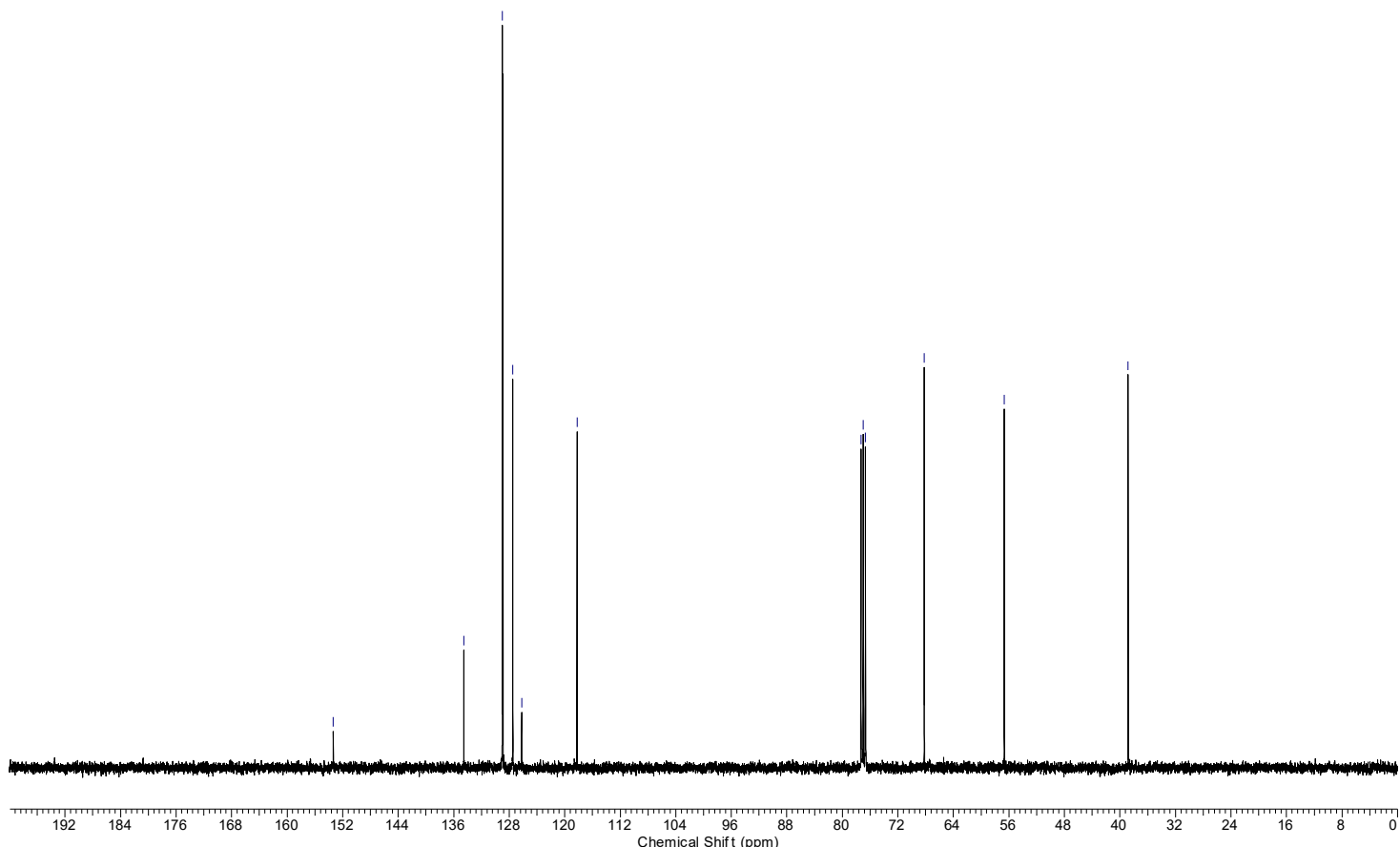




\section{3b Carbamate Scope: Ynamides}

$N$-(3-Methylbut-1-yn-1-yl)- $N$-phenyltosylamide, 13a

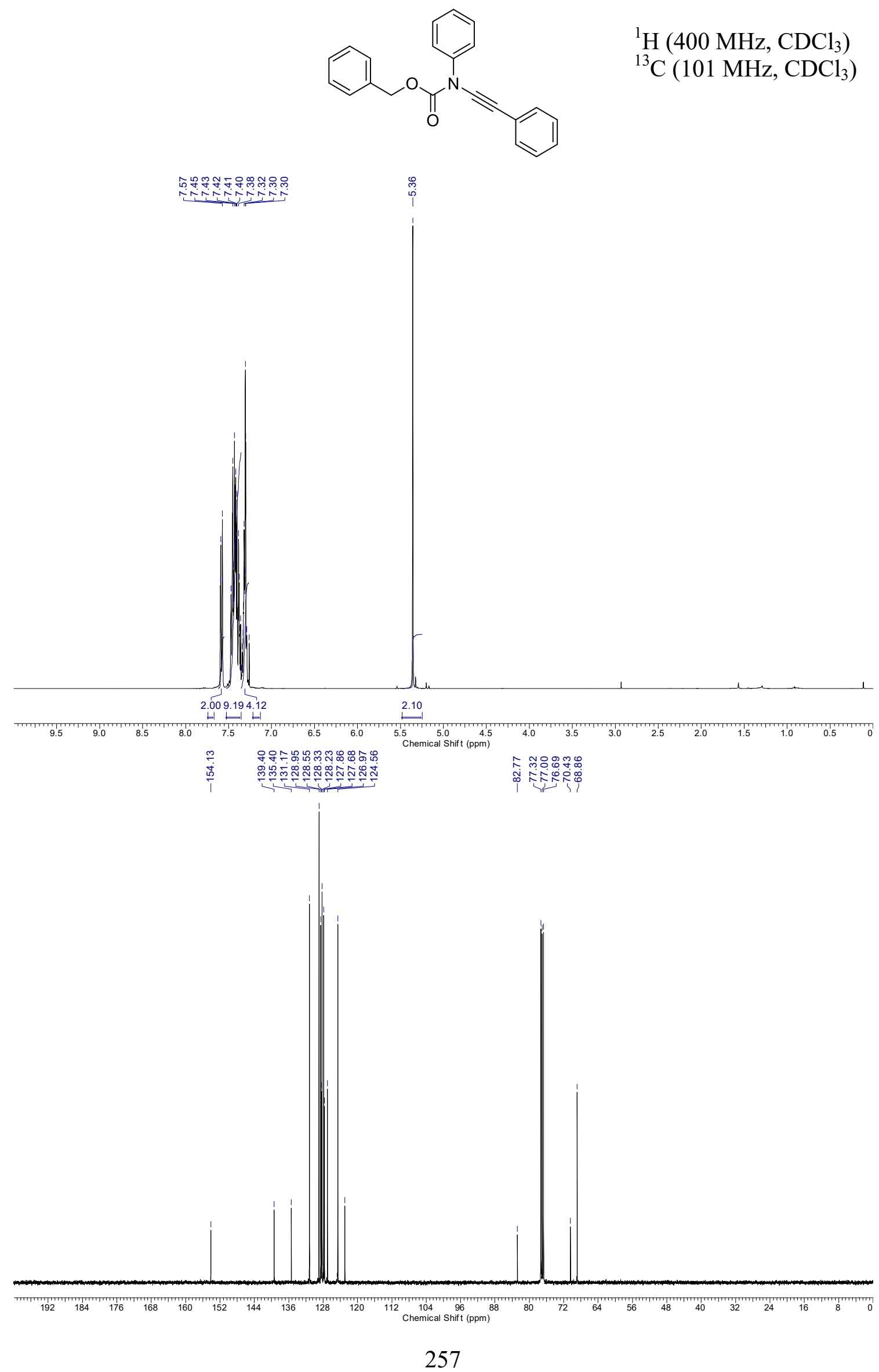


Benzyl ((4-chlorophenyl)ethynyl)(phenyl)carbamate, 13b
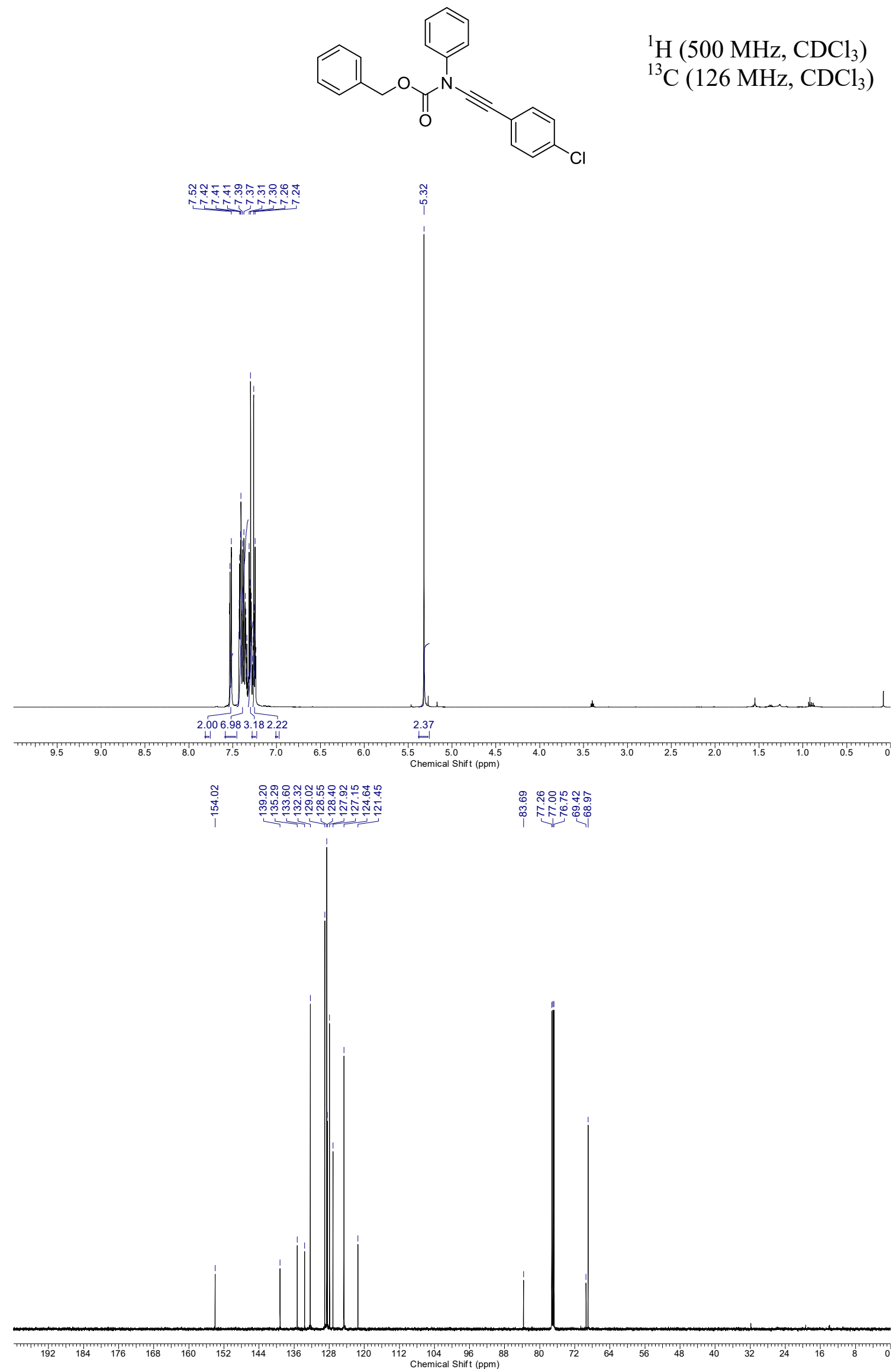
Benzyl phenyl(prop-1-yn-1-yl)carbamate, 13c

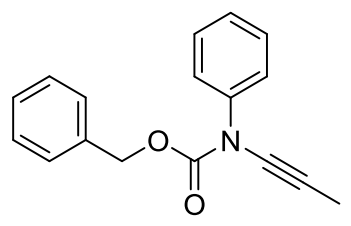

${ }^{1} \mathrm{H}\left(500 \mathrm{MHz}, \mathrm{CDCl}_{3}\right)$

${ }^{13} \mathrm{C}\left(126 \mathrm{MHz}, \mathrm{CDCl}_{3}\right)$
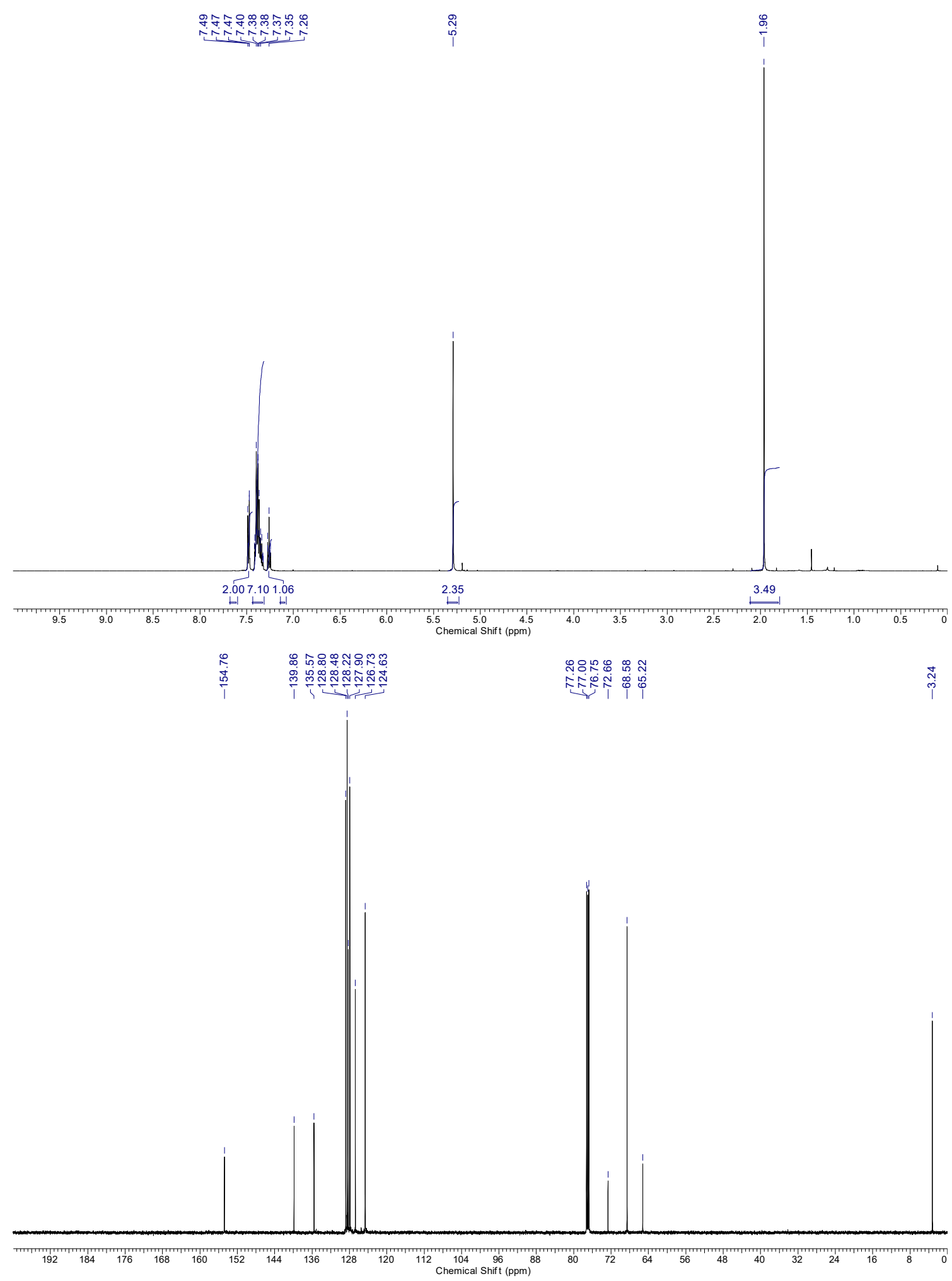
Benzyl phenyl(prop-1-yn-1-yl)carbamate, 13d

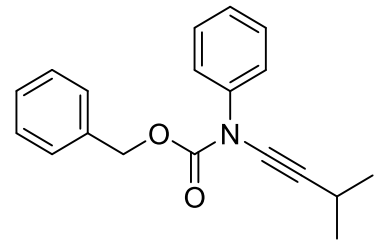

${ }^{1} \mathrm{H}\left(500 \mathrm{MHz}, \mathrm{CDCl}_{3}\right)$

${ }^{13} \mathrm{C}\left(126 \mathrm{MHz}, \mathrm{CDCl}_{3}\right)$

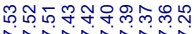

ల్ల

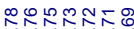

$\operatorname{4in} \sin 4$

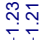

I

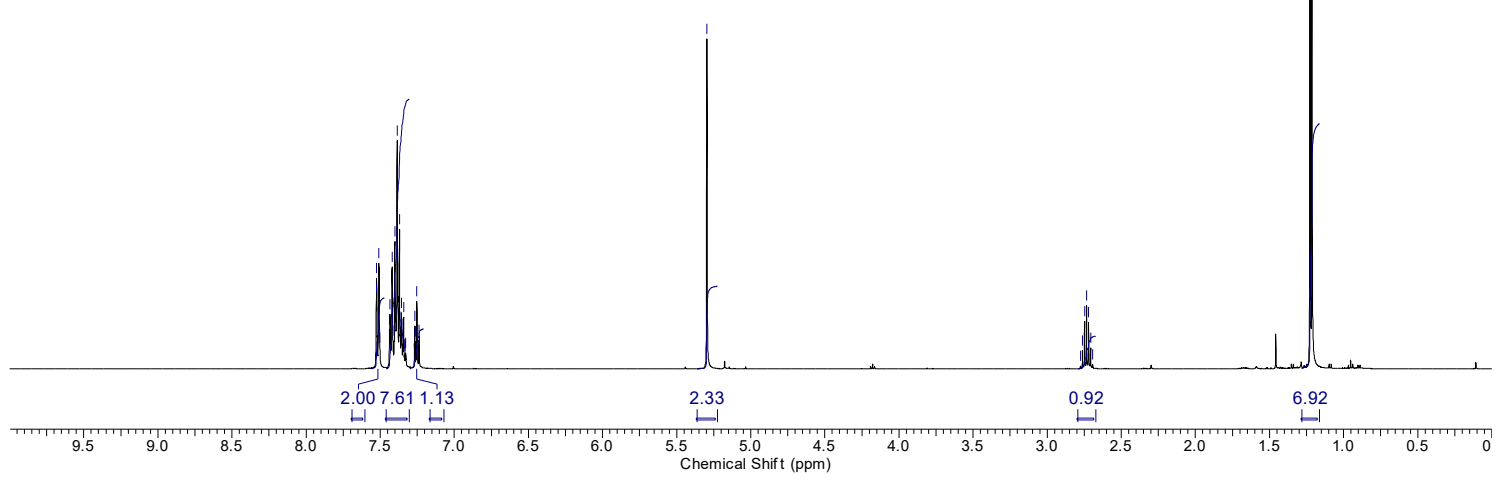

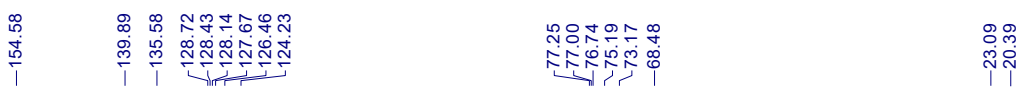

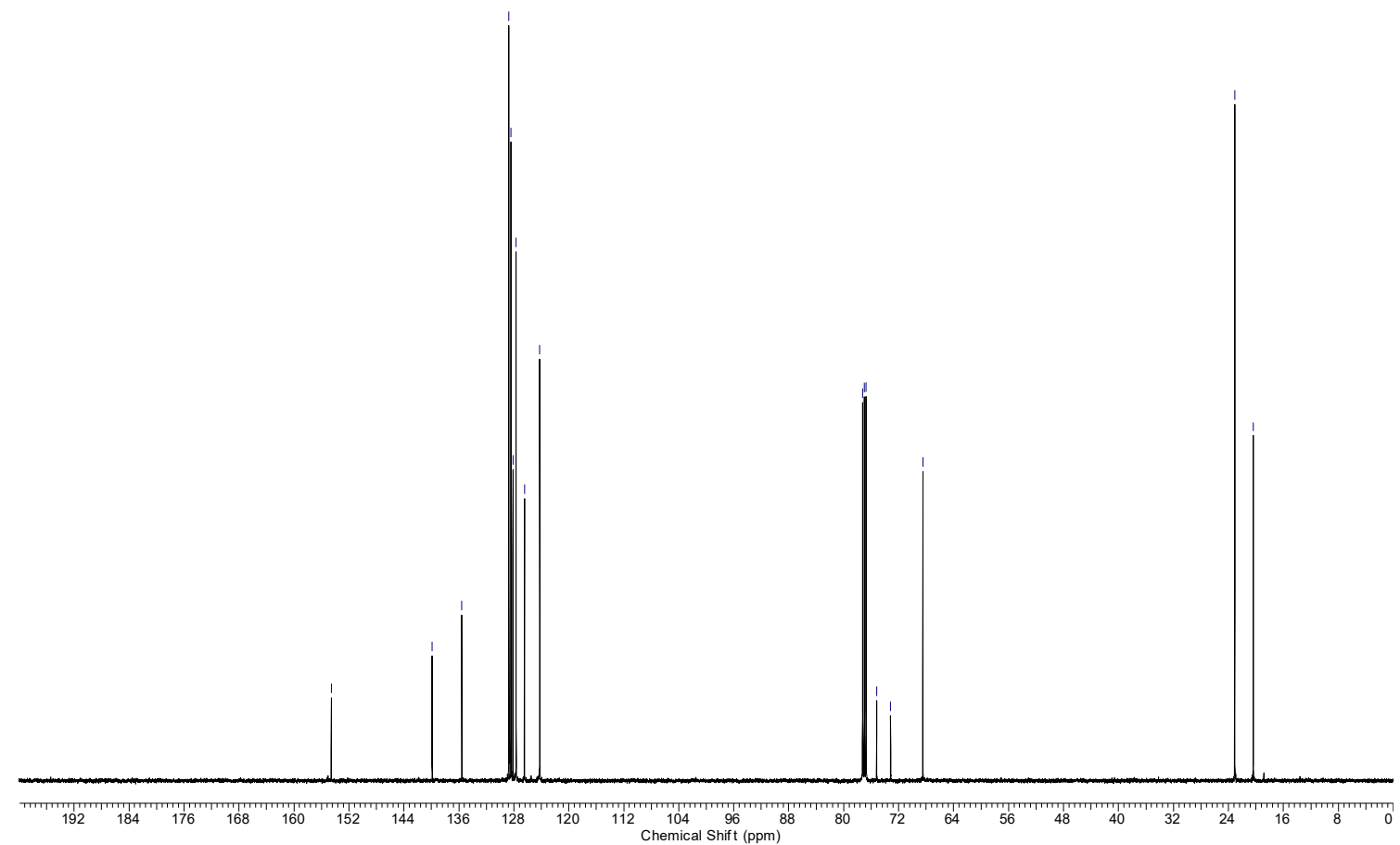


Ethyl ((4-chlorophenyl)ethynyl)(phenyl)carbamate, 13e
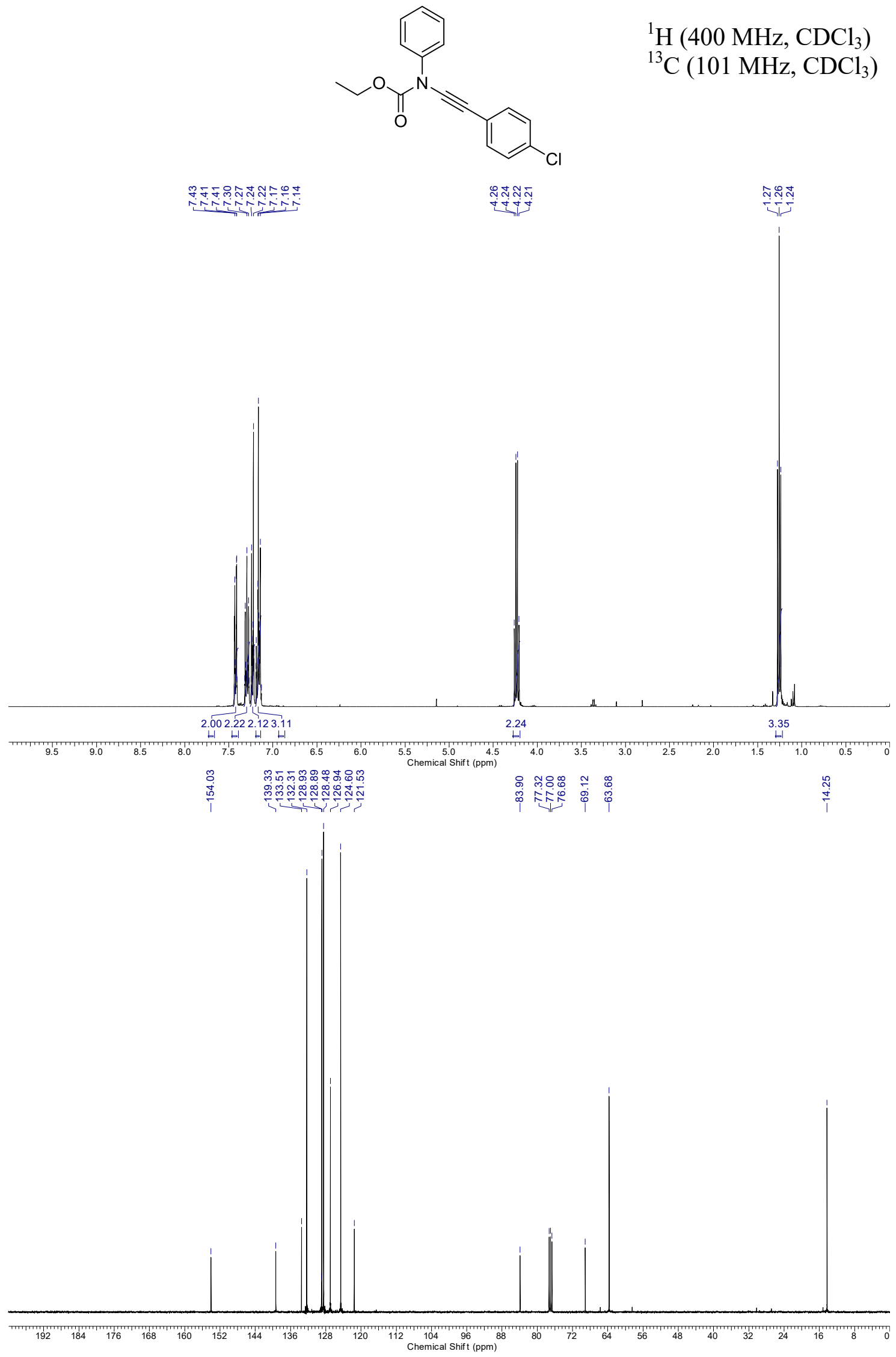
i-Propyl ((4-chlorophenyl)ethynyl)(phenyl)carbamate, $13 f$
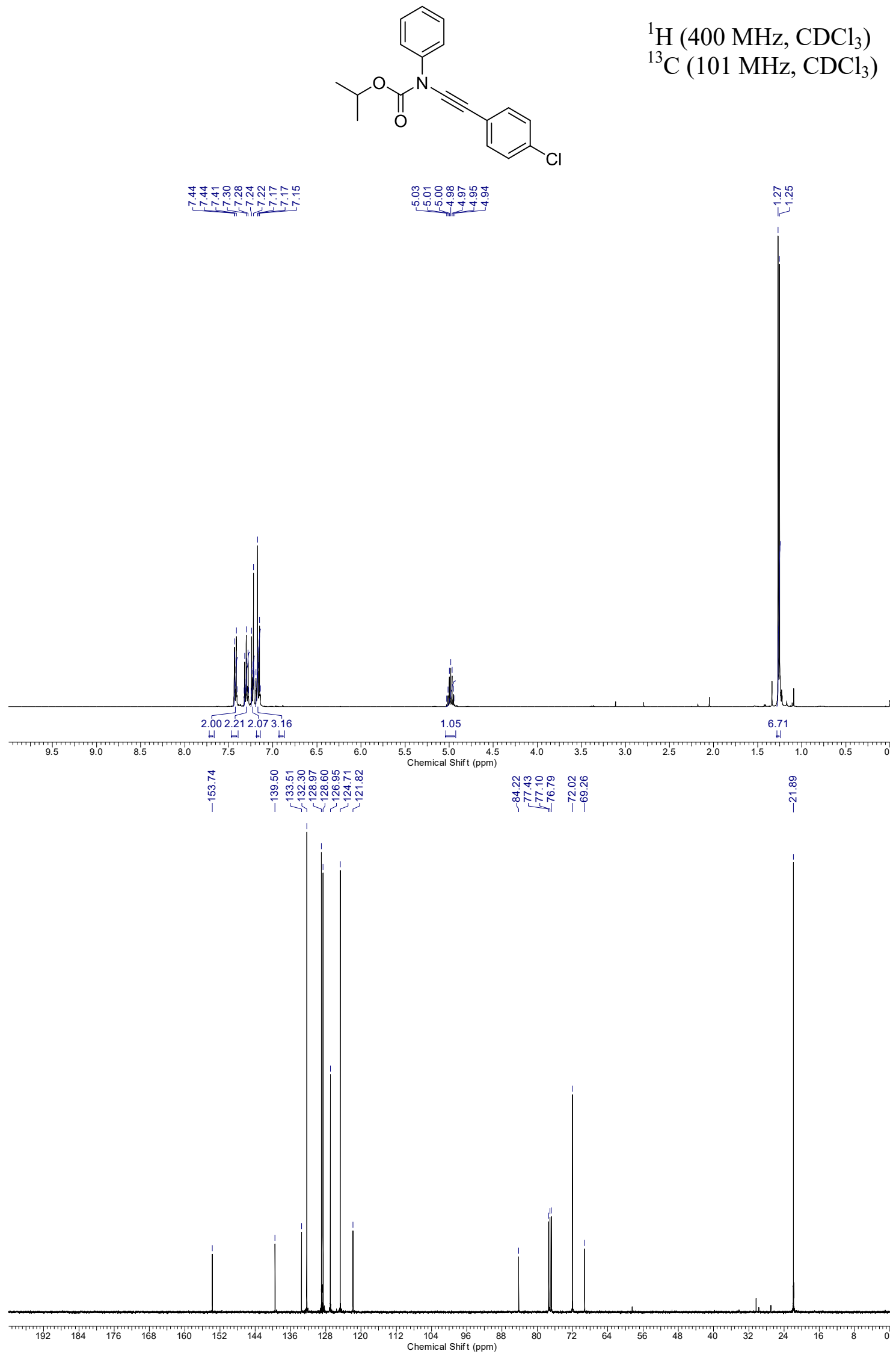
t-Butyl ((4-chlorophenyl)ethynyl)(phenyl)carbamate, 13g
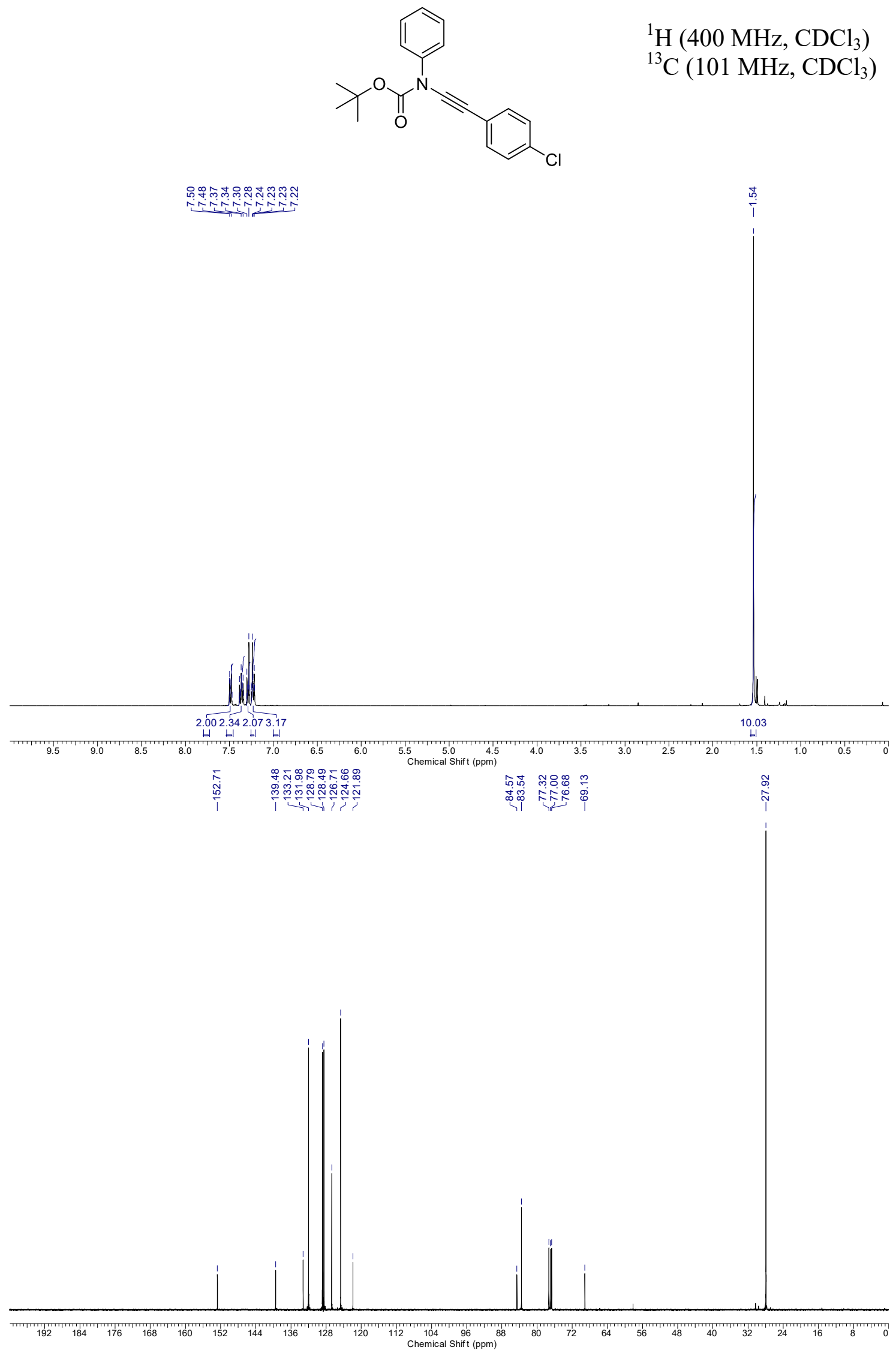
Methyl (2-bromophenyl)((4-chlorophenyl)ethynyl)carbamate, $13 \mathrm{~h}$

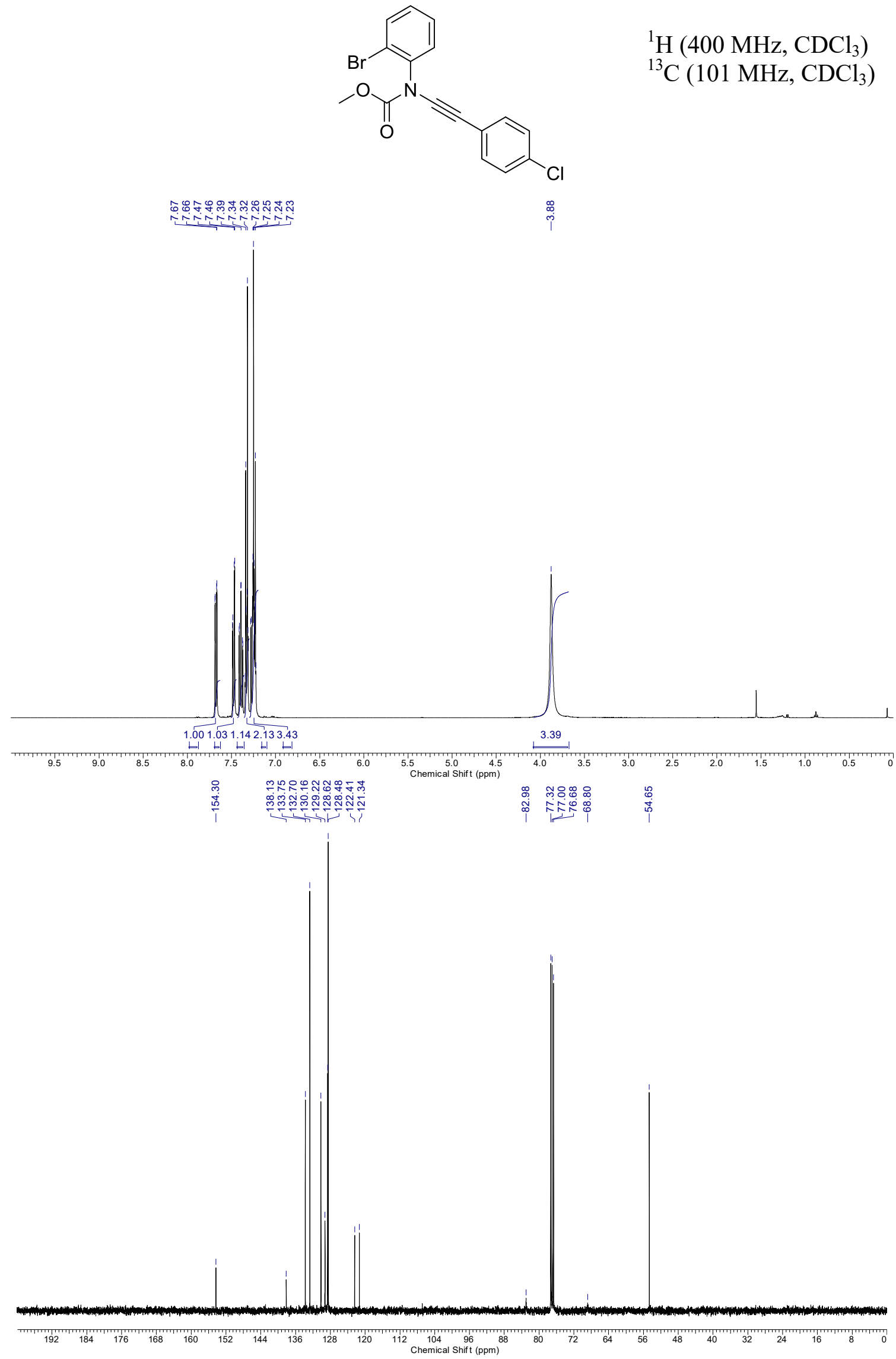




\section{3c Carbamate Scope: Miscellaneous}

Benzyl (Z)-/(E)-(2-chloro-1-phenylvinyl)(phenyl)carbamate, $(Z)-/(E)-11$

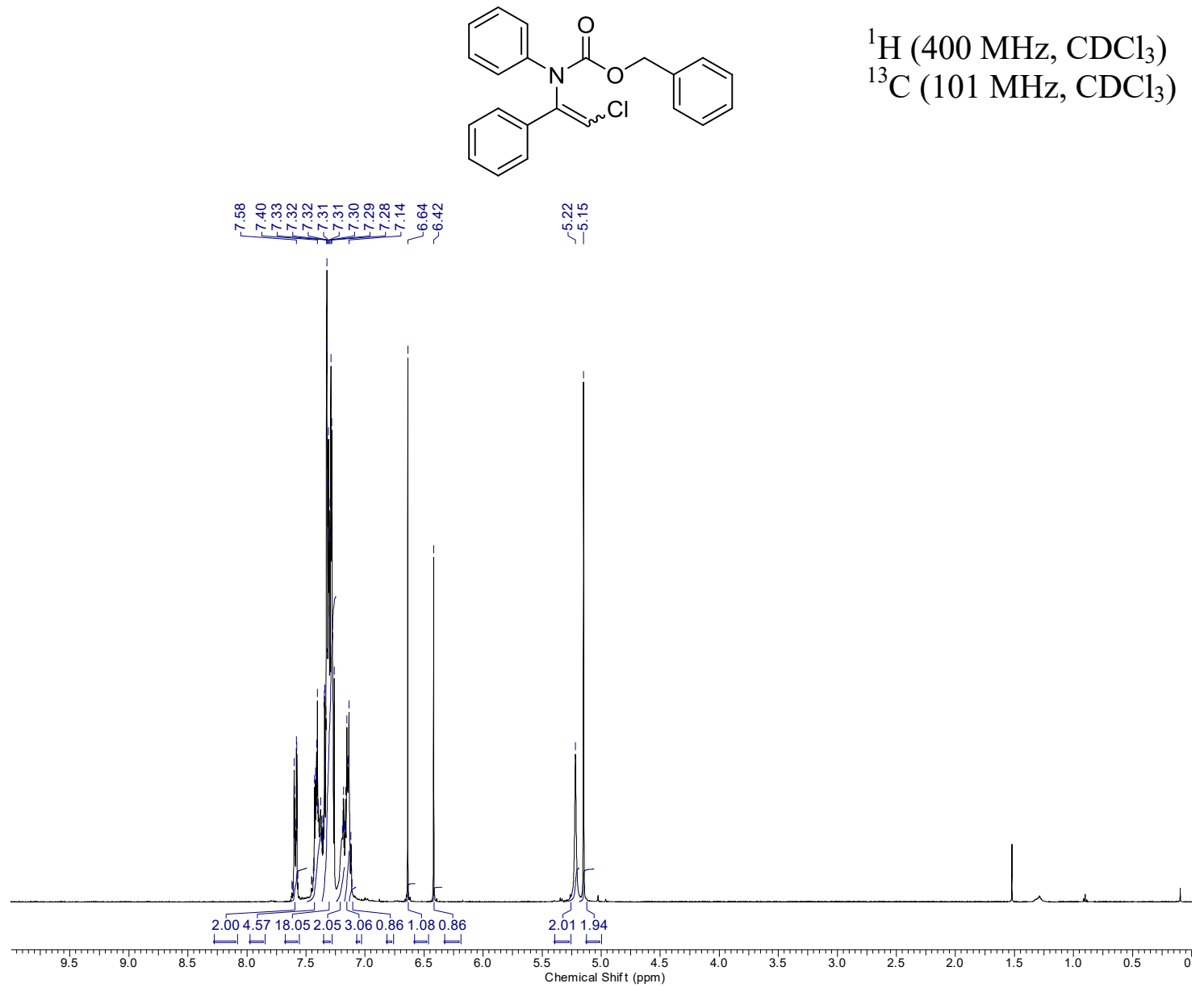

${ }^{1} \mathrm{H}\left(400 \mathrm{MHz}, \mathrm{CDCl}_{3}\right)$

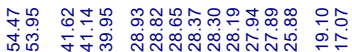

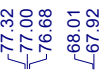

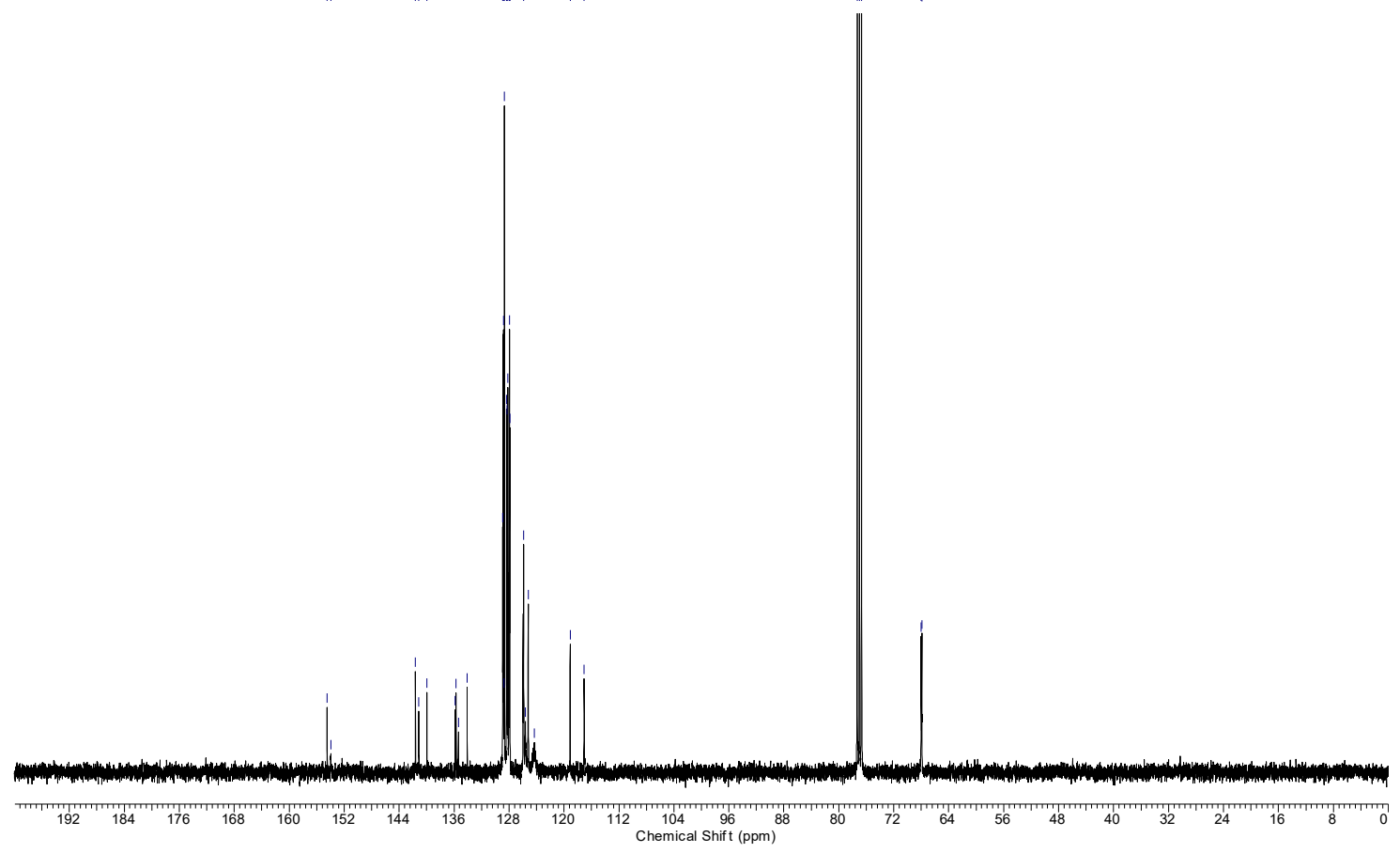


Benzyl (E)-(2-chloro-1-phenylvinyl)(phenyl)carbamate, $(E)-11$

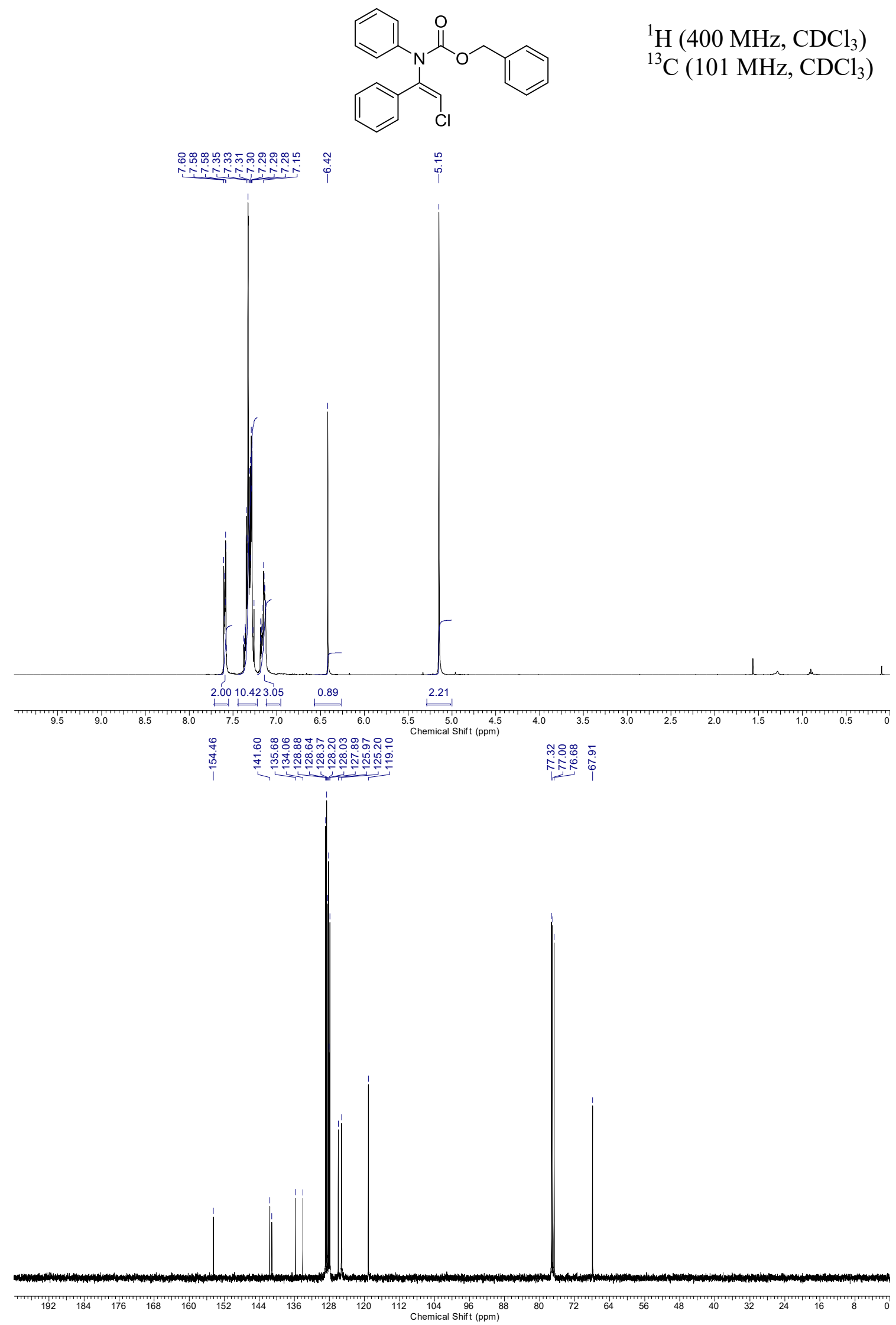


Benzyl (E)-2-chloro-3-phenyl-3-(phenylamino)acrylate, 12

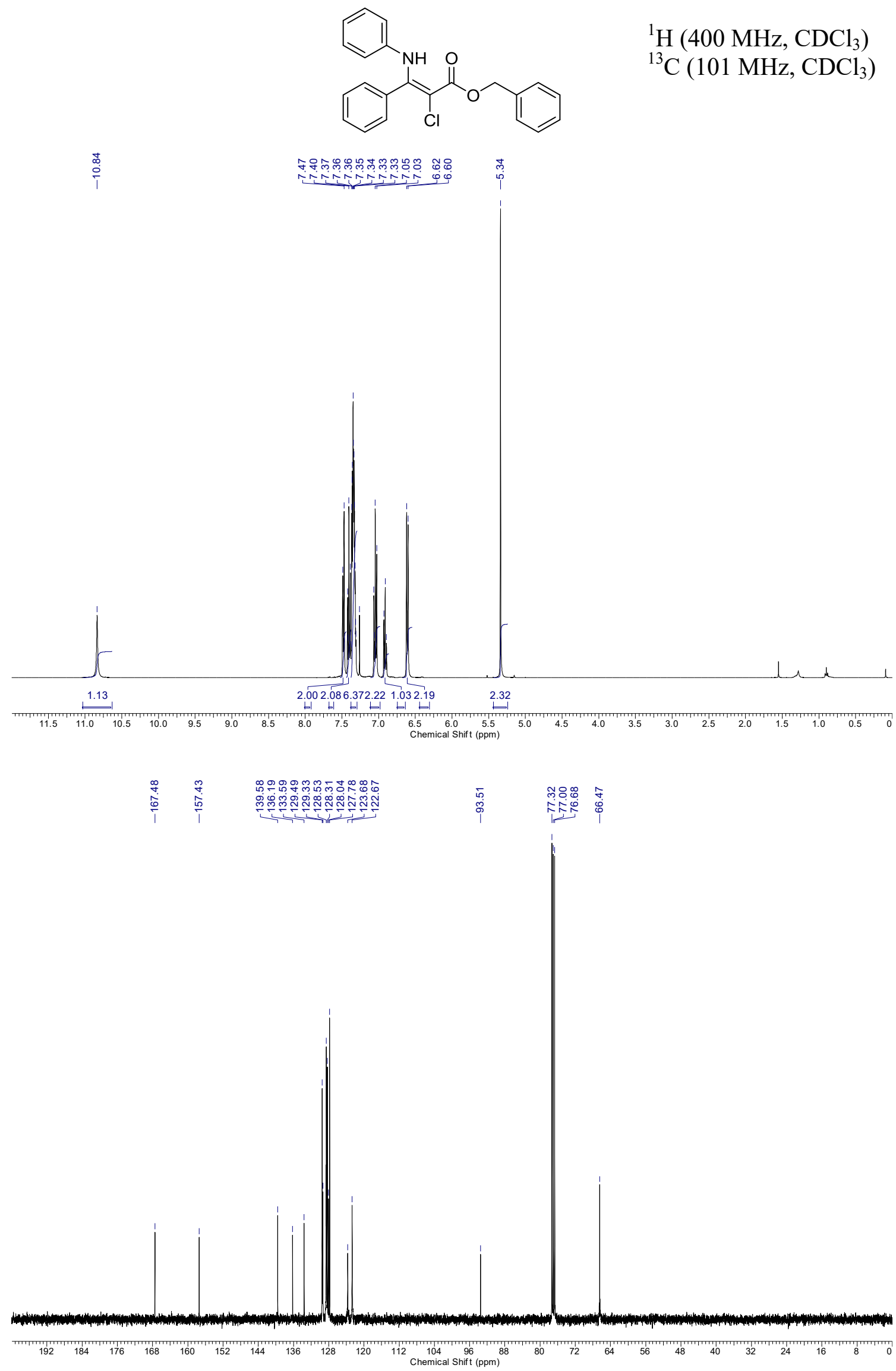




\section{3,4-Diphenyloxazol-2(3H)-one, S5}<smiles>O=c1occ(-c2ccccc2)n1-c1ccccc1</smiles>

${ }^{1} \mathrm{H}\left(400 \mathrm{MHz}, \mathrm{CDCl}_{3}\right)$

${ }^{13} \mathrm{C}\left(101 \mathrm{MHz}, \mathrm{CDCl}_{3}\right)$

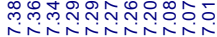

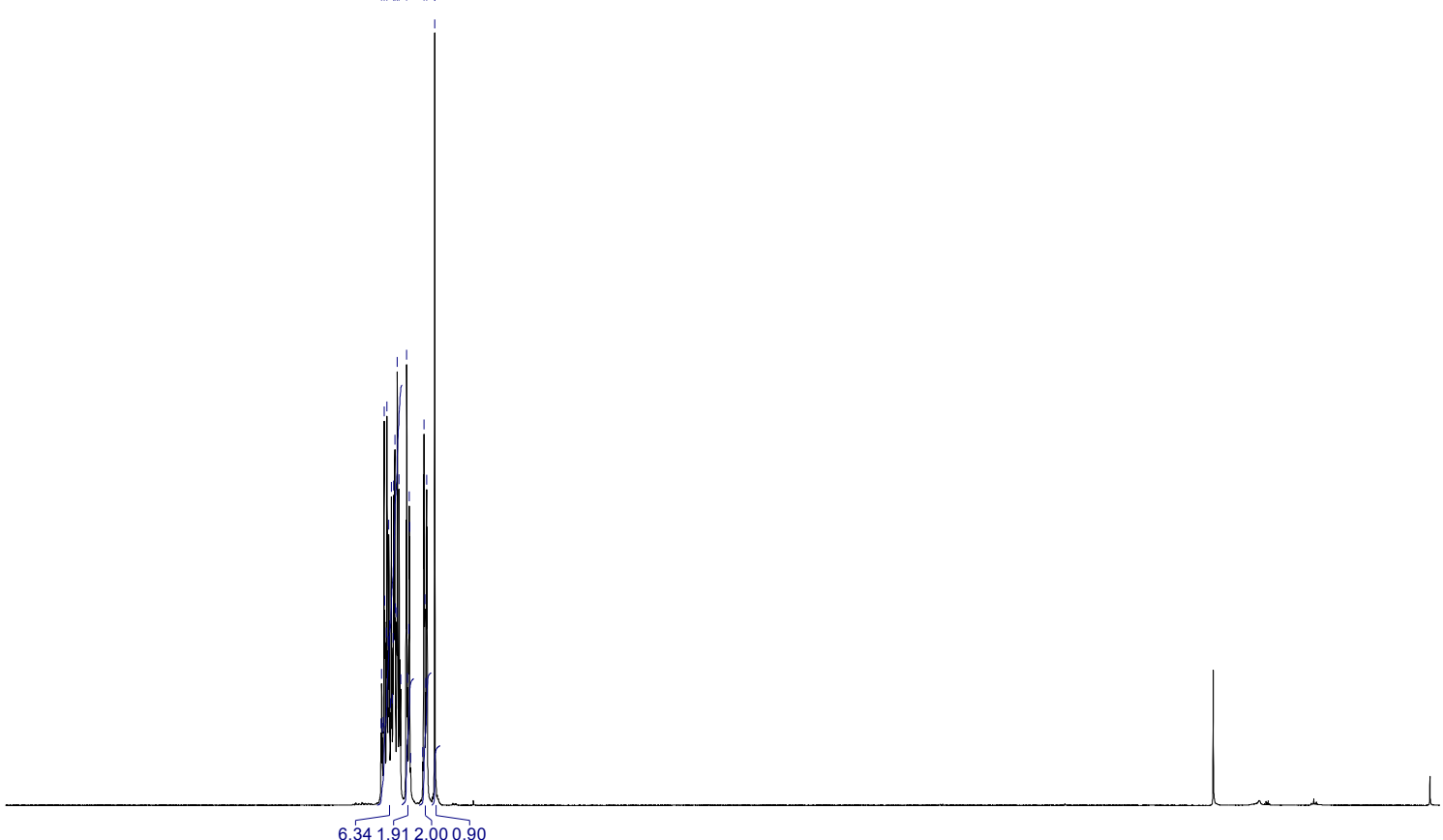

6.341 .912 .000 .90

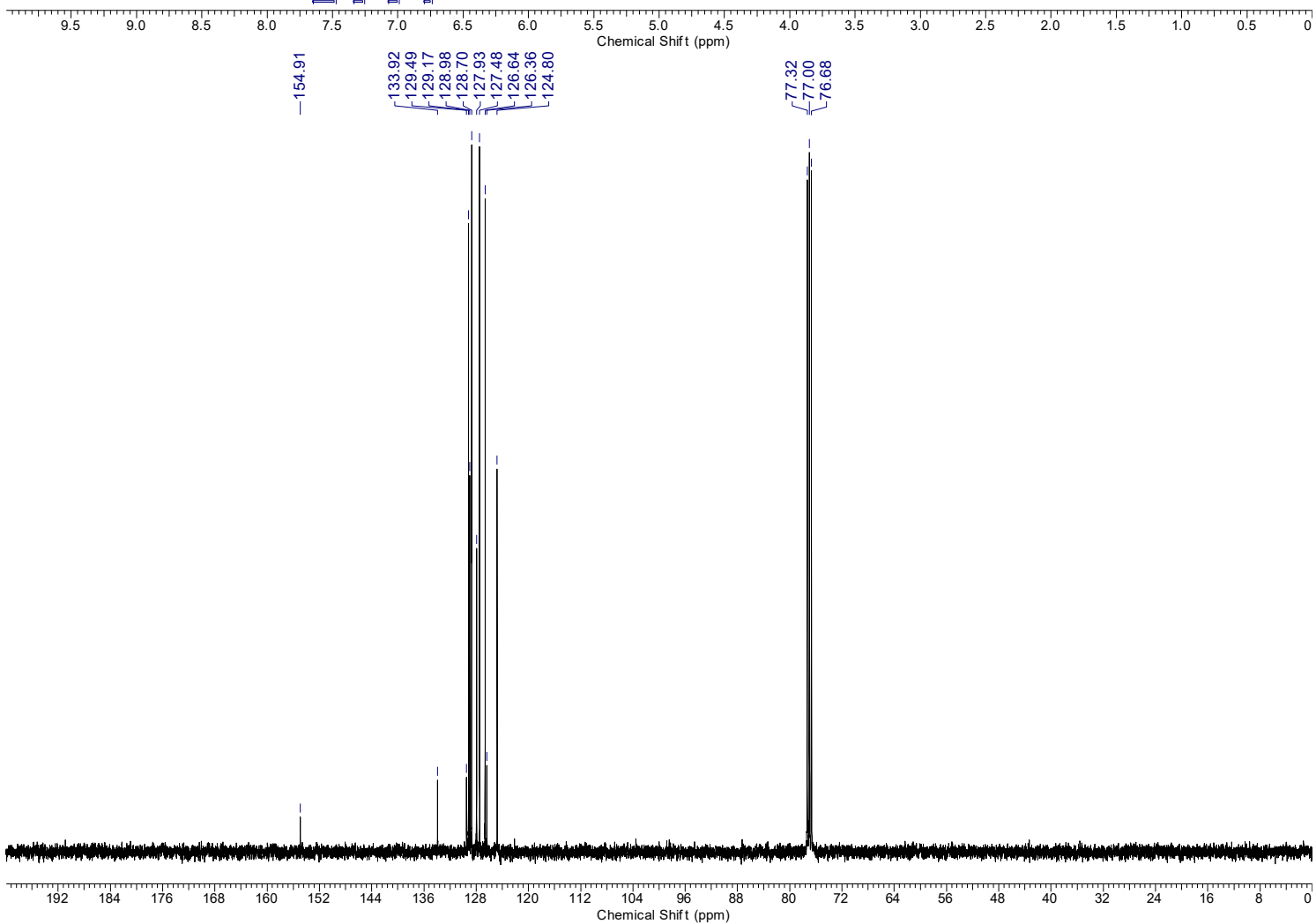


Dibenzyl (1,4-diphenylbuta-1,2,3-triene-1,4-diyl)-bis(phenylcarbamate), S6

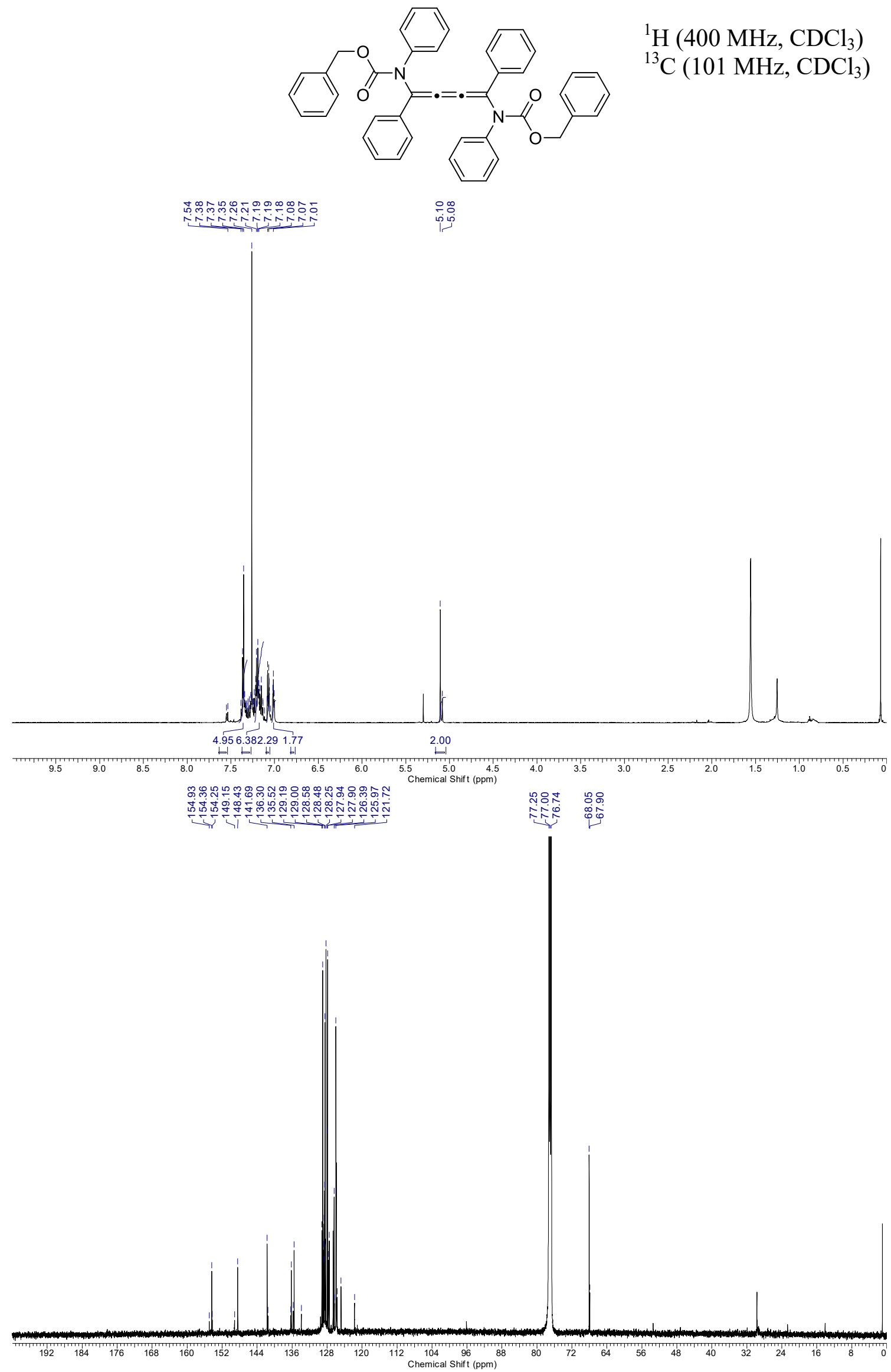




\section{4a Urea Scope: Dichloroenamides}

(E)-1-(1,2-Dichlorovinyl)-3-methyl-1,3-diphenylurea, 9h

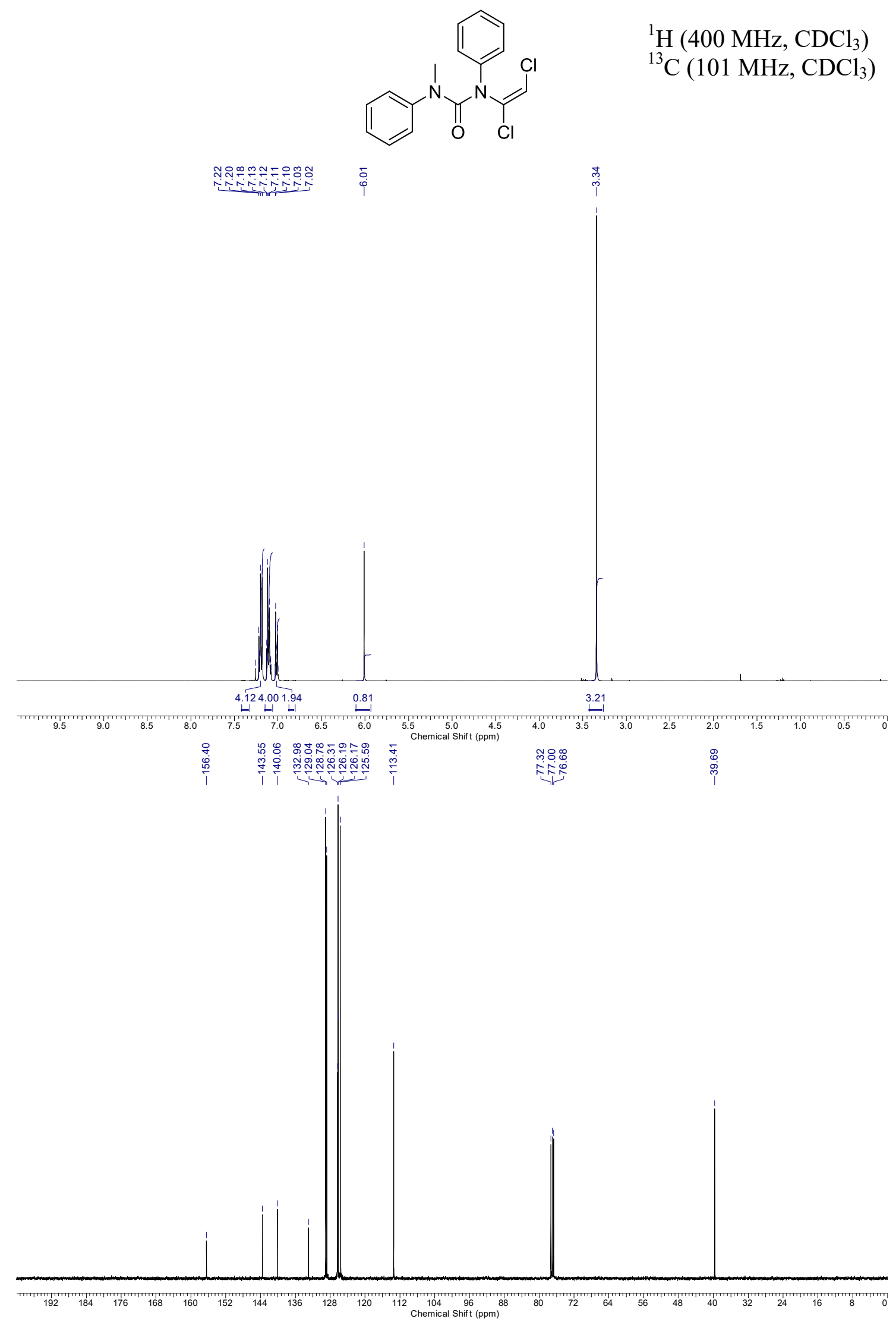


(E)-N-(1,2-Dichlorovinyl)- $N$-phenylpyrrolidine-1-carboxamide, 9i

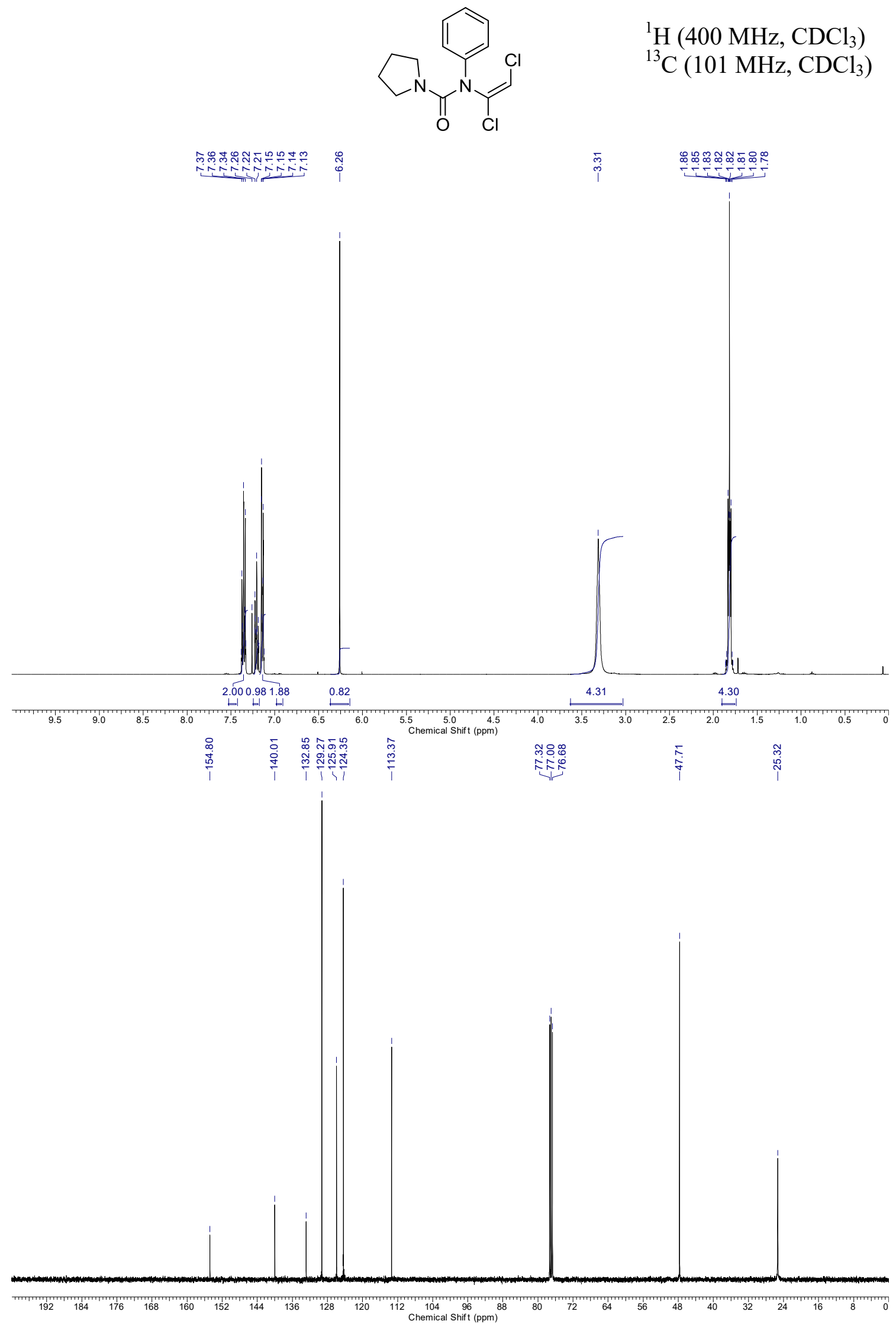


(E)-N-(1,2-Dichlorovinyl)- $N$-phenylmorpholine-4-carboxamide, 9 j

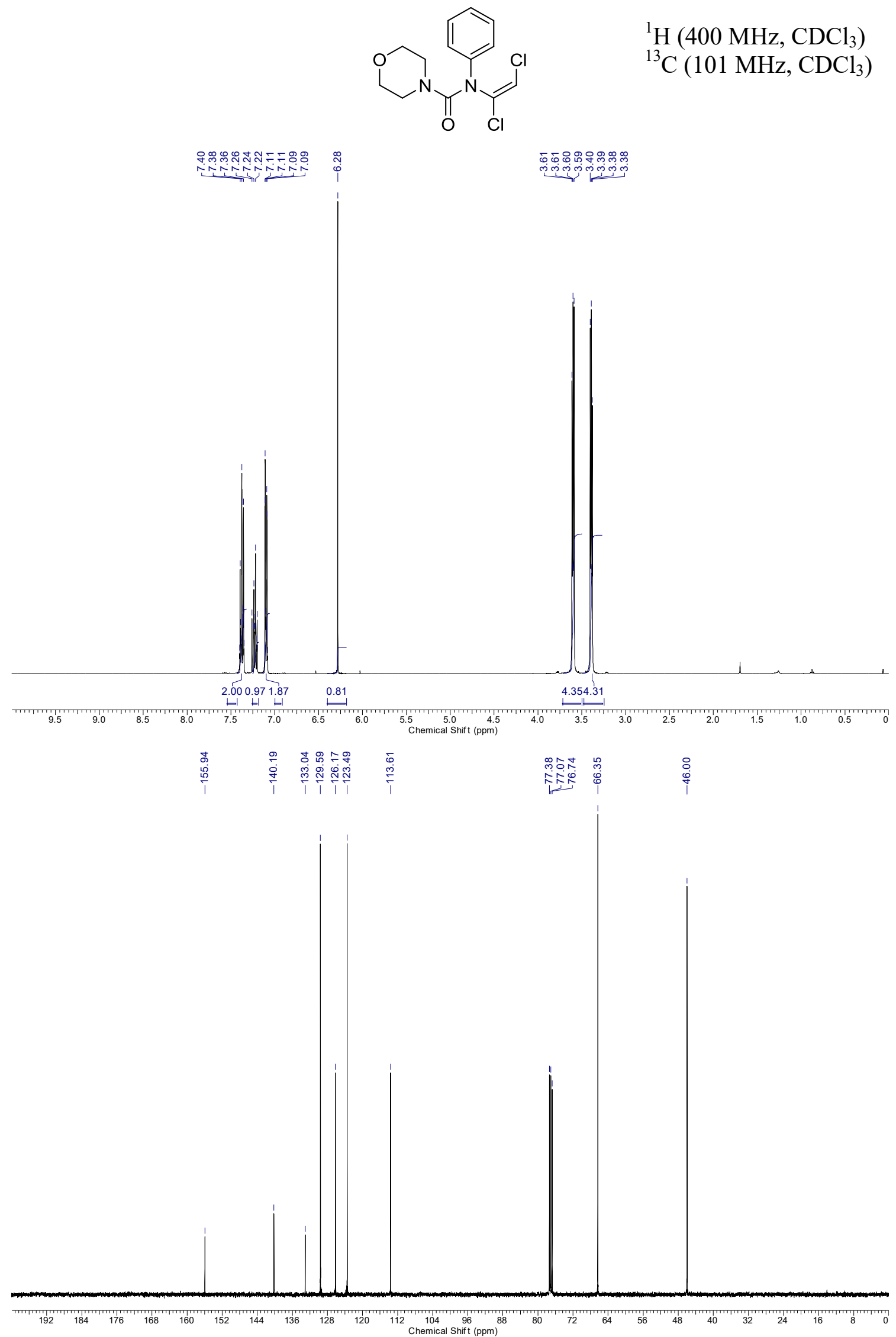


(E)-1,1-Dibenzyl-3-(1,2-dichlorovinyl)-3-phenylurea, 9k

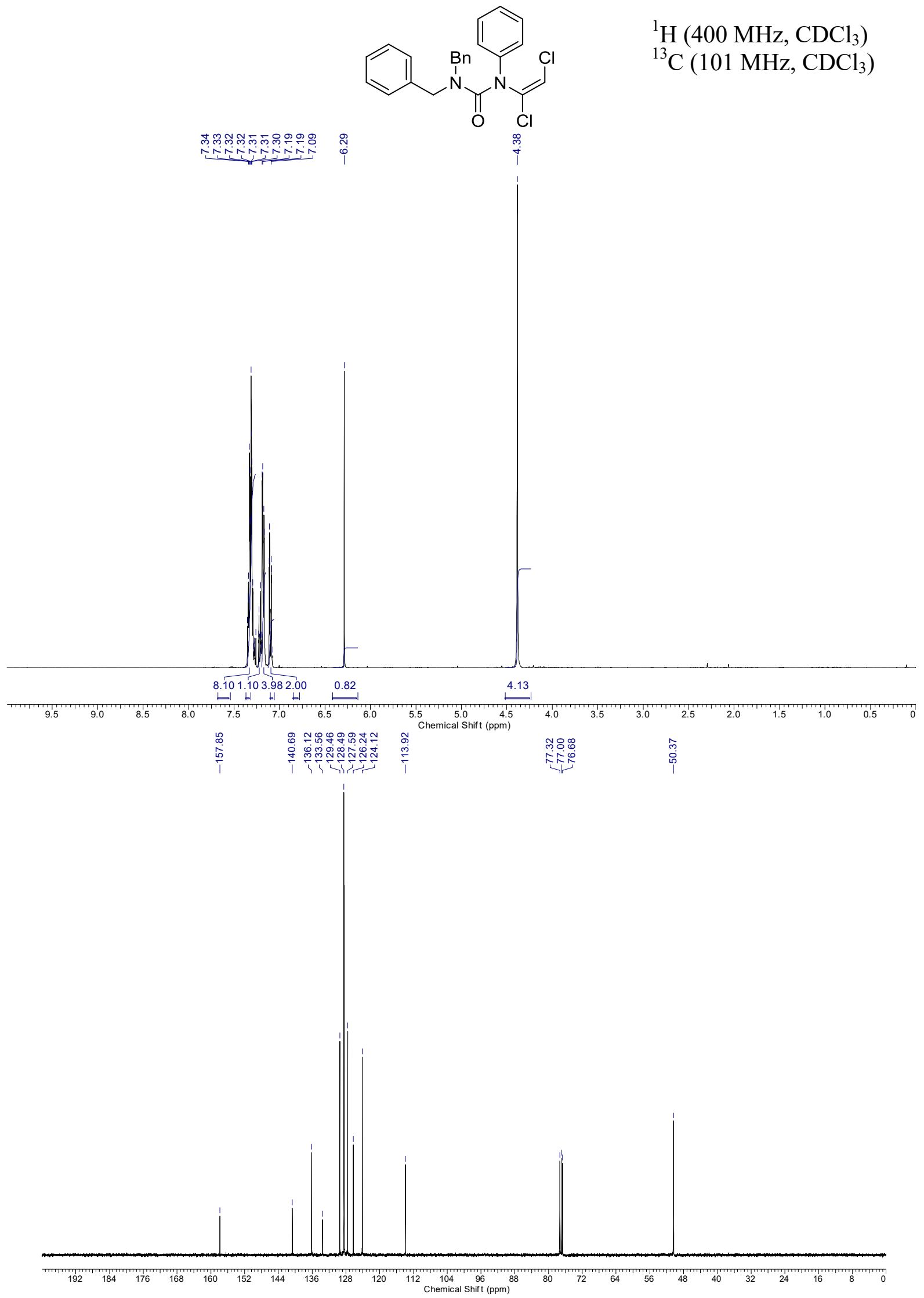


(E)-1,1,3-Tribenzyl-3-(1,2-dichlorovinyl)urea, 91<smiles>O=C(N(Cc1ccccc1)Cc1ccccc1)N(Cc1ccccc1)/C(Cl)=C\Cl</smiles>

${ }^{1} \mathrm{H}\left(400 \mathrm{MHz}, \mathrm{CDCl}_{3}\right)$

${ }^{13} \mathrm{C}\left(101 \mathrm{MHz}, \mathrm{CDCl}_{3}\right)$
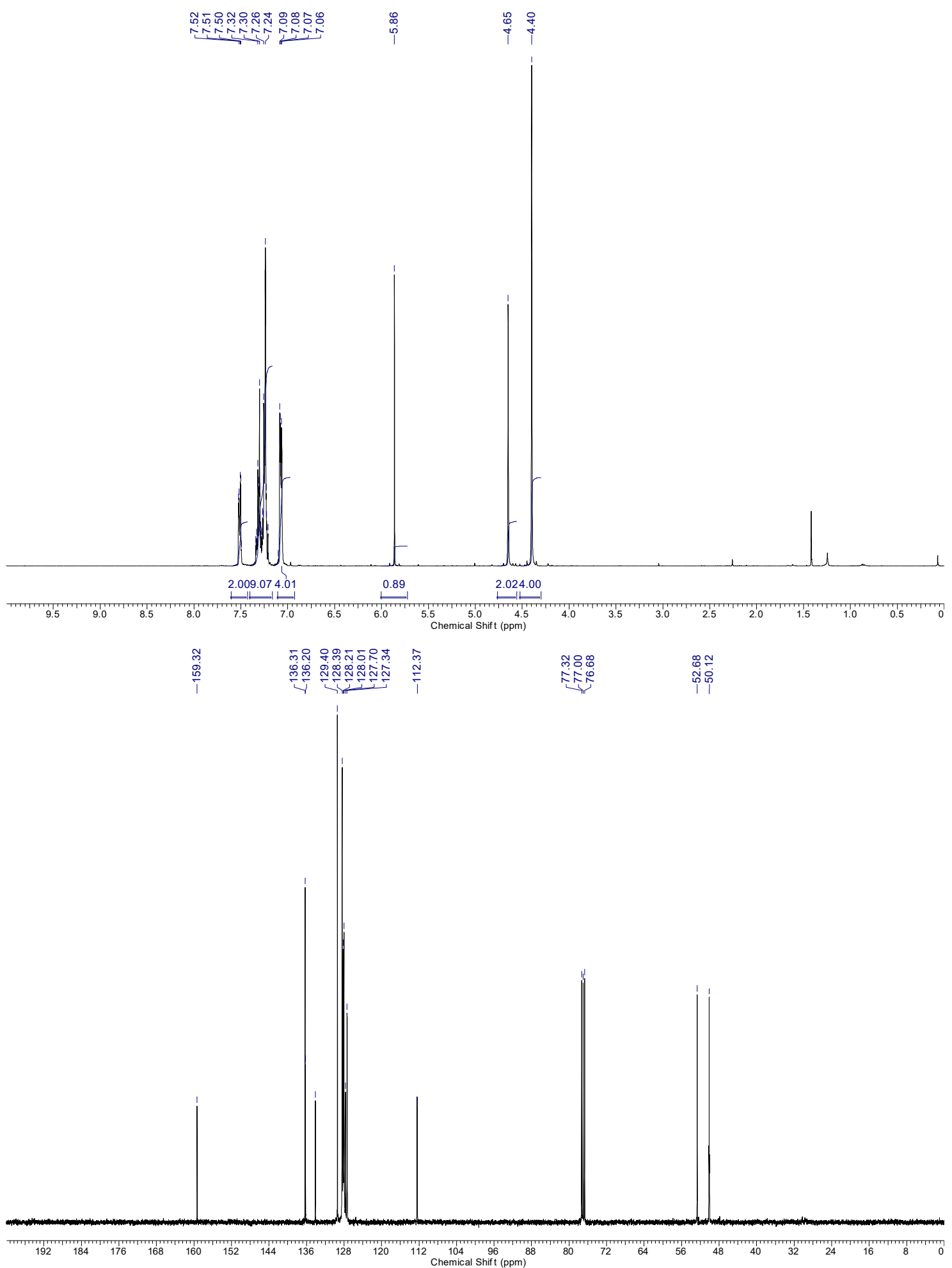


\section{4b Urea Scope: Ynamides}

\section{1-((4-Chlorophenyl)ethynyl)-3-methyl-1,3-diphenylurea, 13i}
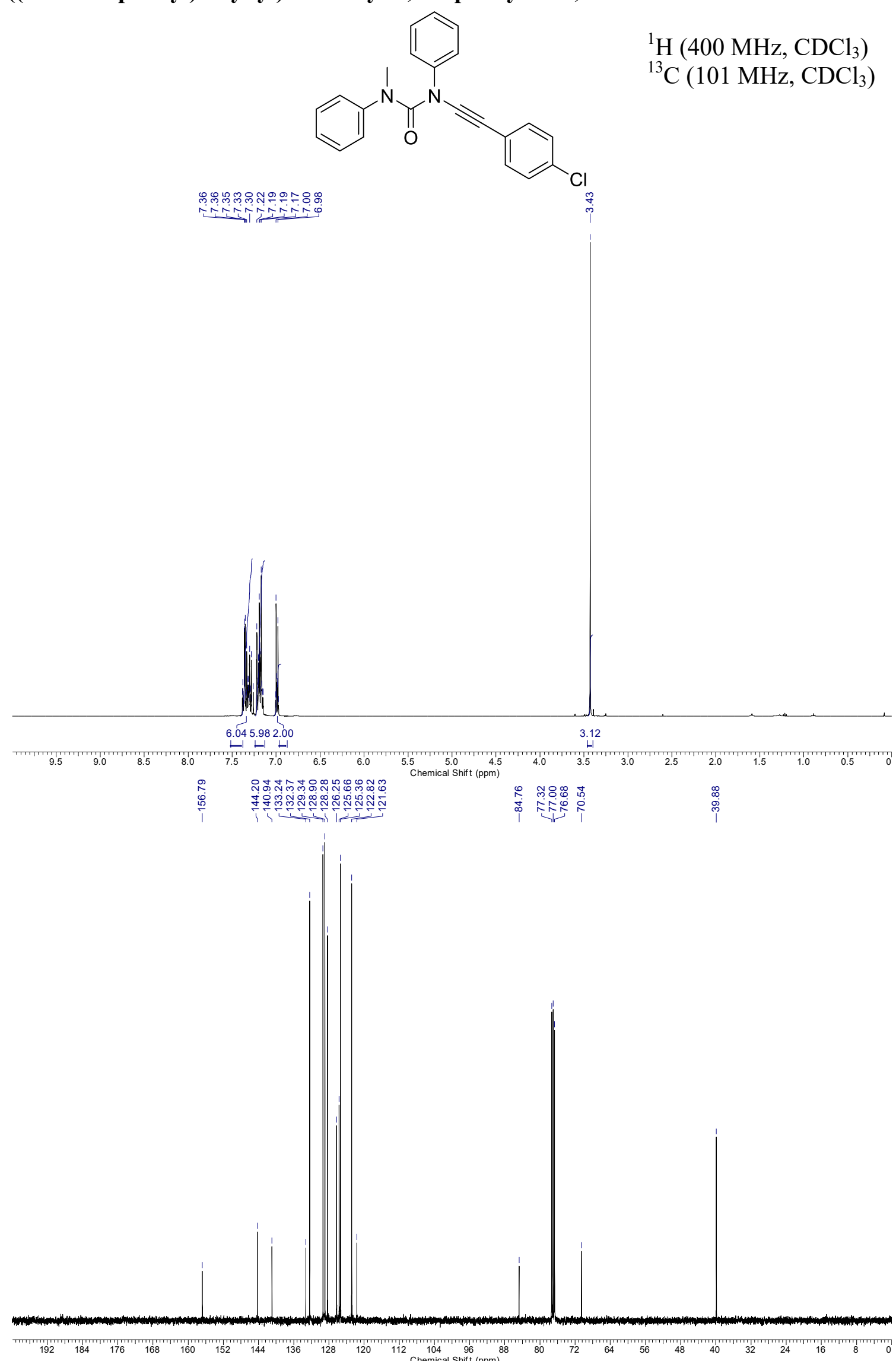
$N$-((4-Chlorophenyl)ethynyl)- $N$-phenylpyrrolidine-1-carboxamide, $13 \mathbf{j}$

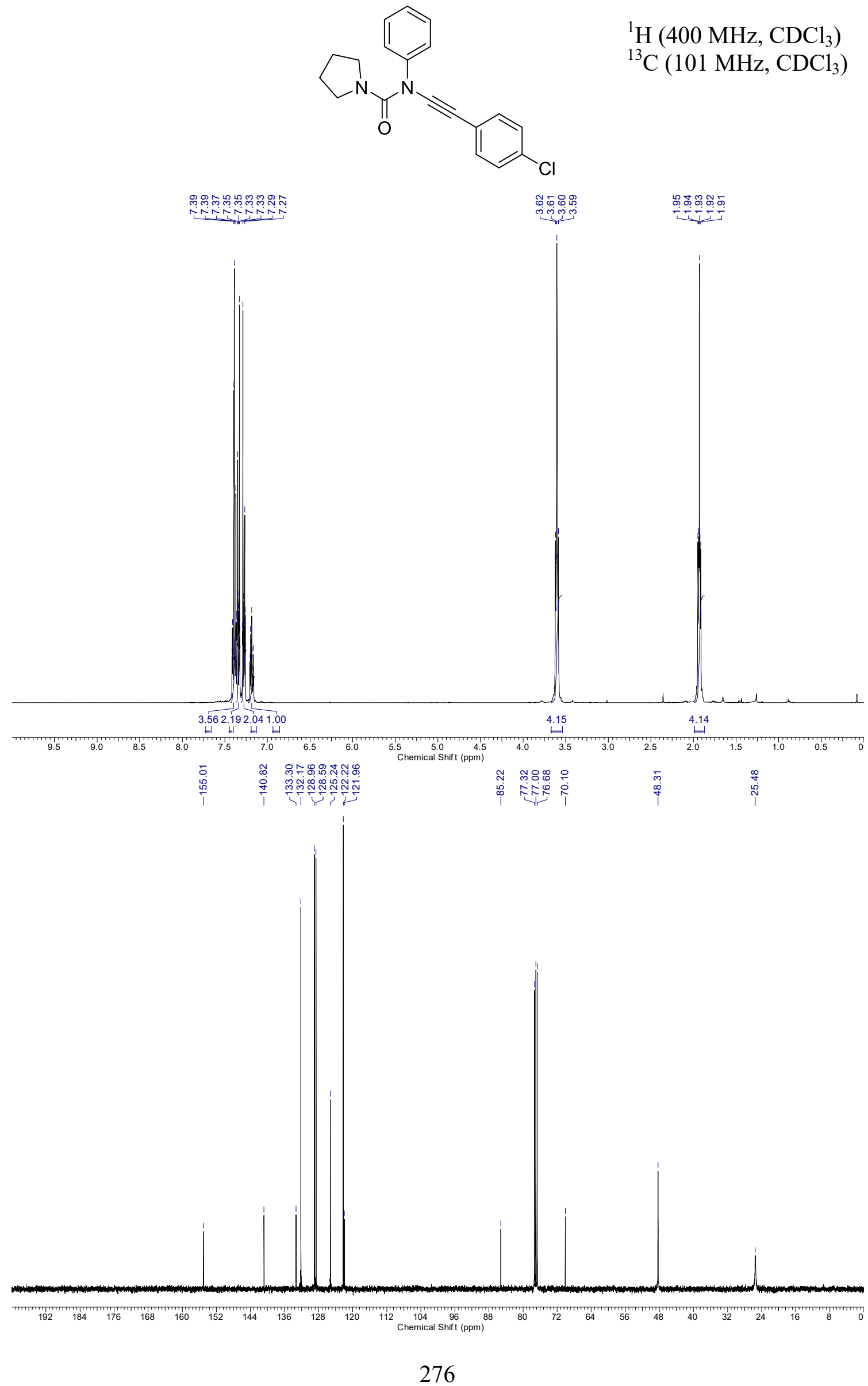


$N$-((4-Chlorophenyl)ethynyl)- $N$-phenylmorpholine-4-carboxamide, 13k

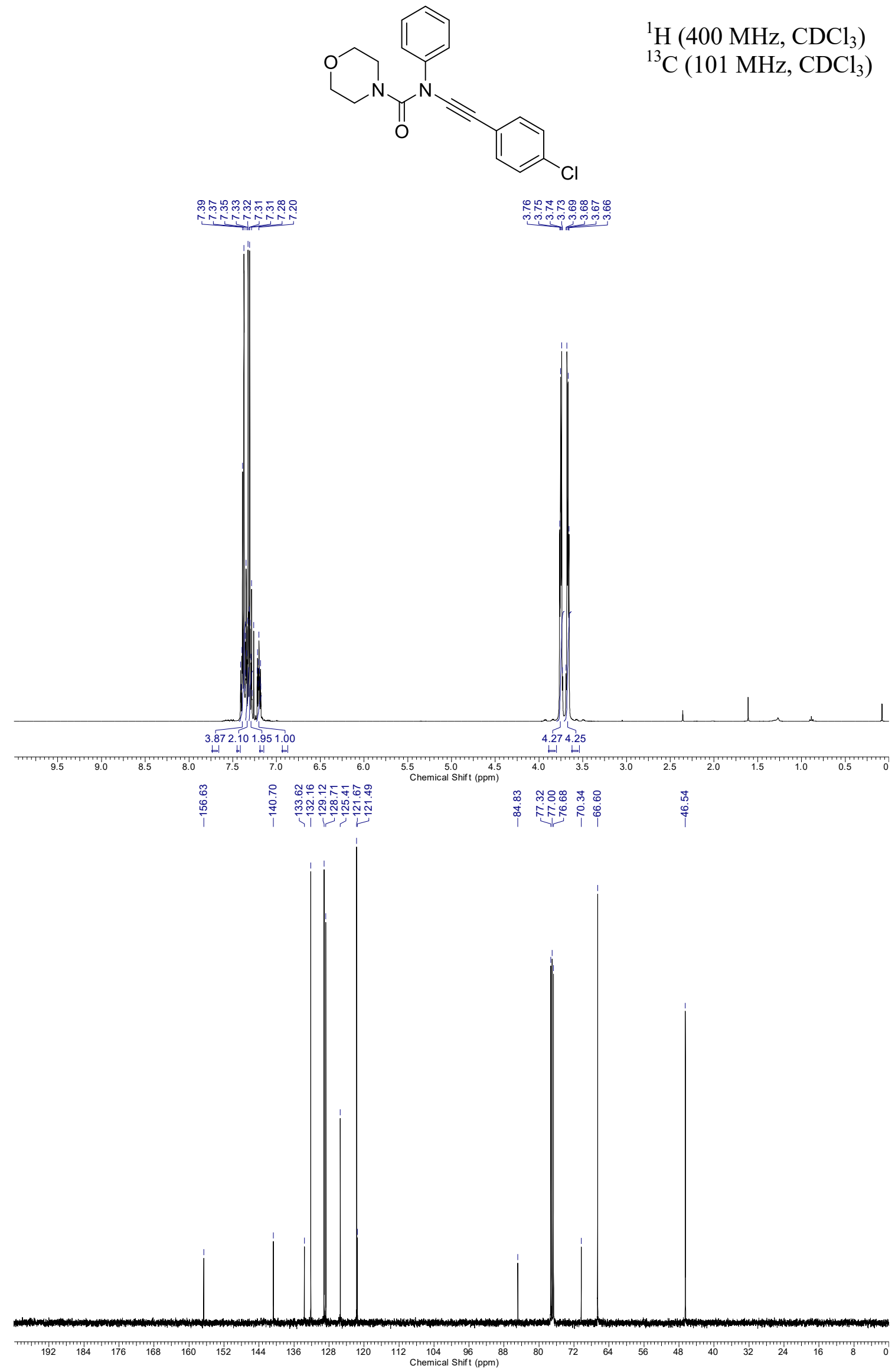


1,1-Dibenzyl-3-((4-chlorophenyl)ethynyl)-3-phenylurea, 131
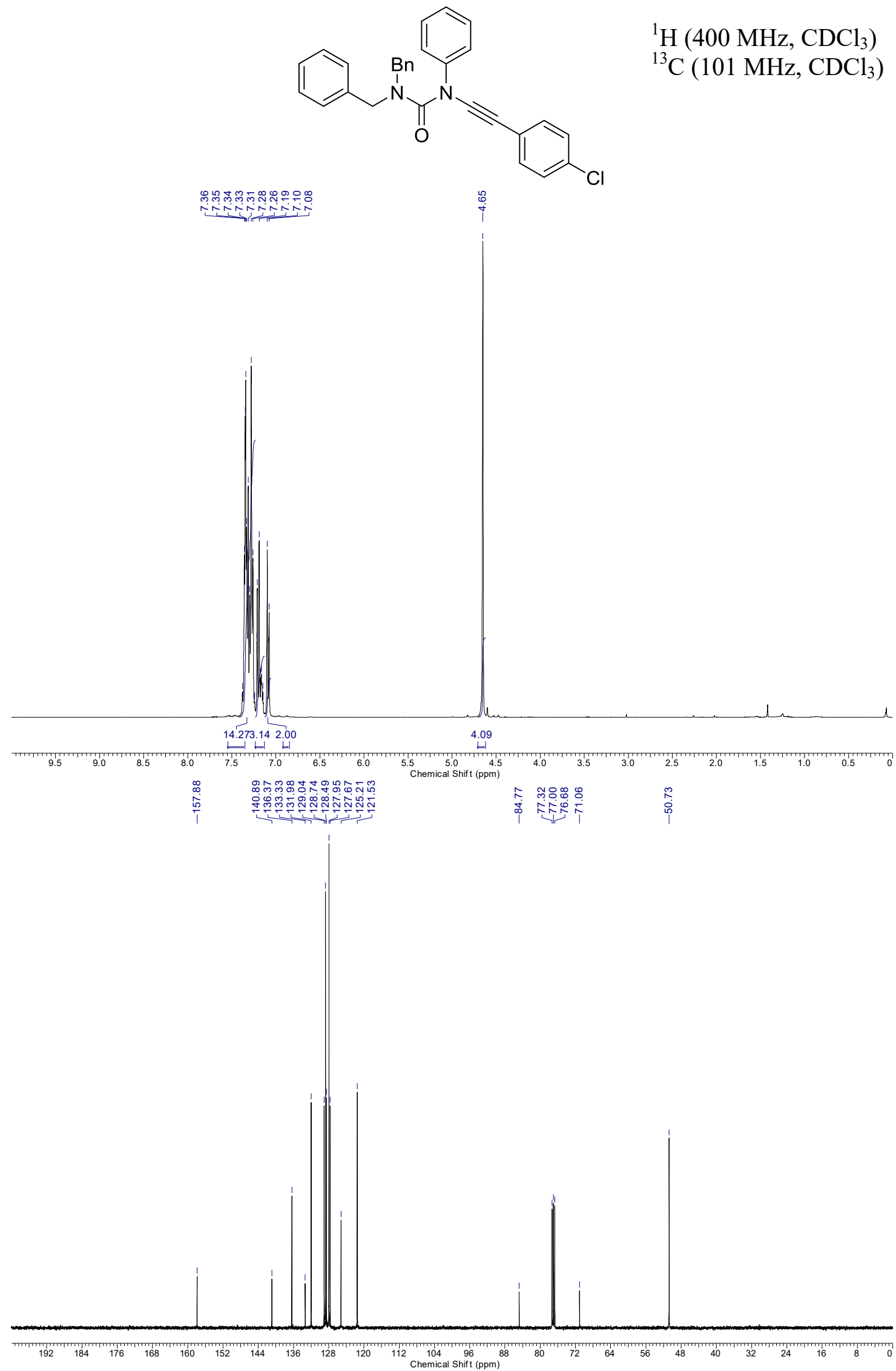


\section{1,1,3-Tribenzyl-3-((4-chlorophenyl)ethynyl)urea, 13m}

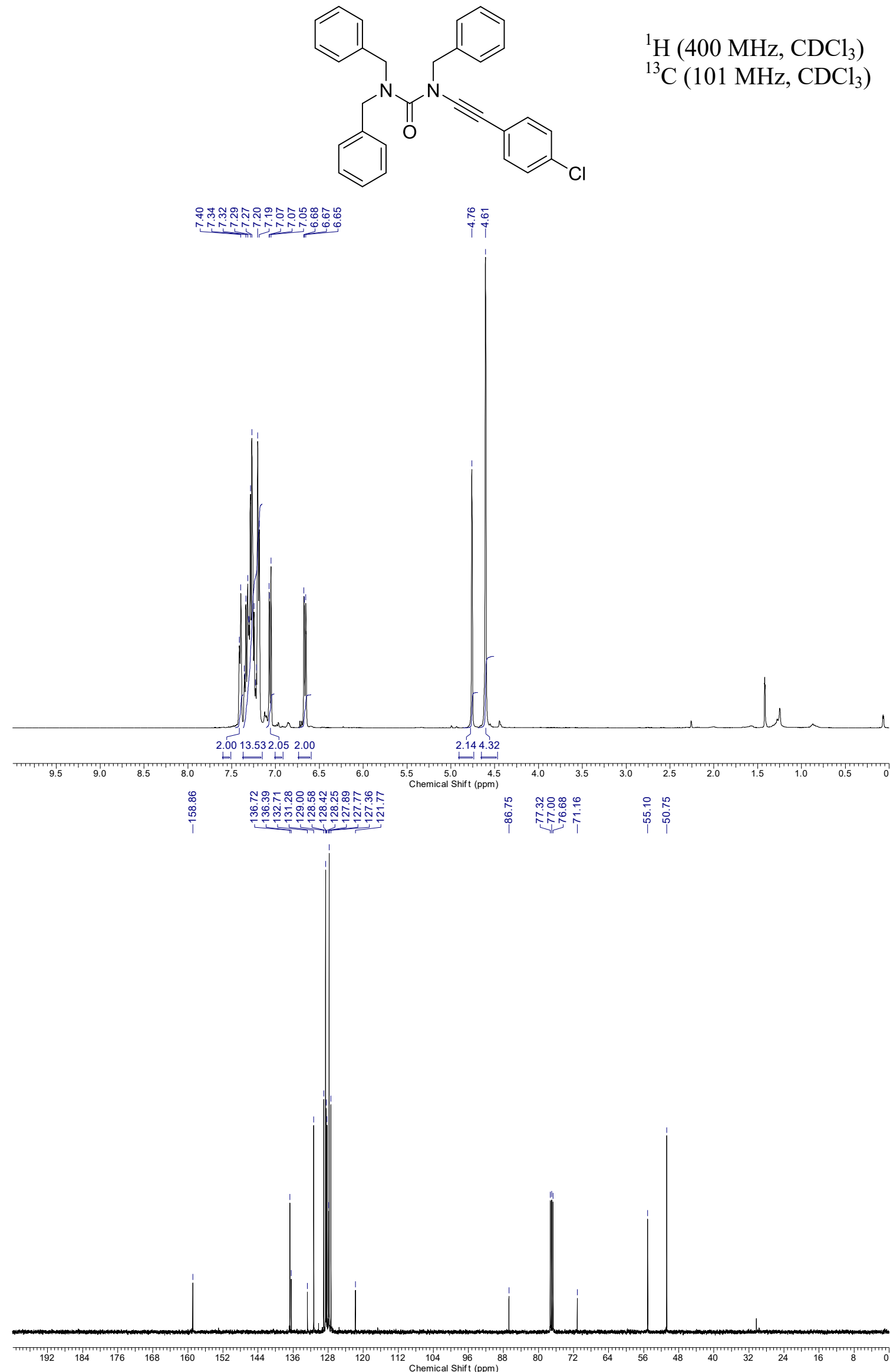




\section{4c Urea Scope: Miscellaneous}

(Z)-1,1-Dibenzyl-3-(2-chloro-1-(4-chlorophenyl)vinyl)-3-phenylurea, S7

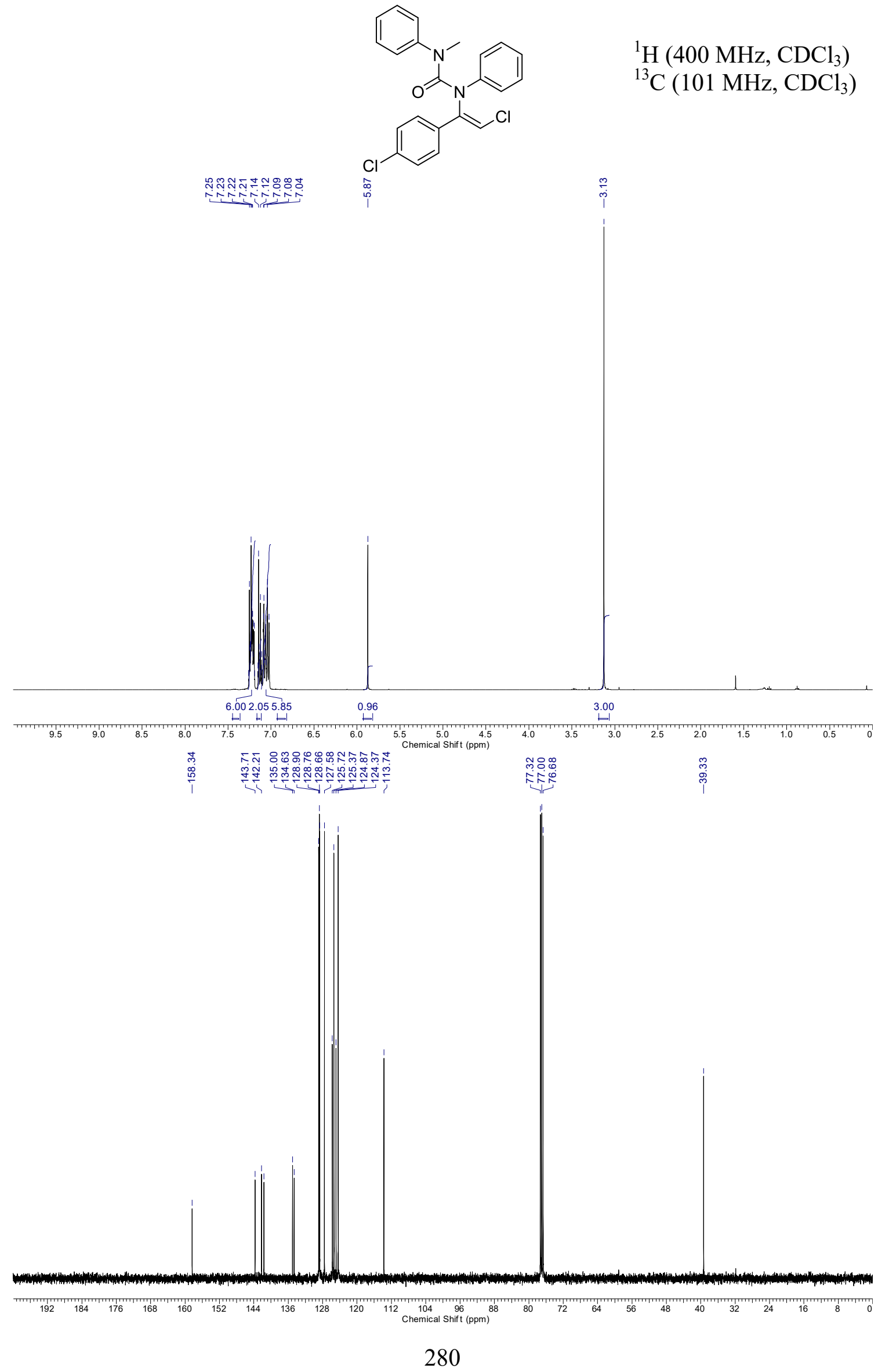


(E)-1,1'-(1,4-Bis(4-chlorophenyl)buta-1,2,3-triene-1,4-diyl)bis(3-methyl-1,3-diphenyl urea), $\mathrm{S8}$

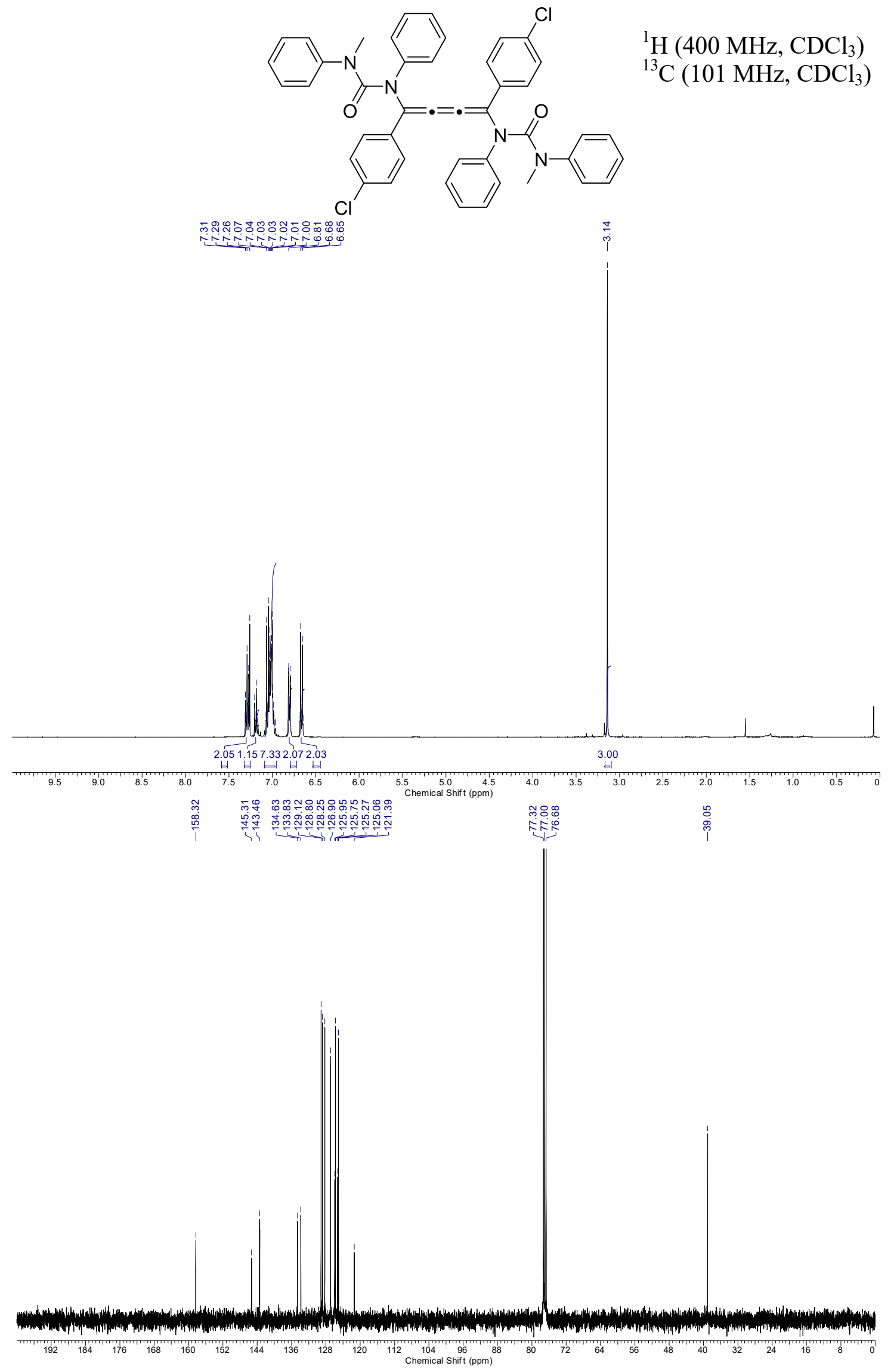




\section{5a Amide Scope: Dichloroenamides}

(E)- $N$-(1,2-Dichlorovinyl)- $N$-phenylbenzamide, 14a
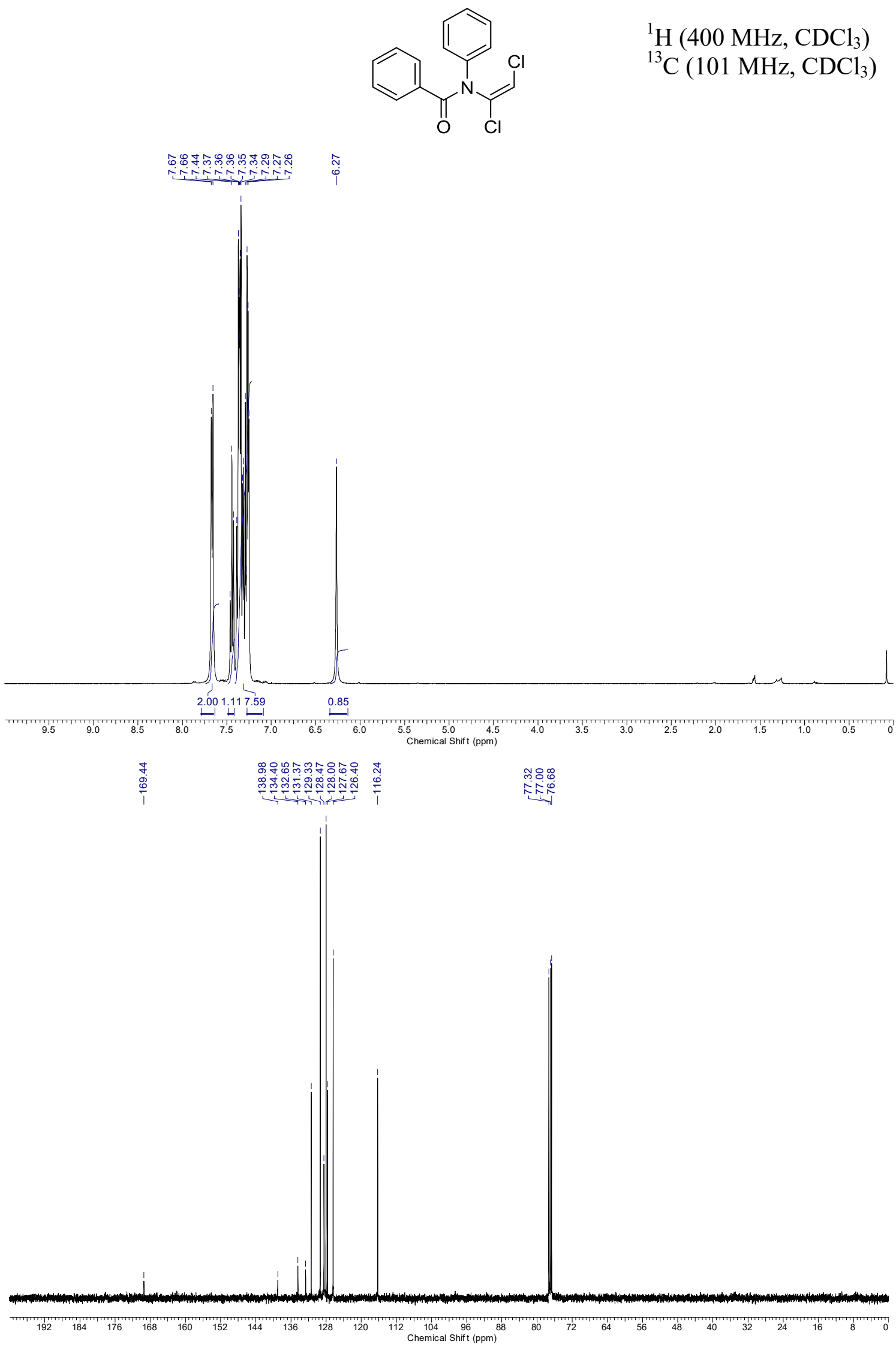
(E)-N-(1,2-Dichlorovinyl)-2,4,6-trimethyl- $N$-phenylbenzamide, 14b<smiles>Cc1cc(C)c(C(=O)N(/C(Cl)=C\Cl)c2ccccc2)c(C)c1</smiles>

${ }^{1} \mathrm{H}\left(400 \mathrm{MHz}, \mathrm{CDCl}_{3}\right)$

${ }^{13} \mathrm{C}\left(101 \mathrm{MHz}, \mathrm{CDCl}_{3}\right)$

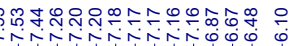

1000

ำกำ
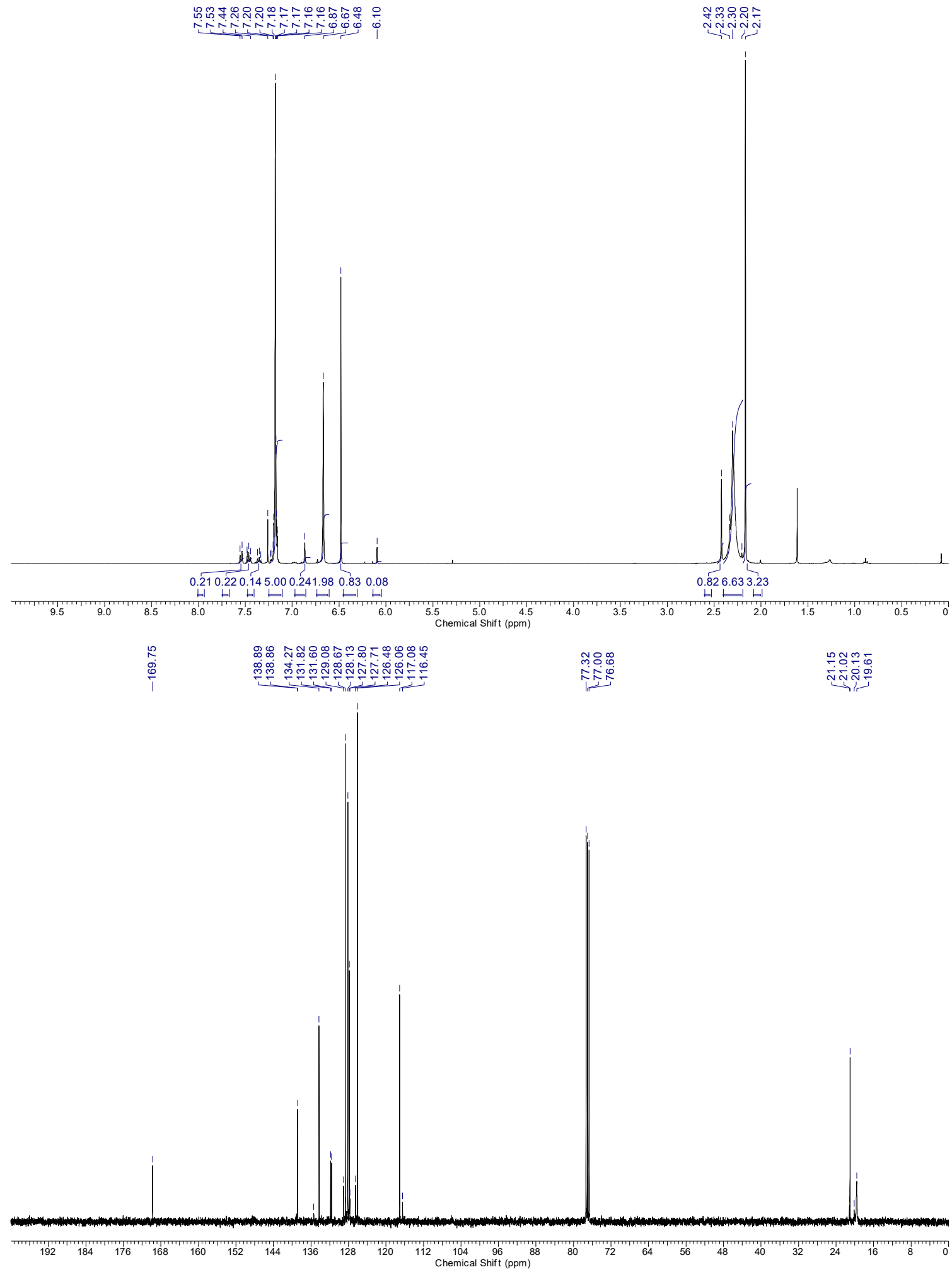
(E)-2,6-Dichloro- $N$-(1,2-dichlorovinyl)- $N$-phenylbenzamide, 14c<smiles>O=C(c1c(Cl)cccc1Cl)N(/C(Cl)=C\Cl)c1ccccc1</smiles>

${ }^{1} \mathrm{H}\left(400 \mathrm{MHz}, \mathrm{CDCl}_{3}\right)$

${ }^{13} \mathrm{C}\left(101 \mathrm{MHz}, \mathrm{CDCl}_{3}\right)$
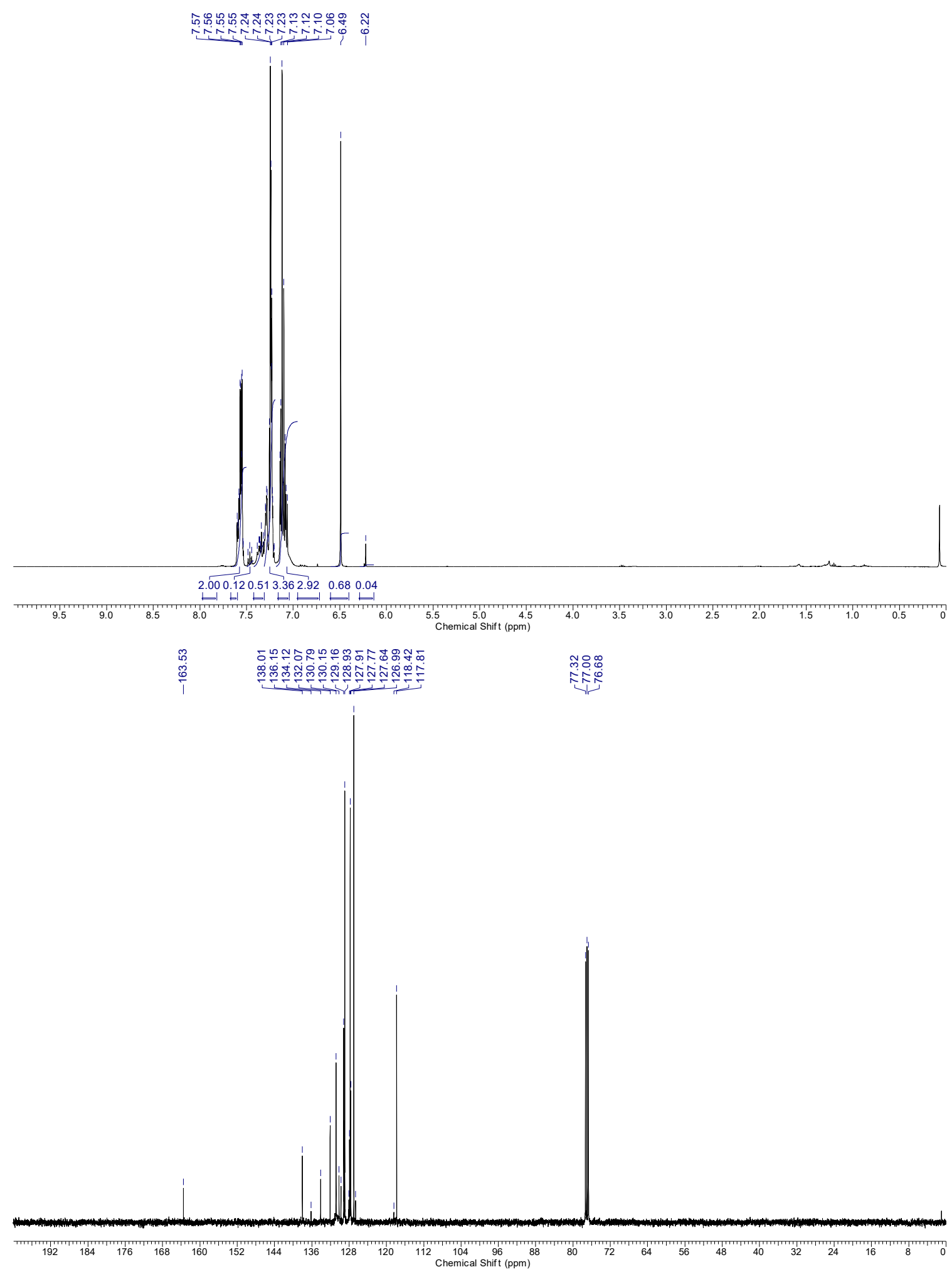
(E)-N-(1,2-Dichlorovinyl)- $N$-phenylpivalamide, 14d
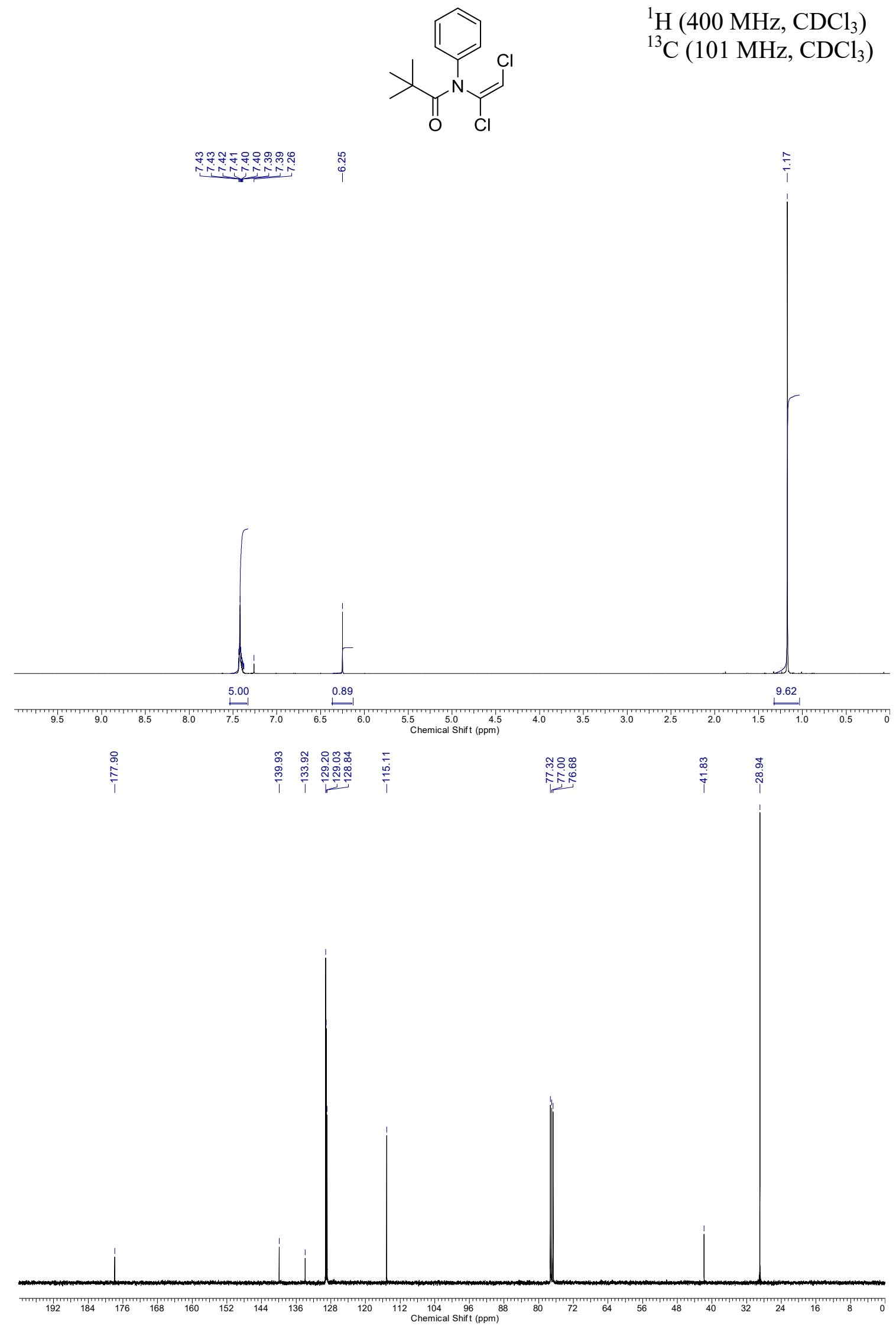
(E)- $N$-Benzyl- $N$-(1,2-dichlorovinyl)benzamide, $14 \mathrm{e}$

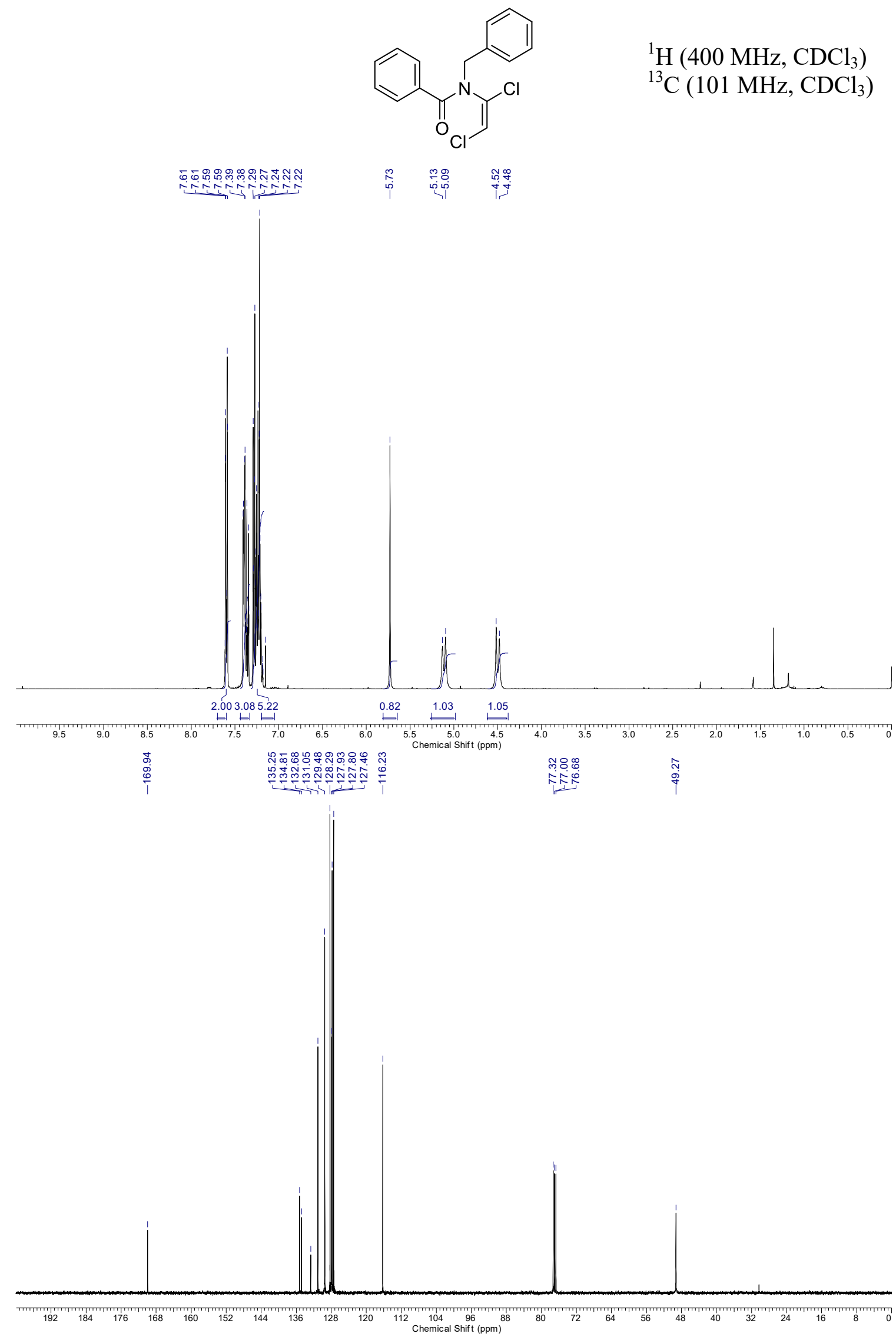


(E)- $N$-(1,2-Dichlorovinyl)-4-(dimethylamino)- $N$-phenylbenzamide, $14 f$<smiles>CN(C)c1ccc(C(=O)N(/C(Cl)=C\Cl)c2ccccc2)cc1</smiles>

${ }^{1} \mathrm{H}\left(400 \mathrm{MHz}, \mathrm{CDCl}_{3}\right)$

${ }^{13} \mathrm{C}\left(101 \mathrm{MHz}, \mathrm{CDCl}_{3}\right)$

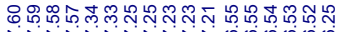

ritisinititiogogo
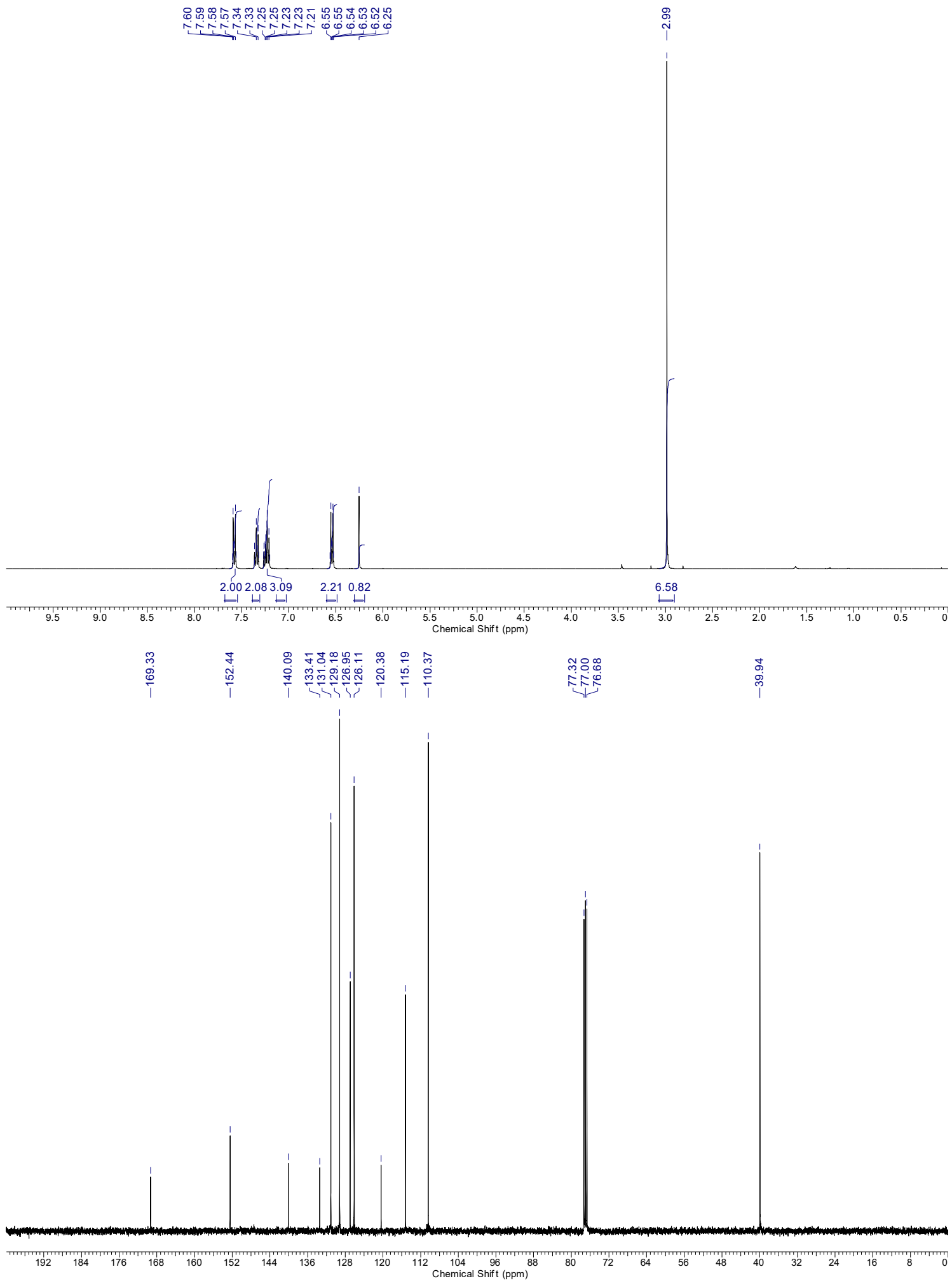
(E)- $N$-(1,2-Dichlorovinyl)- $N$-phenylfuran-2-carboxamide, 14g<smiles>O=C(c1ccco1)N(/C(Cl)=C\Cl)c1ccccc1</smiles>

${ }^{1} \mathrm{H}\left(400 \mathrm{MHz}, \mathrm{CDCl}_{3}\right)$

${ }^{13} \mathrm{C}\left(101 \mathrm{MHz}, \mathrm{CDCl}_{3}\right)$

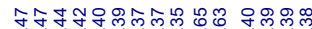

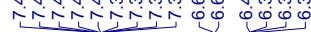
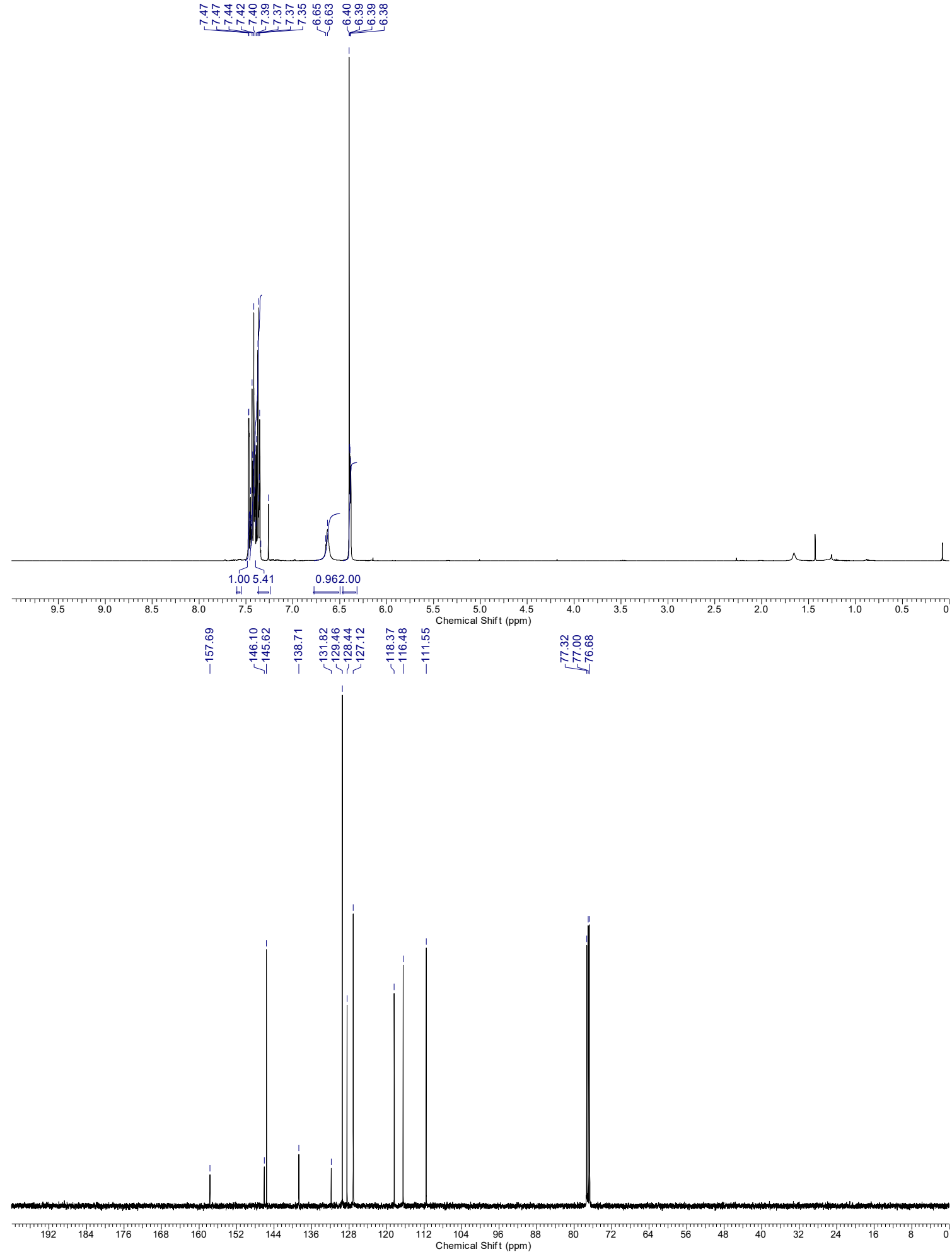
(E)-N-(1,2-Dichlorovinyl)- $N$-phenylacetamide, $14 \mathrm{~h}$

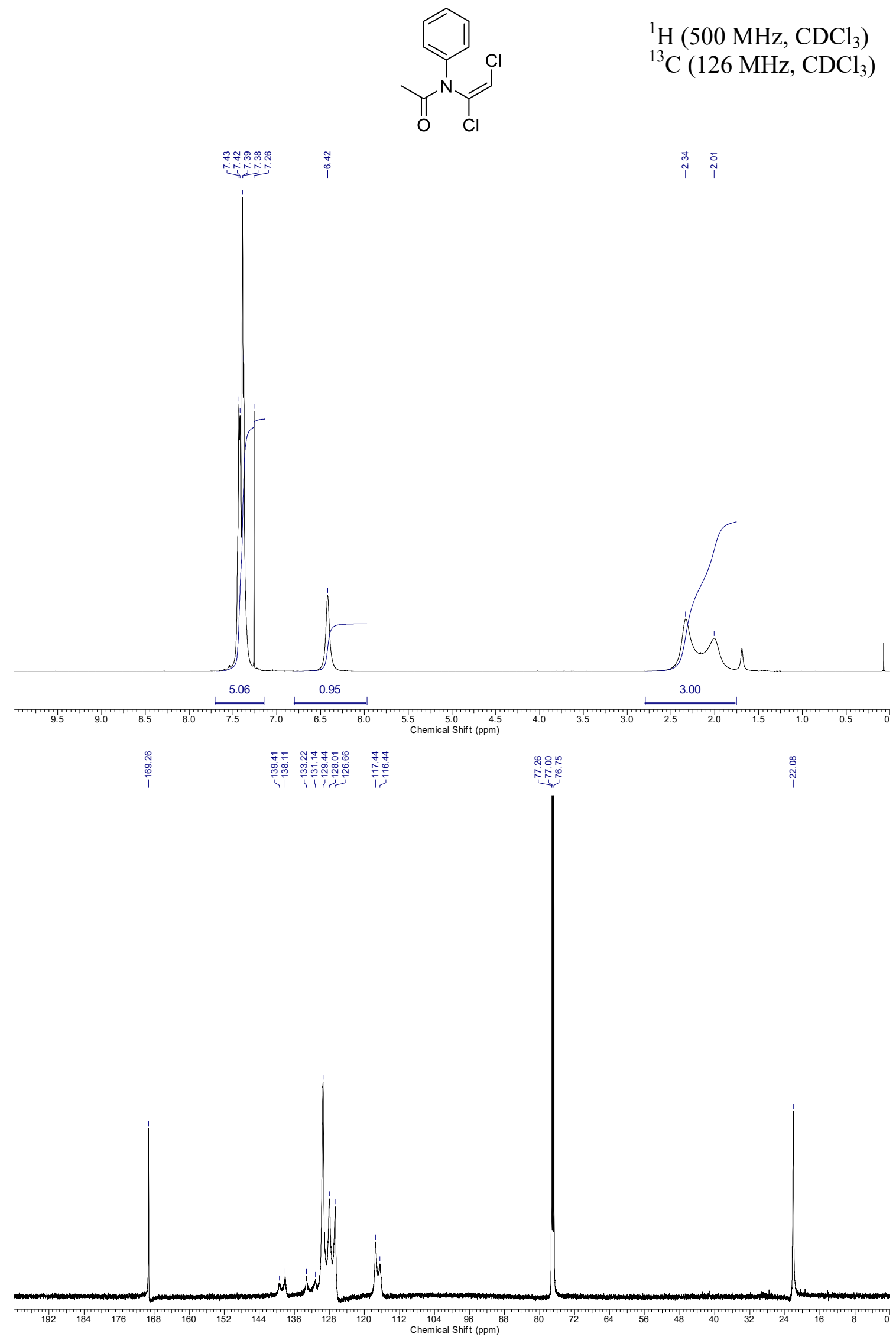


(E)-N-(1,2-Dichlorovinyl)- $N$-phenylpropionamide, 14i

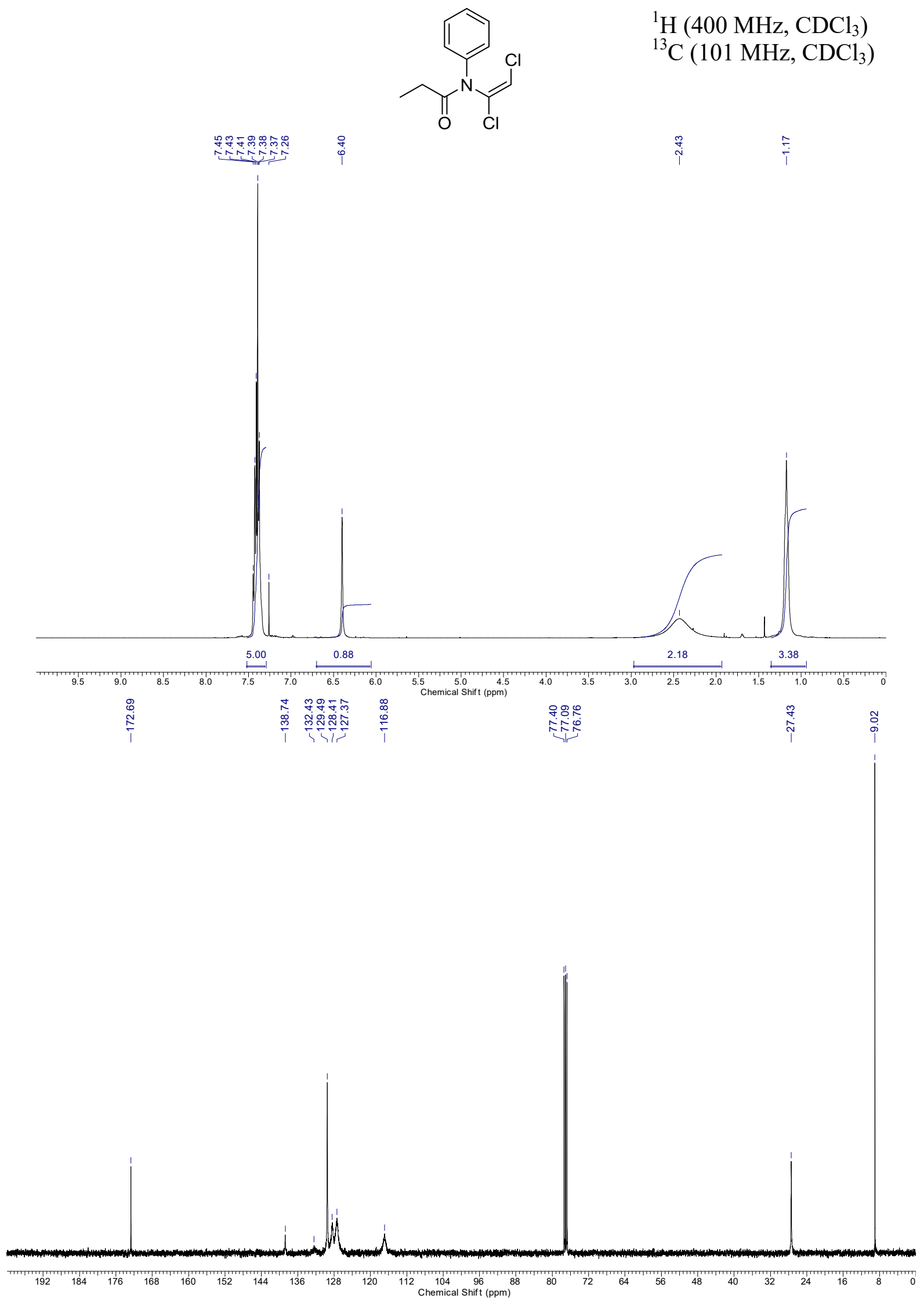


(E)- $N$-Benzyl- $N$-(1,2-dichlorovinyl)propionamide, $14 \mathbf{j}$
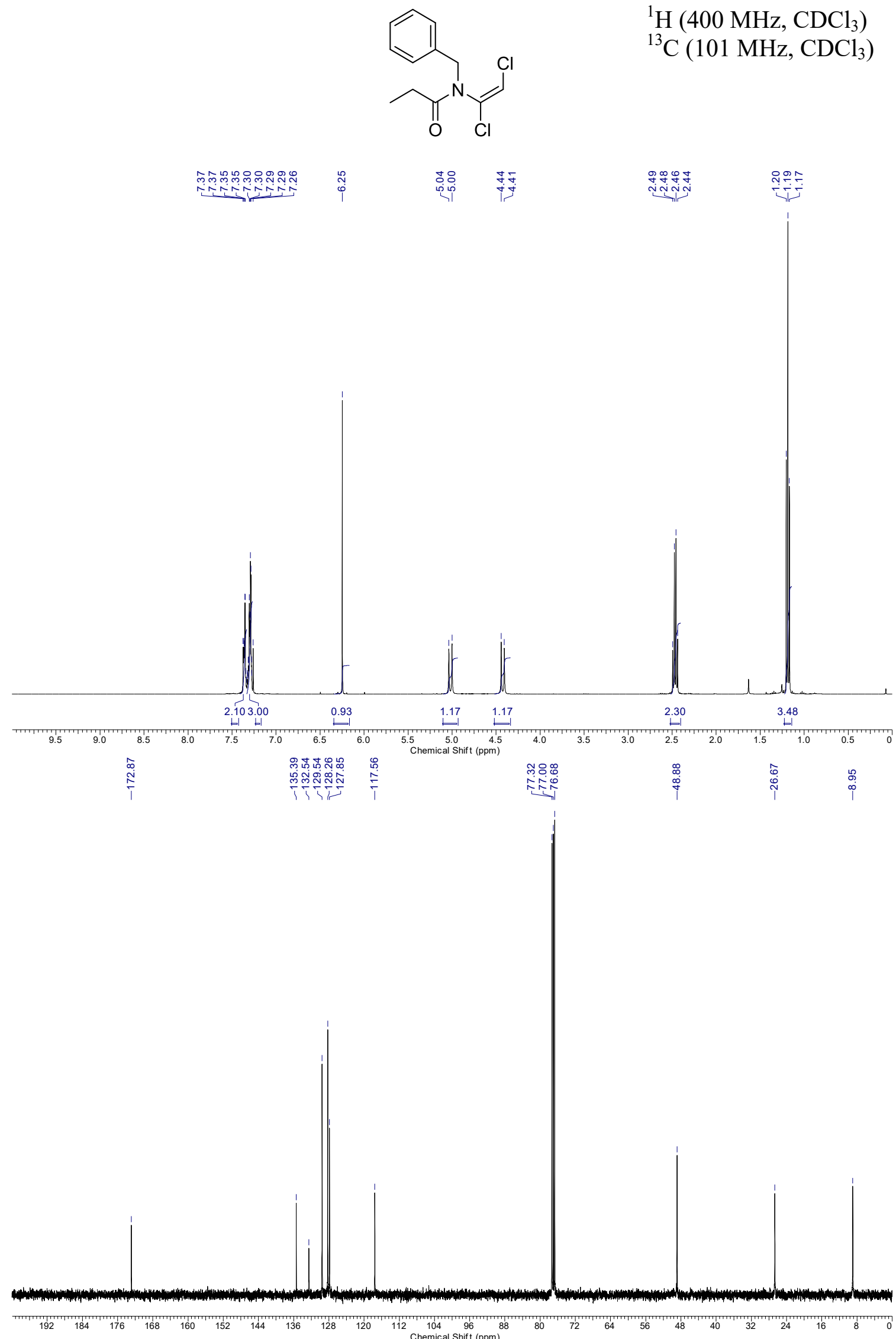
(E)-1-(1,2-Dichlorovinyl)pyrrolidin-2-one, 14k<smiles>O=C1CCCN1C(Cl)=CCl</smiles>

${ }^{1} \mathrm{H}\left(500 \mathrm{MHz}, \mathrm{CDCl}_{3}\right)$

${ }^{13} \mathrm{C}\left(126 \mathrm{MHz}, \mathrm{CDCl}_{3}\right)$
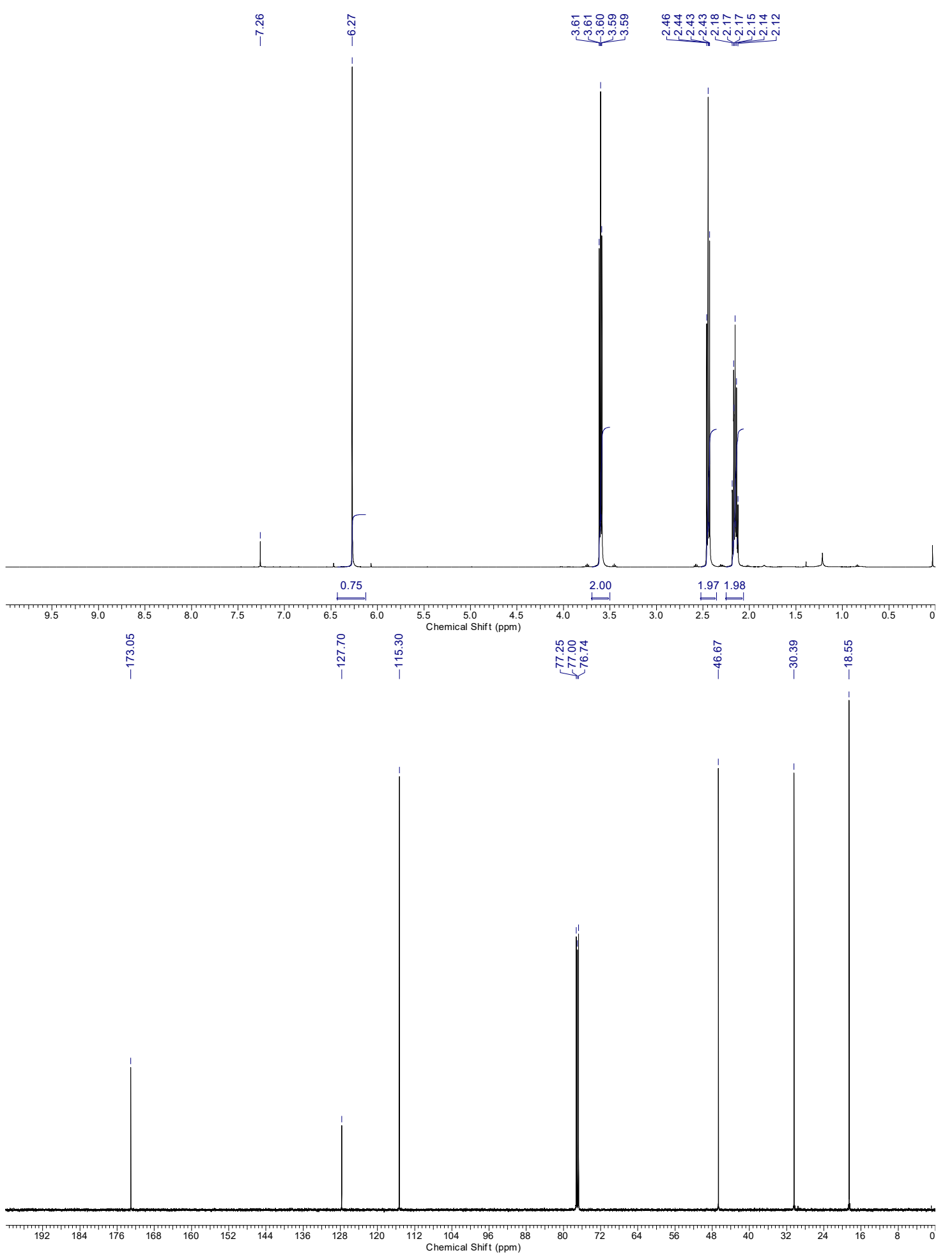


\section{5b Amide Scope: Ynamides}

$N$-((4-Chlorophenyl)ethynyl)-2,4,6-trimethyl- $N$-phenylbenzamide, 17b

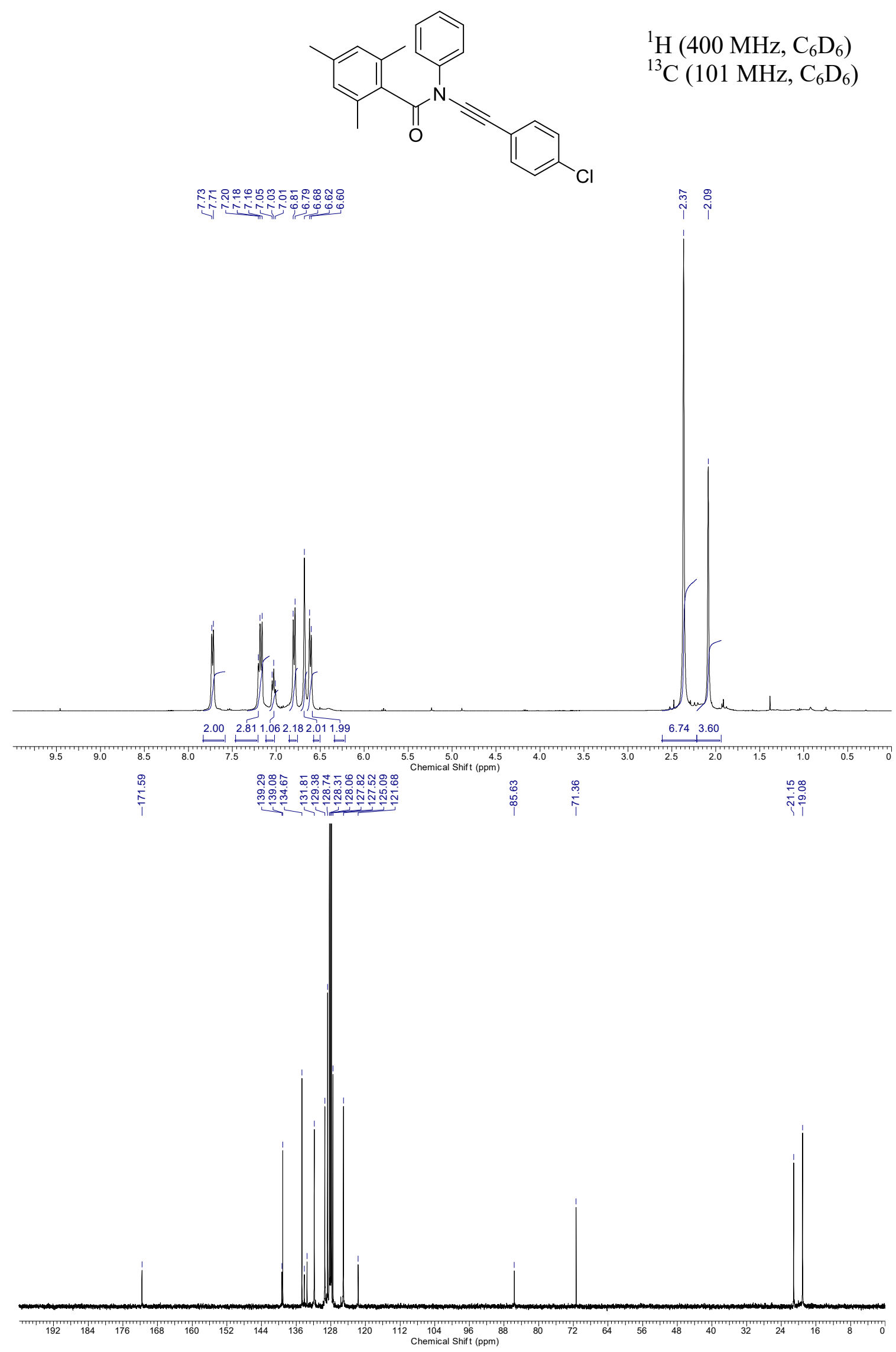


2,6-Dichloro- $N$-((4-chlorophenyl)ethynyl)- $N$-phenylbenzamide, $17 \mathrm{c}$

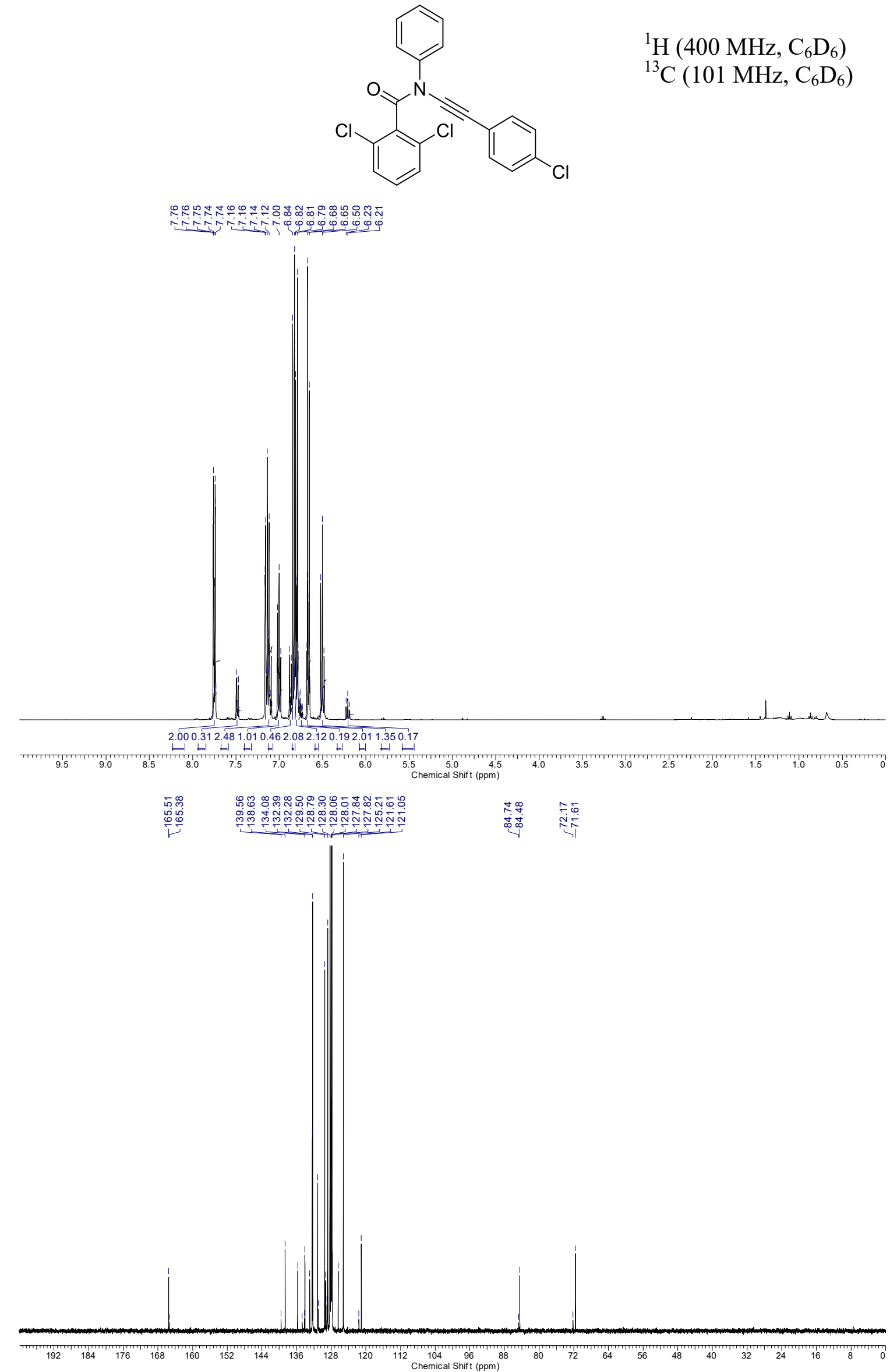


$N$-((4-Chlorophenyl)ethynyl)- $N$-phenylpivalamide, 17d
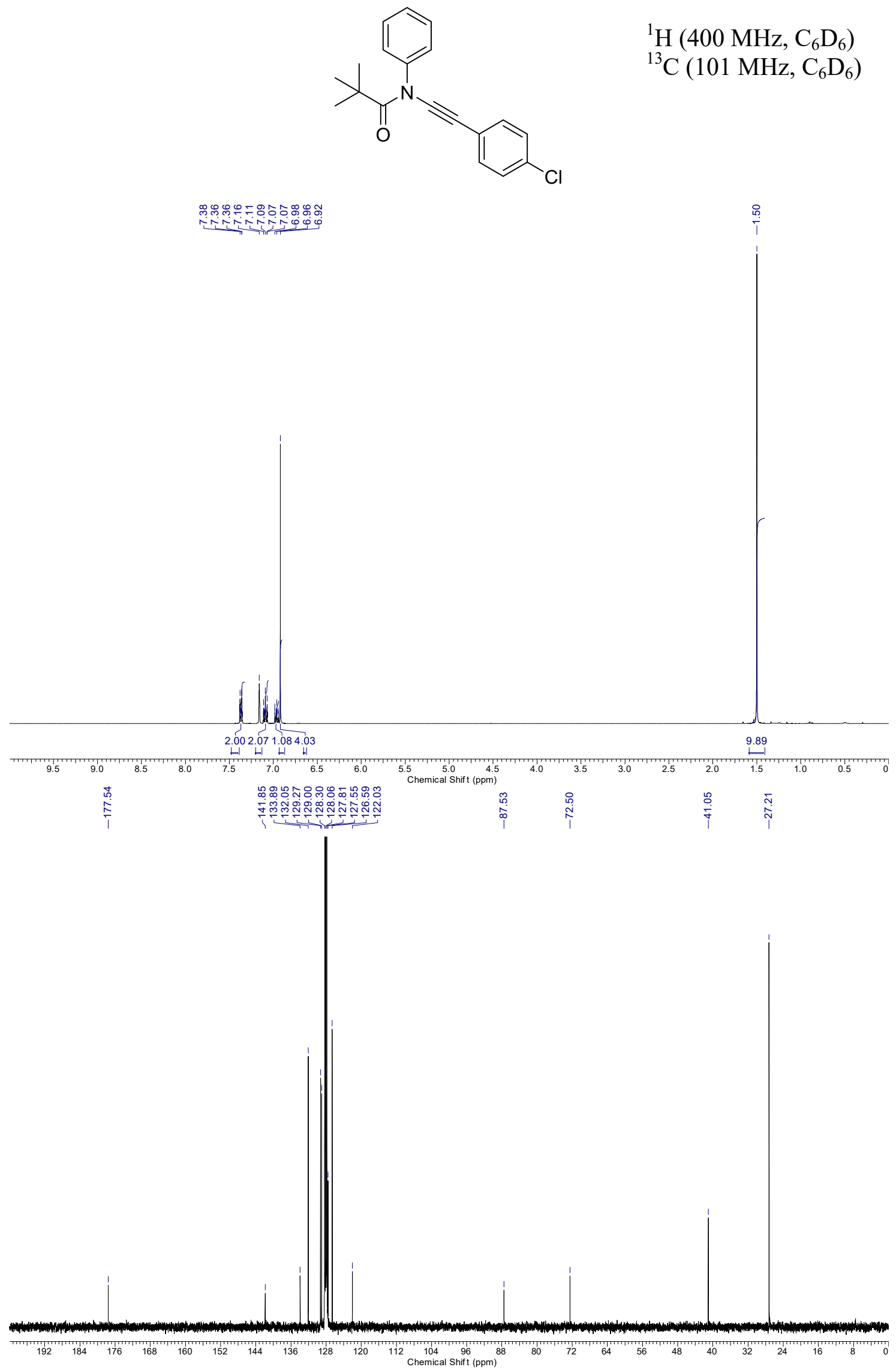
$N$-Benzyl- $N$-((4-chlorophenyl)ethynyl)benzamide, $17 \mathrm{e}$
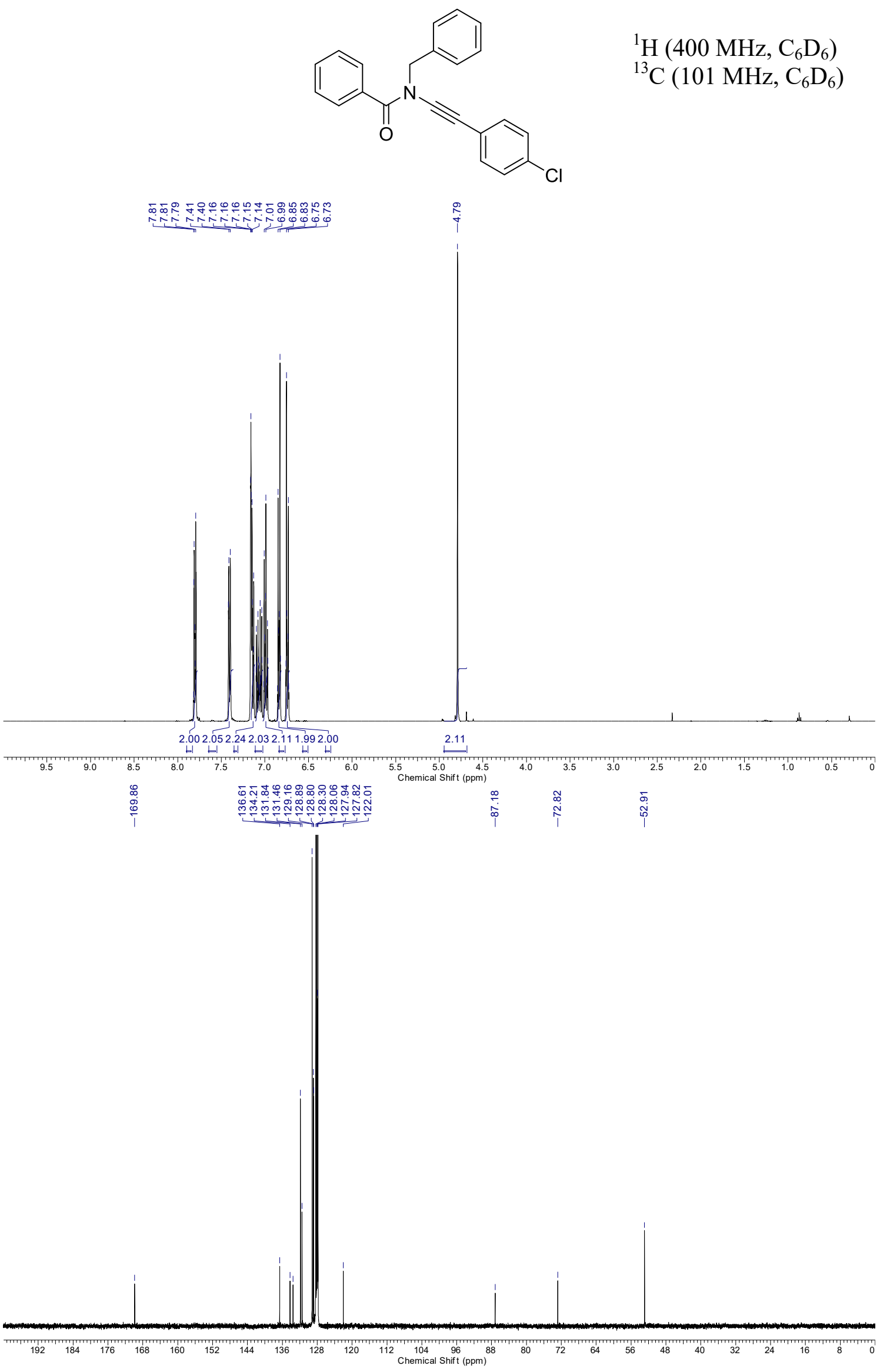


\section{5c Amide Scope: Miscellaneous}

$N$-Phenyl- $N$-((1E,3E)-1,2,4-trichloro-5-oxo-3-phenyl-5-(phenylamino)penta-1,3-dien-1yl)benzamide, 16

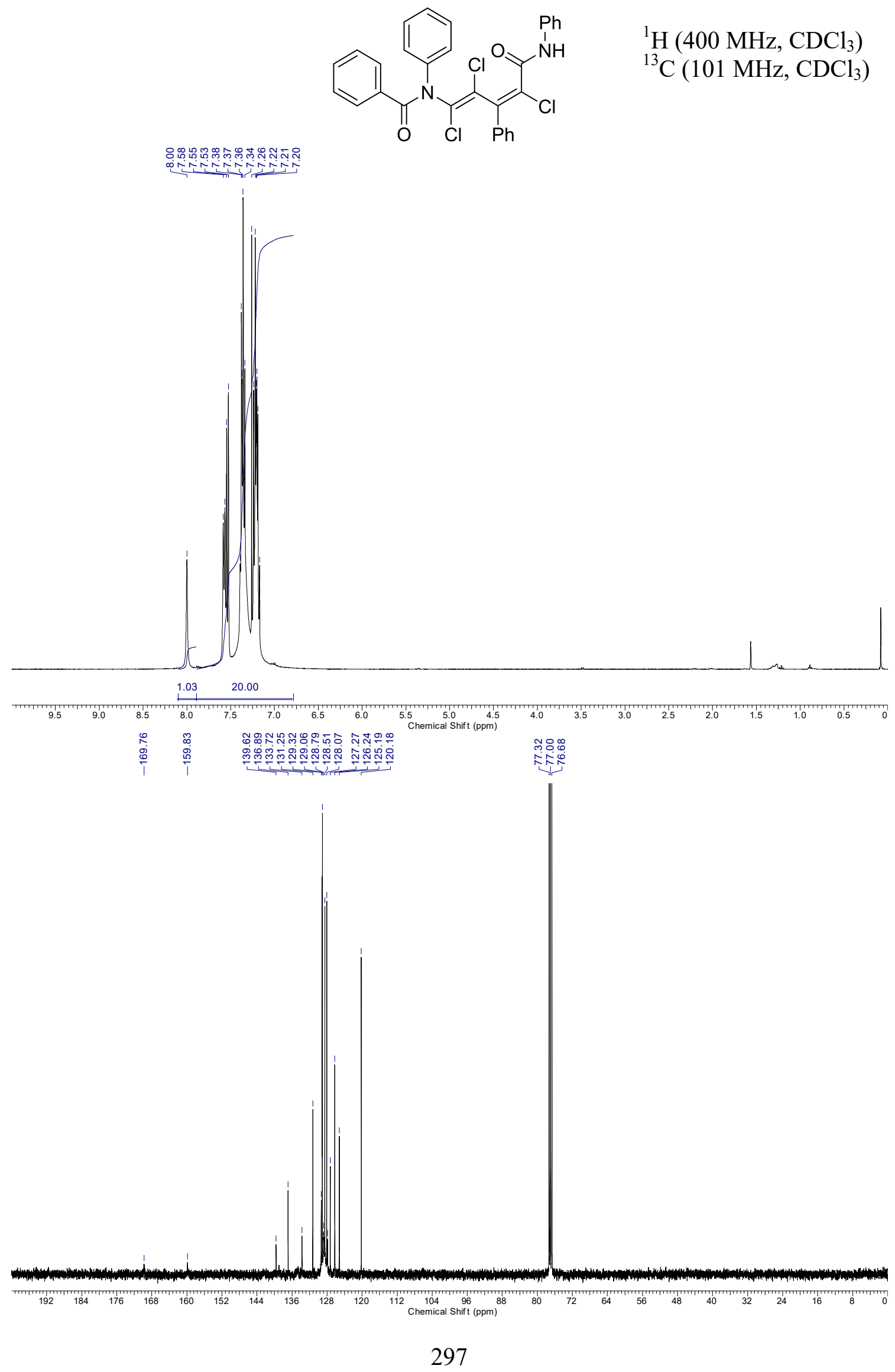


$N$-(2-(4-Chlorophenyl)-2-oxoethyl)- $N$-phenylbenzamide, 18 a
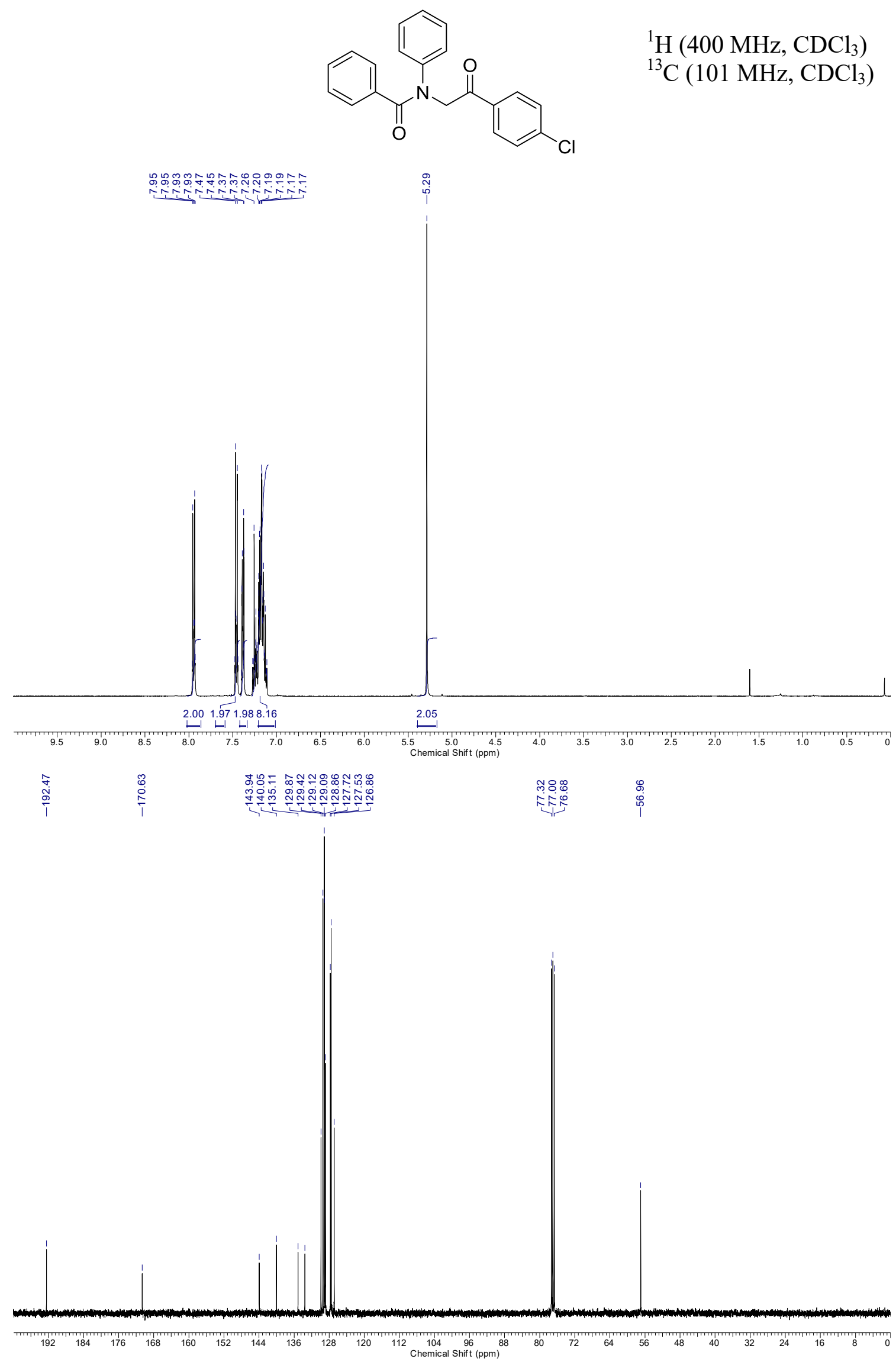
$N$-(2-(4-Chlorophenyl)-2-oxoethyl)-4-(dimethylamino)- $N$-phenylbenzamide, $18 f$

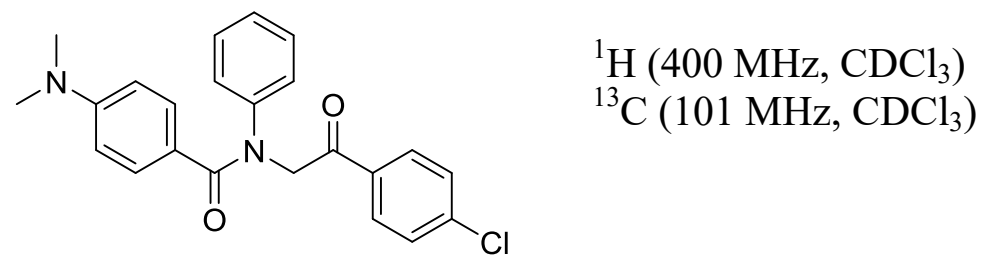

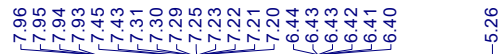
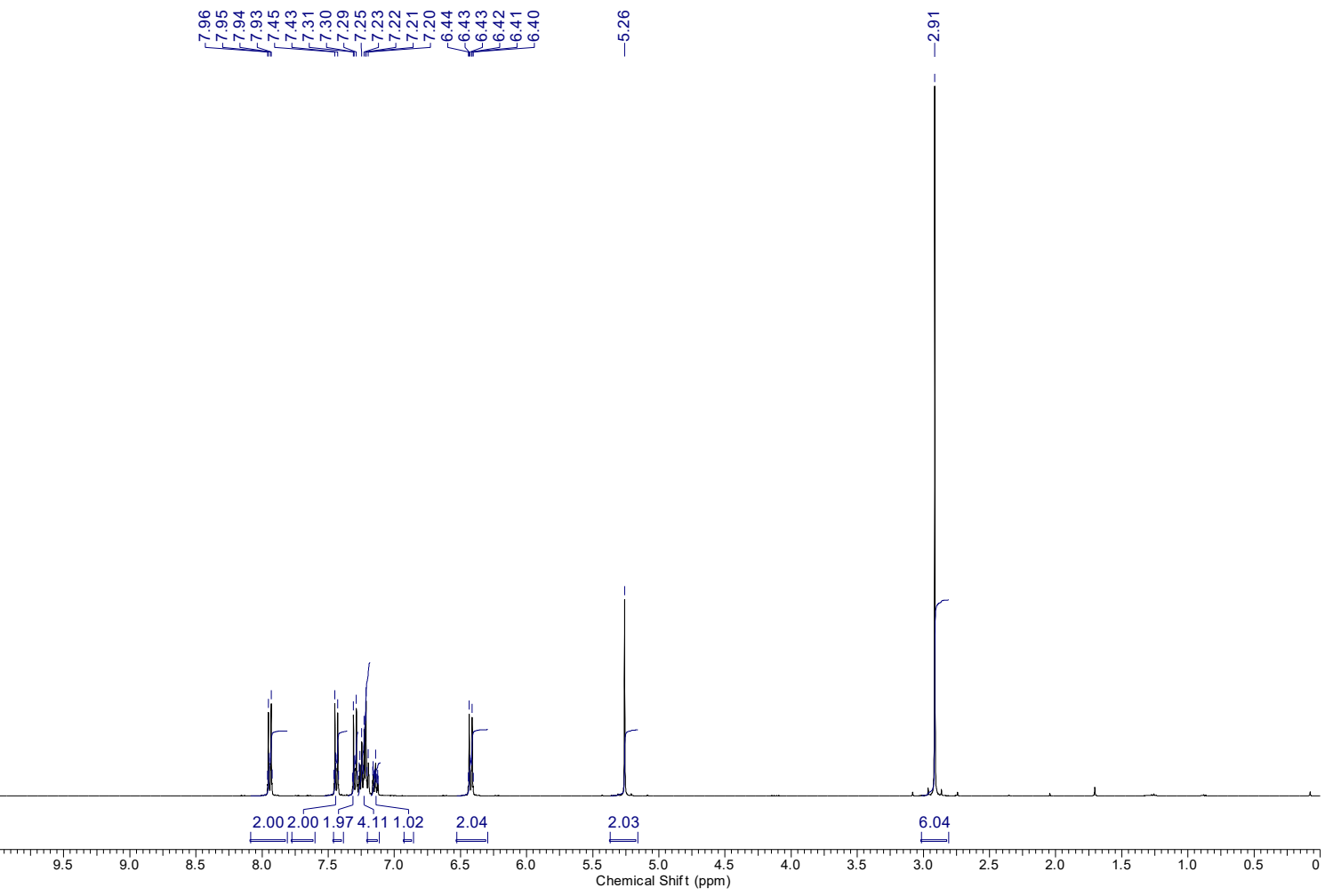

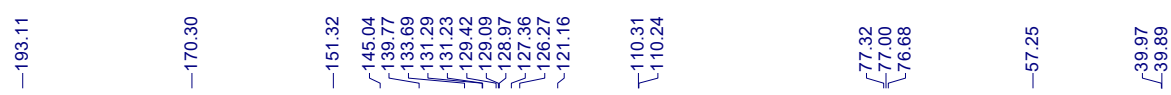

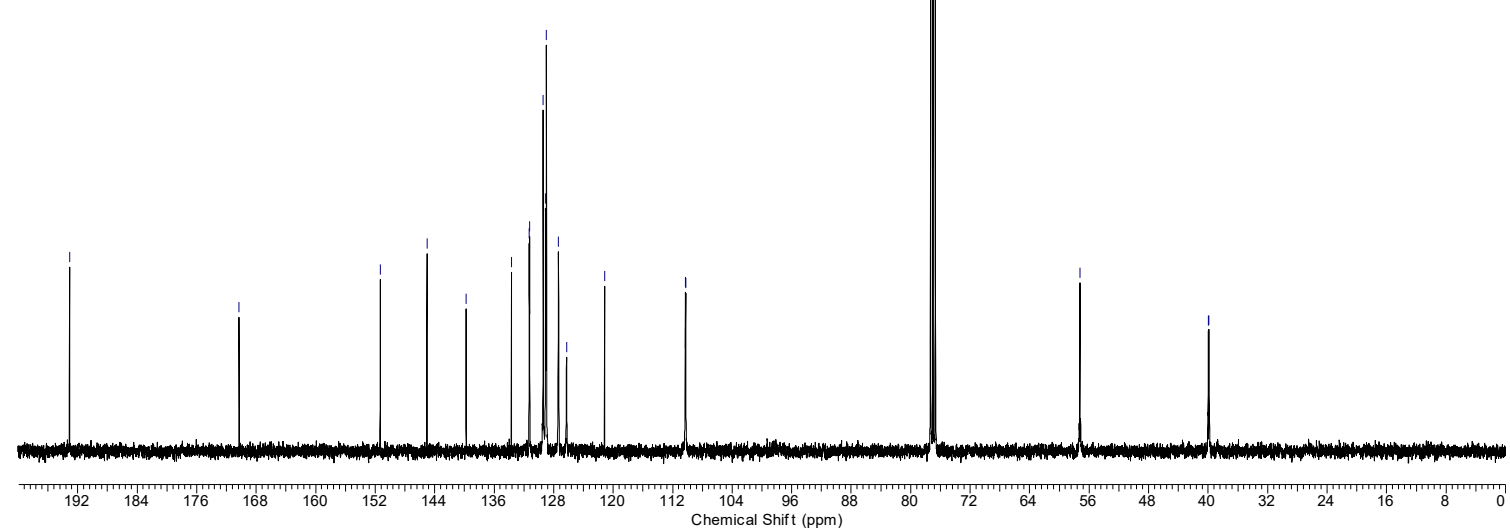




\section{$5 \quad$ X-ray Crystallography}

Low temperature single crystal X-ray diffraction data were collected for 4, 5, 6, 8, S1a, S1b, S1c, S2a $(E)$-11, 12, S5, $(E)-\mathbf{S 8}, \mathbf{1 6}, \mathbf{1 8 a}$ and 18f with a (Rigaku) Oxford Diffraction SuperNova A diffractometer at $150 \mathrm{~K}$. All data were reduced using CrysAlisPro, solved using SuperFlip ${ }^{[1]}$ and the structures were refined using CRYSTALS. ${ }^{[2]}$

The Flack x parameter ${ }^{[3]}$ was refined for S5. Bayesian analysis of the Bijvoet pairs was also carried out using all the data used in the refinement. ${ }^{[4]}$ The Flack parameter (-0.4(3)) and Hooft parameter $(-0.3(2))$ do not refine to sensible values, however this compound is achiral and the absolute configuration was irrelevant for this study. The data was obtained to confirm the atom connectivity and is thus suitable for this purpose.

Further details about the refinements, including disorder modelling and restraints, are documented in the CIF. The crystallographic data have been deposited with the CCDC as entries CCDC 18950571895071.

[1] L. Palatinus \& G. Chapuis, J. Appl. Cryst., 2007, 40, 786-790.

[2] a) P. W. Betteridge, J. R. Carruthers, R. I. Cooper, K. Prout, \& D. J. Watkin, J. Appl. Cryst., 2003, 36, 1487;

b) R. I. Cooper, A. L. Thompson \& D. J. Watkin, J. Appl. Cryst. 2010, 43, 1100-1107.

[3]. H. D. Flack, Acta Crystallogr. A 1983, 39, 876-881; H. D. Flack, G. Bernardinelli, J. Appl. Crystallogr. 2000, 33, 1143-1148.

[4] R. W. W. Hooft, L. H. Straver, A. L. Spek, J. Appl. Crystallogr. 2008, 41, 96-103. 
Table S1 Crystal data and structure refinement for 4 .

CCDC Identification code

Empirical formula

Formula weight

Temperature

Wavelength

Crystal system

Space group

Unit cell dimensions

Volume

Z

Density (calculated)

Absorption coefficient

$\mathrm{F}(000)$

Crystal size

Theta range for data collection

Index ranges

Reflections collected

Independent reflections

Completeness to theta $=74.601^{\circ}$

Absorption correction

Max. and min. transmission

Refinement method

Data / restraints / parameters

Goodness-of-fit on $\mathrm{F}^{2}$

Final $\mathrm{R}$ indices $[\mathrm{I}>2 \operatorname{sigma}(\mathrm{I})]$

$\mathrm{R}$ indices (all data)

Largest diff. peak and hole
1895057

C21 H18 Cl1 N1 O2 S1

383.90

$150 \mathrm{~K}$

$1.54184 \AA$

Monoclinic

P $21 / \mathrm{n}$

$\mathrm{a}=10.04000(10) \AA \quad \alpha=90^{\circ}$.

$\mathrm{b}=11.31380(10) \AA \quad \beta=102.4137(14)^{\circ}$.

$\mathrm{c}=16.9256(2) \AA \quad \gamma=90^{\circ}$.

1877.64(3) $\AA^{3}$

4

$1.358 \mathrm{Mg} / \mathrm{m}^{3}$

$2.959 \mathrm{~mm}^{-1}$

800

$0.32 \times 0.32 \times 0.30 \mathrm{~mm}^{3}$

4.723 to $76.124^{\circ}$.

$-12<=\mathrm{h}<=12,-14<=\mathrm{k}<=12,-21<=\mathrm{l}<=20$

17368

$3905[\mathrm{R}($ int $)=0.0256]$

$99.7 \%$

Semi-empirical from equivalents

0.41 and 0.30

Full-matrix least-squares on $\mathrm{F}^{2}$

3903 / 0 / 235

0.9981

$\mathrm{R} 1=0.0375, \mathrm{wR} 2=0.1000$

$\mathrm{R} 1=0.0380, \mathrm{wR} 2=0.1006$

0.30 and -0.48 e. $\AA^{-3}$ 
Table S2 Crystal data and structure refinement for $\mathbf{5}$.

CCDC Identification code

Empirical formula

Formula weight

Temperature

Wavelength

Crystal system

Space group

Unit cell dimensions

Volume

Z

Density (calculated)

Absorption coefficient

$\mathrm{F}(000)$

Crystal size

Theta range for data collection

Index ranges

Reflections collected

Independent reflections

Completeness to theta $=73.937^{\circ}$

Absorption correction

Max. and min. transmission

Refinement method

Data / restraints / parameters

Goodness-of-fit on $\mathrm{F}^{2}$

Final $\mathrm{R}$ indices $[\mathrm{I}>2 \operatorname{sigma}(\mathrm{I})]$

$\mathrm{R}$ indices (all data)

Largest diff. peak and hole
1895058

C27 H23 N1 O2 S1

425.55

$150 \mathrm{~K}$

$1.54184 \AA$

Monoclinic

P 21/c

$\mathrm{a}=20.8083(5) \AA \quad \alpha=90^{\circ}$.

$\mathrm{b}=6.39940(10) \AA \quad \beta=99.273(2)^{\circ}$.

$\mathrm{c}=16.7452(3) \AA \quad \gamma=90^{\circ}$.

$2200.66(8) \AA^{3}$

$1.284 \mathrm{Mg} / \mathrm{m}^{3}$

$1.489 \mathrm{~mm}^{-1}$

896

$0.54 \times 0.06 \times 0.02 \mathrm{~mm}^{3}$

5.353 to $76.224^{\circ}$.

$-26<=\mathrm{h}<=26,-7<=\mathrm{k}<=7,-17<=\mathrm{l}<=20$

17636

$4535[\mathrm{R}($ int $)=0.0461]$

$99.7 \%$

Semi-empirical from equivalents

0.97 and 0.50

Full-matrix least-squares on $\mathrm{F}^{2}$

4535 / 0 / 280

1.0073

$\mathrm{R} 1=0.0463, \mathrm{wR} 2=0.1191$

$\mathrm{R} 1=0.0539, \mathrm{wR} 2=0.1294$

0.39 and -0.42 e. $\AA^{-3}$ 
Table S3 Crystal data and structure refinement for 6.

CCDC Identification code

Empirical formula

Formula weight

Temperature

Wavelength

Crystal system

Space group

Unit cell dimensions

Volume

Z

Density (calculated)

Absorption coefficient

$\mathrm{F}(000)$

Crystal size

Theta range for data collection

Index ranges

Reflections collected

Independent reflections

Completeness to theta $=73.792^{\circ}$

Absorption correction

Max. and min. transmission

Refinement method

Data / restraints / parameters

Goodness-of-fit on $\mathrm{F}^{2}$

Final $\mathrm{R}$ indices $[\mathrm{I}>2 \operatorname{sigma}(\mathrm{I})]$

$\mathrm{R}$ indices (all data)

Largest diff. peak and hole
1895059

C28 H20 N2

384.48

$150 \mathrm{~K}$

$1.54180 \AA$

Orthorhombic

$\mathrm{P} \mathrm{b} \mathrm{c} \mathrm{a}$

$\begin{array}{ll}\mathrm{a}=8.2568(3) \AA & \alpha=90^{\circ} . \\ \mathrm{b}=10.2424(3) \AA & \beta=90^{\circ} . \\ \mathrm{c}=23.9309(8) \AA & \gamma=90^{\circ} .\end{array}$

2023.82(12) $\AA^{3}$

4

$1.262 \mathrm{Mg} / \mathrm{m}^{3}$

$0.568 \mathrm{~mm}^{-1}$

808

$0.36 \times 0.19 \times 0.12 \mathrm{~mm}^{3}$

6.513 to $76.074^{\circ}$.

$-10<=\mathrm{h}<=9,-8<=\mathrm{k}<=12,-29<=\mathrm{l}<=28$

6246

$2096[\mathrm{R}(\mathrm{int})=0.0211]$

$99.8 \%$

Semi-empirical from equivalents

0.93 and 0.86

Full-matrix least-squares on $\mathrm{F}^{2}$

2096 / 0 / 136

0.9938

$\mathrm{R} 1=0.0361, \mathrm{wR} 2=0.0957$

$\mathrm{R} 1=0.0418, \mathrm{wR} 2=0.1020$

0.22 and -0.21 e. $\AA^{-3}$ 
Table S4 Crystal data and structure refinement for 8 .

CCDC Identification code

Empirical formula

Formula weight

Temperature

Wavelength

Crystal system

Space group

Unit cell dimensions

Volume

Z

Density (calculated)

Absorption coefficient

$\mathrm{F}(000)$

Crystal size

Theta range for data collection

Index ranges

Reflections collected

Independent reflections

Completeness to theta $=74.056^{\circ}$

Absorption correction

Max. and min. transmission

Refinement method

Data / restraints / parameters

Goodness-of-fit on $\mathrm{F}^{2}$

Final $\mathrm{R}$ indices $[\mathrm{I}>2 \operatorname{sigma}(\mathrm{I})]$

$\mathrm{R}$ indices (all data)

Largest diff. peak and hole
1895060

C28 H22 F1 N3 O4 S1

515.56

$150 \mathrm{~K}$

$1.54184 \AA$

Monoclinic

P 21/n

$a=5.98810(10) \AA \quad \alpha=90^{\circ}$.

$\mathrm{b}=18.8011(4) \AA$

$\beta=96.7117(18)^{\circ}$.

$\mathrm{c}=21.7936(5) \AA$

$\gamma=90^{\circ}$.

2436.77(9) $\AA^{3}$

$1.405 \mathrm{Mg} / \mathrm{m}^{3}$

$1.598 \mathrm{~mm}^{-1}$

1072.000

$0.55 \times 0.09 \times 0.06 \mathrm{~mm}^{3}$

4.085 to $76.347^{\circ}$.

$-7<=\mathrm{h}<=6,-23<=\mathrm{k}<=13,-22<=\mathrm{l}<=27$

16144

$5052[\mathrm{R}($ int $)=0.0394]$

$99.7 \%$

Semi-empirical from equivalents

0.91 and 0.57

Full-matrix least-squares on $\mathrm{F}^{2}$

$5051 / 702 / 515$

1.0026

$\mathrm{R} 1=0.0530, \mathrm{wR} 2=0.1397$

$\mathrm{R} 1=0.0606, \mathrm{wR} 2=0.1488$

0.67 and -0.56 e. $\AA^{-3}$ 
Table S5 Crystal data and structure refinement for S1a.

CCDC Identification code

Empirical formula

Formula weight

Temperature

Wavelength

Crystal system

Space group

Unit cell dimensions

Volume

Z

Density (calculated)

Absorption coefficient

$\mathrm{F}(000)$

Crystal size

Theta range for data collection

Index ranges

Reflections collected

Independent reflections

Completeness to theta $=71.484^{\circ}$

Absorption correction

Max. and min. transmission

Refinement method

Data / restraints / parameters

Goodness-of-fit on $\mathrm{F}^{2}$

Final $\mathrm{R}$ indices $[\mathrm{I}>2 \operatorname{sigma}(\mathrm{I})]$

$\mathrm{R}$ indices (all data)

Largest diff. peak and hole
1895061

C20 H20 Cl1 N1 O2 S1

373.90

$150 \mathrm{~K}$

$1.54184 \AA$

Orthorhombic

$\mathrm{P} \mathrm{b} \mathrm{c} \mathrm{a}$

$\begin{array}{ll}\mathrm{a}=14.6482(4) \AA & \alpha=90^{\circ} . \\ \mathrm{b}=13.6946(3) \AA & \beta=90^{\circ} . \\ \mathrm{c}=18.6165(4) \AA & \gamma=90^{\circ} .\end{array}$

$3734.49(15) \AA^{3}$

8

$1.330 \mathrm{Mg} / \mathrm{m}^{3}$

$2.957 \mathrm{~mm}^{-1}$

1568

$0.29 \times 0.11 \times 0.04 \mathrm{~mm}^{3}$

4.751 to $76.046^{\circ}$.

$-18<=\mathrm{h}<=17,-17<=\mathrm{k}<=11,-17<=\mathrm{l}<=23$

16349

$3853[\mathrm{R}(\mathrm{int})=0.0390]$

$99.5 \%$

Semi-empirical from equivalents

0.89 and 0.64

Full-matrix least-squares on $\mathrm{F}^{2}$

$3851 / 0 / 226$

1.0033

$\mathrm{R} 1=0.0400, \mathrm{wR} 2=0.1032$

$\mathrm{R} 1=0.0519, \mathrm{wR} 2=0.1152$

0.39 and -0.42 e. $\AA^{-3}$ 
Table S6 Crystal data and structure refinement for S1b.

CCDC Identification code

Empirical formula

Formula weight

Temperature

Wavelength

Crystal system

Space group

Unit cell dimensions

Volume

Z

Density (calculated)

Absorption coefficient

$\mathrm{F}(000)$

Crystal size

Theta range for data collection

Index ranges

Reflections collected

Independent reflections

Completeness to theta $=73.104^{\circ}$

Absorption correction

Max. and min. transmission

Refinement method

Data / restraints / parameters

Goodness-of-fit on $\mathrm{F}^{2}$

Final $\mathrm{R}$ indices $[\mathrm{I}>2 \operatorname{sigma}(\mathrm{I})]$

$\mathrm{R}$ indices (all data)

Largest diff. peak and hole
1895062

C24 H20 Cl1 N1 O2 S1

421.95

$150 \mathrm{~K}$

$1.54184 \AA$

Triclinic

P -1

$\mathrm{a}=8.3514(3) \AA \quad \alpha=92.601(3)^{\circ}$.

$\mathrm{b}=10.3342(5) \AA \quad \beta=101.701(3)^{\circ}$.

$\mathrm{c}=12.9228(3) \AA \quad \gamma=105.438(4)^{\circ}$.

1046.87(7) $\AA^{3}$

2

$1.338 \mathrm{Mg} / \mathrm{m}^{3}$

$2.706 \mathrm{~mm}^{-1}$

440

$0.51 \times 0.13 \times 0.06 \mathrm{~mm}^{3}$

3.512 to $76.150^{\circ}$.

$-10<=\mathrm{h}<=10,-12<=\mathrm{k}<=12,-13<=\mathrm{l}<=16$

13662

$4314[\mathrm{R}(\mathrm{int})=0.0430]$

$99.7 \%$

Semi-empirical from equivalents

0.85 and 0.53

Full-matrix least-squares on $\mathrm{F}^{2}$

4308 / 0 / 262

1.0320

$\mathrm{R} 1=0.0524, \mathrm{wR} 2=0.1383$

$\mathrm{R} 1=0.0562, \mathrm{wR} 2=0.1409$

0.51 and -0.51 e. $\AA^{-3}$ 
Table S7 Crystal data and structure refinement for S1c.

CCDC Identification code

Empirical formula

Formula weight

Temperature

Wavelength

Crystal system

Space group

Unit cell dimensions

Volume

Z

Density (calculated)

Absorption coefficient

$\mathrm{F}(000)$

Crystal size

Theta range for data collection

Index ranges

Reflections collected

Independent reflections

Completeness to theta $=74.677^{\circ}$

Absorption correction

Max. and min. transmission

Refinement method

Data / restraints / parameters

Goodness-of-fit on $\mathrm{F}^{2}$

Final $\mathrm{R}$ indices $[\mathrm{I}>2 \operatorname{sigma}(\mathrm{I})]$

$\mathrm{R}$ indices (all data)

Largest diff. peak and hole
1895063

C20 H22 Cl1 N1 O2 S1 Si1

404.00

$150 \mathrm{~K}$

$1.54184 \AA$

Orthorhombic

$\mathrm{P} \mathrm{b} \mathrm{c} \mathrm{a}$

$\begin{array}{ll}\mathrm{a}=12.4303(3) \AA & \alpha=90^{\circ} . \\ \mathrm{b}=13.7905(2) \AA & \beta=90^{\circ} . \\ \mathrm{c}=24.5388(5) \AA & \gamma=90^{\circ} .\end{array}$

4206.44(15) $\AA^{3}$

$1.276 \mathrm{Mg} / \mathrm{m}^{3}$

$3.190 \mathrm{~mm}^{-1}$

1696

$0.46 \times 0.26 \times 0.04 \mathrm{~mm}^{3}$

5.065 to $76.201^{\circ}$.

$-12<=\mathrm{h}<=15,-12<=\mathrm{k}<=17,-30<=\mathrm{l}<=29$

15733

$4364[\mathrm{R}(\mathrm{int})=0.0370]$

$99.5 \%$

Semi-empirical from equivalents

0.88 and 0.43

Full-matrix least-squares on $\mathrm{F}^{2}$

4364 / 0 / 235

1.0051

$\mathrm{R} 1=0.0364, \mathrm{wR} 2=0.0958$

$\mathrm{R} 1=0.0433, \mathrm{wR} 2=0.1035$

0.42 and -0.24 e. $\AA^{-3}$ 
Table S8. Crystal data and structure refinement for S2a.

CCDC Identification code

Empirical formula

Formula weight

Temperature

Wavelength

Crystal system

Space group

Unit cell dimensions

Volume

Z

Density (calculated)

Absorption coefficient

$\mathrm{F}(000)$

Crystal size

Theta range for data collection

Index ranges

Reflections collected

Independent reflections

Completeness to theta $=76.331^{\circ}$

Absorption correction

Max. and min. transmission

Refinement method

Data / restraints / parameters

Goodness-of-fit on $\mathrm{F}^{2}$

Final $\mathrm{R}$ indices $[\mathrm{I}>2 \operatorname{sigma}(\mathrm{I})]$

$\mathrm{R}$ indices (all data)

Absolute structure parameter

Largest diff. peak and hole
1895064

C20 H19 N1 O2 S1

337.44

$100 \mathrm{~K}$

$1.54180 \AA$

Orthorhombic

P 212121

$\begin{array}{ll}\mathrm{a}=9.8528(2) \AA & \alpha=90^{\circ} . \\ \mathrm{b}=12.4780(2) \AA & \beta=90^{\circ} . \\ \mathrm{c}=14.5448(2) \AA & \gamma=90^{\circ} .\end{array}$

$1788.18(5) \AA^{3}$

4

$1.253 \mathrm{Mg} / \mathrm{m}^{3}$

$1.691 \mathrm{~mm}^{-1}$

712

$0.27 \times 0.19 \times 0.19 \mathrm{~mm}^{3}$

4.669 to $76.331^{\circ}$.

$-12<=\mathrm{h}<=12,-15<=\mathrm{k}<=15,-18<=\mathrm{l}<=14$

19547

$3719[\mathrm{R}($ int $)=0.0216]$

$99.6 \%$

Semi-empirical from equivalents

0.73 and 0.53

Full-matrix least-squares on $\mathrm{F}^{2}$

$3719 / 0 / 218$

1.0039

$\mathrm{R} 1=0.0232, \mathrm{wR} 2=0.0623$

$\mathrm{R} 1=0.0235, \mathrm{wR} 2=0.0626$

$-0.003(10)$

0.22 and -0.23 e. $\AA^{-3}$ 
Table S9 Crystal data and structure refinement for (E)-11.

CCDC Identification code

Empirical formula

Formula weight

Temperature

Wavelength

Crystal system

Space group

Unit cell dimensions

Volume

Z

Density (calculated)

Absorption coefficient

$\mathrm{F}(000)$

Crystal size

Theta range for data collection

Index ranges

Reflections collected

Independent reflections

Completeness to theta $=73.137^{\circ}$

Absorption correction

Max. and min. transmission

Refinement method

Data / restraints / parameters

Goodness-of-fit on $\mathrm{F}^{2}$

Final $\mathrm{R}$ indices $[\mathrm{I}>2 \operatorname{sigma}(\mathrm{I})]$

$\mathrm{R}$ indices (all data)

Largest diff. peak and hole
1895065

C22 H18 Cl1 N1 O2

363.84

$150 \mathrm{~K}$

$1.54184 \AA$

Triclinic

P -1

$\mathrm{a}=9.1440(8) \AA \quad \alpha=72.112(5)^{\circ}$.

$\mathrm{b}=9.4570(5) \AA \quad \beta=72.362(6)^{\circ}$.

$\mathrm{c}=12.3823(6) \AA \quad \gamma=65.173(7)^{\circ}$.

$905.85(12) \AA^{3}$

2

$1.334 \mathrm{Mg} / \mathrm{m}^{3}$

$1.989 \mathrm{~mm}^{-1}$

380

$0.39 \times 0.21 \times 0.06 \mathrm{~mm}^{3}$

3.830 to $76.185^{\circ}$.

$-10<=\mathrm{h}<=11,-11<=\mathrm{k}<=11,-15<=\mathrm{l}<=15$

18123

$3751[\mathrm{R}($ int $)=0.0322]$

$99.7 \%$

Semi-empirical from equivalents

0.89 and 0.68

Full-matrix least-squares on $\mathrm{F}^{2}$

$3751 / 0 / 235$

0.9984

$\mathrm{R} 1=0.0424, \mathrm{wR} 2=0.1083$

$\mathrm{R} 1=0.0446, \mathrm{wR} 2=0.1108$

0.78 and -0.43 e. $\AA^{-3}$ 
Table S10 Crystal data and structure refinement for $\mathbf{1 2}$.

CCDC Identification code

Empirical formula

Formula weight

Temperature

Wavelength

Crystal system

Space group

Unit cell dimensions

Volume

Z

Density (calculated)

Absorption coefficient

$\mathrm{F}(000)$

Crystal size

Theta range for data collection

Index ranges

Reflections collected

Independent reflections

Completeness to theta $=74.705^{\circ}$

Absorption correction

Max. and min. transmission

Refinement method

Data / restraints / parameters

Goodness-of-fit on $\mathrm{F}^{2}$

Final $\mathrm{R}$ indices $[\mathrm{I}>2 \operatorname{sigma}(\mathrm{I})]$

$\mathrm{R}$ indices (all data)

Largest diff. peak and hole
1895066

C22 H18 Cl1 N1 O2

363.84

$150 \mathrm{~K}$

$1.54184 \AA$

Monoclinic

$\mathrm{C} 2 / \mathrm{c}$

$\mathrm{a}=29.0515(7) \AA \quad \alpha=90^{\circ}$.

$\mathrm{b}=6.12960(10) \AA \quad \beta=98.229(2)^{\circ}$.

$\mathrm{c}=20.6331(5) \AA \quad \gamma=90^{\circ}$.

3636.39(14) $\AA^{3}$

8

$1.329 \mathrm{Mg} / \mathrm{m}^{3}$

$1.982 \mathrm{~mm}^{-1}$

1520

$0.37 \times 0.05 \times 0.02 \mathrm{~mm}^{3}$

4.941 to $76.229^{\circ}$.

$-36<=\mathrm{h}<=32,-7<=\mathrm{k}<=7,-25<=\mathrm{l}<=25$

19564

$3794[\mathrm{R}(\mathrm{int})=0.0285]$

$99.7 \%$

Semi-empirical from equivalents

0.96 and 0.87

Full-matrix least-squares on $\mathrm{F}^{2}$

3793 / 0 / 235

1.0005

$\mathrm{R} 1=0.0309, \mathrm{wR} 2=0.0821$

$\mathrm{R} 1=0.0348, \mathrm{wR} 2=0.0871$

0.27 and -0.21 e. $\AA^{-3}$ 
Table S11 Crystal data and structure refinement for S5.

CCDC Identification code

Empirical formula

Formula weight

Temperature

Wavelength

Crystal system

Space group

Unit cell dimensions

Volume

Z

Density (calculated)

Absorption coefficient

$\mathrm{F}(000)$

Crystal size

Theta range for data collection

Index ranges

Reflections collected

Independent reflections

Completeness to theta $=76.036^{\circ}$

Absorption correction

Max. and min. transmission

Refinement method

Data / restraints / parameters

Goodness-of-fit on $\mathrm{F}^{2}$

Final $\mathrm{R}$ indices $[\mathrm{I}>2 \operatorname{sigma}(\mathrm{I})]$

$\mathrm{R}$ indices (all data)

Largest diff. peak and hole

Absolute structure parameter (Flack)

Absolute structure parameter (Flack)

Hooft probability analysis
1895067

C15 H11 N1 O2

237.26

$150 \mathrm{~K}$

$1.54184 \AA$

Monoclinic

$\mathrm{P} \mathrm{c}$

$\begin{array}{ll}\mathrm{a}=6.0102(3) \AA & \alpha=90^{\circ} . \\ \mathrm{b}=13.3092(6) \AA & \beta=104.129(5)^{\circ} . \\ \mathrm{c}=7.5133(3) \AA & \gamma=90^{\circ} .\end{array}$

582.82(5) $\AA^{3}$

2

$1.352 \mathrm{Mg} / \mathrm{m}^{3}$

$0.733 \mathrm{~mm}^{-1}$

248

$0.36 \times 0.11 \times 0.01 \mathrm{~mm}^{3}$

6.653 to $76.036^{\circ}$.

$-7<=\mathrm{h}<=7,-16<=\mathrm{k}<=16,-9<=\mathrm{l}<=8$

5285

$1797[\mathrm{R}($ int $)=0.0385]$

$99.5 \%$

Semi-empirical from equivalents

0.99 and 0.64

Full-matrix least-squares on $\mathrm{F}^{2}$

1792 / 2 / 164

1.0144

$\mathrm{R} 1=0.0333, \mathrm{wR} 2=0.0795$

$\mathrm{R} 1=0.0358, \mathrm{wR} 2=0.0827$

0.15 and -0.16 e. $\AA^{-3}$

$-0.35(34)$

$-0.29(24)$

P2 (correct) $>99.99 \%$, P3 (correct) 98.98\% 
Table S12 Crystal data and structure refinement for $(E)$-S8.

CCDC Identification code

Empirical formula

Formula weight

Temperature

Wavelength

Crystal system

Space group

Unit cell dimensions

Volume

Z

Density (calculated)

Absorption coefficient

$\mathrm{F}(000)$

Crystal size

Theta range for data collection

Index ranges

Reflections collected

Independent reflections

Completeness to theta $=73.197^{\circ}$

Absorption correction

Max. and min. transmission

Refinement method

Data / restraints / parameters

Goodness-of-fit on $\mathrm{F}^{2}$

Final $\mathrm{R}$ indices $[\mathrm{I}>2 \operatorname{sigma}(\mathrm{I})]$

$\mathrm{R}$ indices (all data)

Largest diff. peak and hole
1895068

$\mathrm{C} 44 \mathrm{H} 34 \mathrm{Cl} 2 \mathrm{~N} 4 \mathrm{O} 2$

721.68

$150 \mathrm{~K}$

$1.54184 \AA$

Triclinic

$\mathrm{P}-1$

$\mathrm{a}=8.3463(5) \AA \quad \alpha=100.889(4)^{\circ}$.

$\mathrm{b}=9.9354(6) \AA \quad \beta=99.320(4)^{\circ}$.

$\mathrm{c}=11.7589(5) \AA \quad \gamma=105.992(5)^{\circ}$.

896.51(9) $\AA^{3}$

1

$1.337 \mathrm{Mg} / \mathrm{m}^{3}$

$1.981 \mathrm{~mm}^{-1}$

376

$0.14 \times 0.09 \times 0.07 \mathrm{~mm}^{3}$

3.931 to $76.247^{\circ}$.

$-10<=\mathrm{h}<=10,-12<=\mathrm{k}<=10,-11<=\mathrm{l}<=14$

7645

$3705[\mathrm{R}($ int $)=0.0212]$

$99.7 \%$

Semi-empirical from equivalents

0.87 and 0.75

Full-matrix least-squares on $\mathrm{F}^{2}$

3689 / 0 / 235

1.0043

$\mathrm{R} 1=0.0367, \mathrm{wR} 2=0.0901$

$\mathrm{R} 1=0.0420, \mathrm{wR} 2=0.0957$

0.31 and -0.33 e. $\AA^{-3}$ 
Table S13 Crystal data and structure refinement for $\mathbf{1 6 .}$

CCDC Identification code

Empirical formula

Formula weight

Temperature

Wavelength

Crystal system

Space group

Unit cell dimensions

Volume

Z

Density (calculated)

Absorption coefficient

$\mathrm{F}(000)$

Crystal size

Theta range for data collection

Index ranges

Reflections collected

Independent reflections

Completeness to theta $=72.954^{\circ}$

Absorption correction

Max. and min. transmission

Refinement method

Data / restraints / parameters

Goodness-of-fit on $\mathrm{F}^{2}$

Final $\mathrm{R}$ indices $[\mathrm{I}>2 \operatorname{sigma}(\mathrm{I})]$

$\mathrm{R}$ indices (all data)

Largest diff. peak and hole
1895069

$\mathrm{C} 30 \mathrm{H} 21 \mathrm{Cl} 3 \mathrm{~N} 2 \mathrm{O} 2$

547.87

$150 \mathrm{~K}$

$1.54180 \AA$

Monoclinic

P $21 / \mathrm{n}$

$\mathrm{a}=12.8532(3) \AA \quad \alpha=90^{\circ}$.

$\mathrm{b}=10.5699(2) \AA \quad \beta=108.431(3)^{\circ}$.

$\mathrm{c}=20.2102(5) \AA \quad \gamma=90^{\circ}$.

2604.86(11) $\AA^{3}$

4

$1.397 \mathrm{Mg} / \mathrm{m}^{3}$

$3.437 \mathrm{~mm}^{-1}$

1128

$0.21 \times 0.09 \times 0.07 \mathrm{~mm}^{3}$

3.629 to $80.169^{\circ}$.

$-10<=\mathrm{h}<=16,-13<=\mathrm{k}<=12,-24<=\mathrm{l}<=25$

16898

$5387[\mathrm{R}(\mathrm{int})=0.0245]$

$99.6 \%$

Semi-empirical from equivalents

0.79 and 0.48

Full-matrix least-squares on $\mathrm{F}^{2}$

$5360 / 0 / 334$

0.9949

$\mathrm{R} 1=0.0310, \mathrm{wR} 2=0.0802$

$\mathrm{R} 1=0.0343, \mathrm{wR} 2=0.0836$

0.32 and -0.24 e. $\AA^{-3}$ 
Table S14 Crystal data and structure refinement for 18a.

CCDC Identification code

Empirical formula

Formula weight

Temperature

Wavelength

Crystal system

Space group

Unit cell dimensions

Volume

Z

Density (calculated)

Absorption coefficient

$\mathrm{F}(000)$

Crystal size

Theta range for data collection

Index ranges

Reflections collected

Independent reflections

Completeness to theta $=71.230^{\circ}$

Absorption correction

Max. and min. transmission

Refinement method

Data / restraints / parameters

Goodness-of-fit on $\mathrm{F}^{2}$

Final $\mathrm{R}$ indices $[\mathrm{I}>2 \operatorname{sigma}(\mathrm{I})]$

$\mathrm{R}$ indices (all data)

Largest diff. peak and hole
1895070

C21 H16 Cl1 N1 O2

349.82

$150 \mathrm{~K}$

$1.54180 \AA$

Triclinic

P -1

$\begin{array}{ll}\mathrm{a}=5.9369(4) \AA & \alpha=82.393(6)^{\circ} . \\ \mathrm{b}=11.1926(10) \AA & \beta=88.343(5)^{\circ} . \\ \mathrm{c}=13.0345(9) \AA & \gamma=79.980(6)^{\circ} .\end{array}$

$845.39(11) \AA^{3}$

2

$1.374 \mathrm{Mg} / \mathrm{m}^{3}$

$2.110 \mathrm{~mm}^{-1}$

364

$0.22 \times 0.14 \times 0.04 \mathrm{~mm}^{3}$

3.421 to $76.591^{\circ}$.

$-7<=\mathrm{h}<=7,-14<=\mathrm{k}<=13,-12<=\mathrm{l}<=16$

9802

$3480[\mathrm{R}(\mathrm{int})=0.0424]$

$99.6 \%$

Semi-empirical from equivalents

0.92 and 0.76

Full-matrix least-squares on $\mathrm{F}^{2}$

3463 / 0 / 226

0.9907

$\mathrm{R} 1=0.0514, \mathrm{wR} 2=0.1382$

$\mathrm{R} 1=0.0598, \mathrm{wR} 2=0.1485$

0.53 and -0.49 e. $\AA^{-3}$ 
Table S15 Crystal data and structure refinement for $\mathbf{1 8 f}$.

CCDC Identification code

Empirical formula

Formula weight

Temperature

Wavelength

Crystal system

Space group

Unit cell dimensions

Volume

Z

Density (calculated)

Absorption coefficient

$\mathrm{F}(000)$

Crystal size

Theta range for data collection

Index ranges

Reflections collected

Independent reflections

Completeness to theta $=74.009^{\circ}$

Absorption correction

Max. and min. transmission

Refinement method

Data / restraints / parameters

Goodness-of-fit on $\mathrm{F}^{2}$

Final $\mathrm{R}$ indices $[\mathrm{I}>2 \operatorname{sigma}(\mathrm{I})]$

$\mathrm{R}$ indices (all data)

Largest diff. peak and hole
1895071

C23 H21 Cl1 N2 O2

392.88

$150 \mathrm{~K}$

$1.54184 \AA$

Triclinic

$\mathrm{P}-1$

$\mathrm{a}=6.0920(3) \AA \quad \alpha=76.239(4)^{\circ}$.

$\mathrm{b}=11.9892(6) \AA \quad \beta=79.136(3)^{\circ}$.

$\mathrm{c}=14.3204(5) \AA \quad \gamma=77.836(4)^{\circ}$.

$982.50(8) \AA^{3}$

2

$1.328 \mathrm{Mg} / \mathrm{m}^{3}$

$1.888 \mathrm{~mm}^{-1}$

412

$0.50 \times 0.17 \times 0.14 \mathrm{~mm}^{3}$

3.212 to $76.298^{\circ}$.

$-7<=\mathrm{h}<=7,-15<=\mathrm{k}<=14,-17<=\mathrm{l}<=16$

11731

$4063[\mathrm{R}(\mathrm{int})=0.0289]$

$99.7 \%$

Semi-empirical from equivalents

0.77 and 0.41

Full-matrix least-squares on $\mathrm{F}^{2}$

4046 / 0 / 253

1.0059

$\mathrm{R} 1=0.0417, \mathrm{wR} 2=0.1106$

$\mathrm{R} 1=0.0435, \mathrm{wR} 2=0.1137$

0.27 and -0.36 e. $\AA^{-3}$ 


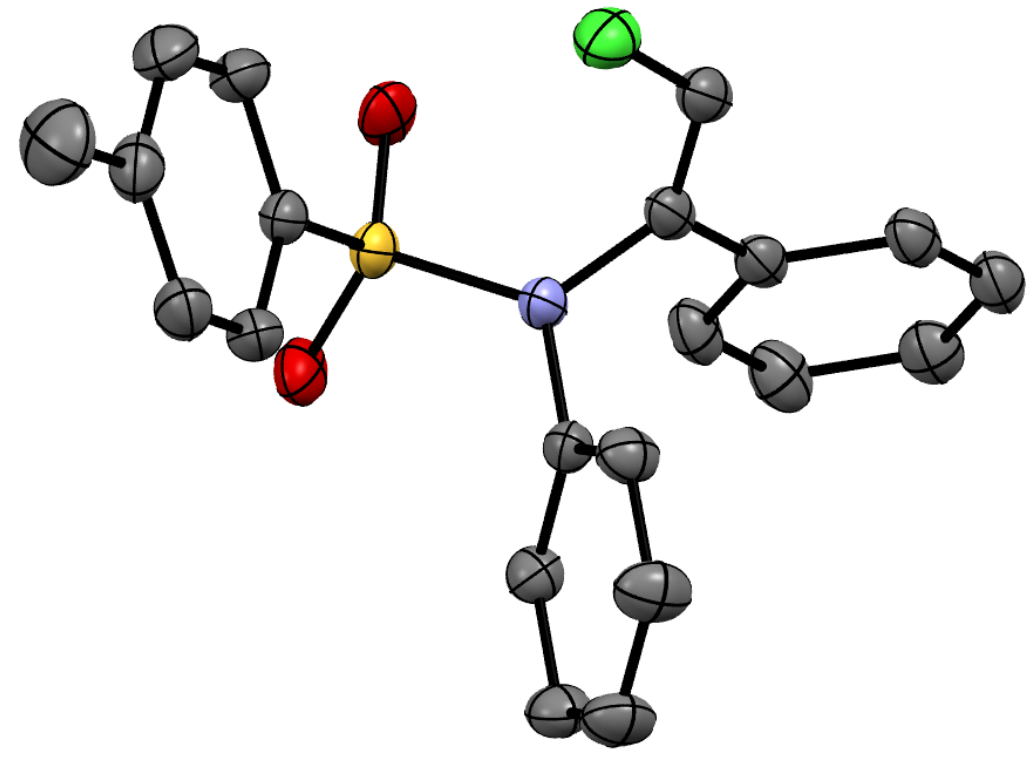

Figure S15: Solid state structure of 4. Displacement ellipsoid plots are drawn at 50\% probability. Hydrogen atoms have been omitted for clarity.

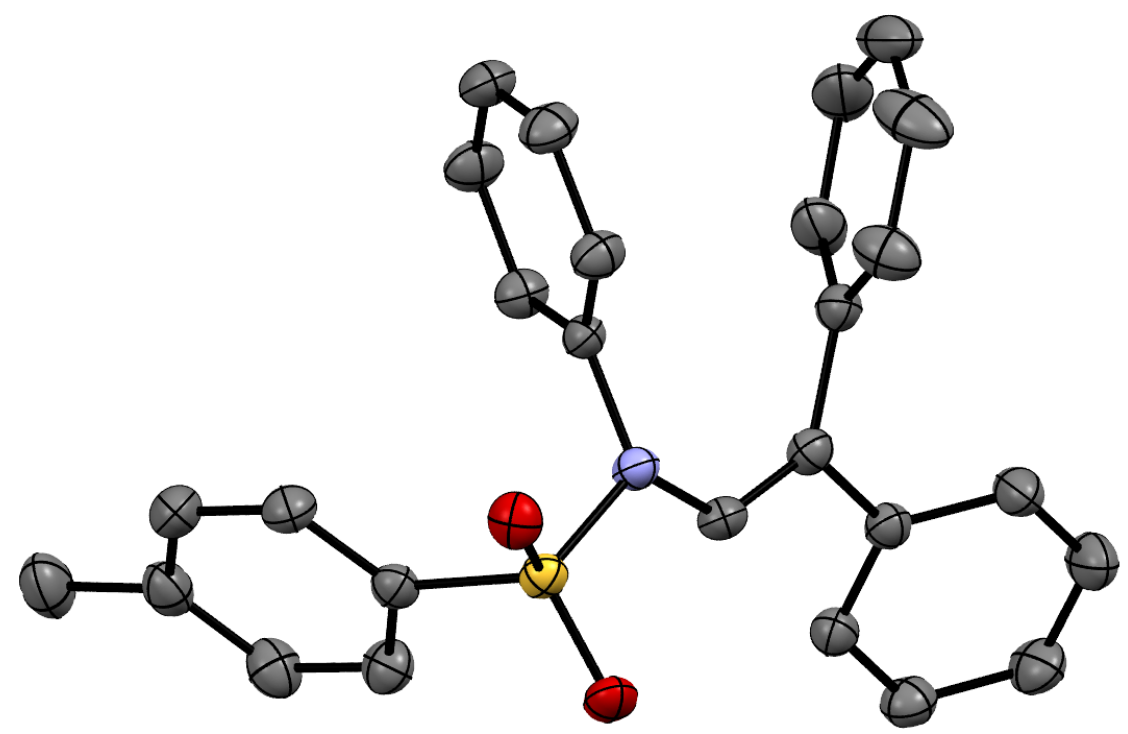

Figure S16: Solid state structure of 5. Displacement ellipsoid plots are drawn at 50\% probability. Hydrogen atoms have been omitted for clarity. 


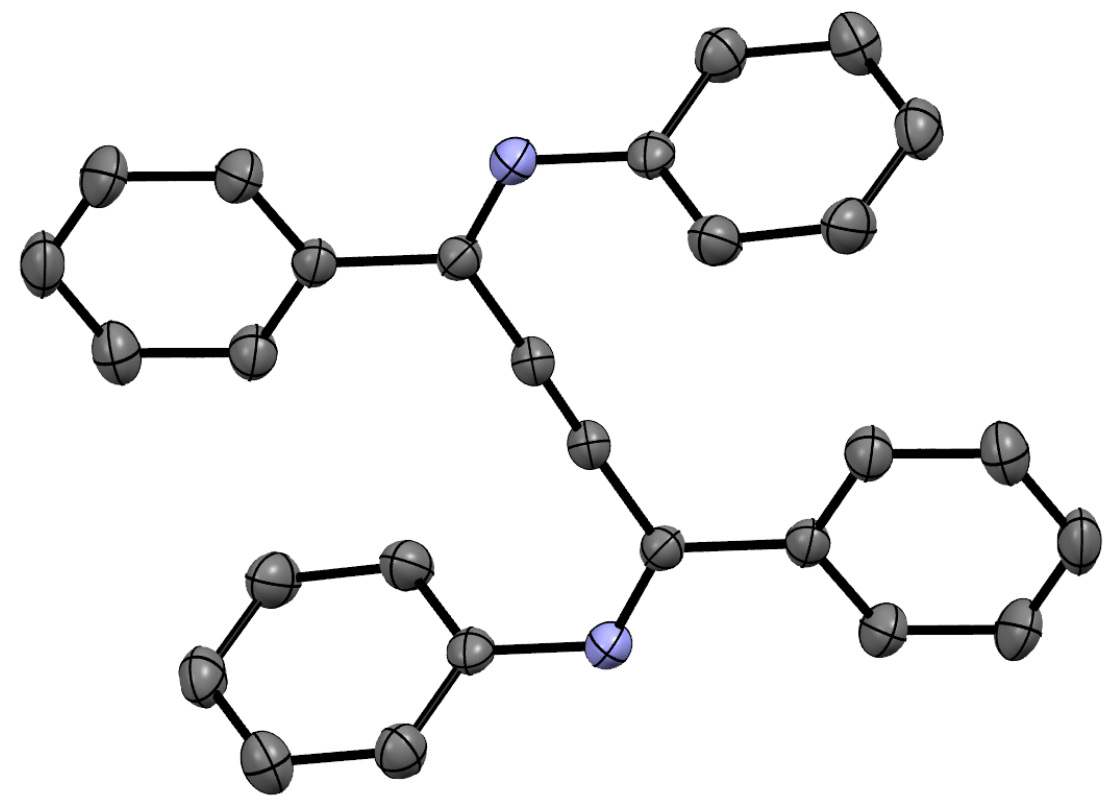

Figure S17: Solid state structure of 6. Displacement ellipsoid plots are drawn at 50\% probability. Hydrogen atoms have been omitted for clarity.

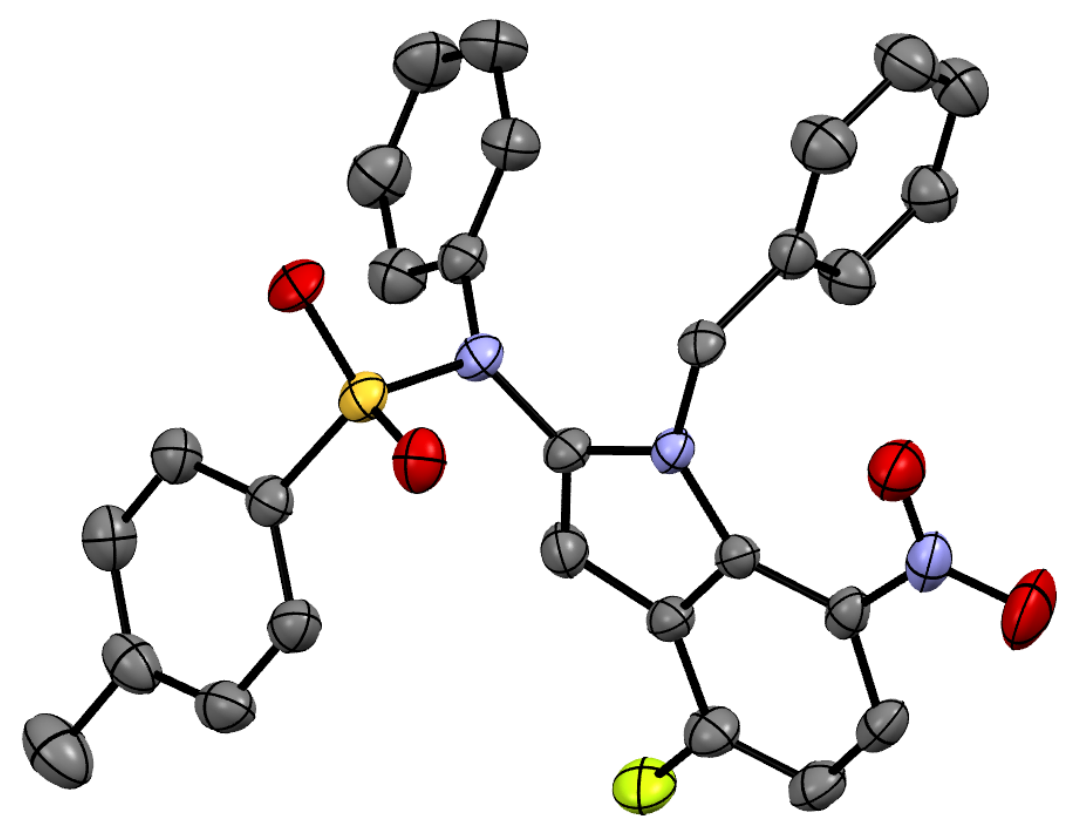

Figure S18: Solid state structure of 8. Displacement ellipsoid plots are drawn at 50\% probability. Hydrogen atoms and disordered components have been omitted for clarity. 


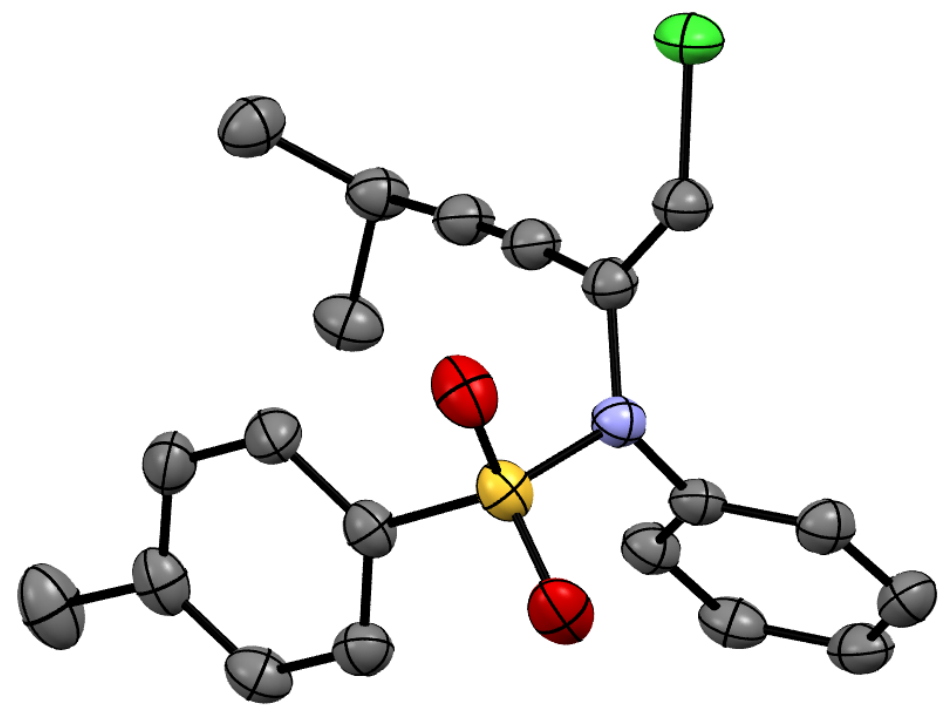

Figure S19: Solid state structure of S1a. Displacement ellipsoid plots are drawn at 50\% probability. Hydrogen atoms have been omitted for clarity.

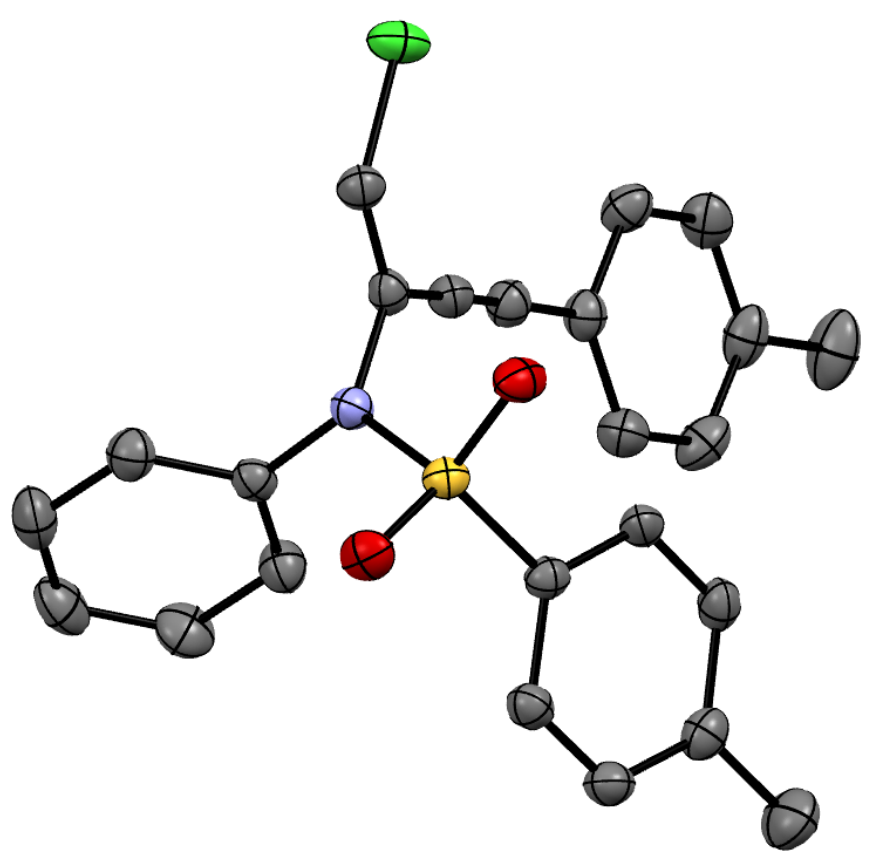

Figure S20: Solid state structure of S1b. Displacement ellipsoid plots are drawn at 50\% probability. Hydrogen atoms have been omitted for clarity. 


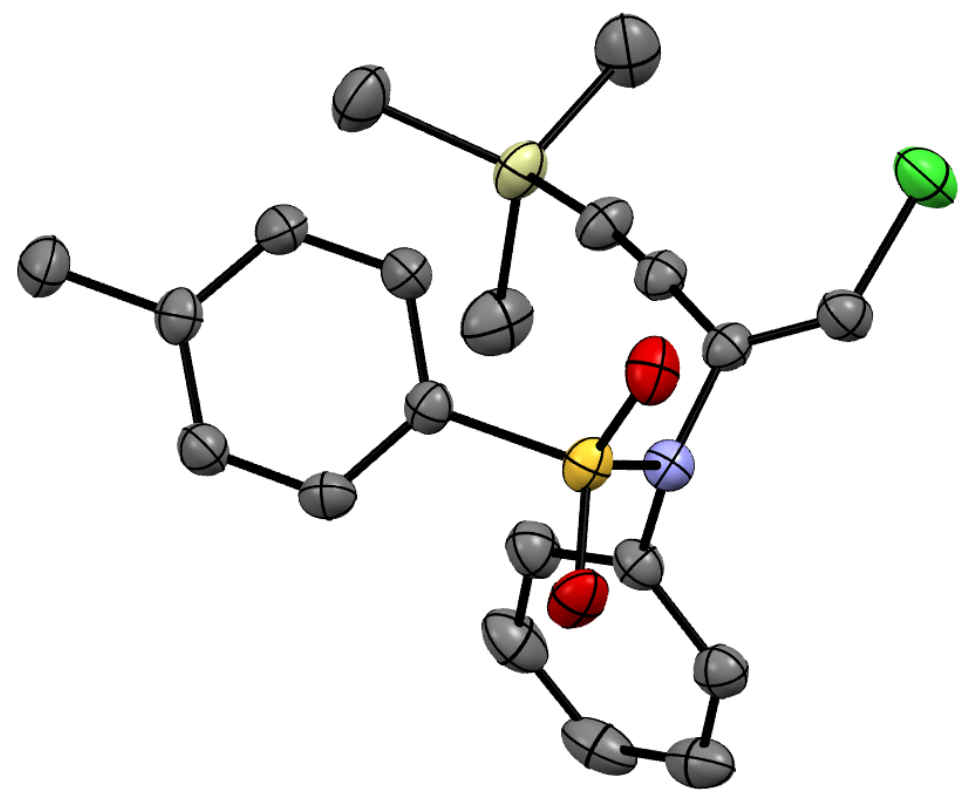

Figure S21: Solid state structure of S1c. Displacement ellipsoid plots are drawn at 50\% probability. Hydrogen atoms have been omitted for clarity.

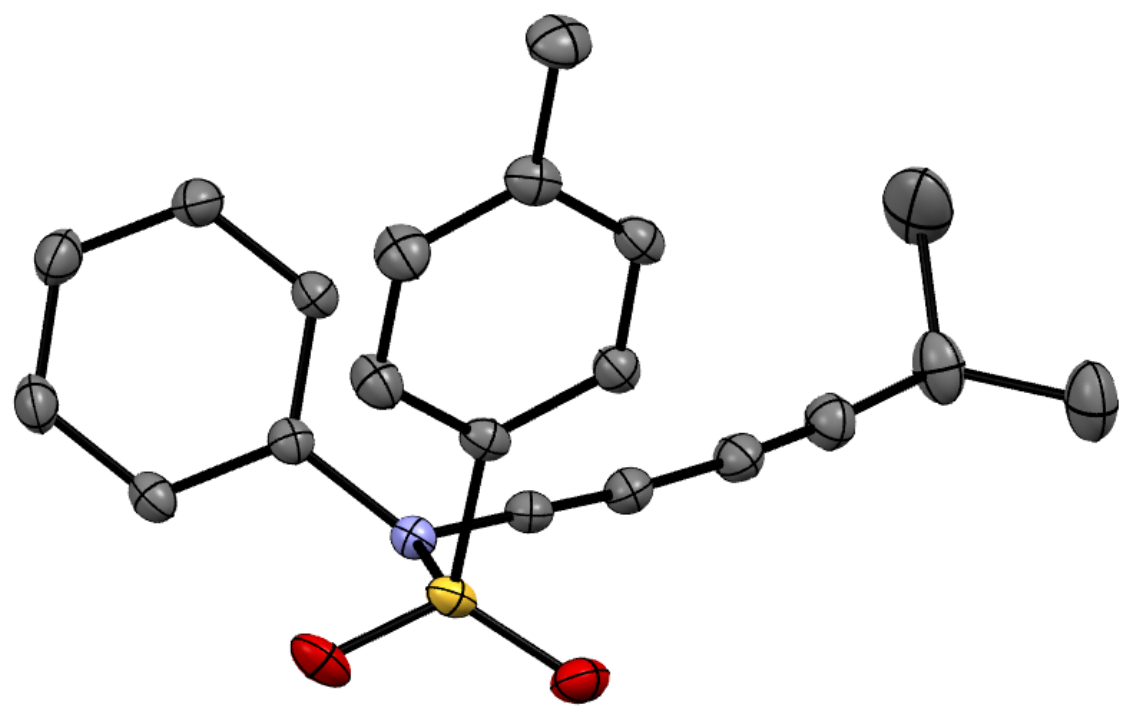

Figure S22: Solid state structure of S2a. Displacement ellipsoid plots are drawn at 50\% probability. Hydrogen atoms have been omitted for clarity. 


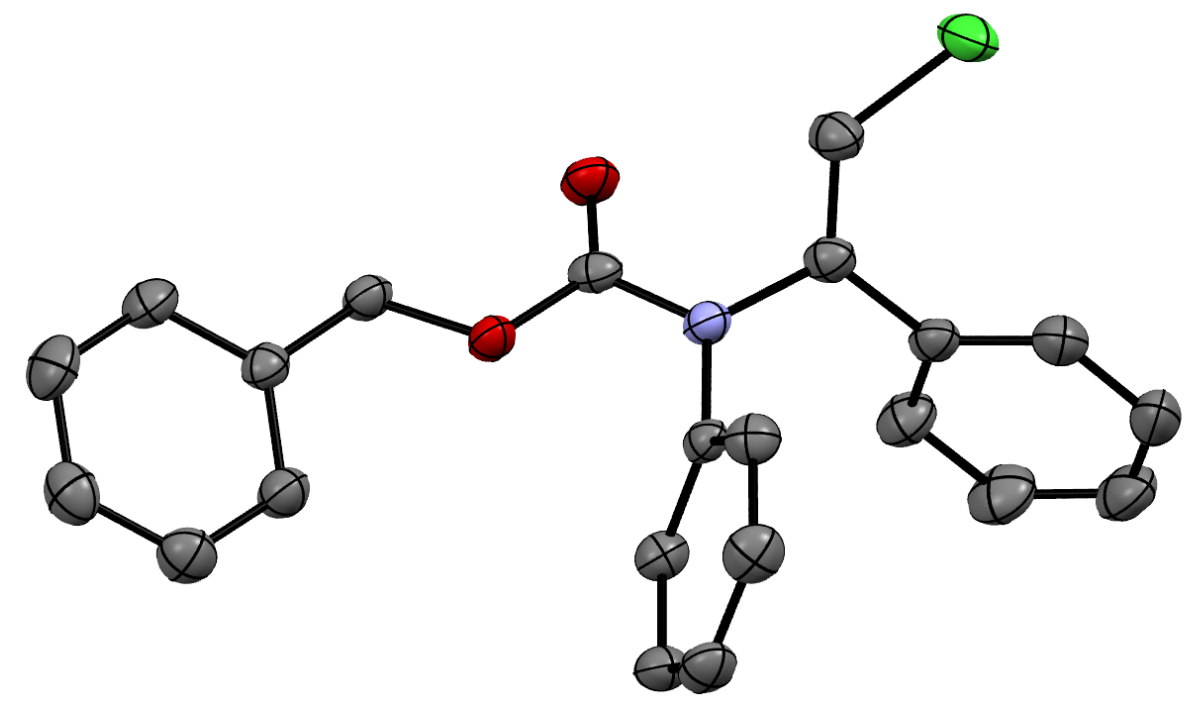

Figure S23: Solid state structure of $(E)-11$. Displacement ellipsoid plots are drawn at 50\% probability. Hydrogen atoms have been omitted for clarity.

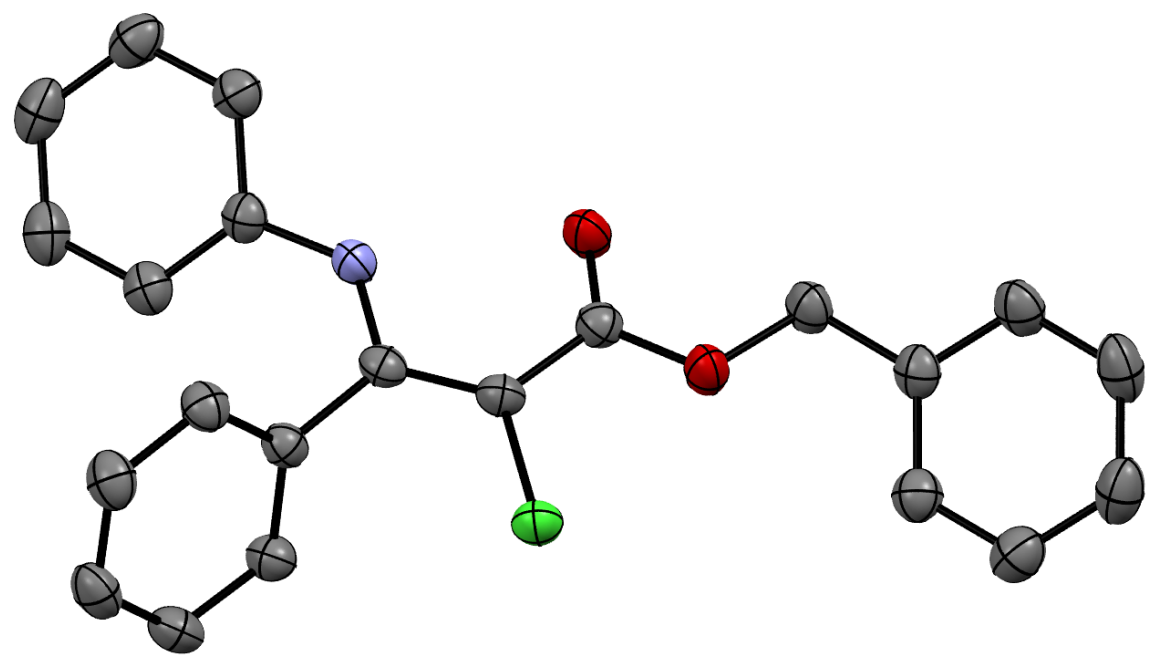

Figure S24: Solid state structure of 12. Displacement ellipsoid plots are drawn at 50\% probability. Hydrogen atoms have been omitted for clarity. 


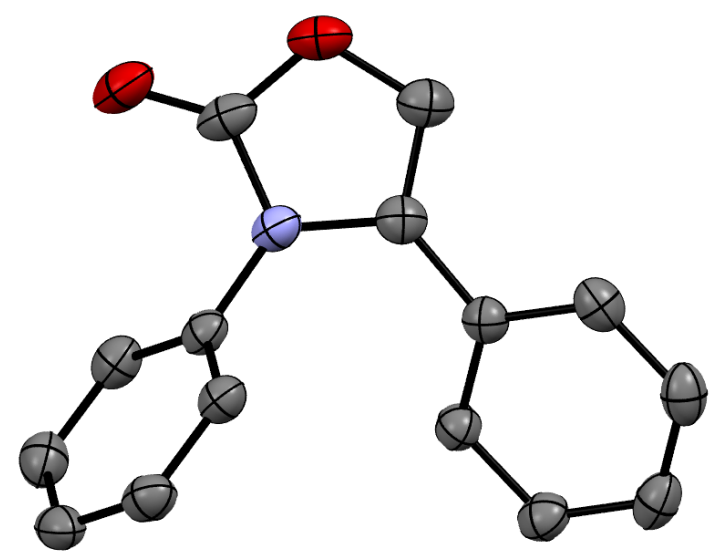

Figure S25: Solid state structure of S5. Displacement ellipsoid plots are drawn at 50\% probability. Hydrogen atoms have been omitted for clarity.

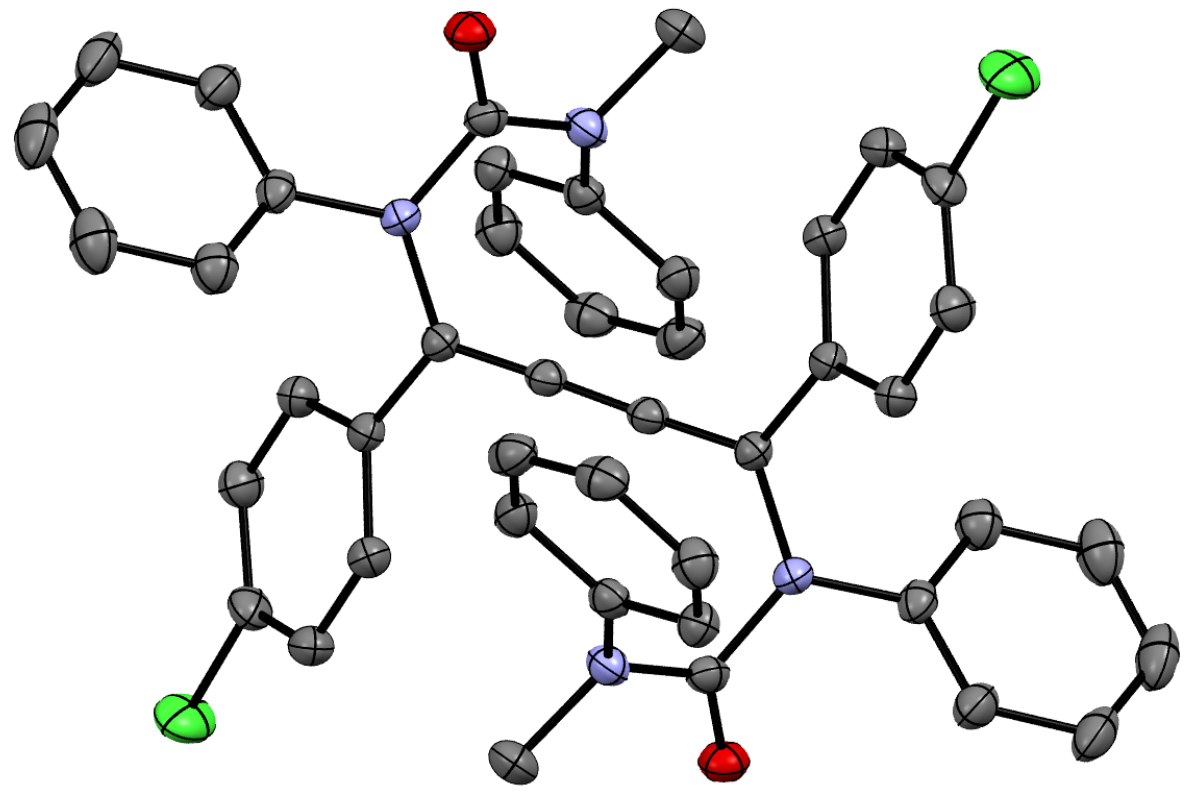

Figure S26: Solid state structure of $(E)$-S8. Displacement ellipsoid plots are drawn at $50 \%$ probability. Hydrogen atoms have been omitted for clarity. 


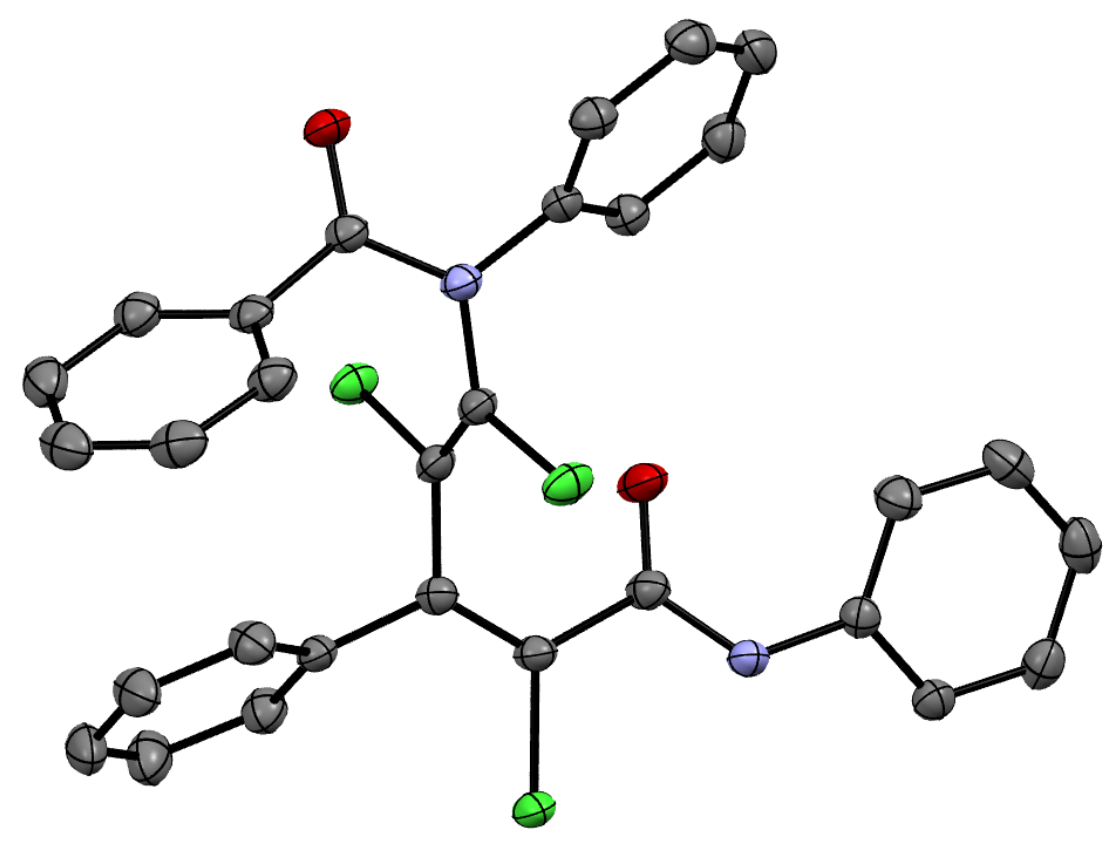

Figure S27: Solid state structure of 16. Displacement ellipsoid plots are drawn at 50\% probability. Hydrogen atoms have been omitted for clarity.

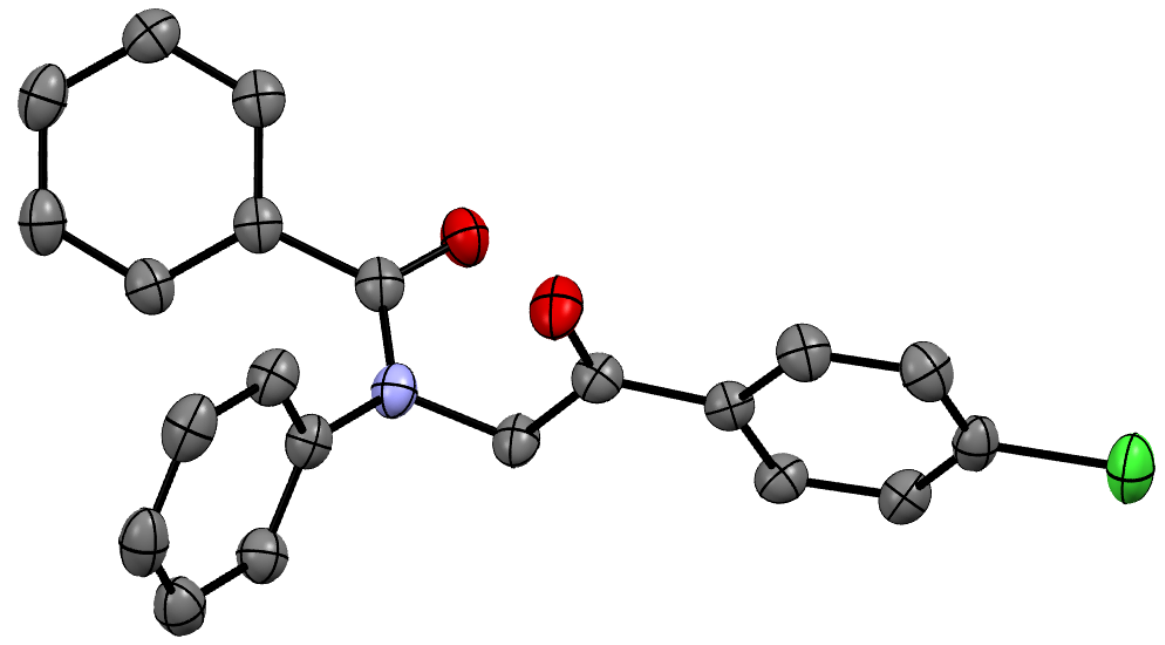

Figure S28: Solid state structure of 18a. Displacement ellipsoid plots are drawn at 50\% probability. Hydrogen atoms have been omitted for clarity. 


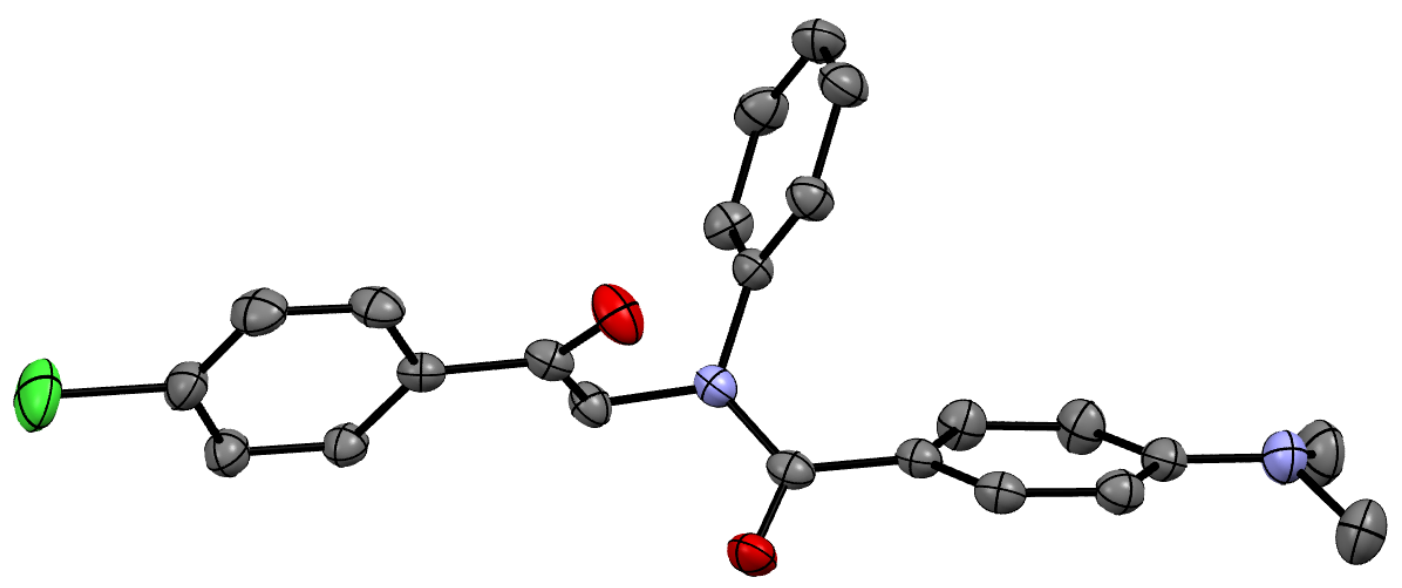

Figure S29: Solid state structure of $\mathbf{1 8 f}$. Displacement ellipsoid plots are drawn at 50\% probability. Hydrogen atoms have been omitted for clarity. 